\title{
BOLETíN MEXICANO \\ de Derecho Comparado 160
}

Nueva Serie Año LIV Número 160 Enero-Abril 2021

Instituto de Investigaciones Jurídicas

Universidad Nacional Autónoma de México

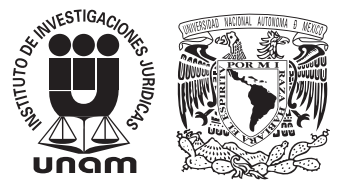




\title{
INSTITUTO DE INVESTIGACIONES JURÍDICAS
}

\author{
Director \\ Dr. Pedro Salazar \\ Secretaria académica \\ Dra. Issa Luna Pla \\ Secretario técnico \\ Lic. Raúl Márquez Romero \\ Jefa del Departamento de Publicaciones \\ Mtra. Wendy V. Rocha Cacho
}

Boletín Mexicano de Derecho Comparado, año LIV, número 160, enero-abril de 2021, editado por la Universidad Nacional Autónoma de México, Ciudad Universitaria, Coyoacán, 04510 Ciudad de México, a través del Instituto de Investigaciones Jurídicas, Circuito Maestro Mario de la Cueva s/n, Ciudad de la Investigación en Humanidades, Ciudad Universitaria, 04510 Ciudad de México, teléfono 555622 7474, correo electrónico: bmdc.ïj@unam.mx. Editora responsable: Raúl Márquez Romero. Número de reserva al título en Derechos de Autor: 04-2015-060912252900-203. ISSN versión electrónica: 2448-4873; ISSN versión impresa: 0041-8633. Número de certificado de licitud de título: 2096. Número de certificado de licitud de contenido: 1327.

Cuidado de la edición: Margarita García Castillo

Formación en computadora: Ricardo Hernández Montes de Oca 


\title{
BOLETÍN MEXICANO DE DEREGHO GOMPARADO
}

\author{
Director y editor \\ Raúl Márquez Romero \\ Coordinación editorial \\ Raúl Márquez Romero \\ Wendy V. Rocha Cacho
}

Comité Editorial

Óscar Cruz Barney (México); Susana Dávalos Torres (México); Flavia Freidenberg (México); Nuria González Martín (México); Luis René Guerrero Galván (México); Ma Carmen Macías Vázquez (México); Raúl Márquez Romero (México); Montserrat Pérez Contreras (México); Alfredo Sánchez Castañeda (México); José María Serna de la Garza (México).

\section{Comité Científico}

Francisco Balaguer Callejón (España); Enrique Calvo Nicolau (México); José Ramón Cossío (México); Héctor Fix Zamudio (México); Lawrence Friedman (Estados Unidos); Sergio García Ramírez (México); Juan Luis González Alcántara (México); Roberto Ibañez Mariel, Universidad Panamericana, (México); Jean-Claude Javillier (Francia); Donald McRae (Canadá); Jorge Madrazo Cuéllar (México); Loretta Ortíz Ahlf (México); Rogelio Pérez Perdomo (Venezuela); Fernando Serrano Migallón (México); Jean Michel Servais (Bélgica); José Luis Soberanes (México); Gerald Torres, Cornell (Estados Unidos); Diego Valadés (México); Arturo Zaldívar Lelo de la Rea (México).

\section{Comité Asesor}

Jorge Carlos Adame Goddard (México); María Mercedes Albornoz (México); César Astudillo (México); Manuel Becerra Ramírez (México); Ingrid Brena Sesma (México); Leticia Bonifaz Alfonzo (México); José Antonio Caballero Juárez (México); Miguel Carbonell (México); Gabriel Cavazos Villanueva (México); Enrique Cáceres Nieto (México); Francisco Contreras Vaca (México); Alexei Julio Estrada (Colombia); Jorge Fernández Ruíz (México); Eduardo Ferrer MacGregor (México); Imer B. Flores (México); Sandy Gaines (Estados Unidos); David Gantz (Estados Unidos); María del Refugio González (México); Leticia García Villaluenga (España); Rodrigo Gutiérrez Rivas (México); Alfonso Herrera García (México); Carla Huerta Ochoa (México); Patricia Kurczyn Villalobos (México); Sergio López Ayllón (México); José Pedro López Elías (México); Ricardo Méndez-Silva (México); Jonathan Pratter (Estados 
Unidos); Gabriela Ríos Granados (México); Carlos Reynoso Castillo (México); Andrés Rodríguez Benot (España); Víctor Manuel Rojas Amandi (México); Javier Saldaña Serrano (México); Miguel Sarre Iguíniz (México); Gustavo Vega Cánovas (México); María Hernany Veytia Palomino (México); Luis Daniel Vázquez Valencia (México); Jorge Witker (México); José Roldán Xopa (México).

Boletín Mexicano de Derecho Comparado por Universidad Nacional Autónoma de México, Instituto de Investigaciones Jurídicas, se distribuye bajo una Licencia Creative Commons Atribución-NoComercial-Sin Derivados 4.0 Internacional

(CG BY-NG-ND 4.0).

Primera edición: 16 de junio de 2021

Universidad Nacional Autónoma de México

Instituto DE InVESTIGACiOnES JuRÍdicas

Circuito Maestro Mario de la Cueva s/n

Ciudad de la Investigación en Humanidades

Ciudad Universitaria, Coyoacán, 04510 Ciudad de México

Hecho en México

ISSN versión electrónica: 2448-4873 
El Boletín Mexicano de Derecho Comparado se encuentra registrado en los siguientes índices, directorios y bases de datos nacionales e internacionales:

Citas Latinoamericanas en Ciencias Sociales y Humanidades (CLASE)

Clasificación Integrada de Revistas Científicas (CIRC)

\section{CONACYT}

Dialnet

Index to Foreign Legal Periodicals (IFLP)

International Political Science Abstracts (IPSA)

Latindex: Sistema Regional de Información en Línea para Revistas Científicas de América Latina, el Caribe, España y Portugal

Matriu d'Informació per a l'Avaluació de Revistes (MIAR)

Scientific Electronic Library Online (SciELO México)

Scielo Citation Index (SCI)

Scopus

Red de Bibliotecas Universitarias (REBIUN)

Red Iberoamericana de Innovación y Conocimiento Científico (REDIB) 


\section{CONTENIDO}

\section{ARTÍCULOS}

Sergio Iván ANzola

RODRÍGUEZ

Julieta Martin Del Gampo

NuÑEZ

Lucía del Carmen Bolaños BOLAÑOS

Rodrigo Camarena

GonZÁLEZ

Mauricio Alejandro GuIM Álfago

Ana María ZorRILLA

NORIEGA

Jorge Ulises Carmona TinOco
Aportes a la discusión sobre la regulación de la abogacía............. 3

La seguridad jurídica en la ley tributaria colombiana................ 35

Deconstruir para reconstruir: un análisis de los órganos constitucionales autónomos en México. . . . . . . . . . . . . . 61

Las vías intraestatales para cumplir las medidas de reparación derivadas de sentencias de la Corte Interamericana de Derechos Humanos. La imperiosa necesidad de un marco jurídico e institucional específico y eficaz en favor de las víctimas .... 99

María Jesús García

El futuro del Estado autonómico en EspaMorales 
Sergio García RamíreZ

Pablo Latorre RodríGuez Moisés Sotelo SÁnchez

Glara Moya Guillem

Gelso de Oliveira Santos Beatriz Mendes Niyama

Alicia Elena Pérez

DUARTE Y NOROÑA

Gerard Rincón ANDREu
Reconocimiento y tutela de derechos humanos. Pluralidad y diversidad en la sociedad democrática. . . . . . . . . . . . . 191

La aprobación del ingreso mínimo vital en España: un modelo para su eventual implementación en México ........ . 237

Tendencias político-criminales frente a la trata de personas y sus consecuencias típicas................... 277

Contribuições da jurisdição da Corte Interamericana na efetivação do direito à educação na América Latina . . . . . . . . 309

Los impactos de la impunidad en México. Reflexiones desde una perspectiva de género.................. 335

La legítima y la causa de desheredamiento por abandono familiar. ¿Hacia una mayor libertad de testar?. . . . . . . . . . . 361 
Esta revista forma parte del acervo de la Biblioteca Jurídica Virtual del Instituto de Investigaciones Jurídicas de la UNAM http://www.juridicas.unam.mx/

https://biblio.juridicas.unam.mx/bjv

https://revistas.juridicas.unam.mx/

\section{ARTÍCULOS}

Universidad Nacional Autónoma de México, IIJ-BJV, 2021

https://revistas.juridicas.unam.mx/index.php/derecho-comparado/issue/archive 


\title{
APORTES A LA DISGUSIÓN SOBRE LA REGULAGIÓN DE LA ABOGACÍA*
}

\author{
CONTRIBUTIONS TO THE DISCUSSION REGARDING \\ THE REGULATION OF LAWYERS
}

\author{
Sergio Iván ANZOLA RODRÍGUEZ** \\ Julieta MARTIN DEL CAMPO NUÑEZ****
}

RESUMEN: La propuesta de establecer la colegiación obligatoria parece gozar de consenso en la profesión jurídica mexicana. $\mathrm{Si}$ bien, coincidimos en la relevancia social que tiene el ejercicio de la abogacía y, por ende, en la necesidad de su regulación, consideramos necesario traer al contexto mexicano preguntas y advertencias que ya han surgido en otros lugares sobre la conveniencia de la regulación (como proyecto en sí mismo), los objetivos que persigue y la mejor forma de alcanzar esos objetivos.

De acuerdo con lo anterior, el presente artículo, más que constituirse como un aporte original, busca traer al contexto mexicano insumos básicos para una discusión más rica
ABSTRACT: The proposal to establish mandatory membership for mexican lawyers seems to enjoy consensus in the legal profession. Although we agree on the social relevance of the practice of law, and, therefore, on the need for its regulation, we consider necessary to bring into the mexican context questions and warnings that have already arisen elsewhere about the desirability of regulation (as a project in itself), the goals it pursues and the best way to achieve those goals.

In accordance with the above, this article, rather than being an original contribution, seeks to bring basic inputs to the mexican context for a richer and more complex

* Recibido el 18 de mayo de 2020; aprobado el 27 de enero de 2021.

** ORCID: 0000-0002-4858-5947. SNI Nivel I, doctor en Derecho y abogado por la Universidad de los Andes; maestro en Derecho con concentración en Derecho internacional Público por la Universidad de Helsinki; actualmente es coordinador de investigación en el Centro de Estudios sobre la Enseñanza y el Aprendizaje del Derecho (CEEAD). Correo electrónico: sergioar@ceead.org.mx.

*** ORCID: 0000-0002-7646-7980. Licenciada en Psicología por la Universidad Nacional Autónoma de México y estudiante de derecho en la Licenciatura en Derecho en la misma institución. Actualmente es asistente de investigación en el Centro de Estudios sobre la Enseñanza y el Aprendizaje del Derecho (CEEAD). Correo electrónico: julietamc@ ceead.org.mx.

Boletín Mexicano de Derecho Comparado, nueva serie, año LIV, núm. 160, enero-abril de 2021, pp. 3-33. 
y compleja sobre la regulación de la profesión jurídica.

Palabras clave: ética profesional, abogados, colegiación obligatoria, barras de abogados. discussion on the regulation of the legal profession.

Keywords: legal ethics and professional responsibility, lawyers, bar membership, bar association.

SumARIO: I. La discusión sobre la colegiación en México. II. Tres aportes a la discusión sobre la regulación a las y los abogados. III. Conclusiones. IV. Bibliografia.

\section{LA DISCUSIÓN SOBRE LA COLEGIACIÓN EN MÉXICO}

En el ejercicio profesional del derecho existe una amplia variedad de opciones para el desempeño de la profesión jurídica que van desde el notariado, la abogacía, la correduría pública, Ministerio Público, la academia y la investigación, entre otras (Darwin Clavijo Cáceres, 2015). Cabe destacar que, respecto al ejercicio profesional en México, cada estado del país cuenta con su propia ley que lo regula conforme al artículo 5o. de la Constitución Política de los Estados Unidos Mexicanos. Por ejemplo, en la Ciudad de México, las profesiones jurídicas tienen en común que para su ejercicio se requiere contar con un título legalmente expedido y registrado por una institución de educación superior autorizada para hacerlo, para posteriormente obtener una cédula profesional mediante trámite ante la Dirección General de Profesiones (Ley Reglamentaria del Artículo 5o. constitucional [Ley Reglamentaria], art. 25).

El título profesional tiene como función principal reconocer que la persona ha concluido los estudios correspondientes o que ha demostrado que cuenta con los conocimientos necesarios para ejercer profesionalmente (Ley Reglamentaria, art. 1). El poder para determinar qué persona tiene los conocimientos necesarios es un poder que yace entonces en las escuelas de derecho. ${ }^{1}$ La cédula profesional al ser expedida tiene efectos de patente para el ejercicio profesional y para identidad en el ejercicio pro-

1 Para febrero de 2019 México contaba con aproximadamente 1,900 escuelas de derecho (Centro de Estudios sobre la Enseñanza y el Aprendizaje del Derecho, 2019).

Esta obra está bajo una Licencia Creative Commons

Atribución-NoComercial-SinDerivar 4.0 Internacional, IIJ-UNAM.

Boletín Mexicano de Derecho Comparado, núm. 160, enero-abril de 2021, pp. 3-33. 
fesional (Ley Reglamentaria, art. 23). Una vez realizado el trámite de título y la cédula profesional, dependiendo de la profesión jurídica elegida existirán distintos requisitos a cumplir para desempeñarse en la profesión.

La Dirección General de Profesiones, la cual depende de la Secretaría de Educación Pública, es la encargada de la vigilancia en el ejercicio profesional en general y posibilita la relación entre el Estado y los colegios de profesionales (Ley Reglamentaria, arts. 1 y 21). En la ley, se reconoce que esta Dirección tiene la facultad de registrar los títulos profesionales, llevar una hoja de servicios de cada profesionista, hacer la anotación en ella cuando se imponga alguna sanción a un profesional, autorizar el ejercicio de una especialidad, expedir cédulas profesionales, realizar una lista de los profesionales que no ejercen, cancelar el registro de los títulos profesionales cuando exista una condena de inhabilitación por vía judicial para el ejercicio de la profesión, entre otras (Código Civil Federal, art. 2104). En la práctica, existe una gama de regulaciones estatales en las que pareciera ser que la Dirección General de Profesiones no tiene facultad de investigar y sancionar a los profesionales por violaciones a la ley y más bien delega esa autoridad a la rama judicial y a los colegios profesionales. Su función parecería limitarse a una de tipo administrativo.

La Ley Reglamentaria en relación con el ejercicio de las profesiones en la Ciudad de México en su artículo 50, inciso r, señala como un propósito de los colegios de profesionistas: "Establecer y aplicar sanciones contra los profesionales que faltaren al cumplimiento de sus deberes profesionales, siempre que no se trate de actos y omisiones que deban sancionarse por las autoridades".

Respecto a las sanciones de las autoridades, la misma ley dedica su capítulo VIII para hablar de los delitos e infracciones que pueden cometer los profesionales por no cumplir la ley, además, toca temas como el conflicto de intereses individuales de los profesionistas y con la sociedad y el secreto profesional, ambos temas, relevantes para el ejercicio de la abogacía. En esta misma línea sobre las sanciones aplicables a quienes ejercen la abogacía, también puede encontrarse que se tipifica la revelación de secretos del cliente, alegar falsos a sabiendas y el conflicto de intereses. Además de la responsabilidad civil a la que igualmente pueden ser sujetos por incumplir el cumplimiento del mandato, y la responsabilidad por daños y perjuicios al procurador o abogado que revele a la parte contraria 
secretos de su cliente o proporcione documentos o datos que lo perjudiquen (Código Civil Federal, art. 2590).

Aun cuando existen estos controles al ejercicio profesional, en general, y aplicables al ejercicio de la abogacía en específico, de acuerdo con la Encuesta sobre la Percepción Pública de la Ciencia y la Tecnología (ENPECYT, se realiza cada dos años) realizada en 2017 por el Instituto Nacional de Estadística y Geografía (INEGI), la respetabilidad de quienes ejercen la abogacía se encuentra en un 6.26 de una escala que va de 1 al 10, donde 10 es el nivel más alto de respetabilidad. De la encuesta también se observa que a mayor edad de las y los encuestados menor calificación se otorga a las y los abogados. Profesiones relacionadas con el sistema de justicia como lo son quienes ejercen la abogacía (6.26), jueces (6.03) y policías (5.32) se encuentran en los últimos lugares del ranking de un total de 17 profesiones. Los primeros lugares de la ENPECYT son ocupados por bomberos (9.34), inventores (9.005) y quienes se dedican a la enfermería (8.93). Ante esta percepción de parte de la ciudadanía, aunado a la necesidad social de acceso a la justicia, la seguridad jurídica, a un Estado de derecho, a mejores servicios profesionales y una defensa adecuada, han surgido propuestas para que los mismos profesionistas sean quienes den las soluciones mediante la auto regulación (Oscar Cruz Barney, 2020, p. 69). Es en este contexto donde ha surgido la propuesta de la colegiación obligatoria y la certificación. Un ejemplo de ello es el Informe de la Relatoría Especial sobre la independencia de los magistrados y abogados. Adición México (A/HRC7177307Add.3, 2011, párrafo 66). Uno de los argumentos recurrentes en favor de la implementación de la certificación y la colegiación obligatoria es que ésta ha rendido frutos en distintos países tanto europeos como americanos (Oscar Cruz Barney, 2020, p. 13).

Es importante hacer una distinción entre la colegiación y la certificación. La certificación se refiere al imperativo ético que existe para atender exclusivamente aquellos asuntos para los que se tiene conocimiento adecuado y suficiente mientras que la colegiación acredita el dominio profesional (Oscar Cruz Barney, 2020, p. 70). En términos prácticos, la certificación podría consistir, por ejemplo, en satisfacer determinados requisitos mediante instrumentos específicos (esto es, cursos o exámenes) a fin de que una vez completados satisfactoriamente el o la profesional en derecho pueda calificarse a sí misma como "certificada". 
La colegiación obligatoria, por otro lado, implica que, en el caso particular del derecho, todo abogado que quiera dedicarse a la práctica jurídica $^{2}$ deba vincularse a un colegio profesional para poder hacerlo, es decir, sería un requisito adicional a los ya contemplados para poder ejercer. Por lo general, los colegios profesionales tienen como objetivo articular y velar por los ideales de la profesión (Oscar Cruz Barney, 2020, p. 71). Lo anterior implica que tendrían varias y diversas funciones: promover cursos de actualización, foros de discusión académica, proyectos para mejorar los servicios de los profesionales del derecho y la administración de justicia, diseñar códigos de ética profesional y velar por su cumplimiento entre otras.

Para los promotores de la colegiación obligatoria, ésta resulta ser una herramienta idónea tanto para garantizar el ejercicio profesional independiente como para asegurar la calidad de los servicios prestados por los profesionistas. Sus promotores argumentan que el hecho que no sea obligatoria dificulta la implementación de reglas generales ${ }^{34}$ para el adecuado ejercicio profesional lo cual repercute en la calidad y en el control para el cumplimiento de las obligaciones de las y los abogados (Oscar Cruz Barney et al., 2013). La presunción acá es que una vez que exista la colegiación obligatoria, habrá estándares más altos de calidad, reglas más cla-

2 No sobra decir que la definición de qué es y qué no es práctica del derecho es problemática en sí misma pues puede implicar cerrar un nicho de trabajo a personas que no sean abogadas (Deborah Rhode, 1990).

3 No obstante, como señalamos anteriormente, ya existen disposiciones tanto en las leyes generales de profesiones de cada Estado, como en el Código Nacional de Procedimientos Penales que imponen obligaciones y deberes éticos similares a los que contendrían los códigos de ética promulgados por los colegios de abogados. Además de estas normas, no sobra recordar que la relación abogado-cliente se rige por un contrato de prestación de servicios el cual debe cumplirse de acuerdo con los términos en él pactados, lo cual sugiere que el régimen de responsabilidad civil contractual también permite en la actualidad la regulación del ejercicio profesional del derecho.

4 La preocupación por contar con normas generales aplicables a todos los abogados la compartimos (aunque con matices como expondremos más adelante cuando nos adentremos en los aportes de Wilkins). Sin embargo, queremos advertir que precisamente la colegiación obligatoria, la cual no implica necesariamente la creación de un único colegio nacional con un único código de ética profesional, puede afectar la pretensión de generalidad pues cada colegio tendría la capacidad de darse su propio código de ética. Lo anterior implicaría, por ejemplo, que dependiendo del colegio profesional del que sea parte el abogado, la forma en que se regulará, por ejemplo, el secreto profesional podrá ser diferente. 
ras y precisas y, presuntamente, una mayor vigilancia a la forma en que se comportan quienes ejercen la abogacía ya sea porque los mismos colegios investigan y sancionan de oficio, o porque los usuarios acuden a ellos. ${ }^{5}$

Los colegios de abogados no sólo se preocupan por el bienestar de los usuarios, también tienen una preocupación acerca del cumplimiento de la misión de la profesión de dar asesoría y representación jurídica libre de presiones tanto del Estado, como de los clientes. Es decir, los colegios buscan preservar la autonomía de los y las abogadas la cual se considera imprescindible para un buen ejercicio del derecho (Juan Manuel Rozas Bravo, 2013, p. 57). Los promotores de la colegiación obligatoria consideran que la mejor forma de tener esa autonomía es por medio de la autoregulación, es decir, que sean los mismos que ejercen la abogacía los que se vigilen entre ellos: ceder el control al Estado (por ejemplo encargarlo a los jueces) puede ser peligroso pues se corre el riesgo de que los jueces castiguen a las y los abogados arbitrariamente a fin de disuadirlos de representar causas que, por X o Y, la Judicatura o el Estado pueda considerar como "sospechosas" o "peligrosas". Oscar Cruz Barney (2013, pp. 80 y 81 ) aborda como la posición de la abogacía independiente y organizada mediante la colegiación puede que no sea necesariamente cómoda para el Estado; por otro lado, ceder el control a los clientes puede implicar no sólo, falta de experticia y conocimiento sobre cómo deben comportarse los y las abogadas, sino también, un potencial abuso de los clientes sobre los profesionales, en el sentido de exigir una práctica del derecho que desconozca los límites de lo legal y éticamente permitido en la representación y asesoría jurídica. Es decir, poner en riesgo la defensa de lo público a costa de la defensa de intereses privados (Oscar Cruz Barney, 2015, p. 100).

Cabe destacar, según la propia normatividad, que los colegios no intervendrán en política o religión (Ley Reglamentaria, art. 48) y si bien juegan un papel fundamental para la actualización de los profesionales no deben ser competencia para las universidades ya que no pretenden ser instituciones educativas superiores. Tampoco deben verse como un negocio pues su fin no es lucrativo.

5 No obstante, este argumento parece no tener sustento empírico al menos en el caso de Estados Unidos y en el caso colombiano señalados en Richard Abel (1981) y Sergio Anzola Rodríguez (2019).

Esta obra está bajo una Licencia Creative Commons

Atribución-NoComercial-SinDerivar 4.0 Internacional, IIJ-UNAM.

Boletín Mexicano de Derecho Comparado, núm. 160, enero-abril de 2021, pp. 3-33. 


\section{TRES APORTES A LA DISCUSIÓN SOBRE REGULACIÓN DE LAS Y LOS ABOGADOS}

El impacto social que tiene el trabajo de los y las abogadas es indudable. Reconocer esto implica aceptar la necesidad de regular la forma en que llevan a cabo su trabajo. En este sentido compartimos plenamente la preocupación por construir y poner en marcha de manera pronta los mecanismos necesarios para balancear y proteger de la mejor forma posible todos los intereses que están en juego en el ejercicio del derecho.

Los aportes que haremos a continuación tienen como propósito invitar a ver el proyecto de regulación como uno complejo. Creemos que este proyecto necesita un análisis más cuidadoso y minucioso que el que se le ha dado hasta ahora. El ímpetu y el deseo por hacer un aporte mediante su implementación es clave para movilizar fuerzas que apoyen el proyecto; no obstante, estimamos que las buenas intenciones no pueden llevarnos a desconocer la complejidad del problema y los múltiples retos inmersos en él.

Como señalamos al inicio, los aportes que hacemos no son originales; son ideas y discusiones adelantadas por académicos estadounidenses entre 1980 y 1990 . Aunque ya son reflexiones "viejas" en la academia jurídica estadounidense, son nuevas en la academia jurídica mexicana (y latinoamericana) que ha investigado muy poco sobre la regulación y la ética profesional de los y las abogadas. Los tres aportes que haríamos podrían entenderse mejor bajo tres preguntas. Cada una de ellas encontrando una respuesta determinada en cada autor que expondremos: ¿para qué regulamos a los y las abogadas? (Richard Abel, 1981), ¿De qué hablamos cuando hablamos de independencia de las y los abogados y cómo podemos perseguirla? (Robert Gordon, 1988) y, por último, ¿cuál es el mejor mecanismo para regular a los y las abogadas? (David Wilkins, 1992).

\section{1. ¿Para qué regulamos a los y las abogadas?}

La necesidad de regular el ejercicio profesional de las y los abogados dada su relevancia social es indudable. No obstante, es necesario observar cuidadosamente el proceso de profesionalización y regulación pues, sus fi- 
nes originales pueden terminar siendo pervertidos en el proceso de implementación y la medicina puede terminar siendo peor que la enfermedad. La mirada crítica a los proyectos de profesionalización no es novedosa en la academia jurídica. Trabajos como el de Richard Abel, basado en la sociología de las profesiones de Magali Larson (1977), ya lo han hecho. Por ende, nuestro objetivo, como señalamos al inicio de este texto, no es desarrollar una mirada novedosa. Nuestro objetivo, más modesto, pero no por eso menos urgente, es traer a la discusión mexicana algunas ideas y argumentos que ya han sido advertidos en otros lugares.

Richard Abel (1981) formula una pregunta que puede parecer tonta, pero termina siendo crucial al momento de pensar en la profesionalización y las ideas que vienen aparejadas con ella como la colegiación y la certificación. Su pregunta es cipor qué, en el caso de la profesión jurídica estadounidense, la American Bar Association (ABA) emplea tantos recursos, tiempos y esfuerzos promulgando reglas que apunten a promover la conducta ética de quienes ejercen la abogacía? La pregunta puede catalogarse como tonta porque su respuesta parece ser obvia: promover un ejercicio ético del derecho y así proteger mejor los derechos e intereses de los ciudadanos cuando interactúan con ya sea como sus clientes, contraparte o terceros no directamente implicados. Gran parte del trabajo de Richard Abel (1981), consiste entonces en demostrar que en realidad las normas jurídicas que pretenden regular las conductas de las y los abogados en realidad no logran hacerlo y tampoco buscan hacerlo.

Demostrado esto, la pregunta se hace más acuciosa. ¿Por qué entonces tanto empeño, esfuerzo y recursos en un proyecto que no logra lo que promete? Para Richard Abel, lo que persiguen las normas y el proyecto de profesionalización no es una práctica ética del derecho o una mayor protección a los derechos de los ciudadanos frente al poder que ostentan los y las abogadas y la asimetría de información que existe en la relación abogado-cliente. El objetivo real de la profesionalización y la proliferación de normas, comités regulatorios y demás, es legitimar el monopolio que quienes ejercen la abogacía tienen sobre la práctica jurídica y así asegurar un nicho de mercado (ingresos económicos) y un alto estatus social para la profesión jurídica (Richard Abel, 1981).

No desarrollaremos a detalle la argumentación de Richard Abel pues creemos que para esos efectos resulta mejor consultar su trabajo directamente, no obstante, explicaremos a grandes rasgos su argumento.

Esta obra está bajo una Licencia Creative Commons

Atribución-NoComercial-SinDerivar 4.0 Internacional, IIJ-UNAM.

Boletín Mexicano de Derecho Comparado, núm. 160, enero-abril de 2021, pp. 3-33. 
Richard Abel señala que es equivocada la creencia que asume que los códigos de ética, barras de abogados, procedimientos sancionatorios, tienen como fin garantizar una práctica "más ética" del derecho. Esto ocurre por tres distintas razones: porque las normas en realidad no indican a quienes ejercen la profesión jurídica cómo comportarse frente a los dilemas éticos con los que se cruzan, porque (incluso si dijeran cómo deben comportarse) no son interiorizadas por las y los abogados y porque (incluso si fueran interiorizadas) en los casos donde algún abogado o abogada se apartara de la conducta que exigen, éstas por lo general no acarrean una sanción aún a pesar que existen mecanismos y órganos facultados para sancionar estas conductas (Richard Abel, 1981). Es importante señalar que, el argumento que desarrolla Richard Abel se basa en el estudio empírico que ha hecho de la profesión jurídica estadounidense y la ABA.

Lo anterior implica dos cosas: primero que pensar que lo que ha ocurrido allá, ocurrirá necesariamente en cualquier otro país o contexto de manera idéntica no es necesariamente cierto pues son contextos diferentes; segundo, que a pesar de lo anterior, es necesario reconocer que en todo caso sí puede ser medianamente predictivo de lo que ocurrirá en otros lugares y proyectos similares al menos por dos razones: porque aun a pesar de variaciones en los sistemas procesales (sistemas inquisitivos, acusatorios o mixtos) el rol de quienes ejercen la abogacía y los dilemas éticos a los que se enfrentan son muy similares (Sergio Anzola Rodríguez, 2019) y porque una de las jurisdicciones que ha hecho mayores esfuerzos por regular la profesión es la estadounidense la cual ha desarrollado múltiples reglas, cánones, jurisprudencia, teoría y doctrina al respecto. El que haya sido una jurisdicción prolífica en la regulación de los y las abogadas y su estudio no quiere decir que sea mejor, pero sí quiere decir, por lo menos, que ha tenido más debates y más experiencia en el asunto, y sólo por eso, ya valdría la pena prestar atención a lo que allí ha ocurrido.

Richard Abel afirma que las normas no tienen un impacto real sobre la conducta de los y las abogadas por la forma en que están diseñadas y redactadas. Para que una norma incida en la conducta de una persona, ésta tiene que indicar de manera clara y concisa la conducta que se espera de esa persona cuando se encuentre frente a determinada situación. Entre más vaga y menos concreta sea la redacción de la norma, menos capacidad tendrá para incidir sobre la conducta de la persona a la que va dirigida. La gran mayoría de normas que regulan el actuar de las y los 
abogados se caracterizan precisamente por esa vaguedad y falta de precisión. Cuando se da el caso opuesto; es decir, cuando las normas parecen sugerir una conducta clara y discernible, el mismo código contempla una serie de estándares o calificativos que permiten reinterpretar la orden que, en un primer momento, pareció ser clara. Esto es, los códigos de ética parecen contener siempre una válvula de escape que no permite determinar de manera clara la conducta que se espera de un abogado (Richard Abel, 1981).

Otro problema propio de las reglas es que éstas no regulan situaciones, escenarios y roles donde hay muchísimos dilemas éticos. Si estos escenarios existen y todos somos conscientes de ellos, pero aun así las normas no los regulan, el argumento según el cual la promulgación de códigos y tribunales de ética apunta a proveer una abogacía "ética" es falso. ${ }^{6}$

Un problema adicional identificado por Richard Abel en el argumento de las normas como promotoras de una abogacía ética es la irrelevancia de las normas en la conducta de los y las abogadas. Para poder afirmar que una conducta determinada ocurre porque así lo ordena un código de ética, esa conducta debe obedecer no a la moralidad común sino, en realidad, a lo que ordena el código de ética. El problema en identificar esta causalidad (es decir que quienes ejercen la abogacía actúan éticamente porque el código de ética se los ordena y no por otra razón) se debe a que muchas disposiciones de los códigos de ética se limitan simplemente a señalar pautas de conducta obvias que deben regular no sólo la conducta de quienes ejercen la abogacía, sino de cualquier persona: no mentir, hacer el trabajo diligentemente, informar a mi cliente sobre los desarrollos de su caso, no sobornar ni coaccionar a otros para que hagan algo a favor mío o de mi cliente, etcétera (Richard Abel, 1981).

6 Esto se conecta con el argumento de David Wilkins (1992) quien aboga por reconocer la amplia diversidad que existe en el ejercicio de la práctica jurídica y por ende la necesidad de contar con diversos mecanismos de control pues no hay un único mecanismo que pueda regular de manera adecuada a toda la profesión jurídica. En este punto es evidente que hay una tensión, al menos prima facie, entre Richard Abel y David Wilkins. Abel pareciera ser un escéptico de la capacidad de las normas mientras que Wilkins sí parece tener más fe en el poder de las normas, siempre y cuando éstas sean sensibles a los distintos contextos. Señalamos que esta tensión es prima facie pues puede ser que Abel sea menos escéptico de las normas si éstas atienden a las advertencias de Wilkins.

Esta obra está bajo una Licencia Creative Commons

Atribución-NoComercial-SinDerivar 4.0 Internacional, IIJ-UNAM.

Boletín Mexicano de Derecho Comparado, núm. 160, enero-abril de 2021, pp. 3-33. 
En resumen, el problema con el diseño y redacción de las normas de la ética profesional de las y los abogados es que pecan por defecto (lo que en inglés denominan underinclusive) al no regular todos los escenarios complejos, o al no indicar claramente la conducta que se espera, y pecan por exceso (lo que denominan overinclusive), es decir, simplemente son una moral común codificada, es decir, nos ordenan hacer cosas que ya tenemos interiorizadas y que obedecemos no porque sean derecho positivizado sino simplemente porque sus órdenes ya son parte de nuestra moral común.

Además de los problemas que Richard Abel encuentra en el diseño y redacción de las normas proferidas por la ABA, argumenta que, en el contexto estadounidense son pocos los esfuerzos por garantizar que los y las abogadas conozcan y aprendan dichas normas (Richard Abel, 1981). Por lo general, los cursos de ética profesional en las facultades de Derecho terminan siendo cursos de relleno y las reglas son memorizadas para contestar exámenes y posteriormente son fácilmente desechadas. Tampoco hay esfuerzos sistemáticos ni obligaciones reales de tomar cursos de actualización o de evaluar periódicamente el conocimiento que se tiene sobre estos temas.

Por otro lado, Richard Abel encuentra que los controles al cumplimiento voluntario y coercitivo no son efectivos. ${ }^{7}$ Aunque es un lugar común afirmar que las y los abogados tienen un interés por ser percibidos dentro del gremio profesional como practicantes éticos que cumplen con los valores y normas jurídicas que rigen el ejercicio profesional, la verdad pareciera ser que la profesión (o al menos sectores significativos de ella) ejercen presión social para que los y las abogadas actúen en contravía de ellas. Según Richard Abel (1981), las y los abogados no sienten una presión real para cumplir las normas de conducta, por el contrario, la presión que sienten parece llevarlos a querer hacer más dinero, ganar los casos a toda costa y ser percibidos como "ganadores" por sus colegas. La ética parece más etiqueta que convicción real.

Si el escenario del cumplimiento voluntario no es halagador, el escenario del cumplimiento coercitivo es aún más gris. Richard Abel (1981) encuentra que, en el contexto estadounidense, son pocos los casos investigados y las sanciones efectivamente impuestas a abogados y abogadas.

7 Este hallazgo coincide con el de Sergio Anzola Rodríguez (2019).

Esta obra está bajo una Licencia Creative Commons Atribución-NoComercial-SinDerivar 4.0 Internacional, IIJ-UNAM. Boletín Mexicano de Derecho Comparado, núm. 160, enero-abril de 2021, pp. 3-33. 
Las conductas violatorias de las normas del código de ética son pocas veces percibidas por los ciudadanos lo que hace que haya pocos casos decididos pues hay muy pocas denuncias que activen los mecanismos de investigación. En los pocos casos que son estudiados, pocas veces se considera que efectivamente hubo una violación al código de ética, o, cuando se encuentra alguna conducta indebida, el mismo código, dada su vaguedad e indeterminación, termina encontrando alguna excepción o justificación a la conducta. Por último, cuando efectivamente se interpone una sanción, esta tiende a ser pequeña o insignificante.

En el caso norteamericano, la proliferación de reglas y estructuras tendientes a vigilar el profesionalismo y conducta ética de las y los abogados no obedece realmente a garantizar un mejor servicio y una protección a los derechos de los clientes como lo vería la sociología funcionalista de Parsons y Durkheim, sino simplemente a asegurar un control del mercado de los servicios jurídicos. Cualquier ocupación en un sistema capitalista buscará controlar los mercados a los que vende sus servicios (Richard Abel, 1981). Las profesiones aspiran a controlar la oferta de servicios controlando la producción de productores (es decir, la producción de quienes ejercen la abogacía) y la producción de servicios (es decir, la prestación de servicios jurídicos). Entre menos abogados y abogadas haya, y, entre menos oferta de servicios jurídicos exista, las y los abogados que se encuentren mejor posicionados al interior de la profesión asegurarán su trabajo y los altos honorarios que serán una consecuencia de la poca oferta junto con la alta demanda. ${ }^{8}$

Las normas sobre la ética profesional de los y las abogadas, además de tratar de asegurar un control de la prestación de servicios (cosa que en últimas logran apenas de manera parcial como el mismo Richard Abel señala) fungen una función importante como medio de legitimación, pues son un intento (fútil pero simbólicamente intento, al fin y al cabo) de las y los abogados de la élite para convencerse de que se han resuelto los dilemas éticos de la profesión y que pueden hacer el bien, mientras se hacen ricos (do well while doing good) (Richard Abel, 1981). En una profesión donde los dilemas éticos son ubicuos y donde la población general ve a los y las abogadas sino como sujetos inmorales, al menos sí como amo-

8 La teoría que Richard Abel (1988) desarrolla en abstracto es narrada históricamente por Jerold Auerbach (1976).

Esta obra está bajo una Licencia Creative Commons

Atribución-NoComercial-SinDerivar 4.0 Internacional, IIJ-UNAM.

Boletín Mexicano de Derecho Comparado, núm. 160, enero-abril de 2021, pp. 3-33. 
rales, los códigos de ética tratan de convencer a los propios abogados y a los ciudadanos de que en realidad sí hay una voluntad por hacer las cosas bien y que esa voluntad no es sólo política, sino que se ve materializada en reglas jurídicas, barras y colegios de abogados que pueden aplicarlas y sancionar a los que se aparten de ellas.

El problema, en todo caso, es que la función es puramente simbólica pues los códigos de ética no solucionan los dilemas éticos, simplemente los describen recogiendo en sus normas todos los valores en tensión, pero sin indicar por cual se debe optar al momento de llegar a una situación dilemática. Que los dilemas éticos no se resuelvan en el código no es algo necesariamente malo, al fin y al cabo, puede resultar mejor dejar que el juicio sobre el cuál es la conducta correcta sea más contextual que categórico como sugiere William Simon (1988); lo que sí está mal, y hacia dónde se dirige la crítica de Richard Abel, es a atribuir a los códigos de ética, y en general a los proyectos de profesionalización, más de lo que son capaces de lograr sin reconocer el lado oscuro que puede esconderse detrás de ellos.

\section{2. ¿De qué hablamos cuando hablamos de independencia de las y los abogados y cómo podemos perseguirla?}

El fomento y garantía de independencia de quienes ejercen la abogacía es uno de los principales objetivos de los proyectos de colegiación obligatoria en México. Sus promotores consideran a los colegios de abogados como el medio idóneo para garantizar la libertad y la independencia en el ejercicio de la profesión(Oscar Cruz Barney, 2020). Incluso, organizaciones internacionales que agrupan a los colegios de los profesionales del derecho, ponen en relieve como uno de sus objetivos, preservar la independencia de quienes ejercen la abogacía (Oscar Cruz Barney, 2020). La Propuesta de Ley General para el Ejercicio de la Abogacía menciona como uno de los derechos de quienes ejercen la abogacía recabar y contener de todos los órganos corporativos la protección de su independencia y lícita actuación profesional (Ley General para el Ejercicio de la Abogacía, art. 37, Oscar Cruz Barney, 2020) y, como una obligación, la de denunciar al colegio cualquier atentado a la libertad, independencia o dignidad de un profesionista o de cualquier miembro de su actividad profesional en el ejercicio 
de sus funciones (Ley General para el Ejercicio de la Abogacía, art. 38, Oscar Cruz Barney, 2020). Para los promotores de la ley la independencia y libertad de las personas que ejercen la abogacía redunda en beneficio de la sociedad y del adecuado ejercicio profesional del derecho (Ley General para el Ejercicio de la Abogacía, art. 66, en Oscar Cruz Barney, 2020).

Según lo anterior la independencia en el ejercicio profesional del derecho parece ser un valor fundamental para la profesión jurídica. Dada la centralidad de este concepto, y basándonos en discusiones y debates que ya han ocurrido en otros lugares y contextos, quisiéramos señalar que al hablar de manera genérica sobre la "independencia de los abogados y abogadas" podemos estar refiriéndonos a distintos tipos de independencias, distintos focos de amenaza a esas independencias, y cada aspiración por "independencia" puede obedecer a razones distintas y requerirá de estrategias o mecanismos distintos para su protección. Al final, puede ser que encontremos razones válidas para apoyar la independencia en cualquiera de sus múltiples variantes. No obstante, creemos que, para tener una mayor claridad conceptual y una discusión más rica alrededor de los proyectos de colegiación y certificación, es conveniente "desempacar" el concepto genérico de independencia y verlo en sus distintas facetas.

El texto en el cual nos basamos e inspiramos para invitar a esta observación minuciosa es el artículo seminal de Robert Gordon The Independence of Lawyers escrito en 1988. En este texto el autor hace un esfuerzo por descifrar a qué se han referido históricamente los y las abogadas estadounidenses al momento de hablar sobre su independencia profesional y cómo han tratado de perseguirla y fomentarla. El texto comienza señalando que bajo la sombrilla de "independencia" pueden caber por lo menos 3 fenómenos distintos: i) independencia regulatoria; ii) independencia sobre las condiciones de trabajo; iii) independencia política. La independencia que a él le interesa entender en su desarrollo histórico es la última, la independencia política de quienes ejercen la abogacía.

A continuación, nos referiremos brevemente a cada una de ellas a fin de mostrar la complejidad que puede subyacer a un término que en México puede estar leyéndose de distintas formas por distintos actores sin que nos percatemos de ello.

Siguiendo a Robert Gordon (1988), por independencia regulatoria nos podemos referir a la prerrogativa que tiene la profesión jurídica para regular sus propias prácticas de manera autónoma sin intromisión alguna

Esta obra está bajo una Licencia Creative Commons

Atribución-NoComercial-SinDerivar 4.0 Internacional, IIJ-UNAM.

Boletín Mexicano de Derecho Comparado, núm. 160, enero-abril de 2021, pp. 3-33. 
de personas externas a la profesión. La independencia regulatoria puede entenderse como un intercambio de favores (no necesariamente justo o equitativo) entre el Estado y un grupo profesional: a cambio de que la profesión jurídica preste sus servicios a la sociedad, a ella se le otorga el beneficio público de autorregular sus prácticas. De esta forma a las abogadas y los abogados se les asigna (por medio de un monopolio que limita el acceso de los legos a las cortes o simplemente mediante la tecnificación de la disciplina jurídica que dificulta el acceso a las cortes para los legos) la responsabilidad de representar a las personas en sus asuntos jurídicos. A cambio de la prestación de este servicio (que no es gratuito y que, al contrario, lucra a los y las profesionales del derecho y sólo en situaciones muy específicas y limitadas se presta como un servicio público) el Estado permite que la profesión jurídica auto regule su práctica: en términos concretos que determine los controles de acceso (quién es abogado, qué requisitos deben cumplirse para ser abogado, qué se define como práctica jurídica, etcétera) y supervisión y permanencia (qué es una representación adecuada, qué entra y qué no entra bajo el secreto profesional, cómo se reparte la toma de decisiones entre abogado y cliente, qué tipo de sanciones deben aplicarse a los infractores de deberes profesionales, etcétera). Esta lógica se sostiene no sólo con base en el intercambio de favores, sino también bajo la idea según la cual, dada la asimetría de conocimiento frente al derecho entre los profesionales del derecho y las personas que no son abogadas, resulta difícil evaluar la calidad del servicio prestado por un abogado sin ser también abogado. El desempeño de un experto, los procesos de formación que deben seguir los que quieren ser expertos algún día, sólo pueden ser definidos y evaluados por los mismos expertos. En este sentido, la tecnificación del campo jurídico y la experticia requerida para desempeñarse en él termina justificando la independencia regulatoria. Permitir que personas no familiarizadas con el derecho determinen los requisitos para el ejercicio y la calidad en el ejercicio puede ser no sólo injusto (se juzgaría con estándares equivocados) sino además peligroso pues podría poner en riesgo el buen desempeño profesional.

Pasando al segundo concepto de independencia, nos referimos a la independencia o autonomía sobre las condiciones de trabajo, la ausencia de injerencia sobre la forma en que una abogada o abogado determina cómo llevar a cabo su trabajo (Robert Gordon, 1988). Esta independencia supone entonces que si bien el cliente determina los objetivos que su 
abogada o abogado debe perseguir, el profesional es quien decide de manera independiente dos cosas: primero, si toma o no el caso (no está obligada por ley a llevar todos los casos que lleguen a su despacho), y decide, de manera independientemente, los medios adecuados bajo el marco de la ley para lograr el fin encargado por su cliente. Bajo esta luz, la independencia significa entonces, un espacio vedado a terceros donde la persona profesional del derecho decide libre de cualquier presión, cómo llevar a cabo su trabajo. Esta independencia protege su labor intelectual y el desarrollo de sus tareas materiales de interferencias del propio cliente, del juez, de superiores jerárquicos, de otros abogados o de barras de abogados o colegios de profesionistas. Esta independencia se materializa en la libertad que tendría el o la abogada para determinar, entre otras cosas, las pruebas a aportar, los testigos a interrogar, las preguntas a formular y los argumentos que se esgrimirán. Se supone que esta independencia es necesaria por el desconocimiento que tendría el cliente sobre los medios y técnica jurídica para alcanzar sus objetivos, y también porque personas externas a la relación abogado-cliente que no deberían conocer el caso, dada la confidencialidad y confianza que rige la relación abogado-cliente, no tendrían la información necesaria ni la autorización del cliente, para determinar cómo llevar a cabo la representación jurídica de sus intereses.

Para Robert Gordon (1988) es comprensible que la profesión jurídica persiga afanosa e insistentemente estos dos tipos de independencias. Tanto la independencia regulatoria como la independencia frente a las condiciones de trabajo otorgan a la profesión jurídica prerrogativas que les reportan beneficios significativos: tienen un monopolio en la prestación de servicios jurídicos que garantiza la protección de su mercado frente a competidores externos y, además, la misma profesión jurídica determina de manera exclusiva la manera en que debe evaluarse la prestación de sus servicios. Leído de esta forma, es decir, pensando exclusivamente en los beneficios que estas independencias reportan a los profesionales del derecho, la búsqueda de ellas puede verse con suspicacia pues dan demasiado poder a la profesión y la dejan exenta de supervisión externa. Atendiendo a esto, estas independencias también se justifican de cara a los intereses de los clientes sosteniendo que sin ellas se puede poner en riesgo, no sólo la prestación de servicios técnicos y expertos a los clientes, también el ambiente de confianza y confidencialidad que, se argumenta, es necesario para una adecuada representación de los intereses del cliente.

Esta obra está bajo una Licencia Creative Commons

Atribución-NoComercial-SinDerivar 4.0 Internacional, IIJ-UNAM.

Boletín Mexicano de Derecho Comparado, núm. 160, enero-abril de 2021, pp. 3-33. 
La tercera noción de independencia, la que desarrolla a fondo Robert Gordon (1988), es la independencia política de las abogadas y los abogados. Para él, esta independencia se caracteriza por los beneficios que reportaría, no sólo a abogados y clientes, sino en términos sociales y políticos a la sociedad en general. Para explicar lo que él entiende por independencia política, hace una descripción de dos visiones de la abogacía que permiten acercarse con mayor precisión a su definición de independencia política. La práctica de la abogacía puede verse desde dos visiones: una liberal que considera que la principal amenaza a la independencia de las y los abogados viene del Estado, y una visión pública que considera a los clientes como principal amenaza para la asesoría jurídica independiente.

En la visión liberal, se considera que la defensa de los derechos individuales de las personas, principalmente cuando es el Estado el que amenaza con vulnerarlos, requiere que las abogadas y los abogados puedan defender los derechos de sus clientes exentos de cualquier presión o control por parte del Estado. Como acertadamente indica Robert Gordon (1988), este argumento llevado al extremo carece de sentido. Cualquier persona que crea decididamente en la importancia de una defensa libre de controles y presiones del Estado, aceptará en algún punto, que el ejercicio de esa defensa debe hacerse dentro de un marco regulatorio y siguiendo determinadas reglas de la ética profesional. Por ende, la discusión no es una de libertad $v s$. regulación, sino sobre la forma y contenido de la regulación, porque esta es siempre necesaria.

Los partidarios de la visión liberal sugieren que la regulación debería permitir a quienes ejercen la abogacía (sobre todo a los abogados defensores en materia penal) un amplio margen de discreción para determinar por sí mismos qué tanto deben colaborar con la administración de justicia (Robert Gordon, 1988). Esta visión supone que la mejor manera de proteger los derechos de todas las personas es por medio de una defensa parcializada de sus derechos donde el abogado de cada parte explota los errores del contrario, los vacíos y contradicciones de la ley y la interpreta de la forma que más beneficie a su cliente. La parcialidad de cada abogado, sumado al rol del juez que funge como garante del debido proceso e igualdad de armas garantiza, aparentemente, el resultado más justo. Para que esta visión pueda materializarse la injerencia del Estado sobre la labor de los abogados y las abogadas debe ser mínima. Las reglas que guían el actuar profesional deberían limitarse a prohibir las tácticas o actuaciones abier- 
tamente ilegales como los sobornos, fabricación o destrucción de pruebas. De ahí en adelante, cualquier regulación adicional como, por ejemplo, una que contemple determinada obligación de compartir con el juez o la contraparte información relevante para el caso, sería vista como una injerencia sospechosa sobre la independencia requerida para el ejercicio profesional.

Del otro lado, la visión pública de la profesión considera que, dado que los abogados no son sólo representantes de sus clientes, sino también representantes del derecho ante sus clientes, la regulación que se les aplica debería asignarles obligaciones para colaborar en la administración de justicia y consolidación del Estado de derecho. Llevada a su extremo, esta visión también pierde poder prescriptivo pues cualquier abogado, por más leal que sea a su cliente, sabe que debe respetar y seguir determinadas normas que limitan lo que puede hacer por su cliente. De nuevo, la discusión no es sobre regulación vs. libertad, sino sobre cuál debe ser el contenido y forma de esa regulación, y cuál debe ser la actitud que los abogados y las abogadas adopten frente a esta regulación, si deben tomarla en serio y tener claro sus límites, o si es una regulación a la que podrían buscarle vacíos y contradicciones a ser explotadas para beneficio de su cliente.

Para la visión pública, la regulación del ejercicio profesional debería ir más allá de regular lo básico (prohibir sobornos, fabricación o destrucción de pruebas, etcétera) y debería regular de manera más concreta las tácticas y estrategias de quienes ejercen la abogacía: establecer la información que estarían obligados a revelar a la contraparte y al juez aun cuando ésta pueda perjudicar a su cliente, establecer límites claros a la forma en que se pueden interpretar las normas, delimitar claramente las demandas o recursos judiciales frívolos, etcétera. Esta regulación limitaría entonces lo que puede hacer un abogado por su cliente. Al estar obligado por la ley a comportarse de determinada manera en la defensa de los intereses de su cliente, el abogado estaría justificado en moderar la parcialidad e intensidad que exhibe en la defensa de su cliente, no por falta de interés o por convicciones personales, sino por respeto a la ley.

Tanto los abogados y las abogadas que simpatizan con la visión pública como los que simpatizan con la visión liberal, encuentran un punto de encuentro sobre la necesidad de mantener cierta independencia frente a sus clientes. Este punto de encuentro yace en la práctica y en el ejercicio

Boletín Mexicano de Derecho Comparado, núm. 160, enero-abril de 2021, pp. 3-33. 
cotidiano del derecho y se materializa en deberes, consejos o máximas del tipo: no desarrollar lazos emocionales con el cliente, no creer absolutamente todo lo que el cliente dice, etcétera (Robert Gordon, 1988). Esta independencia frente al cliente parece ser aceptada y poco problemática. Sin embargo, la idea de independencia que Robert Gordon quiere empujar es aquella que, en su opinión, está cristalizada en el numeral E de la Regla 3.4 del Model Rules of Professional Conduct de la American Bar Association (2020). La traducción al español del título de esta regla podría ser "Lealtad con la contraparte y su abogado". El numeral E dice lo siguiente:

Durante un juicio un abogado no debe aludir a cualquier asunto que el abogado no crea razonablemente que sea relevante o que no esté respaldado por evidencia admisible, afirmar el conocimiento personal de los hechos en cuestión, excepto cuando testifique como testigo, o expresar una opinión personal sobre la justicia de una causa, la credibilidad de un testigo, la responsabilidad de un litigante civil o la culpa o inocencia de un acusado. (Cursiva fuera del texto original)

A Robert Gordon (1988) le interesa de manera específica la obligación que tienen las abogadas y los abogados de abstenerse de expresar su opinión sobre la justicia de una causa, la credibilidad de un testigo o la responsabilidad de un litigante o inocencia de un acusado. Esta regla tiene un propósito evidente y es preservar la efectividad y credibilidad de los abogados y las abogadas como defensores de distintos clientes y distintas causas. Se supone que, para garantizar adecuadamente el acceso a la justicia y la representación y defensa de los derechos de todas las personas, las y los abogados no deben identificarse en exceso con sus clientes y causas. Se aconseja una cierta separación entre la causa, cliente y abogado. Si un abogado se identifica de manera muy estrecha con un determinado grupo de clientes o causas, esto puede mermar su capacidad para defender en un futuro a personas que podrían ser contrapartes de sus clientes.

Por ejemplo, un abogado laboralista dedicado la defensa judicial de un empleador, que manifieste como opinión personal (no como alegato jurídico o en su rol de abogado litigante) que su cliente siempre ha tenido la razón y que es víctima de ataques injustificados y falsos por parte de los empleados que lo demandan, comprometería su capacidad para 
defender de manera efectiva, en un futuro, los derechos de empleados no sólo de quien fue su cliente (el empleador), sino de otro tipo de empleados en general. Esto ocurriría porque su opinión sugeriría no sólo que prestaba sus servicios técnicos y jurídicos, sino que, además, tenía una convicción íntima y personal en la justicia de la causa de su cliente, y posiblemente (dependiendo del caso), de la causa de los empleadores como gremio. La expresión de esta convicción personal menoscabaría la prestación futura de servicios profesionales.

Lo que esta regla sugiere es que, si bien las capacidades técnicas y profesionales de los abogados y abogadas están a la venta, sus convicciones políticas y personales no lo están y no lo deberían estar (Robert Gordon, 1988). Los servicios de representación que compra el cliente se restringen al campo jurídico y su representación técnica. Las convicciones personales del abogado deben quedar a salvo de la comercialización a efectos de poder ser empleadas de manera adecuada, no sólo para otros clientes futuros, sino en la vida pública. Por ejemplo, cuando una reconocida abogada o abogado dedicada al derecho corporativo se identifica en exceso con su cliente y defiende sus intereses con ahínco no sólo por medio de su representación jurídica, sino también en la cotidianidad mediante pronunciamientos de índole personal, se corre el riesgo de que las convicciones personales de esa abogada o abogado sean devoradas por su rol profesional. De esta forma, por ejemplo, el o la abogada hipotética a la que hacemos referencia podría verse impedida de participar u opinar sobre asuntos regulatorios que tengan que ver con la línea de negocios de su cliente. Dicho impedimento no se limitaría a un plano legal como cuando se configura una inhabilidad o un conflicto de interés, sino que incluso podría implicar la pérdida de agencia de la o el abogado, la anulación de su "persona pública", su falta de interés en participar en la vida pública de la sociedad, o al menos, la suspicacia de que en realidad no habla basada en sus convicciones personales y su conocimiento técnico, sino en intereses económicos.

Robert Gordon (1988) alude a la independencia política de las y los abogados como la salvaguarda de esa esfera íntima y personal, a pesar de un ejercicio profesional que implica necesariamente la representación de intereses de terceros. Resulta vital que la vida profesional no impida o limite sobremanera su participación en la vida pública. La preocupación por la participación de los y las abogadas en la vida pública, como bien

Esta obra está bajo una Licencia Creative Commons

Atribución-NoComercial-SinDerivar 4.0 Internacional, IIJ-UNAM.

Boletín Mexicano de Derecho Comparado, núm. 160, enero-abril de 2021, pp. 3-33. 
señala Robert Gordon, es herencia del movimiento federalista y las ideas de Tocqueville. La fe en los abogados y abogadas como una élite burguesa, racional y capaz de frenar los impulsos contradictorios de sectores dispares de la sociedad era una impronta del pensamiento de las abogadas y abogados federalistas. ${ }^{9}$ Traer dichos ideales a la práctica contemporánea del derecho resulta difícil por los cambios sociales ocurridos no sólo en la sociedad en general, sino también en la composición de la profesión jurídica. Además, el proyecto de concebir a las y los abogados como una élite ilustrada y con unas habilidades superiores al resto de los ciudadanos para participar de manera más intensa en la vida pública resulta antidemocrática. No obstante, tampoco es menos cierto que por la formación que reciben, por los trabajos que realizan y por las posiciones de poder y relevancia en el ámbito social, económico y político, aun hoy los y las abogadas siguen siendo actores sumamente relevantes no sólo para defender los intereses de sus clientes sino para dar respuesta a las necesidades y problemáticas sociales dejando a un lado las facciones e intereses comúnmente representados y defendidos en su trabajo jurídico.

Como demuestra esta descripción muy corta del artículo de Robert Gordon (al cual no hacemos justicia pues es mucho más rico de lo que acá podemos demostrar), es evidente que usar la palabra "independencia" de manera genérica no permite tener claridad conceptual sobre el fenómeno específico al cual nos queremos referir. Tener esta claridad y definir de manera clara, qué tipo de independencia es la que se busca promover facilitará el diseño de estrategias para alcanzarla, así como el análisis crítico. Este último punto, el del análisis crítico, es sumamente importante pues el lector cuidadoso y suspicaz, ya se habrá percatado, no sólo de las virtudes que pueden subyacer detrás de los tres conceptos de independencia, sino también de las críticas que pueden hacérsele a ellas. Creemos que esta distinción, que invita a hacer Robert Gordon, es urgente en el debate de la colegiación y profesionalización en México.

\section{3. ¿Cuál es el mejor mecanismo para regular a los y las abogadas?}

Por lo general, las iniciativas y discusiones respecto a la regulación del ejercicio profesional de la abogacía asumen que la única (o si no la me-

9 Esta visión es respaldada por Anthony Kronman (2000).

Esta obra está bajo una Licencia Creative Commons Atribución-NoComercial-SinDerivar 4.0 Internacional, IIJ-UNAM. Boletín Mexicano de Derecho Comparado, núm. 160, enero-abril de 2021, pp. 3-33. 
jor) forma de regular a los y las abogadas es mediante el establecimiento de un cuerpo de profesionales del derecho (en el caso mexicano, los colegios de abogados) que con base en su conocimiento interno de la profesión y unas reglas (código de ética) investigan a los colegiados con base en quejas formuladas por clientes, otros abogados y abogadas o, en algunos casos, terceros interesados.

Este lugar común es cuestionado por David Wilkins (1992), quien escribe desde un contexto donde, por el contrario, existen múltiples mecanismos de control al ejercicio profesional del derecho. El objetivo de David Wilkins es demostrar la importancia que tiene el contexto particular en el que los abogados y abogadas se desempeñan a fin de poder evaluar cuál de esos distintos mecanismos de regulación garantiza de mejor forma los dos elementos que toda regulación del ejercicio profesional de la abogacía persigue: independencia profesional (frente al Estado y frente al cliente) y cumplimiento de las normas que la regulan.

Si bien el contexto histórico en el que David Wilkins escribió su artículo pudo tener el efecto de identificar las virtudes y limitaciones de cada uno de los distintos mecanismos de control existentes, traer sus ideas al contexto mexicano puede resultar útil para expandir la imaginación y, con base en experiencias de otras latitudes, ver qué problemas resuelve de manera adecuada y eficiente la colegiación obligatoria, y qué problemas deja sin resolver, los cuáles nos obligarían a pensar en otra serie de mecanismos concurrentes que garanticen la prestación adecuada de servicios jurídicos en todos los contextos y para todo tipo de usuarios e interesados.

David Wilkins (1992) identifica cuatro mecanismos de control al ejercicio profesional en el contexto en el que él escribe:

1. Controles disciplinarios. Este control se ejerce por las cortes federales de cada Estado con base en las reglas de responsabilidad y ética profesional adoptadas también por cada corte federal. Comúnmente, las reglas adoptadas por cada Estado se basan en las reglas modelo sugeridas por la ABA. Aunque con diferencias importantes, este control es el que más se asemeja al que ejercerían los colegios de abogados en México. Este control apunta a disciplinar a las abogadas y abogados mediante la imposición de sanciones que pueden ir desde amonestaciones formales hasta perder la licencia para practicar. Estas sanciones tienen como fin preservar un bien público (una profesión jurídica competente, ética y responsable) por medio de la

Esta obra está bajo una Licencia Creative Commons

Atribución-NoComercial-SinDerivar 4.0 Internacional, IIJ-UNAM.

Boletín Mexicano de Derecho Comparado, núm. 160, enero-abril de 2021, pp. 3-33. 
disuasión y el castigo. Generalmente, estas investigaciones se adelantan con base en quejas que pueden interponer los clientes, otros abogados y abogadas o terceros interesados.

2. Controles de responsabilidad civil. Este control se ejerce mediante demandas de responsabilidad civil por casos de mala praxis. La activación y uso de este control está limitado al cliente que decide demandar a su exabogado (y que cuenta con los recursos económicos, disposición y tiempo para hacerlo). En este caso lo que normalmente se busca es una indemnización por los daños causados.

3. Controles institucionales. Este control es practicado por la institución con la cual el abogado interactúa. Dicho control se puede ejercer en y por distintos foros: por ejemplo, un juez laboral puede sancionar a un abogado que representa a una de las partes por considerar que actúo de mala fe. Asimismo, la agencia encargada de la recaudación de impuestos puede sancionar a un abogado que representa a un ciudadano en una reclamación por estimar que su interpretación de la ley fue un abuso del derecho. Este control tiene como objetivo garantizar el correcto funcionamiento del procedimiento (administrativo o judicial) con el fin de que se garantice una defensa técnica de los derechos de los ciudadanos, pero, dentro de los límites de la ley y sin trastocar o afectar la función social que está llamada a cumplir la entidad ante la cual el abogado ejerce la representación. Este control se ejerce de manera directa por una dependencia interna de la entidad ante la cual está operando el abogado.

4. Controles legislativos. Cualquier otro tipo de órgano o entidad creada por la rama legislativa que tenga como fin ejercer vigilar la conducta de las y los abogados.

El trabajo de David Wilkins (1992) consiste entonces en analizar qué tan bien funciona cada uno de estos cuatro mecanismos a la luz de dos tipos de argumentos: la independencia que logran garantizar a los y las abogadas, y su efectividad para lograr cumplimiento (entendiendo que un alto índice de cumplimiento es deseable siempre y cuando los costos no superen los beneficios que se reporten). ${ }^{10} \mathrm{El}$ punto importante

10 Dentro del concepto general de costos Wilkins (1992) agrega tres tipos: 1) costos administrativos propios de la operación del mecanismo (salarios, oficinas, computadores, etc.,) 2) costos de participación que son en los que incurren las personas directamente implicadas en un proceso (por ejemplo, es plausible que el cliente que quiere poner una queja contra su ex abogado deba pagar a un abogado para hacerlo, por su parte, el abo-

Esta obra está bajo una Licencia Creative Commons Atribución-NoComercial-SinDerivar 4.0 Internacional, IIJ-UNAM. Boletín Mexicano de Derecho Comparado, núm. 160, enero-abril de 2021, pp. 3-33. 
que suma David Wilkins es la importancia del contexto a la hora de hacer dicha evaluación.

Hace ya bastante tiempo la profesión jurídica se diversificó. Esta diversificación se ha dado por cambios en el mercado de los servicios jurídicos. Las y los abogados pasaron de tener como clientes principalmente a personas naturales, a tener como clientes a personas morales. Estos nuevos clientes tienen otras características y requieren otros servicios: no son usuarios ocasionales de servicios jurídicos, sino que por el contrario son usuarios frecuentes, requieren servicios no sólo (o no principalmente) en la representación en pleitos judiciales sino en el desarrollo cotidiano de sus negocios, tienen una chequera más grande y además, por lo general, están más o menos familiarizados con el derecho y la asimetría de conocimiento entre ellos y sus abogados y abogadas es menor que la que existe entre un abogado y una persona natural que no interactúa frecuentemente con el derecho; incluso, dicha asimetría es casi nula porque muchas veces estos clientes contratan otro abogado (abogado in house), que es el encargado de administrar y evaluar el trabajo que prestan abogadas y abogados externos.

Esta diversificación de clientes, necesidades y servicios implica, a su vez, formas de relacionarse distintas entre quienes ejercen la abogacía y los clientes. No es igual, por ejemplo, la relación de una mujer que acude ante un abogado de familia por primera vez para demandar a su expareja por un tema relativo a la custodia de su único hijo; a la de un abogado in house de una multinacional petrolera que analiza un concepto emitido por un despacho de abogados tributaristas sobre el marco regulatorio en materia fiscal para los inversionistas extranjeros en México. David Wilkins (1992) señala que, ante la diversidad de relaciones existentes, es difícil pensar en un único mecanismo de control que logre garantizar independencia y cumplimiento simultáneamente. La diversidad de relaciones entre abogado y cliente implica, en opinión de Wilkins, diversidad de mecanismos de control sensibles y útiles a cada contexto.

Sumado al reto de la complejidad que se desprende de unas relaciones cada vez más diversas, está el reto estructural que yace en la figura

gado necesitará también un abogado que lo defienda) 3) costos sociales que son cualquier otro tipo de costo que deban asumir personas que no están directamente implicadas en el proceso pero que se pueden ver afectadas por lo que se decida en él.

Esta obra está bajo una Licencia Creative Commons

Atribución-NoComercial-SinDerivar 4.0 Internacional, IIJ-UNAM.

Boletín Mexicano de Derecho Comparado, núm. 160, enero-abril de 2021, pp. 3-33. 
del abogado: el de defender los intereses de su cliente mientras que al mismo tiempo colabora con la administración de justicia; es decir, el reto (en algunos casos más agudo que en otros) de deber lealtad a dos partes que pueden estar enfrentadas. En términos concretos, y ya directamente conectado con el tema de la regulación, este reto se traduce en la dificultad de encontrar un mecanismo de control al ejercicio profesional que prevenga y sancione faltas que cometa el abogado contra el cliente (problemas de agencia) como puede ser cobrar honorarios exorbitantes, no informar sobre el desarrollo del proceso, olvidar interponer un recurso o interponer un recurso equivocado; como faltas que cometa el abogado contra terceros o la misma administración de justicia (externalidades) como puede ser por ejemplo interponer una demanda frívola, hacer una interpretación de la norma que no sea acorde a sus fines, aportar una prueba falsa, etcétera (figura 1).

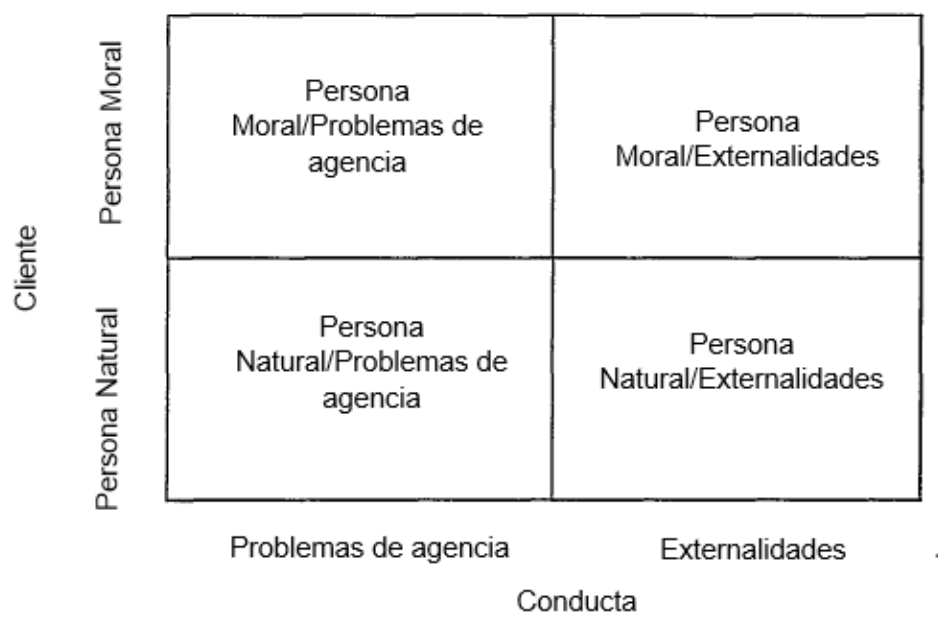

FIGURA 1. Matriz con las posibles interacciones abogado-cliente (David Wilkins, 1992, p. 818).

Si bien no es nuestro propósito reproducir acá la totalidad de argumentos desarrollados por Wilkins en su obra, para sostener su tesis de que no hay un mecanismo de control que pueda garantizar por sí solo la independencia y cumplimiento de las disposiciones. Señalaremos muy bre- 
vemente algunos de los ejemplos que utilizó para mostrar la insuficiencia de los mecanismos frente a distintas situaciones.

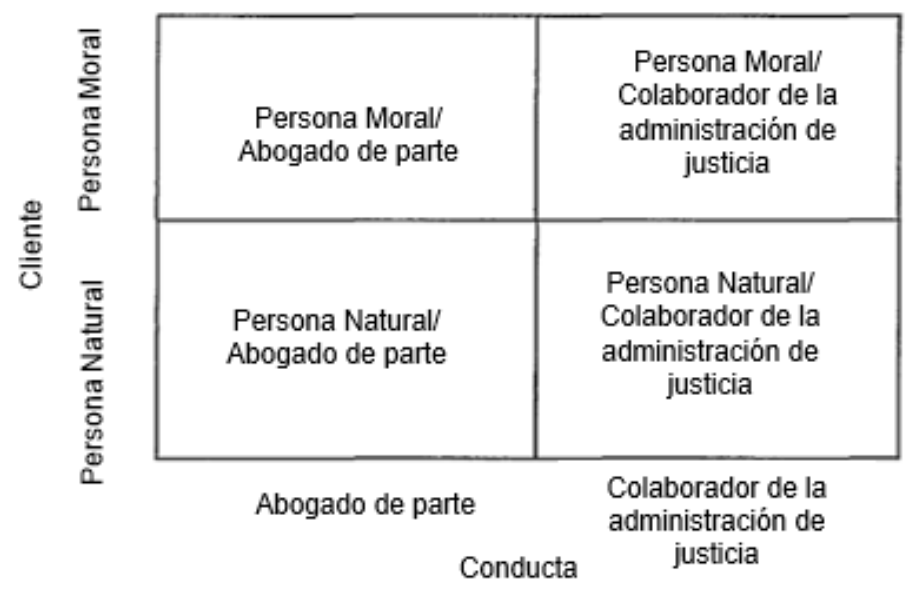

FiguRA 2. Representación gráfica (David Wilkins, 1992, p. 820).

En la figura 2, en los dos cuadrantes de la derecha se contemplan las situaciones en las que los y las abogadas pueden estar cometiendo una conducta que genera una externalidad, es decir, una afectación a terceros o a la administración de justicia (falsificar pruebas, esconder información, etcétera). Frente a estos dos cuadrantes los controles disciplinarios (aquellos que son activados principalmente por los clientes como las quejas ante los colegios de abogadas y abogados) pueden ser inútiles pues, bajo una visión instrumentalista pero en todo caso cándida, es poco probable que los clientes tengan un incentivo para denunciar una conducta de su abogado que en últimas tiene como objetivo beneficiarlos. ${ }^{11}$ Es decir, los controles disciplinarios fallan al no garantizar la independencia del abogado respecto de su cliente. Por el contrario, los controles institucionales (aquellos activados por los foros en los cuales las y los abogados están ejerciendo su trabajo) pueden ser sumamente útiles para detectar

$11 \mathrm{Al}$ menos en el corto plazo pues al largo plazo se corre el riesgo de comprometer incluso la responsabilidad jurídica del representado y también afectar su reputación.

Esta obra está bajo una Licencia Creative Commons

Atribución-NoComercial-SinDerivar 4.0 Internacional, IIJ-UNAM.

Boletín Mexicano de Derecho Comparado, núm. 160, enero-abril de 2021, pp. 3-33. 
y sancionar conductas de este tipo y garantizar la independencia del abogado frente al cliente. ${ }^{12}$

Retornando a la figura 2, pero ahora en los dos cuadrantes de la izquierda, estos se enfocan en las actuaciones que pueden implicar una falla de agencia, es decir, actuar en contra de los intereses del cliente (cobrar honorarios exorbitantes, no mantenerlo informado, emplear una estrategia jurídica manifiestamente equivocada, etcétera). En estos casos pareciera entonces que es donde los controles disciplinarios (las quejas de parte de los clientes ante los colegios de abogados) serían más efectivos pues claramente todo cliente quisiera que se sancionará al abogado que ha actuado en contra de sus intereses. No obstante, David Wilkins (1992) argumenta que ese raciocinio tiene dos problemas.

En el cuadrante superior izquierdo, es decir, problemas de agencia cuando el cliente es una persona moral (pensemos el caso de una multinacional), los estudios empíricos de la sociología jurídica demuestran que los clientes pocas veces hacen uso de los controles disciplinarios; esto es, se abstienen de interponer una queja formal contra sus abogados. Esto ocurre principalmente porque la sanción más efectiva es el no volver a contratar sus servicios. Es una forma de autorregulación del mercado: a los malos prestadores del servicio, no se les contrata de nuevo. La decisión de no contratar de nuevo por lo general se disemina prontamente en el mercado. Esa información es valorada por otros potenciales clientes que, posiblemente, decidirán también no contratar a ese abogado en el futuro. Además de ser una sanción efectiva, también es una sanción que les ahorra costos pues no tienen que acudir ante el mecanismo disciplinario (supongamos el colegio de abogados) y gastar tiempo y recursos en la búsqueda de una sanción. En este sentido, para David Wilkins, los supuestos

12 No obstante, también puede hacerse el contraargumento de que los controles institucionales pueden llegar a afectar la independencia del abogado respecto del Estado pues unos controles demasiado estrictos pueden hacer que los y las abogadas sientan temor de litigar y defender enérgicamente los intereses de sus clientes. El mismo David Wilkins (1992) hace este contraargumento pero, con base en la experiencia propia y el desarrollo de algunos casos y situaciones en el contexto norteamericano argumenta que cuando los controles institucionales han impuesto sanciones a abogadas y abogados esto no ha implicado una merma en la defensa de sus clientes, es decir que sería exagerado argumentar que darle determinado poder al Estado para sancionar a quienes ejercen la abogacía implica inevitablemente afectar su independencia y por ende los derechos de los ciudadanos. 
beneficios que reportaría un control disciplinario en ese cuadrante son superados por los costos de su operación (1992).

El cuadrante izquierdo, donde se presenta un problema de agencia con una persona natural, es posible que se piense que en este caso sí se hará uso del control disciplinario. No obstante, David Wilkins (1992) cree que tampoco en estas situaciones se da ese caso. Hay dos razones para ello: la primera es que en los mecanismos disciplinarios no hay un incentivo material, es decir, el cliente que presenta una queja contra su exabogado no obtendrá ninguna indemnización por el daño causado por su exabogado; a lo sumo obtendrá la satisfacción moral de lograr una sanción contra la persona que lo defraudó. La segunda, y más importante, es que es muy posible que al cliente individual que interactúa por primera vez (o supongamos por segunda vez) con un abogado le será muy difícil percatarse de cuándo ha sido afectado por una conducta irresponsable de su abogado. Dada la asimetría de información que existe entre él (supongamos un obrero que contrata un abogado para demandar a su empleador, o un ingeniero que demanda a la empresa que se apoderó injustamente de un invento suyo) y el abogado respecto del conocimiento jurídico, va a ser muy difícil que pueda detectar el momento y la acción precisa en la que su abogado le falló.

En conclusión, como bien señala David Wilkins (1992):

(...) none of the four enforcement systems will efficiently control lawyer misconduct falling within each quadrant of the matrix. Disciplinary controls are unlikely to deter externality problems by either individual or corporate lawyers. Liability controls will fail to prevent misconduct that does not produce probable damages that outweigh transaction costs. Institutional controls generally ignore- and perhaps for individual clients even exacerbate - agency problems. Legislative controls will either replicate the problems of disciplinary enforcement - if they rely on complaints from injured parties - or dramatically increase enforcement costs - if the institute an active program of monitoring and independent investigation.

El punto de David Wilkins (1992), compartido por nosotros, no es renunciar o demostrar la imposibilidad de regular la conducta de los abogados. Su punto es reconocer que existen: distintos tipos de conductas que se quieren controlar (problemas de agencia y problemas de externalidades), que cualquier mecanismo de control que se quiera implementar

Esta obra está bajo una Licencia Creative Commons

Atribución-NoComercial-SinDerivar 4.0 Internacional, IIJ-UNAM.

Boletín Mexicano de Derecho Comparado, núm. 160, enero-abril de 2021, pp. 3-33. 
tiene unos costos para el Estado, los usuarios y los propios abogados, y que existen distintos tipos de clientes (corporativos/personas naturales, clientes con más poder/clientes con menos poder) y por ende distintos tipos de relaciones entre abogados y clientes. Al observar todos estos factores, como lo hace Wilkins con mucho esfuerzo y paciencia, es posible apreciar las falencias y virtudes que tiene cada mecanismo de control, para cada cuadrante de la matriz. Esto debe entenderse entonces no como una crítica demoledora, sino como una invitación a ver la complejidad del problema, atender a los intereses y necesidades de las personas implicadas en él, y pensar creativamente en diversos modelos de regulación que permitan alcanzar los proteger los intereses en juego sin incurrir en costos excesivos e innecesarios.

\section{GONCLUSIONES}

Como hemos reiterado a lo largo del texto, compartimos la preocupación por establecer mecanismos de regulación al ejercicio del derecho. Los abogados particulares desempeñan un papel fundamental en la consolidación del Estado de derecho. Desafortunadamente, la pregunta por cómo deberían comportarse los abogados (es decir, la pregunta por la ética profesional) y cómo garantizamos que se comporten de esa manera (es decir, la pregunta por los mecanismos institucionales encargados de operativizar los mandatos de la ética profesional) han sido poco explorados no sólo en México sino en general en Latinoamérica. Tal vez nuestras comunidades jurídicas sigan depositando aún mucha fe en las reformas a las normas e instituciones perdiendo de vista que al final esas normas serán interpretadas y operadas por los abogados.

No obstante, consideramos que el proyecto de regular a la profesión jurídica es más complejo de lo que comúnmente se asume. Los trabajos de Richard Abel (1981), Robert Gordon (1988) y David Wilkins (1992) lo demuestran. Pasar por encima de los retos y advertencias que ellos hacen de manera rigurosa, pueden debilitar el proyecto de la regulación y hacer que, así como Richard Abel ve con mucha suspicacia el proyecto de regulación en los EE. UU., el mismo proyecto empiece a tener fuertes detractores en México, y con suficiente razón. Aunque causa preocupación el hecho de que México no cuente actualmente con una regulación efec- 
tiva al ejercicio de la profesión, esa carencia de regulación puede ser vista como una gran oportunidad pues no hay tabús. No hay ideas o propuestas que no se puedan hacer y no hay intereses instalados que sean dificiles de combatir. Tenemos el campo abierto y dispuesto ante nosotros. Por ahora, creemos, es necesario tratar de aprender de los debates y discusiones que han ocurrido en otras latitudes y a partir de ellas nutrir nuestras discusiones internas (que sin duda cada vez serán menos localistas y tendrán que dar cabida a las voces de actores internacionales si nos tomamos en serio la globalización del derecho y las prácticas jurídicas transnacionales). Este escrito no busca entonces ser un aporte original ni novedoso, sino simplemente un ejercicio que nos invite a mirar hacia otros lugares.

\section{BIBLIOGRAFÍA}

ABEL, Richard (1981). Why Does the ABA Promulgate Ethical Rules? Texas Law Review (59), pp. 639-688.

American Bar Association. Fairness to Opposing Party and Counsel. Text of the Model Rules of Professional Conduct, https://www.ame ricanbar.org/groups/professional_responsibility/publications/mo del_rules_of_professional_conduct/model_rules_of_professional_con duct_table_of_contents/

ANZOLA RODRÍGUEZ, Sergio (2019). El malestar en la profesión jurídica: tensiones entre la ética personal y profesional de los abogados. Universidad de los Andes.

Auberbach, Jerold (1976). Unequal Justice. Oxford University Press.

Centro de Estudios sobre la Enseñanza y el Aprendizaje del Derecho (2019). Las escuelas de derecho en México. Ciclo académico 2019-2020. Informe Anual 2019. http://wrwre.ceead.org.mx/assets/informe_2019.pdf

Clavijo Cáceres, Darwin (2015). El enfoque de competencias en la formación del abogado para el siglo XXI. fusticia. (27), pp. 185-212.

Código Civil Federal, 2020.

Código Penal Federal, 2020.

Constitución Política de los Estados Unidos Mexicanos, 2020.

CRUz BARney, Oscar (2020). El ejercicio de la abogacía en México, una propuesta de reordenación: el proyecto de ley general para el ejercicio de la abogacía. UNAM, Instituto de Investigaciones Jurídicas.

Esta obra está bajo una Licencia Creative Commons

Atribución-NoComercial-SinDerivar 4.0 Internacional, IIJ-UNAM.

Boletín Mexicano de Derecho Comparado, núm. 160, enero-abril de 2021, pp. 3-33. 
APORTES A LA DISGUSIÓN SOBRE LA REGULAGIÓN...

Cruz Barney, Oscar (2015). Defensa a la defensa y abogacia en México. UNAM, Instituto de Investigaciones Jurídicas-Ilustre y Nacional Colegio de Abogados de México. https://archivos.juridicas.unam.mx/wrew/bjo/ libros/8/3878/14.pdf

Gruz Barney, Oscar, Ibáñez Mariel, F. y Lozano Díaz, J. A. (2013). Lineamientos para un Código Deontológico de la Abogacía Mexicana. UNAM, Instituto de Investigaciones Jurídicas.

GruZ BARney, Oscar (2013). La colegiación como garantía de independencia de la profesión jurídica: la colegiación obligatoria de la abogacía en México. Cuestiones Constitucionales. Revista Mexicana de Derecho Constitucional (28), pp. 75-101. http://wrww.scielo.org.mx/pdf/cconst/n28/n28a3. $p d f$

GORDON, Robert (1988). The Independence of Lawyers. Yale Law School Legal Scholarship Repository (2), pp. 1-83.

Instituto Nacional de Estadística y Geografía (2017). Encuesta sobre la Percepción Pública de la Ciencia y la Tecnología (ENPEGYT). https://wwre.inegi. org.mx/programas/enpecyt/2017/default.html\#Documentacion

KRONMAN, Anthony (2000). The list lawyer: failing ideals of the legal profession. Belknap Press of Harvard University Press.

Ley Reglamentaria del Artículo 5o. Constitucional, Relativo al Ejercicio de las Profesiones en la Ciudad de México.

LARSON, Magali Sarfatti (1977). The rise of professionalism: a sociological analysis. University of California Press. Naciones Unidas (2011). Informe de la Relatora Especial sobre la independencia de los magistrados y abogados. Adición Misión a México (A/HRC/17/30/Add.3). http://wrere. acnur.org/t3/fileadmin/Documentos/BDL/2015/10052.pdf?view $=1$

RHODE, Deborah (1990). The Delivery of Legal Services by Non-Lawyers. Georgetown Fournal of Legal Ethics (2), pp. 209-234.

Rozas BRAVO, Juan Manuel (2013). El alcance del derecho de defensa y la libertad de expresión de los abogados en el debate forense en España. Juriste International (4), pp. 56-60. https://issuu.com/unionintavocats/ docs/juriste_international_2013_4

Simon, William (1988). The Practice of Justice: ATtheory of Lawyer's Ethics. Harvard University Press.

WiLKInS, David (1992). Who Should Regulate Lawyers. Harvard Law Review (4), pp. 801-887. 


\title{
LA SEGURIDAD JURÍDICA EN LA LEY TRIBUTARIA COLOMBIANA*
}

\author{
LEGAL SECURITY IN THE COLOMBIAN TAX LAW
}

\section{Lucía del Carmen Bolaños BolaÑos**}

RESUMEN: El presente artículo busca evidenciar la problemática actual del sistema tributario colombiano en perspectiva de la seguridad jurídica y la ley tributaria; para ello se parte del principio de justicia como una orientación natural del derecho tributario, los principios que enmarcan la legalidad y la seguridad jurídica para la configuración de la ley tributaria, analizando la jurisprudencia para finalizar con la exposición del caso colombiano su excesiva producción normativa, las reformas tributarias constantes y la disparidad a efectos tributarios generada por el marco de regulación contable vigente, dejando en evidencia la ardua tarea que debe emprender el país para corregir estos defectos jurídicos y lograr un sistema jurídico tributario más equitativo y justo.

Palabras clave: seguridad jurídica, justicia, legalidad, regulación contable.
ABSTRACT: This article seeks to highlight the current problems of the Colombian tax system in perspective of legal security and tax law; for this the principle of justice is based as a natural orientation of the Tax Law, the principles that frame the legality and the legal security for the configuration of the tax law, analyzing the jurisprudence to end with the presentation of the Colombian case, its excessive normative production, the constant tax reforms and the disparity for tax effects generated by the current accounting regulation framework, highlighting the arduous task that the country must undertake to correct these legal defects and achieve a more equitable and fair tax legal system.

Keywords: legal certainty, justice, legality, accounting regulation.

* Recibido el 28 de mayo de 2020; aprobado el 18 de enero de 2021.

** ORCID: 0000-0003-1454-4554. Profesora investigadora de la Universidad Libre de Cali; doctora en Derecho por la Universidad Autónoma de Chile; miembro del grupo de investigación de sistemas penitenciarios y carcelarios. Correos electrónicos: luciad.bola nosb@unilibre.edu.co,lucia.bolanos@uautonoma.cl

Boletín Mexicano de Derecho Comparado, nueva serie, año LIV, núm. 160, enero-abril de 2021, pp. 35-60. 
SUMARIO: I. Introducción. II. La ley tributaria en el Estado social de derecho y la seguridad jurídica. III. La Corte Constitucional y la seguridad jurídica. IV. La seguridad jurídica del sistema tributario colombiano. V. Conclusiones. VI. Bibliografia.

\section{INTRODUCGIÓN}

Como bien lo afirmó el profesor Antonio Enrique Pérez Luño, históricamente la seguridad jurídica ha sido eje e impulsor de la historia jurídica, convirtiéndose en "presupuesto" y "función" indispensable en los ordenamientos jurídicos del Estado de derecho; presupuesto en clave de legalidad positiva propia de los derechos fundamentales, subyacentes del derecho constitucional y, función del derecho, garante de la realización de las libertades (2000, pp. 26-28), consolidándose así, la seguridad jurídica como un valor jurídico ineludible no sólo en el Estado de derecho sino en el Estado social de derecho, en razón del carácter constitucional que le reviste.

Esta seguridad jurídica al ser esencia del Estado social de derecho, tiene alcance a todas las ramas del derecho, y para el caso en análisis del derecho y la ley tributarios. Sin embargo, el sistema jurídico tributario colombiano parece alejarse cada día más de tal anhelo jurídico y se sumerge en la excesiva producción normativa, la complejidad, la inestabilidad y la contrariedad, generando como resultado la inequitativa distribución de la carga tributaria de los contribuyentes.

En este sentido, este artículo busca advertir dicha problemática en el sistema tributario de Colombia y su efecto en la estabilidad, la confianza, la certeza y la justicia misma del sistema; para ello, se parte realizando un análisis de la ley tributaria en el Estado social de derecho, exponiendo algunos planteamientos teóricos y doctrinales, para luego abordar el alcance del concepto desde la perspectiva de la Corte Constitucional, finalizando con el particular caso colombiano y las implicaciones jurídicas que de él se desprenden.

\section{LA LEY TRIBUTARIA EN EL ESTADO SOCIAL DE DERECHO Y LA SEGURIDAD JURÍDICA}

El derecho está connaturalmente orientado hacia lo justo (Karls Larenz, 1985, p. 10), en consecuencia si la Ley es una expresión propia del derecho,

Esta obra está bajo una Licencia Creative Commons

Atribución-NoComercial-SinDerivar 4.0 Internacional, IIJ-UNAM.

Boletín Mexicano de Derecho Comparado, núm. 160, enero-abril de 2021, pp. 35-60. 
deberá albergar justicia, representar justicia e inspirarse en ella; por ende, en cumplimiento de este mandato la generalidad es en esencia el principio inspirador de la ley en el Estado derecho (Gustavo Zagrebelsky, 1995, p. 38), mientras que en el Estado social de derecho la ley se nutre de la desigualdad, en virtud del desarrollo del principio de igualdad diferenciada, lo que rompe con el principio de generalidad y la abstracción normativa.

De este modo, la construcción de leyes en el Estado social de derecho, se recrea en la heterogeneidad de contenido, en razón de los diversos intereses de los grupos sociales y las distintas fuerzas de poder que se entretejen en una amalgama de particularidades sectoriales e individuales, a los que la ley se ha moldeado y trata de dar respuesta en equidad y justicia; en consecuencia, la Ley "no es una garantía absoluta de estabilidad" (Gustavo Zagrebelsky, 1995, p. 29) es más bien, un instrumento de la inseguridad jurídica vía configuración o interpretación en el sentido ampliamente expuesto por los profesores Jorge Streeter, Gustavo Zagrebelsky, Andrés Botero Bernal, Mario Fernando Quinche Ramírez, entre otros; y este parece ser particularmente el caso de la ley tributaria en Colombia.

La ley tributaria para el profesor Jorge Streeter, es una norma específica a la que llama secundaria; en tanto, bajo determinadas circunstancias ordena una conducta o prestación "tributo" de un sujeto pasivo a otro sujeto denominado activo (1968, pp. 7-76), bajo la estricta observancia del principio inglés introducido en la carta magna de 1215 no taxation without representation, exigiendo que no exista tributo sin representación y el principio de legalidad fundado en el aforismo nullum tributum sine lege; en virtud de ambos, debe mediar un acto legislativo en la creación de todo tributo, definiendo claramente sus elementos: i) qué situaciones lo originan "hecho generador"; ii) sobre qué cuantía recaerá el tributo "base imponible", iii) qué porcentual o cuantía será aplicable "tarifa", iv) quién es el sujeto obligado "sujeto pasivo", y a v) quién se le debe "sujeto activo"; elementos que teóricamente concretan los principios de legalidad y seguridad jurídica tributaria, en sentido estricto.

Esta tipología de la ley tributaria y sus condicionantes, es el modelo que ha acogido Colombia instituyéndolo en el artículo 338 de la Constitución Política $(\mathrm{CP})$, reservando en tiempos de paz, la competencia legal para el establecimiento de contribuciones fiscales y parafiscales al Congreso, las asambleas departamentales y los concejos municipales; a la vez que ordena que cualquiera que sea el tipo de contribución, su aplicación 
se hará a partir del periodo que comiencen después de iniciar la vigencia de la ley, la ordenanza o el acuerdo, prohibiendo taxativamente la retroactividad de la norma tributaria en el artículo 363 constitucional.

Así expuesta, la ley tributaria, regula la relación jurídica tributaria originada en virtud de los supuestos de hecho descritos explícitamente en la ley, en razón de ello, lo que debe buscar el intérprete de la norma tributaria ha de ser el significado de la misma dentro de esa específica relación y sus antecedentes, que Jorge Streeter precisa en: i) hecho imponible objetivo y subjetivo, ii) sujetos de la obligación, iii) objeto de la prestación impositiva, iv) modos de extinguir la obligación tributaria, y v) obligaciones formales o accesorias (1968, pp. 12-14). En consecuencia, como bien lo expone el autor, la interpretación de la ley demanda el conocimiento no sólo de la ley tributaria y lo que ella ordena, sino la peculiar relación jurídica que trata de regular, desde su nacimiento hasta su extinción, entiéndase sus elementos y su interrelación.

Pero como se ha expuesto, en el Estado de derecho y más aún en un Estado social de derecho como el colombiano, la realidad es mucho más compleja y desborda la norma; así, el alcance de la norma a los hechos es manifiestamente insuficiente; fenómeno que se presenta no sólo en el derecho tributario, sino en todas las ramas del derecho; situación que teóricamente podría señalarse como la causante de la superproducción normativa, existirán tantas normas como tantas realidades existan.

Desde aquí, para tratar de dar explicación y atribuir la responsabilidad por la inseguridad jurídica, entre disensos y consensos ha transitado la teoría. Algunos, atribuyen la responsabilidad al Congreso y al Ejecutivo, como agentes productores de inseguridad (Mario Fernando Quinche, 2010, p. 122), otros responsabilizan a las cortes de cierre, en tanto les reviste la facultad de hacer y rehacer el derecho vía interpretativa (Javier Tamayo, 2006, p. 396), o cambiando incluso la CP por la aplicación de la doctrina de la sustitución o por la inconstitucionalidad por sustitución (Diego Mauricio Higuera, 2016, p. 215), y otro sector asegura que la misma ley origina la inseguridad, vía lagunas, omisiones, complejidades que entran a ser corregidas por la jurisprudencia y la línea jurisprudencial, en tanto se producen subreglas de derecho que han de servir como reglas de conducta y estándar de crítica a la actividad del administrador de justicia (Diego Eduardo López Medina, 2010, pp. 140 y 141). 
De esta suerte, lo cierto es que la inseguridad no estriba en las complejas relaciones humanas que la norma pretende regular y que sin importar el origen o los responsables, Colombia es un Estado que soporta una especie de superinflación normativa, que acrecienta la inseguridad jurídica del sistema, ocasionándose la ruptura de las fuentes del derecho, los principios de certeza, confianza legítima, buena fe e igualdad; en suma, es una fisuración del principio de seguridad jurídica del derecho, fenómeno que se siente con mayor rigor en materia jurídico tributaria, como se verá más adelante.

Preliminarmente, se coincide con el profesor Mario Fernando Quinche Ramírez, pues se cree que de una parte, es en el órgano legislativo, la ausencia de técnica y método para la elaboración de proyectos de ley (2010, p. 122), su presentación y aprobación con fundamento en razón jurídica social, cultural, política, financiera y económica de manera proporcionada y pertinente, con visión de prospectiva y no cortoplacista, reconociendo el arraigo en lo nacional pero con la mirada erguida en el contexto universal; lo que sin duda lleva a la promulgación de múltiples y variadas leyes de corto alcance en tiempo y en espacio, oscuras, con vacíos normativos y hasta contradictorias; de otra parte, está el órgano ejecutivo, que ante la complejidad de las leyes, hace uso de diversos decretos que tratan de dar alcance a la norma, en algunos casos sin conseguirlo, enrareciendo más el universo jurídico y ocasionando inestabilidad.

Cualquiera que fuera el caso, en Colombia la configuración de leyes está a la orden del día, parece que se padeciera una suerte de "síndrome normativo" (Andrés Botero Bernal, 2010, pp. 13-21), se producen tantas normas y a tal grado, que día a día los códigos son acrecentados por las abultadas adiciones normativas de cada periodo.

Por ejemplo, en materia tributaria desde el 2005 hasta hoy se pueden mencionar algunas de ellas: Ley 863 de 2003 teóricamente orientada a estimular el crecimiento económico y saneamiento de las finanzas públicas; Ley 1111 de 2006 que reformó la renta, el IVA, el impuesto al patrimonio, la renta presuntiva, el impuesto de timbre, el impuesto a las remesas y transformó algunos apartes de procedimiento tributario, ley modificada parcialmente por la Ley 1151 de 2007 por medio de la cual se expidió el Plan Nacional de Desarrollo; la Ley 1370 de 2009 por la cual se modificó el impuesto al patrimonio, Ley 1429 de 2010 focalizada en la formalización y generación de empleo por medio de una serie de estímulos 
tributarios, Ley 1430 de 2010 reforma planteada para el control y la competitividad, Ley 1607 de 2012 reforma completa del sistema tributario; ${ }^{1}$ Ley 1739 de 2014 presentada como un mecanismo de lucha contra la evasión, Ley 1819 de 2016 cuya pretensión se fundamentó en una reforma estructural aunado a combatir la evasión y la elusión; Ley 1943 de 2018 mal llamada ley de financiamiento y de equilibrio presupuestal y, la actual Ley 2010 de 2019 que se denominó Ley de crecimiento económico, empleo, inversión, fortalecimiento de las finanzas públicas, progresividad, equidad y eficiencia del sistema tributario, disposición, que se distanció ampliamente de su tan prominente título, esta mención genérica de algunas normas tributarias deja en evidencia que en Colombia, la única constante en el sistema jurídico tributario, es el cambio.

\section{LA CORTE CONSTITUCIONAL Y LA SEGURIDAD JURÍDICA}

La Corte Constitucional ha identificado en la seguridad jurídica dos dimensiones: i) la dimensión objetiva, cuyo cimiento se encuentra en el artículo 83 de la CP y el principio de buena fe relacionado estrechamente con la confianza legítima; ordenando al administrador de justicia actuaciones con fundamento jurídico, coherentes, estables y consistentes a las circunstancias de cada caso, proscribiendo la contrariedad y protegiendo las expectativas legítimas de las personas sobre las decisiones judiciales su razonabilidad, consistencia y uniformidad (Sentencia C 284/2015), y ii) la dimensión subjetiva, inherente a la certeza que se acuña en la seguridad, relacionada directamente con las esperanzas legítimas de los administrados, que ante casos idénticos se interprete y aplique la ley de forma igual, ${ }^{2}$ son las expectativas de la persona frente sus derechos y obligaciones en razón de sus acciones.

1 Esta ley fue objeto de una serie de decretos reglamentarios, debido a la complejidad normativa y la ausencia de claridad en cuanto al alcance de algunas categorías conceptuales para la determinación de los sujetos obligados, el hecho generador, la base y la tarifa aplicable a cada caso; entre ellos, Decreto: 2763/2012, 2634/2012 0099/2013, 0187/2013, 0568/2013, 862/2013, 1244/2013, 1694/2013, 1793/2013, 1828/2013, 1848/2013,2418/2013, 2701/2013, 3033/2013.

2 La identificación de estas dos dimensiones, la expone de manera general pero clara (Jorge Zavala Egas, 2010, p. 220).

Esta obra está bajo una Licencia Creative Commons

Atribución-NoComercial-SinDerivar 4.0 Internacional, IIJ-UNAM.

Boletín Mexicano de Derecho Comparado, núm. 160, enero-abril de 2021, pp. 35-60. 
En este sentido, en reciente jurisprudencia la Corte Constitucional recordó que la seguridad jurídica es una condición necesaria para la materialización de un orden justo y la concreción de los derechos y libertades de los ciudadanos; pues su cumplimiento representa una garantía para identificar aquello que es ordenado, prohibido y permitido en el ordenamiento jurídico (Sentencia SU-072/2018); por ende, la seguridad jurídica es un sustrato de la justicia y la igualdad, que exige que en un Estado social de derecho la seguridad jurídica vaya más allá de la estabilidad de la ley en el territorio y en el tiempo; pues la estabilidad en sí misma, debe obrar como una garantía jurídica en la interpretación y aplicación de la ley para los administrados (Sentencia SU-337/2017).

De este modo, en virtud del principio de seguridad jurídica, objetivamente es un mandato constitucional, legal e institucional que conmina al administrador de justicia que ante la identidad de circunstancias fácticas, determine las leyes aplicables, las interprete y reconozca los mismos derechos y obligaciones, y subjetivamente es una garantía para que el sujeto de derechos acuñe expectativas ciertas, sobre las consecuencias jurídicas que han de tener sus actuaciones en el ordenamiento jurídico al que él se encuentra obligado.

De otra parte, la Corte Constitucional también señaló los instrumentos para la preservación de la seguridad jurídica: i) la CP, al ordenar mediante el artículo 230 el sometimiento de los jueces al imperio de la ley, ii) la ley, con alcance a los criterios de interpretación y aplicación de la ley, iii) la unificación de jurisprudencia, por medio de la cual se precisa con autoridad y vocación de generalidad el significado y alcance de las diferentes áreas del ordenamiento jurídico, $i v)$ la doctrina y el precedente judicial vinculante, la primera como simple criterio orientador y la segunda como criterio vinculante, garante de la estabilidad de las decisiones y reglas judiciales establecidas con autoridad, v) el Código de Procedimiento Administrativo y Contencioso Administrativo (CPACA), y en concreto los artículos 10 y 102 orientados a asegurar la eficacia de la jurisprudencia unificada y aplicada por extensión (Sentencia C-284/2015).

En este sentido la Corte Constitucional hacia febrero de 2015, ya se había pronunciado reiterando la línea anterior y unificando la jurisprudencia, al analizar la procedencia del control judicial vía tutela sobre providencias que vulneraran los derechos fundamentales. La Corporación en su examen, recordó el carácter ineludible de la unificación de jurispru- 
dencia, como una herramienta para hacer frente a la disparidad semántica de las normas y reglas jurídicas, dada la ambigüedad del lenguaje y vacíos que dan lugar a múltiples interpretaciones o significados (Sentencia C-053/2015); por lo cual, la unificación de jurisprudencia permitía la determinación de reglas y subreglas de derecho de obligatoria observancia para el operador judicial, para casos en los cuales se presente la similitud de las circunstancias fácticas y tengan cabida la aplicación de las mismas normas de derecho.

De este modo la Corte Constitucional dio alcance a la providencia de 2011, que ordenó la unificación y extensión de la jurisprudencia en las actuaciones judiciales y administrativas, en virtud del derecho de igualdad ordenado en el artículo 13 constitucional y la efectiva protección y mismo trato de los administrados, a fin de garantizar la efectividad de los derechos, la buena fe, la coherencia del orden jurídico, en tanto y en cuanto, a todas las personas les revista el derecho de exigir al administrador de justicia, que en su ejercicio reconozcan los mismos derechos a quienes de hallen en una misma situación de hecho prevista en la ley (Sentencia C-816/2011).

\section{LA SEGURIDAD JURÍDICA \\ EN EL SISTEMA TRIBUTARIO COLOMBIANO}

El estudio preliminar del universo del derecho tributario colombiano permite afirmar que el sistema tributario puede juzgarse como uno de los mayores exponentes del fenómeno jurídico de implosión normativa; la evidencia de ello, en un estatuto tributario abultado, contentivo de normas oscuras, contradictorias, complejas, que dejan en evidencia palmaria los defectos que le acompasan.

El ejemplo más reciente (sin ser el único), menos que vergonzoso para la comunidad jurídica nacional e internacional, lo acaecido con Ley 1943 de 2018 conocida como Ley de Financiamiento.

En este punto es preciso aclarar el contexto en el cual se generó la anecdótica situación, que denota la inseguridad jurídica derivada en los dos órganos del poder: el órgano ejecutivo y el legislativo. En Colom- 
bia, los periodos presidenciales son de cuatro años sin reelección, ${ }^{3}$ donde el Estado está a cargo de la dirección de la economía (CP, art. 333) y el presidente como dirigente del Estado debe diseñar un Plan Nacional de Desarrollo (PND), que en una parte general describe todos los planes, programas y proyectos que espera ejecutar en el cuatrienio, y en la otra parte, detalla los presupuestos plurianuales que soportan el plan de inversiones y gastos, especificando los recursos necesarios para la ejecución; todo dentro de un marco de sostenibilidad fiscal (EOP 111, 1996); por lo cual, es un deber presentar balanceados los presupuestos, en una correspondencia entre ingresos, gastos e inversión.

El equilibrio presupuestal, obedece a que en Colombia, la ejecución del presupuesto financiero históricamente ha sido deficitario; desde 1898 el gobierno ha tenido que lidiar con la insuficiencia de ingresos para solventar los gastos e inversión estatal (Roberto Junguito y Hernán Rincón, 2004, pp. 1-160), desbalance que con menor o mayor deterioro se ha mantenido y en 2018 llegó a 27 billones equivalentes al 2.23\% del PIB (MinHacienda, 2020). Por esta razón, es una práctica común que, al tenor de las necesidades financieras de cada cuatrienio, el gobierno de turno expida una serie de normas orientadas a la consecución de los recursos que le hagan falta, y ha sido mucho más habitual que la solución sea la emisión de leyes tributarias que cambian total o parcialmente el sistema tributario, como se advirtió previamente.

En este contexto, el actual presidente Iván Duque Márquez, presentó en el mes de noviembre de 2018 el presupuesto de rentas y recursos de capital para la vigencia 2019, seguidamente en diciembre de 2018 fue presentada la Ley 1943, con la cual el presidente buscó financiar los planes de inversión y funcionamiento del PND; sin embargo, varios fueron los problemas que se derivaron de esta habitual práctica colombiana.

De un lado la Ley 1943, que creó, modificó y eliminó impuestos, estableció regímenes especiales, exenciones y modificó tarifas, fue mal llamada Ley de financiamiento para el restablecimiento del equilibrio del presupuesto general y otras disposiciones, negando la naturaleza y la relación

3 Los efectos de la reelección presidencial en Colombia han tenido fuertes defensores y detractores, en virtud de ello, fue prohibida por la CP de 1991, pero el artículo 197 fue reformado y se permitió en el 2004, tras caldeados debates fue nuevamente prohibida en el 2015, al respecto puede verse (Sebastián Rubiano, 2009, pp. 208-247). 
misma del contenido del lenguaje con las cosas, pues como lo expone Michel Foucault, es la quijotesca imaginación de la semejanza (1971, pp. 53-56), ya que claramente fue una reforma tributaria en sentido extenso; pero éste fue el menor de los problemas, ya que en contra de esta ley se presentaron una serie de demandas, en ejercicio de la acción pública de inconstitucionalidad, tanto por vicios de fondo como de forma. Como resultado el 16 de octubre de 2019 la Corte Constitucional emitió la sentencia en virtud de la demanda de inconstitucionalidad expediente D-13207 por vicios de procedimiento en la formación de la ley.

La alta corporación al someter a análisis los cargos, constató que la ley no cumplió con las reglas de procedimiento, pues omitió la publicidad del texto, con lo cual, se contrariaba el diseño institucional de bicameralismo, se cercenaba la facultad de modificación de las plenarias, se desconocía el rol de las comisiones de conciliación y se eliminaba por completo el sistema de frenos, pesos y contrapesos propio de un Estado social de derecho; magno error, que dejaba sin sustento financiero los planes, proyectos y programas propuestos por el gobierno del presidente Duque. Todo un país en el oscuro y complejo mundo de la incertidumbre financiera, social y empresarial.

Se ha de rescatar que la Corte Constitucional, como supremo intérprete de ley facultada para preservar el orden constitucional, de conformidad con el artículo 241 constitucional, cumplió a cabalidad su función, pues ratificó que la omisión de publicidad generaba invalidez en la deliberación, consentimiento y aprobación del proyecto por parte del Congreso de la República, rompiendo con el principio de consecutividad, y por lo tanto, viciaba insubsanablemente el nacimiento de la ley; pero a la par, dada la gravedad de los efectos de su inconstitucionalidad plena e inmediata, por un lado el Tribunal, otorgó un plazo de un poco más de dos meses para que el ejecutivo y el legislativo, de conformidad con sus competencias en materia tributaria, surtieran el procedimiento para que ratificaran, derogaran, modificaran o presentaran una nueva ley, contentiva de los preceptos normativos declarados inconstitucionales, y por otro, dispuso efectos a futuro a fin de no afectar situaciones jurídicas consolidadas, aunado a la declaración de inexequibilidad diferida (Sentencia C-481/2019), proscribiendo así las reclamaciones por pago de lo no debido a que se vieran tentados a presentar los contribuyentes que en virtud de la Ley 1943 habían cumplido con las obligaciones formales y sustan-

Esta obra está bajo una Licencia Creative Commons

Atribución-NoComercial-SinDerivar 4.0 Internacional, IIJ-UNAM.

Boletín Mexicano de Derecho Comparado, núm. 160, enero-abril de 2021, pp. 35-60. 
ciales que en ella se ordenaban; ${ }^{4}$ en todo caso, la plenitud de los efectos empezaría a regir desde el 1o. de enero del 2020.

Difícilmente se puede aludir a un caso similar, en el que las finanzas de un país queden prácticamente en el limbo, a causa del incumplimiento de una de las reglas más básicas de procedimiento en la formación de la ley "la publicidad"; menos aún, uno que da esencia y forma a la democracia representativa y deliberativa propia del modelo de Estado y, es exigida por la tipología de la ley tramitada; en tanto, que como se indicó al inicio, siendo la Ley 1943 una reforma tributaria, esta debía cumplir con los dos principios nucleicos de toda ley tributaria no taxation without representation y nullum tributum sine lege, y ello nunca se dio.

Este ejemplo es uno de los más recientes de los muchos que se podrían recrear y que dan cuenta del síndrome de producción normativa con sus defectos jurídicos asociados, puesto que, primariamente se ocasiona complejidad tributaria vía abundancia, reiteración y hasta contradicción normativa.

Otro de los particulares casos lo ocasionó la Ley 1430 de 2010, que fue objeto de demanda de inconstitucionalidad total, por varios cargos: i) incumplimiento del requisito establecido en el artículo 161 superior, de publicación del informe de conciliación con por lo menos un día de antelación; a la par de ii) ausencia de debate del informe de conciliación; iii) vulneración del artículo 182 del Reglamento del Congreso, Ley 5 de 1992; iv) falta de publicación con un día de antelación y alcance sustancial de la aclaración presentada al informe de conciliación en el procedimiento legislativo; v) ausencia de debate y aprobación por una minoría de la aclaración presentada al informe de conciliación en el procedimiento legislativo de la ley, y vi) vulneración del artículo 187 del Reglamento del Congreso por la conformación de la Comisión Accidental de Conciliación en el trámite de la ley (Sentencia C-076/2012).

La relevancia del caso, está en razón del análisis de los salvamentos de voto que presentaron tres magistrados: María Victoria Calle Correa,

4 La Unidad Administrativa Especial de la Dirección de Impuestos y Aduanas Nacionales (UAE_DIAN), se vio abocada a pronunciarse mediante conceptos de la Subdirección de Gestión Normativa y Doctrina de Bogotá, Resoluciones, para dar claridad al complejo y enrevesado panorama que se enfrentaban los contribuyentes, puede verse: (DIAN, Concepto 100208221-129/2020; DIAN, Resolución 007/2020; DIAN, Resolución 0008/2020; DIAN, Resolución 000042/2020), por mencionar algunos.

Esta obra está bajo una Licencia Creative Commons 
Jorge Iván Palacio Palacio y Nilson Pinilla Pinilla, quienes se distanciaron de la decisión del colegiado de desestimar los cargos y declarar exequible la ley acusada; pues a juicio de los magistrados, se debió declarar fundados los cargos y consecuentemente declarar inexequible la disposición demandada, posición que se comparte, dada la pertinencia e idoneidad de los argumentos expuestos.

Los magistrados en su análisis, encuentran de una parte, que la Corte Constitucional invirtió la carga de la prueba para el demandante, al desconocer la obligación del Congreso de probar que la publicación se realizó en tiempo, e ignorando como prueba la constancia expedida por el subgerente de la Imprenta Nacional sobre la fecha de publicación; de otra, resaltan que la exigencia de publicación con el plazo mínimo de un día de antelación previsto en el artículo 161 constitucional, es garante de una racionalidad mínima en la deliberación y toma de decisiones, que en ningún caso puede tratarse como ritualidad o trámite, puesto que las leyes tributarias y en especial las adversas al contribuyente, deben sujetarse al rigor constitucional como un mandato material de acatamiento por la seguridad que debe regir el funcionamiento de la economía, siguiendo las reglas de juego aunque ellas conduzcan a resultados inesperados, ello, dado que en el caso la Ley 1430 se publicó en 2011 y no el Diario Oficial 47.937 del 29 de diciembre de 2010 como señalaba el encabezado de la Ley y que la Corte presumió como veraz, pese a que la certificación de la imprenta señalaba el inicio del proceso de digitación el 30 de diciembre de 2010, con claro desconocimiento de las evidencias, incurriendo en un error de incoherencia, al considerar una parte y no el todo (Sentencia C-076/2012).

Los magistrados hacen alusión a dos principios a saber: i) las dudas deben resolverse en favor del legislador y ii) en caso de duda debe resolverse más bien contra el fisco, a los que la Corte debió recurrir sopesándolos para dar solución al caso, considerando que la ley ocasionaba efectos adversos al contribuyente y, no acudir como lo hizo, a una ficción jurídica, donde la realidad era una, pero se obró sin explicitarlo como si hubiese sido otra, para evitar consecuencias indeseables (Sentencia C-076/2012), como las que se podrían derivar de la declaratoria de inconstitucionalidad de la Ley 1430 de 2010, en cuanto entre otras medidas, se realizaban eliminaciones de beneficios tributarios y se modificaban otros. 
Tan evidente ha sido dicha problemática y aún lo sigue siendo, que en 2016 en Colombia se realizó un intento de compilación normativa tratando de unificar las disposiciones tributarias vigentes por medio de un Decreto Único de Reglamentación Tributaria ([DUT], Minhacienda, 2016), en un esfuerzo por racionalizar y simplificar el ordenamiento jurídico; pese a ello, lo cierto es que hoy coexisten normas repetitivas, contradictorias e incompletas, que en reversan el sistema tributario, dificultando el entendimiento y aplicación de la ley por parte del contribuyente, enmarañando la administración de justicia tributaria por parte del administrador y obnubilando la interpretación de la ley por parte del legislador, lesionando el principio de justicia tributaria como sustrato de todas las exigencias formales y materiales de esta particular ley.

$\mathrm{Al}$ respecto el profesor Jorge Streeter, señala acertadamente que la ley tributaria, en cuanto origina una obligación de carácter legal, debe enmarcarse en las máximas garantías de la legalidad y la seguridad jurídica (1968, p. 11), con alcance a los elementos de la relación tributaria, lo que se entiende como la imperativa observancia del Estado, en cabeza del legislador al momento de configurar la ley, el administrador de justicia en la interpretación y el contribuyente en su aplicación; evidentemente el Estado colombiano es el mejor contra ejemplo de la observancia de los mandatos que se derivan de la seguridad jurídica y sus garantías, en tanto, que los colombianos debieron cumplir con las obligaciones impositivas ordenadas mediante la imaginaria "Ley 1943" hasta la emisión de una nueva ley tributaria, y esto sólo sucedió hasta diciembre de 2019, un año después con la emisión de la Ley 2010 de 2019, reformada versión de la ley de financiamiento, mal llamada por el gobierno ley de promoción del crecimiento económico, el empleo, la inversión de las finanzas públicas y la progresividad, equidad, eficiencia del sistema tributario, afiligranada denominación, que trataba de recubrir el exabrupto jurídico.

En este vaivén de inseguridad jurídica tributaria, por un lado, vía producción normativa, por otro, vía interpretación y aplicación normativa, ha transitado Colombia. Sumado a ello, el hecho de que en Colombia es una constante en el sistema jurídico tributario, que las diversas reformas tributarias se traten de justificar en la consecución de objetivos constitucionalmente relevantes y legítimos, reiterados jurisprudencialmente por la Corte Constitucional y que me permito citar: 
i) Recuperación y desarrollo de áreas geográficas gravemente deprimidas en razón de desastres naturales o provocados por el hombre; ii) Fortalecimiento patrimonial de empresas o entidades que ofrecen bienes o servicios de gran sensibilidad social; iii) Incremento de la inversión en sectores altamente vinculados a la generación de empleo masivo; iv) Protección de determinados ingresos laborales; v) Protección a los cometidos de la seguridad social; vi) En general, una mejor redistribución de la renta global que ofrece el balance económico del país (Sentencia G-1107/2001).

Sin embargo, la mayoría de los beneficios tributarios establecidos en las reformas tributarias lejos de concretar los fines constitucionales prometidos, han acrecentado la inequitativa distribución de la carga tributaria.

Excepcionalmente, se quedan al margen los beneficios tributarios estipulados en las reformas tributarias promulgadas en favor de la recuperación y desarrollo de áreas geográficas, severamente perjudicadas por desastres naturales; reformas que, en efecto, de alguna manera sí han contribuido en mayor o menor medida al cometido constitucional.

Uno de estos casos, la promulgación de la Ley 218 de 1996, expedida para conseguir la reconstrucción de la región del departamento del Cauca, especialmente la Zona Norte, Popayán, Santander de Quilichao y Caloto, que fueron particularmente afectadas por un terremoto que devastó las zonas, y para ello, por medio de la Ley 218 se establecieron una serie de exenciones tributarias que propiciaron la creación y asentamiento de industrias, de zonas francas, la generación de empleo, el mejoramiento de la infraestructura vial, la infraestructura de los servicios públicos y la dinamización de la economía en general (Centro de Investigaciones en Economía y Finanzas [CIENFI], 2008, pp. 99-102); salvo este ejemplo, las demás reformas tributarias en el mejor de los casos no han producido efecto alguno y en casos extremos, lejos de coadyuvar al objetivo constitucional, han acrecentado las situaciones de inequidad e injusticia del sistema tributario; este es el caso, de la Ley 1429 de 2010 que buscó formalizar y generar nuevos empleos en el país, otorgando beneficios tributarios, que sí fueron aprovechados por los empresarios, pero a cambio de una tasa marginal de generación de empleo (Juan Diego Espinel, 2016, p. 40), una relación costo-beneficio negativa para el país; que si bien disminuyó directamente el costo de salarios y prestaciones sociales para los empre-

Esta obra está bajo una Licencia Creative Commons

Atribución-NoComercial-SinDerivar 4.0 Internacional, IIJ-UNAM.

Boletín Mexicano de Derecho Comparado, núm. 160, enero-abril de 2021, pp. 35-60. 
sarios, no generó la tasa de ocupación laboral estimada, y que sí aminoró directamente el recaudo fiscal.

Corroborando lo expuesto, Colombia ha sido catalogado por organismos nacionales e internacionales en diversos informes, como uno de los países de Latinoamérica más inestables en materia jurídico tributaria, con una tasa nominal de tributación elevada para las personas jurídicas, pero que por efectos de la aplicación de los beneficios tributarios la tasa de tributación efectiva es ostensiblemente menor (CEECT, 2015, p. 10) ocasionando que, comparativamente, la tributación real en términos del PIB llegue a un modesto $19.4 \%$ del PIB, 3.7 puntos porcentuales por debajo de la media de Sur América que alcanzó un 23.1\% para el 2018 (OEGD Publishing, 2020, p. 65).

$\mathrm{Al}$ enrarecido universo normativo expuesto de manera general, sobre el cual se cimienta la estructura del sistema tributario colombiano, se sumó la incertidumbre jurídica generada a partir de 2010, en cuanto en 2009 por medio de la Ley 1314 se acogieron los principios y normas de contabilidad e información financiera y aseguramiento de la información, ordenando la implementación de las (otra vez mal llamadas) Normas Internacionales de Información Financiera (NIIF).

Esta dinámica de estandarización internacional de contabilidad en la que entró Colombia desde el 2009 con las NIIF, obedeció a los requerimientos de los organismos multilaterales como la Organización Mundial del Comercio (OMC), la Organización para la Cooperación y Desarrollo Económico (OCDE), el Fondo Monetario Internacional (FMI) y el Banco Mundial (BM); estos dos últimos organismos desde el 2003 promovieron el informe Reports on the Observance of Standards and Codes (ROSG), por el cual se iniciaba el velado proceso de legitimación de un novedoso sistema de representación de la información financiera ajustado a los requerimientos de los grupos empresariales, multinacionales y transnacionales que transaran en bolsa, justificado teóricamente en objetivos de aseguramiento, competitividad, productividad y desarrollo equilibrado de los mercados, con el hipotético supuesto de facilitar el libre y justo intercambio de los mercados.

La adopción de estándares de representación contable para generar información financiera "razonable" a los propósitos de los agentes que cotizaban en bolsa, lejos de generar una pretendida uniformidad, ocasionó una disparidad de la información contable y financiera; puesto que, 
la aplicación de determinados estándares está mediada por aquello que los agentes establezcan como principios rectores de valoración, medición y representación en las políticas contables; así, en consecuencia dos entes económicos pertenecientes al mismo sector industrial, comercial o de servicios, con similares características podrían llegar a representaciones contables y financieras marcadamente diferentes, en razón de sus políticas.

Pero, además de las disímiles representaciones contables y financieras de entes económicos semejantes, la inseguridad tributaria obedeció principalmente al artículo 4o. de la Ley 1314, que establecía la autonomía de las normas tributarias frente a las nuevas normas de contabilidad y en caso de incompatibilidad entre estas, prevalecería la norma fiscal, generando partidas de conciliación fiscal y extrafiscal, que aún hoy, permanecen en los estados financieros, ocasionando mayor o menor valor en el resultado del ejercicio, fuente de partida para el cálculo de la alícuota impositiva por impuesto de renta y complementarios.

Desde entonces y hasta hoy, se han dado fuertes debates académicos y jurídicos sobre la interpretación del artículo, más aún sobre el alcance del nuevo modelo de las reglas a las cuales debían someterse los empresarios según el grupo al que pertenecieran: grandes empresas, medianas empresas o microempresas.

De otra parte, el cuestionamiento sobre el nuevo marco de regulación contable no fue, ni es de poca monta, ello en cuanto, a que el cuerpo de reglas es producido por un organismo internacional de carácter privado, la International Accounting Standards Board (IASB), que en 2015 estaba conformado por 16 miembros de los cuales $11^{5}$ de ellos eran parte de las grandes firmas de auditoría (Lucía del Carmen Bolaños, 2015, p. 13), organismo que emitió las International Financial Reporting Standards (IFRS); pues bien, el asunto cuestionable se deriva de una pregunta fundamental: ¿cómo es posible que unos estándares construidos, direccionados y de propiedad de una institución de carácter eminentemente privado,

5 Dentro de los once miembros se cuentraban: Ian Mackintosh de Copers \& Lybrand; Philpe Danjou de Arthur Andersen \& Co.; Patrick Finegan de Mody's Investors Service; Prabhakar Kalavacherla de KPMG; Paul Pacter de Deloitte y posteriormente KPMG; Martin Edelman de KPMG y ZEB; Mary Tokar de KPMG; John Smith de Deloitte; Darel Scot de Grupo FirstRand Banca; Takatsugu Ochi de la Corporación de Recursos de Sumitomo; Amaro Luiz de Oliveira Gomes Ex-Jefe del Departamento Financiero del Sistema de Regulación del Banco Central de Brasil; Chungwo Suh de KASB.

Esta obra está bajo una Licencia Creative Commons

Atribución-NoComercial-SinDerivar 4.0 Internacional, IIJ-UNAM.

Boletín Mexicano de Derecho Comparado, núm. 160, enero-abril de 2021, pp. 35-60. 
se acogieran como normas de regulación contable que son de carácter eminentemente público?, es por lo menos en principio una antinomia jurídica.

Me explico, en Colombia, de acuerdo con el artículo 93 constitucional entran a formar parte del sistema jurídico, las normas de carácter internacional en virtud de un convenio, tratado o pacto internacional debidamente firmado, sólo cuando son aprobados por el gobierno y ratificados por el Congreso; sobre los cuales opera el control de constitucionalidad previo y automático (A. Ramelli Arteaga, 2004, pp. 157-175); este no fue el caso de las NIIF; en tanto, estos estándares son emitidos por un organismo de carácter privado y no entraron al ordenamiento en virtud de convenio, tratado o pacto internacional; más aún, todos los derechos sobre este conjunto de estándares, pertenecen al organismo privado que las produce la IASB; pero las normas de carácter contable en Colombia regulan la representación y suministro de información contable y financiera de carácter público, por ende, al menos teóricamente existe una disparidad conceptual, que podría interpretarse como una representación de las palabras sin las cosas.

De este modo, la contabilidad se enfrentó a una transformación conceptual y contextual, aparentemente natural, porque esa simulación de naturalidad la ordena el capital (Lucía del Carmen Bolaños, 2015), situación que vuelve aún más complejo el sistema jurídico tributario; por cuanto, la contabilidad como sistema de información, suministra la materia prima esencial para conocer con mayor grado de precisión el origen o no de la obligación tributaria en el marco de los presupuestos jurídicos definidos por la ley tributaria, para un buen número de personas jurídicas y personas naturales; pero el nuevo sistema de información contable y representación financiera permite el uso de sistemas de medición y valoración disímiles para los agentes económicos, según los métodos definidos en las políticas contables; por ende, un mismo hecho económico puede ser medido, valorado y representado de forma diferente; en consecuencia, si las representaciones de los hechos económicos, de los cuales da cuenta la contabilidad, no son tal, ¿cómo determinar la existencia o inexistencia de la relación jurídico tributaria?, pues también puede ser o no ser.

Este efecto o defecto jurídico, se ha agudizado por otro fenómeno, el de la globalización, como una serie compleja de procesos, que en los ordenamientos jurídicos tiene un efecto bidireccional; por un lado reordena 
la reconstrucción de paradigmas y, por otro la reorganización de los poderes de los gobiernos; de este modo, paulatinamente se ha ido configurando un orden jurídico supranacional, engendrado por la lógica impuesta por las tecnoestructuras a los diferentes gobiernos (Miguel Carbonell, 2009, p. 22), que demanda la flexibilización, invisibilización o anulación de las fronteras físicas y jurídicas para la movilidad transfronteriza de capitales; ${ }^{6}$ es el frenesí de la globalización en virtud del cual los estados ven limitada y restringida su potestad legislativa tributaria (Marco García, 2014, p. 127), donde la riqueza real queda oculta, las cargas fiscales que recaen sobre los capitales estables y volátiles se disminuyen, incrementando la presión fiscal sobre los rendimientos del trabajo y la propensión al consumo, anulando los principios tradicionales que cimientan la tributación: la justicia, la equidad, la capacidad contributiva y la no confiscatoriedad, generando un nuevo régimen de formación normativa que castra uno de los principios democráticos y de derecho, otrora tan reclamado y defendido por la sociedad "la representación" (Marco García, 2014, pp. 127-131).

En este nuevo orden global, se consolidan instrumentos de regulación teóricamente no vinculantes; pero que superan ampliamente la actividad legislativa (Marco García, 2014, p. 133), ¡la derrumban! Al dar paso a la aplicación de un derecho flexible, dúctil, el llamado soft law, donde la discrecionalidad es la regla y la imperatividad derivada de la precisión de la ley es la excepción; un sombrío panorama donde la soberanía legislativa de los estados se desdibuja ante el poder del mercado internacional, que encuentra el balance de la distribución de la carga tributaria, en una mayor exacción para las personas y la sociedad en general y, una menor para las rentas generadas por capital total o parcialmente internacional, ignorando la razón misma del derecho "la justicia"; sin embargo, su legitimidad no se cuestiona se asume en razón del poder que las origina, tal cual, lo anticipó Ferdinand Lasalle en 1863, es la supremacía de los factores reales y efectivos del poder, hoy ejercida por los mercados internacionales, sobre, como diría el autor, el papel escrito "la norma interna" (1999, p. 62); es sin duda la construcción de un nuevo orden en el mundo,

6 Una de las explicaciones de esta dinámica de acuerdo con Chikin, es la necesaria compensación bilateral en las relaciones económicas internacionales, que difícilmente se pueden incorporar en resoluciones institucionales multipartitas (1989, p. 861).

Esta obra está bajo una Licencia Creative Commons

Atribución-NoComercial-SinDerivar 4.0 Internacional, IIJ-UNAM.

Boletín Mexicano de Derecho Comparado, núm. 160, enero-abril de 2021, pp. 35-60. 
pero sin conocer qué es lo ordenado o qué se está ordenando, ocultando el temor inconsciente generado por la incertidumbre que hay en el fondo (Artur Max Neef, A. Lizalde y M. Hopenayn, 1998, pp. 34 y 35), es una sumisión profunda en la confusión constante de las palabras, reitero, sin las cosas; así, se confunde la sugerencia con la regla y la ley con la justicia.

Es un nuevo orden de las cosas, en una lógica de entrada y salida de capitales, para la ejecución de actividades de producción, industriales, de servicios o repatriación de capitales, que en casos ya conocidos han generado efectos negativos, daños irremediables, puesto que ha de recordarse, por ejemplo, la explotación extensiva de los recursos naturales no renovables como si realmente lo fueran, dejando el rastro del daño ambiental $^{7}$ o ecológico puro (A. Ruda González, 2006), en la mayoría de los casos irreparables.

Así, en esta coyuntura de país, Colombia construye su política fiscal, que podría caracterizarse como reaccionaria; en tanto, da respuestas cortoplacistas a las necesidades financieras de cada cuatrienio, dejando de lado la función redistributiva de la exacción, por lo cual, es políticamente débil la construcción de una Hacienda Pública responsable, exteriorizada en el gasto con calidad; quizá por ello, en ningún gobierno los recursos tributarios recaudados han resultado suficientes para la financiación del gasto y la inversión pública.

Aunado a ello, como ya se mencionó las constantes reformas tributarias por medio de normas inequitativas que poco o nada contribuyen a un sistema tributario justo (Julio Roberto Piza, 2014, pp. 159-166), complejas (David Domínguez, 2014) que afectan la equidad y progresividad del sis-

7 Uno de los casos internacionales que ejemplifica el devastador efecto medioambiental, es la Oroya ubicada en la cordillera central de Perú, que en 2013 contaba con una población de 33.000 habitantes y hoy cuenta con tan sólo 11.000, siendo calificada como una de las ciudades más contaminadas del mundo, ello debido a la explotación minera de Doe Run Perú (DRP), una filial del grupo estadounidense RENCO. La extracción de DRP desde su inicio generó contaminación al aire con la generación de humo extremadamente tóxico por las emisiones de dióxido de azufre (SO2) plomo, micropartículas, niveles de arsénico y cadmio, lo que dejó un alto grado de intoxicación en la población evidenciado en presencia de plomo en la sangre e intoxicación que es irreversible. A su retiro DRP se declaró ilíquida y entró en proceso de liquidación dejando a la población en mayor abandono y condenada a padecer las secuelas la ejecución irresponsable de una actividad económica contaminante (FIDH, 2013, pp. 6-19).

Esta obra está bajo una Licencia Creative Commons Atribución-NoComercial-SinDerivar 4.0 Internacional, IIJ-UNAM. Boletín Mexicano de Derecho Comparado, núm. 160, enero-abril de 2021, pp. 35-60. 
tema (Camilo Francisco Caycedo, 2014, pp. 36-45); en virtud, del establecimiento de un régimen de beneficios tributarios que aumentan el gasto tributario e inclinan la balanza en favor de algunos contribuyentes y en detrimento de muchos otros (Jairo Bautista, 2011, pp. 70-72), ello queda evidenciado en los informes de la UAE_DIAN, desde el 2004 a 2016 donde claramente se puede advertir el efecto del régimen de beneficios tributarios. (Gloria Yori y Enrique Bravo, 2004)

Es realmente un problema de la mayor relevancia; de un lado, un exceso de producción normativa, con reformas constantes de los elementos del tributo y la relación tributaria que subyacen en la ley tributaria; de otro, la interpretación de esa misma ley, que en sede de complejidad normativa conmina al error del legislador en la configuración de la ley, el administrador en la interpretación de la ley y la administración de la justicia en el ámbito tributario, y al contribuyente en la compresión y aplicación de esa ley para la determinación de las obligaciones accesorias y la cuantificación de la alícuota de la obligación sustancial.

Este contexto denota que en Colombia, el sistema jurídico tributario debe ser objeto de un trabajo razonado y concluyente, que simplifique la norma por medio de la unificación de las ya existentes, la claridad de las que puedan llegar y la continuidad de las mismas, sin que ello signifique su invariabilidad; sumado a ello, la invaluable tarea que debería comenzar la Corte Constitucional, en la consolidación de la jurisprudencia para la construcción de líneas jurisprudenciales sólidas, por medio de las sentencias de unificación, que posibiliten que ante la inexistencia de norma, las lagunas normativas u omisiones legislativas, los sujetos de la obligación tributaria cuenten con una herramienta clara en la lectura, entendimiento, interpretación y aplicación de la ley, lo que sin duda contribuiría directamente a la seguridad jurídica tributaria como una de las principales fuentes de la justicia en la relación jurídico tributaria y por tanto en el sistema tributario.

\section{Gonclusiones}

Hoy la ley, pese a que debe sujetarse al principio de justicia como sustrato de todas las exigencias formales y materiales que ordena el derecho, se ha convertido en un instrumento de la inseguridad jurídica vía configuración

Esta obra está bajo una Licencia Creative Commons

Atribución-NoComercial-SinDerivar 4.0 Internacional, IIJ-UNAM.

Boletín Mexicano de Derecho Comparado, núm. 160, enero-abril de 2021, pp. 35-60. 
e interpretación, ello en razón, que en el Estado social de derecho la ley se ha distanciado del principio de generalidad y se ha incrustado en el principio de igualdad diferenciada, en virtud del cual se ha explosionado la emisión de normas específicas para grupos muy particulares.

Históricamente la ley tributaria se ha enmarcado en dos principios nucleicos de la seguridad jurídica, no taxation without representation y nullum tributum sine lege; por ende, no puede ni debe existir impuesto sin representación, deliberación y ley que defina expresamente los elementos del tributo; cualquiera sea el impuesto, está conminado a la inconstitucionalidad si ello no se cumple.

La Corte Constitucional en Colombia, ha dado alcance al concepto de seguridad jurídica vía jurisprudencial, identificando una dimensión objetiva relacionada de manera directa con el artículo 83 de la CP y el principio de buena fe en correspondencia con la confianza legítima, y una dimensión subjetiva, inherente al sujeto de derechos y sus expectativas de previsibilidad de las consecuencias jurídicas derivadas de sus acciones, dentro del ordenamiento jurídico al cual se encuentra obligado. Así, ha ordenado a la jurisdicción ordinaria y administrativa unificar la jurisprudencia, en aras de garantizar que a iguales circunstancias de hecho les sean imputables las mismas consecuencias jurídicas, en cumplimiento en extenso del mandato constitucional de igualdad del artículo 13.

El caso colombiano es en extremo singular, su ordenamiento jurídico tributario se caracteriza por la excesiva emisión normativa aparejada a las necesidades financieras del gobierno de turno; así, se emiten leyes tributarias, que cambian parcial o totalmente el sistema tributario, incluso en el mismo periodo; sumado a ello el reciente régimen contable bajo NIIF por el cual se permite la representación de la información de los hechos económicos de manera diversa a los agentes económicos, por lo cual la información base para la determinación de la alícuota impositiva y algunas obligaciones accesorias, añade incertidumbre, acrecentando la disparidad y consecuentemente la desigualdad jurídico tributaria, pues una norma puede ser interpretada y aplicada en razón de las políticas contables fijadas por cada organización.

De otra parte, Colombia al igual que otros estados latinoamericanos ha acogido los lineamientos de organismos multilaterales como el FMI, el BM, la OCDE, la OMC, cuyas recomendaciones lejos de ser simples sugerencias se han convertido en mandatos obligatorios, regulaciones 
dúctiles que han dado paso a la discrecionalidad del legislador y el operador jurídico, con claros efectos negativos para el contribuyente, puesto que como se advirtió líneas atrás, el poder que ejercen los mercados internacionales se incrusta en una mayor carga tributaria para la población y una menor carga para los capitales de cuño internacional.

La declaratoria reciente de inconstitucionalidad diferida de la Ley de financiamiento 1943, que era el andamiaje que sostenía todo el PND del actual gobierno del presidente Duque, dejó en evidencia que Colombia es el contraejemplo del cumplimiento de una de las exigencias de la ley tributaria; en tanto que la ley tributaria al dar origen a una obligación de carácter legal debe (tiene) gozar de las máximas garantías de legalidad y seguridad jurídica.

Queda claro que si el gobierno colombiano no corrige la política para la configuración de un sistema jurídico tributario con normas claras, concretas, permanentes pero no perpetuas, difícilmente mejorará su dinámica interna de desarrollo económico y social altamente inequitativo y, por tanto, injusta.

Se cree que una de las alternativas que el gobierno debe explorar y fomentar con mayor rigor, es la consolidación de un órgano especializado en derecho tributario, que opere de manera permanente en varios frentes: i) como un consejo de políticas fiscales de largo plazo, ii) como organismo de carácter técnico compilador de las normas, las que existen y las que puedan llegar, iii) como consejo consultivo y de apoyo a los contribuyentes, iv) como organismo de apoyo en la fiscalización para el cumplimiento de la regulación vigente; pues como se explicó, la inseguridad jurídica es la manifestación de una serie de factores, que deben ser tratados como un todo, pero sin descuidar las partes, que si bien de algún modo se han estudiado en comisiones temporales, como la Comisión de Expertos para la Equidad Tributaria conformada en 2015, su temporalidad rompe con la rigurosidad que demanda este tema fundamental.

\section{BIBLIOGRAFÍA}

BAUtista, Jairo Alonso (2011). Equidad o inequidad tributaria: la distribución del impuesto a la renta en Colombia: 1990-2002. Cuadernos de Contabilidad (30).

Esta obra está bajo una Licencia Creative Commons

Atribución-NoComercial-SinDerivar 4.0 Internacional, IIJ-UNAM.

Boletín Mexicano de Derecho Comparado, núm. 160, enero-abril de 2021, pp. 35-60. 
Bolaños Bolaños, Lucía del Carmen (2015). NIIF para PyMes: relación costo beneficio del proceso de adopción y convergencia para las PyMes en Colombia. Encuentro Nacional de Profesores de Contaduría Pública (4).

Botero Bernal, Andrés (2010). Diagnóstico de la eficacia del derecho en Colombia y otros ensayos. Ensayos jurídicos sobre teoría del derecho. Universidad de Buenos Aires. La Ley.

Garbonell, Miguel (2009). Globalización y derecho: algunas coordenadas para el debate". En Miguel CARBOnELL y Rodolfo VÁsQUEZ (coords.), Globalización y derecho. Quito. Ministerio de Justicia y Derechos Humanos.

Caycedo Tribín, Camilo Francisco (2014). Una aproximación a las modificaciones introducidas por la Ley 1607 de 2012 al régimen de las personas jurídicas desde la perspectiva del principio constitucional de eficiencia. Instituto Colombiano de Derecho Tributario (70).

Centro de Investigaciones en Economía y Finanzas Cienfi (2008). 10 años de la Ley Páez. Transformación de la economía caucana. Santiago de Cali. Universidad ICESI.

Chinkin, Christine Mary (1989). The Challenge of Soft Law: Development and Change in International Law. The International and Comparative Law Quarterly, 38(4), pp. 850-866. http://wwere.jstororg/stable/759917

Comisión de Expertos para la Equidad y la Competitividad Tributaria (2015). Informe final presentado al Ministerio de Hacienda y Crédito Público. https://wwrw.fedesarrollo.org.co/sites/default/files/LIBAgosto2016Comision. $p d f$

Domínguez, David (2014). El régimen tributario de las personas naturales después de la Ley 1607 de 2012. Revista de Derecho Privado (70).

ESPINEL PINZÓn, Juan Diego (2016). Evaluación de los resultados de la Ley 1429 de 2010 -De formalización y generación de empleo vista desde los beneficios otorgados en reducción de aportes parafiscales para las pequeñas empresas en la ciudad de Bogotá (tesis de maestría). http://bdigital.unal.edu.co/52426/

Find Information Concerning (2013). Complejo metalúrgico de la Oroya: donde la inversión se protege por encima de los derechos humanos. International Federation for Human Rights. https://wrere.fidh.org/IMG/pdf/informe_la_oroya. $p d f$ 
FOUCAULT, Michel (1971). Las palabras y las cosas: una arqueología de las ciencias humanas, trad. Elsa Cecilia Frost. Siglo Veintiuno Editores Argentina.

García Bueno, Marco César (2014). El derecho tributario nacional frente a la normativa internacional fiscal: el soft law. En Ríos GRANADOS, Gabriela (coord.), Derechos humanos de los contribuyentes. UNAM, Instituto de Investigaciones Jurídicas.

Higuera Jiménez, Diego Mauricio (2016). Análisis dinámico de la línea jurisprudencial respecto de la sustitución de la Constitución. Revista Principia Iuris (26).

Junguito, Roberto y Rincón, Hernán (2004). La política fiscal en el siglo XX en Colombia. Borradores de Economía (318).

LARENZ, Karls (1985). Derecho justo: fundamentos de ética jurídica, trad. de Luis Diez de Picazo. Civitas.

LASALLE, Ferdinand (1999). ¿Qué es una Constitución? Panamericana. https:// wrevelaleph.com/

López MedinA, Diego Eduardo (2010). El derecho de los jueces. Universidad de los Andes.

Max NeEF, Artur Manfred, Lizalde, Antonio y Hopenayn, Martín (1998). Desarrollo a escala humana: conceptos, aplicaciones y algunas reflexiones. Icaria Editorial.

Oecd Publishing (2020). Revenue Statistics in Latin America and the Caribbean 1990-2018. Centro de Política y Administración Tributaria OCDE. https://read.oecd-ilibrary.org/taxation/revenue-statistics-in-latin-america-andthe-caribbean-2019_25666b8d-en-es\#page4

PÉREZ LuÑO, Antonio Enrique (2000). La seguridad jurídica: una garantía del derecho y la justicia. Boletín de La Facultad de Derecho (15).

PIZA, Julio Roberto (2014). Equidad y simplicidad en el impuesto a la renta de las personas. Revista de Derecho Fiscal (7).

Quinche RAmíRez, Mario Fernando (2010). La seguridad jurídica frente a las sentencias definitivas. Tutela contra sentencia. Estudios SocioJurídicos (12).

Ramelli ArTeaga, A. (2004). Sistema de fuentes de derecho internacional público y "bloque de constitucionalidad" en Colombia". Cuestiones Constitucionales (11).

Esta obra está bajo una Licencia Creative Commons

Atribución-NoComercial-SinDerivar 4.0 Internacional, IIJ-UNAM.

Boletín Mexicano de Derecho Comparado, núm. 160, enero-abril de 2021, pp. 35-60. 
Rubiano Galvis, Sebastián (2009). La independencia del Banco de la República y la reelección presidencial. Mayorías sin democracia. Desequilibrio de poderes y Estado de derecho en Colombia. De Justicia.

RUDA GONZÁLEZ, A. (2006). El daño ecológico puro. La responsabilidad civil por el deterioro del medio ambiente (tesis doctoral). https://dugi-doc.udg.edu/bitstream/handle/10256/4774/targ.pdf? sequence $=5$ Eis Allowed $=y$

STREETER, Jorge (1968). La interpretación de la Ley Tributaria. Revista de Derecho Económico (21-22).

TAMAYO JARAmillo, Javier (2006). El nuevo derecho, el escepticismo ante las normas y el uso alternativo del derecho. Revista Facultad de Derecho y Ciencias Políticas (36).

YORI PARRA, Gloria y Bravo Díaz, Enrique (2004). Los beneficios tributarios en el impuesto sobre la renta en Colombia. Año 2003. Departamento Administrativo Espacial Dirección de Impuestos y Aduanas Nacionales. https:// wrwedian.gov.co/dian/cifras/Cuadernos\%20de\%20Trabajo/Los\%20benefi cios $\% 2$ tributarios $\% 20$ en $\% 20$ el $\% 2$ impuesto $\% 20$ sobre $\% 20$ la $\% 2$ renta $\% 20$ en\%20Colombia.\%20A\%C3\%B10\%202003.pdf

ZAGREBELSKY, Gustavo (1995). El derecho dúctil: ley, derechos y justicia, trad. Marina Gascón. Trotta.

Zavala Egas, Jorge (2010). Teoría de la seguridad jurídica. Iuris Dictio (14).

Leyes, decretos y jurisprudencia

Congreso de la República de Colombia, Decreto 1625, 2016.

Congreso de la República de Colombia, Ley 1943, 2018.

Congreso de la República de Colombia, Ley 1429, 2010.

Congreso de la República de Colombia, Ley 1314, 2009.

Congreso de la República de Colombia, Ley 218,1996.

Constitución Política de Colombia, 1991, Colombia.

Ministerio de Hacienda y Crédito Público, Estatuto Orgánico de Presupuesto, Decreto 111, 1996.

Sentencia C 481/ 2019, Corte Constitucional de Colombia. https://wrwre. corteconstitucional.gov.co/Relatoria/2019/C-481-19.htm

Sentencia SU 072/ 2018, Corte Constitucional de Colombia. https:// wrere.corteconstitucional.gov.co/Relatoria/2018/SU072-18.htm 
Sentencia SU 337/2017, Corte Constitucional de Colombia. https://wrwre. corteconstitucional.gov.co/Relatoria/2017/SU337-17.htm

Sentencia C 284/2015, Corte Constitucional de Colombia. https://wrwre. corteconstitucional.gov.co/Relatoria/2015/C-284-15.htm

Sentencia C 053/2015, Corte Constitucional de Colombia. https://wrew. corteconstitucional.gov.co/Relatoria/2015/SU053-15.htm

Sentencia C 816/2011, Corte Constitucional de Colombia. https://wrere. corteconstitucional.gov.co/Relatoria/2011/C-816-11.htm

Sentencia C 076/2012, Corte Constitucional de Colombia. https://wrere. corteconstitucional.gov.co/Relatoria/2012/C-076-12.htm

Sentencia C 1107 de 2001, Gorte Constitucional de Colombia. https:// wrwre.corteconstitucional.gov.co/Relatoria/2001/C-1107-01.htm

Sitios oficiales y páginas web

Ministerio de Hacienda y Crédito Público. Balance Fiscal del Gobierno General (\%) PIB. https://wrere.minhacienda.gov.co/webcenter/portal/Estadisticas/ pages_macroeconomia/balancegobiernogeneralpib 


\title{
DEGONSTRUIR PARA REGONSTRUIR: UN ANÁLISIS DE LOS ÓRGANOS CONSTITUCIONALES AUTÓNOMOS EN MÉXICO*
}

\author{
DECONSTRUCTING TO RECONSTRUCT: AN ANALYSIS OF \\ AUTONOMOUS CONSTITUTIONAL AGENCIES IN MEXICO
}

\author{
Rodrigo CAMAREna GonZÁlez** \\ Mauricio Alejandro GuIM Álfago ${ }^{* * *}$
}

Ana María ZORRILLA NORIEGA*****

RESUMEN: Este artículo busca mostrar que la concepción dominante sobre los órganos constitucionales autónomos (OCA) está equivocada. Estos organismos no son completa ni igualmente independientes del resto de poderes del Estado. $\mathrm{Al}$ contrario, se caracterizan por tener una variedad de diseños que les dan diferentes niveles de autonomía.
ABSTRACT: This article argues that the mainstream conception about the autonomous constitutional agencies is mistaken. These agencies are neither complete nor equally independent from the other branches of government. On the contrary, there is a variety of institutional designs that grants them different levels of autonomy. Acknowledging this variety of designs is the first step

* Recibido el 6 de julio de 2020; aprobado el 23 de noviembre de 2020.

En esta investigación, agradecemos el apoyo a Óscar Alfaro, Paula Amato, Fernanda Araujo, Gianmarco Coronado, Luisa Garza, Aitana González, José Luis Méndez, Mariana Ortega y Marco Sánchez. Asimismo, agradecemos a los asistentes del Workshop Intersecciones, organizado por el Centro de Estudios Constitucionales de la Suprema Corte de Justicia de la Nación (SCJN), el 31 de octubre de 2019. Por sus valiosos comentarios, gracias a José Pablo Abreu, Lucero Ibarra, Gladys Morales, Fabiola Navarro, Xisca Pou, Julio Ríos, Camilo Saavedra, Gilberto Suárez y Ricardo Uvalle. Finalmente, gracias a José Antonio Escorcia y Regina Lazarín por realizar una revisión de forma en la última etapa de elaboración de este trabajo.

** ORCID: 0000-0001-6661-0176. Doctor en Derecho, profesor de tiempo completo en el Departamento de Derecho del ITAM y miembro del Sistema Nacional de Investigadores (candidato). Correo electrónico: rodrigo.camarena@itam.mx

*** ORCID: 0000-0003-2839-1448. Doctor en Derecho, profesor de tiempo completo en el Departamento de Derecho del ITAM. Correo electrónico: mauricio.guim@itam.mx.

**** ORCID: 0000-0002-5160-3624. Coordinadora de la Clínica en Derecho y Política Pública y del Proyecto de Cultura de la Legalidad en el Departamento Académico de Derecho del ITAM; doctora en Derecho por el Instituto de Investigaciones Jurídicas de la

Boletín Mexicano de Derecho Comparado, nueva serie, año LIV, núm. 160, enero-abril de 2021, pp. 61-98.

Esta obra está bajo una Licencia Creative Commons Atribución-NoComercial-SinDerivar 4.0 Internacional, IIJ-UNAM. 
Entender esta variedad de diseños es el primer paso para identificar las causas, reales o percibidas, sobre los defectos del sistema actual de equilibrio institucional, así como las consecuencias que un régimen bien diseñado podría generar. Hasta este momento, la discusión generalmente se ha limitado a si deben existir o no este tipo de organismos. A partir de este trabajo, los debates podrían abordar nuevos cuestionamientos sobre cómo deben diseñarse y cuánta autonomía habría que otorgarles.

Palabras clave: organismos constitucionales autónomos, autonomía, diseño institucional. for understanding the causes, real or perceived, of the flaws in the current system of institutional balance, as well as the consequences that a well-designed regime could generate. Until today, most of the debate has been limited to the convenience or undesirability of having this kind of agencies. This article may be the starting point for discussions on how decisionmakers should design these agencies and how much autonomy they should grant them.

Keyzords: autonomous constitutional agencies, autonomy, institutional design.

SUMARIO. I. Introducción. II. ¿Por qué tener un cuarto poder? Costos y beneficios de la autonomía. III. Radiografia constitucional y administrativa de los órganos constitucionales autónomos en México. IV. Implicaciones del régimen común y diferenciado. V. Conclusiones y preguntas para futuras investigaciones. VI. Fuentes de información.

\section{INTRODUCGIÓN}

Desde la toma de posesión de Andrés Manuel López Obrador como presidente de México, han ocurrido una serie de confrontaciones en contra de varios OCA. El episodio más emblemático fue la eliminación, en el 2019, del Instituto Nacional para la Evaluación de la Educación, que apenas había sido creado como OCA en el 2013. ${ }^{1}$ Sin embargo, existen otros episodios como la decisión de rechazar una recomendación de la Comisión

UNAM, maestra en Derecho y Gobierno por American University Washington College of Law. Correo electrónico: ana.zorrilla@itam.mx

1 Véase Decreto por el que se reforman, adicionan y derogan diversas disposiciones de los artículos 3o., 31 y 73 de la Constitución Política de los Estados Unidos Mexicanos, en materia educativa. Diario Oficial de la Federación (DOF), 15 de mayo de 2019, y Decreto por el que se reforman los artículos 3o. en sus fracciones III, VII y VIII, y 73, fracción XXV, y se adiciona un párrafo tercero, un inciso d al párrafo segundo de la fracción II y una

Esta obra está bajo una Licencia Creative Commons

Atribución-NoComercial-SinDerivar 4.0 Internacional, IIJ-UNAM.

Boletín Mexicano de Derecho Comparado, núm. 160, enero-abril de 2021, pp. 61-98. 
Nacional de Derechos Humanos ([CNDH], Recomendación 29/2019) o de remover al secretario ejecutivo del Consejo Nacional de Evaluación de la Política de Desarrollo Social. Detrás de estas confrontaciones, frecuentes después de todo cambio de gobierno, subyace algo más profundo: el cuestionamiento sobre si México debiera o no tener este tipo de organismos.

Lo que ahora está ocurriendo hubiera sido impensable hace algunos años. Entre 1993 y 2013, se creó una decena de OCA. ${ }^{2}$ El espíritu de la época señalaba que sólo por medio de estos organismos se podría crear el contexto institucional necesario para modernizar e impulsar el desarrollo de México. Se crearon tantos OCA durante este periodo que este fenómeno fue denominado como autonomitis (Jorge Alcocer, 2013). La elección de López Obrador como presidente ha empezado a revertir esta tendencia. Desde el principio de su sexenio, han surgido diversas críticas respecto a los OCA. Un claro ejemplo fue el conflicto que existió en torno a los salarios de ciertos funcionarios públicos, en vista de la Ley Federal de Remuneraciones de los Servidores Públicos. Esta ley, que ha sido cuestionada por varios OCA y declarada inconstitucional en algunas de sus disposiciones por la Suprema Corte de Justicia de la Nación ([SGJN], Acción de Inconstitucionalidad 105/2018), se ha mantenido incólume en cuanto a su propósito principal (Banco de México, 2019, p. 2).

El interés sobre estos organismos en el debate político actual no es consistente con el poco progreso académico logrado al respecto. Pese a las innumerables noticias que se producen diariamente sobre los OCA, se conoce todavía poco sobre cuáles son sus causas y efectos en un sistema constitucional. Existen dos razones por las que esto ocurre: una metodológica y otra histórica. La primera radica en que, una vez que uno de estos organismos empieza a funcionar, el sistema en el que opera es tan complejo que es difícil aislar el efecto que la institución tiene sobre un problema

fracción IX al artículo 3o. de la Constitución Política de los Estados Unidos Mexicanos. DOF, 26 de febrero de 2013.

2 La lista incluye, además de los mencionados, el Instituto Nacional de Estadística y Geografía, el Instituto Nacional de Transparencia, Acceso a la Información y Protección de Datos Personales, el Instituto Federal de Telecomunicaciones, la Comisión Federal de Competencia Económica y la Fiscalía General de la República. Se excluye al Tribunal Federal de Justicia Administrativa y a los Tribunales Agrarios por tener funciones predominantemente jurisdiccionales. También se excluye a las universidades cuya autonomía se reconoce por ley, no por la Constitución. 
político o regulatorio respecto a las innumerables variables que interactúan para producir resultados. La razón histórica se refiere a que el pensamiento dominante sobre estas instituciones ha sido influenciado por la idea de que son órganos completa e igualmente independientes (José Roldán Xopa, 2018, p. 183; Leticia Bonifaz, 2017, p. 178; Pedro Salazar Ugarte, 2017, p. 104; Maco Antonio Zeind, 2018, p. 172, y Ileana Moreno Ramírez, 2005, p. XVI). Incluso cuando se detecta una diferenciación en la regulación de cada uno, suele asumirse que la homogeneización es el ideal al que hay que aspirar, sin estudiar la diversidad de los regímenes jurídicos de los OCA (Marco Antonio Zeind, 2018). Esta homogeneización puede explicarse a la luz del influyente trabajo de García-Pelayo sobre los organismos constitucionales y sus cuatro características distintivas: estar previstos en la Constitución; ser constitutivos del Estado; funcionar como formadores de la voluntad estatal; así como constituirse en un marco de paridad jurídica entre todos los órganos de este tipo (Manuel GarcíaPelayo, 1981). Pero, incluso cuando se estudian estos órganos por medio de otros lentes analíticos como el cuarto poder en países latinoamericanos (Bruce Ackerman, 2007), o la nueva separación de poderes en el sur global (David Bilchitz y David E. Landau, 2018), la postura predominante ha sido agruparlos bajo similitudes, en lugar de separarlos con base en sus diferencias.

Este artículo cuestiona esta concepción dominante, que ha sido sostenida por periodistas, académicos, políticos, e incluso la SCJN. Esta última ha sostenido que los OCA guardan "autonomía e independencia de los poderes primarios" (Controversia Constitucional [CG] 32/2005. SGJN, 2006) y que su estatus jurídico les otorga "absoluta autonomía" sujeta a "criterios eminentemente técnicos y ajenos a cualquier otro interés". (CG117/2014.SCJN, 2015)

Esta concepción obscurece dos cuestiones que son centrales para comprender las causas y los efectos de estos organismos en un sistema constitucional. Una es la enorme variedad de diseños que existen en estas instituciones; más allá de unas cuantas islas de similitudes, estos organismos se caracterizan por tener un océano de diferencias, muchas de las cuales tienen un impacto en el grado de independencia que, de hecho, pueden ejercer. La otra cuestión son las soluciones de compromiso, que implica asignar ciertas funciones a órganos separados de los poderes tradicionales del Estado; la autonomía tiene beneficios, pero también costos que deben

Esta obra está bajo una Licencia Creative Commons

Atribución-NoComercial-SinDerivar 4.0 Internacional, IIJ-UNAM.

Boletín Mexicano de Derecho Comparado, núm. 160, enero-abril de 2021, pp. 61-98. 
tomarse en cuenta al considerar si la solución a un problema social, político o regulatorio es crear un órgano autónomo más.

Entonces, la homogeneización que ha sido descrita implica el peligro de pasar por alto los diversos tipos y grados de autonomía que se otorgan a los OCA. Ignorar la existencia de este esquema diferenciado de autonomías es particularmente relevante si se considera que las funciones atribuidas a cada uno de estos órganos, y sus relaciones con los otros entes públicos, son distintas en cada caso.

La tesis central de este trabajo es sencilla: demostrar que la concepción dominante sobre los OCA está equivocada porque estos organismos no son completa ni igualmente independientes del resto de poderes del Estado. Al contrario, se caracterizan por tener una variedad de diseños que - a menos que se considere que el diseño institucional no influye en el comportamiento de una institución - les dan de facto diferentes niveles de autonomía.

En este sentido, la hipótesis que se pretende demostrar es que la diversidad de diseños institucionales en los OCA supera la visión homogeneizadora que ha predominado hasta este momento. Esto puede tener relevantes implicaciones; si bien hasta este momento la discusión generalmente se ha limitado a si tener OCA o no, a partir de este trabajo los debates podrían abordar nuevos cuestionamientos sobre cómo deben diseñarse y cuánta autonomía habría que otorgarles.

El artículo se estructura de la siguiente manera. En la sección II se resume la literatura relevante sobre las razones para separar cierta función de los tres poderes clásicos. En esta literatura se considera esta decisión como una solución en la que no es posible capitalizar los beneficios de estos cuartos poderes sin incurrir también en ciertos costos. La sección III explica las razones por las que la concepción dominante sobre los OCA está equivocada: ninguno de ellos es completamente independiente y cada uno presenta un distinto nivel de autonomía. Para mostrar esta diferencia, el artículo utiliza una base de datos original e inédita sobre el diseño institucional de los OCA. El resultado más interesante del análisis de estos datos es que, si bien estos organismos tienen un pequeño régimen jurídico común que les da un piso de autonomía, también tienen un régimen diferenciado. En la sección IV se analizan las implicaciones que estos regímenes tienen y se reflexiona sobre cómo los resultados de esta investiga- 
ción podrían impulsar el conocimiento sobre las causas y los efectos de la existencia estos organismos en un sistema constitucional.

\section{II. ¿POR QUÉ TENER UN GUARTO PODER? COSTOS Y BENEFICIOS DE LA AUTONOMÍA}

Las agencias independientes o cuarto poder tienen su origen en 1887, con la creación de la Interstate Commerce Commision en los Estados Unidos de América (Peter Strauss, 1984, p. 609). Desde entonces, se han creado alrededor de 60 agencias independientes más, ${ }^{3}$ dentro de las que la Oficina de Protección Financiera del Consumidor es la más reciente (2011).

En un principio, la creación de estas agencias enfrentó fuertes cuestionamientos constitucionales. Se criticaba que estos organismos no estaban previstos por la Constitución, atentaban contra el carácter unitario e individual del Poder Ejecutivo y carecían de legitimidad democrática (Christopher Yoo et al., 2005). Sin embargo, actualmente las razones prácticas para tener estos organismos han prevalecido y pocas personas cuestionan su constitucionalidad.

En contraste con el caso estadounidense, en México se han establecido órganos autónomos directamente en la Constitución. En 1993 se le reconoció autonomía constitucional al Banco de México (Banxico); en 1994 al entonces Instituto Federal Electoral (ahora Instituto Nacional Electoral, INE); en 1999 a la Comisión Nacional de Derechos Humanos (GNDH), y en 2006 al Instituto Nacional de Estadística y Geografía (INEGI). Para el 2014 ya había diez OCA. La característica principal de estos organismos es que no forman parte de la división tripartita clásica de Montesquieu.

Aunque las características de las agencias autónomas han sido teorizadas por mucho tiempo en la literatura estadounidense, hasta la fecha existe poca bibliografía en habla hispana sobre este tema. El uso de la literatura estadounidense sirve, por un lado, para aprovechar la experiencia que se ha tenido en ese sistema constitucional respecto a la diversidad de órganos técnicos, reguladores y cuasi-judiciales que gozan ciertos ni-

3 Véase Office of Information and Regulatory Affairs, Fall 2019 Unified Agenda of Regulatory and Deregulatory Actions. https://wwrw.reginfo.gov/public/do/eAgendaMain

Esta obra está bajo una Licencia Creative Commons

Atribución-NoComercial-SinDerivar 4.0 Internacional, IIJ-UNAM.

Boletín Mexicano de Derecho Comparado, núm. 160, enero-abril de 2021, pp. 61-98. 
veles de autonomía. Por otro lado, resulta de utilidad contrastar esta literatura frente a un nuevo contexto en el que las autonomías externas a los tres poderes clásicos están previstas en la Constitución, en vez de una ley o un decreto presidencial.

Esta literatura define a las agencias autónomas de varias maneras. ${ }^{4}$ El consenso académico es que su característica fundamental es la inmunidad de sus titulares de ser removidos libremente por el Poder Ejecutivo (Geoffrey Miller, 1988, p. 216; Kirti Datla y Richard Revesz, 2013, p. 773; Elena Kagan, 2010, p. 2376; Sunstein, 1990: 426; Moreno, 2015: 470; Lisa Bressman y Robert Thompson, 2010, p. 610). Una vez en sus cargos, no es a la autoridad que los designó a quien deben temer, sino a la que puede removerlos (Geoffrey Miller, 1988, p. 216).

En la literatura mexicana se considera que los OCA tienen el mayor grado de autonomía posible. Para algunos, su característica esencial es que realizan funciones predominantemente técnicas y distanciadas de la política tradicional (Jaime Cárdenas Gracia, 2001, p. 17). Para otros, se trata de organismos encaminados a corregir un diseño institucional inadecuado (John Ackerman, 2007; Lorenzo Córdova Vianello, 2011). Otros sostienen que su esencia es la falta de subordinación a los poderes clásicos (José Luis Caballero, 2000, p. 156). Mientras tanto, otros consideran que su atipicidad es su signo distintivo (Ileana Moreno, 2005). Además de situarse fuera de la división tripartita tradicional, el común denominador es que estos organismos - y sus garantías institucionales - están contemplados en la Constitución. Por este motivo, el estatus de OCA supera otras expresiones de autonomía.

Un grado de menor autonomía se manifiesta en la administración paraestatal, que se integra por entidades que generalmente tienen personalidad jurídica y patrimonio propio. ${ }^{5}$ Otro grado aún menor de autonomía es la de los órganos desconcentrados, que se encuentran en la esfera del Poder Ejecutivo y están jerárquicamente subordinados a alguna secretaría de Estado (LOAPF, art. 17). Se trata de entidades que generalmente

4 Para algunos autores son aquellas que ejercen potestades administrativas, pero no forman parte del Poder Ejecutivo (Jacob Gersen, 201 1, pp. 333 y 374; David Lewis, 2003, p. 44). Para otros, son aquellas que ejercen potestades administrativas, normativas y jurisdiccionales respecto a un sector económico específico (Aulana Peters, 1988, p. 286).

5 Véase Ley Federal de Entidades Paraestatales (1986). México, artículo 14, y Ley Orgánica de la Administración Pública Federal ([LOAPF], 1976). México, artículos 45-50. 
carecen de personalidad jurídica y patrimonio propio, ${ }^{6}$ pero gozan de distintas formas de autonomía operativa.

La tesis central de este artículo se apoya en la afirmación de que cierta entidad tiene mayor o menor autonomía cuando posee la capacidad de tomar decisiones sin sufrir consecuencias por haberlas tomado. Tal como se detalla más adelante, estas consecuencias pueden ser negativas (castigos) o positivas (premios).

Cierta literatura distingue entre independencia y autonomía, considerando a la primera una cuestión de diseño institucional y a la segunda una predisposición a actuar con independencia. Sin embargo, en este artículo autonomía e independencia son considerados como sinónimos, en el entendido de que la finalidad del diseño institucional mediante el que se otorga cierto tipo y grado de autonomía a un órgano es, justamente, facilitar la predisposición para su actuación independiente.

La creación de un órgano autónomo impacta, primeramente, en la remoción de una facultad originalmente atribuida a alguno de los poderes estatales tradicionales para que pase a manos de un órgano técnico. Además, la autonomía es un mecanismo para: i) promover decisiones estrictamente técnicas y crear incentivos para desarrollar esta especialización; ${ }^{7}$ ii) garantizar la estabilidad de las políticas públicas en el tiempo, ${ }^{8}$ y iii) proteger a los reguladores de la captura por parte de las industrias reguladas (Marver Bernstein, 1955, p. 4; Jacob Gersen, 2011, p. 347).

Sin embargo, establecer un órgano autónomo también puede tener al menos tres costos en la vida política del Estado. El primero es que, si bien la autonomía de un órgano le puede permitir sancionar sin temor a represalias políticas, esta misma condición que lo exime de control político puede hacerlo más susceptible a la manipulación externa (Susan

6 Existen órganos que, aunque son formalmente como desconcentrados, sí cuentan con personalidad jurídica y patrimonio propio. Éste es el caso, por ejemplo, del Instituto Nacional de Bellas Artes. (Cfr. José Roldán Xopa, 2008, p. 231)

7 La actuación de un órgano que depende del presidente puede contagiarse por las presiones políticas o electorales de su superior. En teoría, un órgano con un diseño que le brinde autonomía prestará menos atención a dichas consideraciones (Paul Verkuil, 1988, p. 260; Auleana Peters, 1988, p. 290; Rachel Barkow, 2010, p. 20; Lisa Bressman y Robert Thompson, 2010, p. 612).

8 Los cambios de gobierno suelen amenazar la estabilidad de las políticas implementadas durante cada administración. (Lisa Bressman y Robert Thompson, 2010, pp. 613 y 614; Peter Conti-Brown, 2017, p. 361). 
Bartlett, 1988, p. 223; Geoffrey Miller, 1988, p. 297). Además, no siendo responsable ante autoridad alguna, una institución autónoma podría promover políticas que beneficien principalmente a los proyectos personales de sus miembros. El segundo costo es la "visión de túnel". ${ }^{9}$ Cuando una institución está especializada en una sola industria, enfrenta el riesgo de enfocarse excesivamente en un solo problema e ignorar otros que, aunque no son su especialidad, deberían considerarse en un proceso de decisión racional y en un diseño acertado de política pública. El tercer costo es la falta de coordinación. Cuando surgen diferencias entre dos órganos autónomos, o entre un órgano del Poder Ejecutivo y uno autónomo, suele no existir un superior que pueda resolver la controversia (Auleana Peters, 1988, p. 288). Sin embargo, en el contexto mexicano, la SCJN podría resolver estas diferencias mediante una controversia constitucional.

Hasta este momento, la autonomía se ha descrito como la capacidad de un órgano para actuar como un cuarto poder, independiente respecto a las preferencias del Poder Ejecutivo (Peter Strauss, 1984, p. 578; Aulena Peters, 1988, p. 286). Sin embargo, como se ha señalado, debe considerarse que en la realidad no existe una independencia total del resto de los poderes; tanto el ejecutivo como el legislativo influyen o condicionan las decisiones de estos organismos (Richard Wiley, 1988, p. 282; Auleana Peters, 1988, p. 287; Peter Strauss, 1984, p. 594). Para empezar, el financiamiento de órganos autónomos proviene del presupuesto, que es preparado por el ejecutivo y aprobado por el legislativo. Estas facultades presupuestarias otorgan a los poderes clásicos un poderoso medio de control (Kirti Datla y Richard Revesz, 2013, p. 822; Peter Strauss, 1984, p. 588; Rachel Barkow, 2010, p. 42).

Por otra parte, los poderes clásicos influyen en las decisiones de los entes autónomos mediante sus facultades de nombramiento. Los titulares de los órganos autónomos suelen ser designados por el presidente y ratificados por el Senado, o viceversa. Ambas instituciones pueden designar funcionarios que compartan sus intereses o ideología (Alan Morrison, 1988, pp. 253-254; Glen Robinson, 1988, p. 242; Raches Barkow, 2010, p. 42). En los casos más drásticos, tanto el presidente como el Congreso podrían exigir compromisos a cambio de nombrar o ratificar a los titulares de los entes autónomos (Auleana Peters, 1988, p. 287).

9 Para el desarrollo de este concepto, véase (Stephen Breyer, 1995, p. 10).

Esta obra está bajo una Licencia Creative Commons Atribución-NoComercial-SinDerivar 4.0 Internacional, IIJ-UNAM. Boletín Mexicano de Derecho Comparado, núm. 160, enero-abril de 2021, pp. 61-98. 
Además, el Congreso suele contar con mecanismos de monitoreo que pueden ser estratégicamente aprovechados para influir en las decisiones de un órgano autónomo, tales como requerir información o interpelar a sus titulares (Auleana Peters, 1988, p. 294; Mathew McCubbins, Roger Noll y Barry Weingast, 1987, pp. 249-250; Mathew McCubbins, Roger Noll y Barry Weingast, 2007, 1705). La paradoja de estos mecanismos es que, para protegerse de ellos, muchas veces se requiere no más autonomía, sino una mayor dependencia a otro poder del Estado. Se piensa, por ejemplo, que ubicarse bajo el manto protector del presidente puede implicar una menor propensión respecto a la manipulación por parte del Congreso o incluso de la prensa (Geoffrey Miller, 1988, p. 297). Independientemente de estos mecanismos, existen causales extraordinarias por las que sí es posible remover a los titulares de los órganos autónomos, así como mecanismos excepcionales de remoción, entre los que destaca el juicio político (Mathew McCubbins, Roger Noll y Barry Weingast, 1987, p. 248).

Finalmente, el Congreso y el presidente también tienen la posibilidad de influir en las decisiones de los órganos autónomos mediante su facultad de aumentar, disminuir, o eliminar sus potestades (Mathew McCubbins, Roger Noll y Barry Weingast, 2007, p. 1705). ${ }^{10}$ Así, un Poder Ejecutivo o Legislativo inconforme con alguna decisión de un órgano autónomo puede responder: 1) eliminando la potestad que permitió al órgano tomar esa decisión; 2) concediéndole otras potestades que lo distraigan de la potestad que permitió la decisión cuestionada; o 3) complicando el procedimiento administrativo necesario para tomar decisiones similares. En casos extremos, también existe la posibilidad de eliminar al órgano autónomo por completo, siguiendo el procedimiento que se requiera para reformar la norma mediante la que fue creado. El efecto de cualquiera de estas opciones es, en definitiva, incrementar los costos en los que los órganos autónomos incurren al tomar decisiones desfavorables para el resto de los poderes.

10 En este sentido, los poderes Legislativo y Ejecutivo conservan su poder para complicar o simplificar los procedimientos administrativos necesarios para tomar decisiones (Mathew McCubbins, Roger Noll y Barry Weingast, 1987, p. 254; Mathew McCubbins, Roger Noll y Barry Weingast, 1989).

Esta obra está bajo una Licencia Creative Commons

Atribución-NoComercial-SinDerivar 4.0 Internacional, IIJ-UNAM.

Boletín Mexicano de Derecho Comparado, núm. 160, enero-abril de 2021, pp. 61-98. 
Hasta este momento, solamente se han considerado mecanismos de control equivalentes a castigos. Sin embargo, cada una de las medidas anteriores puede ser reformulada como un premio. Por ejemplo, en lugar de sancionar a un órgano autónomo con una disminución del presupuesto, se le puede premiar con un aumento.

Por todo lo que se ha explicado hasta ahora, algunos autores dudan que exista una diferencia significativa entre las políticas de un órgano autónomo y otro que no lo es (Susan Bartlett, 1988; Glen Robinson, 1988; Alan Morrison, 1988). Otros autores, en lugar de definir la autonomía en términos categóricos, la conciben como un espectro en el que un órgano puede ser más o menos autónomo dependiendo de su diseño institucional (Kirti Datla y Richard Revesz, 2013, p. 773). En este artículo se propone que, en la medida en la que un órgano esté sometido a menos controles y goce de más protecciones, será más independiente. La autonomía institucional, desde esta perspectiva, es más una cuestión de grados que de categorías.

\section{RADIOGRAFÍA CONSTITUCIONAL Y ADMINISTRATIVA DE LOS ÓRganos CONSTitucionales AUTÓNOMOs En MéXico}

a) Organización de los datos. Tal como se comentó previamente, la hipótesis principal que se pretende demostrar mediante este artículo es que, si bien la concepción dominante en México considera a los OCA como completa e igualmente autónomos, lo cierto es que éstos presentan una gran variedad de diseños institucionales que produce diferentes niveles de independencia. En este sentido, es necesario documentar tal variedad.

Partiendo de una base de datos inédita sobre el diseño de estos organismos, la información fue organizada en cuatro categorías bien establecidas en la literatura de la nueva economía institucional (Mathew McGubbins, Roger Noll y Barry Weingast, 1987; Lean Jacques Laffont y David Martimort, 2002). Esta literatura parte de la premisa de que los actores políticos y sus delegados responden a incentivos, motivo por el que uno de los objetivos primordiales del diseño institucional es justamente crear incentivos para conseguir los fines deseados.

Lo anterior se logra resolviendo los problemas de selección adversa y riesgo moral que caracterizan a toda relación agente-principal, lo que implica: 
crear filtros para seleccionar a los titulares de los organismos autónomos; establecer mecanismos de monitoreo para observar y fiscalizar su comportamiento; e implementar un sistema de premios y castigos para incentivar o desincentivar los comportamientos deseados. A estas categorías, en este estudio se agrega otra denominada autonomía institucional, en la que se captura la capacidad que tiene un organismo para autogobernarse, así como la disponibilidad de remedios judiciales para protegerse de invasiones a sus competencias. En la tabla 1, se resumen estas cinco categorías y se proporcionan ejemplos de los aspectos estudiados respecto a cada una de ellas.

\section{Tabla 1. Estudio analítico de los órganos constitucionales autónomos}

\begin{tabular}{|c|c|}
\hline Categorías & Rubros de análisis \\
\hline Filtros & $\begin{array}{l}\text { O Requisitos para ser integrante del órgano superior. } \\
\text { o Duración del cargo. } \\
\text { o Prohibiciones durante el encargo y al salir. } \\
\text { o Nivel salarial. } \\
\text { o Procedimiento para el nombramiento. } \\
\text { o Publicidad de las comparecencias. } \\
\text { o Mecanismos de deliberación. }\end{array}$ \\
\hline Monitoreo & $\begin{array}{l}\text { O Nivel de publicidad de sus deliberaciones y decisiones. } \\
\text { O Escrutinio sobre la vida privada de los funcionarios. } \\
\text { o Obligación de presentar declaración patrimonial, de intereses } \\
\text { y fiscal. } \\
\text { o Obligación de rendir informes y publicar planes anuales. } \\
\text { ○ Obligación de comparecer ante otros poderes. } \\
\text { ○ Obligaciones en materia de transparencia. }\end{array}$ \\
\hline Sanciones & $\begin{array}{l}\text { - Posibilidad de remoción. } \\
\text { o Sujeción al régimen de responsabilidades administrativas. } \\
\text { o Órganos competentes para juzgarlos. } \\
\text { o Posibilidad de ser sujetos a juicio político. }\end{array}$ \\
\hline
\end{tabular}

Esta obra está bajo una Licencia Creative Commons

Atribución-NoComercial-SinDerivar 4.0 Internacional, IIJ-UNAM.

Boletín Mexicano de Derecho Comparado, núm. 160, enero-abril de 2021, pp. 61-98. 


\begin{tabular}{|c|c|}
\hline Categorías & Rubros de análisis \\
\hline Premios & $\begin{array}{l}\text { O Posibilidad de reelección. } \\
\text { ○ Posibilidad de aumentar su presupuesto. } \\
\text { o Prohibición de recibir premios, condecoraciones o reconoci- } \\
\text { mientos, o de ocupar cargos diplomáticos u honoríficos. } \\
\text { o Protecciones: fuero constitucional o inmunidades penal, civil } \\
\text { o administrativa. } \\
\text { - Protección jurídica o policial para los titulares o sus parientes. }\end{array}$ \\
\hline $\begin{array}{l}\text { Autonomía } \\
\text { institucional }\end{array}$ & $\begin{array}{l}\text { O Sección de la Constitución y rango de la ley que lo regula. } \\
\text { ○ Atribuciones a su cargo y tipo de potestades que ejerce. } \\
\text { ○ Complejidad del área que regula. } \\
\text { ○ Integración de su órgano superior y mecanismos de votación. } \\
\text { ○ Posibilidad de impugnación de sus decisiones. } \\
\text { ○ Obligación de consultar sus decisiones o de coordinarse con } \\
\text { otros órganos. } \\
\text { O Intervención en el proceso legislativo que desarrolla sus fa- } \\
\text { cultades. } \\
\text { O Posibilidad de promover controversias constitucionales. } \\
\text { - Sujeción al proceso de mejora regulatoria. } \\
\text { O Presupuesto: preparación, aprobación y pago. } \\
\text { Fuentes de autofinanciamiento. } \\
\text { - Flexibilidad para contratar, disciplinar y despedir personal. }\end{array}$ \\
\hline
\end{tabular}

FUENTE: elaboración propia.

La base de datos se concentra en aquellos aspectos del diseño institucional que sirven para restringir o potenciar la autonomía por medio de medidas impuestas por otros poderes del Estado. Esto implica que el enfoque del análisis esté en los órganos superiores de gobierno; son ellos los que están sujetos a los filtros, monitoreo, premios o castigos señalados en la tabla $1 .{ }^{11}$

11 El diseño de los órganos inferiores de los OCA es crucial para cumplir su función. Sin embargo, éstos no se relacionan directamente con los tres poderes, por lo que se escapan del propósito principal de este trabajo: documentar los diferentes niveles de autonomía que cada OCA tiene vis-a-vis los poderes clásicos. 
b) Régimen jurídico común. Los datos recolectados en esta investigación permiten observar que existe un régimen de diseño común y uno diferenciado. En la tabla 2 se incluyen las características que para cada categoría se prevén en el régimen común.

Tabla 2. Régimen jurídico común de los órganos constitucionales autónomos ${ }^{12}$

\begin{tabular}{|l|l|l|}
\hline Categoría & $\begin{array}{l}\text { Rubro } \\
\text { de análisis }\end{array}$ & \multicolumn{1}{c|}{ Descripción } \\
\hline \multirow{4}{*}{ Filtros } & $\begin{array}{l}\text { Prohibiciones } \\
\text { durante el encargo } \\
\text { y al salir. }\end{array}$ & $\begin{array}{l}\text { Restricciones respecto al uso de } \\
\text { información privilegiada hasta un año } \\
\text { después de dejar el empleo. }\end{array}$ \\
\hline \multirow{2}{*}{ Monitoreo } & $\begin{array}{l}\text { Obligación } \\
\text { de presentar } \\
\text { declaraciones. }\end{array}$ & $\begin{array}{l}\text { Los funcionarios de todos los OCA están } \\
\text { obligados a presentar su declaración } \\
\text { patrimonial, de intereses y fiscal anual. }\end{array}$ \\
\cline { 2 - 3 } & $\begin{array}{l}\text { Obligación de } \\
\text { comparecer ante } \\
\text { otros poderes. }\end{array}$ & $\begin{array}{l}\text { Las cámaras del Congreso los pueden } \\
\text { convocar para que informen acerca de } \\
\text { una ley o negocio. }\end{array}$ \\
\cline { 2 - 4 } & $\begin{array}{l}\text { La Ley General de Transparencia y } \\
\text { Acceso a la Información Pública y la Ley } \\
\text { Federal de Transparencia y Acceso a la } \\
\text { Información Pública aplican a todos los } \\
\text { órganos constitucionales autónomos. }\end{array}$ \\
\cline { 2 - 3 } & $\begin{array}{l}\text { Obligaciones } \\
\text { en materia de } \\
\text { transparencia. }\end{array}$ & $\begin{array}{l}\text { La Cámara de Diputados designa a los } \\
\text { titulares de los órganos de control interno } \\
\text { de los OCA. }\end{array}$ \\
\hline
\end{tabular}

12 Fuentes utilizadas: CPEUM, arts. 74, fracción VIII, y 93; Ley General de Responsabilidades Administrativas ([LGRA], 2016, arts. 2o., fracción V, 3o., fracción X, 32, 33, 36 52, 55 y 56; Ley General de Transparencia y Acceso a la Información Pública (2015, art. 1o., párrafo 2).

Esta obra está bajo una Licencia Creative Commons

Atribución-NoComercial-SinDerivar 4.0 Internacional, IIJ-UNAM.

Boletín Mexicano de Derecho Comparado, núm. 160, enero-abril de 2021, pp. 61-98. 


\begin{tabular}{|c|c|c|}
\hline Categoría & $\begin{array}{l}\text { Rubro } \\
\text { de análisis }\end{array}$ & Descripción \\
\hline \multirow{3}{*}{ Sanciones } & $\begin{array}{l}\text { Sujeción al } \\
\text { régimen general de } \\
\text { responsabilidades } \\
\text { administrativas. }\end{array}$ & $\begin{array}{l}\text { La Ley General de Responsabilidades } \\
\text { Administrativas es aplicable a los OCA. }\end{array}$ \\
\hline & $\begin{array}{l}\text { Órganos } \\
\text { competentes para } \\
\text { juzgarlos. }\end{array}$ & $\begin{array}{l}\text { Si se trata de responsabilidad } \\
\text { administrativa, el Tribunal Federal de } \\
\text { Justicia Administrativa. Si se trata de } \\
\text { responsabilidad penal, el Poder Judicial } \\
\text { Federal. }\end{array}$ \\
\hline & $\begin{array}{l}\text { Posibilidad de los } \\
\text { titulares de ser } \\
\text { sujetos a juicio } \\
\text { político. }\end{array}$ & $\begin{array}{l}\text { La Cámara de Diputados acusa y la } \\
\text { Cámara de Senadores resuelve mediante } \\
\text { el voto de dos terceras partes de los } \\
\text { presentes. }\end{array}$ \\
\hline Premios & $\begin{array}{l}\text { Protección jurídica } \\
\text { o policial para } \\
\text { los titulares o sus } \\
\text { parientes. }\end{array}$ & $\begin{array}{l}\text { El Servicio de Protección Federal se } \\
\text { encarga de la protección de personas, } \\
\text { bienes e instalaciones. }\end{array}$ \\
\hline \multirow[b]{2}{*}{$\begin{array}{l}\text { Autonomía } \\
\text { institucional }\end{array}$} & $\begin{array}{l}\text { Posibilidad } \\
\text { de promover } \\
\text { controversias } \\
\text { constitucionales }\end{array}$ & $\begin{array}{l}\text { Cualquier OCA puede promover } \\
\text { controversias constitucionales en contra } \\
\text { de otro, del Poder Ejecutivo o del } \\
\text { legislativo. }\end{array}$ \\
\hline & $\begin{array}{l}\text { Sujeción al } \\
\text { proceso de mejora } \\
\text { regulatoria. }\end{array}$ & $\begin{array}{l}\text { La Ley General de Mejora Regulatoria } \\
\text { obliga a los OCA a inscribirse y } \\
\text { actualizar permanentemente el Catálogo } \\
\text { Nacional de Regulaciones, Trámites } \\
\text { y Servicios. Sin embargo, no están } \\
\text { obligados a presentar una agenda } \\
\text { regulatoria. }\end{array}$ \\
\hline
\end{tabular}

FUENTE: elaboración propia. 
En comparación con el régimen diferenciado, el régimen común es mínimo. Además, las pocas características compartidas se refieren a mecanismos para controlar o influir en las decisiones de los OCA, y no a garantías institucionales de autonomía.

Las dos categorías del régimen común más reguladas son las de monitoreo y sanciones, que están íntimamente conectadas; para sancionar, es necesario observar el comportamiento que se busca incentivar o desincentivar. A todos los OCA les aplican la Ley General de Transparencia y Acceso a la Información Pública, la Ley Federal de Transparencia y Acceso a la Información Pública, y la Ley General de Responsabilidades Administrativas; es decir, todos forman parte de los sistemas nacionales en materia de responsabilidades, transparencia y rendición de cuentas. Además, el Congreso puede convocar a los titulares de los OCA a comparecer y la Cámara de Diputados designa a los titulares de los órganos de control fiscal interno de estos organismos. Por otra parte, las autoridades competentes para juzgarlos son las mismas, y todos los titulares de los OCA pueden ser sujetos a juicio político.

La categoría de filtros es prácticamente nula dentro del régimen común. Esto significa que los mecanismos para evitar que personas no confiables o no capacitadas sean titulares varían según cada organismo. Por otro lado, en cuanto a la autonomía institucional, todos los OCA tienen la facultad de acudir al Poder Judicial para defender sus atribuciones. Sin embargo, esto no es suficiente para resistir a los mecanismos indirectos de control político, dentro de los que destaca el control presupuestario a cargo de la Cámara de Diputados. La única excepción es el Banxico, que aprueba su presupuesto de gasto corriente bajo un criterio de "congruencia" con el presupuesto federal. ${ }^{13}$

Lo anterior conduce a afirmar que el régimen común de los OCA no constituye un piso de autonomía común; en todo caso, sería más preciso hablar de un piso mínimo de dependencia o de control. Por ejemplo, tanto la obligación institucional de transparencia como la personal de presentar declaraciones son medios para garantizar cierta responsabilidad política, no garantías de autonomía. Esto, en definitiva, permite cuestionar el pun-

13 Ley del Banco de México ([LBM], 1993, art. 46, fracción XI). Sin embargo, véase, Ley Federal de Presupuesto y Responsabilidad Hacendaria ([LFPRH], 2006, art. 5.1).

Esta obra está bajo una Licencia Creative Commons

Atribución-NoComercial-SinDerivar 4.0 Internacional, IIJ-UNAM.

Boletín Mexicano de Derecho Comparado, núm. 160, enero-abril de 2021, pp. 61-98. 
to de vista según el que todos los OCA son homogeneizados y agrupados bajo el marco común del cuarto poder.

c) Régimen jurídico diferenciado. Así como los OCA tienen un régimen jurídico común, cada uno de ellos también tiene un régimen diferenciado. Si bien la base de datos elaborada en esta investigación incluye el régimen diferenciado de cada uno de los nueve OCA, en este artículo se utilizan como ejemplos el INE, el Banxico y la CNDH. Se eligieron estas tres instituciones porque son las figuras más recurrentes en el paradigma mundial del cuarto poder: una comisión de calificación electoral, un banco central y una comisión de derechos humanos (Bruce Ackerman, 2000, pp. 38-40; David Bilchitz y David Landau, 2018, p. 3).

Existe una abundante evidencia empírica que confirma la expansión mundial de estos tres órganos autónomos y que parece reflejar un consenso sobre las virtudes de contar con ellos. En el caso de los órganos electorales, existe un temor generalizado de que los funcionarios de elección popular manipulen las elecciones en su beneficio (Bruce Ackerman, 2000). En el caso de los bancos centrales, el consenso es apostar por políticas macroeconómicas dirigidas por expertos aislados de la política (Jan Kleineman, 2001). Finalmente, en el caso de las comisiones de derechos humanos, los Principios de París ${ }^{14}$ sugieren que éstas sean independientes por mandato legislativo o constitucional para que vigilen a los poderes clásicos del Estado.

En México, las causas que motivaron la creación de estos tres organismos fueron crisis de índole económica, social o política. La crisis inflacionaria de los años ochenta, junto con la presión de organismos multilaterales de crédito, originaron la autonomía del Banxico (Carlos Matute y Ana Luisa Hernández, 2015; Geoffrey Shepherd, 1999). La presencia por décadas de un partido hegemónico y las controvertidas elecciones presidenciales de 1988 ocasionaron la creación del Instituto Federal Electoral (ahora INE) (John Ackerman, 2007, p. 52; Lorenzo Córdova Vianello, 2011, p. 267). De manera similar, el reclamo nacional e internacional por violaciones masivas de derechos fundamentales motivó la creación de una Dirección de Derechos Humanos en 1989, que en 1999 se transformaría en la

14 Resolución 48/134 de la Asamblea General de la Organización de las Naciones Unidas, del 20 de diciembre de 1993.

Esta obra está bajo una Licencia Creative Commons Atribución-NoComercial-SinDerivar 4.0 Internacional, IIJ-UNAM. Boletín Mexicano de Derecho Comparado, núm. 160, enero-abril de 2021, pp. 61-98. 
CNDH (Jorge Carpizo, 2000, p. 28; Margaret Keck y Kathryn Sikkink, 1998, pp. 110-114; Human Rights Watch, 1993, pp. 3 у 6-9).

En las siguientes tres tablas, se resume el régimen jurídico diferenciado de estos tres OCA. Así, se busca ejemplificar los mecanismos de control en los que este tipo de órganos difieren y que, a su vez, determinan sus diferentes grados de autonomía.

Tabla 3. Régimen jurídico diferenciado del Instituto Nacional Electoral ${ }^{15}$

\begin{tabular}{|c|c|}
\hline Rubro & Descripción \\
\hline \multicolumn{2}{|l|}{ Filtros } \\
\hline $\begin{array}{l}\text { Requisitos para ser } \\
\text { integrante del órgano } \\
\text { superior. }\end{array}$ & $\begin{array}{l}\text { Ciudadano mexicano por nacimiento, sin otra nacio- } \\
\text { nalidad; buena reputación; no haber sido candidato } \\
\text { ni haber desempeñado un cargo de elección popular } \\
\text { en los últimos cuatro años; y no ser ni haber sido } \\
\text { miembro del Servicio Profesional Electoral Nacional. }\end{array}$ \\
\hline Duración en el cargo. & o Nueve años. \\
\hline $\begin{array}{l}\text { Prohibiciones durante } \\
\text { el encargo y al salir. }\end{array}$ & $\begin{array}{l}\text { Los consejeros no pueden tener otro empleo con } \\
\text { excepción de aquellos en que actúen en represent- } \\
\text { ación del INE y los no remunerados en asociaciones } \\
\text { docentes, científicas, culturales, de investigación o } \\
\text { de beneficencia. } \\
\text { Durante los dos años siguientes a la conclusión de } \\
\text { su encargo, no pueden desempeñar cargos en los } \\
\text { poderes públicos en cuya elección hayan partici- } \\
\text { pado, de dirigencia partidista, ni ser postulados a } \\
\text { cargos de elección popular. }\end{array}$ \\
\hline
\end{tabular}

15 (CPEUM, art. 41, fracción V, apartados A y D, 99, 102, inciso B, párrafo 7; Ley General de Instituciones y Procedimientos Electorales [LGIPE], 2014, arts. 36, 38, 39, inciso 1, 41, incisos 1 y 4, 43, 44, fracción 1, inciso z, 92, inciso 1, 442 y 456; Acuerdo del Consejo General del Instituto Nacional Electoral por el que se aprueba el Estatuto del Servicio Profesional Electoral Nacional y del Personal de la Rama Administrativa, 2016, art. 394, fracciones VIII, X y XI).

Esta obra está bajo una Licencia Creative Commons

Atribución-NoComercial-SinDerivar 4.0 Internacional, IIJ-UNAM.

Boletín Mexicano de Derecho Comparado, núm. 160, enero-abril de 2021, pp. 61-98. 


\begin{tabular}{|c|c|}
\hline Rubro & Descripción \\
\hline $\begin{array}{l}\text { Procedimiento para } \\
\text { el nombramiento } \\
\text { del titular o los } \\
\text { integrantes del órgano } \\
\text { superior. }\end{array}$ & $\begin{array}{l}\text { Los consejeros son electos por el voto de las dos ter- } \\
\text { ceras partes de los miembros presentes de la Cá- } \\
\text { mara de Diputados. }\end{array}$ \\
\hline \multicolumn{2}{|l|}{ Monitoreo } \\
\hline $\begin{array}{l}\text { Nivel de publicidad de } \\
\text { sus deliberaciones y } \\
\text { decisiones. }\end{array}$ & $\begin{array}{l}\text { ○ Sesiones públicas. } \\
\text { ○ El Consejo General ordena la publicación en el Dia- } \\
\text { rio Oficial de la Federación de los acuerdos y resolucio- } \\
\text { nes de carácter general que pronuncie y de aquellos } \\
\text { que así lo determine. }\end{array}$ \\
\hline $\begin{array}{l}\text { Obligación de rendir } \\
\text { informes a otros } \\
\text { poderes y de publicar } \\
\text { planes anuales. }\end{array}$ & ○ No existe. \\
\hline \multicolumn{2}{|l|}{ Sanciones } \\
\hline $\begin{array}{l}\text { Posibilidad de } \\
\text { remoción. }\end{array}$ & $\begin{array}{l}\text { - Solamente pueden ser removidos por causa grave } \\
\text { en los términos del título IV de la Constitución. }\end{array}$ \\
\hline \multicolumn{2}{|l|}{ Premios } \\
\hline $\begin{array}{l}\text { Posibilidad de } \\
\text { reelección. }\end{array}$ & ○ No podrán ser reelectos. \\
\hline $\begin{array}{l}\text { Protecciones: fuero } \\
\text { constitucional o } \\
\text { inmunidades. }\end{array}$ & $\begin{array}{l}\text { - Gozan de fuero constitucional. } \\
\text { ○ No existe disposición que proteja sus opiniones. }\end{array}$ \\
\hline \multicolumn{2}{|l|}{ Autonomía institucional } \\
\hline $\begin{array}{l}\text { Sección de la } \\
\text { Constitución y rango } \\
\text { de la ley que lo regula. }\end{array}$ & $\begin{array}{l}\text { - Previsto en el apartado A de la fracción V del ar- } \\
\text { tículo } 41 \text { de la Constitución, en el capítulo I del } \\
\text { título segundo: "De la soberanía nacional y de la } \\
\text { forma de gobierno". } \\
\text { - Regulado por la Ley General de Instituciones y Pro- } \\
\text { cedimientos Electorales. }\end{array}$ \\
\hline
\end{tabular}




\begin{tabular}{|c|c|}
\hline Rubro & Descripción \\
\hline $\begin{array}{l}\text { Atribuciones que } \\
\text { ejerce. }\end{array}$ & $\begin{array}{l}\text { - Ejerce atribuciones esencialmente regulatorias y } \\
\text { sancionadoras. Además, fiscaliza y sanciona las vio- } \\
\text { laciones a derechos político-electorales. }\end{array}$ \\
\hline $\begin{array}{l}\text { Integración de su } \\
\text { órgano superior } \\
\text { y mecanismos de } \\
\text { votación. }\end{array}$ & $\begin{array}{l}\text { El Consejo General se conforma por un consejero } \\
\text { presidente y diez consejeros electorales. Hay con- } \\
\text { sejeros del poder legislativo y representantes de los } \\
\text { partidos políticos con voz, pero sin voto, así como } \\
\text { un Secretario Ejecutivo. } \\
\text { o Se necesita la mayoría para sesionar, con la presen- } \\
\text { cia del consejero presidente. Las decisiones se to- } \\
\text { man por mayoría, salvo casos en los que explícita- } \\
\text { mente se requiere mayoría calificada. }\end{array}$ \\
\hline $\begin{array}{l}\text { Posibilidad de } \\
\text { impugnación de sus } \\
\text { decisiones. }\end{array}$ & $\begin{array}{l}\text { Las decisiones del INE pueden impugnarse ante el } \\
\text { Tribunal Electoral del Poder Judicial de la Federa- } \\
\text { ción. }\end{array}$ \\
\hline $\begin{array}{l}\text { Obligación de } \\
\text { consultar sus } \\
\text { decisiones con otros } \\
\text { órganos. }\end{array}$ & $\begin{array}{l}\text { No existe obligación para el INE de consultar sus } \\
\text { decisiones con otros órganos. }\end{array}$ \\
\hline $\begin{array}{l}\text { Presupuesto: } \\
\text { preparación, y } \\
\text { aprobación. }\end{array}$ & $\begin{array}{l}\text { - Una vez que el Consejo General aprueba el an- } \\
\text { teproyecto de presupuesto, se remite al ejecutivo } \\
\text { para su inclusión en el proyecto de Presupuesto de } \\
\text { Egresos de la Federación. Éste último es revisado y } \\
\text { aprobado por la Cámara de Diputados. }\end{array}$ \\
\hline $\begin{array}{l}\text { Flexibilidad para } \\
\text { contratar, disciplinar } \\
\text { y despedir personal } \\
\text { burocrático o asesores. }\end{array}$ & $\begin{array}{l}\text { - El INE cuenta con un servicio civil de carrera lla- } \\
\text { mado Servicio Profesional Electoral Nacional para } \\
\text { los puestos técnicos y ejecutivos. } \\
\text { - En el estatuto de dicho servicio se prevén las causas } \\
\text { del despido laboral, tales como la pérdida de con- } \\
\text { fianza, más de tres faltas injustificadas en } 30 \text { días, } \\
\text { o el incumplimiento grave o reiterado de sus fun- } \\
\text { ciones. }\end{array}$ \\
\hline
\end{tabular}

FUENTE: elaboración propia. 


\section{Tabla 4. Régimen jurídico diferenciado del Banco de México ${ }^{16}$}

\begin{tabular}{|c|c|}
\hline Rubro & Descripción \\
\hline \multicolumn{2}{|l|}{ Filtros } \\
\hline $\begin{array}{l}\text { Requisitos para } \\
\text { ser titular o } \\
\text { integrante del } \\
\text { órgano superior. }\end{array}$ & $\begin{array}{l}\text { Ciudadano mexicano por nacimiento y no haber adqui- } \\
\text { rido otra nacionalidad; reconocida competencia en mate- } \\
\text { ria monetaria; haber ocupado por lo menos durante cinco } \\
\text { años cargos de alto nivel en el sistema financiero mexica- } \\
\text { no o en instituciones que ejerzan funciones de autoridad } \\
\text { en materia financiera. El requisito de experiencia en car- } \\
\text { gos públicos es prescindible para dos miembros, siempre } \\
\text { y cuando sean destacados economistas, financieros o ju- } \\
\text { ristas. }\end{array}$ \\
\hline $\begin{array}{l}\text { Duración en el } \\
\text { cargo. }\end{array}$ & $\begin{array}{l}\text { El cargo de gobernador del Banco dura seis años y el car- } \\
\text { go de Subgobernador dura ocho años. Los periodos de los } \\
\text { subgobernadores son escalonados. El periodo del gober- } \\
\text { nador del Banco comienza el 1o. de enero del cuarto año } \\
\text { calendario del periodo correspondiente al presidente de } \\
\text { la República. }\end{array}$ \\
\hline $\begin{array}{l}\text { Prohibiciones } \\
\text { durante el } \\
\text { encargo y al } \\
\text { salir. }\end{array}$ & $\begin{array}{l}\text { No pueden ocupar otros cargos con excepción de aquellos } \\
\text { en los que actúen en representación del Banco y de los no } \\
\text { remunerados en asociaciones docentes, científicas, cultu- } \\
\text { rales o de beneficencia. }\end{array}$ \\
\hline $\begin{array}{l}\text { Procedimiento } \\
\text { para el } \\
\text { nombramiento } \\
\text { del titular o los } \\
\text { integrantes del } \\
\text { órgano superior. }\end{array}$ & $\begin{array}{l}\text { - La designación de los miembros de la Junta de Gobierno } \\
\text { se lleva a cabo por el presidente, con aprobación de la Cá- } \\
\text { mara de Senadores o de la Comisión Permanente. }\end{array}$ \\
\hline
\end{tabular}

16 (CPEUM, art. 28, párrafo 7; LBM, artículos 2, 21, 38, 39, 40, 43, 44-47, fracción XIII, 51, y 55; Ley Federal de Procedimiento Administrativo, 1994, art. 3; Ley Federal de Presupuesto y Responsabilidad Hacendaria, 2006, art. 5).

Esta obra está bajo una Licencia Creative Commons Atribución-NoComercial-SinDerivar 4.0 Internacional, IIJ-UNAM. Boletin Mexicano de Derecho Comparado, núm. 160, enero-abril de 2021, pp. 61-98. 


\begin{tabular}{|c|c|}
\hline Rubro & Descripción \\
\hline \multicolumn{2}{|l|}{ Monitoreo } \\
\hline $\begin{array}{l}\text { Nivel de } \\
\text { publicidad } \\
\text { de sus } \\
\text { deliberaciones y } \\
\text { decisiones. }\end{array}$ & $\begin{array}{l}\text { - Las deliberaciones en principio son confidenciales y sólo } \\
\text { con la autorización expresa de la Junta de Gobierno se } \\
\text { puede efectuar alguna comunicación sobre los asuntos } \\
\text { que se tratan en sus sesiones. }\end{array}$ \\
\hline $\begin{array}{l}\text { Obligación de } \\
\text { rendir informes } \\
\text { a otros poderes } \\
\text { y de publicar } \\
\text { planes anuales. }\end{array}$ & $\begin{array}{l}\text { O Informes trimestrales al Ejecutivo y al Congreso, respecto } \\
\text { a la inflación, la evolución económica, la política moneta- } \\
\text { ria y las actividades del propio Banco. } \\
\text { o Exposición anual ante el Ejecutivo y Congreso sobre la } \\
\text { política monetaria a seguir en el ejercicio respectivo. } \\
\text { O Informe anual al Congreso sobre el ejercicio de las atri- } \\
\text { buciones conferidas por la Ley para la Transparencia y } \\
\text { Ordenamiento de los Servidores Financieros. } \\
\text { - El gobernador debe rendir un informe anual ante las } \\
\text { comisiones del Senado. }\end{array}$ \\
\hline \multicolumn{2}{|l|}{ Sanciones } \\
\hline $\begin{array}{l}\text { Posibilidad de } \\
\text { remoción }\end{array}$ & $\begin{array}{l}\text { - La solicitud de remoción de los miembros de la Junta de } \\
\text { Gobierno se presenta por el presidente de la República } \\
\text { o dos miembros de la Junta de Gobierno, según causales } \\
\text { establecidas en la Ley del Banco de México. El presidente } \\
\text { da su opinión y la remite al Senado para la resolución } \\
\text { definitiva. }\end{array}$ \\
\hline \multicolumn{2}{|l|}{ Premios } \\
\hline $\begin{array}{l}\text { Posibilidad de } \\
\text { reelección. }\end{array}$ & $\begin{array}{l}\text { O Reelección ilimitada, siempre y cuando no tengan } 65 \text { años } \\
\text { al inicio del periodo. }\end{array}$ \\
\hline $\begin{array}{l}\text { Protecciones: } \\
\text { fuero } \\
\text { constitucional o } \\
\text { inmunidades. }\end{array}$ & ○ No tienen fuero. \\
\hline
\end{tabular}

Esta obra está bajo una Licencia Creative Commons

Atribución-NoComercial-SinDerivar 4.0 Internacional, IIJ-UNAM.

Boletín Mexicano de Derecho Comparado, núm. 160, enero-abril de 2021, pp. 61-98. 


\begin{tabular}{|c|c|}
\hline Rubro & Descripción \\
\hline \multicolumn{2}{|c|}{ Autonomía institucional } \\
\hline $\begin{array}{l}\text { Sección de la } \\
\text { Constitución y } \\
\text { rango de la ley } \\
\text { que lo regula. }\end{array}$ & $\begin{array}{l}\text { - Previsto en los párrafos sexto y séptimo del artículo } 28 \text { de } \\
\text { la CPEUM, en el capítulo I del título primero: "De los } \\
\text { derechos humanos y sus garantías." } \\
\text { o Regulado por la Ley del Banco de México. }\end{array}$ \\
\hline $\begin{array}{l}\text { Atribuciones } \\
\text { que ejerce. }\end{array}$ & $\begin{array}{l}\text { ○ Atribuciones esencialmente regulatorias e informativas. } \\
\text { ○ Proveer al país de moneda nacional y procurar la estabili- } \\
\text { dad del poder adquisitivo de la misma. } \\
\text { ○ Propiciar el sano desarrollo del sistema financiero y de los } \\
\text { sistemas de pagos. }\end{array}$ \\
\hline $\begin{array}{l}\text { Integración } \\
\text { de su órgano } \\
\text { superior y } \\
\text { mecanismos de } \\
\text { votación. }\end{array}$ & $\begin{array}{l}\text { - La Junta de Gobierno se conforma por cinco miembros, } \\
\text { que incluyen al Gobernador del Banco. } \\
\text { - El quórum es de por lo menos tres de sus miembros. Se } \\
\text { requiere aprobación de la mayoría de los presentes. }\end{array}$ \\
\hline $\begin{array}{l}\text { Posibilidad de } \\
\text { impugnación de } \\
\text { sus decisiones. }\end{array}$ & $\begin{array}{l}\text { - Cuando sus decisiones son actos jurídicos administrativos, } \\
\text { éstas pueden ser impugnadas por vía judicial o adminis- } \\
\text { trativa. }\end{array}$ \\
\hline $\begin{array}{l}\text { Obligación de } \\
\text { consultar sus } \\
\text { decisiones con } \\
\text { otros órganos. }\end{array}$ & $\begin{array}{l}\text { - El secretario y el subsecretario de Hacienda y Crédito Pú- } \\
\text { blico tienen voz, pero no tienen voto. } \\
\text { - La Comisión de Cambios, encargada de la política cam- } \\
\text { biaria, es un órgano mixto presidido por el Secretario de } \\
\text { Hacienda, y conformado por tres miembros de la admi- } \\
\text { nistración pública y tres miembros del Banco. }\end{array}$ \\
\hline $\begin{array}{l}\text { Presupuesto: } \\
\text { preparación, y } \\
\text { aprobación. }\end{array}$ & $\begin{array}{l}\text { El Banco cuenta con su propio presupuesto, el cual debe } \\
\text { ser congruente con el federal. Sin embargo, anualmente } \\
\text { debe entregar su remanente - una vez constituidas las } \\
\text { reservas- al gobierno federal. } \\
\text { o Puede hacer adecuaciones a su presupuesto sin requerir } \\
\text { autorización de la Secretaría de Hacienda y Crédito Pú- } \\
\text { blico. }\end{array}$ \\
\hline
\end{tabular}




\begin{tabular}{|l|l|}
\hline Rubro & Descripción \\
\hline $\begin{array}{l}\text { Flexibilidad } \\
\text { para contratar, } \\
\text { disciplinar } \\
\text { y despedir } \\
\text { personal } \\
\text { burocrático o } \\
\text { asesores. }\end{array}$ & $\begin{array}{l}\text { Al Gobernador le corresponde designar y remover a todo } \\
\text { el personal, excepto a los tres primeros niveles jerárquicos. } \\
\text { También le corresponde fijar, en función de los tabula- } \\
\text { dores aprobados por la Junta de Gobierno, los sueldos del } \\
\text { personal. }\end{array}$ \\
\hline
\end{tabular}

FUENTE: elaboración propia.

Tabla 5. Régimen jurídico diferenciado de la Comisión Nacional de Derechos Humanos ${ }^{17}$

\begin{tabular}{|l|l|}
\hline Rubro & Descripción \\
\hline \multicolumn{2}{|l|}{ Filtros } \\
\hline $\begin{array}{l}\text { Requisitos para ser } \\
\text { titular o integrante } \\
\text { del órgano superior. }\end{array}$ & $\begin{array}{l}\text { ○ Ciudadano mexicano por nacimiento; experien- } \\
\text { cia en materia de derechos humanos o actividades } \\
\text { afines; no desempeñar ni haber desempeñado cargos } \\
\text { públicos en el año anterior a su elección; y buena } \\
\text { reputación. }\end{array}$ \\
\hline $\begin{array}{l}\text { Duración en el } \\
\text { cargo. }\end{array}$ & ○ Cinco años. \\
\hline $\begin{array}{l}\text { Prohibiciones } \\
\text { durante el encargo y } \\
\text { al salir. }\end{array}$ & $\begin{array}{l}\text { O Las funciones del presidente de la CNDH son in- } \\
\text { compatibles con el desempeño de cualquier otro car- } \\
\text { go, exceptuando las actividades académicas. }\end{array}$ \\
\hline
\end{tabular}

17 (CPEUM, artículo 102, apartado B, párrafos 7, 10 y 11; Ley de la Comisión Nacional de los Derechos Humanos [LCNDH], 1992, arts. 5, 9, 10, 12, artículo 15, fracciones VII-X, 17, 20, 13, 46, 52 y 76; Reglamento Interno de la Comisión Nacional de los Derechos Humanos, 2003, arts. 8 y 21).

Esta obra está bajo una Licencia Creative Commons

Atribución-NoComercial-SinDerivar 4.0 Internacional, IIJ-UNAM.

Boletín Mexicano de Derecho Comparado, núm. 160, enero-abril de 2021, pp. 61-98. 


\begin{tabular}{|c|c|}
\hline Rubro & Descripción \\
\hline $\begin{array}{l}\text { Procedimiento para } \\
\text { el nombramiento } \\
\text { del titular o los } \\
\text { integrantes del } \\
\text { órgano superior. }\end{array}$ & $\begin{array}{l}\text { - El presidente es elegido por el voto de dos terceras } \\
\text { partes de los miembros presentes de la Cámara de } \\
\text { Senadores o la Comisión Permanente. }\end{array}$ \\
\hline \multicolumn{2}{|l|}{ Monitoreo } \\
\hline $\begin{array}{l}\text { Nivel de publicidad } \\
\text { de sus deliberaciones } \\
\text { y decisiones. }\end{array}$ & $\begin{array}{l}\text { - En la Gaceta de la Comisión Nacional de los } \\
\text { Derechos Humanos, mensualmente se publican las } \\
\text { recomendaciones, documentos, informes y materi- } \\
\text { ales varios que, por su importancia, deban darse a } \\
\text { conocer. }\end{array}$ \\
\hline $\begin{array}{l}\text { Obligación de rendir } \\
\text { informes a otros } \\
\text { poderes y de publicar } \\
\text { planes anuales. }\end{array}$ & - Informe anual ante los tres poderes. \\
\hline \multicolumn{2}{|l|}{ Sanciones } \\
\hline $\begin{array}{l}\text { Posibilidad de } \\
\text { remoción. }\end{array}$ & $\begin{array}{l}\text { - El presidente solamente puede ser removido por } \\
\text { causa grave en los términos del título IV de la } \\
\text { Constitución. }\end{array}$ \\
\hline \multicolumn{2}{|l|}{ Premios } \\
\hline $\begin{array}{l}\text { Posibilidad de } \\
\text { reelección. }\end{array}$ & ○ El presidente puede ser reelecto una sola vez. \\
\hline $\begin{array}{l}\text { Protecciones: fuero } \\
\text { constitucional o } \\
\text { inmunidades. }\end{array}$ & $\begin{array}{l}\text { No tiene fuero constitucional. } \\
\text { - El presidente de la CNDH y los visitadores generales } \\
\text { no pueden ser sujetos a responsabilidad civil, penal o } \\
\text { administrativa, por las opiniones y recomendaciones } \\
\text { que formulen, o por los actos que realicen, en ejerci- } \\
\text { cio sus funciones. }\end{array}$ \\
\hline
\end{tabular}




\begin{tabular}{|c|c|}
\hline Rubro & Descripción \\
\hline \multicolumn{2}{|c|}{ Autonomía institucional } \\
\hline $\begin{array}{l}\text { Sección de la } \\
\text { Constitución y rango } \\
\text { de la ley que lo } \\
\text { regula. }\end{array}$ & $\begin{array}{l}\text { - Prevista en el apartado B del artículo } 102 \text { de la } \\
\text { Constitución, dentro del capítulo IV "Del Poder } \\
\text { Judicial". } \\
\text { Regulada por La Ley de la Comisión Nacional de } \\
\text { los Derechos Humanos. }\end{array}$ \\
\hline $\begin{array}{l}\text { Atribuciones que } \\
\text { ejerce. }\end{array}$ & $\begin{array}{l}\text { Ejerce atribuciones de investigación, recomendación } \\
\text { y denuncia. Conoce de quejas en contra de actos u } \\
\text { omisiones de cualquier autoridad (con excepción del } \\
\text { Poder Judicial) que violen los derechos humanos. } \\
\text { Formula recomendaciones públicas no vinculatorias, } \\
\text { así como denuncias y quejas ante las autoridades res- } \\
\text { pectivas. }\end{array}$ \\
\hline $\begin{array}{l}\text { Integración de su } \\
\text { órgano superior } \\
\text { y mecanismos de } \\
\text { votación. }\end{array}$ & $\begin{array}{l}\text { El Consejo Consultivo está integrado por diez perso- } \\
\text { nas y es presidido por el presidente de la CNDH. El } \\
\text { Consejo toma sus decisiones por mayoría de votos de } \\
\text { los miembros presentes. } \\
\text { O El presidente cuenta con funciones unipersonales } \\
\text { como emitir o aprobar recomendaciones o interpo- } \\
\text { ner acciones de inconstitucionalidad ante la SCJN. } \\
\text { - Además, la CNDH se integra por una secretaría eje- } \\
\text { cutiva, visitadores generales, así como el número de } \\
\text { visitadores adjuntos y personal profesional, técnico } \\
\text { y administrativo necesario para la realización de sus } \\
\text { funciones. }\end{array}$ \\
\hline $\begin{array}{l}\text { Posibilidad de } \\
\text { impugnación de sus } \\
\text { decisiones. }\end{array}$ & $\begin{array}{l}\text { - La SCJN ha determinado que las recomendaciones } \\
\text { de la CNDH no son impugnables mediante juicio de } \\
\text { amparo. }^{18}\end{array}$ \\
\hline
\end{tabular}

18 Amparo en revisión (AR) 448/2015. Primera Sala de la SCJN. 2015. 7/10/2015; Segunda Sala de la SCJN. AR 1066/2015. Primera Sala de la SCJN. 6/04/2016 y. AR 648/2017. Segunda Sala de la SCJN. 25/10/2017.

Esta obra está bajo una Licencia Creative Commons

Atribución-NoComercial-SinDerivar 4.0 Internacional, IIJ-UNAM.

Boletín Mexicano de Derecho Comparado, núm. 160, enero-abril de 2021, pp. 61-98. 


\begin{tabular}{|c|c|}
\hline Rubro & Descripción \\
\hline $\begin{array}{l}\text { Obligación de } \\
\text { consultar sus } \\
\text { decisiones con otros } \\
\text { órganos. }\end{array}$ & $\begin{array}{l}\text { - La CNDH puede solicitar a la Cámara de Senadores } \\
\text { o a las legislaturas estatales, se llame a comparecer a } \\
\text { las autoridades responsables, para explicar el motivo } \\
\text { de su rechazo a cierta recomendación emitida por la } \\
\text { Comisión. }\end{array}$ \\
\hline $\begin{array}{l}\text { Presupuesto: } \\
\text { preparación, y } \\
\text { aprobación. }\end{array}$ & $\begin{array}{l}\text { El presidente de la CNDH remite el anteproyecto de } \\
\text { presupuesto de egresos de la comisión a la Secretaría } \\
\text { de Hacienda. Después, con base en el proyecto re- } \\
\text { mitido por el presidente de la República, el presu- } \\
\text { puesto es modificado o aprobado por la Cámara de } \\
\text { Diputados. }\end{array}$ \\
\hline $\begin{array}{l}\text { Flexibilidad para } \\
\text { contratar, disciplinar } \\
\text { y despedir personal } \\
\text { burocrático o } \\
\text { asesores. }\end{array}$ & $\begin{array}{l}\text { O Corresponde al presidente de la GNDH nombrar y } \\
\text { remover libremente a todo el personal. }\end{array}$ \\
\hline
\end{tabular}

FUENTE: elaboración propia.

El contraste de estos tres organismos revela con claridad elementos relevantes del régimen diferenciado en cada una de las cinco categorías. Dentro de los filtros, el requisito de pericia técnica - principal fundamento para distanciarlos de los poderes clásicos-, no es estricto. Quizás con el objetivo de ciudadanizar al órgano electoral, no existe requisito de estudios o experiencia para ser consejero. Esta falta de filtro puede matizarse por el Comité Técnico que evalúa a los candidatos a consejeros (CPEUM, art. 41, apartado V, inciso a). Para Banxico, si bien no hay requisitos formales de estudios para formar parte de la Junta de Gobierno, los aspirantes deben contar con reconocida competencia en materia monetaria y haber ocupado un cargo de autoridad financiera por cinco años; de este último requisito puede eximírsele a dos miembros. Finalmente, para ser presidente de la GNDH se requiere experiencia en materia de derechos humanos; 
ésta podría ser, por ejemplo, haber sido activista. Entonces, de los tres mecanismos de filtros, los más demandantes son los del Banxico.

En cuanto al monitoreo, el Banxico, a diferencia del INE y la GNDH, es monitoreado desde muchos ángulos. El INE no tiene obligación de rendir informe alguno. La CNDH solamente debe rendir un informe anual ante los tres poderes. En claro contraste, el Banxico es controlado por medio de los cuatro informes ante los poderes ejecutivo y legislativo señalados en la tabla 4.

Otro aspecto notable del monitoreo es la obligación de publicidad de las deliberaciones y decisiones de los OCA. La obligación más estricta corresponde al INE, pues las sesiones de todos sus órganos de dirección son públicas; además de que debe ordenar la publicación de sus decisiones de carácter general. En un nivel intermedio está la GNDH, que publica mensualmente aquellas recomendaciones, documentos, informes y materiales que por su trascendencia deben ser públicas. El menor grado de publicidad corresponde a las deliberaciones del Banxico; que en principio son confidenciales y sólo con la autorización expresa de la Junta de Gobierno se puede comunicar algún asunto tratado.

En la categoría de sanciones, el Banxico es único porque sólo este organismo cuenta con un mecanismo especial de remoción de sus miembros. El presidente de la República o dos subgobernadores pueden iniciar este procedimiento por una de las causales previstas en la ley (LBM, arts. 43 y 44). La resolución es emitida por el Senado, o en su caso, la Comisión Permanente, por mayoría absoluta. En cambio, en el juicio político, mecanismo accesible para remover a otros titulares de OCA, intervienen ambas cámaras del Congreso y la resolución se da por mayoría calificada del Senado. Entonces, en el caso del Banxico bastaría que el presidente contara con dos subgobernadores aliados para iniciar un golpe de Estado en contra de un miembro incómodo de la Junta de Gobierno. Si se obtiene mayoría dentro de ésta última, el asunto pasaría al Senado. Con una mayoría regular del Senado se concretaría el golpe. Esta remoción fast-track jamás podría suceder con los titulares del INE o la CNDH.

Por otra parte, en la categoría de premios, el INE y la GNDH tienen un trato privilegiado. Los consejeros del INE son los únicos que gozan de fuero, es decir, inmunidad penal ordenada por la Constitución respecto a cualquier tipo de delito durante su encargo; siendo la Cámara de Di- 
putados la única competente para remover esta protección. ${ }^{19}$ De manera similar, los altos funcionarios de la CNDH cuentan con inviolabilidad de opinión otorgada por ley; lo que significa que las opinione ${ }^{20}$ de su Presidente o los visitadores en ejercicio de sus funciones no pueden dar lugar a sanciones jurídicas, ni siquiera de naturaleza civil (LCNDH, art. 13). La Ley Federal de Responsabilidad Patrimonial del Estado confirma esta protección que distingue a la GNDH de cualquier otro OCA (art. 2o., último párrafo).

A esta protección subyace una justificación análoga a la inviolabilidad de los legisladores: los defensores de derechos humanos deben poder conducirse con la más amplia libertad posible y estar escudados respecto a represalias por criticar a otros funcionarios. En cambio, un subgobernador del Banxico podría ser procesado penalmente o ser obligado a pagar una indemnización civil por opiniones difamatorias. Quizá el legislador decidió otorgar especial protección a servidores públicos cuyas funciones son más políticas que técnicas. ¿Pero por qué no brindó inviolabilidad de opinión a los consejeros electorales o fuero al presidente de la GNDH? La decisión parece cuando menos, coyuntural. Dado este trato diferenciado, un escéptico podría argumentar que basta crear la supuesta comisión de un delito para presionar a un funcionario del Banxico mediante un procedimiento penal.

Por último, en cuanto a su autonomía institucional, la Junta de Gobierno del Banxico se compone de cinco integrantes, mientras que los órganos superiores del INE y la GNDH tienen once. Esta diferenciación puede interpretarse como un mayor poder individual para cada uno de los integrantes de la Junta del Banxico. Sin embargo, la composición aparentemente colegiada de la GNDH desaparece en vista de las facultades individuales de su presidente, del carácter consultivo $-\mathrm{y}$ no autoritativo- del Consejo y de la calidad honoraria de sus diez miembros. Puede existir una convención política de que el presidente tome en cuenta al Consejo, pero a falta de disposición legal, tal convención puede ser vio-

19 Así, se protege a funcionarios de ataques políticos, independientemente de que el presunto delito esté o no relacionado con sus funciones (Felipe Tena Ramírez, 1978, pp. 583-587).

20 La GNDH puede, incluso, declarar responsable de violaciones a derechos humanos a alguien que la justicia penal exoneró. Véase (CNDH, 2016).

Esta obra está bajo una Licencia Creative Commons Atribución-NoComercial-SinDerivar 4.0 Internacional, IIJ-UNAM. Boletin Mexicano de Derecho Comparado, núm. 160, enero-abril de 2021, pp. 61-98. 
lada sin consecuencias jurídicas. ${ }^{21}$ Si se parte de la premisa de que, a menor número de miembros, mayor es la autonomía que recae en cada uno, entonces el presidente de la GNDH sería un ente sumamente autónomo.

La posibilidad de impugnación de las decisiones es otro factor que debilita o fortalece la autonomía. Las decisiones y normas del INE no sólo son impugnables, sino que existe todo un sistema contencioso-electoral mediante el que pueden revocarse. Algunas decisiones del Banxico pueden también ser impugnadas en sede administrativa. En cambio, la imposibilidad de impugnar las recomendaciones de la CNDH sugiere que, en este sentido, ésta cuenta con el mayor grado de autonomía.

$\mathrm{El}$ aspecto anterior debe entenderse junto con otro relevante factor que determina el grado de autonomía de una institución: la obligatoriedad de sus decisiones. Un órgano que no puede imponer sus decisiones al momento de dictarlas tiene más necesidad de persuadir y considerar las posibles reacciones de los destinatarios. Por ejemplo, si bien las resoluciones de la GNDH son inatacables, éstas no son vinculantes. Bajo este entendimiento, el Banxico tiene el grado intermedio de autonomía: decisiones impugnables pero obligatorias.

La obligación de consultar o coordinarse con otros entes públicos también influye en la autonomía institucional. Cuando otros funcionarios intervienen, entonces la decisión originaria del órgano de gobierno puede modificarse. Esto resulta claro cuando los otros funcionarios dependen jerárquicamente del Poder Ejecutivo, como ocurre en el caso del Banxico y su relación con la Secretaría de Hacienda. Tanto el secretario como el subsecretario de Hacienda pueden dar su opinión y proponer temas a tratar en las reuniones de la Junta de Gobierno. Además, la Junta debe acatar lo decidido por la Comisión de Cambios, un órgano presidido por el Secretario de Hacienda y conformado por tres miembros de la administración pública y tres del Banco. Aun si los miembros del Banco votan en bloque, para que prevalezcan deben obtener al menos un voto del Poder Ejecutivo.

En la CNDH, la interacción entre el presidente, el Consejo Consultivo y los órganos externos puede llegar a ser ríspida. El Consejo, siendo parte de la misma Comisión, puede incidir en temas como el reglamento inter-

21 Esto sucedió, por ejemplo, cuando el ombudsperson impugnó la reforma que despenalizó la interrupción del embarazo en el Distrito Federal. Véase (GIRE A.C., 2009, p. 17).

Esta obra está bajo una Licencia Creative Commons

Atribución-NoComercial-SinDerivar 4.0 Internacional, IIJ-UNAM.

Boletín Mexicano de Derecho Comparado, núm. 160, enero-abril de 2021, pp. 61-98. 
no, los lineamientos generales o las recomendaciones. Puede, por ejemplo, cuestionar el informe del presidente o pedir información adicional sobre las investigaciones en curso. Por otro lado, el Senado puede negarse a citar a comparecer a funcionarios que hayan rechazado una recomendación (LCNDH, arts. 15, fracción X, y 46). Esta posibilidad de inacción del legislador pone en entredicho la aseveración genérica - cuando la autonomía se ve a la luz de la postura predominante - de que la GNDH es demasiado autónoma (José Ma. Serna, 2018, p. 236).

En cambio, en el caso del INE, los consejeros del poder legislativo y los representantes de los partidos políticos tienen voz, pero no voto. De ahí que, en comparación con el INE, la autonomía de Banxico en su toma de decisiones se vea reducida. Para un escéptico, la composición mixta de la Comisión de Cambios sería una invasión por parte del Poder Ejecutivo; para un optimista, sería una colaboración armoniosa entre poderes y órganos autónomos. El problema puede darse cuando los motivos políticos del gobierno en turno prevalezcan sobre los argumentos técnicos.

Finalmente, la autonomía presupuestaria es la insignia del Banxico (Banco de México, 2019) y funciona como un escudo respecto de amenazas políticas que podrían traducirse en reducciones presupuestarias. El Banxico es el único OCA que cuenta con su propio presupuesto. ${ }^{22}$ Este aspecto de la autonomía es su mayor fortaleza vis-à-vis los otros dos órganos.

Este análisis ejemplifica el régimen diferenciado de los OCA en México, poniendo de manifiesto que estos órganos no son completa ni igualmente independientes. Diferentes diseños producen distintos tipos y niveles de autonomía. Es difícil determinar a priori cuál es la causa de estas distinciones; el régimen diferenciado podría ser consecuencia del tipo de funciones que tiene cada órgano, de las preferencias de un grupo de interés o, incluso, del ingenio de un asesor legislativo. Cualquiera de estas opciones es una posibilidad, y en ausencia de evidencia a favor de una u otra, es mejor dejar este problema para otra ocasión.

22 Si bien el remanente que obtenga debe ser entregado al gobierno federal, no queda claro cuál es el órgano competente para etiquetarlo dentro del presupuesto (Nayeli Meza Orozco, 2016). 


\section{IMPLICACIONES DEL RÉGIMEN COMÚN Y DIFERENCIADO}

La postura predominante ha sido defendida, entre otros actores, por la SCJN, que a su vez se ha inspirado en fuentes académicas que defienden la tesis homogeneizadora de la autonomía. Esto ha ocurrido en al menos tres ocasiones: las controversias constitucionales 32/2005, 31/2006 y $117 / 2014 .^{23}$ En la primera, un municipio impugnó la creación de un OCA local dedicado a la transparencia. La Corte sostuvo que la creación de los OCA no viola la separación de poderes, sino que la robustece porque su esencia es controlar a los entes públicos. Agregó que este tipo de órganos son parte de la "teoría constitucional moderna" (CC32/2005, nota 7, p. 97) surgida en Europa. La Corte, siguiendo la misma línea que GarcíaPelayo, determinó que estos órganos se caracterizan por estar establecidos y configurados directamente en la Constitución; mantener relaciones de coordinación con los otros órganos del Estado; contar con autonomía e independencia funcional y financiera, y atender funciones coyunturales que requieran ser eficazmente atendidas. (CG32/2005, pp. 95 y 96

En la segunda controversia mencionada, el Tribunal Electoral del entonces Distrito Federal demandó a la Asamblea Legislativa y al jefe de Gobierno alegando que ciertas medidas presupuestarias invadían su autonomía financiera. Además de retomar las características mencionadas en el párrafo anterior, la Corte señaló que los OCA surgen en Europa como consecuencia de una nueva concepción del poder y del "equilibrio institucional"; gozan de independencia para realizar funciones que requieren autonomía de los poderes clásicos; y se encuentran a la par de los órganos tradicionales (CC31/2006. Pleno de la SCJN. 7/11/2006, pp. 91 y 92).

En la tercera controversia referida, el Senado argumentó que el Instituto Federal de Telecomunicaciones (IFT) había excedido su facultad reglamentaria al expedir el Acuerdo de Portabilidad Numérica (CG117/2014, nota 8). La Corte ya no sólo analizó a los OCA desde la perspectiva de la teoría constitucional europea, sino que acudió a las agencias independientes estadounidenses. Sin embargo, en lugar de analizar cada OCA a la luz

23 Además, esta premisa de autonomía plena puede observarse en varias sentencias de la SCJN en las que se ha controlado la legalidad de los actos de los OCA. Véase. Contradicción de Tesis 183/2017. Primera Sala de la SCJN 10/01/2018 y AR1100/2015. 16/08/2017.

Esta obra está bajo una Licencia Creative Commons

Atribución-NoComercial-SinDerivar 4.0 Internacional, IIJ-UNAM.

Boletín Mexicano de Derecho Comparado, núm. 160, enero-abril de 2021, pp. 61-98. 
de sus características específicas, los agrupó y asimiló a las agencias reguladoras creadas en Estados Unidos. El Pleno enmarcó, al mismo tiempo, al IFT dentro del concepto de "Estado regulador" (CG117/2014, p. 97) y de la "nueva ingeniería constitucional" (CG117/2014, p. 84). Además, sostuvo que los OCA se encargan de "regular técnicamente ciertos mercados o sectores de manera independiente únicamente por referencia a racionalidades técnicas especializadas" (CG117/2014, p. 108).

Estas definiciones reflejan la concepción equivocada de que los OCA son completa e igualmente autónomos. En la práctica, la autonomía depende de varios factores que varían en cada organismo, dentro de los que destaca el diseño institucional. Diferentes diseños producirán, ceteris paribus, diferentes tipos de comportamiento.

La diferencia en los filtros, instrumentos de monitoreo, premios y castigos de los OCA que se ha mostrado en este artículo hace imposible sostener que, de hecho, estos organismos sean completa e igualmente autónomos. Si bien existe un régimen común, este régimen es mínimo en comparación con el régimen diferenciado.

Si la concepción de los OCA como entidades completa e igualmente autónomas está equivocada, procede entonces preguntarse cuál es la concepción correcta de estos organismos. Esta investigación demuestra que los OCA no pueden definirse por el tipo de funciones que ejercen, ni por su nivel general de independencia. Por un lado, la mayoría de los OCA ejercen una combinación de potestades normativas, ejecutivas y cuasi-jurisdiccionales. Incluso si existiera un criterio objetivo para determinar una función preponderante, ésta sería diferente para cada OCA, lo que impediría que funcionara como un criterio útil para definirlos. Por otro lado, como se ha demostrado, dado que existe una gran variabilidad en el diseño institucional de los OCA, no hay un modelo general que pueda caracterizarlos.

En cambio, lo que sí caracteriza a los OCA es su existencia fuera de la jerarquía de los poderes ejecutivos, legislativo y judicial, y el control indirecto que éstos ejercen por medio de comparecencias, presupuesto, fiscalización, remoción e intermediación, entre otras cuestiones. En todo caso, este control indirecto tiene diferentes grados y modalidades en cada órgano.

Las implicaciones de este trabajo para la investigación de las causas y consecuencias de los OCA en el sistema constitucional, así como del tra- 
tamiento jurídico que deberían recibir, son al menos tres. En primer lugar, conocer el diferente nivel de autonomía de cada OCA expande el rango de preguntas relevantes. Si antes de esta investigación la discusión se centraba en porqué tener OCA, este trabajo da lugar a otras preguntas como cuánta autonomía debe concedérseles y cuál es el diseño idóneo para cada órgano.

En segundo lugar, este trabajo ha demostrado que la autonomía tiene tanto beneficios como costos. Esto significa que el punto óptimo de autonomía nunca es absoluto, sino que representa un equilibrio que depende de las funciones que un órgano ejerce, la materia que regula o vigila, entre otras variables.

En tercer lugar, el conocimiento de la diversidad de diseños institucionales que existen en estos organismos puede ser una poderosa crítica - y el fundamento de una futura reconstrucción - de la dogmática constitucional y administrativa como se entiende actualmente. Como se analizó en este apartado, la deferencia que la SGJN le ha concedido a los OCA se fundamenta en la idea de que se trata de instituciones completa e igualmente independientes, cuando en realidad tienen diferentes diseños institucionales y, por lo tanto, distintos grados de autonomía. Si esto ocurre en la realidad, entonces la autonomía plena de estos organismos no puede ser el fundamento de estas decisiones y, quizás, el grado de deferencia que se les le otorgue no debería ser el mismo.

\section{CONCLUSIONES Y PREGUNTAS PARA FUTURAS INVESTIGACIONES}

Ya sea por sus logros o por sus deficiencias, la autonomitis mexicana es un fenómeno digno de estudio. Este artículo es el primer paso en la sistematización del complejo marco normativo de los OCA en México. El principal resultado de esta investigación es la documentación de un régimen jurídico común y otro diferenciado. Hasta antes de este trabajo, ambos regímenes se encontraban dispersos en múltiples disposiciones constitucionales, leyes generales, leyes federales, leyes orgánicas, reglamentos, estatutos y precedentes judiciales. Además, la visión preponderante según la que los OCA son entidades completa e igualmente autónomas ha operado como un obstáculo para distinguir que en realidad las disposiciones jurídicas que son aplicables a todo el conjunto de OCA son escasas.

Esta obra está bajo una Licencia Creative Commons

Atribución-NoComercial-SinDerivar 4.0 Internacional, IIJ-UNAM.

Boletín Mexicano de Derecho Comparado, núm. 160, enero-abril de 2021, pp. 61-98. 
Este reducido régimen común de los OCA podría estar justificado en los principios de preponderancia legislativa y de imperio de la ley como elemento esencial del Estado de derecho. Las comparecencias, la dependencia presupuestaria y el juicio político son medios que el Congreso puede usar para evitar que el comportamiento de los OCA se aleje de sus preferencias. Por otro lado, el régimen común de responsabilidades para los servidores públicos garantiza que nadie esté por encima de la ley.

La contribución del enfoque metodológico desarrollado en este trabajo para el debate sobre el cuarto poder en México es la identificación de que, en medio de estas islas de régimen común, existe un océano de normas que constituyen el régimen diferenciado. Éste, en ocasiones, puede ser producto de una serie de cambios coyunturales y carentes de una lógica institucional clara. En otras, sin embargo, puede constituir un esquema deliberado en el que el grado de autonomía o responsabilidad de cada órgano ha sido calibrado de manera razonada según sus funciones específicas. En futuros trabajos de investigación, podría analizarse hasta qué grado este régimen diferenciado se explica por la diversidad y la naturaleza de las tareas que se atribuyen a estos organismos.

La documentación de estos dos regímenes pone en serio cuestionamiento la afirmación genérica de que todos los OCA son completa e igualmente independientes. Esto es incorrecto como afirmación descriptiva y también como afirmación aspiracional; los OCA mexicanos no son ni deberían ser completa e igualmente independientes.

Existen muchas vías por explorar en el ámbito de los OCA. Dado que el camino por delante está lleno de obstáculos, callejones sin salida y no pocas trampas, sería insensato recorrerlo sin un buen mapa. Este trabajo ha sido un intento por construir este mapa. Se espera que otros académicos y legisladores lo usen para llevar a los OCA a su destino original: el equilibrio óptimo entre autonomía y responsabilidad.

\section{FUENTES DE INFORMACIÓN}

Ackerman, Bruce (2000). The New Separation of Powers. Harvard Law Reviere, 113(663).

Ackerman, Bruce (2017). Good-bye Montesquieu. En Susan Rose-Ackerman, Susan et al. (eds.). Comparative Administrative Law, Edward Elgar, Cheltenham, Northampton. 
Ackerman, John (2007). Organismos autónomos: El caso de México. MUNAM. AlcOCER, Jorge (29/01/2013). Autonomitis. Reforma.

BARKOW, Rachel E. (2010). Insulating Agencies: Avoiding Capture Through Institutional Design. Texas Law Review, 89.

Bartlett Foote, Susan (1988). Independent Agencies Under Attack: A Skeptical View of the Importance of the Debate. Duke Law Fournal, 199, pp. 223-237.

Bernstein, Marver H. (1955). Regulating Business by Independent Commission. Princeton University Press.

Bilchitz, David y Landau, David E. (2018). The Evolution of Separation of Powers in the Global North and Global South. En David BILCHITZ y David LANDAU (eds.), The Evolution of the Separation of Powers: Between the Global North and the Global Edward Elgar Publishing Limited. Bonifaz Alfonzo, Leticia (2017). La división de poderes en México: entre la política y el derecho. Fondo de Cultura Económica.

Bressman, Lisa Schultz y Thompson, Robert B. (2010). The Future of Agency Independence. Vanderbilt Law Review, 63.

Breyer, Stephen. 1995. Breaking the Vicious Circle: Toward Effective Risk Regulation. Harvard University Press.

Caballero OchOA, José Luis (2000). Los órganos constitucionales autónomos: más allá de la división de poderes. Anuario del Departamento de Derecho de la Universidad Iberoamericana (30).

CÁRDEnAS GRACIA, Jaime (2001). Justificación de los órganos constitucionales autónomos. Derecho y Cultura (2).

CARPIZO, Jorge (2000). La reforma constitucional de 1999 a los organismos protectores de los derechos humanos. Cuestiones Constitucionales. Revista Mexicana de Derecho Constitucional, Cuestiones Constitucionales (3). Conti-Brown, Peter (2017). The Power and Independence of the Federal Reserve. Princeton University Press.

CóRDOVA VIANELLO, Lorenzo (2011). Incumplimiento de la ley y pérdida de credibilidad en las instituciones. En Esthela GUTIÉRREZ GARZA (ed.), Cambiar a México con participación social, México. Siglo XXI, UANLSenado de la República.

Datla, Kirti y Revesz, Richard L. (2013). Deconstructing Independent Agencies (and Executive Agencies). Cornell Law Review, 98.

García-Pelayo, Manuel (1981). El status del Tribunal Constitucional. Revista Española de Derecho Constitucional, I(1).

Esta obra está bajo una Licencia Creative Commons

Atribución-NoComercial-SinDerivar 4.0 Internacional, IIJ-UNAM.

Boletín Mexicano de Derecho Comparado, núm. 160, enero-abril de 2021, pp. 61-98. 
Gersen, Jacob E. (2011). Designing Agencies. En D. Farber y A. O’Connell (eds.). Research Handbook in Public Law and Public Choice, Edward Elgar. University of Chicago Law \& Economics.

Human Rights Watch (1993). Neres from Americas Watch, V(1).

Keck, Margaret E. y SikKInK, Kathryn (1998). Activists Beyond Borders: Advocacy Networks in International Politics. Cornell University Press.

Kleineman, Jan (2001). Central Bank Independence: The Economic Foundations, the Constitutional Implications and Democratic Accountability. Kluwer Law International.

LAFFONT, Jean Jacques y MARTIMORT, David (2002). Theory of Incentives: The Principal-Agent Model. Princeton University Press.

Lewis, David E. (2003). Presidents and the Politics of Agency Design: Political Insulation in the United States Government Bureaucracy. Stanford University Press.

Kagan, Elena (2010). Presidential Administration. Harvard Law Review, 114(2245).

Matute GonzÁlez, Carlos y Hernández Ángeles, Ana Luisa (2015). Banco de México. Revista de Administración Pública, 138(3).

MaCubbins, Mathew D., Nold, Roger G. y Weingast, Barry R. (1987). Administrative Procedures as Instruments of Political Control. Fournal of Law, Economics, Ë Organization, 3(2).

MaCubbins, Mathew D., Nold, Roger G. y Weingast, Barry R. (1989). Structure and Process, Politics and Policy: Administrative Arrangements and the Political Control of Agencies. Virginia Law Review, 75(2). MaCubbins, Mathew D., Nold, Roger G. y Weingast, Barry R. (2007). The Political Economy of Law. En A. Mitchell Polinsky and Steven Shavell (eds.), Handbook of Law and Economics, 2.

Meza Orozco, Nayeli (2016). Hacienda puede usar remanente de Banxico en Pemex: Carstens. Forbes México.

MilleR, Geoffrey P. (1988). Introduction: The Debate over Independent Agencies in Light of Empirical Evidence. Duke Law Fournal, 1998, pp. 215-222.

Miller III, James C. (1988). A Reflection on the Independence of Independent Agencies. Duke Law Fournal, 1998, pp. 297-299.

Moreno, Ángel Manuel (2015). Presidential Coordination of the Independent Regulatory Process. Harvard Law Review, 129(2). 
MORENo RAmíREz, Ileana (2005). Los órganos constitucionales autónomos en el ordenamiento jurídico mexicano. Porrúa.

Morrison, Alan B. (1988). "How Independent Are Independent Regulatory Agencies? Duke Law Fournal, pp. 252-256.

Peters, Aulana L. (1988). Independent Agencies: Government's Scourge or Salvation? Duke Law Journal, pp. 286-296.

Robinson, Glen O. (1988). Independent Agencies: Form and Substance in Executive Prerogative. Duke Law Fournal, pp. 238-251.

RoldÁn Xopa, José (2008). Derecho administrativo. Oxford University Press.

Roldán Xopa, José (2018). La ordenación constitucional de la economía. Del Estado regulador al Estado garante. Fondo de Cultura Económica.

Salazar Ugarte, Pedro (2017). El Poder Ejecutivo en la Constitución mexicana: Del metaconstitucionalismo a la constelación de autonomías. Fondo de Cultura Económica.

Serna de la Garza, José Ma. (2018). Mexico's National Commission on Human Rights: An Autonomous Constitutional Agency with Too Much Autonomy? En David BILchitz y David LANDAU (eds.), The Evolution of the Separation of Powers: Between the Global North and the Global South. Edward Elgar Publishing Limited.

SHEPHERD, Geoffrey (1999). El desafío de la reforma administrativa en América Latina. Revista del Centro Latinoamericano de Administración para el Desarrollo. Reforma y Democracia (13).

STRauss, Peter L. (1984). The Place of Agencies in Government: Separation of Powers and the Fourth Branch. Columbia Law Review, 84(3).

Sunstein, Cass R. (1990). Paradoxes of the Regulatory State. University of Chicago Law Review, 57(2).

Tena Ramírez, Felipe (1978). Derecho constitucional mexicano (16a. ed.). Porrúa.

VALADÉS, Diego (2006). El control del poder (2a. ed.). Porrúa-UNAM.

VerkuiL, Paul R. (1988). The Purposes and Limits of Independent Agencies. Duke Law Journal, 1988, pp. 257-279.

WILEY, Richard E. (1988). "Political" Influence at the FCG. Duke Law Journal, 1988, pp. 280-285.

Yoo, Christopher S. et al. (2005). The Unitary Executive in the Modern Era 1945-2004. Iowa Law Review, 76(4), pp. 1935-2018.

ZEIND, Marco Antonio (2018). Órganos constitucionales autónomos, 423. Tirant Lo Blanch.

Esta obra está bajo una Licencia Creative Commons

Atribución-NoComercial-SinDerivar 4.0 Internacional, IIJ-UNAM.

Boletín Mexicano de Derecho Comparado, núm. 160, enero-abril de 2021, pp. 61-98. 


\title{
LAS VÍAS INTRAESTATALES PARA GUMPLIR LAS MEDIDAS DE REPARAGIÓN DERIVADAS DE SENTENCIAS DE LA CORTE INTERAMERICANA DE DERECHOS HUMANOS. LA IMPERIOSA NEGESIDAD DE UN MARGO JURÍDICO E INSTITUCIONAL ESPECÍFICO Y EFICAZ EN FAVOR DE LAS VÍCTIMAS*
}

\author{
THE INTRA-STATES PATHWAYS TO COMPLY WITH REPARATIONS \\ ORDERS IN THE INTER-AMERICAN COURT OF HUMAN \\ RIGHTS JUDGMENTS. THE IMPERIOUS NEED OF A SPECIFIC \\ AND EFFECTIVE LEGAL AND INSTITUTIONAL FRAMEWORK \\ FOR THE VICTIMS
}

\section{Jorge Ulises CARmona TinOCO**}

RESUMEN: El artículo se centra en el deber y la necesidad de que los Estados cuenten con un marco jurídico e institucional específico, a efecto de cumplir con las reparaciones dictadas en las sentencias de la Corte Interamericana de Derechos Humanos (Corte IDH). Con ese propósito se ofrece a manera de introducción un panorama de las bases, signos distintivos y situación que guardan las medidas de reparación, así como el cumplimiento general de las sentencias de la Corte IDH, muchas de las cuales se encuentran en la fase internacional de supervisión a cargo de ésta. Esto es indicativo de lo importante que es mirar hacia lo que hacen internamente los Estados del Continente Americano para cumplir con dichas sentencias,
ABSTRACT: The paper focuses on the duty and the need for the States to have a specific legal and institutional framework in order to comply with reparations orders, in the Inter-American Court of Human Rights judgments. With this purpose, the introduction to this article provides an overview of the basis, key features and situation of the reparation orders, many of which still remain at the international monitoring compliance with judgment stage. This points out how important is turning at what States are internally doing in order to implement the Inter-American Tribunal's reparation decisions. Hence a detailed and systematic account is offered as to the different kind or legal and administrative measures States have taken, as well as

* Recibido el 21 de septiembre de 2020; aprobado el 22 enero de 2021.

** ORCID: 0000-0003-4134-6334. Investigador en el Instituto de Investigaciones Jurídicas de la UNAM; investigador nacional nivel II, por el Conacyt. Correo electrónico: jcarmona@unam.mx.

Boletín Mexicano de Derecho Comparado, nueva serie, año LIV, núm. 160, enero-abril de 2021, pp. 99-154. 
para lo cual se ofrece un recorrido detallado y sistemático de los diversos tipos de medidas normativas y administrativas, así como de proyectos de reformas constitucionales y legislativas, que se han generado en varios países del Continente para hacer frente al deber de cumplimiento de sentencias de la Corte IDH. La última parte del artículo se enfoca en el caso de México, donde se aborda a fondo el marco jurídico, administrativo y de precedentes judiciales actual, que muestra los avances y los problemas que existen para hacer frente al cumplimiento de reparaciones en favor de las víctimas, así como los cambios que deben realizarse para hacer posible el cumplimiento de los fallos aún pendientes.

Palabras clave: víctimas de violaciones a los derechos humanos; reparaciones de violaciones a los derechos humanos; cumplimiento de sentencias de la Corte IDH; deberes de los Estados frente a los derechos humanos; reforma constitucional; reformas legales; programa nacional de derechos humanos.
Constitutional amendments and draft legislations, concerning their duty to obey the Inter-American Court of Human Rights judgments. The final part of the article focuses on Mexico, explaining in depth its legal, administrative and judicial precedents frameworks to comply with Court's decisions for the victims, its progress and problems, as well as changes to be made towards compliance of still pending judgements.

Keyzords: victims of human rights violations, reparations of human rights violations, compliance of Inter-American Court of Human Rights judgements, State duties towards human rights, constitutional reform, draft legislations, national program of human rights.

SUMARIO: I. Introducción sobre la naturaleza y justificación de las reparaciones dictadas por la Corte IDH. II. Las medidas normativas o de otra indole de algunos paises, para el cumplimiento de las sentencias de la Corte IDH. III. Los casos de México con sentencia ante la Corte IDH a agosto del 2020. IV. La etapa iniciada con la reforma constitucional del 10 de junio de 2011 y su impacto en el cumplimiento de las sentencias. V. El marco jurídico, institucional y jurisprudencial actual para cumplir/ejecutar las sentencias de la Corte IDH en los casos de México. VI. Conclusiones y propuesta. VII. Bibliografia.

\section{INTRODUCGIÓN SOBRE LA NATURALEZA Y JUSTIFICAGIÓN DE LAS REPARACIONES DIGTADAS CORTE IDH}

Los derechos humanos consagrados jurídicamente, son una vía para buscar el respeto, protección y realización de la dignidad humana, en sus múltiples

Esta obra está bajo una Licencia Creative Commons

Atribución-NoComercial-SinDerivar 4.0 Internacional, IIJ-UNAM.

Boletín Mexicano de Derecho Comparado, núm. 160, enero-abril de 2021, pp. 99-154. 
manifestaciones y contextos. En los últimos setenta años, pero en particular a partir de la década de los años ochenta del siglo pasado, hemos presenciado como al nivel universal y regional se han venido adoptando instrumentos internacionales que detallan tales derechos y sus correspondientes deberes, que buscan proteger a personas en determina condición, abordar los derechos involucrados en temas específicos, o encontrar una ruta normativa para buscar sancionar o, en su caso, erradicar determinadas conductas que atentan contra la dignidad humana.

Si bien los estándares comunes compartidos en las constituciones vigentes de muchos países en la mitad del siglo pasado hicieron posible arribar a un consenso, para recoger los derechos humanos en el ámbito internacional; no cabe duda, que el desarrollo de la protección supra nacional de la persona humana ha tenido a su vez un impacto cada vez mayor en los contenidos constitucionales de finales del siglo XX y lo que va del siglo XXI, generándose una especie de influencia recíproca.

La consagración normativa de los derechos humanos ha venido acompañada de su garantía interna e internacional. En el primer caso, por medio de los instrumentos que integran la llamada jurisdicción constitucional de la libertad, ${ }^{1}$ en el segundo caso, de los sistemas de protección internacional, tanto universal como regionales, que declaran o deciden jurisdiccionalmente la responsabilidad internacional de los Estados por la violación a los derechos humanos y las consecuencias que esto trae consigo, principalmente el deber jurídico de reparar dichas trasgresiones en favor de las víctimas, de sus familiares o quienes se determine que tengan derecho a la reparación.

Quien inquiera sobre el tema de las reparaciones en materia de derechos humanos, de inicio se enfrentará al problema de cómo puede repararse el desconocimiento o la trasgresión de la dignidad de las personas. El encuadramiento jurídico de la protección de la dignidad por medio de los derechos humanos y su expresión normativa provee una serie de conceptos y herramientas jurídicas que son un camino para tal efecto,

1 Bajo el rubro de jurisdicción constitucional de la libertad se contemplan, en términos generales, todos aquellos instrumentos, preponderantemente jurisdiccionales, previstos en la Constitución para la protección de los derechos de la persona (Héctor Fix-Zamudio, 1993, pp. 293 y ss). 
sin que por ello se desconozca las implicaciones filosóficas y en particular éticas de la cuestión.

Desde el punto de vista teórico jurídico, la trasgresión o inobservancia de una regla de derecho trae aparejada la actualización de las consecuencias previstas por la propia norma o el sistema de normas de que se trate. La naturaleza y especificidad de tales consecuencias es algo variable y viene determinado por varios factores; cuando se trata de Estados como sujetos del derecho internacional, sometidos a una jurisdicción supra nacional de derechos humanos, la declaración judicial de responsabilidad trae aparejada en favor de las víctimas las denominadas medidas de reparación o reparaciones.

Así como sucede en el ámbito interno de los Estados, donde existen similitudes y diferencias entre las diversas figuras que integran el citado sector de la jurisdicción constitucional de la libertad, ${ }^{2}$ de igual manera, en el ámbito internacional, también existen afinidades y marcadas diferencias, el tema de las reparaciones no es la excepción, pues, por ejemplo, mientras en el sistema europeo las sentencias sólo declaran la responsabilidad del Estado, dejando un notorio margen de apreciación para efectos del cumplimiento del fallo, incluyendo la reparación, ${ }^{3}$ en el ámbito interamericano, en cambio, desde la propia Convención Americana sobre Derechos Humanos (CADH), señala en el artículo 63.1:

Cuando decida que hubo violación de un derecho o libertad protegidos en esta Convención, la Corte dispondrá que se garantice al lesionado en el goce de su derecho o libertad conculcados. Dispondrá, asimismo, si ello fuera procedente, que se reparen las consecuencias de la medida o situación que ha configurado la vulneración de esos derechos y el pago de una justa indemnización a la parte lesionada.

2 Así se puede constatar al observar cómo operan en los diversos países figuras como el habeas corpus, el mandamiento de seguridad, la acción o recurso de inconstitucionalidad, la acción, recurso o juicio de amparo, entre otros (Héctor Fix-Zamudio, 1988, pp. 53-97).

3 El vigente artículo 41 del Convenio Europeo de Derechos Humanos (luego de los protocolos 11 y 14), establece: Satisfacción equitativa. Si el Tribunal declara que ha habido violación del Convenio o de sus Protocolos y si el derecho interno de la Alta Parte Contratante sólo permite de manera imperfecta reparar las consecuencias de dicha violación, el Tribunal concederá a la parte perjudicada, si así procede, una satisfacción equitativa. Véase (Luis M. Cruz, 2010). 
El citado artículo establece parámetros e hipótesis diferenciadas, pues lo primero a atender es el restablecimiento en el goce del derecho o libertad conculcados, por supuesto cuando la naturaleza de éstos lo permitan. A lo anterior se deben sumar la reparación de las consecuencias de la afectación a los derechos y el pago de una justa indemnización.

El ejercicio y desarrollo jurisprudencial que la Corte IDH ha dado a esa potestad es simplemente impresionante y denota el compromiso, la voluntad y creatividad del tribunal y sus integrantes a lo largo ya de varias décadas, por tomarse en serio su papel y poner en el centro de sus determinaciones a las víctimas y la reparación a afectaciones de que han sido objeto, cuando así corresponde. En la ameritada opinión de Sergio García Ramírez (2003):

Las complicaciones de nuestra norma han suscitado una constante reflexión jurisprudencial que permita hacer luz donde hay algunas sombras y construir, a fuerza de sentencias, un corpus sobre las reparaciones. A éste han llegado, desde luego, las enseñanzas de la jurisprudencia formada por otros órganos internacionales, frecuentemente acogida por la Corte Interamericana, y de una copiosa doctrina. Es interesante advertir cómo se avanza en el espacio de las reparaciones en cada nueva sentencia sobre la materia que dicta la Corte, e incluso en las resoluciones de fondo (p. 131).

El tipo de acciones o medidas que determine la Corte IDH en cada caso depende del derecho conculcado, del número y condición de las víctimas, del contexto en que ocurrieron las violaciones causadas a los derechos, de los actos u omisiones atribuibles a las autoridades, agentes o instancias estatales involucradas y del tipo de deber genérico y específico que se incumplió. ${ }^{4}$ Asimismo, si bien la Corte IDH conoce de casos con-

4 Los instrumentos internacionales consagran derechos que traen consigo correlativos deberes, genéricos y específicos, a cargo primordialmente de los Estados, y de sus respectivos gobiernos en el ámbito interno (incluyendo los órganos de creación de normas, de aplicación de éstas o de solución de controversias en sentido amplio. Los deberes genéricos corresponden con los ya conocidos de respeto, protección, garantía y realización de los derechos de la persona; mientras que los deberes específicos son más diversos e involucran la armonización normativa (creación, modificación, derogación y abrogación normativa), el establecimiento de órganos e instancias, la modificación de prácticas administrativas y de procedimientos, el cambio de criterios jurisdiccionales y no jurisdiccionales, la generación e implementación de políticas públicas, y la asignación de recursos económicos presupuestales, entre muchas otras. 
cretos, éstos pueden ser indicativos de una determinada situación o contexto que trasciende al caso en cuestión, lo que da pie a las denominadas medidas de no repetición, no sólo en beneficio de los afectados directos, sino también para otras personas que estuvieran en una circunstancia similar - o de la población misma-, que requiere ser atendida en términos del deber de prevención de violaciones a los derechos humanos. ${ }^{5}$

Esto ha dado origen, a un nutrido catálogo de medidas de reparación que se ha ido ramificando como respuesta a los tipos de casos y situaciones que han sido sometidos al conocimiento de la Corte IDH, de los que se ha ocupado la doctrina en su análisis y clasificación (Sergio García Ramírez, 2011, pp. 167-199; Víctor M. Rodríguez Rescia, 1999, pp. 667687; Jorge F. Calderón Gamboa, 2015; Yuria Saavedra Álvarez, 2013; Jacqueline Pinacho Espinosa, 2019). El propio tribunal interamericano ha señalado (2020):

para comprender la gran amplitud de medidas ordenadas por la Corte IDH es posible agruparlas dentro de las siguientes formas de reparación: medidas para garantizar a las víctimas el derecho conculcado, restitución, rehabilitación, satisfacción, búsqueda de paradero y/o identificación de restos, garantías de no repetición, la obligación de investigar, juzgar y, en su caso, sancionar a los responsables de las violaciones a derechos humanos, indemnizaciones y reintegro de costas y gastos" (p. 62).

Sin duda el catálogo seguirá ampliándose pues está lejos de ser un numerus clausus; aún más, se avizora un panorama por demás importante e interesante si se consideran los casos cada vez más frecuentes sobre derechos económicos, sociales, culturales y ambientales, sobre los que se está

5 Para Sergio García Ramírez (2003) “... hay reparaciones debidas precisamente a la víctima, sujeto lesionado, como la indemnización por daños y perjuicios causados, la condena en costas, la atención al proyecto de vida; pero también las hay que se dirigen a restituir o reparar, reponer o preservar bienes que exceden al lesionado inmediato - aunque pudieran abarcarlo - y corresponden a la sociedad en su conjunto; tal ocurre cuando se dispone la reforma de una norma que se opone a la Convención o se ordena investigar y sancionar al responsable de la violación de derechos, libertades o garantías, que por serlo se convierte, bajo la ley doméstica, en autor de un delito. La persecución de los delitos pretende satisfacer al ofendido, pero ante todo permite mantener incólumes los bienes jurídicos colectivos que se atienden a través de la justicia penal” (p. 133).

Esta obra está bajo una Licencia Creative Commons

Atribución-NoComercial-SinDerivar 4.0 Internacional, IIJ-UNAM.

Boletin Mexicano de Derecho Comparado, núm. 160, enero-abril de 2021, pp. 99-154. 
pronunciando el tribunal interamericano (Manuel Ventura Robles, 2013, pp. 1-20).

Otro tema igual de relevante es la evaluación del impacto de las medidas de reparación en los diversos países, es decir, si las mismas han o no contribuido y de qué manera a resolver problemáticas estructurales o fuentes de agravio recurrente en materia de derechos humanos. Entre éstas encontramos los casos derivados por la sola vigencia de normas contrarias a los derechos humanos, que han debido ser modificadas, abrogadas o derogadas por sentencia de la Corte IDH o, por otro lado, la falta de normatividad para la efectiva realización de los derechos o la necesidad de generar políticas públicas de gran calado para resolver situaciones endémicas de riesgo o desigualdad (Pablo Saavedra Alessandri, 2017, pp. 470 y ss).

Esta escueta mirada introductoria a la ratio y base jurídica de las reparaciones dictadas por la Corte IDH, no desconoce o minimiza el largo camino que deben seguir las víctimas o sus representantes en las instancias del ámbito interno; los recursos jurídicos y procedimientos que deben ser agotados, que en muchos casos son difíciles y lentos, y el costo y tiempo que debe dedicarse para poder acudir a instancias internacionales. Consideramos que incluso todo esto se justificaría plenamente si una vez emitida una sentencia que declara la responsabilidad y las consecuencias para un Estado por la violación a los derechos humanos, este se aprestara a cumplir a cabalidad, con rapidez, diligencia y eficacia, lo establecido por la decisión de la Corte IDH; lamentablemente, esto no es así en muchos casos, sumando al camino recorrido por las víctimas, además, los intrincados caminos de la burocracia interna y la etapa internacional de supervisón del cumplimiento del fallo, que no en pocas veces iguala o supera en tiempo a la duración de la tramitación misma del asunto, tan sólo ante la propia Corte IDH, misma que ha señalado (2020):

Tanto el número de reparaciones ordenadas, como su naturaleza y complejidad de cumplimiento impacta en el tiempo que un caso puede estar en la etapa de supervisión de cumplimiento. El cumplimiento de algunas medidas implica un mayor nivel de dificultad. El archivo de un caso requiere el cumplimiento de todas las medidas de reparación por parte del Estado encontrado internacionalmente responsable. De esta manera, no es inusual que algunos casos en etapa de supervisión de cumplimiento de sentencia tengan 
pendiente el cumplimiento de solamente una medida de reparación, mientras que otros tienen pendiente el cumplimiento de múltiples reparaciones. Es por ello que, a pesar de que en muchos casos se ha procedido a declarar el cumplimiento de múltiples medidas de reparación.

Desde otro ángulo, los asuntos de violaciones a los derechos humanos inician en los Estados y, llegado el momento, si la Corte IDH emite una sentencia favorable a las víctimas, corresponde al propio Estado el cumplimiento de lo ordenado en la resolución, esto es, en cierto sentido los asuntos se generan y terminan en los propios Estados, esto último bajo la supervisión internacional, que deben contemplar normas, instituciones y procedimientos para prevenir, investigar, sancionar y reparar las posibles violaciones a los derechos humanos, pero también para dar debida atención a las recomendaciones - provenientes por ejemplo de la CIDH-y al cumplimiento de las sentencias de la Corte IDH, sin lo cual el respeto y la eficacia de los derechos humanos se convierte al final del camino en una mera utopía.

Sorprendería a cualquiera el hecho de saber que a pesar de la dificultad material y temporal que entraña recorrer el largo camino de las instancias internas, hasta las de índole internacional, no existen en la gran mayoría de los Estados mecanismos expresos y específicos para acatar las decisiones de estas últimas en ámbito interno de los Estados en casos concretos. En términos llanos, refiriéndonos exclusivamente al sistema interamericano de protección de los derechos humanos, el cumplimiento de las sentencias de la Corte IDH (que involucra básicamente el tema de reparaciones), dependen en la gran mayoría de los casos de la voluntad política coyuntural de los Estados, porque no existen en la mayoría de los países instrumentos o mecanismos jurídicos internos para hacerlas valer o exigir su cumplimiento, mediante reglas claras; en el Informe Anual de la Corte IDH del 2019, se señala que se encontraban en etapa de supervisión de cumplimiento 223 casos, que implican la supervisión de 1153 medidas de reparación, lo que da cuenta de la relevancia del tema y la complejidad que ha adquirido el mismo (Corte IDH, 2).

Esta situación dificitaria y preocupante, no es exclusiva de la Corte IDH y sus sentencias, de hecho es un fenómeno negativo que se observa en general respecto a las resoluciones de los órganos internacionales de garantía de los derechos humanos al nivel universal y regional, lo que 
resume Rachel Murray (2020, pp. 1-21) como una "implementation crisis" (crisis de cumplimiento), que es relevante atender por su impacto respecto a las víctimas primordialmente, pero también con relación a la eficacia de los órganos y procedimientos de garantía internacional de los derechos humanos. Una gran parte de la situación actual de este problema es originada por cómo procesa la maquinaria interna de los propios Estados la atención a las recomendaciones y el cumplimiento a las sentencias internacionales.

En este sentido, más allá de las atribuciones de la Corte IDH para dar seguimiento al cumplimiento de sus propias determinaciones, consideramos como un complemento necesario de lo anterior saber cómo los Estados recepcionan y cumplen en el ámbito interno con las sentencias de la Corte IDH, con qué marco jurídico e institucional cuentan para ello, cuáles son los mejores ejemplos y posibles mejores prácticas sobre el particular. Nuestra hipótesis consiste en que si bien los Estados tienen un margen reconocido para el cumplimiento de las medidas ordenadas - cuya amplitud depende del tipo y carácter de la medida de que se trate - en las sentencias del tribunal interamericano, contar con normatividad, órganos internos de supervisión y procedimientos internos claros y específicos es la opción más acorde con los propios derechos humanos; para tal efecto ofrecemos un recorrido de las diversas opciones que hemos encontrado en algunos países del Continente Americano, y nos concentraremos en la parte última en un análisis más a profundidad del orden jurídico e institucional mexicano. Con lo anterior pretendemos ilustrar la situación en diversos países y, a su vez, justificar la necesidad de contar con una legislación específica y reglas claras, que aborden la cuestión del cumplimiento interno de las sentencias del tribunal interamericano, en particular en el tema de las reparaciones a favor de las víctimas, lo que por ende consideramos que repercutirá en un mayor grado de cumplimiento de las propias sentencias.

\section{LAS MEDIDAS NORMATIVAS O DE OTRA ÍNDOLE DE ALGUNOS PAÍSES, PARA EL GUMPLIMIENTO DE LAS SENTENCIAS DE LA CORTE IDH}

Resulta sumamente complicado ofrecer un panorama completo y detallado de la manera en que cada uno de los países ha hecho frente a los compro- 
misos internacionales, derivados de los casos en los que se han visto involucrados en el sistema interamericano. Por lo regular la atención de dichos compromisos no manifiesta un patrón claro y consistente, pues está vinculada en muchas ocasiones a criterios de voluntad política, de oportunidad, de importancia y costos políticos y depende en gran medida de la disposición de quienes están a cargo de órganos claves en el propio Estado. ${ }^{6}$

Es importante traer a colación la obligación de cumplimiento de los Estados a las sentencias de la Corte IDH, derivada del artículo 68.1 de la CADH y lo previsto en el 68.2 respecto a que la parte del fallo que disponga indemnización compensatoria se podrá ejecutar en el respectivo país por el procedimiento interno vigente para la ejecución de sentencias contra el Estado, a la luz del deber de adoptar disposiciones de derecho interno prevista en el artículo 2o., que al respecto señala:

Si el ejercicio de los derechos y libertades mencionados en el artículo 1 no estuviere ya garantizado por disposiciones legislativas o de otro carácter, los Estados Partes se comprometen a adoptar, con arreglo a sus procedimientos constitucionales y a las disposiciones de esta Convención, las medidas legislativas o de otro carácter que fueren necesarias para hacer efectivos tales derechos y libertades.

En nuestra opinión, lo anterior es una base convencional clara y suficiente, para que la Corte IDH, con motivo de la solicitud del informe de cumplimiento de las reparaciones ordenadas a partir de la sentencia, requiera al Estado en cuestión que ofrezca el marco jurídico e institucional interno con que cuenta para el efectivo cumplimiento de las reparaciones ordenadas en virtud del fallo y que, de no contar con éste o ser el mismo

6 Véase a este respecto el reciente y muy completo trabajo de Rachel Murray y Christian De Vos (2020, pp. 22-47), precisamente sobre las problemáticas, obstáculos y opciones que observaron al estudiar nueve Estados y la manera en que hacían frente a las recomendaciones y sentencias internacionales en materia de derechos humanos. Para las personas autoras, no es nada sencilla la opción de contar con legislación para dar cuenta de las diversas acciones y procesos a detonar para cumplir con éstas, y se inclinan más por el establecimiento de comisiones o comités de alto nivel en el ámbito del poder ejecutivo, que estén en contacto directo con las víctimas y que se encarguen de la coordinación de instancias y acciones para la implementación, con tramos e instancias de responsabilidad claros, entre otras características y requisitos para su debida operatividad.

Esta obra está bajo una Licencia Creative Commons

Atribución-NoComercial-SinDerivar 4.0 Internacional, IIJ-UNAM.

Boletín Mexicano de Derecho Comparado, núm. 160, enero-abril de 2021, pp. 99-154. 
insuficiente, se provea lo conducente como parte de la obligación derivada del citado artículo 2o. de la Convención.

Así, consideramos que hay base jurídica para considerar que la mejor opción es contar con un marco normativo específico y claro para cumplir cabalmente con las sentencias interamericanas, así como también para evitar en mayor medida discrecionalidades laxas en sus fronteras, o también obstáculos estructurales de iure o de facto, de atribuciones o competenciales, ya que de lo contrario podría agregarse a algunos casos un factor adicional de desigualdad de trato hacia las víctimas, a la hora de atenderlos en el ámbito interno. Sin embargo, hay que precisar que el sólo hecho de que no se cuente con dicho marco no implica ipso facto que el Estado se halle en una situación de incumplimiento, eso sería objeto de un estudio en específico de caso por caso y país por país. Lo anterior también dificulta un seguimiento puntual de cómo fueron atendidos los compromisos desde dentro del Estado; la etapa de seguimiento al cumplimiento de la sentencia por parte de la Corte IDH, ${ }^{7}$ los informes presentados por los Estados, las audiencias que ésta realiza para tal efecto y las resoluciones que dicta en consecuencia, son sin duda un insumo importante para saber la situación de cumplimiento de un determinado país. ${ }^{8}$

Otra problemática adicional, sin duda, es la que presentan los Estados federales para articular el cumplimiento de las sentencias en los casos generados en instancias locales o que para el ello se requiera la participación de éstas, pues más allá de la cláusula federal del artículo 28 de la $\mathrm{CADH},{ }^{9}$

7 Incorporada al Reglamento del 2000, por medio de las reformas al mismo de enero de 2009 (artículo 63), que corresponde al artículo 69 del Reglamento vigente de noviembre de 2009.

8 Una interesante aproximación a la investigación metodológica del cumplimiento de las sentencias de la Corte IDH es analizada por Tania Vivas Barrera (2014, pp. 165-189).

9 Artículo 28. Cláusula Federal. 1. Cuando se trate de un Estado parte constituido como Estado Federal, el gobierno nacional de dicho Estado parte cumplirá todas las disposiciones de la presente Convención relacionadas con las materias sobre las que ejerce jurisdicción legislativa y judicial. 2. Con respecto a las disposiciones relativas a las materias que corresponden a la jurisdicción de las entidades componentes de la federación, el gobierno nacional debe tomar de inmediato las medidas pertinentes, conforme a su constitución y sus leyes, a fin de que las autoridades competentes de dichas entidades puedan adoptar las disposiciones del caso para el cumplimiento de esta Convención. 3. Cuando dos o más Estados partes acuerden integrar entre sí una federación u otra clase de asociación, cuidarán de que el pacto comunitario correspondiente contenga las disposiciones necesarias para 
en la práctica puede suscitar diversas dificultades, por ejemplo, competenciales o presupuestales.

En una muestra de responsabilidad, compromiso y congruencia con los derechos humanos, los Estados deberían contar en principio con disposiciones constitucionales que integraran sus respectivos catálogos de derechos de la persona, que articularán éstos con los derechos humanos de fuente internacional, pero también que sentaran las bases para la atención de las recomendaciones y el cumplimiento de las sentencias internacionales en la materia. De igual manera, sería importante contar con la normatividad secundaria que detallara la manera de hacer eficaces los mandatos constitucionales de referencia.

Es un hecho que los países usualmente cuentan con marco constitucional, legal o reglamentario sobre el valor jurídico y la jerarquía de los tratados o sobre las relaciones internacionales. Sin embargo, el vertiginoso desarrollo de los derechos humanos de fuente internacional, así como de las instancias internacionales para su protección, han ido paulatinamente separando y decantando lo importante de esos compromisos, no como parte de las relaciones entre Estados, sino del propio Estado hacia las personas, lo que ha generado una rama de tal modo especializada, con principios propios, que ameritan un tratamiento diferenciado a la hora de considerar la jerarquía de los tratados en el ámbito interno, así como la atención de las recomendaciones y el cumplimiento de la sentencias de tribunales internacionales de derechos humanos. ${ }^{10}$

Resulta pertinente aclarar lo anterior, porque en este apartado analizaremos los esfuerzos de aquellos países que han intentado crear una vía jurídica e institucional concreta y de largo alcance, ${ }^{11}$ para hacer frente

que continúen haciéndose efectivas en el nuevo Estado así organizado, las normas de la presente Convención.

10 Hemos tenido oportunidad de abordar la cuestión en otros trabajos, cuya actualización y puesta al día se plasman en esta investigación (Jorge Ulises Carmona Tinoco, 2008, pp. 335-396; 2011, pp. 323-381; 2013, pp. 99-124). Véase también (Viviana Krsticevic, 2007 y 2009).

11 Cabe señalar el artículo 27 del Convenio de Sede entre Costa Rica y la Corte Interamericana de Derechos Humanos, del 10 de septiembre de 1981, por el cual se acordó: "Las resoluciones de la corte y, en su caso de su presidente, una vez comunicadas a las autoridades administrativas o judiciales correspondientes de la República, tendrán la misma fuerza ejecutiva y ejecutoria que las dictadas por Tribunales costarricenses". Ejemplo citado por Thomas Buergenthal (2001, p. 191).

Esta obra está bajo una Licencia Creative Commons

Atribución-NoComercial-SinDerivar 4.0 Internacional, IIJ-UNAM.

Boletin Mexicano de Derecho Comparado, núm. 160, enero-abril de 2021, pp. 99-154. 
a los compromisos derivados de las decisiones de la Corte IDH. En cualquier escenario, la falta de dicho marco o la existencia éste, en ningún caso puede ser invocado por el Estado para efecto de incumplir con la CADH, ni con las sentencias de la Corte IDH, atentos al artículo 27 de la Convención de Viena sobre Derecho de los Tratados de 1969, que prohíbe de manera expresa que los Estados invoquen cualquier norma de su derecho interno, so pretexto de incumplir una obligación internacional. ${ }^{12}$ En este sentido, toda alusión a falta, insuficiencia u obscuridad de normas jurídicas, atribuciones o competencias, es técnicamente insostenible.

\section{El cumplimiento de las sentencias por vía de medidas ad hoc}

Amén de la ruta ideal que señalamos, se pueden identificar diversos tipos de respuestas de los Estados para cumplir con las sentencias de la Corte IDH, la primera de ellas son las medidas ad hoc para el caso específico de que se trate, como un ejemplo de lo anterior, es la manera en que Honduras atendió el aspecto de reparación económica derivada de los casos Velásquez Rodríguez y Godínez Cruz ante la Corte IDH, mediante un decreto de reforma al presupuesto de egresos, con el fin de crear una partida para hacer frente a dicho compromiso (véase Tania Rodríguez Huerta, 1996, pp. 17-20). Puede también mencionarse la forma en que Panamá atendió lo resuelto por la Corte en el caso Baena Ricardo y otros, mediante un decreto de gabinete publicado oficialmente el 16 de abril de 2002, que establece las bases para el cumplimiento del fallo y consideró el aspecto económico previsto en la sentencia como parte de la deuda nacional, para efectos del pago correspondiente. ${ }^{13}$

Esta opción sería viable en los casos en que los Estados hubieran aceptado la competencia de la Corte para un caso en particular o por un tiempo determinado, pero no cuando tal aceptación fue general y para todos los casos, ambas hipótesis en términos del artículo 62 de la CADH.

12 Dicho precepto señala en su parte conducente: Artículo 27. El derecho interno y la observancia de los tratados. Una parte no podrá invocar las disposiciones de su derecho interno como justificación del incumplimiento de un tratado...

13 Véase Decreto de Gabinete número 8, publicado en la Gaceta Oficial de Panamá, del 16 de abril de 2002 . 


\section{El cumplimiento de las sentencias coordinadas}

por instancias administrativas creadas para tal efecto

Otro caso es de aquellos países que, más allá de dejarlo a cargo de las atribuciones usuales de los ministerios o secretarías de relaciones exteriores, o de las secretarías o ministerios del interior, han optado por generar instancias administrativas, que reúnen diversas dependencias y entidades de la administración pública, encargadas de impulsar las acciones y dar seguimiento, entre otros, a las sentencias de la Corte IDH; ejemplos identificados de esta ruta son Guatemala, México, Ecuador, Paraguay y Colombia.

\section{A. Guatemala}

Por Acuerdo Gubernamental 486-91, se creó en 1991 la Comisión Presidencial Coordinadora de la Política del Ejecutivo en Materia de Derechos Humanos ([Copredeh), https://copredeh.gob.gt, 10/09/2020), que ha sido modificada por diversos acuerdos gubernativos en años posteriores. Dicha instancia reúne representantes de diversos ministerios y entes gubernamentales; funciona como un órgano asesor de la Presidencia de la República en materia de derechos humanos, y está a cargo, entre otras acciones, de coordinar a las instancias gubernativas, elaborar propuestas y acciones de monitoreo a las recomendaciones internacionales, participar en las reparaciones correspondientes, y a partir de 2016 interviene en representación del Estado, en los casos ante la Comisión y la Corte IDH (Acuerdo Gubernamental 266-2016). Recientemente, por medio del Acuerdo Gubernativo número 99-2020, del 30 de julio de 2020, fueron derogados los acuerdos que dieron origen y sustento a dicha instancia, misma que desaparece en virtud de no cumplir la visión para la que fue creada, sin que se señale a quien corresponderán sus funciones.

\section{B. México}

En nuestro país se cuenta con una instancia similar denominada Comisión Intersecretarial para Atender los Compromisos Internacionales 
de México en Materia de Derechos Humanos, creada mediante decreto del 17 de octubre de 1997, aproximadamente un año antes de que aceptara la competencia contenciosa de la Corte IDH, el 16 de diciembre de 1998; posteriormente, se cambió su denominación y por Acuerdo emitido en 2003 se le consideró con carácter permanente. La Comisión Intersecretarial cuenta con atribuciones expresas en el tema de cumplimiento de sentencias - aun cuando no las ha ejercido a cabalidad - , lo cual abundaremos en un apartado posterior de este mismo trabajo.

\section{Ecuador}

En virtud del Decreto 1317, del 9 de septiembre de 2008, se asignó al Ministerio de Justicia y Derechos Humanos la atribución de coordinar la ejecución de decisiones internacionales, atribuciones que posteriormente pasaron a la recién creada Secretaría de Derechos Humanos, por Decreto 560 del 14 de noviembre de 2018, misma que a partir de entonces tiene a su cargo: artículo 2o. “a) ... la coordinación de la ejecución de sentencias, medidas cautelares, medidas provisionales, acuerdos amistosos, recomendaciones, y resoluciones originados en el Sistema Interamericano de Derechos Humanos...".

\section{Paraguay}

Por Decreto 2.290, del 19 de junio de 2009, se creó la Red de Derechos Humanos del Poder Ejecutivo (https://wrere.derechoshumanos.gov.py/ index.php/red-de-ddhh-del-poder-ejecutivo/red-de-derechos-humanos-del-poder-ejecutivo, 9/09/2020), cuyo Reglamento fue aprobado por Resolución 584, del 4 de julio de 2016, del Ministerio de Justicia, quien coordina la referida Red, misma que está integrada por un gran número de dependencias y que si bien cuenta con amplias atribuciones en materia de derechos humanos, no señala expresamente alguna relacionada directamente con la atención de recomendaciones o cumplimiento de sentencias de la Corte IDH, aunque ello no se descarta. 


\section{E. Colombia}

En Colombia podemos mencionar el Grupo Interno de Trabajo de Seguimiento a las órdenes y recomendaciones de los órganos internacionales en materia de derechos humanos (GSORO), establecido en 2015 y adscrito a la Dirección de Derechos Humanos y Derecho Internacional Humanitario del Ministerio de Relaciones Exteriores, que tiene por objeto, entre otros, dar seguimiento a las sentencias de la Corte IDH, así como proponer, desarrollar y ejecutar las medidas y acciones que permitan su cumplimiento. ${ }^{14}$

Consideramos que esta vía tiene aspectos positivos en diversos sentidos, por supuesto condicionada al final a su eficacia, para no ser considerada una instancia burocrática más o mera fachada de un supuesto cumplimiento. En nuestra experiencia en el caso de México, por muchos años los temas relacionados con los compromisos internacionales en materia de derechos humanos involucraban sólo a la Cancillería, que recababa insumos del resto de las instancias de la administración o de las entidades federativas, no obstante, permeaba en la administración en general desconocimiento acerca de la naturaleza jurídica de los compromisos adoptados, así como del valor jurídico de las recomendaciones o de las sentencias internacionales; por ello la creación de dicha instancia tenía un propósito didáctico para la administración participante, pero también de coordinarlas y comprometerlas a las acciones necesarias que estuviesen en su campo de atribuciones y competencias, para cumplir con aquellas.

\section{El posible cumplimiento de sentencias a partir de una base constitucional expresa.} El caso de México y el proyecto de reforma constitucional de noviembre de 2001

Antes de entrar al tema se debe aclarar que contar con una base constitucional no implica suplir o eludir la necesidad de normas secundarias,

14 Creado por Resolución 5674, del 10 de septiembre de 2015, como un grupo adscrito a la Dirección de Derechos Humanos y Derecho Internacional Humanitario del Ministerio de Relaciones Exteriores, disposición que se reprodujo en la Resolución 9709, del 5 de diciembre de 2017, "Por la cual se crean los Grupos Internos de Trabajo del Ministerio de Relaciones Exteriores", acto administrativo vigente a la fecha. Véase https://wrwrecancilleria.gov.co/en/internacional/derechos/ordenes-recomendaciones (11/09/2020). 
necesarias para aplicar el mandato constitucional, pero sí ofrece una base jurídica sólida que no deja duda de la ruta a seguir. Cabe recordar que el tema de la eficacia de las decisiones de la Corte IDH formó parte de la iniciativa de reforma constitucional al artículo 21 (http://sil.gobernacion. gob.mx/Archivos/Documentos/2001/12/asun_1409_20011210_742531.pdf, 9/09/2020), elaborada por el Poder Ejecutivo en noviembre de 2001, en el contexto de la ratificación del Estatuto de Roma por parte de México, que se dio finalmente el 28 de octubre de 2005.

La iniciativa del Ejecutivo consideraba, entre otros tribunales internacionales, a la Corte IDH y no únicamente a la Corte Penal. La propuesta del Ejecutivo consistía en agregar algunos párrafos al artículo 21 constitucional, de manera que estableciera en la parte correspondiente:

La jurisdicción de los tribunales internacionales establecidos en tratados de los que los Estados Unidos Mexicanos sean parte, será reconocida en los términos y conforme a los procedimientos establecidos en dichos tratados.

En los casos del orden penal, los procedimientos que lleven a cabo dichos tribunales, así como el cumplimiento de sus resoluciones y sentencias, serán reconocidos y ejecutados por el Estado Mexicano de conformidad con lo dispuesto en el tratado internacional respectivo.

Las resoluciones, así como las sentencias irrevocables emitidas por tales tribunales, gozarán de fuerza obligatoria, las autoridades administrativas y judiciales del fuero federal, común y militar deberán garantizar su cumplimiento conforme a lo dispuesto en las leyes.

La iniciativa presentada por el Poder Ejecutivo en los primeros días de diciembre de 2001 a la Cámara de Senadores mencionaba al respecto en la exposición de motivos que la acompañó:

La propuesta de reforma que, por su conducto, someto a la consideración del Poder Revisor de la Constitución implica la adición de tres párrafos al artículo 21 constitucional, mismos que se explican a continuación:

a) El primer párrafo está encaminado a resolver el aspecto de la aceptación de la competencia de tribunales internacionales establecidos en tratados de los que México sea parte, de conformidad con los procedimientos especificados en los tratados correspondientes. El reconocimiento de los procedimientos de cada institución internacional cuya competencia se reconozca re- 
sulta fundamental, ya que evitaría incurrir en insuficiencias de tipo procesal al momento de cumplir con los compromisos adquiridos por México.

b) El segundo de ellos se refiere, de manera específica, a los casos de orden penal y tiene por objeto facilitar la cooperación en la realización de procedimientos de investigación y persecución de delitos graves y en la ejecución de las sentencias y resoluciones de tribunales con jurisdicción en esta esfera y cuya competencia sea reconocida por México.

Esto excluiría a los tribunales especiales establecidos directamente por el Consejo de Seguridad de las Naciones Unidas, respecto de los cuales nuestro país ha expresado reservas. En cambio, permitiría a México colaborar con cualquier tribunal establecido en un tratado internacional del que México sea parte y, en especial, con la Corte Penal Internacional en la persecución de los crímenes más graves, que atentan contra la paz, la seguridad y el bienestar de la humanidad en su conjunto. Además, destaca el hecho de que, para colaborar eficazmente en la lucha contra la impunidad, el Estado mexicano reconocerá y ejecutará las resoluciones y sentencias dictadas por los tribunales internacionales, siempre que sean conforme a los términos de los instrumentos jurídicos que los establecen.

c) El tercer párrafo tiene por objeto garantizar el cumplimiento, por parte de las autoridades nacionales, tanto administrativas como judiciales, de las resoluciones y sentencias de los órganos jurisdiccionales internacionales cubiertos por la reforma. Cabe señalar que el reconocimiento de competencia de tribunales internacionales sería nugatorio si no viene acompañado de la adopción de medidas que permitan ejecutar, de manera eficaz, sus decisiones. (cursivas agregadas)

No obstante, luego de su paso por los órganos legislativos la reforma al artículo 21, publicada el Diario Oficial de la Federación, del 20 de junio de 2005, sólo se refirió a la Corte Penal Internacional y de una manera criticable, pues tal como fue finalmente aprobada la reforma constitucional es dudoso que su texto sea compatible con el tipo de obligaciones derivadas del Estatuto de Roma. El texto del artículo 21 vigente en la parte correspondiente señala de manera escueta "El Ejecutivo Federal podrá, con la aprobación del Senado en cada caso, reconocer la jurisdicción de la Corte Penal Internacional", al dejar de lado la propuesta del Ejecutivo se perdió una importante oportunidad de dotar al ordenamiento mexicano con disposiciones del más alto rango, que permitirían hacer frente de mejor manera a sus obligaciones derivadas de sentencias de la Corte IDH. 


\section{Los paises con proyectos de ley o reformas legislativas} para el cumplimiento de las sentencias

Otra opción es la de aquellos países que han intentado proyectos de ley o cuentan con una ley enfocada o especializada en el tema de atención o cumplimiento de resoluciones internacionales de derechos humanos. En este rubro podemos mencionar varios proyectos en Argentina y Brasil, y una ley vigente en Colombia, pero que sólo se ocupa de ofrecer un marco para la atención de recomendaciones internacionales, no de sentencias de la Corte IDH.

\section{A. Argentina}

a) El proyecto de Ley 1830/99 (https://wwre.senado.gob.ar/parlamentario/ comisiones/verExp/1830.99/S/PL, 11/09/2020). El 17 de abril de 2001 fue presentada al Senado argentino un proyecto de Ley sobre las recomendaciones derivadas del artículo 50 de la Convención Americana, aunque incluye también a las sentencias de la Corte IDH. Si bien dicho proyecto no prosperó a la fecha, es un antecedente que debe tenerse en consideración, y que en la parte central de su exposición de motivos o fundamentos señala:

Ahora, si asumimos que la mayor eficacia de cualquier sistema de protección internacional de los derechos humanos radica en la existencia de mecanismos jurisdiccionales al efecto, o sea en la intervención de un tribunal que dicte una sentencia definitiva y obligatoria para los Estados partes en el tratado, deberá aceptarse igualmente que el gran desafío del sistema gravitará finalmente en los mecanismos jurídicos que hagan posible la ejecución eficaz de la decisión judicial en el ámbito interno del Estado que ha violado las obligaciones convencionales...

En el estado actual del derecho de los derechos humanos y considerando la recepción constitucional que el mismo ha tenido a partir de la reforma constitucional de 1994, el meollo del problema radica - a mi criterio- en ofrecer alternativas jurídicas que favorezcan y refuercen la obligación internacional de acatar y ejecutar lo que los Estados asumen. 
El proyecto distingue entre sentencias de la Corte no indemnizatorias y aquellas que entrañan el pago de indemnizaciones (artículos 3o. y 4o.). En el primer caso las obligaciones del Estado serán disponer el cese de la situación que dio origen al pronunciamiento y adoptar a la brevedad las medidas ejecutivas, judiciales o legislativas correspondientes. En el caso de que sean las provincias o la Ciudad Autónoma de Buenos Aires las implicadas, el gobierno nacional debe notificarles la resolución y otorgarles un plazo razonable para su cumplimiento; si en el plazo concedido no se obtiene el cumplimiento de referencia, corresponderá al gobierno nacional retomar el asunto y determinar la adopción de las medidas administrativas, judiciales o políticas que crea conveniente a fin de dar cumplimiento a las obligaciones internacionales y determinar las responsabilidades en que se hubiera incurrido con motivo del incumplimiento (artículo 3o.).

En el segundo caso, cuando las sentencias implican indemnizaciones, el Estado argentino por intermedio del Poder Ejecutivo nacional deberá notificar el informe o la sentencia a la provincia comprometida o a la Ciudad Autónoma de Buenos Aires y presentarse ante el órgano jurisdiccional competente según el derecho interno para su determinación, la cual tramitará por vía incidental previa convocatoria por parte del magistrado interviniente a una audiencia de conciliación (artículo 4o.).

De llegarse a una conciliación en la que haya acuerdo en relación con el monto y conceptos de la indemnización, deberá ser homologada por el magistrado que hubiere intervenido, esta decisión, así como la que en su caso se dictara en el incidente de determinación, tiene los alcances y efectos de cosa juzgada (artículo 5o). Tanto la aplicación, como la procedencia de las indemnizaciones, se guiarán y determinarán por los magistrados, con base en el principio del perjuicio probado y según los criterios establecidos por la Corte Interamericana de Derechos Humanos, la legislación interna argentina y la jurisprudencia nacional (artículo 6o.).

Con el fin de hacer frente a la obligación financiera derivada de los procedimientos señalados, toca al Poder Ejecutivo nacional incluir en el proyecto de presupuesto correspondiente al ejercicio inmediato posterior al del acuerdo judicialmente aprobado o resolución judicial firme, el crédito correspondiente para la atención de las indemnizaciones que se debieran abonar (artículo 7o.).

Un aspecto relevante del proyecto es la participación que se da a las provincias o a la Ciudad de Buenos Aires, cuando resulten involucradas, en los procedimientos ante la Comisión o la Corte, para lo cual se prevé que el Poder Ejecutivo nacional deberá invitarlas formalmente

Esta obra está bajo una Licencia Creative Commons

Atribución-NoComercial-SinDerivar 4.0 Internacional, IIJ-UNAM.

Boletín Mexicano de Derecho Comparado, núm. 160, enero-abril de 2021, pp. 99-154. 
y coordinar su actuación con el área competente del Ministerio de Relaciones Exteriores de la Nación (artículo 8o.). En este mismo precepto se prevé el derecho de repetición contra las provincias o de la Ciudad Autónoma de Buenos Aires y de los agentes y funcionarios responsables de la violación de los derechos humanos todo lo pagado en concepto de indemnizaciones. El proyecto finalmente fue archivado el 13 de agosto de 2001.

b) El proyecto de Ley 2538/00 (https://wreresenado.gob.ar/parlamentario/ comisiones/verExp/2538.00/S/PL, 11/09/2020). Se trata de un proyecto presentado al Senado argentino para una "Ley sobre instrumentación de un mecanismo para dar cumplimiento a disposiciones de organismos verificadores de tratados sobre derechos humanos", que consta de siete preceptos que reseñamos a continuación.

El artículo 1o. del proyecto refiere la obligatoriedad de las decisiones firmes de los organismos de verificación de los tratados internacionales con rango constitucional. ${ }^{15} \mathrm{Si}$ se contempla indemnización, la misma debe ser cubierta por el Poder Ejecutivo en un plazo de noventa días o, en caso justificado, incluir el monto en el presupuesto inmediato para que esto se lleve a cabo, sumándole intereses (artículo 2o.); en caso de que la indemnización no esté determinada, se prevé en principio un procedimiento arbitral o de amigable composición para solventarla (artículo 4o.). Si el asunto tiene que ver con alguna provincia, el Estado hará frente a la obligación y establecerá por separado la manera de reintegrar por parte de aquella el pago realizado (artículo 3o.).

Para el caso de que se prevean conceptos diversos a la indemnización, se deben adoptar de manera inmediata las medidas administrativas, judiciales o legislativas que correspondan, también en el plazo de 90

15 Cabe recordar que conforme al artículo 75.22 de la Constitución argentina, ...la Declaración Americana de los Derechos y Deberes del Hombre; la Declaración Universal de Derechos Humanos; la Convención Americana sobre Derechos Humanos; el Pacto Internacional de Derechos Económicos, Sociales y Culturales; el Pacto Internacional de Derechos Civiles y Políticos y su Protocolo Facultativo; la Convención sobre la Prevención y la Sanción del Delito de Genocidio; la Convención Internacional sobre la Eliminación de todas las Formas de Discriminación Racial; la Convención sobre la Eliminación de todas las Formas de Discriminación contra la Mujer; la Convención contra la Tortura y otros Tratos o Penas Crueles, Inhumanos o Degradantes; la Convención sobre los Derechos del Niño; en las condiciones de su vigencia, tienen jerarquía constitucional. Así como aquellos tratados sobre derechos humanos que, luego de ser aprobados por el Congreso, requerirán del voto de las dos terceras partes de la totalidad de los miembros de cada Cámara. 
días de notificada la resolución, o las correspondientes si se trata de una provincia a efecto de que ella cumpla (artículo 5o.). Un tema interesante es que el propio proyecto prevé la aplicación retroactiva de las reglas establecidas, para aquellos casos que al momento de su entrada en vigor no se encuentren ya resueltos (artículo 6o.). El proyecto de referencia, desafortunadamente, terminó siendo archivado el 8 de abril del 2002.

\section{B. Brasil. Los proyectos de Ley 3.214/2000, 4.667/2004, y 420/200916}

a) Proyecto de Ley 3.214/2000 (https://wwwe.camara.leg.br/proposicoesWeb/ prop_mostrarintegrajjsessionid $=811$ CDB572153EA9E025BB34CDC6E1218.pr oposicoesWebExterno1? codteor $=1121372$ Efilename $=$ Dossie $+-P L+3214 / 2000$, 8/09/2020). Sobre los efectos jurídicos de las decisiones de la CIDH y de la Corte IDH, y de otras resoluciones. El proyecto refiere que las decisiones de la CIDH y de la Corte IDH, producen efectos jurídicos inmediatos en el ámbito del ordenamiento interno brasileño (artículo 1o.); las decisiones que tengan carácter indemnizatorio se considerarán como títulos ejecutivos judiciales y estarán sujetos a ejecución directa contra la hacienda pública federal (artículo 2o.); se prevé la acción regresiva (repetición) contra las personas físicas o jurídicas, privadas o públicas responsables directa o indirectamente de los actos ilícitos que dieron lugar a la decisión indemnizatoria (artículo 3o.).

b) Proyecto de Ley 4.667/2004 Sobre los efectos jurídicos de las decisiones de los organismos internacionales de protección de los derechos humanos y de otras resoluciones (https://wrere.camara.leg.br/proposicoesWeb/fichadetramitacao.idProposic $\left.a_{0}=273650,8 / 09 / 2020\right)$. El proyecto de referencia retoma íntegramente el ya reseñado $3.214 / 2000$, pero amplía su alcance a todos los organismos internacionales de protección de los derechos humanos, a cuyas resoluciones se les da de igual manera efectos jurídicos inmediatos en el ámbito del ordenamiento interno, así como el tratamiento ya analizado en el punto anterior.

Durante su paso por el procedimiento interno legislativo, el proyecto derivó en el 4.667-D, de 2004 (https://wrew.camara.leg.br/proposicoesWeb/

16 Sobre el tema de la ejecución de las sentencias de la Corte IDH en Brasil, véase Helio Bicudo (2001, pp. 229-236), y más recientemente Daniela Menengoti y Jonas Dos Santos (2019, pp. 1-34).

Esta obra está bajo una Licencia Creative Commons

Atribución-NoComercial-SinDerivar 4.0 Internacional, IIJ-UNAM.

Boletin Mexicano de Derecho Comparado, núm. 160, enero-abril de 2021, pp. 99-154. 
prop_mostrarintegra?'codteor $=795170$ Efilename $=$ REDACAO+FI, 9/09/2020), que eliminaría el carácter de título ejecutivo judicial y agregaría al original la responsabilidad de los entes federados respecto a la reparación en favor de las víctimas, y que en los casos en que la obligación fuese pecuniaria respondería internacionalmente la Unión, sin que esto extinguiera la responsabilidad del ente federado (artículo 2o.).

Luego de algunos cambios ulteriores en la Cámara de Diputados como Cámara de origen, al pasar al Senado se le asignó el número 170/2010, que finalmente fue archivado.

c) Proyecto de ley 420/2009 (https://www25.senado.leg.br/web/atividade/ materias/-/materia/93252/pdf, 10/09/2020). Se trata de un proyecto de reforma al Código Procesal Civil de 1973, para incluir entre los títulos ejecutivos judiciales a las sentencias dictadas por la Corte IDH, así como regular el procedimiento para su cumplimiento; dicho proyecto no prosperó al darse prioridad a un proyecto de reforma más amplia al mencionado Código (proyecto de ley del Senado 166/2010), que no hizo referencia el tema.

\section{Colombia, la Ley 288 de 1996}

El 5 de julio de 1996 el Congreso colombiano expidió la Ley 288 (https://wwwedefensoria.gov.co/public/Normograma\%202013_html/Normas /Ley_288_1996.pdf, 5/09/2020) con la finalidad de establecer instrumentos para la indemnización de perjuicios a las víctimas de violaciones de derechos humanos en virtud de lo dispuesto por determinados órganos internacionales de derechos humanos.

Dicha ley, como su denominación lo indica, se concentra únicamente en el rubro económico de las reparaciones y por medio de los preceptos que la componen se establece el procedimiento a seguir para que el Gobierno Nacional proceda a cubrir las indemnizaciones de perjuicios causados por violaciones de los derechos humanos que se hayan declarado, ollegaren a declararse, en decisiones expresas de la Comisión Interamericana y del Comité de Derechos Humanos de Naciones Unidas (artículos 1o. y 2o.). Llama la atención de inmediato que la Ley se ocupe sólo de estos organismos internacionales, pero no de la Gorte IDH. 


\section{El cumplimiento a partir de leyes generales sobre sentencias de tribunales internacionales. La Ley 27775 en Perú ${ }^{17}$}

Un grupo adicional sería el de aquellos países que contaran con normatividad relacionada con el cumplimiento de las sentencias de tribunales internacionales en general, cuya jurisdicción haya aceptado el Estado, entre las que se encuentran las resoluciones de la Corte IDH. Tal es el caso de Perú, sobre el que ahondaremos en virtud de ser una legislación vigente.

El 5 de julio de 2002 fue expedida en Perú la Ley 27775, que Regula el Procedimiento de Ejecución de Sentencias Emitidas por Tribunales Supranacionales. El propio Código Procesal Constitucional (Ley 28237), publicado el 31 de mayo de 2004, remite a la Ley 27775 y señala en concordancia con ésta y con el artículo 205 de la Constitución de 1993, ${ }^{18}$ lo siguiente:

Artículo 115. Ejecución de resoluciones.

Las resoluciones de los organismos jurisdiccionales a cuya competencia se haya sometido expresamente el Estado peruano no requieren, para su validez y eficacia, de reconocimiento, revisión, ni examen previo alguno. Dichas resoluciones son comunicadas por el Ministerio de Relaciones Exteriores al presidente del Poder Judicial, quien, a su vez, las remite al tribunal donde se agotó la jurisdicción interna y dispone su ejecución por el juez competente, de conformidad con lo previsto por la Ley 27775, que regula el procedimiento de ejecución de sentencias emitidas por tribunales supranacionales.

17 Dicho precepto tendría su antecedente en el artículo 40 de la Ley de Hábeas Corpus y Amparo 23506, de 1982, que establecía "La resolución del organismo internacional a cuya jurisdicción obligatoria se halle sometido el Estado peruano, no requiere para su validez y eficacia de reconocimiento, revisión ni examen previo alguno. La Corte Suprema de Justicia de la República recepcionará las resoluciones emitidas por el organismo internacional, y dispondrá su ejecución y cumplimiento de conformidad con las normas y procedimientos internos vigentes sobre ejecución de sentencias". Dicha Ley, así como la Constitución de 1979 bajo la cual fue expedida fueron abrogadas (Thomas Buergenthal, 2001, p. 191).

18 Dicho precepto señala: "Artículo 205. Agotada la jurisdicción interna, quien se considere lesionado en los derechos que la Constitución reconoce puede recurrir a los tribunales u organismos internacionales constituidos según tratados o convenios de los que el Perú es parte".

Esta obra está bajo una Licencia Creative Commons

Atribución-NoComercial-SinDerivar 4.0 Internacional, IIJ-UNAM.

Boletín Mexicano de Derecho Comparado, núm. 160, enero-abril de 2021, pp. 99-154. 
El solo título de la Ley 27775 marca una diferencia con el ejemplo colombiano que vimos en el apartado previo, que dedica la regulación únicamente a las determinaciones de la Comisión Interamericana y al Comité de Derechos Humanos de Naciones Unidas.

El artículo 1o. de la mencionada Ley 27775 declara como de interés nacional el cumplimiento de las sentencias dictadas en los procesos seguidos contra el Estado peruano ante tribunales internacionales, constituidos por tratados ratificados por Perú de acuerdo con su Constitución Política. El ejemplo que nos interesa es el de la Corte Interamericana de Derechos Humanos, cuya competencia fue reconocida por Perú el 21 de enero de 1981, que fue retirada unilateralmente el 9 de julio de 1999, lo cual fue desconocido por la propia Corte en sus sentencias del 24 de septiembre de ese mismo año. Posteriormente, el 29 de enero de 2001 fue retirada por el gobierno su declaración de julio de 1999. No obstante, puede afirmarse válidamente que la declaración de 1981 ha permanecido vigente desde entonces.

El artículo 2o. de la ley prevé las reglas de ejecución de sentencias supranacionales, según las cuales se requiere en principio que dichas decisiones contengan condena de pago de suma de dinero en concepto de indemnización por daños y perjuicios a cargo del Estado o sean meramente declarativas.

Una vez emitida la resolución internacional y comunicada al Estado por medio del Ministerio de Relaciones Exteriores, ésta se debe encargar de trascribirla al presidente de la Corte Suprema, quien a su vez la remitirá a la Sala en que se agotó la jurisdicción interna, para que disponga su ejecución por el juez especializado o mixto que conoció el proceso previo (artículo 2o.).

De no existir proceso interno previo, por ejemplo, en los casos internacionales en que se declaró innecesario el agotamiento de los recursos internos, el presidente de la Corte dispondrá el juez especializado o mixto competente para conocer de la ejecución de la resolución.

El juez que agotó la jurisdicción interna, dentro de los diez días de recibida la comunicación de la Corte Suprema, posee atribuciones para ordenar a los órganos e instituciones estatales concernidas, sea cuales fuesen éstas, el cese de la situación que dio origen a la sentencia internacional, indicando la adopción de las medidas necesarias (artículo 4o.). Si la sentencia internacional se refiere a alguna resolución judicial en el ámbito interno, el juez competente debe adoptar las disposiciones que resulten perti- 
nentes para la restitución de las cosas al estado en el que se encontraban antes de que se produzca la violación declarada por medio de la sentencia (artículo 4o.).

Si la sentencia internacional establece el pago de una suma determinada de dinero, el juez a quien corresponda conocer del asunto debe disponer que se notifique al Ministerio de Justicia para que cumpla con el pago en el término de diez días. Dicho ministerio debe incorporar y mantener en su presupuesto una partida que sirva de fondo suficiente para atender exclusivamente el pago de sumas de dinero en concepto de reparación de daños y perjuicios impuesto por sentencias de tribunales internacionales en procesos por violación de derechos humanos, así como el pago de las sumas que se determinen en las resoluciones de los procedimientos conexos con ellas (artículo 7o.).

Si se trata de una condena de pago de una suma de dinero por determinar, el juez dará traslado de la solicitud del ejecutante (el beneficiario de la reparación), con los medios probatorios que ofrezca, al Ministerio de Justicia por el término de diez días. El representante del Ministerio de Justicia puede formular contradicción exclusivamente sobre el monto pretendido, ofreciendo medios probatorios.

Formulada la contradicción o sin ella, el juez debe ordenar el desahogo de los medios probatorios pertinentes en audiencia de conciliación, en el plazo no mayor de 30 días y pronunciar la resolución dentro de los 15 días siguientes. Existe posibilidad de apelar la resolución, misma que debe ser resuelta por la Sala de la Corte Superior correspondiente, también en un término de 15 días.

En el caso de que en la sentencia se deje a salvo el derecho de la víctima para reclamar en el ámbito interno, otros daños y perjuicios de los que no se ocupó la litis internacional, se deberá hacer el reclamo mediante la interposición de la demanda correspondiente, siguiendo el trámite del proceso abreviado previsto en el título II de la sección quinta del Código Procesal Civil.

Si la parte afectada tuviera pretensiones diversas sobre reparaciones, que fueren distintas a la condena o declaración contenida en la sentencia del tribunal internacional tiene expedita la vía procedimental prevista en el Código Procesal Civil y sujeta a las reglas de competencia correspondientes (artículo 3o.).

En las hipótesis previstas en los párrafos anteriores, es posible optar por la tramitación de un procedimiento arbitral de carácter facultativo,

Esta obra está bajo una Licencia Creative Commons

Atribución-NoComercial-SinDerivar 4.0 Internacional, IIJ-UNAM.

Boletín Mexicano de Derecho Comparado, núm. 160, enero-abril de 2021, pp. 99-154. 
regulado por disposiciones específicas, para la determinación: a) del monto a pagar, b) de la responsabilidad patrimonial y c) del monto indemnizatorio en su caso. En este caso, el procurador del Estado del Ministerio de Justicia debe contar con autorización para ello (artículo 8o.).

Una hipótesis adicional que prevé la ley es el cumplimiento de medidas provisionales que dictare la Corte IDH, las que deben ser de inmediato cumplimiento, para lo cual el juez especializado o mixto debe ordenar su ejecución dentro del término de 24 horas de haber sido recibida la comunicación de la decisión respectiva.

Como es usual en los casos en que el Estado tiene que hacer frente a reparaciones por los actos de sus servidores públicos, se prevé el derecho de repetición, que según la Ley 27775, en su artículo 5o., una vez fijada la responsabilidad personal de la autoridad, funcionario o empleado público que dio motivo al procesamiento internacional, el Estado representado por el Procurador correspondiente iniciará proceso judicial para obtener a su vez, el resarcimiento de los daños y perjuicios que se le ha ocasionado.

Una vez culminados los procedimientos de cumplimiento de la sentencia internacional, corresponde a la Corte Suprema de Justicia, por conducto del Ministerio de Relaciones Exteriores, comunicar a la Corte IDH acerca de las medidas de cumplimiento adoptadas. De igual manera, el beneficiario debe ser periódicamente informado de las medidas que se adopten (artículo 6o.).

No obstante que la ley mencionada constituye un esfuerzo importante hacia el cumplimiento efectivo de las determinaciones de la Corte Interamericana, en enero de 2007 fue presentado al Congreso de Perú el proyecto de Ley 853/2006 que solicita expresamente la derogación de la Ley 27775, con el fin, según se alega, de uniformar los procedimientos para la atención de obligaciones de dar suma de dinero a cargo del Estado, de manera que ahora se tramitarían de conformidad con la Ley 27584 que regula el procedimiento contencioso administrativo.

Si bien el proyecto de referencia no prosperó, en la exposición de motivos se critica la Ley 27775 como un ordenamiento que va en contra de la prohibición constitucional de establecer leyes especiales, y que además resulta discriminatoria para las personas, pues el procedimiento para quienes se vean beneficiados por una sentencia derivada de un órgano jurisdiccional internacional es distinto del que tienen que llevar a cabo quienes tienen a su favor una sentencia emanada de órganos internos. 
Consideramos que los autores de la iniciativa que pretende derogar la Ley 27775 no se percatan que en ésta no únicamente están reguladas las hipótesis de la condena en dinero, sino también otras modalidades que pueden adquirir las sentencias de la Corte Interamericana. Además, las sentencias internacionales derivan de un procedimiento iniciado luego de haberse agotado los previstos en el ámbito interno, por lo que sus etapas han sido diversas y más largas, lo que justificaría una respuesta en el sentido de crear un procedimiento interno específico y expedito para atender dichas resoluciones, por lo que consideramos que en todo caso habría que buscar la manera de que las sentencias dictas en el ámbito interno sean cumplidas de una manera más expedita.

\section{LOS CASOS DE MÉXICO GON SENTENCIA ANTE LA CORTE IDH A AGOSTO DEL 2020}

La Corte IDH ha decidido hasta ahora un total de 11 casos respecto a México, de los cuales, actualmente, 9 están en etapa de supervisión de cumplimiento de la sentencia, pues por lo que se refiere al caso Alfonso Martín del Campo Dodd, éste fue decidido en excepciones preliminares a favor del Estado por sentencia del 3 de septiembre de 2004, y en el caso Castañeda Gutman, decidido en 2008, se declaró cumplida en definitiva la sentencia de fondo y archivar el asunto por resolución de la Corte IDH, del 28 de agosto de 2013.

El resto de los casos aún no dados por cumplidos son: caso González y otras, "Campo Algodonero" (sentencia del 16 de noviembre de 2009); caso Radilla Pacheco (sentencia del 23 de noviembre de 2009); caso Fernández Ortega y otros (sentencia del 30 de agosto de 2010); caso Rosendo Cantú y otra (sentencia del 31 de agosto de 2010); caso Cabrera García y Montiel Flores (sentencia del 26 de noviembre de 2010); caso García Cruz y Sánchez Silvestre (sentencia del 27 de noviembre de 2018); caso Trueba Arciniega y otros (sentencia del 27 de noviembre de 2018); caso Alvarado Espinoza y otros (sentencia del 28 de noviembre de 2018); caso Mujeres víctimas de tortura sexual en Atenco (28 de noviembre de 2018). ${ }^{19}$

19 Un resumen de los casos señalados, con relación al tema de reparaciones en cada uno de ellos puede consultarse en Pinacho (2019, pp. 87 y ss.).

Esta obra está bajo una Licencia Creative Commons

Atribución-NoComercial-SinDerivar 4.0 Internacional, IIJ-UNAM.

Boletin Mexicano de Derecho Comparado, núm. 160, enero-abril de 2021, pp. 99-154. 
En los tres últimos casos, aún no se cuenta con alguna determinación en etapa de supervisión de cumplimiento de sentencia por parte de la Corte IDH. En el caso "campo algodonero" hay una resolución en 2013; en el caso Radilla han sido dictadas cinco resoluciones entre 2011 y 2015; en el caso Fernández Ortega hay tres resoluciones, la última en 2015; en el caso Rosendo Cantú se han dictado cuatro, la última de ellas en marzo del 2020; caso Cabrera García se han dictado dos; y en el caso García Cruz también dos. (https://wrerr.Corte IDH.or.cr/casos_en_supervision_por_ pais.cfm)

El análisis minucioso de la situación actual del cumplimiento de las sentencias en cada uno de los casos señalados excedería el objeto de nuestro trabajo, pero en general involucran medidas de muy diversa índole, pues algunos casos implican violaciones y situaciones complejas, como "campo algodonero" o el de mujeres víctimas de tortura sexual en Atenco. No obstante, el aspecto que nos ocupa es el marco normativo, institucional y jurisprudencial, con que cuenta nuestro país para que en todos los casos pendientes se dé cabal cumplimiento a la sentencia de la Corte IDH y muy en particular en el tema de las reparaciones en favor de las víctimas, lo que a su vez permitirá al tribunal interamericano verificar y, en su momento, declarar por cumplidas sus respectivas sentencias.

Sin duda alguna, la reforma constitucional en materia de derechos humanos de junio de 2011 marca la pauta para la reparación cabal y efectiva que merecen las víctimas en cada uno de los casos aún vigentes (Sergio García Ramírez, 201 1), a lo cual dedicaremos los apartados siguientes.

\section{LA ETAPA INICIADA CON LA REFORMA CONSTITUCIONAL DEL 10 DE JUNIO DE 2011 Y SU IMPACTO EN EL GUMPLIMIENTO DE LAS SENTENCIAS}

El 10 de junio de 2011 fue publicada en el Diario Oficial de la Federación la más importante reforma en materia de derechos humanos, que se haya llevado a cabo en la historia de la vigente Constitución federal de 1917. La modificación involucró cambios a la denominación del capítulo I del título primero; así como los artículos: 1o, 3o, 11, 15, 18, 29, 33, 89, 97, 102 apartado B, y 105, fracción II de la Constitución Política de los Estados Unidos Mexicanos. 
Si pudiéramos resumir en una frase la naturaleza de los cambios realizados, diríamos que se trata de la reforma que armoniza la Constitución con el derecho internacional de los derechos humanos. Esto no significa que antes de la reforma estaban del todo desarticulados, ni tampoco que fueran inexistentes las obligaciones estatales con respecto a los derechos humanos de fuente internacional.

No debe perderse de vista que la reforma en comento está estrechamente vinculada, a aquella publicada en el Diario Oficial del 6 de junio de 2011 y que tuvo por objeto una modificación a los artículos 94, 103, 104 y 107 constitucionales, la cual implica, entre otras cuestiones, cambios trascendentes al juicio de amparo. De esta reforma, llamamos la atención por su trascendencia en el tema que nos ocupa al cambio del artículo 103, fracción I, que prevé la procedencia del amparo "Por normas generales, actos u omisiones de la autoridad que violen los derechos humanos reconocidos y las garantías otorgadas para su protección por esta Constitución, así como por los tratados internacionales de los que el Estado Mexicano sea parte".

A partir de la reforma en materia de derechos humanos, la Constitución federal y los derechos humanos de fuente internacional forman un conjunto normativo superior indisoluble, en beneficio de la persona, imponiendo los correlativos deberes de las autoridades de todo el país para hacer efectivos tales derechos.

En particular, consideramos necesario destacar el párrafo tercero del artículo 1o. reformado, que prevé en su última que el Estado tendrá el deber de prevenir, investigar, sancionar y reparar las violaciones a los derechos humanos, de conformidad con lo que establezca la ley. Los deberes enunciados son reflejo de los reconocidos a nivel internacional ante las violaciones a los derechos humanos, y van dirigidos a impedir que se produzcan éstas y, en los casos es que los esfuerzos en este sentido no hayan sido suficientes, implica esclarecer los hechos; determinar las violaciones cometidas; someter a los responsables a la justicia para que reciban el castigo que en derecho proceda, es decir, no permitir la impunidad de las violaciones; y lo que es más relevante para las víctimas, que es reparar las consecuencias de las transgresiones a los derechos humanos.

Si bien la reforma constitucional no llegó a hacer referencia a las sentencias de la Corte IDH, sin duda proporciona una base sólida para derivar su autoridad y necesario cumplimiento por parte de las autoridades.

Esta obra está bajo una Licencia Creative Commons

Atribución-NoComercial-SinDerivar 4.0 Internacional, IIJ-UNAM.

Boletín Mexicano de Derecho Comparado, núm. 160, enero-abril de 2021, pp. 99-154. 
Enseguida nos ocuparemos sobre cómo se encuentra estructurado el orden jurídico interno, incluso anterior a la mencionada reforma, con relación a la recepción y cumplimiento de las sentencias de la Corte IDH, en particular en el tema de reparaciones, así como también de las estructuras administrativas, órganos e instancias con atribuciones para intervenir en la materia.

\section{EL MARCO JURÍDICO, INSTITUGIONAL Y JURISPRUDENCIAL ACTUAL PARA GUMPLIR/EJEGUTAR LAS SENTENCIAS DE LA CORTE IDH EN LOS CASOS DE MÉXICO}

\section{El marco jurídico}

a) La Constitución federal. Carece de un precepto expreso sobre el tema de las sentencias de la Corte IDH. Sin embargo, una interpretación sistemática y armónica de diversos preceptos deja en claro el tema; en principio podemos señalar el artículo 133 al situar a los tratados internacionales como partes de la "Ley Suprema" de toda la Unión. En segundo término, a la luz del artículo 1o. de la Constitución, en su texto derivado de la reforma constitucional del 10 de junio de 2011, las personas gozarán "de los derechos humanos reconocidos en esta Constitución y en los tratados internacionales de los que el Estado Mexicano sea parte, así como de las garantías para su protección..." (párrafo primero), en consecuencia, todas las autoridades deben garantizar los derechos humanos, para lo cual se deberán investigar, sancionar y reparar tales violaciones (párrafo tercero).

De esta manera, al estar prevista en la Convención Americana la obligatoriedad de las sentencias de la Corte Interamericana y el compromiso de los Estados de cumplirlas (artículo 68.1), esto forma parte del tratado que es incorporado al orden jurídico interno en sus términos, pero además forma parte de los deberes de garantía de los derechos humanos, y se vincula a los ya señalados de investigación, sanción y reparación de sus violaciones.

b) La Ley sobre Celebración de Tratados. La ley fue publicada en el Diario Oficial de la Federación del 2 de enero de 1992, y regula el tema en térmi- 
nos inspirados en la Convención de Viena sobre Derecho de los Tratados de 1969.

En particular, traemos a colación el texto del artículo 11, que establece:

Las sentencias, laudos arbitrales y demás resoluciones jurisdiccionales derivados de la aplicación de los mecanismos internacionales para la solución de controversias legales a que se refiere el artículo 8o., tendrán eficacia y serán reconocidos en la República, y podrán utilizarse como prueba en los casos de nacionales que se encuentren en la misma situación jurídica, de conformidad con el Código Federal de Procedimientos Civiles y los tratados aplicables.

Los artículos 8o. y 9o. de la misma ley, condicionan lo anterior a diversos extremos y excepciones. En primer lugar, los tratados que contengan mecanismos de solución de controversias deben prever igualdad de trato para los mexicanos y extranjeros; asegurar la garantía de audiencia y el debido ejercicio del derecho de defensa, y garantizar la imparcialidad del órgano de decisión.

Como excepción extrema a la eficacia interna de las resoluciones internacionales, el artículo 9 señala que éstas no serán reconocidas si está de por medio la seguridad del Estado, el orden público o cualquier otro interés esencial de la nación.

Tales preceptos fueron adoptados varios años antes de que México aceptara la competencia contenciosa de la Corte Interamericana en diciembre de 1998, y no resultan compatibles con las reglas que rigen a los derechos humanos, pues sería inconcebible y contradictorio, que el Estado alegara cuestiones de seguridad nacional o el orden público para dejar de cumplir con una sentencia de dicho tribunal. No obstante, resulta relevante y de utilidad el artículo 11 mencionado, pues es un fundamento claro que integra el marco jurídico de ejecución de las sentencias de la Corte IDH.

c) La Ley Federal de Responsabilidad Patrimonial del Estado. Por otro lado, en el tema de reparaciones derivadas tanto de los informes de la Comisión, como de sentencias de la Corte Interamericana, la reforma al artículo 113 constitucional publicada el 14 de junio de 2002 (en vigor a partir del 1o. de enero de 2005), y la posterior ley reglamentaria de dicho precepto publicada en el Diario Oficial el 31 de diciembre de 2004, que reguló 
dicho aspecto, vino a ofrecer una vía procedimental para el cumplimiento de dichas obligaciones (véase Álvaro Castro, 2002).

El artículo 113 constitucional señala en su párrafo segundo: "La responsabilidad del Estado por los daños que, con motivo de su actividad administrativa irregular, cause en los bienes o derechos de los particulares, será objetiva y directa. Los particulares tendrán derecho a una indemnización conforme a las bases, límites y procedimientos que establezcan las leyes".

Enseguida, analizaremos los preceptos más sobresalientes de la Ley Federal de Responsabilidad Patrimonial del Estado, que es reglamentaria del artículo 113 constitucional en lo relativo a ésta última. Dicha ley tiene por objeto fijar las bases y los procedimientos para reconocer el derecho a la indemnización a quienes, sin obligación jurídica de soportarlo, sufran daños en cualquiera de sus bienes y derechos como consecuencia de la actividad administrativa irregular del Estado, esto es, de acuerdo con la propia Ley, la actividad estatal que cause daño a los bienes y derechos de los particulares en virtud de no existir fundamento legal o causa jurídica de justificación para legitimar el daño de que se trate (artículo 1o.).

Los sujetos de la ley son los entes públicos federales, entendiéndose por tales los poderes Fudicial, Legislativo y Ejecutivo de la Federación, organismos constitucionales autónomos, dependencias, entidades de la administración pública federal, la Procuraduría General de la República, los tribunales federales administrativos y cualquier otro ente público de carácter federal (artículo 2o.).

Para efectos del presente trabajo destaca el contenido del mencionado artículo 2o. que ordena que la Ley será aplicable para cumplimentar los fallos de la Corte Interamericana de Derechos Humanos, asi como las recomendaciones de la Comisión Interamericana de Derechos Humanos, aceptadas estas últimas por el Estado Mexicano, en cuanto se refieran a pago de indemnizaciones.

El artículo 2o. de la ley establece de manera adicional que el ente público federal que haya sido declarado responsable, de entre los ya señalados, es en todo caso el encargado de aceptar y cumplir las recomendaciones de la Comisión Interamericana. Lo mismo se afirma de los fallos de la Corte Interamericana en materia de reparación. En ambos casos, se precisa, corresponderá a la Secretaría de Relaciones Exteriores ser el conducto para informar de los cumplimientos respectivos a la Comisión o a la Corte, según corresponda.

Esta parte del precepto merece ser aclarada, pues ambos órganos declaran en todo caso la responsabilidad del Estado en su conjunto, más no 
la de un ente específico, lo cual en todo caso puede derivarse de los propios hechos del asunto, las conclusiones de la comisión o los puntos resolutivos de la decisión de la Corte, así, la identificación precisa del ente que provocó la responsabilidad es más bien una cuestión interna. Por último, cabría señalar que el esquema señalado sólo se refiere a la intervención de entes federales, pero no así cuando sean entes locales cuyos actos $\mathrm{u}$ omisiones hubieren provocado la responsabilidad estatal a nivel internacional, lo cual sigue siendo entonces un problema por resolver en el ámbito interno, pero frente a un deber de índole internacional pues el artículo 28 de la Convención Americana asigna al gobierno federal el deber de hacer cumplir dichos compromisos en esta hipótesis.

Consideramos que la inclusión de la posibilidad de la aplicación de la ley que se comenta, para las reparaciones ordenadas en las sentencias de la Corte no fue técnicamente razonada, pues ésta es por lo regular la que se ha encargado de fijar el monto de la reparación económica cuando proceda. En todo caso correspondería a dicho tribunal decidir si la reparación otorgada es adecuada con la responsabilidad internacional declarada y con los estándares internacionales de reparación, así como la fijada en casos similares previos.

d) La Ley General de Victimas. De acuerdo con el artículo 2o. transitorio de la reforma constitucional en materia de derechos humanos de 2011, la ley sobre reparación debía ser expedida en el término de un año, a partir de la entrada en vigor de la reforma. Sin embargo, fue en enero de 2013 que se publicó en el Diario Oficial de la Federación la vigente Ley General de Víctimas, que viene a detallar lo conducente no sólo respecto al artículo 1o. constitucional, sino también los artículos 17, 20, y 73 fracción XXIX-X de la misma Constitución, así como a los tratados internacionales, en virtud de que reúne normativamente la atención de las víctimas del delito y de violaciones a los derechos humanos.

En virtud de que se trata de un ordenamiento amplio que reúne aspectos sustantivos, administrativos y procedimentales, que consta de 180 artículos y ha sufrido dos reformas en 2013 y 2017, nos limitaremos a destacar las partes de su contenido que resultan de mayor relevancia al tema de las sentencias internacionales. En este sentido, en primer lugar, la ley al ser general tiene un ámbito de validez nacional — no sólo federal一, y es aplicable a las autoridades de todos los ámbitos de gobierno, $y$ de sus poderes constitucionales, así como a cualquiera de sus oficinas, dependencias, organismos o ins-

Esta obra está bajo una Licencia Creative Commons

Atribución-NoComercial-SinDerivar 4.0 Internacional, IIJ-UNAM.

Boletín Mexicano de Derecho Comparado, núm. 160, enero-abril de 2021, pp. 99-154. 
tituciones públicas o privadas que velen por la protección de las víctimas, a proporcionar ayuda, asistencia o reparación integral.

Otro de sus aspectos torales es la figura central de la reparación integral a la que tiene derecho las víctimas, que comprende las medidas de restitución, rehabilitación, compensación, satisfacción y garantias de no repetición, en sus dimensiones individual, colectiva, material, moral y simbólica. Cada una de estas medidas será implementada a favor de la víctima teniendo en cuenta la gravedad y magnitud del hecho victimizante cometido o la gravedad y magnitud de la violación de sus derechos, asi como las circunstancias y características del hecho victimizante (artículo 1o., 27, 61 y ss.); esto rubros coinciden con los que dicta la Corte IDH mediante sus sentencias en favor de las víctimas.

Uno de los objetos de la Ley es precisamente reconocer y garantizar los derechos de las víctimas del delito y de violaciones a derechos humanos, en especial el derecho a la asistencia, protección, atención, verdad, justicia, reparación integral, debida diligencia y todos los demás derechos consagrados en ella, en la Constitución, en los Tratados Internacionales de derechos humanos de los que el Estado mexicano es parte y demás instrumentos de derechos humanos (artículo 2o., fracción I).

La calidad de víctima, requisito indispensable para que éstas puedan acceder a la reparación integral a la que tienen derecho, viene dado y es reconocido por ser así considerada en las determinaciones de los organismos internacionales de protección de derechos humanos a los que México les reconozca competencia, atento a lo previsto en el artículo 110, fracción V. En este sentido, en el rubro de la reparación en favor de las víctimas, previsto en las sentencias de la Corte IDH, la Ley de Víctimas, sus órganos (la Comisión Ejecutiva de Atención a Víctimas) y procedimientos, juegan un papel de suma trascendencia.

\section{El marco institucional}

A. El cumplimiento de las sentencias de la Corte IDH en los programas o planes de derechos humanos del gobierno federal en México

a) Los primeros programas nacionales de derechos humanos de 1998 y 2005. Una de las recomendaciones a los Estados derivada de la Declaración 
y Programa de Acción de Viena de 1993, ${ }^{20}$ en el marco de las Naciones Unidas, es el de contar con un plan de acción nacional en el que se determinen las medidas necesarias para que ese Estado mejore la promoción y protección de los derechos humanos.

El primer intento a este respecto fue el Programa Nacional para la Promoción y Fortalecimiento de los Derechos Humanos, que se dio a conocer a la opinión pública el 21 de diciembre de 1998, mismo que involucraba únicamente tareas de algunas dependencias del Gobierno federal y de la Comisión Nacional de los Derechos Humanos; para entonces, el Gobierno de México recién había aceptado la competencia contenciosa de la Corte IDH el 16 de diciembre de 1998.

Posteriormente fue elaborado un Programa Nacional de Derechos Humanos, que se divulgó el 5 de agosto de 2005, mucho más amplio y diverso que el anterior, de alguna forma vinculado al Diagnóstico sobre la Situación de los Derechos Humanos en México divulgado el 8 de diciembre de 2003, que fue coordinado por la Oficina en México del Alto Comisionado para los Derechos Humanos.

Los programas de referencia se gestaron en el marco de la entonces Comisión Intersecretarial para Atender los Compromisos Internacionales de México en Materia de Derechos Humanos, creada mediante decreto del 17 de octubre de 1997. Años después, el 11 de marzo de 2003, la mencionada Comisión fue establecida con carácter permanente por Acuerdo del Ejecutivo, bajo la denominación de Comisión de Política Gubernamental en Materia de Derechos Humanos. Tanto su composición como alcances fueron modificados, incluso su titularidad, que correspondía a la Cancillería, ahora está bajo la coordinación de la Secretaría de Gobernación y se diversificó su operación, de manera que se ha abierto a la participación de la sociedad civil.

b) El Plan Nacional de Derechos Humanos de 2008-2012. El Programa Nacional de 2005 sería sustituido por el Plan Nacional de Derechos Humanos (PNDH) 2008-2012, que fue promulgado por medio del Decreto publicado en el Diario Oficial de la Federación del 29 de agosto de 2008. Dicho Plan está vinculado al Plan Nacional de Desarrollo 2007-2012 del Ejecutivo federal.

20 Dicho programa fue producto de la Conferencia Mundial de Derechos Humanos, celebrada en Viena del 14 al 25 de junio de 1993.

Esta obra está bajo una Licencia Creative Commons

Atribución-NoComercial-SinDerivar 4.0 Internacional, IIJ-UNAM.

Boletin Mexicano de Derecho Comparado, núm. 160, enero-abril de 2021, pp. 99-154. 
El PNDH señalado tuvo en su elaboración una dinámica distinta a la de los anteriores planes, pues éste habría estado a cargo de la Secretaría de Gobernación, que instrumentó procesos de consulta y participación de instituciones y organizaciones ciudadanas de diversa índole, a los que se sumaron los resultados de algunos foros patrocinados por la Secretaría de Relaciones Exteriores.

De inmediato destaca el hecho que el PNDH, es en realidad un plan ubicado en el ámbito de la administración pública federal, pero no resulta en parámetros vinculantes para los poderes legislativo y judicial, ni para los órganos constitucionales autónomos, así como tampoco para autoridades en las entidades federativas o de índole municipal. Situación ésta que le ha restado alcances y eficacia y que, además, impacta a las posibles políticas públicas diseñadas para su implementación.

En relación con la estructura del PNDH, la misma cuenta con cuatro grandes objetivos, el cuarto de los cuales señala: "Fortalecer el cumplimiento de las obligaciones internacionales derivadas de Tratados e instrumentos jurídicos de derechos humanos y promover ese cumplimiento al interior del Poder Legislativo, Judicial y ante los tres órdenes de gobierno".

El propio PNDH menciona dos estrategias para lograr el objetivo cuarto, la primera de ellas enfocada a la necesaria armonización legislativa al momento de incorporar al ordenamiento estándares de derechos humanos de fuente internacional.

La segunda estrategia, que atañe directamente a nuestro tema, consiste en "Impulsar el seguimiento de las recomendaciones, observaciones generales y opiniones consultivas de los organismos internacionales en materia de derechos humanos, así como el cumplimiento de sentencias de órganos jurisdiccionales internacionales". Cabría mencionar que el término seguimiento no es indicativo de los que se pretende al final, pues "impulsar el seguimiento" no significa o equivale a cumplimiento o atención siguiendo la nomenclatura más difundida a nivel internacional, cuando se hace alusión a recomendaciones, en este sentido, la estrategia nació debilitada por cuanto se refiere al tema que mencionamos.

Cabe mencionar que la primera sentencia condenatoria para el Estado mexicano ante la Corte IDH, fue la emitida el 6 de agosto de 2008, en el caso Castañeda Gutman vs. México, misma que fue dada por completamente cumplida por la propia Corte IDH, por resolución del 28 de agosto de 2013. 
c) El PNDH 2014-2018. El eje central del PNDH 2014-2018 (Diario Oficial de la Federación del 30 de abril de 2014) fue la implementación de la reforma constitucional, del 10 de junio, en materia de derechos humanos. El PNDH inicia con un diagnóstico de la situación de los derechos humanos, en cuya parte final se afirma:

El Estado debe "organizar el poder público para garantizar a las personas bajo su jurisdicción el libre y pleno ejercicio de los derechos humanos". Por lo cual es necesario construir una política de Estado en la materia, lo que implica dar cumplimiento a las obligaciones constitucionales y convencionales de promoverlos, respetarlos, protegerlos y garantizarlos con un impacto real en el proyecto de vida de las personas. A ello se avoca el presente Programa por medio de sus objetivos, estrategias y líneas de acción.

La apuesta de la presente administración es garantizar una efectiva ejecución del Programa por parte de las distintas dependencias del Ejecutivo Federal, así como contar con la colaboración de los otros poderes, órganos autónomos, estados, municipios y sociedad civil, en el ámbito de sus respectivas atribuciones legales. El fin de este Programa es llegar al 2018 con la efectiva implementación de la reforma constitucional, con mecanismos fortalecidos de prevención y protección de violaciones a derechos humanos, así como de garantías sólidas de los mismos. Asimismo, se aspira a contar con una eficiente coordinación entre las instancias involucradas en la política de Estado en la materia, así como de información que permita evaluar el impacto y resultado de dicha política. Con ello, se consolidarán las bases de una sociedad de derechos y se contribuirá a una nueva etapa en el desarrollo de México.

El Programa buscó articular las estrategias, objetivos y metas nacionales, reflejadas en el Plan Nacional de Desarrollo, con los objetivos a su vez del Programa Sectorial de Gobernación y los seis objetivos del Programa Nacional de Derechos Humanos: 1. Lograr la efectiva implementación de la reforma constitucional de derechos humanos; 2. Prevenir violaciones de derechos humanos; 3. Garantizar el ejercicio y goce de los derechos humanos; 4. Fortalecer la protección de los derechos humanos; 5. Generar una adecuada articulación de los actores involucrados en la política de Estado de derechos humanos; 6. Sistematizar la información en materia de derechos humanos para fortalecer las políticas públicas. Destaca para efecto de nuestro tema, que la estrategia 3.3 para lograr los objetivos del mencionado Programa Sectorial de Gobernación es:

Esta obra está bajo una Licencia Creative Commons

Atribución-NoComercial-SinDerivar 4.0 Internacional, IIJ-UNAM.

Boletin Mexicano de Derecho Comparado, núm. 160, enero-abril de 2021, pp. 99-154. 
"Coordinar el cumplimiento de recomendaciones y sentencias en materia de derechos humanos".

Los mencionados seis objetivos del Programa Nacional se corresponden a su vez con sus estrategias y acciones, de las cuales destacamos dentro del objetivo 4, ya citado, la estrategia 4.3. Garantizar la efectividad de los mecanismos para atender sentencias, resoluciones o recomendaciones de organismos nacionales e internacionales de derechos humanos, a cargo y como responsables a la Secretaría de Gobernación, la Secretaría de Relaciones Exteriores y la Comisión Nacional para Prevenir Erradicar la Violencia contra las Mujeres. El objetivo y estrategia señalados se corresponden con diversas acciones, entre las que citamos con relación a nuestro tema: 4.3.1. Generar un sistema de evaluación permanente sobre el cumplimiento de recomendaciones, resoluciones y sentencias; 4.3.2. Promover reformas al marco jurídico para la efectiva atención de resoluciones de organismos internacionales y cooperación con los mismos; 4.3.3. Asegurar que en la ejecución de los programas derivados del Plan Nacional de Desarrollo se atiendan recomendaciones, resoluciones y sentencias; y 4.3.4. Impulsar que los informes de los poderes y órdenes de gobierno reporten el cumplimiento de recomendaciones, resoluciones y sentencias.

De igual manera, en materia de reparaciones, podemos señalar, también dentro del objetivo 4, la estrategia 4.1. Fortalecer los mecanismos de exigibilidad y justiciabilidad de los derechos humanos, para lo cual se señala como acción: 4.1.6. Impulsar la adopción de soluciones amistosas y reparación del daño a nivel internacional con el consentimiento de la víctima.

d) Algo sobre el aún pendiente PNDH 2019-2024. Al momento de culminar el presente trabajo, las actuales autoridades del gobierno mexicano señalaban, septiembre de 2020, que el PNDH se encuentra aún en etapa consultiva, que consistió en la realización a partir de junio de 2019 de foros temáticos en diversas entidades federativas, por parte de la Secretaría de Gobernación, por medio de la Subsecretaría de Derechos Humanos, Población y Migración, y su Dirección General de Política Pública de Derechos Humanos (DGPPDH). A dicha etapa de consulta ha seguido una denominada técnica, consistente en revisar y consultar las Estrategias y Líneas de Acción de 5 Objetivos Prioritarios del Programa, que se espera pueda culminarse y darse a conocer a tiempo para ser implementado y evaluados sus resultados. 
No obstante, cabe señalar que, en el programa sectorial correspondiente a la Secretaría de Gobernación, derivado del Plan Nacional de Desarrollo 2019-2024, publicado en el Diario Oficial de la Federación del 25 de junio de 2020, en el objetivo prioritario 3, denominado Garantizar, promover y proteger los derechos humanos mediante políticas públicas y mecanismos que aseguren el ejercicio pleno de sus derechos; estrategia prioritaria 3.1. (Establecer una política nacional de derechos humanos que garantice a las víctimas de violaciones graves su derecho a la memoria, verdad, justicia, reparación y no repetición), contiene como acciones puntuales relevantes a nuestro tema la número 3.1.2 que señala: implementar un mecanismo permanente de seguimiento y cumplimento de las recomendaciones y sentencias de los organismos nacionales e internacionales de derechos humanos; así como la número 3.1.3: fortalecer y consolidar los mecanismos para la atención integral a víctimas de violaciones graves de derechos humanos y garantizar su acceso a la memoria, verdad, justicia, reparación y no repetición de las víctimas de violaciones de derechos humanos.

\section{B. Las atribuciones de la Secretarías de Relaciones Exteriores, de la Secretaría de} Gobernación, así como de la Comisión de Política Gubernamental en Materia de Derechos Humanos

a) La Secretaría de Relaciones Exteriores. El secretario de Relaciones Exteriores tiene entre sus facultades no delegables, de acuerdo con el Reglamento Interior de la propia Secretaría (Diario Oficial de la Federación del 8 de enero de 2009), las de acordar las acciones correspondientes al cumplimiento de los compromisos internacionales de México, en coordinación con las dependencias competentes del Ejecutivo federal y sus órganos desconcentrados (artículo 7o., fracción XII). La Cancillería cuenta con una Subsecretaría para Asuntos Multilaterales y Derechos Humanos, de la que depende la Dirección General de Derechos Humanos y Democracia de la propia Secretaría, a la que corresponde representar al gobierno de México en los litigios o procedimientos derivados de las quejas y denuncias presentadas en contra del Estado mexicano ante organismos internacionales de derechos humanos, y promover la adopción de las medidas necesarias para resolver, conforme a derecho dichas quejas o denuncias (artículo 29, fracción XI).

Esta obra está bajo una Licencia Creative Commons

Atribución-NoComercial-SinDerivar 4.0 Internacional, IIJ-UNAM.

Boletin Mexicano de Derecho Comparado, núm. 160, enero-abril de 2021, pp. 99-154. 
b) La Secretaría de Gobernación. En el mismo tenor, de conformidad con la Ley Orgánica de la Administración Pública Federal (Diario Oficial de la Federación del 29 de diciembre de 1976), se atribuye a la Secretaría de Gobernación conducir la política interior que competa al Ejecutivo y no se atribuya expresamente a otra dependencia, y expresamente vigilar el cumplimiento de los preceptos constitucionales por parte de las autoridades del país; coordinar, en vinculación con las organizaciones de la sociedad civil, la promoción y defensa de los derechos humanos y dar seguimiento a la atención de las recomendaciones que emitan los organismos competentes en dicha materia, así como dictar las medidas administrativas necesarias para tal efecto (artículo 27, fracciones I y VII). Dentro de la estructura administrativa de la Secretaría de Gobernación (Diario Oficial de la Federación del 2 de abril de 2013), se cuenta con la Subsecretaría de Derechos Humanos, la Unidad para la Defensa de los Derechos Humanos, la Dirección General de Política Pública de Derechos Humanos, y la Dirección General de Estrategias para la Atención de Derechos Humanos; a la Unidad referida corresponde someter a consideración del superior jerárquico la forma en que serán atendidas las recomendaciones y sentencias dictadas por organismos internacionales en materia de derechos humanos cuya competencia, procedimientos y resoluciones sean reconocidos por el Estado mexicano (artículo 24, fracción VI, del Reglamento Interno).

Por lo que se refiere a la Dirección General de Política Pública, entre otras funciones, le corresponde recomendar reformas al marco jurídico en materia de derechos humanos y las garantías para su protección (artículo 25, fracción VIII), y establecer mecanismos para el seguimiento de los compromisos asumidos por el Estado mexicano en materia de derechos humanos (fracción XI).

Como puede observarse de los preceptos señalados, al menos en el ámbito administrativo, se cuenta con instancias con atribuciones en materia de atención nacional de los compromisos internacionales en materia de derechos humanos, dentro de lo cual se encuentra el cumplimiento de las sentencias de la Corte IDH, que incluye el tema de reparaciones, así como para hacer los cambios normativos que permitan su cumplimiento.

c) La Comisión de Política Gubernamental en Materia de Derechos Humanos. La Comisión Intersecretarial para Atender los Compromisos Internacionales de México en Materia de Derechos Humanos, fue creada mediante decreto del 17 de octubre de 1997, con el propósito de coordinar las acciones del gobierno federal para el cumplimiento de los mencionados com- 
promisos; el secretario técnico de la Comisión era el titular de la Dirección General de Derechos Humanos de la Cancillería.

El 11 de marzo de 2003, como se mencionó en apartados previos, el mecanismo de la Comisión Intersecretarial fue establecido con carácter permanente por Acuerdo del Ejecutivo publicado en esa fecha en el Diario Oficial de la Federación, bajo la denominación de Comisión de Política Gubernamental en Materia de Derechos Humanos (CPGMDH). La Secretaría de Gobernación funge como presidente del organismo y como vicepresidente la Secretaría de Relaciones Exteriores.

Entre las funciones asignadas a la Comisión, en el tema específico objeto del presente trabajo están las de (artículo 3o. del acuerdo):

V. Crear los mecanismos de coordinación permanente para que las dependencias y entidades de la Administración Pública Federal, colaboren de manera oportuna y completa conforme a la ley, a efecto de que se atiendan las obligaciones internacionales del Gobierno mexicano;

IX. Coordinar las acciones de las dependencias y entidades de la Administración Pública Federal tendientes a dar cumplimiento a las sentencias, resoluciones y recomendaciones dictadas por organismos internacionales de derechos humanos cuya competencia, sea reconocida por el Estado mexicano...

La CPGMDH ha venido operando y ampliando su estructura y su conformación, así como fortaleciendo su trabajo con la participación de un mayor número de entidades y de la sociedad civil. Hace un par de años, la Comisión de referencia presentó un informe de labores 20132018 (https://wrere.gob.mx/cms/uploads/attachment/file/426417/Informe_de_ actividades_2013-2018_CPGMDH.pdf,11/09/2020), en el que no aparece ninguna mención al respecto de la participación de ésta en el seguimiento al cumplimiento a alguna de las sentencias emitidas contra México por la Corte IDH, actividad sobre la cual ha estado más bien al margen, a pesar de contar con atribuciones para ello.

d) El Sistema Nacional de Atención a Victimas y la Comisión Ejecutiva de Atención a Victimas (CEAV). La Ley General de Víctimas, que analizamos en lo sustantivo párrafos atrás, trajo consigo el establecimiento del CEAV, una estructura de política y coordinación nacional y un órgano ejecutivo, respectivamente, con importantes atribuciones, entre otras, sobre el tema que nos ocupa. 
De acuerdo con el artículo 79 de la ley señalada, el Sistema Nacional de Atención a Víctimas será la instancia superior de coordinación y formulación de políticas públicas y tendrá por objeto proponer, establecer y supervisar las directrices, servicios, planes, programas, proyectos, acciones institucionales e interinstitucionales, y demás políticas públicas que se implementen para la protección, ayuda, asistencia, atención, acceso a la justicia, a la verdad y a la reparación integral a las víctimas en los ámbitos local, federal y municipal. Entre las atribuciones del Sistema está la de elaborar propuestas de reformas en materia de atención a víctimas (artículo 81, fracción IV).

El sistema lo encabeza el presidente de la República y lo integran todas las instituciones y entidades públicas federales, estatales, del gobierno de la Ciudad de México y municipales, organismos autónomos, y demás organizaciones públicas o privadas, encargadas de la protección, ayuda, asistencia, atención, defensa de los derechos humanos, acceso a la justicia, a la verdad y a la reparación integral de las víctimas.

Para la operación del Sistema y los objetos y finalidades de la Ley, se establece la Comisión Ejecutiva y Comisiones de víctimas en las entidades federativas. La CEAV es un órgano con personalidad jurídica y patrimonio propios; con autonomía técnica y de gestión; que tiene por objeto garantizar, promover y proteger los derechos de las víctimas del delito y de violaciones a derechos humanos, en especial los derechos a la asistencia, a la protección, a la atención, a la verdad, a la justicia, a la reparación integral y a la debida diligencia (artículos 79 y 84$)$.

Entre sus funciones y facultades, corresponde a la CEAV asegurar la participación de las víctimas tanto en las acciones tendientes a garantizar el cumplimiento de las obligaciones derivadas de sentencias internacionales en materia de derechos humanos dictadas en contra del Estado mexicano (artículo 88, fracción IX). De igual manera, la CEAV tiene a su cargo el Fondo, la Asesoría Jurídica Federal y el Registro Nacional de Víctimas, instrumentos indispensables para la determinación de las medidas y reparaciones que la misma determine y otorgue por medio de sus procedimientos (artículo 84). 


\section{El marco jurisprudencial}

\section{A. La discusión de la sentencia del caso Rosendo Radilla ante la Suprema Corte de Justicia de la Nación (SCFN)}

Con motivo de la publicación en el Diario Oficial de la Federación del 9 de febrero de 2010, de los fragmentos de la sentencia dictada por la Corte Interamericana de Derechos Humanos en el caso Rosendo Radilla Pacheco vs. Estados Unidos Mexicanos, según lo ordenado por el mismo tribunal internacional, la SCJN inició la tramitación del denominado expediente "varios" 489/2010, que culminó con una resolución del 7 de septiembre de dos mil diez en la que determinó discutir las consecuencias de la sentencias de la Corte Interamericana para el Poder Judicial de la Federación.

Así surgió con posterioridad el expediente "varios" 912/2010, dentro de cuya discusión en julio de 2011 - cuando entró en vigor la reforma constitucional en materia de derechos humanos-- derivaron importantes criterios en armonía con la reforma constitucional.

La SCJN en el considerando quinto de su resolución del 14 de julio de 2011, emitió diversos criterios, de los que destacan para efectos de este trabajo los siguientes:

17... esta Suprema Corte no es competente para analizar, revisar, calificar o decidir si una sentencia dictada por la Corte Interamericana de Derechos Humanos, esto es, en sede internacional, es correcta o incorrecta, o si la misma se excede en relación con las normas que rigen su materia y proceso. Esta sede de jurisdicción nacional no puede hacer ningún pronunciamiento que cuestione la validez de lo resuelto por la Corte Interamericana de Derechos Humanos, ya que para el Estado Mexicano dichas sentencias constituyen, como ya dijimos, cosa juzgada y, por ende, lo único procedente es acatar y reconocer la totalidad de la sentencia en sus términos.

19. Así, las resoluciones pronunciadas por aquella instancia internacional cuya jurisdicción ha sido aceptada por el Estado Mexicano, son obligatorias para todos los órganos del mismo en sus respectivas competencias, al haber figurado como Estado parte en un litigio concreto...

Los criterios de la SCJN vienen no sólo a confirmar la firmeza e incuestionabilidad de las sentencias de la Corte Interamericana, sino tam- 
bién su obligatoriedad para todos los órganos del Estado mexicano en sus respectivas competencias, a los que corresponde la mera ejecución del fallo de que se trate, sin objeciones, obstáculos o cuestionamientos.

\section{B. Otros criterios recientes del Poder Fudicial de la Federación, sobre la autoridad y efectos de las sentencias de la Corte IDH en el ámbito interno}

En el marco de aplicación de la reforma constitucional en materia de derechos humanos y luego de los importantes criterios derivados del caso Rosendo Radilla, los tribunales del Poder Judicial de la Federación, han venido emitiendo un cúmulo importante de criterios que tienen que ver con el derecho internacional de los derechos humanos. Algunos de éstos se han referido a las sentencias de la Corte IDH, los cuales reseñamos y comentamos a continuación.

Un primer criterio es una tesis aislada de la Primera Sala de la SCJN, que reafirma la obligación de cumplir las sentencias de la Corte IDH, así como la obligatoriedad de los criterios interpretativos previstos en éstas, en los casos que involucren al Estado mexicano. La tesis es del rubro y tenor siguientes:

Corte Interamericana de Derechos Humanos. Efectos de sus sentencias en el ordenamiento jurídico mexicano. El Estado mexicano se adhirió a la Convención Americana sobre Derechos Humanos el 24 de marzo de 1981 y reconoció la competencia contenciosa de la Corte Interamericana de Derechos Humanos el 16 de diciembre de 1998, mediante declaración unilateral de voluntad que fue publicada en el Diario Oficial de la Federación el 24 de febrero de 1999. En ese sentido, los artículos 133 y 1o. de la Constitución Política de los Estados Unidos Mexicanos reconocen la vigencia de los tratados internacionales en nuestro ordenamiento jurídico interno y establecen la obligación de las autoridades nacionales de aplicar los derechos humanos de conformidad con la Constitución y los tratados internacionales vigentes en nuestro país. Por lo anterior, la ratificación de la Convención Americana sobre Derechos Humanos y el reconocimiento de la jurisdicción contenciosa de la Corte Interamericana de Derechos Humanos, generan como una consecuencia ineludible que las sentencias emitidas por dicho tribunal internacional, en aquellos casos en los cuales México haya sido parte en el juicio, resulten obligatorias para el Estado mexicano, incluidos todos los jueces y 
tribunales que lleven a cabo funciones materialmente jurisdiccionales. Esta obligatoriedad alcanza no sólo a los puntos resolutivos de las sentencias en comento, sino a todos los criterios interpretativos contenidos en las mismas. (Tesis: 1a. XIII/2012 (10a.))

Otra tesis aislada, también proveniente de la Primera Sala de la SCJN, desde otro ángulo, reafirma y fundamenta el deber de todas las autoridades de cumplir con lo ordenado en las sentencias de la Corte IDH. Se trata de la tesis bajo el rubro:

Sentencias de la Corte Interamericana de Derechos Humanos. Todas las autoridades del Estado mexicano, incluyendo el Poder Judicial de la Federación, deben acatar lo ordenado en aquéllas. El Poder Judicial de la Federación tiene la obligación de acatar una orden que le incumba por estar contenida en una sentencia de un tribunal internacional, como sería el caso de juzgar a los perpetradores de violaciones de derechos humanos declaradas por el organismo internacional. Así, conforme a las obligaciones internacionales adquiridas soberanamente por México, todos sus Poderes deben cumplir con lo ordenado en las sentencias emitidas contra el Estado mexicano. Esto tiene su fundamento en el artículo 26 de la Convención de Viena sobre el Derecho de los Tratados, que establece el principio pacta sunt servanda, y que prescribe que todo tratado en vigor obliga a las partes y debe ser cumplido por ellas de buena fe y, para el caso específico del Sistema Interamericano de Protección de Derechos Humanos, en el artículo 68.1 de la Convención Americana sobre Derechos Humanos que establece que los Estados Parte se comprometen a cumplir la decisión de la Corte Interamericana de Derechos Humanos, en todo caso en que sean partes. ( Tesis: 1a. CXLIV/2014 (10a.))

Otra tesis aislada proveniente del mismo asunto que la anterior, dejó en claro que por medio del juicio de amparo es posible reclamar en sede interna el cumplimiento de aspectos de la sentencia de la Corte IDH, pero no al grado de que la instancia interna invada las atribuciones del propio tribunal interamericano respecto a la calificación del cumplimiento o incumplimiento de la sentencia respectiva por parte del Estado. Este criterio es de utilidad para hacer planteamientos respecto a las medidas de reparación señaladas en la propia sentencia interamericana. El rubro y texto de la tesis es del tenor siguiente: 
Sentencias de la Corte Interamericana de Derechos Humanos. Obligaciones derivadas de aquellas cuyo cumplimiento puede analizarse en el juicio de amparo. El artículo 103, fracción I de la Constitución Federal establece que el juicio de amparo procede contra normas generales, actos u omisiones de la autoridad que violen los derechos humanos reconocidos en la Constitución y en los tratados internacionales de los que el Estado Mexicano sea parte y las garantías otorgadas para su protección; del que se deriva que el juicio constitucional requiere para su procedencia no sólo de la existencia de un acto de autoridad (positivo o negativo) o de una norma jurídica del que se pueda predicar una probable violación a los derechos humanos, sino que además se trate de un acto de autoridad apto para su conocimiento judicial. Excepcionalmente, no se actualiza esta propiedad de justiciabilidad cuando la Constitución otorga claramente la determinación de una cuestión a una de las ramas u órganos políticos, o determinados órganos especializados para ser resuelta por criterios de oportunidad o de especialidad. No tomar ello en consideración implicaría, por parte del Poder Judicial mexicano, sustituirse en esas facultades de apreciación y arriesgar la racionalidad constitucional de un determinado diseño institucional. Esta categoría de casos es sumamente excepcional y esta Suprema Corte se niega a encontrar especies del mismo de manera ordinaria, salvo que satisfagan contundentemente las notas constitutivas de dicha categoría y no se genere una incoherencia al interior del modelo de estado constitucional, lo cual requiere un análisis casuístico. Así, los actos de autoridad cuyo escrutinio implique indefectiblemente un pronunciamiento simultáneo sobre la interrogante de si una sentencia de la Corte Interamericana está cumplida o no constituye un "núcleo duro" de una cuestión no justiciable en sede interna, por las razones ya expuestas. No obstante, a medida que existan actos que se alejen de este punto fijo, de manera casuística, las juezas y los jueces de amparo deben determinar si esta potencial intromisión en el ejercicio de facultades especiales atribuidas con exclusividad a un órgano internacional se diluye al grado de verse derrotada por el principio pro actione y, por tanto, por la procedencia del juicio constitucional. La exigencia de justiciabilidad se robustecerá a medida que el análisis de los actos reclamados no exija de los jueces constitucionales responder a la interrogante de si la sentencia internacional está o no cumplida, sino exija la respuesta de cuestiones incidentales o indirectas y del acto reclamado dependa la satisfacción de un derecho del quejoso - por ejemplo, actos reclamados por la víctima declarada y/o beneficiaria de reparaciones - (Tesis: 1a. CXLIII/2014 (10a.), énfasis agregado).

Una tesis adicional, en la misma línea que las precedentes y derivada del mismo asunto, abona al reconocimiento de las atribuciones de la Cor-

Esta obra está bajo una Licencia Creative Commons Atribución-NoComercial-SinDerivar 4.0 Internacional, IIJ-UNAM. Boletín Mexicano de Derecho Comparado, núm. 160, enero-abril de 2021, pp. 99-154. 
te IDH de seguimiento y calificación del cumplimiento de sus determinaciones. La tesis es la siguiente:

Sentencias de la Corte Interamericana de Derechos Humanos. La determinación de si están cumplidas es una facultad exclusiva de ese órgano, por lo que no es cuestión justiciable en el juicio de amparo (interpretación de la fracción XVIII del artículo 73 de la ley de amparo abrogada). Esta Primera Sala de la Suprema Corte de Justicia de la Nación considera que el Poder Judicial de la Federación, aun en ejercicio de sus poderes de control constitucional, no está facultado para pronunciarse sobre el cumplimiento o incumplimiento, por parte de las autoridades nacionales, de las sentencias emitidas por la Corte Interamericana de Derechos Humanos en contra del Estado mexicano. Esta calificación de no justiciabilidad en sede interna no rompe con la coherencia del modelo de Estado Constitucional, pues no implica el reconocimiento de una categoría de casos impune al escrutinio de los derechos humanos; por el contrario, justamente, su reconocimiento conlleva el respeto a un diseño institucional reconocido constitucionalmente que da cabida a un medio internacional de protección de los derechos humanos, por lo que al existir un obstáculo técnico, cuya teleología es evitar una inapropiada interferencia del Poder Judicial de la Federación en un diseño supranacional, cuando se impugne la omisión de las autoridades de dar cumplimiento a la sentencia de dicho tribunal, se actualiza la causal de improcedencia prevista en la fracción XVIII del artículo 73 de la Ley de Amparo abrogada, en relación con la fracción I del artículo 103 de la Constitución federal, interpretado este último a contrario sensu. (Tesis: 1a. CXLII/2014 (10a.))

Un criterio adicional e igual de importante, en este caso para la labor de las organizaciones no gubernamentales que representan a las víctimas en el ámbito internacional, es el que de alguna manera tener por legitimadas a dichas organizaciones para actuar en ese carácter ante las instancias de carácter interno, incluyendo la interposición del juicio de amparo. La tesis es del rubro y texto siguientes:

Representación legal de las víctimas ante la Corte Interamericana de Derechos Humanos. Efectos en el ordenamiento jurídico mexicano. Si un particular o una persona jurídica ha sido representante legal de las víctimas ante la Corte Interamericana de Derechos Humanos, dicha representación surte todos sus efectos en el ordenamiento jurídico mexicano, ya sea ante las autoridades administrativas o ante los tribunales locales o federales mexicanos. Lo

Esta obra está bajo una Licencia Creative Commons

Atribución-NoComercial-SinDerivar 4.0 Internacional, IIJ-UNAM.

Boletin Mexicano de Derecho Comparado, núm. 160, enero-abril de 2021, pp. 99-154. 
anterior se deriva de que la ratificación de la Convención Americana Sobre Derechos Humanos y el reconocimiento de la jurisdicción contenciosa de la Corte Interamericana de Derechos Humanos generan como una consecuencia ineludible que las sentencias emitidas por dicho tribunal internacional, en aquellos casos en los cuales México haya sido parte en el juicio, resulten obligatorias para el Estado mexicano, lo cual incluye el reconocimiento de personalidad de los representantes legales de las víctimas que se haya realizado en dicha resolución. Lo anterior no limita la posibilidad de que, a través de los cauces previstos en la legislación aplicable, las víctimas revoquen dicha representación, en cuyo caso, los representantes no podrán actuar ante los órganos mexicanos. (Tesis: 1a. XV/2012 (10a.))

Los criterios que hemos citado se suman a las consideraciones sobre el marco jurídico interno para dar eficacia a las sentencias de la Corte IDH, incluyendo el tema de las reparaciones que la misma haya dictado en el caso concreto. Dicho marco, proporciona una base importante, aunque en mucho perfectible para contar con reglas claras sobre la manera de proceder por parte de las autoridades de manera completa y eficaz, en particular para cumplir con las reparaciones en favor de las víctimas.

\section{CONCLUSIONES Y PROPUESTA}

Primera. Cuando la Corte IDH declara en una sentencia la responsabilidad de un Estado por violaciones a los Derechos Humanos, debe también disponer, si la naturaleza de las afectaciones lo permiten, la restitución en favor de las víctimas en el goce de los derechos conculcados, así como también la reparación de las consecuencias que tales violaciones hayan traído consigo y, de proceder, el pago de una indemnización. En ejercicio de dicho deber y atribución prevista en la $\mathrm{CADH}$, el tribunal interamericano ha desarrollado a lo largo de su existencia un nutrido cuerpo de jurisprudencia sobre las medidas y acciones que integran la restitución, la reparación propiamente dicha y la indemnización, las cuales toca a los Estados llevar a cabo en el ámbito interno y acreditar como parte del cumplimiento de la sentencia en el ámbito internacional, por medio de la etapa de supervisión ante la propia Corte IDH. En este sentido, el marco jurídico e institucional con que cuenten los Estados en el ámbito interno resulta relevante para efectos del cumplimiento efectivo de las mencionadas sentencias. 
Segunda. No obstante que la obligatoriedad de las sentencias de la Corte IDH tiene base convencional y está fuera de duda, así como el correlativo deber de los Estados para cumplirlas, no existe uniformidad en la manera en que el marco jurídico e institucional de éstos está diseñado para responder a dicho compromiso. Una panorama sobre las rutas que han seguido los Estados para este efecto arroja que en algunos casos se han intentado reformas constitucionales para dejar en claro desde la carta magna el carácter y vinculatoriedad de las sentencias de la Corte IDH, así como el deber de las autoridades nacionales de proveer su cumplimiento; otra ruta es la de aquellos Estados que han desarrollado legislación específica o proyectos de ley para el cumplimiento de las sentencias interamericanas, o de las sentencias internacionales en general; una ruta más es la que muestran los Estados que han preferido crear cuerpos o instancias administrativas de coordinación de las acciones del Gobierno en tal sentido; y por último están los casos de Estados que han preferido cumplir con algún aspecto de las sentencias vía actos ad hoc, esto es, acuerdos o decretos, o apertura de expedientes judiciales (discusión del caso Radilla Pacheco ante la SCJN), para efecto del cumplimiento de algún punto de un caso específico.

Tercera. Amén de las iniciativas y proyectos analizados, lo cierto es que al día de hoy sólo el Perú cuenta con una ley vigente aplicable al cumplimiento de las sentencias de la Corte IDH; mientras que en el caso de Colombia, Ecuador, México y Paraguay - la existente en Guatemala fue recientemente desaparecida-, se cuenta con instancias de coordinación creadas por decreto administrativo, que entre sus atribuciones tienen las de impulsar o llevar a cabo las acciones tendientes a cumplir con las sentencias del tribunal interamericano. Además, no se debe perder de vista el papel central que tienen en estos procesos las dependencias encargadas de las relaciones exteriores, las instancias encargadas de la política interior e incluso las presidencias en cada uno de los países.

Cuarta. Si bien los Estados no podrían invocar la normatividad existente o la falta de ella, para dejar de cumplir con las sentencias de la Corte IDH, atendiendo además de la $\mathrm{CADH}$, a la Convención de Viena sobre Derechos de los Tratados (artículo 27), es importante que cuenten con reglas internas claras que hagan posible un eficaz cumplimiento de aquellas, como parte de su deber de contar con disposiciones de carácter interno para hacer efectivos los derechos humanos, pero también para

Esta obra está bajo una Licencia Creative Commons

Atribución-NoComercial-SinDerivar 4.0 Internacional, IIJ-UNAM.

Boletín Mexicano de Derecho Comparado, núm. 160, enero-abril de 2021, pp. 99-154. 
respetar la igualdad y no discriminación de las propias víctimas en los diversos casos a la hora de la reparación; de igual manera, la normatividad permitirá distribuir las responsabilidades internas en el cumplimiento, así como el apoyo de los órganos no vinculados con las violaciones cometidas, pero cuyas atribuciones son determinantes para reparar éstas (por ejemplo en el caso de reformas legislativas, de pago de indemnizaciones o de procuración e impartición de justicia); esto permitiría a su vez contar con bases para el cumplimiento cabal y eficaz de los aspectos pecuniarios y no pecuniarios que el caso amerite, y zanjar las dificultades que pudieran surgir en los Estados federales, por la distribución de atribuciones y competencias.

Quinta. El análisis que realizamos a la situación de México arrojó que cuenta con un marco jurídico, institucional y jurisprudencial atinente al tema del cumplimiento de las sentencias de la Corte Interamericana, aunque esto no significa que se encuentre debidamente articulado o sea del todo eficaz. Por lo que se refiere al marco jurídico, si bien no se cuenta con un precepto constitucional expreso, la reforma de junio de 2011 en materia de derechos humanos provee una base sólida para efecto del cumplimiento de las sentencias de la Corte IDH, como parte de los deberes de garantía y de reparación de violaciones a los derechos humanos que corresponden a todas las autoridades del país. Existen a su vez disposiciones en la legislación en materia de tratados, de responsabilidad patrimonial del Estado y más recientemente en la de víctimas, que requieren una necesaria depuración y de armonización entre sí, en tanto, la ley de víctimas es la que ofrece el marco más avanzado y pro persona (así sea en lo sustantivo), por lo que debe guiar el tema de reparación integral.

Sexta. En el ámbito institucional, el tema de cumplimiento de sentencias interamericanas y de la atención de víctimas de violaciones a los derechos humanos, se ha contemplado en los planes o programas nacionales de derechos humanos, con estrategias, acciones específicas e instancias responsables, que acompañan la labor institucional en la materia durante el sexenio presidencial de que se trate; asimismo, las secretarías de Gobernación y de Relaciones Exteriores y, además, la Comisión de Política Gubernamental en materia de derechos humanos y la propia Comisión Ejecutiva de Atención a Víctimas, tiene atribuciones expresas al respecto, incluso para proponer cambios normativos. Sin embargo, el seguimiento y eficacia que han demostrado en el tema que nos ocupa ha sido clara- 
mente insuficiente, pues siguen estando en la etapa de supervisión de cumplimiento de sentencia ante la Corte IDH aún nueve casos, que merecen una decidida actuación del Estado mexicano para su cabal atención.

Séptima. Por lo que respecta al Poder Judicial de la Federación, como parte del cuerpo jurisprudencial que se ha venido formando a partir de la entrada en vigor de la reforma constitucional de 2011 en materia de derechos humanos, que dio pie a la décima época de la jurisprudencia, podemos destacar la importancia de la discusión del caso Radilla y de los criterios derivados de éste, así como de aquellos que han permitido dejar en claro la importancia y autoridad que tienen las sentencias de la Corte IDH, así como los precedentes de ésta, a lo que se suman algunas tesis de las que dimos cuenta, sobre la posibilidad y alcances del juicio de amparo, como una vía para que las víctimas o sus representantes puedan exigir de las autoridades acciones relacionadas con el cumplimiento de las sentencias interamericanas.

Octava. Consideramos que están puestas las bases para una posible ley específica para ejecutar adecuadamente las sentencias de la Corte Interamericana, sobre todo en el tema de repraciones en favor de las víctimas, la cual debe atender las siguientes pautas:

- La normatividad debe ser general, de ámbito y aplicación nacional, y no únicamente federal, asimismo, debe cumplir con un principio básico de igualdad para todas las victimas derivadas de los casos que decida la mencionada Corte, y ser complementada con un adecuado marco de responsabilidades para los servidores públicos que no cumplan con sus obligaciones en la materia.

- De contemplarse procedimientos específicos para el cumplimiento de las sentencias, los mismos deberán ser accesibles, ágiles, sencillos, completos y definitivos, tendientes sobre todo a la ejecución de los decididos, más no como una instancia de cuestionamiento ulterior o de prolongación indefinida del cumplimiento, y que en ellos cualquier carga procedimental se establezca en los términos más favorables a las víctimas o peticionarios. Se debe cuidar sobre todo que no incidan en el procedimiento impugnaciones internas ulteriores, por lo que en muchos casos es de suma utilidad que intervengan los órganos jurisdiccionales de mayor grado y últimos, cuyas determinaciones son inimpugnables.

Esta obra está bajo una Licencia Creative Commons

Atribución-NoComercial-SinDerivar 4.0 Internacional, IIJ-UNAM.

Boletín Mexicano de Derecho Comparado, núm. 160, enero-abril de 2021, pp. 99-154. 
- Que el marco jurídico que se establezca no se concentre únicamente en los temas de reparación económica, sino busque ser omnicomprensivo a efecto de cumplir con la reparación integral, de manera que la atención de la sentencia de la Corte IDH sea cabal en todos y cada uno de sus rubros. A su vez, que el procedimiento de ejecución cumpla con el principio de máxima publicidad, de cara a la sociedad, salvo las excepciones que por su propia naturaleza ameriten reserva, misma que debe ser acotada a su mínimo nivel. En este sentido, además, debe garantizarse una difusión adecuada del cumplimiento de las sentencias internacionales y lo que derive de ellas en el ámbito interno, con el fin de que éstas tengan además un efecto multiplicador y preventivo, que permita a las autoridades nacionales motivarlas a corregir su actuación y a ajustarla a los estándares de derechos humanos.

- Que los cambios o la normatividad no sólo abarquen el cumplimiento de sentencias de la Corte Interamericana, sino también la atención de recomendaciones internacionales, de órganos presentes o futuros; en el caso de México esto implicaría abarcar al menos a la CIDH y a los Comités de Naciones Unidas encargados de supervisar tratados de derechos humanos, tanto en su modalidad de quejas individuales, como de recomendaciones derivadas de otras atribuciones de supervisión internacional (por ejemplo, análisis de informes y visitas en el terreno).

\section{BIBLIOGRAFÍA}

Bicudo, Helio (2001). Cumplimiento de las sentencias de la Corte Interamericana de Derechos Humanos y de las Recomendaciones de la Comisión Interamericana de Derechos Humanos. Corte Interamericana de Derechos Humanos. El Sistema Interamericano de Protección de los Derechos Humanos en el Umbral del Siglo XXI (Memoria del Seminario), tomo I, pp. 229-236.

Buergenthal, Thomas (2001). Implementation fo the Judgments of the Interamerican Court of Human Rights. Corte Interamericana de Derechos Humanos. El Sistema Interamericano de Protección de los Derechos 
Humanos en el Umbral del Siglo XXI (Memoria del Seminario), tomo I, pp. 185-196.

Calderón Gamboa, Jorge F. (2015). La evolución de la "reparación integral" en la jurisprudencia de la Corte Interamericana de Derechos Humanos, GNDH.

Carmona Tinoco, Jorge Ulises (2013). Actualidad y necesidades del marco jurídico mexicano para la cabal ejecución de las sentencias de la Corte Interamericana de Derechos Humanos. En Edgar Corzo Sosa, Jorge Ulises Carmona Tinoco y Pablo Saavedra Alessandri (coords.), Impacto de las sentencias de la Corte Interamericana de Derechos Humanos (pp. 99-124). México: Tirant lo Blanch-UNAM-Instituto Iberoamericano de Derechos Humanos-Corte Interamericana de Derechos Humanos.

Carmona Tinoco, Jorge Ulises (2008). El marco jurídico e institucional mexicano para atender las recomendaciones de la Comisión Interamericana de Derechos Humanos y cumplir con las sentencias de la Corte Interamericana de Derechos Humanos. En Ricardo Méndez Silva (coord.), Derecho internacional de los derechos humanos. Culturas y Sistemas Jurídicos Comparados, tomo. I (pp. 335-396). México: UNAM.

Carmona Tinoco, Jorge Ulises (2011). La necesidad de políticas públicas para la eficacia de las decisiones de los órganos del sistema interamericano de protección de los derechos humanos. En Andre y Luis Eduardo Zavala, Políticas públicas y derechos humanos en México, Escuela de Gobierno John F. Kennedy de la Universidad de Harvard-Escuela de Graduados de Graduados en Administración Pública y Política Pública del Tecnológico de Monterrey.

CASTRO ESTRADA, Álvaro (2002). Nueva garantía constitucional. La responsabilidad patrimonial del Estado. Porrúa.

Corte Interamericana de Derechos Humanos (2020). Informe Anual 2019. Corte Interamericana de Derechos Humanos.

Cruz, Luis M. (2010). La reparación a las víctimas en el Convenio Europeo de Derechos Humanos. Revista Española de Derecho Internacional, LXII(1), pp. 89-117.

FIX-ZAMUDIO, Héctor (1993). La Constitución y su Defensa. Fusticia constitucional, ombudsman y derechos humanos. Comisión Nacional de Derechos Humanos, pp. 293 y ss. 
FIX-ZAMUDIO, Héctor (1988). La protección procesal de las garantías individuales en América Latina. Latinoamérica: Constitución, proceso y derechos humanos. Miguel Ángel Porrúa-UDUAL, pp. 53-97.

GARCía RAMíREZ, Sergio (2003). Las reparaciones en el sistema interamericano de protección de los derechos humanos en el umbral del siglo XXI, tomo I (2a. ed.), Corte Interamericana de Derechos Humanos-Gobierno de los Estados Unidos Mexicanos- Agencia Española de Cooperación Internacional, pp. 129-158.

GARCÍA RAMÍREZ, Sergio (2011). Reparaciones de fuente internacional por violación de derechos humanos (sentido e implicaciones del párrafo tercero del artículo 1o. Constitucional bajo la reforma de 2011). En Miguel Carbonell y Pedro SALAZAR (coords.), La reforma de derechos humanos: un nuevo paradigma (pp. 167-199). México: UNAM.

KRSTICEVIC, Viviana (coord.) (2007). Implementación de las decisiones del sistema interamericano de derechos humanos: jurisprudencia, normativa y experiencias nacionales. Center for Justice and International Law.

KRSTICEVIC, Viviana (2009). Implementación de las decisiones del sistema interamericano de derechos humanos: aportes para los procesos legislativos. Center for Justice and International Law.

Menengoti Gonçalves Ribeiro, Daniela y Dos SAntos NetTo, Jonas (2019). O cumprimento das decisões da Corte Interamericana pelo Brasil: dialógica com a aplicabilidade Imediata das normas definidoras de direitos e garantias fundamentais. Revista Electrónica do Curso de Direito, 14(3), 1-34.

MurRAY, Rachel (2020). Addressing the Implementation Crisis: Securing Reparation and Righting Wrongs. Journal of Human Rights Practice, 12(1), 1121.

Murray, Rachel y De Vos, Christian (2020). Behind the State: Domestic Mechanisms and Procedures for the Implementation of Human Rights Judgments and Decisions. Fournal of Human Rights Practice, 12(1), 22-47. PinAcho EsPinosa, Jacqueline Sinay (2019). El derecho a la reparación del daño en el sistema interamericano. Comisión Nacional de Derechos Humanos. RodríGuez Huerta, Tania Gabriela (1996). La ejecución de las sentencias de la Corte Interamericana de Derechos Humanos, el Caso de Honduras. Revista Lex (7), 17-20. 
RoDRÍGUEz RESCIA, Víctor M. (1999). Las reparaciones en el sistema interamericano de protección de derechos humanos. ILSA fournal of International \& Comparative Law, 5(3), 667-687.

SAAVEDRA Alessandri, Pablo (2017). Algunas reflexiones en cuanto al impacto estructural de las decisiones de la Corte Interamericana de Derechos Humanos. En Eduardo Ferrer Mac-Gregor, Armin Von BOGDANDY, Mariela MORALES ANTONIAZZI (coords.), Ius constitutionale commune en América Latina (pp. 457-502). Querétaro. Instituto de Estudios Constitucionales del Estado de Querétaro-Max Planck Institute.

SAAVEdRA Álvarez, Yuria (2013). Teoría de las reparaciones a la luz de los derechos humanos. Suprema Corte de Justicia de la Nación-Oficina en México del Alto Comisionado de las Naciones Unidas para los Derechos Humanos-Comisión de Derechos Humanos del Distrito Federal.

Ventura Robles, Manuel (2013). Impacto de las reparaciones ordenadas por la Corte Interamericana de Derechos Humanos y aportes en la justiciabilidad de los derechos económicos, sociales y culturales. Revista Red Pensar, 2(1), 1-20.

Vivas BARrerA, Tania Giovanna (2014). Panorama de cumplimiento de condenas dictadas por la Corte Interamericana de Derechos Humanos. Revista Principia Iuris (22), 165-189. 


\title{
EL FUTURO DEL ESTADO AUTONÓMICO EN ESPAÑA: ¿BLOQUEO O REFORMULACIÓN?*
}

\author{
THE FUTURE OF THE STATE OF AUTONOMIES IN SPAIN: \\ BLOCKAGE OR REFORMULATION?
}

\author{
María Jesús GARcía MORALES*
}

RESUMEN: El Estado autonómico fue la gran invención de la Constitución Española de 1978. España dejó de ser un Estado centralista y optó por un alto grado de descentralización. A lo largo de cuatro décadas, el Estado de las autonomías se ha consolidado, pero también debe resolver dos crisis diversas: el desgaste del modelo territorial tras cuarenta años de funcionamiento y la crisis de Cataluña. Entre los posibles escenarios, la reformulación del Estado autonómico es la salida más razonable. Es preciso identificar cuáles son los problemas de la organización territorial española y examinar de qué manera los sistemas sobre todo federales pueden ayudar a resolverlos. Sin embargo, una reforma constitucional en sentido fede-
ABSTRACT: The State of autonomies was the great invention of the Spanish Constitution of 1978. Spain ceased to be a centralist state and opted for a high degree of decentralisation. The State of Autonomies has consolidated over the past four decades, but it must also resolve two different crises: the crisis of the territorial model after 40 years in existence and the crisis in Catalonia. Among potential scenarios, the reformulation of the State of Autonomies is the most reasonable solution. It is necessary to identify the specific problems of Spanish territorial organisation and explore how other systems, especially federal ones, can help to resolve them. However, a constitutional reform in a federal sense is virtually impossible.

* Recibido el 17 de marzo de 2020; el 18 de enero de 2021.

Este trabajo se presentó en el Simposio Verfasssungsentwicklungen im Vergleich: Italien 1947-Deutschland 1949-Spanien 1978 con motivo de los aniversarios de las Constituciones de Alemania, Italia y España, los días 4 y 5 de abril de 2019, en la Academia de la Fundación Konrad Adenauer, en Berlín. El trabajo es una versión ampliada y adaptada del original publicado en alemán: María Jesús García Morales (2021). "Zukunftsperspektiven des spanischen Autonomienstaates: Blockade oder Neuformulierung?". Hermann-Josef Blanke; Siegfried Magiera; Christian Pielow y Albrecht Weber (Hrsg.), Verfasssungsentwicklungen im Vergleich: Italien 1947-Deutschland 1949-Spanien 1978. Berlin: Duncker \& Humblot.

** ORCID: 0000-0002-8436-9176. Profesora titular de Derecho constitutional en la Universitat Autònoma de Barcelona. Correo electrónico: mariajesus.garcia@uab.cat.

Boletín Mexicano de Derecho Comparado, nueva serie, año LIV, núm. 160, enero-abril de 2021, pp. 155-190. 
ral es prácticamente imposible. La responsabilidad de reformar el modelo territorial corresponde a los partidos políticos y las divergencias entre ellos sobre cuáles deben ser los cambios son antagónicas. Deberían recuperarse consensos, como se hizo en España en 1978. Sin cambios, persistirán los problemas.

Palabras clave: Estado autonómico, federalismo, descentralización, secesión, asimetría.
The responsibility for reforming the territorial model rests with political parties, and the differences among them about what changes should be implemented are irremediable. Consensus needs to be reached again, as occurred in Spain in 1978. If nothing changes, problems will persist.

Keyreords: State of autonomies, federalism, decentralisation, secession, asymmetry.

SUMARIO: I. Introducción. II. El punto de partida: el Estado autonómico tiene el apoyo mayoritario, pero con diferencias entre territorios. Historia de un éxito y de un fracaso. III. Los problemas: El Estado autonómico debe hacer frente a dos crisis diferentes. IV. Las salidas: ¿La reformulación del Estado autonómico y el federalismo para España? V. Conclusión: El fututo del Estado autonómico es una incógnita. VI. Bibliografia.

\section{INTRODUCGIÓN}

La llamada cuestión territorial ha sido un problema constante en la historia constitucional española y también uno de los temas más conflictivos de la democracia en España desde su inicio. La Constitución Española de 1978 (en adelante CE) inventó el llamado Estado autonómico: era la gran novedad e incógnita. España se transformó rápidamente en un sistema con una descentralización territorial muy notable. Sin embargo, el tiempo ha demostrado que la cuestión territorial es un problema que la Constitución no ha podido todavía solucionar. Desde hace años, su importancia sobrepasa la organización territorial del poder, pues se ha convertido en uno de los asuntos con mayor impacto en la vida constitucional, en la política y en la convivencia en España.

A los cuarenta años de vigencia de la CE, el Estado autonómico ha pasado de ser valorado como un éxito a un fracaso. Sin embargo, los datos confirman que este modelo tiene el apoyo mayoritario, aunque no el mismo en todos los territorios. La crisis del Estado autonómico no es una, sino dos crisis distintas simultáneas y en parte sucesivas: por una

Esta obra está bajo una Licencia Creative Commons

Atribución-NoComercial-SinDerivar 4.0 Internacional, IIJ-UNAM.

Boletín Mexicano de Derecho Comparado, núm. 160, enero-abril de 2021, pp. 155-190. 
parte, la crisis del modelo de organización territorial tras cuarenta años de existencia y, por otro lado, las demandas de secesión en Cataluña. Esas dos crisis necesitan soluciones diversas. Urge reformular el Estado autonómico, pero ¿cómo? El federalismo es el espejo donde observar cómo otros países resuelven problemas de división territorial de poder. Las reformas son necesarias y hay vías de solución, pero es altamente incierto que se puedan llevar a cabo.

\section{EL PUNTO DE PARTIDA: EL ESTADO AUTONÓMICO TIENE EL APOYO MAYORITARIO, PERO CON DIFERENCIAS ENTRE TERRITORIOS. HISTORIA DE UN ÉXITO Y DE UN FRAGASO}

España ha sido a lo largo de su historia, mayoritariamente, un Estado sin regiones autónomas. La historia del constitucionalismo español empezó en 1812 muy influenciado por el modelo francés. Salvo el breve paréntesis de la II República, España ha sido históricamente un Estado centralizado. ${ }^{1}$ Por ello, en el ámbito comparado, es un caso interesante de cómo un modelo territorial de procedencia napoleónica se ha federalizado progresivamente (Sabine Kuhlmann y Hellmut Wollmann, 2019, p. 149). La descentralización territorial como forma de organización del poder fue en 1978 la solución para integrar en España a dos territorios con una fuerte identidad regional que reivindicaban su propia autonomía: el País Vasco y Cataluña.

El territorio de España tiene una extensión de 506,000 km2, una población de 46.5 millones de habitantes. El País Vasco tiene una superficie de 7,233 km2 y 2,170,868 de habitantes. Por su parte, Cataluña tiene una extensión que alcanza los 32,106 km2, donde viven 7,488,717 habitantes. Ambos territorios son ricos y, en particular, Cataluña, genera una de las aportaciones más importantes a la economía española. ${ }^{2}$ Cata-

1 Eliseo Aja (2014, pp. 31-36). Durante la I República se redactó el Proyecto de Constitución Federal de 1873 que no llegó a ser aprobado por las Cortes. Por ello, la Constitución de la II República es el primer texto donde se aprobó la descentralización política en España. (Alejandro Nieto García, 2016, pp. 1069-1088; Joaquín Varela Suanzes-Carpegna, 2016, pp. 1089-1109).

2 Contabilidad Regional de España. Revisión estadística 2019. INE: En 2018, Cataluña tuvo una aportación al PIB del19\%, sólo superada por la Comunidad de Madrid con el 19.2\%, https//wrwre.ine.es. 
luña y el País Vasco tienen una historia, una cultura y una lengua propias. ${ }^{3}$ Los dos territorios han reivindicado el reconocimiento de una posición singular en el conjunto del Estado.

$\mathrm{El}$ artículo 2 de la CE, uno de los que generaron más debate durante la elaboración de la Constitución, refleja la indeterminación del modelo de organización territorial en España: "La Constitución se fundamenta en la indisoluble unidad de la Nación española [...], y reconoce y garantiza el derecho a la autonomía de las nacionalidades y regiones que la integran [...]". Con esta ambigua fórmula, fruto de posiciones políticas antagónicas, el nacionalismo moderado se sintió en aquel momento integrado en la Constitución (Jordi Solé Tura, 2019, p. 135).

El título VIII de la CE (De la organización territorial del Estado) concretó el artículo 2 de la CE: "España se organizaría en comunidades autónomas, además, de municipios y provincias" (artículo 137 de la CE). De esta manera, junto al Estado central, la distribución vertical del poder se diseñó en tres niveles territoriales: las comunidades autónomas con una autonomía política - con capacidad de autogobierno y autoorganización, cuya máxima expresión y rasgo definitorio frente a la autonomía administrativa es la capacidad de aprobar leyes en su ámbito de competenciasy los municipios y provincias con autonomía administrativa, que integran la administración local. ${ }^{4}$

A diferencia de las provincias que tienen una larga tradición en la historia constitucional española, pues su origen se remonta a la Constitución de Cádiz de 1812, que siguió el modelo del departamento francés y su esquema de administración centralista siguiendo criterios de eficacia y no identitarios ${ }^{5}$ las autonomías como tales no han existido hasta la Constitución de 1978. Las comunidades autónomas se constituyeron como nuevas

3 Más del 20\% de la población habla vasco, una lengua de origen no latino: $22.3 \%$ en 1991 y 28.4\% en 2016, VI Encuesta Sociolingüística (2016), http://wrere.euskadi.eus. En Cataluña, el catalán, una lengua latina, $94.4 \%$ de la población lo entiende y $81.2 \%$ lo habla, en 1981 sólo era 31.5\%, Enquesta d'usos lingüístics de la població (2018), https:// wrere.idescat.cat.

4 Desde su más temprana jurisprudencia, véase SSTC 32/1981, 76/1983.

5 Las provincias españolas se previeron en la Constitución de Cádiz, pero datan de 1833 con el Decreto de división provincial de Javier de Burgos (Francisco Velasco Caballero, 2011, p. 627; Beatriz Tomás Mallén, 2018, p. 1949). Sobre el enraizamiento de la provincia en la vida española, el clásico de José Ortega y Gasset (1967, p. 52, p. 161).

Esta obra está bajo una Licencia Creative Commons

Atribución-NoComercial-SinDerivar 4.0 Internacional, IIJ-UNAM.

Boletín Mexicano de Derecho Comparado, núm. 160, enero-abril de 2021, pp. 155-190. 
entidades políticas sobre la base de "las provincias limítrofes con características históricas, culturales y económicas comunes, los territorios insulares y las provincias con entidad regional histórica" (CE, art. 143; Eliseo Aja et al., 1985, pp. 91-96).

En ningún momento, la Constitución define a España como un Estado autonómico, ni menos aun como un Estado federal. A diferencia de varias Constituciones del entorno europeo como los textos alemán, austriaco o suizo - donde se mencionan cada una de las unidades territoriales: Länder o, en su caso, cantones— ${ }^{6}{ }^{6}$ en el texto español ni dice cuáles son, ni tampoco se enumeran las comunidades autónomas que componen el Estado autonómico. La Constitución permite un sistema descentralizado, pero no lo desarrolla (Pedro Cruz Villalón, 1981, pp. 53-63).

No existe deliberadamente en la CE un modelo territorial. Se trata de un modelo abierto que debía ir concretándose en el tiempo (Luis López Guerra, 1995, p. 189; Manuel Aragón Reyes, 2006, pp. 1-24). La Constitución desplazaba esa responsabilidad a los actores políticos. Con ese diseño, en 1978, hubiera sido posible una autonomía política sólo para el País Vasco, Cataluña y Galicia, las llamadas "comunidades históricas", 7 y una descentralización administrativa para el resto.

Al buscar una fórmula para integrar en España a nacionalistas vascos y catalanes, el territorio se acabó dividiendo en diecisiete comunidades autónomas, ${ }^{8}$ cada una de las cuales tiene un Parlamento, un gobierno y sus propias instituciones de autogobierno, salvo el Poder Judicial que es único y corresponde al Estado central. Hay también dos ciudades autónomas en el Norte de África (Ceuta y Melilla) con gobierno propio, pero sin Parlamento.

6 La Ley Fundamental de Bonn menciona los dieciséis länder en el preámbulo, la Constitución austriaca los ocho Länder (artículo 2) y la Constitución suiza los veintiséis cantones (artículo 1).

7 Esta denominación no está en la Constitución. Se utiliza para hacer referencia a los tres territorios que, bajo la II República, "en el pasado hubieren plebiscitado favorablemente proyectos de Estatuto de autonomía" (reconocimiento indirecto en la disposición transitoria segunda de la CE). A diferencia del País Vasco y de Cataluña, la identidad regional y el sentimiento nacionalista no es tan acusado en Galicia.

8 Por orden de constitución como comunidad autónoma: País Vasco, Cataluña, Galicia, Andalucía, Principado de Asturias, Cantabria, La Rioja, Región de Murcia, Comunidad Valenciana, Aragón, Castilla-La Mancha, Canarias, Comunidad Foral de Navarra, Extremadura, Islas Baleares, Comunidad de Madrid y Castilla y León. 
En la actualidad, la autonomía no es algo que corresponda sólo al País Vasco y a Cataluña, sino a diecisiete comunidades autónomas. La posibilidad de un Estado asimétrico, con un estatus especial para el País Vasco y Cataluña, acabó en una España simétrica, con una sustancial igualdad entre todas las comunidades autónomas, salvo excepciones, como claramente el sistema de financiación propio del País Vasco. Los grandes partidos de ámbito estatal decidieron ese desarrollo mediante pactos políticos, los llamados "Pactos Autonómicos". 9

La percepción sobre el Estado autonómico por parte de los ciudadanos y los partidos políticos es diferente. Las encuestas muestran que el apoyo de los ciudadanos al Estado autonómico ha ido subiendo paulatinamente hasta situarse por encima de 65\% (en 2019). ${ }^{10}$ Tanto el número de personas que prefieren un Estado sin comunidades autónomas $(15.9 \%),{ }^{11}$ como de los que están en favor de la posibilidad de independencia de las comunidades autónomas ha ido bajando y representa una minoría $(7.9 \%) .{ }^{12}$

Esos datos deben matizarse según los territorios. En el País Vasco y Cataluña las demandas de secesión son ciertamente más altas que en el resto de España. Sin embargo, en ambos casos la mayoría de la población se muestra en favor de la unidad de España. El independentismo es la opción preferida para una cuarta parte de los vascos $(22 \%)$, mientras que esa opción en Cataluña se acerca a la mitad de la población (43.7\%). ${ }^{13}$

La valoración del Estado autonómico por parte de los partidos políticos es curiosamente muchas veces más negativa que la que tienen los ciudadanos. Los dos grandes partidos, la socialdemocracia (PSOE) y los conservadores (PP), así como otros partidos de ámbito estatal, como

9 Por medio de los I Acuerdos Autonómicos de 1981 (UCD-PSOE) se cerró el mapa de comunidades autónomas y mediante los II Pactos Autonómicos de 1992 (PSOE-PP) se pactó la igualación de competencias entre comunidades autónomas.

10 La mayoría de los españoles y las españolas se muestran favorables a mantener el Estado autonómico, tal y como está, 43.3\% en junio de 2019 (frente al 32.6\% en julio de 2013). Un porcentaje más bajo representan tanto aquellos que creen que las comunidades autónomas deben tener menor o mayor autonomía (alrededor de 13\% y 12\% respectivamente). Barómetros CIS, http://wrewe.cis.es.

11 Barómetros CIS: 15.9\% (junio 2019) frente 9.7\% (julio 2019), http://wrew.cis.es.

12 Barómetros CIS: 7.9\% (junio 2019) frente 12.4\% (noviembre 2014), http://wrere.cis.es.

13 País Vasco: Euskobarómetro (2019, 42), https://wrwre.ehu.eu. Cataluña: CEO Dossier de premsa del BOP. 3a onada $(2019,63)$. El punto máximo fue $48.7 \%$ en octubre de 2017 , http://wrere.ceo.gencat.cat.

Esta obra está bajo una Licencia Creative Commons

Atribución-NoComercial-SinDerivar 4.0 Internacional, IIJ-UNAM.

Boletín Mexicano de Derecho Comparado, núm. 160, enero-abril de 2021, pp. 155-190. 
los liberales (Ciudadanos) y aquellos que se sitúan en el espectro de la izquierda (Podemos), apoyan el Estado autonómico. Sin embargo, disienten sobre cómo la organización territorial debe evolucionar en España. Sólo el partido de ultraderecha defiende una supresión de las comunidades autónomas. Los partidos nacionalistas y separatistas en el País Vasco y Cataluña mantienen un discurso que critica habitualmente el Estado autonómico.

Los partidos nacionalistas y separatistas son clave para entender la vida constitucional y la cuestión territorial en España. Ello radica no sólo en que han gobernado casi ininterrumpidamente en estas comunidades autónomas, sino también en su decisiva influencia en el Parlamento y en el gobierno central. El sistema español es parlamentario en el nivel central y autonómico: ergo un presidente de gobierno sale elegido por un parlamento y es responsable ante éste.

En el nivel central, cuando ninguno de los dos grandes partidos estatales tiene mayoría absoluta, deben gobernar en minoría habitualmente con el apoyo de los partidos nacionalistas y separatistas periféricos en el Parlamento central. ${ }^{14}$ Se trata de una dinámica frecuente en un país donde no ha habido tradición de gobiernos de coalición en el Estado central. ${ }^{15}$ Los partidos nacionalistas y separatistas no pueden prohibirse, aunque persigan fines contrarios a la Constitución, como puede ser la ruptura de la integridad territorial, pues el Tribunal Constitucional español - a diferencia del Tribunal Constitucional Federal alemán - ha rechazado el principio de la democracia militante (SSTC 48/2003, 235/2007, 12/2008).

Más allá de la percepción por los ciudadanos y por los partidos políticos, la historia del Estado autonómico se mide por hechos objetivos. Aunque todavía existe una brecha entre comunidades autónomas ricas y pobres, ${ }^{16}$ se han reducido las enormes desigualdades económicas en-

14 En la vida política española, el papel de los partidos nacionalistas y separatistas se visibiliza especialmente en dos momentos claves: la elección de presidente del gobierno en España mediante la votación de la investidura y el debate y la aprobación parlamentarios de la Ley General de Presupuestos del Estado.

15 La primera coalición de un Gobierno de España (PSOE-Podemos) desde la II República se presentó el 30 de diciembre de 2019.

16 Las comunidades con PIB per capita más alta son por este orden: Comunidad de Madrid, el País Vasco, Navarra y Cataluña (INE, 2019, p. 29).

Esta obra está bajo una Licencia Creative Commons Atribución-NoComercial-SinDerivar 4.0 Internacional, IIJ-UNAM. Boletín Mexicano de Derecho Comparado, núm. 160, enero-abril de 2021, pp. 155-190. 
tre territorios de las que se partían en 1978. El Estado social se implantó en España con el Estado autonómico, porque la mayoría de los ámbitos de la política social (asistencia y servicios sociales, sanidad o educación) caen en el ámbito de competencia de las comunidades autónomas. Por lo que respecta al País Vasco y Cataluña, ambos territorios han tenido, con la Constitución de 1978, el nivel más alto de autonomía de toda su historia.

La aceptación del Estado autonómico empezó, sin embargo, a resquebrajarse a partir de 2008. La crisis económica no llegó sola. Las comunidades autónomas ejecutaron los recortes en prestaciones sociales y se cuestionó el exceso de gasto en las comunidades autónomas: la descentralización territorial era cara, ineficiente y, para los partidos nacionalistas y separatistas, además, insuficiente. En paralelo a la crisis económica, en el País Vasco y Cataluña crecieron las demandas de más autonomía. Mientras en el País Vasco, esas tendencias se frenaron, en Cataluña crecieron y han llegado hasta cuotas nunca vistas. Es el indicador más claro de que el Estado autonómico no ha podido integrar a ciertos territorios el objetivo con el que se inventó - en un proyecto común llamado España (véase José Tudela, 2016, pp. 185-207).

\section{LOS PROBLEMAS: EL ESTADO AUTONÓMICO DEBE HACER FRENTE A DOS CRISIS DIFERENTES}

El Estado autonómico debe encarar dos crisis diferentes: por un lado, la crisis del sistema de organización territorial español tras cuarenta años de existencia y, por otro, la crisis de Cataluña. El intento de secesión unilateral en el marco de la crisis catalana no es la causa, sino la consecuencia de una crisis previa del Estado autonómico en su conjunto.

\section{El desgaste del sistema de organización territorial en España tras cuarenta años de existencia}

El conflicto con Cataluña no puede entenderse sin tener en cuenta los problemas estructurales y funcionales que el Estado autonómico viene arrastrando desde hace años (Santiago Muñoz Machado, 2013, pp. 1056). Estos problemas radican esencialmente en materia de financiación,

Esta obra está bajo una Licencia Creative Commons

Atribución-NoComercial-SinDerivar 4.0 Internacional, IIJ-UNAM.

Boletín Mexicano de Derecho Comparado, núm. 160, enero-abril de 2021, pp. 155-190. 
distribución de competencias, así como relaciones entre el Estado central y las comunidades autónomas y entre las propias comunidades autónomas.

La GE no regula una "Constitución financiera", por lo menos en el sentido de la Ley Fundamental de Bonn. Por ello, en España no se habla de Constitución financiera, sino de sistema de financiación. Una de las peculiaridades más significativas del Estado autonómico es que hay dos sistemas de financiación: uno, para el País Vasco y también Navarra, que se halla garantizado en la disposición adicional primera de la CE, y, otro, para el resto de las comunidades autónomas.

El sistema de financiación que rige en el País Vasco y Navarra constituye un privilegio histórico, que permite una gran autonomía financiera a ambos territorios y una menor aportación a la solidaridad interterritorial que el resto de las comunidades autónomas. Cataluña es una de las comunidades que más aporta en comparación con los ingresos que recibe. ${ }^{17}$ Ese desequilibrio ha sido un factor clave para el incremento exponencial de los partidarios de la independencia.

Otro tema no exento de problemas en cada país suele ser el sistema de reparto de competencias. Por su parte, la distribución de competencias en España se basa en muchos ámbitos en una técnica de reparto donde las bases o la legislación básica son unos principios generales que corresponden regular al Estado central, mientras que el desarrollo legislativo y ejecutivo de los mismos corresponde al Parlamento, o, en su caso, al gobierno de las comunidades autónomas (por ejemplo, "bases y coordinación de la planificación general de la actividad económica", conforme al artículo 149.1. $13^{\mathrm{a}}$ de la CE). Esta técnica de reparto competencial ha provocado que el Estado central haya podido intervenir en casi todas las competencias de las comunidades autónomas.

Esta circunstancia ha generado muchos conflictos, especialmente con el País Vasco y con Cataluña, dos territorios especialmente reivindicativos de sus competencias (y de más competencias). Hasta la crisis catalana, tales conflictos se han presentado en términos jurídicos ante el Tri-

17 Según datos publicados en 2019: Cataluña se encuentra en la tercera posición respecto a las comunidades autónomas que más recursos aportan por habitante tras la Comunidad de Madrid e Islas Baleares y en la décima posición en relación con los ingresos. Ministerio de Hacienda (2017). Informe sobre financiación definitiva de las comunidades autónomas por medio del sistema de financiación, http://hacienda.gob.es. Sobre los sistemas de financiación en España, véase Antoni Zabalza y Julio López-Laborda (2017, pp. 119-152). 
bunal Constitucional. Esta tarea de delimitación de competencias entre el Estado central y las comunidades autónomas ha sido una de las más importantes que ha llevado a cabo la jurisdicción constitucional española (Pedro Cruz Villalón, 1991, pp. 249-260). Las soluciones del Tribunal Constitucional tienen naturaleza jurídica y, consiguientemente, son insatisfactorias siempre políticamente para una de las partes.

La cuestión de las relaciones entre el Estado central y las comunidades autónomas y entre comunidades autónomas es también otro importante problema en España. No hay una institución donde el Estado central y las comunidades autónomas puedan cooperar en la elaboración de las leyes del Estado central que afectan a las competencias autonómicas. El Senado no es una Cámara de representación territorial, una cuestión pendiente en casi todos los sistemas federales y sin soluciones claras (véase José María Porras Ramírez, 2021, pp. 322-334). Al no existir una institución política donde discutir estos temas, los conflictos entre el Estado central y las comunidades autónomas son recurrentes.

La cooperación intergubernamental es un problema que presenta perfiles propios en el Estado autonómico (María Jesús García Morales, 2016, pp. 121-146). A diferencia de los países descentralizados o federales de su entorno, en España no existe casi cooperación formalizada entre las comunidades autónomas (cooperación horizontal). No hay una Conferencia de Presidentes de las Comunidades Autónomas, ni Conferencias Sectoriales donde sólo se reúnen las comunidades. Los acuerdos de cooperación o convenios interadministrativos interautonómicos son casi inexistentes. ${ }^{18}$ No hay autocoordinación entre comunidades autónomas.

La cooperación existente se formaliza entre el Estado central y las comunidades autónomas (cooperación vertical). En 2004, se constituyó la Conferencia de Presidentes formada por el presidente del gobierno central y los jefes de los ejecutivos de cada una de las comunidades autónomas. Sin embargo, esta Conferencia no se ha reunido regularmente. Resulta sorprendente que los actores políticos no hayan percibido como necesaria una institución que debería ser el símbolo máximo del diálogo interterritorial.

18 Los convenios entre comunidades autónomas son la única técnica de cooperación regulada por la CE, art. 145. Al respecto, véase Ignacio González García (201 1, pp. 303412) y Vicente Juan Calafell (2006, pp. 154-192).

Esta obra está bajo una Licencia Creative Commons

Atribución-NoComercial-SinDerivar 4.0 Internacional, IIJ-UNAM.

Boletín Mexicano de Derecho Comparado, núm. 160, enero-abril de 2021, pp. 155-190. 
El instrumento de cooperación más importante en España son las Conferencias Sectoriales multilaterales, entre las más relevantes, se cuentan las Conferencias Sectoriales de Agricultura, de Medio Ambiente o de Sanidad. También una cuestión tan crucial como la participación de las comunidades autónomas en asuntos europeos — un tema que no está regulado en la Constitución - se realiza por medio de las correspondientes Conferencias Sectoriales. ${ }^{19}$ Son miembros de las Conferencias Sectoriales los ministros del gobierno central y los consejos autonómicos del ramo. La presidencia de una conferencia sectorial corresponde siempre al ministro del gobierno central. Las comunidades autónomas no perciben a estas conferencias como un instrumento de participación en asuntos generales, sino más bien como instituciones del gobierno central. En las conferencias sectoriales, son frecuentes las ausencias de representantes del País Vasco y Cataluña.

Los gobiernos nacionalistas o separatistas prefieren claramente el procedimiento bilateral en lugar de la cooperación multilateral. La cooperación bilateral formalizada por medio de las llamadas comisiones bilaterales entre miembros del gobierno central y del Ejecutivo de una comunidad autónoma es una singularidad del Estado autonómico. Existen comisiones bilaterales entre el Estado central y cada una de las comunidades autónomas. Sin embargo, la bilateralidad tiene un fuerte simbolismo en el imaginario nacionalista: representa un dualismo (por ejemplo, catalán vs. español), donde se reúnen dos gobiernos sin las otras comunidades autónomas, y proporciona la percepción del reconocimiento de la posición especial de ese territorio respecto al resto. En la praxis, es difícil encontrar temas que sólo pueden tratarse con una comunidad autónoma (María Jesús García Morales, 2013, pp. 92-96).

19 La entrada de España en las Comunidades Europeas (hoy Unión Europea) se produce el 1o. de enero de 1986, por tanto, con posterioridad a la aprobación de la Constitución. A diferencia de Ley Fundamental de Bonn o la Constitución italiana, la participación de los entes territoriales en asuntos europeos no está regulada en el texto constitucional, sino por medio de acuerdos de una conferencia sectorial, la Conferencia de Asuntos Relacionados con la Unión Europea, donde se fija como locus institucional de dicha participación las Conferencias Sectoriales, mientras que en Alemania el texto constitucional prevé que sea el Bundesrat o en Italia se deja la cuestión abierta con remisión a la decisión del legislador. Sobre la necesidad de atención constitucional a esta cuestión (Ana M. Carmona Contreras, 2019, pp. 86-89). 
¿Y la administración local? Hasta el momento, el foco de los desafíos de la organización territorial española se ha planteado en las relaciones entre el Estado y las comunidades autónomas, sin contemplar la administración local que, en ese debate ha sido relegada a la irrelevancia política. Como se vio, la Constitución reconoce, junto a las comunidades autónomas, dos niveles más de división territorial del poder: la provincia y los municipios (CE, art. 137).

Las provincias - con casi dos siglos de existencia e inspiradas en el centralismo francés - son una pieza de difícil encaje en la nueva organización territorial de 1978. Deben coexistir con las comunidades autonómicas que responden a una filosofía diversa de la eficacia administrativa y tienen una autonomía cualitativamente distinta: la autonomía política. La decisión constitucional de mantener la provincia tiene consecuencias: preserva su garantía institucional y la hace indisponible para el legislador (Eduardo García de Enterría, 1991, pp. 7-10; Mayte Salvador Crespo, 2007). La función más importante de las provincias es prestar asistencia financiera y técnica a los municipios más pequeños, pero las comunidades autónomas pueden crear entes locales supramunicipales, de modo que su superposición con la provincia es disfuncional en términos de eficacia y no concita respaldo en algunos territorios, como particularmente Cataluña y el País Vasco (Luis Cosculluela Montaner, 2011, pp. 45-67).

\section{La crisis de Cataluña}

Desde 2010, a los problemas de la organización territorial española se ha sumado un nuevo reto, el más importante al que el Estado de las Autonomías debe hacer frente: la crisis de Cataluña y las demandas de secesión. La crisis catalana es la cara más visible de las crecientes tendencias secesionistas en países de la Unión Europea ${ }^{20}$ y la secesión un viejo conocido en el federalismo comparado. ${ }^{21}$

El gobierno central optó por trasladar el problema a los tribunales que han dado una respuesta jurídica ya sea en sede nacional, o bien euro-

20 Así, el Tribunal Constitucional Federal sobre el caso de Baviera (2 BvR 349/16) y la Corte Costituzionale italiana (sentencia 118/2015) sobre las leyes regionales del Véneto.

21 Texas vs. White, de 1868, del Tribunal Supremo de los Estados Unidos de América, Reference Re Secession of Quebec del Tribunal Supremo de Canadá, del 20 de agosto de 1998.

Esta obra está bajo una Licencia Creative Commons

Atribución-NoComercial-SinDerivar 4.0 Internacional, IIJ-UNAM.

Boletín Mexicano de Derecho Comparado, núm. 160, enero-abril de 2021, pp. 155-190. 
pea, que no puede por sí sola resolver una crisis de naturaleza política. ${ }^{22}$ Por otro lado, los nacionalistas (posteriormente, separatistas), que se habían centrado en construir la idea de "nación catalana" distinta de la española, pero dentro de España, han iniciado una nueva fase basada en la desobediencia al Estado de derecho y a la Constitución - que no consideran suyos - así como en la demanda de independencia unilateral al margen del rule of law (Gonzalo Quintero Olivares, 2019b, p. 68).

Las señales de alarma empezaron hace una década: el número de partidarios de la independencia crecía enormemente. En 2007, 14.5\% era partidario de la independencia. ${ }^{23}$ Diez años más tarde ese porcentaje superaba $40 \%$. El ascenso del movimiento separatista tiene varias causas, pero hay una fecha clave. ${ }^{24}$ En 2010, el Tribunal Constitucional declaró determinadas previsiones del Estatuto de Autonomía catalán inconstitucionales. Estas disposiciones regulaban aspectos muy sensibles y con gran relevancia para Cataluña, entre ellos, la autodefinición de Cataluña como nación en el Preámbulo, la lengua catalana como lengua preferente en la escuela, en la administración pública y en los medios de comunicación catalanes, así como la regulación de un sistema de financiación para Cataluña similar al del País Vasco (STC 31/2010).

El nuevo Estatuto de Autonomía catalán pretendía dar a Cataluña una posición especial en el marco del Estado autonómico, pero sin una previa reforma constitucional. La sentencia del Tribunal Constitucional provocó una profunda frustración en una parte muy significativa de la población catalana. A continuación de ese pronunciamiento, el partido nacionalista conservador catalán solicitó al Estado central la regulación de un sistema de financiación para Cataluña, el llamado "pacto fiscal", similar al que había previsto el Estatuto. Sin embargo, esa reivindicación no fue atendida por el gobierno de Madrid, que alegó que dicha reforma sólo podía hacerse previa revisión de la Constitución. A partir de ese momento, el nacionalismo conservador catalán que ha gobernado Cataluña durante más de veinte años y que había apoyado parlamentariamente

22 Por ejemplo, STS 459/2019 del 14 de octubre de 2019 (proceso penal contra los líderes independentistas), Sentencia del Tribunal de Justicia de la Unión Europea (Gran Sala), del 19 de diciembre de 2019 (asunto C-502/19 Junqueras i Vies).

23 Sondeig Opinió Catalunya (2019), ICPS, https://wrere.icps.cat.

24 Un relevante testimonio a cargo de quien fue Letrado Mayor del Parlamento de Cataluña, Antoni Bayona (2019, pp. 105-131).

Esta obra está bajo una Licencia Creative Commons Atribución-NoComercial-SinDerivar 4.0 Internacional, IIJ-UNAM. Boletín Mexicano de Derecho Comparado, núm. 160, enero-abril de 2021, pp. 155-190. 
a los (diversos) gobiernos de España en minoría - ya fueran del PSOE, ya fueran del PP_, inició su viraje hace las demandas de independencia.

En la CE no está previsto el derecho a la autodeterminación. El referéndum suele ser una de las vías para plantear la secesión de una parte del territorio. El texto constitucional prevé en contadas ocasiones la celebración de esta forma de democracia directa.

El referéndum consultivo se prevé para decisiones políticas de especial trascendencia. La decisión formal de convocatoria corresponde al rey, pero la propuesta y decisión material es del presidente del gobierno, previamente autorizado por el Congreso de los Diputados (CE, art. 92). Las comunidades autónomas pueden convocar consultas populares no referendarias, pero no referéndums sin la autorización del Estado central (CE, art. 149.1.32). La regulación española en esta materia es más restrictiva que en otros ordenamientos jurídicos. Ello se debe a los intentos de los partidos nacionalistas y separatistas en España por materializar referéndums de autodeterminación (Carlos Garrido y Eva Saénz, 2019, p. 15. En el panorama comparado, Karl-Peter Sommermann, 2015, p. 11).

El Tribunal Constitucional no ha cerrado la puerta a un referéndum consultivo de autodeterminación, pero en la práctica los requisitos exigidos lo hacen extraordinariamente difícil. En España, la jurisprudencia constitucional considera que un referéndum consultivo sobre la independencia es posible bajo dos condiciones. ${ }^{25}$

Primero, preguntar a la población de un territorio sobre la independencia no es una consulta popular no referendaria, sino un referéndum. Las consultas se ciñen expresamente al ámbito de las competencias autonómicas y, en su caso, locales. La pregunta sobre una eventual secesión de una parte del territorio excedería las competencias de una comunidad autónoma. Una parte del territorio no puede decidir sobre la integridad territorial del Estado, sino que dicha cuestión corresponde a España en su conjunto.

Y, segundo, un referéndum de independencia sólo es legítimo previa reforma de la Constitución. El texto constitucional prevé la unidad y la indivisibilidad del territorio español (CE, art. 2) y una eventual respuesta afirmativa a semejante pregunta sería una reforma de la Constitución

25 SSTC 103/2008, 51/2017, 114/2017. STG 114/2017 recurre expresamente a Reference Re Secession of Quebec del Tribunal Supremo de Canadá, del 20 de agosto de 1998.

Esta obra está bajo una Licencia Creative Commons

Atribución-NoComercial-SinDerivar 4.0 Internacional, IIJ-UNAM.

Boletín Mexicano de Derecho Comparado, núm. 160, enero-abril de 2021, pp. 155-190. 
por un procedimiento no previsto para ello. No pueden ser, por tanto, objeto de pregunta cuestiones fundamentales que quedaron cerradas por el constituyente y que quedan sustraídas de los poderes constituidos, sin antes una reforma constitucional.

De este modo, la Constitución permite que un partido político pueda defender la independencia de un territorio, pero no permite que, cuando ese partido llegue al poder, el Parlamento y el gobierno de una comunidad autónoma organicen un referéndum de autodeterminación sin las condiciones que ha señalado la mencionada jurisprudencia.

A pesar de las reiteradas prohibiciones del Tribunal Constitucional, ${ }^{26}$ el 1o. de octubre de 2017, se convocó en Cataluña un referéndum ilegal y pocos días después se declaró en el Parlamento autonómico la independencia de este territorio (Carmen Plaza, 2018, pp. 373-392; Eduard Roig, 2017, pp. 24-61; Josu de Miguel, 2018, pp. 133-166).

La primera aplicación del artículo 155 de la CE - una importación casi textual de la coerción federal prevista en el artículo 37 de la Ley Fundamental de Bonn - fue la respuesta del Estado central a la reiterada desobediencia del gobierno y del Parlamento catalanes. La primera aplicación del artículo 155 de la CE se concretó en la adopción de medidas duras, tales como el cese del presidente y del gobierno de Cataluña, así como la disolución del Parlamento catalán. ${ }^{27}$

La aplicación del artículo 155 de la CE frenó un proceso de secesión. Las medidas adoptadas han servido para restablecer el cumplimiento de la Constitución en una parte del territorio, pero no han resuelto la crisis catalana. La praxis ha demostrado que el artículo 155 de la CE no es un instrumento útil, ni suficiente, cuando la crisis constitucional que ha

26 De forma particularmente explícita: Providencia del 7 de septiembre de 2017, que incluyó advertencias directas y expresas y fue notificada a todos los miembros del Gobierno catalán. Además, Providencia del 4 de abril de 2017, SSTC 90/2017, 51/2017, ATC 24/2017, ATC 141/2016, Providencia del 1o. de agosto de 2016, SSTC 259/2015, 135/2015, 137/2015, 138/2015, 317/2015, 103/2008. Nótese el abultado número de resoluciones que han tratado la crisis catalana. Y es que una de las peculiaridades del caso español es el gran número de resoluciones que han ocupado al Tribunal Constitucional con el tema de la secesión. Específicamente sobre la desobediencia al Tribunal Constitucional (Gonzalo Quintero, 2019a, p. 123).

27 En vigor desde el 27 de octubre de 2017 hasta el 2 de junio de 2018. Medidas declaradas constitucionales (SSTC 89/2019, 90/2019). Véase Javier García Roca (2019, pp. 503-524). 
desencadenado su aplicación se debe a un problema político, como es un intento de secesión apoyado por una parte muy importante de la población (María Jesús García Morales, 2019, pp. 12 y 13).

Tras la aplicación del artículo 155 de la CE, los partidos separatistas han ganado de nuevo las elecciones en Cataluña. Hay un gobierno y un Parlamento, que insisten en actuar en contra del orden constitucional. Más de dos millones de personas - sobre cinco millones de electoresno creen en el ordenamiento constitucional, aprueban la desobediencia al mismo y no quieren ser más españoles.

Es importante destacar que los separatistas no han alcanzado (de momento) el 50\% de los votos, un techo de cristal que no se ha roto (todavía) y que, en caso de conseguirse, tendría un importante valor simbólico y político. En las últimas elecciones autonómicas consiguieron $47.3 \%$ de los votos frente $51.7 \%$ que suman las opciones que, de una y otra forma, no reivindican la independencia. (Elecciones autonómicas del 21 de diciembre de 2017, Francesc Pallarés, 2018, p. 437)

Sin embargo, los separatistas tienen la mayoría en el Parlamento catalán, algo que viene sucediendo a causa del vigente sistema electoral y de cómo traduce los votos en escaños. Cataluña no constituye a efectos electorales una única demarcación. El derecho electoral prevé cuatro demarcaciones electorales en este territorio (las cuatro provincias catalanas), en las que los territorios más rurales y menos poblados están sobrerrepresentados. ${ }^{28}$ Los separatistas no tienen en las elecciones autonómicas una mayoría de votos, ni la han tenido antes. Pero, desde 2010, el número de personas que en Cataluña no se sienten españoles es muy considerable, lo que constituye obviamente un motivo de enorme preocupación y reflexión.

28 En Cataluña las cuatro provincias (y circunscripciones electorales) son Barcelona, Tarragona, Girona y Lleida, siendo estas dos últimas las que cuentan con menos habitantes y donde más votos obtienen las opciones separatistas, véase por ejemplo, los resultados electorales en 2017 (Franccisco Pallarés, 2018, p. 436). Sobre la proporcionalidad de un sistema electoral en zonas escasamente pobladas en el ámbito del Convenio Europeo de Derechos Humanos (Jochen Frowein y Wolfgang Peukert, 2009, pp. 684-685). Sobre el debate proporcionalidad, igualdad y tamaño de las circunscripciones, el trabajo clásico de Jochen Frowein (1974, pp. 72-110). Sobre el caso español, Dieter Nohlen y Rainer Olaf Schultze (1985, p. 183; Dieter Nohlen, 2019, p. 16).

Esta obra está bajo una Licencia Creative Commons

Atribución-NoComercial-SinDerivar 4.0 Internacional, IIJ-UNAM.

Boletín Mexicano de Derecho Comparado, núm. 160, enero-abril de 2021, pp. 155-190. 


\section{LAS SALIDAS: ¿LA REFORMULACIÓN DEL ESTADO AUTONÓMICO Y EL FEDERALISMO PARA ESPAÑA?}

En este contexto, ¿cuáles son los posibles escenarios y salidas? La disolución del Estado autonómico parece impensable: a pesar de sus problemas, esta organización territorial tiene el apoyo mayoritario de la población, aunque en unos territorios, más que en otros, y, además, las demandas de secesión no tienen (por el momento) el respaldo de la mayoría, ni en Cataluña, ni en el País Vasco. El escenario actual de mantener el Estado autonómico sin reformas prolongará la situación de bloqueo.

Por ello, la solución más viable para salir del atasco y del impasse pasa por la reformulación de la organización territorial española. Lo ideal y lo más razonable sería una gran reforma del Estado autonómico que, identificados cuáles son nuestros problemas, examine cómo han solucionado esos mismos problemas otros países federales o con un nivel de descentralización similar. Ello debería mejorar el sistema existente y conseguir dar un acomodo al separatismo que permitiera seguir juntos y dar más estabilidad a la vida constitucional española.

\section{Algo sobre el federalismo en España}

En España no existe tradición federal. En la historia constitucional española ha dominado la voluntad de construir el Estado sobre el modelo centralista y monolingüe. El federalismo en España ha tenido más detractores que defensores. Para sus detractores, la diversidad y el federalismo se han visto históricamente como potencial riesgo de disgregación, mientras que para sus defensores era justamente la vía que la evitaba (Xavier Arbós, 2006, p. 16).

El pensamiento federal, además, ha surgido, habitualmente, vinculado a una ideología y especialmente a Cataluña. ${ }^{29}$ La vía federal permitía obtener en este territorio autonomía y reconocimiento de su identidad

29 El representante y defensor más destacado del federalismo en España fue el político y estudioso catalán, Francesc Pi i Margall, presidente de la I República en España (18731874) y bajo la vigencia de la cual se elaboró el fracasado proyecto de Constitución federal de 1873 (Alejandro Nieto, 2016, pp. 1077-1078).

Esta obra está bajo una Licencia Creative Commons Atribución-NoComercial-SinDerivar 4.0 Internacional, IIJ-UNAM. Boletín Mexicano de Derecho Comparado, núm. 160, enero-abril de 2021, pp. 155-190. 
regional dentro de España. Las ideas federales han sido importantes particularmente para el movimiento catalanista y también para el movimiento obrero y anarquista. ${ }^{30}$

La opción federal estuvo presente en la elaboración de la Constitución de 1978. No es una casualidad que la Constitución evite la palabra "federal". ${ }^{31}$ Si se hubiera introducido la palabra "federal" o "federalismo", no hubiera sido posible el consenso constitucional. Sin embargo, a pesar de las reticencias hacia el federalismo (todavía hoy), para la mayoría de la academia española el Estado autonómico funciona en la praxis como un sistema federal.

El federalismo ha despertado en España un gran interés en la doctrina, en particular, entre los iuspublicistas. Sin embargo, el federalismo no ha tenido el mismo eco en la mayoría de los partidos políticos. No está en el discurso del partido conservador, ni liberal, que no han mostrado ninguna empatía por el término "federal". Los partidos nacionalistas y separatistas no simpatizan con el federalismo porque significa igualdad y pacto, mientras que ellos reivindican un estatus especial o, en su caso, la independencia. El único partido que ha asumido el federalismo en su discurso es la socialdemocracia y, claramente, la socialdemocracia catalana. ${ }^{32}$ Pocos políticos y pocos ciudadanos saben qué es y qué significa ser un Estado federal.

En España, el término federalismo no es una palabra políticamente "neutra". La vinculación del federalismo con determinados partidos políticos - y, por tanto, con una ideología - es un problema porque lo convierte en la opción de un determinado partido y no se entiende como una forma de Estado que nada tiene que ver con la ideología de un partido. Por esa razón, el Estado autonómico difícilmente se definirá textualmente en una eventual reforma como federal. Ciertamente, el federalismo no se percibe en la actualidad abiertamente como factor de disgregación

30 Gumersindo Trujillo Fernández (1967, pp. 91-135). El catalanismo es un movimiento que reivindica los valores y la cultura catalanes. Su relevancia política se inició en la segunda mitad del siglo XIX, véase John H. Elliott (2018, p. 249).

31 Sobre ello, Xavier Arbós (2006, p. 35).

32 El PSC representa en Cataluña al PSOE. Las Declaraciones del PSOE sobre el federalismo: Declaración de Granada (2013) y Declaración de Barcelona (2017), http:// wrere.psoe.es.

Esta obra está bajo una Licencia Creative Commons

Atribución-NoComercial-SinDerivar 4.0 Internacional, IIJ-UNAM.

Boletín Mexicano de Derecho Comparado, núm. 160, enero-abril de 2021, pp. 155-190. 
- como en el pasado - , pero la palabra federal en España todavía se evita y todavía genera en ciertos sectores un absoluto rechazo.

2. Objetivos y contenidos de una reforma federal:

great expectations, pero grandes discrepancias

\section{A. ¿Para qué el federalismo y qué modelos?}

No hay duda. La parte que precisa una reforma más urgente de la $\mathrm{CE}$ es la correspondiente a la organización territorial. Un alto porcentaje de la población en Cataluña apoya la independencia, pero simultáneamente se muestra en favor de una reforma de las comunidades autónomas que les conceda más autonomía. ${ }^{33}$

La reforma constitucional del Estado autonómico en sentido federal es la propuesta que cuenta con sólidos apoyos en la doctrina iuspublicista. ${ }^{34}$ La idea federal en España sólo puede entenderse en conexión con la existencia de nacionalismos y separatismos (Juan José Solozábal Echavarría, 2017a, pp. 15 y 16). El objetivo primordial sigue siendo el mismo a lo largo de nuestra historia: integrar a los movimientos nacionalistas y separatistas para salvaguardar la unidad mediante la autonomía y el reconocimiento de las identidades regionales.

Es extremadamente difícil lograr este objetivo: ¿es posible conseguirlo?, y, en ese caso, ¿cómo hacerlo? Es muy poco probable que los términos "federal" o "federalismo" aparezcan en una futura reforma constitucional. Pero, llegado el caso, tal reforma deberá plantearse elementos del federalismo. $^{35}$

$3371.9 \%$ en Cataluña (frente 45.4\% en el conjunto de España): CEO Dossier de premsa de l'enquesta "Percepció sobre el debat territorial a Espanya. 2019", 38, http://wrwre. ceo.gencat.cat.

34 Veáse, entre otros, una de las últimas propuestas elaborada por un grupo de profesores de Derecho constitucional y de Derecho administrativo: Ideas para la reforma de la Constitución (2017) http://wwre.idp.net. Anteriormente, remarcable el Informe del Consejo de Estado sobre las modificaciones de la Constitución Española (Francisco Rubio Llorente y José Álvarez Junco, 2006).

35 Ramón Punset Blanco y Leopoldo Tolivar Alas (2020; en particular, el trabajo de Juan José Solozábal Echavarría, p. 32). 
El federalismo sirve para integrar la diversidad y puede ser una alternativa a la disgregación. La concesión de autonomía y la participación en el nivel federal son instrumentos que han acreditado su solvencia para reducir tensiones internas y restablecer la estabilidad del Estado y de la vida constitucional. ${ }^{36}$ En Europa, no hay ningún Estado federal que haya sido un Estado federal y haya dejado de serlo. Por el contrario, Estados tradicionalmente centralizados han asumido elementos de los Estados federales (Pedro Cruz Villalón, 2013, p. 59).

El derecho comparado puede desempeñar aquí un papel crucial. ${ }^{37}$ Hay una pluralidad de sistemas federales. El federalismo alemán es uno de los paradigmas más destacados en España, pero también Canadá y el Reino Unido son otros modelos para tener en cuenta, porque comparten con el Estado autonómico tendencias secesionistas. En todo caso, España deberá encontrar su propio modelo de organización territorial, que comprenda su peculiar contexto. La perspectiva comparada debe servir para conocer y discutir soluciones extranjeras. La recepción de soluciones de otros países debe hacerse con suma prudencia, pues muchas fórmulas pueden ser buenas y eficaces en su país de origen, pero quizá no funcionen en España (Wilhelm Hofmeister y José Tudela, 2017, p. 12).

\section{B. Vías de solución para problemas crónicos del Estado autonómico: reformas} jurídicas y no jurídicas

Debe quedar claro lo que una reforma constitucional puede conseguir y lo que no. Una reforma en sentido federal basada en un gran pacto constitucional puede no sólo servir para incrementar la autonomía en determinados territorios donde hay un sentimiento más fuerte de autogobierno, sino también para mejorar los problemas que viene arrastrando el Estado autonómico. Dicha reforma puede crear un marco normativo mejor que intente solucionar los problemas estructurales y funcionales y que los territorios, en los que hay demandas de secesión claras, vuelvan a sentirse parte de un todo o, por lo menos, aunque nunca dejen su senti-

36 Peter Hilpold (2008, p. 177); Alberto López Basaguren (2016, p. 55). Sobre Canadá después de los dos referéndums en Québec, Guy Laforest (2010, p. 11).

37 Sobre la relevancia creciente del método comparado en el espacio jurídico europeo, Armin von Bogdandy (2013, p. 177).

Esta obra está bajo una Licencia Creative Commons

Atribución-NoComercial-SinDerivar 4.0 Internacional, IIJ-UNAM.

Boletín Mexicano de Derecho Comparado, núm. 160, enero-abril de 2021, pp. 155-190. 
miento independentista, puedan vivir dentro de un Estado en el que entienden que encuentran un acomodo.

Esta reforma constitucional en sentido federal del Estado autonómico debería mejorar aspectos que España comparte con los sistemas federales. Se debe conseguir una distribución más clara y eficiente de las competencias, un sistema de financiación más solidario y equitativo y unas relaciones entre el Estado central y las comunidades autónomas - en particular, la reforma del Senado-, que hagan más efectiva la integración de los distintos territorios en el Estado en su conjunto por medio de mecanismos de participación de las comunidades, tanto en asuntos domésticos, como en asuntos europeos.

Una reforma federal por sí sola no será suficiente, sin una lealtad institucional por parte del Estado central y de las comunidades autónomas, y sin lo que se da en llamar una cultura federal. En España, el principio de la lealtad constitucional, que se correspondería con el principio alemán de la Bundestreue, es también - como en el caso germano- un principio constitucional no escrito, pero en la jurisprudencia del Tribunal Constitucional español es más bien una especie de soft law que ni el Estado central, ni las comunidades autónomas han interiorizado (Pedro Cruz Villalón, 1990, p. 121)..$^{38}$

Resta el problema del thinking federal (Daniel J. Elazar, 1990, p. 33). En España, es necesaria otra perspectiva de la diversidad. Ello debe empezar por los políticos y por los funcionarios: ningún presidente del gobierno del Estado central ha hecho previamente carrera en la política autonómica y casi todos los funcionarios de Madrid proceden de Madrid y no de otras comunidades autónomas. Hay, por tanto, una marcada visión de los problemas "desde el centro" que queda reducida a ese círculo, donde se suele compartir una misma forma de ver y solucionar las cosas, muchas veces diversa de los puntos vista o de las sensibilidades "periféricos". Otro dato para reflexionar es que la gran mayoría de la población nunca ha vivido más de un año fuera de su comunidad autónoma. ${ }^{39}$ Es necesaria más movilidad para conocer y comprender la pluralidad.

38 En general, sobre la lealtad institucional en España, Leonardo Álvarez Álvarez (2008, pp. 493-524).

39 En Cataluña el 78.2\% y en el resto de España el 73.4\%. CEO Dossier de premsa de l'enquesta "Percepció sobre el debat territorial a Espanya. 2019", 51, http://wrere.ceo. gencat.cat. 
Hay otro punto que debería contemplar la reformulación del Estado autonómico en clave federal: la reforma de la administración local. Hasta el momento, el foco de los desafíos de la organización territorial española se ha planteado en las relaciones entre el Estado y las comunidades autónomas, sin contemplar la administración local. Esa marginación de uno de los niveles de organización territorial se debe a que la administración local no ha sido considerada como un sujeto institucional relevante en el Estado autonómico (Manuel Zafra Víctor, 2012, pp. 82 y 83). El debate en este punto debe centrarse, principalmente, en cuál debe ser el futuro de la provincia y de sus órganos de gobierno, las diputaciones provinciales.

La provincia ha devenido un "cascarón vacío" (Santiago Muñoz Machado, 2007, p. 245), pero su supresión - como nivel de la administración territorial — ${ }^{40} \mathrm{y}$ de las diputaciones provinciales es una cuestión compleja. Por un lado, se trata de un tema fuertemente emocional, ya que los sentimientos sobre la provincia varían ostensiblemente entre territorios. Por otro, es una cuestión de cirugía jurídica mayor, pues precisa una reforma constitucional y además debería enmarcarse en una reforma legal del régimen local de gran envergadura. ${ }^{41}$

\section{Vias de solución para las demandas de secesión: plurinacionalidad, asimetría y... ¿un derecho a la secesión?}

Sólo una reforma de estos aspectos no resolverá el problema de Cataluña. Cataluña y el País Vasco nos llevan de nuevo a un tema largamente conocido en nuestra historia y en el Estado autonómico: cuál y cómo debe ser el reconocimiento y la garantía de una identidad regional propia y diferenciada en determinados territorios. En relación con ello, se plantean

40 En ningún caso, se discute la supresión de la provincia como circunscripción electoral, esto es, como división del territorio para la elección de diputados y senadores, prevista como tal en la Constitución. En España, hay 50 provincias: Instituto Nacional de Estadística: http://wrere.ine.es. De acuerdo con los artículos 68.1 de la CE y artículos 69.2,3 y 4. de la CE: resultan 52 circunscripciones para el Congreso de los Diputados y 59 para el Senado.

41 Pedro Escribano Collado (2016, pp. 1995-2017); Miguel Sánchez Morón (2017, pp. 46-51). Un documento importante, aunque no propició una reforma constitucional, como el Informe del Consejo de Estado sobre Modificaciones de la Constitución española (E 1/2005), de febrero de 2006 propuso eliminar la provincia como entidad local (apartado IV.5.4, pp. 201-205).

Esta obra está bajo una Licencia Creative Commons

Atribución-NoComercial-SinDerivar 4.0 Internacional, IIJ-UNAM.

Boletín Mexicano de Derecho Comparado, núm. 160, enero-abril de 2021, pp. 155-190. 
tres viejas cuestiones que han vuelto a aflorar: la plurinacionalidad del Estado, las asimetrías y un eventual derecho a la secesión.

La definición como Estado plurinacional no está expresamente en las Constituciones europeas. ${ }^{42}$ En la elaboración de la Constitución, Cataluña quiso identificarse como "nación", un término que no fue aceptado. ${ }^{43}$ En su lugar, se incluyó "nacionalidad" en el artículo 2 de la CE ("reconoce y garantiza el derecho a la autonomía de las nacionalidades y regiones"). La palabra "nacionalidad" (como "nación" o "plurinacionalidad") es extraña por lo menos en los federalismos centroeuropeos - referentes en el Estado autonómico - donde es más común referirse a identidades regionales al hablar de federalismo.

La propuesta de introducir en una reforma de la Constitución la fórmula de España como "Nación de Naciones" o como "Estado plurinacional" pretende dar un mayor reconocimiento a Cataluña y, al País Vasco, que no aceptará menos y, sobre todo apaciguar las reivindicaciones separatistas. Estas formulaciones se basan en la distinción entre dos conceptos de nación: la cultural y la política. La única nación política sería España, pero podrían existir también naciones culturales dentro de esa unidad. ${ }^{44}$

El concepto de plurinacionalidad abre, sin embargo, muchos interrogantes jurídicos: ¿cuántas naciones culturales hay?, ¿quién decide qué territorio es una nación?, ¿con qué criterios? y ¿qué consecuencias se extraen de ello? Desde el punto de vista político, posiblemente, el reconocimiento de la plurinacionalidad es insuficiente para los separatistas que demandan el derecho a la autodeterminación, salvo que la plurinacionalidad pueda interpretarse como una puerta hacia el derecho a la secesión.

La cuestión de la asimetría tampoco es nueva ni en España, ni en el mundo del federalismo comparado (por ejemplo, significativamente

42 Por el contrario, la plurinacionalidad se menciona en las Constituciones latinoamericanas. La Constitución de Bolivia de 2009 prevé incluso el reconocimiento expreso como Estado plurinacional. En el ámbito europeo, por ejemplo, en Gran Bretaña, se acepta en su vocabulario la referencia a Escocia como nación (Michael Keating, 2015, p. 74).

43 Entrevista a Miquel Roca, uno los "padres" de la Constitución Española. La Vanguardia (06/12/2018), https://wwrw.lavanguardia.com.

44 En la doctrina iuspublicista, en favor, Juan José Solozábal Echavarría (2017b, pp. 16 23); muy críticos, Roberto L. Blanco Valdés (2005, pp. 119-145); Francisco Sosa Wagner e Igor Sosa Mayor (2007, pp. 167-185). Entre los historiadores, José Álvarez Junco (2016, pp. 213-282). Una visión más allá de la percepción en España,Joseph Weiler (2018, pp. 7-18). 
en Canadá o Italia). La CE diseña y permite la asimetría. ${ }^{45}$ La asimetría existe en la GE en virtud de los llamados "hechos diferenciales" de algunas comunidades autónomas. Se trata de circunstancias objetivas, como la historia o la lengua propia, con base en los cuales esas comunidades autónomas ostentan una posición peculiar respecto al resto.

La mayor asimetría que ampara la $\mathrm{CE}$ en el caso de algunas comunidades autónomas es la existencia de un sistema de financiación propio en el País Vasco y Navarra con base en derechos históricos, conocidos como "derechos forales". Una supresión de este privilegio o de los derechos forales en la Constitución es impensable. Extender el sistema vasco a otras comunidades autónomas, además de dudas jurídicas, plantea problemas sobre su viabilidad económica.

Cataluña, y otras comunidades autónomas, tienen competencias en materia de lengua que se proyectan también en sus competencias en cultura y educación. En este ámbito, hay un fuerte componente emocional en la defensa de la lengua catalana. En Cataluña, hay un modelo educativo donde la lengua vehicular es el catalán. Asimismo, Cataluña tiene también competencias en materia de derecho civil propio. Es la comunidad autónoma que más uso ha hecho de esas competencias hasta el punto de que Cataluña tiene un código civil propio (la Compilació de Dret civil de Catalunya).

Una vía de las vías que más se discuten para introducir nuevas asimetrías es introducir una nueva disposición adicional en la Constitución para Cataluña que reconozca sus derechos históricos: igual que existe una disposición adicional vasca y navarra, habría una disposición adicional catalana. Con base en esa previsión, Cataluña podría pedir un sistema de financiación como el vasco y podría blindar su sistema educativo en lengua catalana algo que forma parte de la idiosincrasia, del "núcleo duro", de la autonomía catalana.

Pero ¿y las otras comunidades autónomas?, ¿van a aceptar más asimetrías? Las asimetrías pueden provocar agravios comparativos inaceptables para el resto de las comunidades autónomas. Aunque la igualdad de los territorios acostumbra a ser un pilar de los sistemas federales, la perspectiva comparada muestra que hay países (por ejemplo, Canadá), donde existe un cierto margen para la asimetría. La CE permite la asimetría, pero

45 Luis López Guerra (1995, p. 178); Enric Fossas (1999, pp. 275-297).

Esta obra está bajo una Licencia Creative Commons

Atribución-NoComercial-SinDerivar 4.0 Internacional, IIJ-UNAM.

Boletín Mexicano de Derecho Comparado, núm. 160, enero-abril de 2021, pp. 155-190. 
en casos muy limitados. La experiencia con el sistema de financiación vasco pone a las claras que las asimetrías son conflictivas y difícilmente asumibles por el resto de los territorios. ${ }^{46}$

El reconocimiento y la garantía de la plurinacionalidad y de la asimetría no son con toda seguridad propuestas fáciles, pero no se puede negar que hay cierto margen jurídico. Aunque la CE no prevé ni cláusulas de intangibilidad en el caso de su reforma, ni la democracia militante, parece realmente difícil un eventual reconocimiento y garantía en el texto constitucional del ius secessionis, una aspiración de nacionalistas y separatistas.

El Tribunal Constitucional ha negado con rotundidad que haya un derecho de secesión en la Constitución. Asimismo, el alto tribunal ha rechazado la existencia de un "derecho a decidir", un concepto usado por el movimiento separatista que el tribunal viene a equiparar con el derecho a la autodeterminación. El Tribunal Constitucional ha recordado también que durante la elaboración de la Constitución se descartó justamente la propuesta de reconocer el derecho a la autodeterminación de los pueblos del Estado. ${ }^{47}$ Asimismo, ha recurrido en su argumentación al derecho público comparado, donde tampoco se constatan precedentes de reconocimiento del ius secessionis en los sistemas federales y con un mayor nivel de descentralización territorial. ${ }^{48}$

\section{Las ideas federales y la política constitucional: la reforma constitucional como mission impossible $o$ ¿hay otras salidas?}

La reforma de la Constitución sería la opción óptima. Es la sede normativa donde deben estar las normas básicas de la división territorial

46 Sobre los problemas de las asimetrías véase Stephan Dion (1999, pp. 197-213).

47 STC 114/2017 y STS 459/2019, del 14 de octubre de 2019.

48 STC 114/2017, recuerda como "excepción anecdótica", Etiopía y el Archipiélago de San Cristóbal y Las Nieves. Asimismo, recuerda que existe acuerdo en que las Constituciones de Sudáfrica (sección 235 de su Constitución), Canadá (Reference Re Secession of Quebec del Tribunal Supremo, del 20 de agosto de 1998) o Estados Unidos (Texas vs. White, 1868, Tribunal Supremo) no amparan un derecho a la secesión. El Tribunal Constitucional recuerda también, que los Tratados internacionales prevén el derecho a la autodeterminación en contextos de descolonización. Sobre el derecho a decidir en España, en favor, en particular, Mercè Barceló Serramalera et al., 2015, en contra, entre otros, Joaquín Tornos (2019, pp. 19 y 20). Sobre la posibilidad de constitucionalizar el derecho a la sece- 
del poder. Sin embargo, la reforma de la Constitución es una decisión política que necesita un pacto político y, en España, no existe una cultura política de búsqueda del consenso. La historia y más cuarenta años de vida constitucional en democracia constatan que la cultura de la reforma constitucional no está en nuestro ADN nacional. ${ }^{49}$

Hubo consenso en 1978 y, ulteriormente, sólo en momentos muy puntuales. A diferencia de muchos Estados europeos, en Madrid no ha habido nunca un gobierno de gran coalición. No existe tampoco una tradición de coaliciones (la primera coalición se produjo en diciembre de 2019 entre PSOE-Podemos). Hay una tendencia al conflicto y a la polarización. La política se basa en la lógica que divide entre amigo y enemigo. Quien pacta, cede y quien cede es traidor. Con esa forma de hacer política, es lógico que las reformas constitucionales sean poco habituales en España. ${ }^{50}$

Sería también un grave error acometer una reforma constitucional $\mathrm{u}$ otras relevantes reformas en un momento de enorme tensión o crispación. Un acuerdo de los dos grandes partidos sobre el Estado autonómico parece impensable, pues ambos partidos defienden opciones opuestas. Y, sin embargo, una reforma del Estado autonómico necesita el pacto de los dos grandes partidos en España. Una reforma constitucional que aborde la organización territorial debe involucrar también a los partidos nacionalistas y separatistas, pero sus reivindicaciones - en particular, su principal reivindicación, un referéndum de autodeterminación - resultan inasumibles por los dos grandes partidos.

La palabra diálogo es la más invocada para resolver la crisis, pero el diálogo requiere abrir el baile con temas concretos sobre los que se pueda empezar a hablar, discutir, negociar y, en su caso, llegar a acuerdos.

Imaginar que una reforma constitucional llegue a prever un derecho a la secesión, parece (por el momento) imposible. Por su parte, la convocatoria de un referéndum sobre la autodeterminación, pactada con el

sión en España,Benito Aláez Corral (2015, pp. 136-183). En general sobre el derecho a la autodeterminación, Peter Hilpold (2008, pp. 117-141).

49 Marta Lorente (2018, p. 2008); Ignacio Sotelo (2006, p. 70).

50 En cuarenta años de vida de la CE, sólo se han llevado a cabo dos reformas constitucionales. La primera, en 1992, sirvió para introducir el derecho sufragio activo de los ciudadanos de la Unión Europea en las elecciones locales (CE, art. 13.2), y, la segunda, en 2011, con relación al límite de endeudamiento público a raíz de la crisis económica y financiera (CE, art. 135).

Esta obra está bajo una Licencia Creative Commons

Atribución-NoComercial-SinDerivar 4.0 Internacional, IIJ-UNAM.

Boletín Mexicano de Derecho Comparado, núm. 160, enero-abril de 2021, pp. 155-190. 
Estado central, no es una opción jurídica viable de acuerdo con la actual jurisprudencia del Tribunal Constitucional que considera posible un referéndum de ese estilo, pero mediante una previa reforma de la Constitución, pues el propio texto constitucional garantiza la unidad y la indivisibilidad de España en los términos vistos. ${ }^{51}$ En el Tratado de la Unión Europea, estas cuestiones, así como si un Estado permite o no permite la secesión corresponde a "su identidad nacional" (TUE, art. 4.2). ${ }^{52}$

Ante ese escenario, resulta muy difícil romper el círculo vicioso y surge irremediablemente la siguiente cuestión: ¿hay otras salidas? Los aspectos que tienen un problema "de origen", esto es, que están deficientemente regulados en la propia la Constitución y esa es la causa directa de la disfunción, deben abordarse con una reforma constitucional, como el Senado. Sin embargo, existen otros muchos aspectos donde no es imprescindible la reforma constitucional.

Hay problemas del Estado autonómico que podrían cambiarse sin necesidad de reformas jurídicas. Para ello, bastaría con que se cambiaran dinámicas políticas: la mejoras en la cooperación vertical y horizontal pasan por cambios de comportamiento en los actores, fundamentalmente, los gobiernos, tales como hacer funcionar la Conferencia de Presidentes, impulsar un mayor papel de las comunidades autónomas en las conferencias sectoriales, o colaborar entre ellas mismas sin el gobierno central. Asimismo, hay temas que requieren reformas jurídicas sin que sea obligatoria una reforma constitucional: así, en materia de financiación, o en materia de transferencia de competencias del Estado central a las comunidades autónomas.

Con la prudencia que aconsejan los hechos - el escenario es dinámico y la política a veces imprevisible-, parece probable que la resolución de la crisis de Cataluña haya de conducir al reconocimiento de más asime-

51 Las referencias a la indivisibilidad en otras Constituciones europeas, véase Albert Weber (2019, p. 177).

52 Artículo 4.2 TUE: "La Unión respetará la igualdad de los Estados miembros ante los Tratados, así como su identidad nacional, inherente a las estructuras fundamentales políticas y constitucionales de éstos, también en lo referente a la autonomía local y regional. Respetará las funciones esenciales del Estado, especialmente las que tienen por objeto garantizar su integridad territorial, mantener el orden público y salvaguardar la seguridad nacional. En particular, la seguridad nacional seguirá siendo responsabilidad exclusiva de cada Estado miembro". 
tría financiera y competencial. El Tribunal Constitucional en la sentencia sobre el Estatuto de Autonomía catalán de 2006 no declaró que muchas pretensiones fueran materialmente inconstitucionales, sino que se trataba de cuestiones que sólo podía regular el Estado central - como en el caso del sistema de financiación- y no el Estatuto de Autonomía de una comunidad autónoma, que es una norma pactada entre el Estado central y la correspondiente Comunidad. ${ }^{53}$

La cuestión de la financiación ha sido uno de los motivos que ha generado más apoyo de la población de Cataluña a la independencia. La CE no regula, como se indicó, este tema, sino que lo hace una ley del Estado central (CE, art. 157), la llamada Ley Orgánica para la Financiación de las Comunidades Autónomas. Por tanto, hay margen para introducir reformas legales en el sistema de financiación sin pasar necesariamente por una operación de revisión constitucional.

Asimismo, la Constitución dispone de instrumentos para crear asimetrías de competencias mediante un tipo especial de leyes del Estado central por medio de las cuales se pueden transferir o delegar en las comunidades autónomas "facultades correspondientes a materias de titularidad estatal que por su propia naturaleza sean susceptibles de transferencia o delegación" (CE, art. 150.2). Ambos casos serían leyes orgánicas: un tipo especial de ley que no necesita la mayoría de una reforma constitucional, pero sí precisa una mayoría reforzada (la mayoría absoluta del Congreso de los Diputados). En términos políticos, estas leyes requieren normalmente el pacto entre varios partidos que asegure dicha mayoría.

Existe, pues, un margen muy estrecho para reconocer materialmente nuevas asimetrías más allá de los hechos diferenciales previstos en la Constitución y cauces procedimentales para hacerlo. Su eventual reconocimiento se hará posiblemente con ambigüedad — la que muchas veces exige un complejo pacto político- y ello será más que probablemente fuente de conflictos de nuevo.

La utilización de fórmulas ambiguas no solucionará el problema y trasladará al Tribunal Constitucional la interpretación de temas con un contenido altamente político. Además, sería naif pensar que el resto de las comunidades autónomas van a aceptar privilegios para otras sin más y que los partidos separatistas renunciarán a más peticiones porque en su "pro-

53 STC 31/2010.

Esta obra está bajo una Licencia Creative Commons

Atribución-NoComercial-SinDerivar 4.0 Internacional, IIJ-UNAM.

Boletín Mexicano de Derecho Comparado, núm. 160, enero-abril de 2021, pp. 155-190. 
grama de máximos" la meta final es la autodeterminación. Es necesario aceptar que las soluciones a las crisis sólo podrán ser con un alto grado de probabilidad provisionales. La historia se repite...

\section{Conclusión: EL Fututo del Estado AUTONÓMICO ES UNA INCÓGNITA}

La España actual no es posible como proyecto común sin un amplio reconocimiento de la autonomía territorial. El Estado autonómico se creó para dar respuesta a las fuertes demandas de autogobierno del País Vasco y Cataluña. El desarrollo del Estado autonómico en clave de simetría entre las comunidades autónomas, salvo algunas excepciones, no ha funcionado.

Una reforma de la Constitución, que reconozca a Cataluña una posición especial dentro de España, puede ser una opción en teoría. En la práctica, el problema radica en cómo negociar y concretar cuál debería ser esa posición especial para Cataluña (¿financiera?, ¿competencial?, ¿ambas?), la posición del resto y, en particular, del País Vasco, una comunidad autónoma ya con un estatus especial y con demandas secesionistas arraigadas, aunque (en estos tiempos) mucho menos activas que en Cataluña (Alberto López, 2020). Pero es muy difícil que el derecho a la autodeterminación se reconozca y se garantice en la Constitución.

La urgencia de las reformas en el Estado autonómico ha venido marcada por la crisis catalana. Hay que reflexionar por qué en Cataluña hay más de dos millones de personas que en los últimos diez años no quieren ser españoles y se jactan de desobedecer la Constitución. Cataluña, es el territorio en España donde la Constitución tiene menor apoyo social y ello no tiene visos de cambiar radicalmente a corto y a medio plazo. ${ }^{54}$

La vinculación que une a los ciudadanos con la Constitución debería restablecerse. Una Constitución sólo funciona si las personas creen en él y lo respetan. En caso contrario, la convivencia se desintegra y el sistema se puede acabar derrumbando (Rudolf Smend, 2010, pp. 136-142). En España, hace falta más pedagogía sobre la pluralidad y más formación acerca de los valores constitucionales sobre los que se ha producido el pe-

54 En 1978, más de 90\% de la población en Cataluña votó en favor de la CE. Hoy el porcentaje supera ligeramente $50 \%$. 
riodo más largo de convivencia pacífica en España, unos valores que son también valores de la Unión Europea de la que formamos parte.

En España se vive con el separatismo. Esto no es nuevo. Siempre ha existido (José Ortega y Gasset,1999, pp. 24 y 25). El ordenamiento constitucional permite ciertamente esta ideología, pero no la secesión unilateral. Corresponde al Estado proponer a la población, donde se incluye aquella que un día optó por un switch off emocional con España, un proyecto común atractivo. Los separatistas han conseguido crear una vinculación emocional muy fuerte hacia secesión, pero es necesario más realismo: la independencia no es fácil, las consecuencias económicas son graves y no hay mayoría para ello (con la cautela, de momento).

Sería deseable que los actores políticos para la reforma del Estado autonómico supieran recuperar el consenso que fue clave en 1978 para la aprobación de la Constitución de la democracia. El futuro del Estado autonómico es más incógnita que nunca. Sin embargo, hay que encontrar una salida. De lo contario, hay algo seguro: sin cambios políticos y jurídicos los problemas del Estado autonómico no tardarán en agudizarse.

\section{BIBLIOGRAFÍA}

AJA, Eliseo (2014). Estado autonómico y reforma federal. Alianza. AJA, Eliseo et al. (1985). Sistema jurídico de las comunidades autónomas. Tecnos. AlÁEz Corral, Benito (2015). Constitucionalizar la secesión para armonizar la legalidad constitucional y el principio democrático en Estados territorialmente descentralizados como España. Revista d'Estudis Federals i Autonòmics (22), 136-183.

Álvarez Álvarez, Leonardo (2008). La función de la lealtad en el Estado autonómico. Teoría y Realidad Constitucional (22), 493-524.

Álvarez Junco, José (2016). Dioses útiles. Naciones y nacionalismos. Galaxia Gutenberg.

ARAGÓn REYES, Manuel (2006). La construcción del Estado autonómico. Revista General de Derecho Constitucional (1), 1-24.

ARBÓs MARÍn, Xavier (2006). Doctrinas constitucionales y federalismo en Espa$\tilde{n} a$. ICPS.

Barceló i Serramalera, Mercè et al. (2015). El derecho a decidir. Teoría y práctica de un nuevo derecho. Atelier.

Esta obra está bajo una Licencia Creative Commons

Atribución-NoComercial-SinDerivar 4.0 Internacional, IIJ-UNAM.

Boletín Mexicano de Derecho Comparado, núm. 160, enero-abril de 2021, pp. 155-190. 
Bayona, Antoni (2019). No todo vale. La mirada de un jurista a las entrañas del procés, (2a ed.). Península.

BLANCO VALDÉS, Roberto L. (2005). Nacionalidades históricas y regiones sin historia. Alianza.

CALAFEll FerRÁ, Vicente Juan (2006). Los convenios entre comunidades autónomas. CEPG.

Carmona Contreras, Ana M. (2019). Sobre el futuro de la Constitución: proyección y encaje europeos. Revista de las Cortes Generales (107), 61-92.

Cosculluela Montaner, Luis (2011). El debate sobre la abolición de la provincia y la reforma de las diputaciones. Anuario del Gobierno Local (pp. 45-67). Fundación Democracia y Gobierno Local.

CRUZ Villalón, Pedro (1981). La estructura del Estado o la curiosidad del jurista persa. Revista de la Facultad de Derecho de la Universidad Complutense (4), 53-63.

Gruz Villalón, Pedro (1990). La doctrina constitucional sobre el principio de cooperación. En Juan Cano Bueso (coord.), Comunidades autónomas e instrumentos de cooperación interterritorial (pp. 119-134). Madrid, Sevilla: Tecnos.

CruZ Villalón, Pedro (1991). La construcción jurisprudencial del Estado de las Autonomías. Revista Vasca de Administración Pública (31), 249260.

CRuZ Villalón, Pedro (2013). Rasgos básicos del derecho constitucional de los Estados en perspectiva comparada. En Armin VON BOGDANDY Pedro Cruz Villalón y Peter Huber, El derecho constitucional en el espacio jurídico europeo (pp. 15-68). Valencia: Tirant lo Blanch.

Dion, Stephan (1999). El federalismo fuertemente asimétrico: improbable e indeseable. En Enric Fossas y Ferran REQUeJO (eds.), Asimetría y Estado plurinacional. El debate sobre la acomodación de la diversidad en Canadá, Bélgica y España (pp. 197-215). Madrid: Trotta.

ElAZAR, Daniel J. (1990). Exploración del federalismo. Hacer.

Elliott, John H. (2018). Catalanes y escoceses. Taurus.

Escribano Collado, Pedro (2016). Provincias y diputaciones: una polémica sin proyecto institucional. En José María Baño León (coord.), Memorial para la reforma del Estado. Estudios en homenaje al profesor Santiago Muñoz Machado (pp. 1995-2017). Madrid: CEPG. 
FOSSAS, Enric (1999). Asimetría y plurinacionalidad en el Estado autonómico. En Enric Fossas y Ferran Requejo (eds.), Asimetría y Estado plurinacional. El debate sobre la acomodación de la diversidad en Canadá, Bélgica y España (pp. 275-301). Madrid: Trotta.

FroweIn, Jochen Abr. (1974). Die Rechtsprechung des Bundesverfassungsgerichts zum Wahlrecht. Archiv des öffentlichen Rechts, 99(1), 72-110. FroweIn, Jochen Abr. y Peukert. Wolfgang (2009). Europäische Menschenrechtskonvention EMRK-Kommentar (3a ed.). Kehl am Rhein, Straßburg, Arlington: N.P. Engel.

GARCÍA DE ENTERRÍA, Eduardo (1991). La provincia en la Constitución. En Rafael GÓMEZ-FERRER MORANT (dir.), La provincia en el sistema constitucional (pp. 5-17). Madrid: Diputación de Barcelona. Civitas.

García Morales, María Jesús (2013). Intergovernmental Relations in Spain and the Constitutional Court Ruling on the Statute of Autonomy of Catalonia: What's Next? En Alberto LóPEZ BaSAGUREN y Leire Escajedo SAn EPIFANIO (eds.), The Ways of Federalism in Western Countries and the Horizons of Territorial Autonomy in Spain, II (pp. 83-109). Berlín: Heidelberg. Springer.

García Morales, María Jesús (2016). El gobierno central y los gobiernos autonómicos en España... ¿trabajan juntos? Istituzioni del federalismo (1), 117-161.

García Morales, María Jesús (2019). Bundeszwang und Sezession in Spanien: Der Fall Katalonien”. Die Öffentliche Verwaltung (1), 1-13.

GARCía ROGA, Javier (2019). Il tempo moderato de la intervención coercitiva del Estado (artículo155 de la CE) en Cataluña: un comentario a las SSTC 89 y 90/2019, en particular, proporcionalidad y test de necesidad o razonabilidad de las medidas. Teoría y Realidad Constitucional (44), 503-524.

GARRIDO LÓPEZ, Carlos y Eva SAÉNZ RoyO (2019). El referéndum autonómico y la peculiaridad española. En Carlos GARRIDO LÓPEZ y Eva SAÉnz Royo (coords.), Referéndums y consultas populares en el Estado autonómico (pp. 15-26). Madrid: Marcial Pons.

GÓMEZ-FERRER MORANT, Rafael (dir.) (1991). La provincia en el sistema constitucional. Diputación de Barcelona. Civitas.

GonzÁlez García, Ignacio (2011). Parlamento y convenios de cooperación. CEPG.

Esta obra está bajo una Licencia Creative Commons

Atribución-NoComercial-SinDerivar 4.0 Internacional, IIJ-UNAM.

Boletín Mexicano de Derecho Comparado, núm. 160, enero-abril de 2021, pp. 155-190. 
HilPOLD, Peter (2008). Die Sezession - zum Versuch der Verrechtlichung eines faktischen Phänomens. Zeitschrift für öffentliches Recht (63), 117-141.

Hofmeister, Wilhelm y TudeLA, José (2017). "Prefacio". En Wilhelm Hofmeister y José Tudela (eds.), Sistemas federales. Una comparación internacional (pp- 7-12). Konrad Adenauer Stiftung, Fundación Manuel Giménez Abad.

INE (2019). España en cifras 2019. Madrid. Catálogo de Publicaciones de la Administración General del Estado. http://ine.es

KeAting, Michael (2015). The Scottish Independence Referendum and After. Revista d'Estudis Federals i Autonòmics (21), 73-98.

Kuhlmann, Sabine y Wollmann, Hellmut (2019). Introduction to Comparative Public Administration (2a ed.). Cheltenham y Northampton. Edward Elgar Publishing.

SolÉ TuRA, Jordi (2019). Nacionalidades y nacionalismos. El Viejo Topo.

LAFOREST, Guy (2010). The meaning of Canadian Federalism in Quebec. Revista d'Estudis Federals i Autonòmics (11), 10-55.

López Basaguren, Alberto (2016). Crisis del sistema autonómico y demandas de secesión: ¿es el sistema federal "la alternativa"? Teoría y Derecho (19), 46-61.

López Basaguren, Alberto (2020). El País Basc i la reforma territorial. Politica \& Prosa (17). https://politicaprosa.com/el-pais-basc-i-la-reforma-territorial/

López Guerra, Luis (1995). El modelo autonómico. Autonomies. Revista Catalana de Dret Públic (20), 171-186.

Lorente SARiÑena, Marta (2018). De la reforma de la Constitución. Breve historia de una ausencia (1810-1978). En Benigno PENDÁs (dir.), España constitucional (1978-2018). Trayectorias y Perspectivas, I (pp. 43774389). Madrid: CEPG.

Miguel BÁRCEnA, Josu de (2018). El proceso soberanista ante el Tribunal Constitucional. Revista Española de Derecho Constitucional (113), 133-166.

Muñoz Machado, Santiago (2007). Derecho público de las comunidades autónomas, II. (2a ed.). Iustel.

MuÑoz Machado, Santiago (2013). Crisis y reconstitución de la estructura territorial del Estado. Iustel.

Nieto García, Alejandro (2016). El federalismo español en 1873. En José María BAÑo LEÓN (coord.), Memorial para la reforma del Estado. Estu- 
dios en Homenaje al profesor Santiago Muñoz Machado (pp. 1069-1088). Madrid: CEPG.

Nohlen, Dieter y SchulTze, Rainer-Olaf (1985). Los efectos del sistema electoral español sobre la relación entre sufragios y escaños. Un estudio con motivo de las elecciones a Cortes de 1982. Revista Española de Investigaciones Sociológicas (30), 179-200.

NoHLen, Dieter (2019). La democracia. Instituciones, Contexto y Conceptos. Ediciones Olejnik.

OrTega y Gasset, José (1967). La redención de las provincias. Alianza Editorial.

ORTEGA Y GASSET, José (1999). España invertebrada. Universidad de Extremadura. Servicio de Publicaciones.

PALLARÉS, Francesc (2018). Las elecciones catalanas del 21-D-2017. Informe Comunidades Autónomas 2017 (pp. 425-443). IDP.

PlazA, Carmen (2018). Catalonia's secession process at the Constitutional Court: A Never-Ending Story? European Public Law, 24(3), 373-392.

Porras RAMírez, José María (2021). Der spanische Senat als Kammer der territorialen Vertretung. Eine anstehende Verfassungsreform. En Hermann-Josef Blanke; Siegfried Magiera; Christian Pielow y Albrecht WEBER (eds.), Verfasssungsentwicklungen im Vergleich: Italien $1947-$ Deutschland 1949 - Spanien 1978 (pp. 332-334). Duncker \& Humblot.

Punset Blanco, Ramón y TOlivar Alas, Leopoldo (coord.) (2020). España: el federalismo necesario. Reus.

QuiNTERo Olivares, Gonzalo (2019a). La "sentencia catalana" y la desobediencia. Teoría y Derecho (26), 68-73.

QUiNTERO OLIVARES, Gonzalo (2019b). La tormenta catalana y la capacidad del derecho penal: sobre la Sentencia 459/2019, del 14 de octubre de 2019. El Cronista del Estado Social y Democrático de Derecho (82-83), 68-73.

Roig Molés, Eduard (2017). Procés sobiranista i Tribunal Constitucional. Anàlisi d'un impacte recíproc. Revista catalana de dret públic (54), 2461.

Rubio Llorente, Francisco y Álvarez Junco, José (eds.) (2006). Informe del Consejo de Estado sobre la reforma constitucional. Texto del informe y debates académicos. Consejo de Estado y CEPG.

Esta obra está bajo una Licencia Creative Commons

Atribución-NoComercial-SinDerivar 4.0 Internacional, IIJ-UNAM.

Boletín Mexicano de Derecho Comparado, núm. 160, enero-abril de 2021, pp. 155-190. 
SAlvAdOR CRESPO, Mayte (2007). La autonomia provincial en el sistema constitucional español. Intermunicipalidad y Estado autonómico. Fundación Democracia y Gobierno Local, Instituto Nacional de Administración Pública. SÁnchez Morón, Miguel (2017). ¿Deben suprimirse las diputaciones provinciales? El Cronista del Estado Social y Democrático de Derecho (65), 4651.

SMEND, Rudolf (2010). Verfassung und Verfassungsrecht. En Rudolf Smend, Staatrechtliche Abhandlungen und andere Aufsätze (4a ed.) (pp. 117276). Duncker \& Humblot.

SolozÁbal EchaVArRía, Juan José (2017a). Pensamiento político federal español: Azaloa, Solé Tura y Trujillo, Revista de Estudios Políticos, 178, $13-45$.

SOlOzÁBAl EchavarRía, Juan José (2017b.). España: Nación de Naciones. El Cronista del Estado Social y Democrático de Derecho (68), 237-252.

SOlOzÁBAL EchavarRíA, Juan José (2020). ¿Crear una federación o federalizar el Estado autonómico? En Ramón Punset Blanco y Leopoldo Tolivar Alas (coords.), España: el federalismo necesario (pp. 15-32) Madrid: Reus.

Sommermann, Karl-Peter (2015). "Citizen Participation in Multi-Level Democracies: An Introduction". En Christina Fraenkel-Haeberle; Sabine Kropp; Francesco Palermo y Karl-Peter Sommermann (eds.), Citizen Participation in Multi-Level Democracies (pp. 1-12). Leiden, Boston: Brill Nijhoff.

Sotelo MarTínez, Ignacio (2006). España: un federalismo tan necesario como improbable. Política Exterior, 20 (111), 65-74.

Sosa Wagner, Francisco y Sosa Mayor, Igor (2007). El Estado fragmentado (4a ed.). Fundación Alfonso Martín Escudero. Trotta.

VON Bogdandy, Armin (2013). Historia y futuro del derecho Constitucional en Europa. En Armin VOn Bogdandy, Pedro GruZ Villalón y Peter Huber, El derecho constitucional en el espacio jurídico europeo (pp. 143180). Valencia: Tirant lo Blanch.

Tomás Mallén, Beatriz (2018). Art. 141. En Pablo Pérez Tremps y Alejandro SAIZ ARnAIZ (dirs.), Comentario a la Constitución Española. Librohomenaje a Luis López Guerra (pp. 1949-1961). Valencia: Tirant lo Blanch.

TORnOS MAS, Joaquín (2019). La inexistencia del derecho a decidir y la inexistencia de una causa de exoneración de responsabilidad penal. El Cronista del Estado Social y Democrático de Derecho (82-83), 18-23. 
Tudela Aranda, José (2016). El fracasado éxito del Estado autonómico. Marcial Pons.

TRUjILlO FERNÁNDEZ, Gumersindo (1967). Introducción al federalismo español (2a ed.). Cuadernos para el Diálogo.

WeBer, Albrecht (2019). European Constitutions Compared. Beck, Nomos, Hart.

ZABALZA, Antoni y LÓPEZ-LABORDA, Julio (2017). The uneasy coexistence of the Spanish foral and common regional finance systems. Investigaciones Regionales - Fournal of Regional Research (37), 119-152.

VARELA SUANZES-CARPEGNA, Joaquín (2016). La cuestión territorial en las dos Repúblicas. En José María BAÑo LEÓn (coord.), Memorial para la reforma del Estado. Estudios en Homenaje al profesor Santiago Muñoz Machado (pp. 1089-1 109). GEPG.

Velasco Caballero, Francisco (2011). Provincias. En Manuel Aragón Reyes (dir.) y César AguAdo REnedo (coods.). Temas básicos de derecho constitucional. Tomo II (pp. 627-631). Aranzadi Thomson Reuters.

WEILER, Joseph H. H. (2018). ¿Quién teme a una nación de naciones? / Who's Afraid of a Nation of Nations?, Actualidad Furídica Uría Menéndez (50), 7-18.

ZAFRA, Víctor Manuel (2012). La provincial: lo importante no es el nombre, lo importante es la función. Intermunicipalidad en el Estado autonómico. El Cronista del Estado Social y Democrático de Derecho (27), 66-83. 


\title{
RECONOCIMIENTO Y TUTELA DE DERECHOS HUMANOS. PLURALIDAD Y DIVERSIDAD EN LA SOCIEDAD DEMOGRÁTICA*
}

\author{
RECOGNITION AND PROTECTION OF HUMAN RIGHTS: \\ PLURALITY AND DIVERSITY IN DEMOCRATIC SOCIETY
}

\section{Sergio GARCÍA RAMÍREZ**}

RESUMEN: En este artículo se subraya que el orden público nacional e internacional, sustentado en valores y principios acogidos en ambos planos de la normativa jurídica, entraña la vigencia del principio de igualdad entre todas las personas, que es garantía
ABSTRACT: This article underlines the fact that national and international public order, based on values and principles enshrined in both levels of legal provisions, embodies the principle of equality among all persons, which is a guarantee for individuals and a

* Recibido el 9 de octubre de 2020; aprobado el 18 de enero de 2021.

Originalmente, este artículo constituyó una contribución para la Relatoría General del Congreso de la Academia de Derecho Internacional de Derecho Comparado (2021). Por ello, se analiza la materia tomando en cuenta un cuestionario formulado por los relatores generales del Congreso, Laurence Burgorgue-Larsen y Krzysztof Wojtyczek sobre Diversity and Plurality in the Law: Human Rights/Diversité et Pluralité dans le droit: droits humains. En este trabajo se ofrece un panorama sintético del orden jurídico interamericano sobre los temas vinculados directamente con pluralidad y diversidad, concentrado en el tratamiento "regional" de esta materia, sin examinar los sistemas nacionales particulares. En notas a pie de página se hallan las principales fuentes del panorama. En éstas aparecen documentos de la organización regional de Estados (OEA), tratados y convenciones, decisiones de los órganos internacionales de supervisión y algunas referencias a la doctrina interamericana. Por supuesto, esta relación de fuentes es ejemplificativa. Existen una copiosa jurisprudencia y una creciente doctrina acerca de los temas que aquí menciono, ampliamente examinados en el ya largo itinerario del Sistema Interamericano.

** ORCID: 0000-0002-9164-8464. Investigador en el Instituto de Investigaciones Jurídicas; investigador emérito del Sistema Nacional de Investigadores (México); profesor emérito de la Universidad Nacional Autónoma de México y exjuez y expresidente de la Corte Interamericana de Derechos Humanos. Correo electrónico:sgrïjunam@gmail.com.

Agradezco la colaboración de Irving Rodríguez (asistente de investigación, Sistema Nacional de Investigadores, Consejo Nacional de Ciencia y Tecnología) y Tania González Kazén (analista, Observatorio del Sistema Interamericano, Instituto de Investigaciones Jurídicas, UNAM).

Boletín Mexicano de Derecho Comparado, nueva serie, año LIV, núm. 160, enero-abril de 2021, pp. 191-235. 
para los individuos y principio rector de la función del Estado. Sin perjuicio de este postulado, es preciso observar las diferencias reales que existen entre los individuos y los grupos en el seno de una misma sociedad nacional, y garantizar el respeto a esa diversidad, en varios ámbitos y con múltiples consecuencias. Esto entraña la existencia y aplicación de otro principio, que complementa al de igualdad: especificidad, que no significa, en modo alguno, discriminación. En la sociedad contemporánea hay múltiples factores de diversidad y pluralidad. De hecho, la sociedad democrática es una sociedad heterogénea, en la que florecen múltiples requerimientos, intereses, convicciones y opiniones. De todo ello deriva un derecho a la diversidad: la posibilidad de "ser diferente" y la consecuente facultad de existir y convivir dentro de la pluralidad social, fijando y alcanzando el destino particular libremente elegido. Asimismo, esta situación es el fundamento de los deberes específicos del Estado para el respeto y la garantía de los derechos individuales. El presente artículo revisa esta materia desde la perspectiva de la jurisprudencia de la Corte Interamericana de Derechos Humanos (Corte IDH). El tribunal regional ha adoptado criterios de gran importancia y trascendencia sobre esta materia, con sustento en buen número de instrumentos interamericanos, invocados en el artículo al que corresponde este resumen. Esos criterios figuran en un amplio conjunto de opiniones consultivas y sentencias emitidos por la Corte IDH. Las vertientes de la pluralidad y la especificidad que aquí se examinan están relacionadas con la situación de grupos (mujeres, indígenas, parejas, familias, por ejemplo) y con el ejercicio de derechos básicos (identidad, convicción, expresión, opción política, también, por ejemplo). Se pasa revista a los deberes del Estado guiding principle of the State's role. Without prejudice to this premise, it is necessary to observe the real differences that exist between individuals and groups within the same national society, and to ensure respect for this diversity, in various spheres and with multiple consequences. This implies the existence and application of another principle, which complements that of equality: specificity, which in no way means discrimination. In contemporary society, there are multiple factors of diversity and plurality. In fact, democratic society is a heterogeneous society in which numerous requirements, interests, convictions, and opinions thrive. This gives rise to a right to diversity arises: the possibility of "being different" and the ensuing right to exist and co-exist within social plurality, establishing and achieving one's own freely chosen destiny. This situation is also the basis for the specific duties of the State to respect and guarantee individual rights. This article examines this issue from the perspective of Inter-American Court of Human Rights (IACHR) case law. The Regional Court has adopted criteria of great importance and transcendence in this matter, based on a good number of inter-American instruments mentioned in the article covered by this review. These criteria are to be found in a wide range of advisory opinions and judgments issued by the IACHR. The aspects of plurality and specificity examined herein are related to the situation of groups (for example, women, indigenous people, couples, and families) and to the exercise of basic rights (for example, identity, conviction, expression, and political opinion). The duties of the guarantor State are discussed, and emphasis is placed on the application of economic, social, cultural,and environmental rights. 
garante y se pone énfasis en la aplicación de los derechos económicos, sociales, culturales y ambientales.

Palabras clave: orden jurídico interamericano; declaraciones internacionales; convenciones internacionales; pluralidad/ diversidad; Corte IDH; discriminación/ trato diferente; igualdad/especificidad; individuos/grupos; indígenas; convicciones; expresión; parejas/familia; democracia/ derechos políticos; identidad; deberes del Estado.
Keywords: inter-american legal system; international declarations; international conventions; plurality/diversity; Inter-American Court of Human Rights; discrimination/ different treatment; equality/specificity; individuals/groups indigenous peoples; convictions; expression; couples/family; democracy/political rights; identity; duties of the State.

Sumario: I. Preámbulo: hipótesis y objetivo. II. Marco normativo interamericano: principios y normas. III. Diversidad y pluralidad en la sociedad heterogénea. IV. Discriminación y trato diferente. V. Órdenes jurídicos especiales: indígenas. VI. Libertad de convicciones y expresión. VII. Parejas y familia. VIII. Temas de bioética. IX. Democracia y derechos políticos. X. Tensión entre órdenes normativos. XI. Pro persona y otros principios especificos. XII. Identidad personal. XIII. Estado garante. XIV. Derecho común regional y estatutos especiales. XV. Derechos económicos, sociales, culturales y ambientales. XVI. Estado garante de derechos de integrantes de grupos y sectores. XVII. Bibliografia.

\section{PreÁmbulo. Hipótesis de trabajo}

Los derechos humanos son el dato más universal del orden jurídico, en el sentido de que todas las personas (físicas) son titulares de derechos y libertades que los Estados deben respetar y garantizar. Sin embargo, las condiciones en que actúan y se desarrollan los individuos distan mucho de ser las mismas. Existe, pues, diversidad material (y, eventualmente, jurídica) entre los individuos. Además, éstos pueden asumir diversos objetivos individuales o integrarse (de grado o por el imperio de los hechos) en grupos distintos en el seno de una misma sociedad nacional y universal. Si el orden jurídico no reconoce esta diversidad y estas facultades de orientación propia (con sustento en la autonomía individual), los derechos humanos 
resultarían ilusorios o estarían sujetos al imperio de órganos de poder o mayorías populares.

De lo anterior deriva la necesidad de preguntar si el orden jurisdiccional interamericano (criterios de la Corte IDH) reconocen y protegen los derechos de quienes ejercen su derecho a la diversidad (ser "diferentes" y respetados como tales), su facultad de existir y convivir dentro de la pluralidad que prevalece en una sociedad, elegir su destino particular y la forma de alcanzarlo. Este trabajo parte de la hipótesis de que la jurisprudencia del tribunal de San José sobre la materia reconoce y tutela los derechos de quienes ejercen su derecho a la diversidad de vida, desarrollo y convicciones. Aquí se aporta una respuesta a esta interrogante, con sustento en el análisis de las decisiones de la Corte IDH sobre diversos extremos en los que se manifiesta el tratamiento de la materia por esa vía jurisdiccional.

\section{MARCO NORMATIVO INTERAMERICANO: PRINCIPIOS Y NORMAS}

Como dije en el preámbulo, el reconocimiento de la diversidad y la pluralidad en una sociedad (mundial, regional o nacional) constituye un dato radical del orden jurídico de los derechos humanos atento a los valores y principios de la democracia, a la que me referiré en sus dimensiones a) formal o representativa, b) participativa, y c) integral o material (sistema de vida), ${ }^{1}$ que aparecen en la normativa interamericana ( $c f r$. Opinión Consultiva OC8/87, 1987, párrafo 26 y San Miguel Sosa y otras vs. Venezuela, 2018, párrafos 117 y 144). Aludiré con frecuencia a la sociedad democrática, constantemente invocada por la jurisprudencia interamericana. La naturaleza y el contenido de ese concepto deben apreciarse a partir de la centralidad reconocida al ser humano, el marco que proveen los derechos y libertades reconocidos por el moderno orden constitucional e internacional, y las ideas más avanzadas en torno al papel de la sociedad y el Estado en la protección de los derechos básicos del ser humano.

En el establecimiento, desarrollo y aplicación de ese orden jurídico ocupa un lugar primordial el principio de igualdad, al que se reconoce

1 Cfr. Amaya Úbeda de Torres (2007); Asdrúbal Aguiar Aranguren (2012); Laurence Burgorgue-Larsen y Amaya Úbeda de Torres (2008, pp. 649-650); Carta Democrática Interamericana ([CDI], 11/09/2001, art. 2); CIDH (2011, párrafo 5); Yatama vs. Nicaragua (2005, párrafos 192-193), y Gelman vs. Uruguay (2011, párrafo 239).

Esta obra está bajo una Licencia Creative Commons

Atribución-NoComercial-SinDerivar 4.0 Internacional, IIJ-UNAM.

Boletín Mexicano de Derecho Comparado, núm. 160, enero-abril de 2021, pp. 191-235. 
jerarquía de ius cogens internacional. ${ }^{2}$ Por supuesto, no pretendo internarme en este concepto. Me atengo a la caracterización que provee la Convención de Viena sobre el Derecho de los Tratados acerca de las normas imperativas (ius cogens) y a la recepción de este asunto en la jurisprudencia de la Corte de San José (supra, III). Considero que en el mismo orden puede figurar - con diversas formulaciones - el principio de especificidad (cfr. Sergio García Ramírez, 2018, p. 182 y 2019, p. 658), complemento de la igualdad. Especificidad implica trato diferente (es decir, "específico") a quienes son también diferentes (de hecho, o en virtud del orden normativo), a fin de rescatarles de la injusticia o la inequidad en la que se podría incurrir si se aplica en forma mecánica e indistinta el criterio de igualdad formal.

Del modo en que se ha considerado que el principio de igualdad y no discriminación forma parte del ius cogens internacional, se puede considerar que la adopción de criterios específicos para atender situaciones también específicas - adopción ampliamente reconocida por el derecho internacional convencional - se inscribe igualmente en el ius cogens. Sin embargo, esta consideración no forma parte de las conclusiones del presente trabajo. $\mathrm{Al}$ amparo de la especificidad, que acoge correctivos y modalidades indispensables para establecer el sentido y el alcance de la igualdad, se desenvuelve la tutela de los derechos de quienes forman parte de grupos diversos dentro de la sociedad plural.

En este trabajo me referiré exclusivamente al orden jurídico interamericano, vinculado al Sistema regional de protección de esos derechos y formalmente construido a partir de 1945 ( $c f r$. Unión Panamericana, 1956, pp. 20-24). El Sistema es heterogéneo y se proyecta con intensidad y alcances diversos en el conjunto de Estados que componen "Las Américas". Esta expresión pone de manifiesto la pluralidad material y jurídica que caracteriza a la región: varias Américas (Sergio García Ramírez, 2019, pp. 113 y 114); en cada una, Estados con rasgos propios, y en cada Estado, grupos y sectores con características singulares. Todo esto debe ser consi-

2 Cffr. CIDH (2019, p. 25); Informe 64/ 11 (2011, párrafo 359); Informe 75/15, (2015, párrafo 144); Opinión Consultiva OC-18/0 (2003, párrafo 101), y Opinión Consultiva OC-24/ 17 (2017, párrafo 61). Sobre el principio de igualdad, cfr. Rodrigo Uprimmy Yepes y Luz María Sánchez Duque (2019, pp. 708 y ss).

Esta obra está bajo una Licencia Creative Commons Atribución-NoComercial-SinDerivar 4.0 Internacional, IIJ-UNAM. Boletin Mexicano de Derecho Comparado, núm. 160, enero-abril de 2021, pp. 191-235. 
derado al examinar las normas y prácticas sobre diversidad y pluralidad en el ámbito americano.

El derecho interamericano — "duro" y "suave": doble marco para la atención de la diversidad y la pluralidad - se deposita en numerosos instrumentos, cada vez más abundantes y comprensivos, en acuerdos o declaraciones de instancias políticas regionales, y en resoluciones y sentencias de los órganos de supervisión creados en el marco del Sistema. La jurisprudencia regional ha precisado que la norma internacional se compone con dos elementos: texto convencional e interpretación jurisdiccional (cfr. Almonacid Arellano y otros vs. Chile, 2006, párrafo 124, y Gelman vs. Uruguay (2013, párrafo 66).

Aquí aludiré tanto a la Organización de los Estados Americanos, cuya Carta constitutiva data de 1948, ${ }^{3}$ como a la Comisión (1959) (cfr. Unión Panamericana, 1960, p. 11; Felipe González Morales, 2013, pp. 31 y 32, y Bertha Santoscoy (1995, párrafo 18) y a la Corte (cfr. Corte IDH 2005 y Sergio García Ramírez, 2018b, pp. 23-72) interamericanas de derechos humanos. La organización y la normativa a la que me estoy refiriendo tienen correspondencias en el sistema universal y en otros sistemas regionales. ${ }^{4}$ De ellos ha tomado conceptos y orientaciones el Sistema Interame-

3 En la IX Conferencia Internacional Americana sobre Problemas de la Guerra y de la Paz (1945) los Estados americanos convinieron consolidar el derecho interamericano. Posteriormente, adoptaron la Carta de la Organización de los Estados Americanos en la Novena Conferencia Internacional Americana, en Bogotá, Colombia (1948). (Cfr. Unión Panamericana, 1956, pp. 124-145)

4 En el ámbito universal: Declaración Universal de los Derechos Humanos, Pacto Internacional de Derechos Civiles y Políticos, Pacto Internacional de Derechos Económicos, Sociales y Culturales, Convención Internacional sobre la Eliminación de todas las Formas de Discriminación Racial, Convención sobre la Eliminación de todas las Formas de Discriminación contra la Mujer, Convención sobre los Derechos del Niño, Convención contra la Tortura y otros Tratos o Penas Crueles, Inhumanos o Degradantes, Convención Internacional sobre la protección de los Derechos de todos los Trabajadores Migratorios y de sus Familiares, Convención sobre los Derechos de las Personas con Discapacidad y Convención Internacional para la Protección de todas las Personas contra las Desapariciones Forzadas, así como sus respectivos comités. En el ámbito europeo: Convenio Europeo de Derechos Humanos, que estableció una Comisión — suprimida por el Protocolo 11 de 1999 — y un Tribunal Europeo de Derechos Humanos. En el continente africano, la Unión Africana acogió la Carta Africana sobre los Derechos Humanos y de los Pueblos; además, la Comisión y la Corte Africanas sobre Derechos Humanos y de los Pueblos, establecidas por la Carta Africana y su Protocolo 
ricano en un proceso de diálogo y fertilización recíproca. Muchas decisiones iniciales de las instancias interamericanas recibieron la influencia de la regulación mundial, así como de la europea. Reconozco esta circunstancia, pero me limito a considerar la tutela de la diversidad y la pluralidad en nuestro ámbito regional.

En la región americana y en los órganos que constituyen su andamiaje institucional figuran entes destinados a la promoción o la defensa de derechos e intereses de grupos y sectores sociales, con alcance continental (por ejemplo, mujeres y niños). ${ }^{5}$ En la Comisión Interamericana operan relatorías que tienen el mismo propósito. ${ }^{6}$

Para los fines de este trabajo, tomaré en cuenta tanto las más relevantes declaraciones regionales (generales: Declaración Americana de Derechos y Deberes del Hombre, de $1948,{ }^{7}$ y especiales: así, en torno a los derechos de pueblos indígenas, ${ }^{8}$ y otros documentos que enuncian principios, reglas y medidas), como los tratados, convenciones y protocolos más significativos y los pronunciamientos emitidos por los órganos del sistema, principalmente las opiniones consultivas (Convención Americana sobre

para la creación de una Corte Africana de los Derechos Humanos y de los Pueblos, respectivamente.

5 Instituto Interamericano del Niño, la Niña y Adolescentes, Comisión Interamericana de Mujeres y Programa Interamericano sobre los Derechos Humanos de la Mujer y la Equidad e Igualdad de Género.

6 La CIDH cuenta con 13 relatorías que brindan atención prioritaria a ciertos grupos, comunidades y pueblos. Entre ellas, las relatorías sobre los derechos de los pueblos indígenas, de las mujeres, de los migrantes, los derechos de la niñez, personas afrodescendientes y contra la discriminación racial, personas LGBTI, personas mayores y personas con discapacidad. http://wrere.oas.org/es/cidh/mandato/relatorias.asp Asimismo, cfr. Felipe González Morales, 2013, pp. 195-204.

7 La Declaración Americana de los Derechos y Deberes del Hombre (DADDH) fue aprobada en 1948 en la IX Conferencia Internacional Americana en Bogotá. Es el primer instrumento relativo al reconocimiento y protección de derechos humanos con alcance supranacional. (Cfr. Unión Panamericana, 1956, pp. 203-209)

8 La Declaración Americana sobre los Derechos de los Pueblos Indígenas fue aprobada el 14 de junio de 2016, en el 46 Periodo Ordinario de Sesiones de la Asamblea General de la Organización de Estados Americanos. El proceso de creación de este instrumento comenzó en 1989, cuando la Asamblea General encargó a la CIDH un primer borrador (cfr. Felipe González Morales, 2013, p. 256, y Fergus Mackay, pp. 159 y ss.). La Declaración reconoce los derechos humanos de mujeres, hombres, niños, niñas y adolescentes indígenas. Sus disposiciones protegen la diversidad, la identidad cultural y el desarrollo. https:// wrere.oas.org/es/sadye/documentos/res-2888-16-es.pdf

Esta obra está bajo una Licencia Creative Commons Atribución-NoComercial-SinDerivar 4.0 Internacional, IIJ-UNAM. Boletin Mexicano de Derecho Comparado, núm. 160, enero-abril de 2021, pp. 191-235. 
Derechos Humanos [CADH], 1969, art. 64), las sentencias (CADH, arts. 61-63) y otras resoluciones del tribunal regional y varias declaraciones, recomendaciones y principios de la Comisión Interamericana $(\mathrm{CADH}$, art. 41).

La Declaración Americana de 1948 y la CADH de 1969 proclaman la universalidad de los derechos reconocidos en ellas y rechazan la discriminación en su ejercicio (DADDH, art. II, y CADH, art. 1o.). En consecuencia, favorecen el reconocimiento de la diversidad y la pluralidad entre los individuos - con doble fuente: origen y elección - y, por ende, entre los grupos y sectores en los que aquéllos aparecen, desarrollan su existencia y procuran su destino. A este respecto, retengamos el propósito enunciado por los autores de la Convención: "consolidar en este Continente, dentro del cuadro de las instituciones democráticas, un régimen de libertad personal y de justicia social, fundado en el respeto de los derechos esenciales del hombre" (CADH, preámbulo). Entre éstos se halla el derecho de elegir y ejercer sus facultades en los distintos planos a los que se refiere este trabajo.

\section{DIVERSIDAD Y PLURALIDAD \\ EN LA SOCIEDAD HETEROGÉNEA}

Los textos interamericanos recogen la diversidad y pluralidad que caracterizan a la sociedad de esta región, y sustentan la decisión política y jurídica de amparar a los individuos en el ejercicio tanto de los derechos comunes como de los derechos específicos inherentes a esas diversidades y pluralidades. El mismo espíritu anima a la Carta Democrática Interamericana (CDI). De ahí - por ejemplo - el reconocimiento que esta fórmula sobre el "régimen plural de partidos y organizaciones políticas" (CDI, art. 3o.) como componente fundamental del ejercicio de la democracia.

En los países de "las Américas" concurren comunidades o sectores diferentes, con características acentuadas que reclaman tratamiento específico. Los instrumentos del sistema - fundacionales o posteriores - contienen expresiones que acreditan esta orientación tutelar. En el mismo sentido opera el concepto de sociedad democrática, al que antes me referí, mencionado en la normativa y en los pronunciamientos de los órganos del Sistema, tanto cuando aluden a la fuente de los derechos y de los co- 
rrespondientes deberes de los Estados, como cuando se pronuncian sobre las limitaciones o restricciones de aquéllos. ${ }^{9}$

Antes de revisar algunas cuestiones específicas relacionadas con la materia de este trabajo, conviene destacar la amplia legitimación que la normativa interamericana concede para plantear la violación a un derecho. ${ }^{10}$ No se exige que el solicitante, cuya gestión abre la vía internacional, sea víctima de la violación alegada. Esa legitimación abarca a "cualquier persona o grupo de personas, o entidad no gubernamental legalmente reconocida en uno o más Estados miembros de la Organización" (OEA). Con ello se abre la puerta a planteamientos de grupos que pudieran ostentar intereses, derechos o pretensiones diferentes de los correspondientes a la mayoría de la población. El planteamiento puede desembocar en una decisión que reconozca derechos de los integrantes del grupo y que, por lo tanto, asegure el respeto y garantice la pluralidad. ${ }^{11}$

Los Estados Americanos presentan diversas formas de organización política, entre ellas la federal. ${ }^{12}$ Ésta (y sus equivalentes en la división por regiones) implica diversidades sociales y políticas que es preciso atender. Empero, la protección de los derechos humanos trasciende esas diversidades. En la CADH figura la llamada "cláusula federal"13 (art. 28)

9 Cfr. CIDH (2009, párrafos 67-73; Informe 75/15, caso 12.923, Fondo, Rocío San Miguel Sosa y otras, 2015, párrafo 136; Herrera Ulloa vs. Costa Rica, 2004, párrafo 120; Claude Reyes y otros vs. Chile, 2006, párrafos 88-92, y San Miguel Sosa y otra, 2018, párrafos 117 y 144, y Amaya Úbeda de Torres, Democracia y derechos humanos en Europa y América, Madrid, Reus, 2007, pp. 579 y ss.

10 "Cualquier persona o grupo de personas, o entidad no gubernamental legalmente reconocida en uno o más Estados miembros de la Organización, puede presentar a la Comisión peticiones que contengan denuncias o quejas de violación de esta Convención por un Estado parte" (CADH, art. 44). En el mismo sentido, "Convención de Bélem do Pará" (art. 12), y Convención Interamericana sobre la Protección de los Derechos Humanos de las Personas Mayores (art. 36).

11 Cfr. Héctor Faúndez Ledesma (2004, pp. 252-257); Osvaldo Alfredo Gozaíni (2016, pp. 52 y ss); CIDH, Informe 32/05, Petición 642/2003 (2005); Informe 98/09, Petición 4355-02 (2009), y Pueblos Kaliña y Lokono vs. Surinam (2015, párrafos 2 y puntos resolutivos 1-3). Alcalá-Zamora criticó la referencia a "grupos" de individuos, porque constituye una denominación imprecisa. (Cfr. Niceto Alcalá-Zamora, 1974, p. 330).

12 Tienen estructura federal: Argentina, Brasil, Canadá, Estados Unidos, México y Venezuela.

13 "Cuando se trate de un Estado parte constituido como Estado federal, el gobierno nacional de dicho Estado parte cumplirá todas las disposiciones de la presente Convención 
que responde a este sentido tutelar. El Estado no puede invocar su organización federal para omitir el cumplimiento de las obligaciones derivadas de la normativa internacional. ${ }^{14}$

\section{DISGRIMINAGIÓN Y TRATO DIFERENTE}

El principio de igualdad, invocado por la Corte IDH como norma de jus cogens internacional, se asocia a la proscripción de cualquier forma de discriminación. Los textos interamericanos mencionan algunas variantes de ésta (raza, color, sexo, idioma, religión, opiniones políticas o de otro orden, origen nacional o social, posición económica, nacimiento o cualquier otra condición social). ${ }^{15}$

$\mathrm{Al}$ analizar el concepto de discriminación, la jurisprudencia interamericana destaca la legitimidad de las diferencias de trato a personas o grupos, justificada por la diversidad de condiciones en las que éstos se encuentran. ${ }^{16}$ Así queda a salvo la tutela diferenciada de personas cuya situación de hecho justifica esa tutela (Roberto Berizonce, 2009, pp. 97 y ss.). Esa protección diferenciada opera tanto en el examen de la diversidad y la pluralidad, como en la atención a los grupos vulnerables y sus integrantes.

Como desarrollo de las normas regionales que implican una profunda relectura de los principios tutelares inherentes a la diversidad y la pluralidad, cabe mencionar algunos instrumentos emitidos para combatir formas genéricas o específicas de discriminación o manifestaciones de violencia que reduce o desconoce derechos de amplios sectores de la sociedad. Estos documentos, que mencionaremos en el presente trabajo, figuran

relacionadas con las materias sobre las que ejerce jurisdicción legislativa y judicial".

14 Cfr. Garrido Baigorria vs. Argentina (1998, párrafo 46); Escher y otros vs. Brasil (2009, párrafo 219), y Garibaldi vs. Brasil (2009, párrafo 146).

15 Cfr. CADH (art. 1); Protocolo Adicional a la Convención Americana sobre Derechos Humanos en materia de Derechos Económicos, Sociales y Culturales "Protocolo de San Salvador" (art. 3); Convención Interamericana contra el Racismo, la Discriminación Racial y Formas Conexas de Intolerancia (art. 1); Convención Interamericana contra Toda Forma de Discriminación e Intolerancia (art. 1).

16 Cfr. CIDH, Informe 04/01, Caso 11.625 (2001, párrafo 31); CIDH, Compendio sobre la igualdad y no discriminación. Estándares Interamericanos, op. cit., párrafo 36; OC-4/84 (1984, párrafos 55-57), y OC-18/03 (2003, párrafo 89).

Esta obra está bajo una Licencia Creative Commons

Atribución-NoComercial-SinDerivar 4.0 Internacional, IIJ-UNAM.

Boletín Mexicano de Derecho Comparado, núm. 160, enero-abril de 2021, pp. 191-235. 
en el orden regulador característico de nuestra región. Disponen y detallan medidas de diverso carácter - no sólo legislativas - en relación con grupos y sectores de la sociedad. Queda de manifiesto la pluralidad de ésta y el propósito de brindar tutela específica a tales grupos y sectores.

Un ejemplo destacado sobre un sector social de suma importancia es la tutela de derechos específicos de las mujeres prevista en la Convención de Belém do Pará, ${ }^{17}$ destinada a enfrentar la violencia. ${ }^{18}$ Su predecesora mundial, la CEDAW, ${ }^{19}$ se concentró en puntos de discriminación, ${ }^{20}$ muchos de los cuales entrañan violencia. Belém do Pará obedece al objetivo - procurado frente a escollos y resistencias de diversa naturalezade avanzar en el reconocimiento y la protección de los derechos de las mujeres, y ha informado cambios en la normativa de los Estados de la región (Luz Patricia Mejía, 2012, pp. 196-197 y Comisión Interamericana de Mujeres, 2001, p. 91). Esta convención, aplicada por la Corte IDH con designio transformador (Sergio García Ramírez, pp. 11 y ss. Y Esther Vicente, 2010, pp. 149 y ss.), ocupa un lugar eminente en la jurisprudencia

17 La Convención Interamericana para Prevenir, Sancionar y Erradicar la Violencia contra la Mujer ("Convención de Belém do Para") fue adoptada en Belém do Para, Brasil, en 1994. Dispone obligaciones de cumplimiento inmediato y deberes de carácter progresivo. Establece el derecho de las mujeres a una vida libre de violencia; ésta constituye una ofensa a la dignidad humana. https://wrew.oas.org/juridico/spanish/tratados/a-61.html. Asimismo, cfr. Felipe González Morales (2013, p. 241).

18 Se denomina "violencia" a "cualquier acción o conducta, basada en su género, que cause muerte, daño o sufrimiento físico, sexual o psicológico a la mujer, tanto en el ámbito público como en el privado". "Convención de Belém do Para" (art. 1).

19 La Convención sobre la Eliminación de Todas las Formas de Discriminación contra la Mujer (CEDAW) fue adoptada el 18 de diciembre de 1979. Es el segundo instrumento internacional más ratificado por los Estados miembros de la ONU, después de la Convención sobre los Derechos del Niño. Se orienta a proteger y promover la igualdad de género y la creación de políticas e instituciones con perspectiva de género con el fin de erradicar los estereotipos, prejuicios y discriminación hacia las mujeres.

20 “ $[\mathrm{L}]$ a expresión ‘discriminación contra la mujer’ denotará toda distinción, exclusión o restricción basada en el sexo que tenga por objeto o resultado menoscabar o anular el reconocimiento, goce o ejercicio por la mujer, independientemente de su estado civil, sobre la base de la igualdad del hombre y la mujer, de los derechos humanos y las libertades fundamentales en las esferas política, económica, social, cultural y civil o en cualquier otra esfera". CEDAW (art. 1). 
interamericana, principalmente a través de la incorporación de perspectiva de género, criterio rector con gran fuerza expansiva. ${ }^{21}$

Otra convención que reconoce derechos de numerosos grupos y ordena la adopción de medidas que concurran a protegerlos es la relativa a quienes padecen restricciones derivadas de alguna forma de discapacidad. ${ }^{22}$ Se ordena a los Estados poner en práctica medidas conducentes al efectivo ejercicio de libertades y derechos (art. III), cuya práctica tropieza con múltiples obstáculos.

En la misma línea figura la Convención sobre adultos mayores, condición etaria - antípoda de la niñez - en la que se encuentra un apreciable número de personas con creciente presencia en la población americana. ${ }^{23}$ Esa convención, al igual que las mencionadas anteriormente, alienta medidas normativas y sociales de amplio espectro. ${ }^{24}$

21 En el caso González y otras ("Campo Algodonero"), la Corte señala que la capacitación con perspectiva de género: “...implica no sólo un aprendizaje de las normas, sino el desarrollo de capacidades para reconocer la discriminación que sufren las mujeres en su vida cotidiana. En particular, las capacitaciones deben generar que todos los funcionarios reconozcan las afectaciones que generan en las mujeres las ideas y valoraciones estereotipadas en lo que respecta al alcance y contenido de los derechos humanos". (2009, párrafo 540). Se ha implementado la perspectiva de género en varios casos en que se analiza la violencia contra las mujeres, por ejemplo: Penal Miguel Castro Castro vs. Perú (2006, párrafo 5); Rosendo Cantú y otra vs. México (2010, párrafos 108, 177, 182, 246, punto resolutivo 17); Velásquez Paiz y otros vs. Guatemala (2015, párrafos 229-269, puntos resolutivos 3 y 4); Mujeres Víctimas de Tortura Sexual en Atenco (2018, párrafos 338-365, puntos resolutivos 3 y 6), y Fernández Ortega vs. México (2010, párrafos 118, 131, 193, 196, 197 y 198).

22 La Convención Interamericana para la Eliminación de Todas las Formas de Discriminación contra las Personas con Discapacidad fue adoptada en la Ciudad de Guatemala el 6 de julio de 1999. Reafirma los derechos humanos de quienes presentan alguna forma de discapacidad, en un marco de dignidad e igualdad. Reconoce la validez de aplicar acciones afirmativas para promover la integración y desarrollo de las personas con discapacidad. Cfr. Felipe González Morales (2013, p. 248). La Convención se encuentra disponible en: https://wrere.oas.org/juridico/spanish/tratados/a-65.html

23 En 2018, 8.87\% de la población mundial tenía 65 años o más. En América Latina y el Caribe y Norteamérica la proporción es de 8 y 16\%, respectivamente. Cffr. http://wdi. worldbank.org/table/2.1\#

24 Entre los derechos que reconoce la Convención Americana sobre la Protección de los Derechos Humanos de las Personas Mayores, se encuentran los relativos a igualdad y no discriminación por razones de edad (art. 5), autonomía e independencia (art. 7), libertad de expresión (art. 14), seguridad social para garantizar una vida digna (art. 17), recreación (art. 22) e identidad cultural (art. 21).

Esta obra está bajo una Licencia Creative Commons

Atribución-NoComercial-SinDerivar 4.0 Internacional, IIJ-UNAM.

Boletín Mexicano de Derecho Comparado, núm. 160, enero-abril de 2021, pp. 191-235. 
Los instrumentos de más reciente ingreso en el derecho convencional americano, recientemente suscritos en Antigua, Guatemala, reconocen la existencia y los derechos de diversos grupos y sectores y combaten cualesquiera formas de discriminación, ${ }^{25}$ entre ellas, acentuadamente, la que obedece a motivos étnicos. ${ }^{26}$ La adopción de esta normativa internacional ha marchado lentamente. ${ }^{27}$

Agreguemos los lineamientos promovidos por la Cumbre Judicial Iberoamericana ${ }^{28}$ para garantizar el acceso a la justicia de individuos que se hallan en situación de vulnerabilidad (Reglas de Brasilia ${ }^{29}$ y Protocolo de Santiago), ${ }^{30}$ situación característica de los desiguales, los diferen-

25 La Convención Interamericana contra Toda Forma de Discriminación e Intolerancia fue adoptada en La Antigua, Guatemala el 5 de junio de 2013. Protege el principio de igualdad y no discriminación e intolerancia con respecto a diversos grupos de la sociedad, como migrantes, refugiados, desplazados, grupos religiosos, personas con discapacidad, condición social, etcétera. Doce Estados formaron esta Convención (Argentina, Bolivia, Brasil, Chile, Colombia, Costa Rica, Ecuador, Haití, México, Panamá, Perú, Uruguay). Hasta 2020 sólo dos (México y Uruguay) la han ratificado. Convención. http://wrere.oas. org/es/sla/ddi/tratados_multilaterales_interamericanos_A69_discriminacion_intolerancia.asp

26 La Convención Interamericana contra el Racismo, la Discriminación Racial y Formas Conexas de Intolerancia fue adoptada en La Antigua, Guatemala, el 5 de junio de 2013. Protege el principio de igualdad y dispone medidas y derechos en favor de las personas que sufren discriminación racial, con el fin de salvaguardar su dignidad en una sociedad pluralista y democrática.

27 Doce Estados suscribieron este instrumento (Argentina, Bolivia, Brasil, Chile, Colombia, Costa Rica, Ecuador, Haití, México, Panamá, Perú, Uruguay). Sólo cuatro (México, Ecuador, Antigua y Barbuda, Costa Rica y Uruguay) la han ratificado. http://wrere.oas. org/es/sla/ddi/tratados_multilaterales_interamericanos_A-68_racismo.asp

28 La Cumbre Judicial Iberoamericana es "una estructura de cooperación, concertación e intercambio de experiencias, que se articula a través de las máximas instancias de los Poderes Judiciales de la región Iberoamericana”. Se integra por las judicaturas de Andorra, Argentina, Bolivia, Brasil, Chile, Colombia, Costa Rica, Cuba, Ecuador, El Salvador, España, Guatemala, Honduras, México, Nicaragua, Panamá, Paraguay, Perú, Portugal, Puerto Rico, República Dominicana, Uruguay y Venezuela. http://wrere.cumbrejudicial. org/institucional/quienes-somos

29 Reglas de Brasilia sobre Acceso a la Justicia de las Personas en Condición de Vulnerabilidad, XIV Cumbre Judicial Iberoamericana, Brasilia, 2008. https://www.acnur.org/ fileadmin/Documentos/BDL/2009/7037.pdf

30 Protocolo iberoamericano de actuación judicial para mejorar el acceso a la justicia de personas con discapacidad, migrantes, niñas, niños, adolescentes, comunidades y pueblos indígenas, XVII Cumbre Judicial Iberoamericana, Santiago, 2014. http://wrere.cum- 
tes, los distintos, los ajenos: ${ }^{31}$ es decir, el vasto ejército de quienes invocan el respeto y la garantía de la diversidad, derivada de múltiples factores.

En la revisión del estado que guarda el derecho interamericano de los derechos humanos es necesario tomar en cuenta el importante progreso que implican estos últimos documentos, impulsados por el diálogo jurisdiccional de los lustros recientes, que supera el tradicional aislamiento o reticencia de los órganos judiciales. La Cumbre Judicial Iberoamericana favorece la atención especial de los derechos de ciertos sectores que en América son mayoritarios, en su conjunto - y propicia una suerte de "Derecho judicial codificado" (Sergio García Ramírez, 2016a, p. 85), expresión que utilizo para fines expositivos. De este naciente marco normativo se benefician la pluralidad y la diversidad, tanto como la tutela de los grupos vulnerables.

\section{V. ÓRDENES JURÍDICOS ESPECIALES: INDÍGENAS}

Numerosas decisiones de la Comisión y de la Corte han inspirado o recogido la normativa dispuesta o propuesta por los instrumentos, tratados y protocolos que se mencionan en este panorama. Por otra parte, también cabe señalar un proceso inverso: la generación, por vía jurisdiccional, de criterios que constituyen el fundamento de ciertos tratados (así, en materia de desaparición forzada). ${ }^{32}$

brejudicial.org/productos-y-resultados/productos-axiologicos/item/38-protocolo-de-acceso-a-la-justiciapara-personas-y-grupos-vulnerables

31 "(S)e consideran en condición de vulnerabilidad aquellas personas que, por razón de su edad, género, estado físico o mental, o por circunstancias sociales, económicas, étnicas y/o culturales, encuentran especiales dificultades para ejercitar con plenitud ante el sistema de justicia los derechos reconocidos por el ordenamiento jurídico. Podrán constituir causas de vulnerabilidad, entre otras, las siguientes: la edad, la discapacidad, la pertenencia a comunidades indígenas o a minorías, la victimización, la migración y el desplazamiento interno, la pobreza, el género y la privación de libertad". Reglas de Brasilia, sección 2a. Beneficiarios de las Reglas.

32 En sus primeros casos contenciosos, la Corte estableció la caracterización de la desaparición forzada de personas, retomada por la Convención Interamericana sobre Desaparición Forzada de Personas. Cffr. Velásquez Rodríguez vs. Honduras (1988, párrafos 155-158), y Godinez Cruz vs. Honduras (1989, párrafos 163-167).

Esta obra está bajo una Licencia Creative Commons

Atribución-NoComercial-SinDerivar 4.0 Internacional, IIJ-UNAM.

Boletín Mexicano de Derecho Comparado, núm. 160, enero-abril de 2021, pp. 191-235. 
También debemos citar la admisión de los órdenes jurídicos especiales que existen y subsisten en varios países de la región. Destacan tanto la Declaración Americana sobre los Derechos de los Pueblos Indígenas - vinculada con la previa Declaración de Naciones Unidas - ${ }^{33}$ como el fuerte reconocimiento jurisprudencial del régimen jurídico establecido por medio de los usos y las costumbres de esos pueblos. ${ }^{34}$ Este reconocimiento alcanza a la normativa nacional y a la jurisprudencia de varios países de la región. $^{35}$

La jurisprudencia interamericana ha conocido violaciones sistemáticas de derechos de los miembros de comunidades indígenas, tema que suscitó el análisis de la titularidad de derechos humanos por personas colectivas, no sólo individuales. ${ }^{36}$ Frente al amplio número de graves violaciones, que implicaban el desconocimiento de derechos ancestrales, la Corte IDH rescató el respeto y la vigencia del orden consuetudinario y desarrolló una nueva lectura sobre el derecho de los indígenas y sus comunidades a disponer de sus bienes, al amparo de la CADH y bajo parámetros distintos de los generalmente aplicables al derecho de propiedad. ${ }^{37}$

33 Declaración de las Naciones Unidas sobre los Derechos de los Pueblos Indígenas, 13 de septiembre de 2007. https://wrere.un.org/development/desa/indigenous-peoples-es/declaracionsobre-los-derechos-de-los-pueblos-indigenas.html

34 Cfr. CIDH, OEA/Ser.L/V/II (2015, párrafo 102); OAS/Ser.L/V/II (2019, párrafo 242); Comunidad Mayagna (Sumo) Awas Tingni vs. Nicaragua (2001, párrafos 138 y 151); Comunidad Indígena Sawhoyamaxa vs. Paraguay (2006, párrafo 83); Pueblo Saramaka vs. Surinam (2007, párrafo 178); Tiu Tojín vs. Guatemala (2008, párrafo 96); Pueblo Indígena Kichwa de Sarayaku vs. Ecuador (2012, párrafo 264); Pueblos Indígenas Kuna de Madungandi y Emberá de Bayano y sus Miembros vs. Panamá (2014, párrafo 167); Pueblos Kaliña y Lokono vs. Surinam (2015, párrafos 159 y 283), y Pueblo Indígena Xucuru y sus miembros vs. Brasil (2018, párrafo 131).

35 Cfr. Barie Cletus Gregor (2003, pp. 87 y ss.). Por lo que hace a México, cfr. Constitución Política de los Estados Unidos Mexicanos (art. 2, inciso A, fracción II); Tribunal Electoral del Poder Judicial de la Federación, Expediente SUP-JDG-9167/2011 (2011, pp. 133 y 134), y Suprema Corte de Justicia de la Nación, Primera Sala, Amparo directo 6/2018.

36 Cfr. Comunidad Mayagna (Sumo) Awas Tingni vs. Nicaragua (2001, párrafos 147-155); Pueblos Kaliña y Lokono vs. Surinam (2015, párrafo 129), y Pueblo Indígena Xucuru y sus miembros vs. Brasil (2018, párrafo 115). Sobre la jurisprudencia interamericana en este tema, cfr. Oswaldo Ruiz Chiriboga y Gina Donoso (2019, pp. 1131 y ss.).

37 En la sentencia del caso Mayagna (Sumo) Awas Tingni la Corte Interamericana determinó que al amparo del artículo 21 de la $\mathrm{CADH}$ se encuentran protegidos los derechos territoriales de los pueblos indígenas. El Tribunal ha mantenido el mismo criterio hasta el caso de Pueblo Indígena Xucuru y sus miembros. Cfr. Maygna (Sumo) Awas Tingni vs. Nicara- 
La consideración de esta materia ha significado un paso adelante en la recepción de la diversidad y la inserción formal de sistemas jurídicos especiales dentro del sistema regulatorio nacional. Otra vía para asegurar el dominio indígena sobre los bienes de la comunidad -o los que ésta requiere para su sustento - radica en el régimen de consulta a los pueblos acerca del aprovechamiento y destino de esos bienes. ${ }^{38}$

La regulación interamericana pretende la preservación de la cultura indígena, que constituye uno de los datos culturales más relevantes en el conjunto indoamericano y figura en el marco de los derechos económicos, sociales y culturales. ${ }^{39}$ Han menudeado las agresiones a la cultura de las comunidades indígenas, e incluso los hechos tendientes a suprimir la transmisión de ésta en el enlace intergeneracional. ${ }^{40}$

Frente a situaciones de ese carácter, la Corte IDH ha ordenado a los Estados adoptar medidas de protección de la cultura indígena. Estas se asocian, entre otros extremos, con el derecho de los niños ${ }^{41}$ al desarrollo en el espacio (material y cultural) de su comunidad y con la supervivencia también material y cultural de las comunidades. Figuran aquí las disposiciones sobre localización y entrega de restos humanos para la práctica

gua (2001, párrafo 148), y Pueblo Indígena Xucuru y sus miembros vs. Brasil (2018, párrafo 116). Cfr. Karla I. Quintana Osuna (2017, pp. 16-24).

38 Cfr. Declaración Americana sobre los Derechos de los Pueblos Indígenas (arts. XXIII, XXVIII inciso 3 y XXIX inciso 4); CIDH, OEA/Ser.L/V/II, Doc. 34 (2007, párrafos 246, 248 y 297); OEA/Ser.L/V/II, Doc. 47/15 (2015, párrafos 172-224); Informe de Fondo 40/04, Caso 12.053, (2004, párrafo 5); Pueblo Saramaka vs. Surinam (2007, párrafos 127 y 128), y Pueblo Indígena Kichwa de Sarayaku vs. Ecuador (2012, párrafos 159-167). Sobre este tema, $c f r$. Rodolfo Stavenhagen (2007, pp. 47 y ss.).

39 Cfr. Protocolo adicional a la Convención Americana sobre Derechos Humanos en materia de Derechos Económicos, Sociales y Culturales "Protocolo de San Salvador", 17 de noviembre de 1988, artículo 14. A este respecto, $c f r$. Laurence Burgorgue-Larsen y Amaya Úbeda de Torres (2009, pp. 660-662).

40 Es necesario proteger la herencia cultural de los pueblos indígenas, su territorio, naturaleza y conocimientos para las generaciones actuales y futuras. A esto se conoce también como "solidaridad intergeneracional". Cfr. Declaración Americana sobre los Derechos de los Pueblos Indígenas (art. XIII, inciso 1); CIDH (2019, párrafo 49). La Corte IDH ha analizado masacres de pueblos indígenas (Masacres de río negro, Masacre Plan de Sánchez) que han dañado la transmisión de su cultura entre generaciones.

41 Cfr. CIDH, OEA/Ser.L/V/II (2009. párrafo 205); OEA/Ser.L/V/II. Doc. 47/15 (2015, párrafos 323-325); Comunidad Indígena Takye Axa vs. Paraguay (2005, párrafo 172); Chitay Nech y otros vs. Guatemala (2010, párrafo 169); Comunidad Indígena Xákmok Kásek vs. Paraguay (2010, párrafos 261-264), y Masacres de Río Negro vs. Guatemala (2012, párrafo 143-144).

Esta obra está bajo una Licencia Creative Commons

Atribución-NoComercial-SinDerivar 4.0 Internacional, IIJ-UNAM.

Boletín Mexicano de Derecho Comparado, núm. 160, enero-abril de 2021, pp. 191-235. 
de honras fúnebres y el proceso de duelo en las comunidades a las que pertenecieron los fallecidos y pertenecen sus allegados, honras y duelo que revisten características especiales. ${ }^{42}$

\section{LIBERTAD DE CONVICGIONES Y EXPRESIÓN}

En la normativa regional hay pronunciamientos que aseguran la libertad de creencia religiosa, inscrita en la "piedra maestra" de los derechos humanos (cfr. Luigi Ferrajoli, 1995). Esta materia ha figurado, con acento y rasgos específicos, en hipótesis de diversa naturaleza: por ejemplo, casos concernientes a la libertad de expresión, a la relación de los pueblos indígenas con sus territorios ancestrales y a los derechos reproductivos, cuestiones que abordo en otros puntos de este artículo. El respeto a las diversas creencias posee gran importancia y actualidad, tomando en cuenta la creciente diversidad de profesiones religiosas en nuestra región.

Por lo que toca a la libre expresión, en sus vertientes individual y social, ${ }^{43}$ derecho que excluye mecanismos de censura previa, la jurisprudencia interamericana se pronunció por la más amplia libertad con respecto a una obra cinematográfica ${ }^{44}$ - inspirada en una literaria - que planteaba aspectos de la vida de Cristo que no coincidían con las creencias

42 Cfr. Masacre Plan de Sánchez vs. Guatemala, Reparaciones (2004, párrafo 85), en esta sentencia son relevantes las declaraciones de Benjamín Manuel Jerónimo, Eulalio Grave Ramírez y Juan Manuel Jerónimo (víctimas) y los dictámenes de Augusto Willemsen-Díaz y Nieves Gómez Dupuis; Comunidad Moiwana vs. Surinam (2005, párrafos 98, 100 y 103), y Masacres de Río negro vs. Guatemala (2012, párrafos 154, 155, 156, 160, 164 y 165).

43 Cfr. OC-5/85 (1985, párrafo 30); "La última tentación de Cristo" (Olmedo Bustos y otros) vs. Chile (2001, párrafos 64-67); Ivcher Bronstein vs. Perú (2001, párrafos 146-149) y punto resolutivo 5; Mémoli vs. Argentina (2013, párrafo 119), y Granier y otros (Radio Caracas Televisión) vs. Venezuela, (2015, párrafo 136). Igualmente, véase Sergio García Ramírez, Alejandra Gonza y Eréndira Nohemí Ramos Vázquez (2019, pp. 39-40), y Laurence BurgorgueLarsen y Amaya Úbeda de Torres (pp. 574-576).

44 Cfr. "La Última Tentación de Cristo" (Olmedo Bustos y otros) vs. Chile (2001, párrafos 70-73). La película censurada fue una adaptación de la novela "La última tentación de Cristo", del escritor griego Nikos Kazantzakis. La modificación corresponde al artículo único, letra a) de la ley de Reforma Constitucional 19.742, mediante la cual se reforma el artículo 19 de la Constitución Política de la República de Chile y que "elimina la censura cinematográfica sustituyéndola por un sistema de calificación y que consagra el derecho a la libre creación artística”. https://wrere.leychile.cl/Navegar?idNorma=188827

Esta obra está bajo una Licencia Creative Commons Atribución-NoComercial-SinDerivar 4.0 Internacional, IIJ-UNAM. Boletín Mexicano de Derecho Comparado, núm. 160, enero-abril de 2021, pp. 191-235. 
mayoritarias de la población. Ese pronunciamiento determinó una reforma constitucional para adecuar la ley suprema interna a la normativa interamericana. Asimismo, la Corte se ha manifestado en favor de la libertad de expresión en el ámbito del debate político, en el que naturalmente se hallan en juego - y deben ser protegidas - las diversas corrientes de pensamiento, características de una sociedad plural. ${ }^{45}$

El tribunal interamericano apreció el nexo entre religión y otros derechos a propósito de las reivindicaciones territoriales de pueblos indígenas. Observó el carácter religioso - espiritual- de la relación entre los pueblos y el ámbito físico en el que han desarrollado su vida, desde tiempos remotos. Esta relación, analizada y respetada por la jurisprudencia, constituye un rasgo diferencial entre el orden jurídico general y el correspondiente a un sector de la población, punto de cruce entre la generalidad y la diversidad. ${ }^{46}$ La cuestión religiosa — vinculada con consideraciones éticas - también quedó a la vista en el examen sobre el acceso a la fecundación asistida, ${ }^{47}$ que atrajo consideraciones científicas y preocupaciones éticas en el complejo espacio de la bioética y el ejercicio de los derechos humanos. Aquí se planteó el derecho a la protección de la vida ${ }^{48}$ (infra, VIII), sujeto a interpretaciones diversas al amparo del relativismo acogido en el primer párrafo del artículo 4o. de la CADH. ${ }^{49}$

En este punto no hubo pronunciamiento directo acerca de la libertad religiosa o la atención a las creencias generales o sectoriales en el ejercicio de ese derecho, pero fue evidente que en la consideración de este asunto figuraba un ingrediente religioso al lado del dato moral. El pronuncia-

45 Cfr. Ricardo Canese vs. Paraguay (2004, párrafos 176-179) y López Lone y otros vs. Honduras (2015, párrafos 162-163).

46 Cfr. CIDH, OEA/Ser.L/V/II (2009, párrafo 150-151); Comunidad Mayagna (Sumo) Awas Tingni vs. Nicaragua (2001, párrafo 149); Comunidad indígena Takye Axa vs. Paraguay (2005, párrafos 131 y 135); Comunidad Indígena Sawhoyamaxa vs. Paraguay (2006, párrafo 118); Pueblo Saramaka vs. Surinam (2007, párrafos 82 y 90), y Kaliña y Lokono..., cit., párrafo 130.

47 Cfr. Artavia Murillo y otros ("Fecundación in vitro") vs. Costa Rica (2012, párrafo 185).

48 Ibidem, párrafos 189 y 264.

49 Cfr. Conferencia Especializada Interamericana sobre Derechos Humanos, San José, Costa Rica, 7-22 de noviembre de 1969, Actas y Documentos, pp. 125 y 159-160; CIDH, Resolución 23/81, Caso 2141, Estados Unidos de América (1981, párrafos 20-31), y Declaración Interpretativa de México. http://wwre.oas.org/es/cidh/mandato/Basicos/convratif.asp. Para una crítica sobre la decisión de la Corte IDH en el caso Artavia Murillo, $c f r$. Francisco Vázquez Gómez-Bisogno (2018, pp. 531-537).

Esta obra está bajo una Licencia Creative Commons

Atribución-NoComercial-SinDerivar 4.0 Internacional, IIJ-UNAM.

Boletín Mexicano de Derecho Comparado, núm. 160, enero-abril de 2021, pp. 191-235. 
miento de la Corte IDH se produjo en favor de los valores de la sociedad laica y de la libertad en el ámbito de las convicciones morales. (Cfr. Artavia Murillo y otros vs. Costa Rica, 2012, párrafo 185-190)

Las convicciones éticas constituyen un punto de encuentro, diferencia y eventual conflicto entre sectores de la sociedad o entre ésta y los individuos que difieren de los conceptos prevalecientes. Traen consigo una oportunidad de contienda entre las convicciones de la generalidad, que pretende prevalencia o exclusividad, y las de individuos o grupos que reclaman su derecho a la diversidad e impugnan disposiciones que pudieran oprimir su libertad o entrañar discriminación. Los pronunciamientos de la Corte IDH reconocen y amparan corrientes de opinión inicialmente minoritarias que han ganado espacios crecientes.

La normativa interamericana sigue una orientación liberal y sustenta el reconocimiento del derecho a conducir la vida conforme a las convicciones del sujeto, sin perder de vista los límites y restricciones recogidos en la propia CADH. En este punto destacan las aportaciones jurisprudenciales a propósito del respeto a la vida privada ${ }^{50}$ a las opciones del individuo para orientar su vida ${ }^{51}$ y al desarrollo de la personalidad. ${ }^{52}$ He aquí un nuevo e importante espacio para la presencia de derechos vinculados a la diversidad y la pluralidad sociales con sustento en una interpretación progresiva de los derechos humanos, que remonta concepciones tradicionales de carácter restrictivo o excluyente.

\section{PAREJAS Y FAMILIA}

En la más reciente jurisprudencia se ha sostenido el derecho a resolver libremente las relaciones de pareja y la integración de la familia, ${ }^{53}$ ámbito

50 Cfr. Tristán Donoso vs. Panamá (2009, párrafo 55); Fernández Ortega y otros...cit., párrafo 129; Rosendo Cantú y otra...cit., párrafo 119, y Atala Riffo y Niñas vs. Chile (2012, párrafo 162).

51 Cfr. I.V. vs. Bolivia (2016, párrafo 150); Atala Riffo y Niñas vs. Chile (2012, párrafo 136, y Flor Fleire vs. Ecuador, 31 de agosto de 2016, párrafo 103.

52 Cfr. Artavia Murillo y otros ("Fecundación in vitro") vs. Costa Rica (2012, párrafo 143); I.V. vs. Bolivia (2016, párrafo 152), y OC-24/17 (2017, párrafo 87).

53 Cfr. CIDH, OAS/Ser.L/V/II.rev.2, doc. 36 (2015, párrafo 330 y recomendación 83); CIDH (2017, párrafo 408); CIDH, OAS/Ser.L/V/II.170, Doc. 184 (2018, párrafo 70); Atala Riffo y Niñas vs. Chile (2012, párrafo 172-177); Forneron e hija vs. Argentina (2012, párrafo 98); OC-24/17 (2017, párrafos 182-199).

Esta obra está bajo una Licencia Creative Commons Atribución-NoComercial-SinDerivar 4.0 Internacional, IIJ-UNAM. Boletín Mexicano de Derecho Comparado, núm. 160, enero-abril de 2021, pp. 191-235. 
en el que surgen preferencias que desbordan el marco tradicional del derecho civil e incluso el constitucional. ${ }^{54}$ Este asunto, que concurre a la tutela de la diversidad, suele aparecer en el examen de los derechos de quienes forman parte de las comunidades LGBTI (tema considerado por la Comisión Interamericana y la jurisprudencia del Tribunal de San José), a propósito de las uniones entre personas del mismo $\operatorname{sexo}^{55}$ y las consecuencias patrimoniales de la unión. ${ }^{56}$ La jurisprudencia interamericana, que analizó bajo criterios de pluralidad la composición familiar de miembros de grupos indígenas, ${ }^{57}$ ha seguido la misma orientación en otros ámbitos que recientemente adquirieron visibilidad.

Esa jurisprudencia no ha rechazado la unión entre personas del mismo sexo bajo fórmulas o figuras jurídicas propias, pero también ha postulado la aplicación a esas uniones de las figuras tradicionales o generales: matrimonio, con los efectos jurídicos que derivan de éste. ${ }^{58}$ Se favorece la generalización de tales figuras con el doble propósito de evitar la formación de compartimientos jurídicos innecesarios y brindar mayor protección a los derechos de la pareja o de los integrantes de la familia.

\section{TEMAS DE BIOÉTICA}

Merecen referencia los desarrollos de la jurisprudencia interamericana sobre problemas de la agenda bioética, tomando en cuenta los diversos planteamientos éticos de grupos que coexisten en la misma comunidad nacional. En otro lugar (supra, VI) aludí a la fecundación artificial, que se

54 La definición clásica del matrimonio figura en algunas constituciones de la región: Colombia (art. 42); Venezuela (art. 77); Ecuador (art. 67); Bolivia (art. 63), y Paraguay (art. 51).

55 Cfr. OC-24/17 (2017, opinión 6 y 8), y CIDH, Informe 122/18 (2018, párrafos 185-188).

56 Cfr. CIDH, OEA/SEer.L/v/11.170 Doc.184 (2018, párrafos 218-223), y Duque vs. Colombia (2016, párrafos 124-125); OC-24/17 (2017, opinión 7).

57 Cfr. Aloeboetoe y otros vs. Surinam (1993, párrafo 17 y 62). Asimismo, el artículo XVII de la Declaración Americana sobre los Derechos de los Pueblos Indígenas reconoce el derecho que tienen los pueblos indígenas de "preservar, mantener y promover sus propios sistemas de familia".

58 Cfr. CIDH, OEA/SEer.L/v/11.170 Doc.184 (2018, párrafos 235-238), y OC-24/17 (2017, párrafo 224). Igualmente, cfr. Beatriz Gimeno (2007, pp. 177 y ss).

Esta obra está bajo una Licencia Creative Commons

Atribución-NoComercial-SinDerivar 4.0 Internacional, IIJ-UNAM.

Boletín Mexicano de Derecho Comparado, núm. 160, enero-abril de 2021, pp. 191-235. 
vincula con el derecho a la protección de la vida, el derecho a la familia y la superación de obstáculos que derivan de una discapacidad o plantean condiciones y barreras para la vida y el desarrollo de quienes la padecen (cfr. Artavia Murillo y otros vs. Costa Rica, 2012, párrafos 288-293). En este último supuesto se encuentran los problemas determinados por la presencia de alguna enfermedad o condición de riesgo que teme o reprueba la mayoría de la sociedad, como el síndrome de inmunodeficiencia adquirida. ( $C f$ r. Gonzáles Lluy y otros vs. Ecuador, 2015, párrafos 236-240)

Añadamos la tutela del principio de autonomía en la relación médicopaciente, que también interesa dentro del estudio de la pluralidad y la diversidad de opiniones, por cuanto puede implicar decisiones diferentes de las que sustenta o recomienda la mayoría ${ }^{59} \mathrm{El}$ ejercicio eficaz de esa autonomía tiene implicaciones en el derecho a la información, ${ }^{60}$ cuyas características ha definido la jurisprudencia interamericana siguiendo las tendencias prevalecientes en esta materia.

\section{DEMOCRACIA Y DEREGHOS POLÍTICOS}

Por supuesto, la orientación de la normativa interamericana hacia el reconocimiento y la protección de la diversidad y la pluralidad se ha manifestado en el ámbito de los derechos políticos ${ }^{61}$ y de otros derechos asociados a la marcha general de la sociedad, entre ellos los vinculados con la libertad de expresión, a la que aludí supra VI. Unos y otros juegan un papel de primer orden en el escenario del Estado constitucional y de las garantías inherentes a una sociedad democrática. ${ }^{62}$

59 Cfr. I.V.vs. Bolivia (2016, párrafos 160-161).

60 Cfr. CIDH, OEA/Ser.L/V/II.152 (2014, párrafos 108 y ss.); I.V. vs. Bolivia (2016, párrafos 155 y ss.), y Poblete Vilches y otros vs. Chile (2018, párrafos 161 y ss).

61 Los Estados pueden regular derechos políticos, sin vulnerar los contenidos mínimos que establece la CADH. No se impone un sistema electoral o una forma específica de ejercer el derecho a votar o ser votado. Algunos grupos (así, los pueblos indígenas) pueden adoptar formas propias de designación de candidatos, tomando en cuenta sus propios usos, costumbres y tradiciones. Cfr. Yatama vs. Nicaragua (2005, párrafo 215-219), y Castañeda Gutman vs. México (2008, párrafo 166).

62 En el marco de estas reflexiones, conviene considerar el impacto que pudieran tener los pronunciamientos de la Corte IDH acerca de algunos extremos de la llamada "justicia transicional", que implica tensión entre decisiones tradicionales sobre tutela de los dere- 
En este espacio de consideraciones, el orden jurídico interamericano de los derechos humanos reconoce y respeta la existencia (coexistencia) de diversas culturas con sus propios valores, requerimientos y expectativas. Aquéllas, frecuentemente ignoradas, rechazadas o subordinadas, emergen con fuerza en el nuevo marco de los derechos humanos, que lejos de imponer visiones unitarias, hegemónicas, procura el rescate de los grupos y sus culturas en el gran conjunto social. El proceso intercultural garantiza el pluralismo y respeta la diversidad. Explícita o implícita, esta idea rige en la normativa, la jurisprudencia y la doctrina más avanzada de nuestra región. ${ }^{63}$ Adelante volveré sobre algunas expresiones de este proceso en la recepción y defensa de las culturas "profundas" de los pueblos americanos.

En esa normativa y en su aplicación por los órganos del Sistema y las instancias domésticas no se autoriza ni alienta la militancia del Estado para promover o favorecer cierta convicción o ideología, en detrimento de las ideas o convicciones de algunos individuos o sectores de la sociedad. ${ }^{64} \mathrm{Al}$ ocuparse de estas cuestiones, los órganos del Sistema se han sobre el respeto a los valores y principios propios de la sociedad democrática.

Este favorecimiento implica tanto la defensa activa de la democracia (formal e integral, en los términos de la Carta Democrática Interamericana, a la que ya me referí) como el rechazo a tentaciones autoritarias que menoscaben aquellos valores y principios o entrañan alguna opresión sobre quienes sustentan opiniones diferentes de las que comparte o se pretende que comparta la mayoría.

Los derechos individuales se hallan limitados por el interés general, en los términos de la $\mathrm{CADH}$ (art. 32, inciso 2), pero esa limitación no entraña militancia que favorezca determinada convicción o desfavorezca otra. Desde luego, se proscriben los mensajes de odio, ${ }^{65}$ y no se ignora

chos humanos, la justicia y la democracia, y disposiciones encaminadas a resolver conflictos internos y establecer la paz. Cfr. Sergio García Ramírez (2017, p. 45), y Humberto A. Sierra Porto (2016, pp. 82 y ss).

63 Por ejemplo, cfr. Comunidad Indígena Xákmok Kásek vs. Paraguay (2010, párrafo 146), y Pueblo Indígena Kichwa de Sarayaku vs. Ecuador (2012, párrafos 219-220).

64 Cfr. OC-24/17 (2017, párrafo 223).

65 "Estará prohibida por la ley toda propaganda en favor de la guerra y toda apología del odio nacional, racial o religioso que constituyan incitaciones a la violencia o cualquier

Boletín Mexicano de Derecho Comparado, núm. 160, enero-abril de 2021, pp. 191-235. 
la orientación finalista inherente al derecho a la educación, acogida en instrumentos mundiales y regionales ${ }^{66}$ orientación nutrida por el respeto a la dignidad humana, a los derechos y libertades que derivan de éste - en favor de individuos y grupos - y al imperio de la sociedad democrática.

La Corte IDH ha emitido decisiones claras asociadas a temas de religión o de convicción moral, ${ }^{67}$ como vimos en líneas anteriores, e igualmente ha salido al paso de las expresiones o actuaciones de autoridades que desbordan su propia competencia o generan divisiones o enfrentamientos en el seno de la sociedad. Estas tensiones divisionistas implican un grave menoscabo para el respeto a la pluralidad ${ }^{68}$ y entrañan lesión o peligro para individuos y grupos.

\section{TENSIÓN ENTRE ÓRDENES NORMATIVOS}

La normativa interamericana recibe los imperativos sobre derechos humanos derivados de la ley interna y los tratados internacionales, y reconoce la posibilidad de acoger derechos inherentes al ser humano no previstos en el estatuto interamericano $\left(\mathrm{CADH}\right.$, art. 29, b) ${ }^{69}$ Éste es el "piso", no el "techo", de los derechos fundamentales. Ya señalamos - y adelante reite-

otra acción ilegal similar contra cualquier persona o grupo de personas, por ningún motivo, inclusive los de raza, color, religión, idioma u origen nacional". CADH (art. 13.5). Asimismo, $c f r$ CIDH, OAS/Ser.L/V/II.rev.2 (2015, párrafos 214 y ss.).

66 La "educación deberá orientarse hacia el pleno desarrollo de la personalidad humana y del sentido de su dignidad y deberá fortalecer el respeto por los derechos humanos, el pluralismo ideológico, las libertades fundamentales, la justicia y la paz". "Protocolo de San Salvador", artículo 13; asimismo, Cfr. Pacto Internacional de Derechos Económicos, Sociales y Culturales, 16 de diciembre de 1966, artículo 13, y Protocolo adicional al Convenio Europeo para la Protección de los Derechos Humanos y de las Libertades Fundamentales, 20 de marzo de1952 (art. 2).

67 La Comisión Interamericana también ha conocido de algunos casos relativos a esta problemática, por ejemplo, Cfr. CIDH, Informe 43/05. (2005, párrafos 84 y ss.).

68 Cfr. CIDH, Institucionalidad democrática, Estado de derecho y derechos humanos en Venezuela, OEA/Ser.L/V/II., 31 diciembre 2017, párrafo 233; Apitz Barbera y otros ("Corte Primera de lo Contencioso Administrativo") vs. Venezuela, 5 de agosto de 2008, párrafo 131, y Perozo y otros vs. Venezuela, 28 de enero de 2009, párrafo 151.

69 Cfr. CADH, artículo 29, b). Sobre este tema, Cfr. Martin, Claudia, "La mobilisation des sources extérieures par la Cour Interaméricaine des droits de l'homme. L'exemple du droit à la vie", en Varios, Les défis de l'interprétation et l'application des droits de l'homme. Del l'ouverture au dialogue, Paris, Éditions A. Pedone, 2017, pp. 243 y ss.

Esta obra está bajo una Licencia Creative Commons Atribución-NoComercial-SinDerivar 4.0 Internacional, IIJ-UNAM. Boletín Mexicano de Derecho Comparado, núm. 160, enero-abril de 2021, pp. 191-235. 
raré- que en el marco del Sistema Interamericano tienten presencia los derechos enunciados por diversos instrumentos que consideran situaciones vinculadas con la diversidad o la pluralidad en el seno de la sociedad, como pueden ser las relacionadas con el estatus migratorio, la pertenencia a pueblos indígenas o la discapacidad.

Como ya se dijo a propósito de la eficacia de los derechos específicos en los que se refleja la pluralidad social, el orden interamericano (principalmente las sentencias de la Corte IDH) sostiene la vigencia y aplicación de órdenes normativos especiales, emanados de grupos o sectores de la sociedad: derecho consuetudinario, usos y costumbres, que deben ser respetados y garantizados por el Estado nacional. ${ }^{70}$ En este sentido, ingresa al orden normativo lo que se ha llamado "derecho social de creación autónoma” (Sergio García Ramírez, 1965, pp. 636-639), que muestra diversas vertientes, entre las que figuran, por lo que toca a la materia del presente trabajo, las correspondientes a derechos humanos.

Aun cuando no se han creado un régimen especial o instancias destinadas a la solución de tensiones o conflictos entre disposiciones generales y normas de grupos específicos, la Corte IDH es competente para resolver litigios de esta naturaleza, o bien, para remitir la solución a instancias nacionales una vez que se ha pronunciado sobre la violación de derechos y la reparación a las víctimas. ${ }^{71}$ Esta competencia resolutiva final (irrecurrible) o el reenvío a la jurisdicción interna implican una legítima injerencia del órgano supranacional en cuestiones cuya atención inicial pudiera corresponder, en principio, al orden jurídico doméstico.

Surge aquí cierta consideración jerárquica (aunque es posible emplear otros términos para caracterizar el enlace entre la justicia interna y la supranacional) ${ }^{72}$ en virtud de que la resolución final compete al órgano supranacional cuando la contienda atañe precisamente a derechos huma-

70 Cfr. Pueblo Indígena Kichwa de Sarayaku vs. Ecuador (2012, párrafos 55 y 264), y Comunidad Indigena Yakye Axa vs. Paraguay (2005, párrafo 63).

71 Cfr. Trabajadores Cesados del Congreso (Aguado Alfaro y otros) vs. Perú (2006, párrafos 148149); Castañeda Gutman vs. México (2008, párrafo 231), y Asociación Nacional de Cesantes y Fubilados de la Superintendencia Nacional de Administración Tributaria (ANCEJUB-SUNAT) vs. Perú (2019, párrafo 225-226).

72 La Suprema Corte de Justicia de México ha denominado a este enlace "parámetro de regularidad constitucional". Cfr. Contradicción de Tesis 293/2011 (2013, p. 41).

Esta obra está bajo una Licencia Creative Commons

Atribución-NoComercial-SinDerivar 4.0 Internacional, IIJ-UNAM.

Boletín Mexicano de Derecho Comparado, núm. 160, enero-abril de 2021, pp. 191-235. 
nos. ${ }^{73}$ La atribución de esta competencia al juzgador supranacional no supone una tercera o cuarta instancia a cargo de éste, ${ }^{74}$ ni suprime la autonomía de las jurisdicciones internas generales o especiales. ${ }^{75}$

Las instancias regionales de supervisión reconocen la necesaria interacción entre diversos órdenes normativos (Diego García-Sayán, 2005, pp. 325-330). Como dije, hay temas en los que se abre la posibilidad de concurrencia de decisiones de órganos internacionales y órganos internos, que a su vez deben tomar en cuenta las modalidades domésticas de protección de derechos humanos correspondientes a miembros de grupos o sectores específicos, lo cual implica el reconocimiento eficaz de la pluralidad social.

\section{PRO PERSONA Y OTROS PRINCIPIOS ESPECÍFICOS}

En sus propias decisiones, la jurisdicción interamericana ha desarrollado principios derivados de instrumentos internacionales, ${ }^{76}$ desarrollo que pue-

73 "El fallo de la Corte será definitivo e inapelable. En caso de desacuerdo sobre el sentido o alcance del fallo, la Corte lo interpretará a solicitud de cualquiera de las partes, siempre que dicha solicitud se presente dentro de los noventa días a partir de la fecha de la notificación del fallo". CADH (art. 67). Igualmente, cfr. Apitz Barbera y otros ("Corte Primera de lo Contencioso Administrativo") vs. Venezuela (2012, párrafos 21 y 22), y Fontevecchia y D’Amico vs. Argentina (2017, párrafo 13).

74 Cfr. Cabrera García y Montiel Flores vs. México (2010, párrafo 16); Palma Mendoza y otros vs. Ecuador (2012, párrafo 18), y Tarazona Arrieta y otros vs. Perú (2014, párrafo 22).

75 Cfr. Sergio García Ramírez (2012, p 18), y Voto razonado del juez Eduardo Ferrer Mac-Gregor Poisot en Gelman vs. Uruguay, Supervisión de Cumplimiento de Sentencia (2013, párrafos 43-66).

76 Para la comunidad LGBTI se han utilizado los Principios de Yogyakarta, cfr. OC24/17 (2017, párrafo 112). Acerca de casos relacionados con pueblos indígenas se ha utilizado el Convenio 169 de la Organización Internacional del Trabajo. Cfr. Comunidad Garifuna de Punta Piedra y sus miembros vs. Honduras (2015, párrafos 91 y ss.). En relación con casos de niñas, niños y adolescentes la Corte IDH ha utilizado y mencionado la Convención sobre los Derechos del Niño. Cfr. Ramírez Escobar y otros vs. Guatemala (2018, párrafo 149. A propósito de personas con discapacidad se ha utilizado la Convención sobre los Derechos de las Personas con Discapacidad. Cfr. Chinchilla Sandoval vs. Guatemala (2016, párrafo 205 y ss.). En lo que respecta a la violencia hacia la mujer se ha utilizado la Convención sobre la eliminación de todas las formas de discriminación contra la mujer, así como los informes del Comité para la Eliminación de la Discriminación contra la Mujer de las Naciones Unidas. Cfr. Velásquez Paiz y otros vs. Guatemala (2015, párrafo 175).

Esta obra está bajo una Licencia Creative Commons Atribución-NoComercial-SinDerivar 4.0 Internacional, IIJ-UNAM. Boletín Mexicano de Derecho Comparado, núm. 160, enero-abril de 2021, pp. 191-235. 
de significar una interpretación pretoriana pro persona (Eduardo Ferrer, 2017, pp. 197 y ss.). A este respecto, vale citar las decisiones tutelares de grupos indígenas, mujeres, niños, discapacitados y miembros de las comunidades LGBTI.

La doctrina ha observado que en forma paralela y por vía de aplicación del principio pro persona se abre paso la aplicación de principios específicos de protección: pro mulier, pro niño, pro indígena, pro discapacitado, pro anciano, pro migrante, etcétera. Cada uno de estos principios constituye el dato rector y la referencia suprema para el reconocimiento y la interpretación de los derechos y libertades de los individuos que integran diversos grupos o sectores sociales.

\section{IDENTIDAD PERSONAL}

Como se sugiere en el documento-cuestionario de los relatores generales mencionado en nota al preámbulo de este artículo, el concepto de diversidad acoge la existencia de múltiples identidades: nacionales, étnicas, culturales, lingüísticas, religiosas, sexuales y otras, con los derechos correspondientes al efectivo ejercicio de aquéllas. La orientación general y creciente del orden jurídico interamericano, expresada en lineamientos diversos, recomendaciones, sentencias y opiniones consultivas favorece enfáticamente el reconocimiento de esas diversas identidades, que a su vez quedan bajo la protección de los deberes generales de respeto y garantía. Compete al individuo, en ejercicio de su libertad, resolver sobre la identidad que desee asumir (pertenencia a grupos o comunidades LGBTI o indígenas, por ejemplo; también, elección de nombre propio). ${ }^{77}$

La asunción de cierta identidad, que puede ser estrictamente individual o significar la integración del individuo en determinado grupo o sector, compete al interesado. La jurisprudencia interamericana asocia la elección de identidad con el derecho a la libertad y al respeto a la vida privada. ${ }^{78}$ Esto aporta caracterizaciones cada vez más amplias de la liber-

77 Cfr. CIDH, OEA/Ser.L/V/II (párrafo 31); OAS/Ser.L/V/II (2019, párrafos 21-22), Comunidad Indígena Xákmok Kásek vs. Paraguay (2010, párrafo 37), Flor Freire vs. Ecuador (2016, párrafos 120-121), y OC-24/17 (2017, párrafos 95, 105, 106, 115 y 116).

78 Cfr. OC-24/17 (2017, párrafos 87-90), y Federico Andreu-Guzmán (2019, pp. 119 $120)$.

Esta obra está bajo una Licencia Creative Commons

Atribución-NoComercial-SinDerivar 4.0 Internacional, IIJ-UNAM.

Boletín Mexicano de Derecho Comparado, núm. 160, enero-abril de 2021, pp. 191-235. 
$\operatorname{tad}^{79}$ y medidas cada vez más protectoras de su efectivo ejercicio, con las importantes consecuencias en distintos órdenes: familiar, laboral, patrimonial, por ejemplo, hacia los que se proyectan la pluralidad social y las opciones individuales.

\section{ESTADO GARANTE}

Los portadores de las identidades particulares son titulares de todos los derechos, generales y especiales, vinculados a su condición humana y a su elección identitaria. Frente a esa titularidad de derechos, se afirman los deberes generales y especiales de los Estados (garantes genéricos de los derechos y libertades de todos los individuos colocados bajo su jurisdicción, y garantes específicos en situaciones de vulnerabilidad personal).

Esta garantía específica, que la jurisprudencia interamericana proyecta sobre amplios sectores de la población - así, los niños, los enfermos mentales, los reclusos_ —, ${ }^{80}$ puede aplicarse directamente a los integrantes de grupos o sectores con características, opciones o decisiones diferentes de los que prevalecen en la mayoría de la sociedad, y por ello constituye un factor relevante para la tutela de los derechos asociados a la pluralidad y la diversidad. Es aquí donde ocurre el benéfico encuentro entre grupos y sectores minoritarios o vulnerables a los que se reconocen derechos genéricos y específicos, y el poder público obligado a garantizar el ejercicio de aquéllos.

Las reglas especiales de tratamiento a cargo del Estado se vinculan con múltiples extremos conducentes al despliegue de la identidad para la práctica de derechos, ${ }^{81}$ entre ellos los relativos a las relaciones familia-

79 La Corte "ha interpretado en forma amplia el artículo 7 de la Convención Americana al señalar que éste incluye un concepto de libertad en un sentido extenso como la capacidad de hacer y no hacer todo lo que esté lícitamente permitido. En otras palabras, constituye el derecho de toda persona de organizar, con arreglo a la ley, su vida individual y social conforme a sus propias opciones y convicciones". Gelman vs. Uruguay (2011, párrafo 129), y Artavia Murillo y otros (Fecundación in Vitro) vs. Costa Rica (párrafo 142).

80 Cfr. "Instituto de Reeducación del Menor" vs. Paraguay (2004, párrafo 160); Ximenes Lopes vs. Brasil (2006, párrafo 138), y Chinchilla Sandoval y otros vs. Guatemala (2016, párrafo 168).

81 Cfr. Niñas Yean y Bosico vs. República Dominicana (2005, párrafos 142, 166, 167, 179 y 185), y OC-24/17 (2017, párrafo 90). 
res, el respeto a las prácticas ancestrales, el acceso a la justicia y la asunción de funciones públicas (participación en el poder formal e informal), despliegue que a su vez desecha formas de exclusión o discriminación. ${ }^{82}$

La condición de garante que incumbe al Estado se proyecta tanto en las obligaciones de hacer o de omitir por parte de los órganos y agentes del poder público, como en la tutela de los individuos frente a las vulneraciones que pudieran derivar de la conducta activa u omisiva de otros particulares ${ }^{83}$ Estas afirmaciones tienen sustento en instrumentos regionales y en resoluciones de los órganos supranacionales de protección. ${ }^{84}$ Desde luego, la elección de cierta identidad ha de fundarse en consideraciones de hecho que le brinden sustento razonable. (Flor Freire vs. Ecuador, 2016, párrafos 103 y 121)

\section{DERECHO COMÚN REGIONAL Y ESTATUTOS ESPECIALES}

La normativa interamericana se ha propuesto asegurar el imperio generalizado de los derechos humanos, bajo reglas de interpretación compartidas, consecuentes con la pretensión de generar un jus commune regional. ${ }^{85}$ A este propósito y en atención a las condiciones propias del mundo americano, todavía asediado por reticencias u oposiciones, obedece la distancia que se

82 Cfr. Aloeboetoe y otros vs. Surinam (1993, párrafos 17 y 62); Yatama vs. Nicaragua (2005, párrafo 215), Masacres de Río Negro...cit., párrafos 153-165; Rosendo Cantú y otra vs. México (2010, párrafo 184-185); Atala Riffo y Niñas vs. Chile (2012, párrafo 172-177); Forneron e hïa vs. Argentina (2012, párrafo 98), y OC-24/17 (2017, párrafos 182-199).

83 Cfr. OC-18/03 (2003, párrafos 100 y 104); Valle Faramillo y otros vs. Colombia (2008, párrafo 77), y López Soto y otros vs. Venezuela (2018, párrafos 138-140).

84 "Convención de Belem do Para" (art. 7); Convención Interamericana contra Toda Forma de Discriminación e Intolerancia (art. 4); Convención Interamericana contra el Racismo, la Discriminación Racial y Formas Conexas de Intolerancia (art. 4); CIDH, Maria da Penha Maia Fernandes, Brasil (2001, párrafos 55-58); Velásquez Rodríguez...cit., párrafo 172, y OC-18/03 (2003, párrafo 141).

$85 \mathrm{El}$ jus commune "se refiere a un enfoque regional sobre el constitucionalismo transformador. Dicho enfoque se nutre de la inquietante experiencia respecto de condiciones de vida inaceptables y apunta a la transformación de la realidad política y social de América Latina por medio del fortalecimiento concertado de la democracia, el Estado de derecho y los derechos humanos" (Armin von Bogdandy, 2015, p. 3); del mismo autor, cfr. (2014).

Esta obra está bajo una Licencia Creative Commons

Atribución-NoComercial-SinDerivar 4.0 Internacional, IIJ-UNAM.

Boletin Mexicano de Derecho Comparado, núm. 160, enero-abril de 2021, pp. 191-235. 
mantiene frente a la idea de un margen nacional de apreciación, que en otra región constituye un principio ampliamente recibido. ${ }^{86}$

Como hemos visto, el reconocimiento del derecho a la diversidad y al ejercicio de la propia identidad en el marco de la libertad, todo ello dentro de la sociedad plural y democrática, implica capacidad normativa por parte de grupos o sectores de la sociedad. El Sistema Interamericano ha reconocido el derecho de éstos a participar en la emisión de las normas que regulan su existencia y la actividad de sus integrantes, que anteriormente se mencionó. ${ }^{87}$ Esta competencia normativa no excluye la vigencia de los derechos humanos, ${ }^{88}$ que son el límite de los órdenes jurídicos específicos, ni implica la erosión o supresión de las sociedades nacionales.

Un tema relevante para estas consideraciones es el acceso de los individuos integrantes de grupos o sectores especiales a las instancias del poder público (cfr. Yatama vs. Nicaragua, 2005, párrafos 215-217 y Laurence Burgorgue-Larsen y Amaya Úbeda de Torres, 2009, pp. 658 y ss.). Los derechos políticos se hallan a salvo de suspensiones, incluso en casos de emergencia o grave perturbación del orden: forman parte del "núcleo duro" de los derechos fundamentales. ${ }^{89}$

Al amparo del Sistema Interamericano - derecho convencional y aplicaciones jurisdiccionales - los indígenas pueden participar por vías propias en la adopción de decisiones políticas, inclusive fuera de los cauces partidarios tradicionales (Yatama vs. Nicaragua, 2005, párrafos 201224). La jurisprudencia ha dejado en el ámbito de los Estados nacionales la decisión sobre procedimientos electorales, pero ha declarado que éstos deben ser congruentes con los requerimientos de representación y actua-

86 Cfr. Javier García Roca (2010); Mireille (2006, p. 78); Néstor P. Sagües (2016, pp. 48 y ss.), y Laurence Burgorgue-Larsen (2013, p. 27).

87 Cfr. CIDH, OEA/Ser.L/V/II (2007, párrafo 293); OEA/Ser.L/V/II. Doc. 65 (2011, párrafo 200), y OEA/Ser.L/V/II. Doc.44/17 (2017, párrafos 172-174).

88 "Los pueblos indígenas tienen derecho a promover, desarrollar y mantener sus estructuras institucionales y sus propias costumbres, espiritualidad, tradiciones, procedimientos, prácticas y, cuando existan, costumbres o sistemas jurídicos, de conformidad con las normas internacionales de derechos humanos". Declaración Americana sobre los Derechos de los Pueblos Indígenas (art. XXll, inciso 1). Asimismo, CIDH, OEA/Ser.L/V/II. Doc.44/17 (párrafos 176 y 181).

89 Cfr. Sergio García Ramírez (2016b, p. 355); Opinión Consultiva OC-6/86, (1986, párrafo 34); Yatama vs. Nicaragua. (2005, párrafo 191), y Castañeda Gutman vs. México (2008, párrafo 140). 
ción propios de la sociedad democrática; en otros términos, la adopción de métodos o fórmulas de participación compete al derecho doméstico, pero éste debe atender la orientación de la normativa supranacional sustentada en los valores y principios de la democracia, de manera que se logre el más amplio ejercicio de los derechos del individuo. (Cfr. Castañeda Gutman vs. México, 2008, párrafo 140)

\section{Derechos EGONÓMicos, SOCIALES, GULTURALES Y AMBIENTALES}

Amerita referencia especial la jurisprudencia más reciente de la Corte IDH, que judicializa derechos económicos, sociales, culturales y ambientales, a cuyo desarrollo progresivo se refiere el artículo 26 de la CADH. ${ }^{90}$ Anteriormente, la tutela de algunos derechos de esta categoría se llevaba a cabo a través de la protección de derechos civiles y políticos (por ejemplo: derecho a la protección de la salud, considerado a la luz de la protección del derecho a la integridad). ${ }^{91}$ La interpretación mayoritaria que hoy prevalece sostiene la justiciabilidad directa de aquellos derechos con sustento en la Carta de la OEA y en el orden jurídico nacional e internacional. ${ }^{92}$

90 "Los Estados Partes se comprometen a adoptar providencias, tanto a nivel interno como mediante la cooperación internacional, especialmente económica y técnica, para lograr progresivamente la plena efectividad de los derechos que se derivan de las normas económicas, sociales y sobre educación, ciencia y cultura, contenidas en la Carta de la Organización de los Estados Americanos, reformada por el Protocolo de Buenos Aires, en la medida de los recursos disponibles, por vía legislativa u otros medios apropiado" (CADH, art. 26). Desarrollo progresivo, sobre este tema, $c f$ r. Víctor Abramovich y Christian Courtis (2014); Sergio García Ramírez (2003, pp. 127-157); Víctor Bazán y Luis Jimena Quesada (2014, pp. 179-182), y Laurence Burgorgue-Larsen y Amaya Úbeda de Torres (2011, pp. 627 y ss.).

91 Cfr. Comunidad Indígena Yakye Axa vs. Paraguay (2005, párrafos 162 y ss.), Ximenes Lopes vs. Brasil (2006, párrafos 124 y ss.), Vera Vera y otra vs. Ecuador (2011, párrafos 43-44); Comunidad Indígena Xákmok Kásek vs. Paraguay (2010, párrafos 194-217); Suárez Peralta vs. Ecuador (2013, párrafo 131), y Gonzales Lluy y otros vs. Ecuador (2015, párrafos 167 y ss.).

92 Cfr. Lagos del Campo vs. Perú (2017); Trabajadores Cesados de Petroperú y otros vs. Perú (2017); San Miguel Sosa y otra vs. Venezuela (2018); Poblete Vilches y otros vs. Chile (2018); Cuscul Pivaral y otros vs. Guatemala (2018), y Muelle Flores vs. Perú (2019). Este criterio no ha sido unánime entre los integrantes de la Corte IDH, $c f r$. votos parcialmente disidentes del juez Humberto Sierra Porto en los casos Muelle Flores vs. Perú, Guscul Pivaral y otros vs. Guatemala, Poblete Vilches y otros vs. Chile, San Miguel Sosa y otras vs. Venezuela, Trabajadores Cesados

Esta obra está bajo una Licencia Creative Commons

Atribución-NoComercial-SinDerivar 4.0 Internacional, IIJ-UNAM.

Boletín Mexicano de Derecho Comparado, núm. 160, enero-abril de 2021, pp. 191-235. 
RECONOCIMIENTO Y TUTELA DE DERECHOS...

Evidentemente, esta interpretación se puede proyectar inmediatamente sobre los diversos grupos y sectores de la sociedad. (Cfrr. Eduardo Ferrer MacGregor 2017, pp. 206 y ss.)

\section{CONCLUSIÓN: DEBERES DEL ESTADO}

En los términos de los párrafos anteriores - especialmente lo dicho sub XIII, supra - , se confirma la hipótesis adelantada al inicio de este trabajo y queda claro que los Estados que figuran en el Sistema Interamericano - y especialmente los que son parte de la normativa convencional y han reconocido la competencia contenciosa de la jurisdicción regional - están obligados a brindar respeto y garantía a los derechos de quienes se hallan sujetos a su jurisdicción y forman parte de grupos o sectores específicos de la sociedad: en este punto concurren y se resuelven los imperativos de la igualdad y la especificidad.

Asimismo, los Estados deben adoptar las medidas necesarias para el ejercicio de aquellos derechos, medidas que tienen gran alcance: jurídico y de otra naturaleza, ${ }^{93}$ y que se proyectan inmediatamente sobre el desempeño de los órganos estatales y mediatamente sobre la conducta de los particulares. En este sentido, los Estados deben emitir disposiciones jurídicas específicas y procurar la remoción de obstáculos sociales (modificaciones culturales) ${ }^{94}$ para asegurar la protección de los derechos inherentes a la diversidad y pluralidad social.

de Petroperú y otros vs. Perú, Lagos del Campo vs. Perú y Gonzales Lluy y otros vs. Ecuador (2015). Además, cfr. votos del juez Eduardo Vio Grossi en los casos Muelle Flores vs. Perú, San Miguel Sosa y otras vs. Venezuela, Trabajadores Cesados de Petroperú y otros vs. Perú y Lagos del Campo vs. Perú.

93 "Si el ejercicio de los derechos y libertades mencionados en el artículo 1 no estuviere ya garantizado por disposiciones legislativas o de otro carácter, los Estados partes se comprometen a adoptar, con arreglo a sus procedimientos constitucionales y a las disposiciones de esta Convención, las medidas legislativas o de otro carácter que fueren necesarias para hacer efectivos tales derechos y libertades". (CADH, art. 2).

94 Cfr. González y otras ("Campo Algodonero") vs. México (2009, párrafos 450 y 541-543); Veliz Franco y otros vs. Guatemala (2014, párrafo 275); Velásquez Paiz y otros vs. Guatemala (2015, párrafo 248); Fernández Ortega y otros vs. Panamá (2009, párrafos 260 y 262=; Rosendo Cantú y otra vs. México (2010, párrafos 245-246 y 249), y Mujeres víctimas de tortura sexual en Atenco (2018, párrafo 218-219). 
A su vez, los individuos pueden exigir la observancia de sus derechos tanto a través de recursos ante los órganos nacionales obligados a atender los mandamientos internacionales y a ejercer, conforme a su competencia, el control de convencionalidad, como por la vía de la tutela internacional contemplada por los tratados del Sistema, en los términos previstos en éstos.

La homogeneidad propia de las sociedades nacionales no impide la natural heterogeneidad en el seno de esas sociedades, consecuente con la libertad y la democracia. Y esa heterogeneidad sustenta - justifica y reclama - normas y medidas especiales que amparen los derechos de individuos, grupos y sectores, sin minar al conjunto de la sociedad y complementando los imperativos de la igualdad con los de la especificidad, que aportan novedades importantes y garantizan, en definitiva, el desarrollo de la personalidad.

El hecho de que los derechos específicos de individuos, grupos o sectores integrados en la sociedad heterogénea, diversa y plural se hallen enmarcados por el derecho internacional de los derechos humanos, y de que éste informe el derecho común interamericano, implica la necesidad de compatibilizar, conciliar o armonizar los órdenes especiales con el orden general de aquellos derechos. ${ }^{95}$ Este proceso de armonización no implica supresión o abolición de los regímenes particulares, sino convergencia entre éstos y el régimen general bajo valores y principios compartidos y con respeto a las facultades que entrañan la libertad y la autonomía a las que nos hemos referido en líneas precedentes. ${ }^{96}$

La normativa interamericana y los criterios sustentados por los órganos regionales de protección de los derechos humanos han tenido muy importante repercusión sobre el orden jurídico de varios Estados del ámbito

95 Cfr. CIDH, OEA/Ser.L/V/II. Doc.44/17 (párrafos 174, 180-181), y Situación de los derechos humanos de los pueblos indígenas...cit., párrafos 43-45.

96 En alguna ocasión la Corte ha atendido la voluntad de la víctima en relación con medidas que generalmente adopta para la protección y el desarrollo de aquélla, cuando pudieran resultar inconvenientes en función del ambiente cultural y las costumbres que prevalecen en el medio en el que la víctima se desenvuelve. C fr. , por ejemplo, Rosendo Cantú y otra vs. México (2010, párrafos 213 y 229), y Fernández Ortega y otros vs. Panamá, (2009), párrafos 244, 247, 259, 262 у 267.

Esta obra está bajo una Licencia Creative Commons

Atribución-NoComercial-SinDerivar 4.0 Internacional, IIJ-UNAM.

Boletín Mexicano de Derecho Comparado, núm. 160, enero-abril de 2021, pp. 191-235. 
latinoamericano. ${ }^{97}$ La influencia del derecho interamericano y de otras fuentes del sistema universal o regional de los derechos humanos se refleja en textos constitucionales y legales, en la proclamación de diversas políticas públicas y en la cada vez más abundante jurisprudencia de tribunales supremos y otros órganos jurisdiccionales de esta región. ${ }^{98}$ La recepción interna del ordenamiento internacional constituye un hecho relevante en el progreso jurídico de varios países y en el avance de la tutela de los derechos humanos, que ya es interesante, aunque debiera ser mayor.

Este proceso de recepción de criterios externos, provenientes tanto del orden interamericano como de las aportaciones de otros sistemas de tutela - especialmente el sistema mundial, por medio de diversas instancias - se manifiesta en los temas examinados en este trabajo. Ocurre en la normativa interna sobre principios y reglas de la sociedad democrática, regulación en torno a sectores vulnerables, pueblos indígenas, trato a diversas minorías, respeto a la identidad, acceso a la justicia y rechazo y reforma de estereotipos y antiguos obstáculos para el libre desarrollo de individuos, grupos y sectores de la sociedad. Como se ha visto a lo largo del presente panorama, en estos ámbitos la normativa doméstica receptora de orientaciones provenientes de la interamericana, contribuye a la recepción, el respeto y la garantía de derechos de signo específico que conciernen a quienes forman parte de grupos diversos al amparo de la diversidad y la pluralidad imperantes en una sociedad democrática.

\section{BIBLIOGRAFÍA}

"Instituto de Reeducación del Menor" vs. Paraguay (2004). Corte IDH. Sentencia del 2 de septiembre. Ximenes Lopes vs. Brasil (2006). Corte IDH. Sentencia del 4 de julio.

97 Cfr. CIDH, OEA/Ser.L/V/II.152 (2014, párrafos 38-56); José Miguel Vivanco (2005, pp. 27-36); Loretta Ortiz Ahlf (2005, pp. 293-302), y varios autores (2006).

98 Cfr. Darío Villaroel Villaroel (2004, pp. 313 y ss. y 393 y ss.); Fernando Silva García y Juan N. Silva Meza (2009, pp. 332 y ss.); varios autores (2016, pp. 13-16); Héctor FixZamudio y Salvador Valencia Carmona (2017, pp. 552 y ss.); Víctor Rodríguez Recia (2018); varios autores (2018, pp. 3-4); Andrés Rousset Siri (2018, pp. 74 y ss.), y varios autores (2018, pp. 571 y ss.). 
"La última tentación de Cristo" (Olmedo Bustos y otros) vs. Chile (2001). Corte IDH. Sentencia del 5 de febrero.

"La Última Tentación de Cristo" (Olmedo Bustos y otros) vs. Chile (2001). Corte IDH. Sentencia del 5 de febrero.

Abramovich, Víctor y COURTIS, Christian (2014). Los derechos sociales como derechos exigibles. 2a. ed. Trotta.

Abramovich, Víctor y COURTIS, Christian (comps.) (2006). La aplicación de los tratados sobre derechos humanos en el ámbito local. La experiencia de una década. Del Puerto-Centro de Estudios Legales y Sociales.

Aguiar Aranguren, Asdrúbal (2012). Furisprudencia de la Corte Interamericana de Derechos Humanos sobre la democracia. Observatorio Iberoamericano de la Democracia.

AlCALÁ-ZAMORA, Niceto (1974). La protección procesal internacional de los derechos humanos. En Varios autores, Veinte años de evolución de los Derechos Humanos (p. 330), México: UNAM, Instituto de Investigaciones Jurídicas.

Almonacid Arellano y otros vs. Chile (2006). Corte IDH. Sentencia del 26 de septiembre.

Aloeboetoe y otros vs. Surinam (1993). Corte IDH. Sentencia del 10 de septiembre.

Amparo directo 6/2018. Primera Sala. Suprema Corte de Justicia de la Nación. 21 de noviembre de 2019.

AndREu-Guzmán, Federico (2019). "Artículo 3. Derecho al reconocimiento de la personalidad jurídica". En Christian STEINER y MarieChristine Fuchs (eds.). Convención Americana sobre Derechos Humanos (pp. 119-120). Konrad Adenauer Stiftung.

Apitz Barbera y otros ("Corte Primera de lo Contencioso Administrativo") vs. Venezuela (2012). Corte IDH. Supervisión de cumplimiento de sentencia. Del 23 de noviembre.

Apitz Barbera y otros ("Corte Primera de lo Contencioso Administrativo") vs. Venezuela (2008). Corte IDH. Sentencia del 5 de agosto.

Artavia Murillo y otros ("Fecundación in vitro") vs. Costa Rica (2012). Corte IDH.

Sentencia del 28 de noviembre.

Asociación Nacional de Cesantes y Jubilados de la Superintendencia Nacional de Ad-

ministración Tributaria (ANCEJUB-SUNAT) vs. Perú (2019). Corte IDH.

Sentencia del 21 de noviembre.

Atala Riffo y Niñas vs. Chile (2012). Corte IDH. Sentencia del 24 de febrero.

Esta obra está bajo una Licencia Creative Commons

Atribución-NoComercial-SinDerivar 4.0 Internacional, IIJ-UNAM.

Boletín Mexicano de Derecho Comparado, núm. 160, enero-abril de 2021, pp. 191-235. 
BAZÁn, Víctor y Fuchs, Marie-Christine (eds.) (2018). Fusticia constitucional y derechos fundamentales. Fusticia y política en América Latina. Konrad Adenauer.

BAZÁn, Víctor y Jimena QUESADA, Luis (2014). Derechos económicos, sociales y culturales: cómo se protegen en América Latina y en Europa.

BERIZOnce, Roberto Omar (2009). Tutelas procesales diferenciadas. RubizalCulzoni.

BOGDANDY, Armin von (2014). Ius constitutionale commune latinoamericanum. Una aclaración conceptual. Ius constitutionale commune en América Latina. Rasgos, potencialidades y desafios. Universidad Nacional Autónoma de México, Instiuto de Investigaciones Jurídicas-Max-Planck.

BogdAndy, Armin von (2015). Ius Constitutionale Commune en América Latina: una mirada a un constitucionalismo transformador. Revista Derecho del Estado (34), p. 3.

Burgorgue-LARSEN, "Les standars, normes imposées ou consenties? En Variosautores. Existe-t-il une exception française en matière de droits fondamentaux? (p. 27). Les Cahiers de l'Institut Louis Favoreu-Aix-MarseillePUAM.

Burgorgue-Larsen, Laurence y Úbeda de Torres, Amaya (2008). Les grandes decisions de la Cour Interamericaine des Drois de L'Homme. Bruylant, pp. 649-650.

Burgorgue-Larsen, Laurence y Úbeda de Torres, Amaya (2011). The Inter-american Court of Human Rights. Case law and commentary. Oxford University Press.

Cabrera García y Montiel Flores vs. México (2010). Corte IDH. Sentencia del 26 de noviembre.

Carta Democrática Interamericana, 11 de septiembre de 2001.

Castañeda Gutman vs. México (2008). Corte IDH. Sentencia del 6 de agosto.

Chinchilla Sandoval vs. Guatemala (2016). Corte IDH. Sentencia del 29 de febrero.

Chitay Nech y otros vs. Guatemala (2010). Corte IDH. Sentencia del 25 de mayo.

CIDH (1981). Resolución 23/81. Caso 2141, Estados Unidos de América. Del 6 de marzo

CIDH (2001). Informe 04/01. Caso 11.625, Fondo, María Eugenia Morales de Sierra. Sentencia del 19 de enero. 
CIDH (2001). Informe 54/01. Caso 12.051, Maria da Penha Maia Fernandes. Del 16 de abril.

CIDH (2004). Informe 75/15. Caso 12.923, Fondo, Rocío San Miguel Sosay otras vs. Venezuela. Herrera Ulloa vs. Costa Rica (2004). Corte IDH. Sentencia del 2 de julio.

CIDH (2004). Informe de Fondo 40/04, Caso 12.053, Comunidades Indígenas Mayas del Distrito de Toledo vs. Belice. Del 12 de octubre.

CIDH (2005). Informe 32/05. Petición 642/2003. Admisibilidad, Luis Ronaldo Cuscul Pivaral y otras personas afectadas por el VIH/SIDA. Del 7 de marzo de 2005.

CIDH (2005). Informe 43/05. Caso 12.219, Fondo, Cristián Daniel Sahli Vera y otros. Del 10 de marzo. CIDH (2017). OEA/Ser.L/V/II. Institucionalidad democrática, Estado de derecho y derechos humanos en Venezuela. Del 31 diciembre.

CIDH (2007). OEA/Ser.L/V/II, Doc. 34. Informe sobre acceso a la justicia e inclusión social: El camino hacia el fortalecimiento de la democracia en Bolivia. Del 28 de junio.

CIDH (2009). Informe 98/09. Petición 4355-02. Admisibilidad, Pueblo Indígena Xucuru. Del 29 de octubre.

CIDH (2009). OEA/Ser.L/V/II. Derechos de los pueblos indígenas y tribales sobre sus tierras ancestrales y recursos naturales. Normas y jurisprudencia del Sistema Interamericano de Derechos Humanos. Del 30 de diciembre.

CIDH (2009). OEA/Ser.L/V/II. Doc.54. Democracia y derechos humanos en Venezuela. Del 30 de diciembre de 2009.

CIDH (2011). Informe 64/11. Caso 12.573, Fondo, Marino López y otros (Operación Génesis). Del 31 de marzo de 2011.

CIDH (2011). OEA/Ser.L/V/II. Doc. 65. Acceso a la justicia para mujeres víctimas de violencia en las Américas. Del 28 de diciembre.

CIDH (2011). OEA/Ser.L/V/II. Doc.79. El camino hacia una democracia sustantiva: la participación política de las mujeres en las Américas.

CIDH (2014). Informe 72/14. Caso 12.665, I.V. Bolivia. OEA/Ser.L/V/ II.152. Del 15 de agosto.

CIDH (2014). OEA/Ser.L/V/II.152. Universalización del sistema interamericano de derechos humanos. Del 14 de agosto.

CIDH (2015). Informe 75/15. Caso 12.923, Fondo, Rocío San Miguel Sosay otras. Del 28 de octubre de 2015.

Esta obra está bajo una Licencia Creative Commons

Atribución-NoComercial-SinDerivar 4.0 Internacional, IIJ-UNAM.

Boletín Mexicano de Derecho Comparado, núm. 160, enero-abril de 2021, pp. 191-235. 
CIDH (2015). OAS/Ser.L/V/II.rev.2, doc. 36. Violencia contra personas LGBTI. Del 12 de noviembre. CIDH (2017). Hacia la garantía efectiva de los derechos de niñas, niños y adolescentes: Sistemas Nacionales de Protección. Del 30 de noviembre.

CIDH (2015). OAS/Ser.L/V/II.rev.2. Violencia contra Personas Lesbianas, Gay, Bisexuales, Trans e Intersex en América.

CIDH (2015). OEA/Ser.L/V/II, Doc. 47/15. Pueblos indígenas, comunidades afrodescendientes y recursos naturales: protección de derechos humanos en el contexto de actividades de extracción, explotación y desarrollo. Del 31 de diciembre.

CIDH (2015). OEA/Ser.L/V/II. Pueblos indígenas, comunidades afrodescendientes y recursos naturales: protección de derechos humanos en el contexto de actividades de extracción, explotación y desarrollo. Del 31 diciembre.

CIDH (2017). OEA/Ser.L/V/II. Doc.44/17. Las mujeres indígenas y sus derechos humanos en las Américas. Del 17 de abril.

CIDH (2018). Informe 122/18. Caso 11.656, Fondo, Marta Lucía Álvarez Giraldo. Del 5 de octubre.

CIDH (2018). OAS/Ser.L/V/II.170, Doc. 184. Avances y Desafios hacia el reconocimiento de los derechos de las personas LGBTI en las Américas. Del 7 de diciembre.

CIDH (2019). OAS/Ser.L/V/II. Situación de los derechos humanos de los pueblos indigenas y tribales de la Panamazonía. Del 29 septiembre.

CIDH (2019). OEA/Ser.L/V/II.171 Doc. 31. Compendio sobre la igualdad y no discriminación: estándares interamericanos. Del 12 de febrero de 2019.

Claude Reyes y otros vs. Chile (2006). Corte IDH. Sentencia del 29 de septiembre.

Cletus Gregor, Barie (2003). Pueblos indigenas y derechos constitucionales en América Latina: un panorama. 2a. ed., Abya Yala.

Comisión Interamericana de Mujeres (2001). Violencia en la Américas. Un análisis regional.

Comunidad Garifuna de Punta Piedra y sus miembros vs. Honduras (2015). Corte IDH. Sentencia del 8 de octubre.

Comunidad Indígena Sawhoyamaxa vs. Paraguay (2006). Corte IDH. Sentencia del 29 de marzo.

Comunidad Indígena Xákmok Kásek vs. Paraguay (2010). Corte IDH. Sentencia del 24 de agosto.

Comunidad Indigena Yakye Axa vs. Paraguay (2005). Corte IDH. Sentencia del 17 de junio. 
Comunidad Mayagna (Sumo) Awas Tingni vs. Nicaragua (2001). Corte IDH. Sentencia del 31 de agosto.

Conferencia Especializada Interamericana sobre Derechos Humanos, San José, Costa Rica, 7-22 de noviembre de 1969, Actas y Documentos, pp. 125 y $159-160$

Constitución Política de los Estados Unidos Mexicanos

Convención Interamericana para la Eliminación de Todas las Formas de Discriminación contra las Personas con Discapacidad. https://wwre. oas.org/juridico/spanish/tratados/a-65.html

Corte IDH (2018). 40 años protegiendo derechos. Corte IDH-Cooperación Alemana para el Desarrollo.

Cuscul Pivaral y otros vs. Guatemala (2018). Corte IDH. Sentencia del 23 de agosto.

Declaración Americana sobre los Derechos de los Pueblos Indígenas

Declaración de las Naciones Unidas sobre los Derechos de los Pueblos Indígenas. https://wrere.un.org/development/desa/indigenous-peoples-es/declaracion-sobre-los-derechos-de-los-pueblos-indigenas.html

Declaración Interpretativa de México. http://wrewe.oas.org/es/cidh/mandato/Basicos/convratif.asp. Para una crítica sobre la decisión de la Corte IDH en el caso Artavia Murillo

Delmas-MarTy, Mireille (2006). Le pluralisme ordonné. Éditions du Seuil.

Duque vs. Colombia (2016). Corte IDH. Sentencia del 6 de febrero.

Escher y otros vs. Brasil (2009). Corte IDH. Sentencia del 6 de julio.

EXPEDIENTE SUP-JDC-9167/2011. Tribunal Electoral del Poder Judicial de la Federación. Juicio para la protección de los derechos políticoelectorales del ciudadano. Del 2 de noviembre.

FAÚNDEZ LEDESMA, Héctor (2004). El sistema interamericano de protección de derechos humanos, 3a. ed. Instituto Interamericano de Derechos Humanos.

Ferrajoli, Luigi (1995). Derecho y razón. Teoría del Garantismo Penal, trad. de Perfecto Andrés Ibáñez, Alfonso Ruiz Miguel, Juan Carlos Bayón Mohino, Juan Terradillos Basoco y Rocío Cantarero Bondré. Trotta.

Ferrer MAG-Gregor Poisot, Eduardo (2017). La justiciabilidad de los derechos económicos, sociales, culturales y ambientales en el sistema interamericano de derechos humanos. Comisión Nacional de Derechos Humanos.

Ferrer MaC-Gregor Poisot, Eduardo, "Le développement du corpus juris interaméricain à travers l'action prétorienne de la Cour interame-

Esta obra está bajo una Licencia Creative Commons

Atribución-NoComercial-SinDerivar 4.0 Internacional, IIJ-UNAM.

Boletin Mexicano de Derecho Comparado, núm. 160, enero-abril de 2021, pp. 191-235. 
ricaine des droits de l'homme", en Varios, Les défis de l'interprétation et l'application des droits de l'homme. Del l'ouverture au dialogue, Paris, Éditions A. Pedone, 2017, pp. 197 y ss.

FiX-Zamudio, Héctor y Valencia Carmona, Salvador (2017). Derecho constitucional mexicano y comparado. 9a. ed. Porrúa.

Flor Fleire vs. Ecuador (2016). Corte IDH. Sentencia del 31 de agosto.

Fontevecchia y D'Amico vs. Argentina (2017). Corte IDH. Supervisión de cumplimiento de sentencia. Del 18 de octubre.

Forneron e hïa vs. Argentina (2012). Corte IDH. Sentencia del 27 de abril.

García Ramírez, Sergio (1965). El derecho social. Revista de la Facultad de Derecho de México (59), pp. 636-639.

García Ramírez, Sergio (2003). Protección jurisdiccional internacional de los derechos económicos, sociales y culturales. Revista Cuestiones Constitucionales (9), pp. 127-157.

García RAMíREZ, Sergio (2007). Los derechos de las mujeres y la jurisdicción interamericana de derechos humanos. En Juan Soroeta Liceras (ed.). Los derechos humanos de la mujer. Cursos de Derechos Humanos de Donostia-San Sebastián. Servicio Editorial de la Universidad del País Vasco.

García Ramírez, Sergio (2012). Control judicial interno de convencionalidad. Poder Judicial del Estado de Aguascalientes.

García Ramírez, Sergio (2016a). Gobernanza, derechos humanos, migración. Revista Escriva. Revista del Colegio de Notarios del Estado de México, p. 85.

GARcía RAMíRez, Sergio (2016b). Tutela de los derechos en situaciones de excepción. Los instrumentos para la supervisión del cumplimiento de las sentencias. En Ramiro Bejarano GuZmán, Pablo Moreno Gruz y Marcela RoDRíguez Mejía (eds). Reconciliación y derecho procesal (p. 355). Bogotá: Asociación Internacional de Derecho Procesal-Instituto Colombiano de Derecho Procesal-Universidad Externado de Colombia.

GARCía RAMíREZ, Sergio (2017). Justicia transicional y jurisprudencia interamericana. En Liliana Dimaro Agudelo MejíA, Giraldo DAMARIS Pabón, Luis Orlando Toro Garzón, Mónica María Bustamante RÚA y Orión VARGAS VÉLEZ (coords.). Fusticia transicional (p. 47). Medellín: Universidad de Medellín. 
García Ramírez, Sergio (2018b). La Corte Interamericana a cuarenta años de su establecimiento. Revista del Posgrado en Derecho de la UNAM (9), pp. 23-72.

GARCía RAMíREZ, Sergio (2018c). Panorama de la jurisprudencia interamericana sobre derechos humanos. Comisikón Nacional de Derechos Humanos.

García Ramírez, Sergio (2019). La Corte Interamericana de Derechos Humanos. 3a. ed. Porrúa.

GARcía RAmírez, Sergio, GonzA, Alejandra y RAmos VÁzQuez, Eréndira Nohemí (2019). La libertad de expresión en la jurisprudencia de la Corte Interamericana de Derechos Humanos. Sociedad Interamericana de PrensaInstituto Nacional de Transparencia, Acceso a la Información y Protección de Datos Personales-Tribunal Electoral del Poder Judicial de la Federación.

GARCíA ROCA, Javier (2010). El margen de apreciación nacional en la interpretación del Convenio Europeo de Derechos Humanos: soberanía e integración. CivitasThomson Reuters.

GARCía-SAYÁn LARRABURE, Diego (2005). Una viva interacción: Corte Interamericana y tribunales internos. En Varios autores. La Corte Interamericana de Derechos Humanos: un cuarto de siglo. 1979-2004 (pp. 325-330). San José: Corte IDH.

Garibaldi vs. Brasil (2009). Corte IDH. Sentencia del 23 de septiembre.

Garrido Baigorria vs. Argentina (1998). Corte IDH. Sentencia del 27 de agosto.

Gelman vs. Uruguay (2011). Corte IDH. Sentencia del 24 de febrero.

Gelman vs. Uruguay (2013). Corte IDH. Sentencia del 20 de marzo. Supervisión de cumplimiento de sentencia.

Gelman vs. Uruguay (2013). Corte IDH. Supervisión de cumplimiento de sentencia. Voto razonado del juez Eduardo Ferrer Mac-Gregor Poisot. Del 20 de marzo.

Godinez Cruz vs. Honduras (1989). Corte IDH. Sentencia del 20 de enero.

Gonzáles Lluy y otros vs. Ecuador (2015). Corte IDH. Sentencia del 1 de septiembre.

GonzÁlez Morales, Felipe (2013). Sistema Interamericano de Derechos Humanos. Tirant lo Blanch.

González y otras ("Campo Algodonero") vs. México (2009). Corte IDH. Sentencia del 16 de noviembre.

Esta obra está bajo una Licencia Creative Commons

Atribución-NoComercial-SinDerivar 4.0 Internacional, IIJ-UNAM.

Boletín Mexicano de Derecho Comparado, núm. 160, enero-abril de 2021, pp. 191-235. 
Gozaíni, Osvaldo Alfredo (2016). Procedimiento en la Comisión y ante la Corte Interamericana de Derechos Humanos. Ediciones Nueva Jurídica.

Granier y otros (Radio Caracas Televisión) vs. Venezuela (2015). Corte IDH. Sentencia del 22 de junio.

I. V. vs. Bolivia (2016). Corte IDH. Sentencia del 30 de noviembre.

Ivcher Bronstein vs. Perú (2001). Corte IDH. Sentencia del 6 de febrero.

Lagos del Campo us. Perú (2017). Corte IDH. Sentencia del 31 de agosto.

López Lone y otros vs. Honduras (2015). Corte IDH. Sentencia del 5 de octubre.

López Soto y otros vs. Venezuela (2018). Corte IDH. Sentencia del 26 de septiembre.

MACKAY, Fergus (1999). Los derechos de los pueblos indigenas en el sistema internacional. Asociación Pro Derechos Humanos-Federación Internacional de Derechos Humanos.

MARTIN, Claudia (2017). La mobilisation des sources extérieures par la Cour Interaméricaine des droits de l'homme. L'exemple du droit à la vie. En Varios autores. Les défis de l'interprétation et l'application des droits de l'homme. Del l'ouverture au dialogue (pp. 243 y ss.). Paris: Éditions A. Pedone.

Masacre Plan de Sánchez vs. Guatemala (2004). Corte IDH. Reparaciones. Del 19 de noviembre. Comunidad Moiwana vs. Surinam (2005). Corte IDH. Sentencia del 15 de junio.

Masacres de Río Negro vs. Guatemala (2012). Corte IDH. Sentencia del 4 de septiembre.

Mejía Guerrero, Luz Patricia (2012). La Comisión Interamericana de Mujeres y la Convención de Belém do Pará. Impacto en el Sistema Interamericano de Derechos Humanos. Revista IIDH (56), pp. 196-197. Mémoli vs. Argentina (2013). Corte IDH. Sentencia del 22 de agosto. Muelle Flores vs. Perú (2019). Corte IDH. Sentencia del 6 de marzo. Mujeres Victimas de Tortura Sexual en Atenco (2018). Corte IDH. Sentencia del 28 de noviembre. Fernández Ortega vs. México (2010). Corte IDH. Sentencia del 30 de agosto.

Niñas Yean y Bosico vs. República Dominicana (2005). Corte IDH. Sentencia del 8 de septiembre.

OC-4/84 (1984). Corte IDH. Propuesta de modificación a la Constitución Política de Costa Rica relacionada con la naturalización. Del 19 de enero. 
OC-5/85 (1985). Corte IDH. Del 13 de noviembre.

Opinión Consultiva OC-18/03. Corte IDH. Condición jurídica y derechos de los migrantes indocumentados. Del 17 de septiembre de 2003. Opinión Consultiva OC-24/17. Corte IDH. Identidad de género, e igualdad y no discriminación a parejas del mismo sexo. Del 24 de noviembre de 2017.

Opinión Consultiva OG-6/86 (1986). Corte IDH. Del 9 de mayo.

Opinión Consultiva OC-8/87. Corte IDH. Del 30 de enero de 1987.

Ortiz Ahlf, Loretta (2005). Armonización legislativa interna de las normas internacionales en materia de derechos humanos. En Varios autores. La armonización de los tratados internacionales de derechos humanos en México (pp. 293-302). México: Secretaria de Relaciones Exteriores-Programa de Cooperación sobre Derechos Humanos México-Comisión Europea.

Palma Mendoza y otros vs. Ecuador (2012). Corte IDH. Sentencia del 3 de septiembre.

Penal Miguel Castro Castro vs. Perú (2006). Corte IDH. Sentencia del 25 de noviembre.

Perozo y otros vs. Venezuela (2009). Corte IDH. Sentencia del 28 de enero.

Poblete Vilches y otros vs. Chile (2018). Corte IDH. Sentencia del 8 de marzo.

Protocolo adicional a la Convención Americana sobre Derechos $\mathrm{Hu}-$ manos en materia de Derechos Económicos, Sociales y Culturales (Protocolo de San Salvador), del 17 de noviembre de 1988.

Pueblo Indígena Kichwa de Sarayaku vs. Ecuador (2012). Corte IDH. Sentencia del 27 de junio. Pueblos Indígenas Kuna de Madungandí y Emberá de Bayano y sus Miembros vs. Panamá (2014). Corte IDH. Sentencia del 14 de octubre.

Pueblo Indígena Xucuru y sus miembros vs. Brasil (2018). Corte IDH. Sentencia del 5 de febrero.

Pueblo Saramaka vs. Surinam (2007). Corte IDH. Sentencia del 28 de noviembre.

Pueblo Saramaka vs. Surinam (2007). Corte IDH. Sentencia del 28 de noviembre.

Pueblos Kaliña y Lokono vs. Surinam (2015). Corte IDH. Sentencia del 25 de noviembre.

Pueblos Kaliña y Lokono vs. Surinam (2015). Corte IDH. Sentencia del 25 de noviembre.

Quintana Osuna, Karla I. (2017). Algunas reflexiones sobre la evolución en el reconocimiento de los derechos de los pueblos indígenas y tri-

Esta obra está bajo una Licencia Creative Commons

Atribución-NoComercial-SinDerivar 4.0 Internacional, IIJ-UNAM.

Boletin Mexicano de Derecho Comparado, núm. 160, enero-abril de 2021, pp. 191-235. 
bales en el Sistema Interamericano. En Karla I. Quintana OsunA y Rogelio FLORES (coords.). Los derechos de los pueblos indigenas. Una visión desde el sistema interamericano de protección de los derechos humanos (pp. 16-24). México: Instituto de Estudios Constitucionales del Estado de Querétaro, Colección Constitución y Derechos.

Ramirez Escobar y otros vs. Guatemala (2018). Corte IDH. Sentencia del 9 de marzo.

Reglas de Brasilia sobre Acceso a la Justicia de las Personas en Condición de Vulnerabilidad (2008). XIV Cumbre Judicial Iberoamericana. https://wrere.acnur.org/fileadmin/Documentos/BDL/2009/7037.pdf

Ricardo Canese vs. Paraguay (2004). Corte IDH. Sentencia del 31 de agosto. Rodríguez Recia, Víctor (2018). Constitución Politica de los Estados Unidos Mexicanos. Instituto Interamericano de Responsabilidad Social y Derechos Humanos.

Rosendo Cantú y otra vs. México (2010). Corte IDH. Sentencia del 31 de agosto.

ROUSSET SIRI, Andrés (2018). Ejecución de sentencias de la Corte Interamericana de Derechos Humanos. Ediar.

Ruiz ChIRIBOGA, Oswaldo y Donoso, Gina (2019). Jurisprudencia de la Corte IDH sobre los Pueblos Indígenas y Tribales Fondo y Reparaciones. En Christian STEInER y Marie-Christine FuCHS (eds.). Convención Americana sobre Derechos Humanos. Comentario (pp. 1131 y ss.). 2a. ed. Bogotá: Konrad Adenauer Stiftung.

SAGÜES, Néstor P. (2016). La interpretación de los derechos humanos en las jurisdicciones nacional e internacional. En José F. PALOMINO Manchego y José Carlos Remotti Carbonell (coords.). Derechos humanos y Constitución en Iberoamérica (pp. 48 y ss.). Lima: Instituto Iberoamericano de Derecho Constitucional-Ilustre Colegio de Abogados de Lima-Iustitia-Universidad Inca Garcilaso de la Vega.

San Miguel Sosa y otras vs. Venezuela (2018). Corte IDH. Sentencia del 8 de febrero de 2018.

Santiago, Alfonso y Bellocahio, Lucía (dirs.) (2018). Historia de la Corte Interamericana de Derechos Humanos. La Ley.

SANTOscoy, Bertha (1995). La Commission Interaméricaine des Droits del Homme. Publications de l'Institut Universitaire de Hautes Etudes Internationales. 
SGJN, Pleno, Contradicción de Tesis 293/2011, 3 de septiembre de 2013, p. 41.

Sierra Porto, Humberto A. (2016). Los retos jurídicos del proceso de paz colombiano. En Ramiro Bejarano Gúzman, Pablo Moreno Cruz y Marcela Rodríguez Mejía (eds.). Reconciliación y derecho procesal (82 y ss.). Bogotá: Asociación Internacional de Derecho Procesal-Instituto0 Colombiano de Derecho Procesal-Universidad Externado de Colombia.

Silva García, Fernando y Silva Meza, Juan N. (2009). Derechos fundamentales. Porrúa.

StaVEnHagen, Rodolfo (2007). Los pueblos indígenasy sus derechos. UNESCO. Suárez Peralta vs. Ecuador (2013). Corte IDH. Sentencia del 21 de mayo.

Tarazona Arrieta y otros vs. Perú (2014). Corte IDH. Sentencia del 15 de octubre.

Tiu Tojín vs. Guatemala (2008). Corte IDH. Sentencia del 26 de noviembre. Trabajadores Cesados de Petroperú y otros vs. Perú (2017). Corte IDH. Sentencia del 23 de noviembre.

Trabajadores Cesados del Congreso (Aguado Alfaro y otros) vs. Perú (2006). Corte IDH. Sentencia del 24 de noviembre.

Tristán Donoso vs. Panamá (2009). Corte IDH. Sentencia del 27 de enero.

ÚBEDA de Torres, Amaya (2007). Democracia y derechos humanos en Europa y en América. Estudio comparado de los sistemas europeo e interamericano de protección de los derechos humanos. Reus.

Úbeda DE TORRes, Amaya (2007). Democracia y derechos humanos en Europa y América. Reus.

Unión Panamericana (1960). Quinta Reunión de Consulta de Ministros de Relaciones Exteriores. Acta Final. Resolución VIII Derechos Humanos.

Unión Panamericana. Conferencias Internacionales Americanas Segundo suplemento 1945-1954. Unión Panamericana (1956). Conferencia Interamericana sobre Problemas de la Guerra y la Paz. Acta Final, "Reorganización, Consolidación y Fortalecimiento del Sistema Interamericano".

UPRIMMY YePES, Rodrigo y SÁNCHEZ DuQUe, Luz María (2019). Artículo 24. Igualdad ante la ley. en Varios autores. Convención Americana sobre Derechos Humanos. Comentario, Christian SteIner y Marie-Christine FuchS (eds.), 2a. ed. Konrad Adenauer Stiftung, 2019, pp. 708 y ss.

Valle Faramillo y otros vs. Colombia (2008). Corte IDH. Sentencia del 27 de noviembre.

Esta obra está bajo una Licencia Creative Commons

Atribución-NoComercial-SinDerivar 4.0 Internacional, IIJ-UNAM.

Boletin Mexicano de Derecho Comparado, núm. 160, enero-abril de 2021, pp. 191-235. 
Varios autores (2005). La Corte Interamericana de Derechos Humanos. Un cuarto de siglo: 1979-2004. Corte IDH.

Varios autores (2016). Temas y tendencias del constitucionalismo moderno. Universidad Nacional Autónoma de México, Instituto de Investigaciones Jurídicas.

VÁzQUEz Gómez-Bisogno, Francisco (2018). El control de convencionalidad. Hacia una teoría de la argumentación convencional. Tirant lo Blanch.

Velásquez Paiz y otros vs. Guatemala (2015). Corte IDH. Sentencia del 19 de noviembre.

Velásquez Rodríguez vs. Honduras (1988). Corte IDH. Sentencia del 29 de julio. Vera Vera y otra us. Ecuador (2011). Corte IDH. Sentencia del 19 de mayo.

ViCENTE, Esther (2010). La Comisión y Corte Interamericanas ante los derechos de las mujeres. En Juan A. CRUz PARCERO y Rodolfo VÁZQUEZ (coords.). Derechos de las mujeres en el derecho internacional (pp. 149 y ss.). Fontamara-Suprema Corte de Justicia de la Nación.

Villaroel Villaroel, Darío (2004). Derecho de los tratados en las constituciones de América. Porrúa.

Vivanco, José Miguel (2005). Experiencias positivas y obstáculos para armonizar la legislación de derechos humanos en América Latina. En Varios autores. La armonización de los tratados internacionales de derechos humanos en México (pp. 27-36). México: Secretaria de Relaciones Exteriores-Programa de Cooperación sobre Derechos Humanos MéxicoComisión Europea.

XVII Cumbre Judicial Iberoamericana (2014). http://wrere.cumbrejudicial. org/productos-y-resultados/productos-axiologicos/item/38-protocolo-de-acceso-ala-justicia-para-personas-y-grupos-vulnerables

Yatama vs. Nicaragua (2005). Corte IDH. Sentencia del 23 de junio de 2005. 


\title{
LA APROBACIÓN DEL INGRESO MÍNIMO VITAL EN ESPAÑA: UN MODELO PARA SU EVENTUAL IMPLEMENTACIÓN EN MÉXICO*
}

\author{
THE APPROVAL OF THE MINIMUM VITAL INCOME IN SPAIN: \\ A MODEL FOR ITS EVENTUAL IMPLEMENTATION IN MEXICO
}

\author{
Pablo LATORRE RODRÍGUEZ** \\ Moisés SOTELO SÁNCHEZ***
}

RESUMEN: La aprobación del ingreso mínimo vital en España por medio del Real Decreto-ley 20/2020, pone de manifiesto la cada vez mayor presencia de este impreciso derecho, el cual vendría a constituir la culminación de los derechos de segunda generación acentuada en su vertiente social. En los últimos años, el derecho al mínimo vital está pasando de ser una reivindicación exigida por determinados colectivos sociales, o una entelequia debatida en los círculos doctrinales, a convertirse en una realidad legal en varios países. Ya en 2017 la UE incentivó su adopción por parte de los Estados miembros como un instrumento para la lucha contra la pobreza, pero no ha sido hasta la crisis social provocada por la pandemia del COVID-19 cuando España ha procedido
ABSTRACT: The approval of the minimum vital income in Spain through Royal Decree-Law 20/2020, highlights the increasing presence of this imprecise right, which would come to constitute the culmination of second generation rights accentuated in its social aspect. In recent years, the right to a vital minimum is going from being a claim demanded by certain social groups, or an entelechy debated in doctrinal circles, to becoming a legal reality in several countries. Already in 2017, the EU encouraged its adoption by the Member States as an instrument to fight poverty, but it was not until the social crisis caused by the COVID-19 pandemic that Spain proceeded to do so. In this work, we will analyze the right in question and its nature, and then carefully study

* Recibido el 5 de julio de 2020; aprobado el 17 de enero de 2021.

** ORCID: 0000-0002-1660-8948. Doctor en Derecho por la Universidad de Zaragoza (España); profesor-investigador en la Facultad de Derecho Mexicali de la Universidad Autónoma de Baja California (México). Correo electrónico: platorre@uabc.edu.mx.

*** ORCID: 0000-0002-1380-3481. Licenciado en Derecho por la Facultad de Derecho Mexicali de la Universidad Autónoma de Baja California (México). Correo electrónico: sotelo.moises@uabc.edu.mx.

Boletín Mexicano de Derecho Comparado, nueva serie, año LIV, núm. 160, enero-abril de 2021, pp. 237-276. 
A ello. En este trabajo, analizaremos el derecho en cuestión y su naturaleza, para después estudiar con atención la forma en que aquel país lo ha regulado, y finalizar analizando la presencia de éste en nuestro sistema jurídico y su potencial aplicación en México

Palabras clave: ingreso mínimo vital, derecho al mínimo vital, derechos humanos, derechos económicos, sociales, y culturales, España. the way in which that country has regulated it, and finish by analyzing its presence in our legal system and its potential application in Mexico.

Keyzerds: vital mínimum income, vital mínimum right, human rights, economical, social, and cultural rights, Spain.

SUMARIO: I. Introducción. II El ingreso mínimo vital: concepto y naturaleza.

III. El ingreso mínimo vital en España. IV. El DMV en México. V. Conclusión: una apuesta por la implementación del DMV en México. VI. Fuentes.

\section{INTRODUCCIÓN}

El derecho al mínimo vital (en adelante DMV) constituye la quintaesencia de los derechos sociales. Su regulación por parte de los países que la han abordado ha venido a aportar una mayor concreción en un derecho, ya de por sí, debatido y difuso. El reconocimiento e implementación de este derecho supone un salto cualitativo enorme en lo que a protección de los derechos humanos se refiere. Comprender sus dimensiones, tanto en el plano doctrinal como en el de la normatividad internacional, es primordial para garantizarlo eficazmente. Por ello, en este trabajo atenderemos a la idea detrás del derecho, a la filosofía que lo inspira, para aproximarnos a un mejor entendimiento de éste que nos permita plantear su adopción en nuestro país como una herramienta de combate contra las desigualdades.

Una sociedad en la que se reconoce y aplica el DMV es una sociedad más justa y respetuosa con los derechos humanos. Debemos continuar trabajando en este sentido para conseguir que la sociedad mexicana se acerque cada día más a los más altos estándares de calidad en la defensa y protección de los derechos humanos, y es allí donde Europa se erige como una referencia indiscutible. Su reciente legislación en España nos brinda la oportunidad perfecta para realizar un estudio comparado

Esta obra está bajo una Licencia Creative Commons

Atribución-NoComercial-SinDerivar 4.0 Internacional, IIJ-UNAM.

Boletín Mexicano de Derecho Comparado, núm. 160, enero-abril de 2021, pp. 237-276. 
con este país con el cual nos unen tantas similitudes, y por este motivo proponerlo como un modelo para una eventual regulación mexicana. Nuestro objetivo en este artículo es presentar esta herramienta jurídica, para después mediante un análisis de la reciente regulación española, y previo examen de la situación mexicana al respecto, plantear la siguiente hipótesis: la adopción por parte de México del ingreso mínimo vital (IMV) con una regulación semejante a la española (pero adaptada) supondría un avance incuestionable en la garantía y promoción de los derechos humanos en nuestro país. Esta es la idea central defendida en este trabajo.

\section{EL DMV: RECONOCIMIENTO Y MATERIALIZACIÓN}

\section{Concepto y naturaleza del DMV}

El DMV se conceptualiza como la culminación de los derechos de segunda generación (económicos, sociales y culturales), subrayando ante todo la vertiente social. Encuentra pues natural anclaje normativo ${ }^{1}$ en normas internacionales como la Declaración Universal de los Derechos Humanos de 1948, que ya desde su preámbulo hace mención al compromiso de "promover el progreso social y a elevar el nivel de vida", y más específicamente en su artículo 22 establece el derecho a "la satisfacción de los derechos económicos, sociales y culturales, indispensables a su dignidad y al libre desarrollo de su personalidad", viéndose esto reforzado cuando en el numeral 25.1 se declara que "toda persona tiene derecho a un nivel de vida adecuado" concretado en salud, bienestar, alimentación, vestido, vivienda, asistencia médica y servicios sociales necesarios, seguros de desempleo, enfermedad, invalidez, viudez, vejez u "otros casos de pérdida de sus medios de subsistencia por circunstancias independientes de su voluntad".

1 E. Carmona Cuenca en su obra El derecho a un mínimo vital con especial referencia a la Constitución Española de 1978 vincula como antecedente más antiguo al DMV en el ámbito jurídico la frumentatio romana, consistente en un mínimo de trigo para los ciudadanos, ya que se trataba de un derecho autentico y no un simple acto de generosidad. De igual forma dentro del derecho romano se encuentran otras figuras jurídicas con características y objetivos similares, tales como la liberalitas o congiaria, cuya característica principal consistía en entregar prestaciones en dinero o alimentos.

Esta obra está bajo una Licencia Creative Commons Atribución-NoComercial-SinDerivar 4.0 Internacional, IIJ-UNAM. Boletin Mexicano de Derecho Comparado, núm. 160, enero-abril de 2021, pp. 237-276. 
Más enfático resulta el Pacto Internacional de Derechos Económicos, Sociales y Culturales de 1966 el cual también incluye el derecho a un nivel de vida adecuado en su artículo 11 agregando el derecho a "una mejora continua de las condiciones de existencia", lo que aporta un carácter dinámico al mismo, y contribuyendo a una mayor concreción en su artículo 12 .

Además de estos documentos jurídicos de carácter internacional, el DMV también hunde sus raíces en otros como la Declaración sobre el Progreso y el Desarrollo en lo Social, de 1969, o la Declaración Universal sobre la Erradicación del Hambre y la Malnutrición, de 1974. A escala regional, la Convención Americana de los Derechos Humanos, de 1969, y el Protocolo de San Salvador, de 1988, que enumera en mayor detalle los derechos sociales y manifiesta su interdependencia indisoluble con otros derechos humanos, son normas fundamentales en este sentido.

En el ámbito europeo sobresalen la Carta Social Europea, la Carta de Derechos Fundamentales de la Unión Europea y su Tratado de Funcionamiento. El Parlamento Europeo emitió, en 2017, una resolución sobre la "Renta mínima como instrumento para la lucha contra la pobreza", donde recomendó a los Estados miembros la introducción de

regímenes de renta mínima adecuados, acompañados de medidas para favorecer la reincorporación al mercado de trabajo de todas las personas capaces de trabajar y de programas de educación y formación adaptados a la situación personal y familiar del beneficiario, con el fin de ayudar a las familias con ingresos insuficientes y permitirles que tengan un nivel de vida digno.

En puridad, no existe un concepto unívoco de "mínimo vital" (S. P. Duque, M. Duque Quintero y P. González Sánchez, 2019, pp. 80-95). En la doctrina, encontramos voces que, como Ferrajoli, entienden que el mínimo vital sería un componente del propio derecho a la vida (L. Ferrajoli, 2011, p. 18), hasta quien como Rawls lo ven como un mecanismo de igualdad social (J. Rawls, 1971). En este sentido el verdadero problema que afecta al DMV ha sido su falta de concreción, y, por tanto (derivada de ella) su materialización, su exigibilidad ante las instancias judiciales

2 Resolución del Parlamento Europeo, del 24 de octubre de 2017, sobre las políticas encaminadas a garantizar la renta mínima como instrumento para luchar contra la pobreza.

Esta obra está bajo una Licencia Creative Commons

Atribución-NoComercial-SinDerivar 4.0 Internacional, IIJ-UNAM.

Boletín Mexicano de Derecho Comparado, núm. 160, enero-abril de 2021, pp. 237-276. 
y su justiciabilidad. ¿Qué es entonces el DMV? La clave está en definir si se trata de un derecho en exclusiva, con un reconocimiento específico, o si es un referente innominado que a modo de cajón de sastre da cabida a lo que diferentes voces e interpretaciones entienden como "mínimo", y dónde entrarían desde la vivienda y alimentación, hasta la salud, la educación y el medio ambiente.

Como expone Espinoza de los Monteros, los derechos sociales se caracterizan por contener un conjunto de expectativas, pretensiones de derechos, recursos y bienes, que albergan la finalidad de satisfacer "necesidades materiales mínimas" (J. Espinoza de los Monteros, 2013, p. 376). El DMV surge con la vocación de ser el agente que satisfaga estas necesidades materiales mínimas o indispensables, mediante la transformación aquellas expectativas y pretensiones ideales en realidades materiales y palpables.

En cuanto a su exigibilidad y justiciabilidad ${ }^{4}$ entendemos el mínimo vital como un parámetro para hacer exigible los derechos económicos, sociales y culturales, no solamente ante los tribunales sino también frente a las administraciones públicas. Como expresa E. Pérez González,

En el sistema jurídico mexicano, el DMV impone, en el marco de las obligaciones de actuación encomendadas a las administraciones públicas, los deberes de promoción, fomento, protección y garantía de los derechos humanos. De este modo, el DMV proporciona un parámetro de exigibilidad frente a la omisión de deberes de actuación administrativa" (E. Pérez González y A. Nettel Barrera, 2017, pp. 317-337).

Ahora bien, acordamos con Carlos Pelayo, que la justiciablidad del mínimo vital pasa por la garantía judicial de este derecho de manera individualizada:

3 Como señala Rosales García, el DMV no sólo busca garantizarle al individuo percibir ciertos recursos, sino permitirle desarrollar un proyecto de vida igual que al común de la sociedad. De allí que también sea una medida de justicia social, propia de un Estado constitucional. (C. M. Rosales García, 2016, p. 115)

4 "La justiciabilidad tiene que ver con el reconocimiento que una sociedad haga de un derecho y con su cumplimiento voluntario; la exigibilidad se relaciona con la posibilidad de hacer compulsivo el cumplimiento o la reparación de un derecho que se ha violentado. Buena parte de la doctrina entiende justiciabilidad con el significado, muy estrecho, de hacer valer un derecho ante los tribunales". 
Una forma de resolver preliminarmente estas dificultades y dar pasos firmes hacia la justiciabilidad de los derechos económicos, sociales y culturales es garantizar, vía judicial, el derecho a un "mínimo vital", es decir, a las condiciones mínimas para que una persona tenga acceso a una vida digna. (C. Pelayo Möller, 2012).

Concluimos así que la exigibilidad del DMV es un camino para hacer efectiva la reclamación de otros derechos humanos de segunda generación, y por consiguiente entendemos prioritaria su regulación normativa, tarea para la cual podemos encontrar inspiración en el modo en que España lo ha ejecutado por medio del IMV, esto es una prestación dirigida a prevenir el riesgo de pobreza y exclusión social mediante la transferencia de recursos económicos suficientes para la cobertura de sus necesidades básicas.

\section{El DMV el IMV,y otros conceptos análogos}

En ocasiones el concepto "mínimo vital" (común al DMV y al IMV) puede ser denominado "mínimo existencial" o "mínimo de subsistencia", utilizándose a menudo estas nomenclaturas como sinónimos. De igual forma, en la doctrina del liberalismo social se utiliza el concepto de "mínimo social", y en algunos casos se le equipara con el concepto de "renta básica universal" o el "salario social básico". Si bien es cierto, dentro del ámbito jurídico suele usarse el concepto de mínimo vital para referirse a diversas cuestiones, todas ellas se relacionan de forma evidente con la protección de las necesidades básicas más fundamentales para el ser humano.

En Latinoamérica no somos ajenos a esta heterogeneidad como comprueba L. A. Petit en su estudio (L. A. Petit, 2019). E. Carmona Cuenca define el derecho a un mínimo vital como el "derecho de todos los individuos que forman una comunidad a contar con una cantidad mínima para hacer frente a sus necesidades más básicas" (E. Carmona Cuenca, 2012, pp. 61-85). En este sentido abunda Indacochea Prevost señala que el DMV "vendría a ser aquel derecho de todo individuo (...) a contar con la cantidad mínima de recursos que le permitan hacer frente a sus necesidades más básicas". La autora acude al profesor Jimena Quesada para afirmar que puede definirse como un "derecho a recursos mínimos

Esta obra está bajo una Licencia Creative Commons

Atribución-NoComercial-SinDerivar 4.0 Internacional, IIJ-UNAM.

Boletin Mexicano de Derecho Comparado, núm. 160, enero-abril de 2021, pp. 237-276. 
garantizados". Finalmente concluye que el contenido que debe otorgarse al mínimo vital depende de lo que resulte necesario en el caso concreto. Por lo que considera suficiente que se defina de manera general "como un derecho a contar con los recursos mínimos para asegurar la subsistencia de cada individuo" (Ú. Indacochea Prevost, 2011, pp. 259, 265, 266 y 283). Por su parte Silva Meza, en la línea ferrajoliana antes señalada, subraya la estrecha relación que guarda el DMV con el derecho a la vida (J. Silva Meza, 2014, pp. 213-240).

Carmona Cuenca en su artículo "El derecho al mínimo vital y el derecho a la renta básica", también comenta la postura de Jimena Quesada, relativa a los recursos mínimos garantizados, considerando que la amplitud del concepto que ofrece éste (la cual engloba los derechos de vivienda, salud, alimentación y educación, que deben ser cubiertos mediante servicios públicos para aquellos que no están en condiciones de proveerse de ellos por sí mismos) le restaría precisión y por tanto eficacia, y que el DMV debería ser tratado como un derecho en específico (E. Carmona Cuenca, 2017, pp. 199-209).

En este sentido sostiene que el mínimo vital "se refiere más bien a la libre disposición de recursos económicos mínimos para hacer frente a las necesidades más perentorias del ser humano" 5 y explica su postura exponiendo que el DMV en principio podría entenderse bien como una disposición a favor de los trabajadores para que el salario que perciben sea suficiente, o bien en pro de las personas que por alguna circunstancia no realizan un trabajo remunerado, inclinándose en favor del segundo supuesto, basando su postura en que los trabajadores ya cuentan con una serie de disposiciones en el marco internacional que protege su salario, y según la autora, el mínimo vital tiene otro objetivo: dar respuesta a las personas que no tienen un trabajo remunerado ni disponen de bienes económicos propios y suficientes.

Se podría concluir entonces que el mínimo vital, como derecho de satisfacción de necesidades básicas, debe tutelar a quienes están más apartados de tener un nivel de vida adecuado. Aun así, la autora no niega dicha relación, incluso sostiene que en países en vía de desarrollo los trabajadores no cuentan con los medios de subsistencia, y en países desarrollados sus salarios son para la mera subsistencia o insuficientes. Por lo que el

5 Ibidem, p. 201. 
mínimo esencial puede tomarse como punto de partida y solamente considera conveniente enfocarlo en los que se encuentran en mayor desventaja. En este orden de ideas el DMV persigue el alcance efectivo de los derechos desde un aspecto material que pretende trascender el universo de la idealidad en el que se sitúan muchos derechos reconocidos en el plano normativo, los cuales no consiguen una materialización real de los mismos comúnmente debido a la falta de medios para hacerlos posibles. El DMV viene a proveer de esos medios necesarios para asegurar el resto de los derechos sociales garantizados y para asegurar que devengan efectivamente una realidad palpable.

Por consiguiente, si el DMV es la institución jurídica que protege esta potestad del individuo, el IMV vendría a ser la herramienta a través de la cual aquel toma forma vigente, la política pública que lo hace tangible, sin embargo, los conceptos de DMV y su materialización en IMV han sido, y son hoy en día, intensamente debatidos en cuanto a su concreción y alcance. Tanto la doctrina como el regulador jurídico abordan el DMV desde diversos ángulos y poniendo el foco en los diferentes aspectos que éste abarca, pero prácticamente todos coinciden en su configuración como el nivel más avanzado al cual los derechos humanos de segunda generación han llegado, encarnando el DMV la sublimación de todos ellos y de su correlativa garantía.

La cuestión respecto a la cual discurre el debate en torno al DMV es su alcance. Aquí es dónde el DMV y su concreción como IMV necesitan una mayor precisión en cuanto a la vinculación que mantienen entre ellos y con otros conceptos relacionados.

En primer lugar, debemos distinguir el IMV de la renta básica universal (RBU). Acudamos a la definición que el profesor belga Van Parijs (uno de los expertos más reconocidos en la materia $)^{6}$ hace de la misma:

[la RBU consiste en] un ingreso pagado por el gobierno a cada miembro pleno de la sociedad, incluso si no quiere trabajar de forma remunerada, sin tomar en consideración si es rico o pobre o, dicho de otra forma, independientemente de sus otras posibles fuentes de renta y sin importar con quién conviva. (P. Van Parijs, 1996, p. 56)

6 Fundamental en este sentido resulta: (P. Van Parijs, 2001 pp. 7-39).

Esta obra está bajo una Licencia Creative Commons

Atribución-NoComercial-SinDerivar 4.0 Internacional, IIJ-UNAM.

Boletín Mexicano de Derecho Comparado, núm. 160, enero-abril de 2021, pp. 237-276. 
El IMV se dirige a los desprotegidos o aquellos con mayores dificultades para acceder a las necesidades básicas, mientras que la RBU es independiente a la situación económica de la persona. La RBU consiste en conceder una cantidad en dinero a todas las personas sin importar su situación laboral, social o económica, por lo que se también sería reclamable por personas sin dificultades económicas o con un alto nivel de ingresos. Es decir, el IMV no se dirige a todos los ciudadanos, sino que se destina para aquellos en una determinada situación de vulnerabilidad económica, debiendo acreditar además determinados requisitos, y la renta básica ciudadana (también llamada así en ocasiones) es, efectivamente, universal desde su raíz (C. Gala Durán, 2020). Las diferencias entre uno y otro concepto aparecen perfectamente esquematizadas en esta cita de Rey Pérez:

La (...) RBU, se caracteriza por ser un ingreso individual, periódico, incondicional y universal, mientras que el (...) ingreso mínimo vital (como ha aprobado recientemente el Gobierno español), son ingresos familiares, periódicos, condicionados y no universales, pues se dirigen solo a aquellos colectivos que tienen necesidad de una ayuda económica para cubrir sus necesidades de subsistencia. (J. L. Rey Pérez, 2020, p. 238)

Con este contraste entre ambos conceptos observamos que difieren no sólo en su objeto y su objetivo, sino también en su propio diseño y por supuesto en su coste a las arcas públicas. El IMV y la RBU no buscan el mismo fin. Un instrumento incondicionado como la RBU, con esa vocación universal ciega a las diferencias resulta inevitable encuadrarlo en una concepción liberal basada en la neutralidad estatal más que en un verdadero Estado social. ${ }^{7}$ Esta discusión walzeriana (M. Walzer, 1991) sobre

7 "Walzer considera que las dos perspectivas universalistas definen dos concepciones diversas del liberalismo, la segunda más democrática que la primera. Lo que Walzer llama "liberalismo 2", en la medida en que autoriza a las comunidades democráticas a determinar la política pública dentro de los vastos límites del respeto a los derechos individuales, también las autoriza a elegir las medidas políticas que resulten más o menos neutrales entre las particulares identidades culturales de los grupos. Y dado que el liberalismo 2 es democrático, puede escoger al liberalismo 1, la neutralidad estatal, por medio de un consenso democrático. Walzer cree que esto es lo que Estados Unidos ha escogido democráticamente. Y el Liberalismo 1 que se incluye en la elección del liberalismo 2 es lo que Walzer habría elegido, porque está en armonía con la interpretación social dominante de 
la naturaleza del Estado benefactor es para nosotros la verdadera clave de la opción entre un modelo u otro. Además de la obvia disparidad económica entre las dos (no asumible por muchos Estados), este desfase en su alcance subjetivo es la esencia de la elección que nos hace posicionarnos en favor del IMV en detrimento de la RBU. Si la RBU es una renta igual para todos no cuenta con un factor igualador, no existe una verdadera redistribución, no nivela, ni mitiga la desigualdad. No negamos un efecto estimulante para la economía a corto plazo, pero enseguida quedará diluido, y a medio-largo plazo acaba perpetuando las condiciones originales que pretendía evitar.

La RBU no desarrolla el DMV. La RBU es un mecanismo igualitarista de redistribución de la renta que no atiende desde su concepción intrínseca a la misma finalidad que el DMV. No podemos caer en la trampa de presentar ambos como mecanismos mediante los cuales un sistema jurídico puede hacer efectiva la protección del DMV. La única vía de implementar el DMV es el IMV.

En otro orden de cosas, también debemos distinguir el IMV de otros conceptos relacionados como el "salario social básico" o la "renta mínima de inserción". Todos ellos tienen como finalidad proteger a las personas contra el desempleo y reincorporarlos a la vida económica por medio de prestaciones económicas, a fin de que puedan satisfacer sus necesidades más básicas. La diferencia con la RBU estriba en que van encaminados a personas en situación de desventaja social, en especial ciudadanos o personas con cierto tiempo de residencia que buscan reinsertarse a la vida económica de la sociedad. La similitud con el mínimo vital reside en que ambos pretenden asegurar que las personas que lo necesiten cuenten con los medios suficientes para satisfacer sus necesidades y puedan reincorporarse a la sociedad de manera productiva, sin embargo, existen discrepancias en cuanto al alcance, duración y beneficiarios de la acción protectora.

Estas figuras jurídicas también guardan similitud, con el concepto de mínimo social descrito por Rawls en su obra Teoría de la justicia, y anteriormente señalado, el cual propone un nivel de recursos mínimos que de-

Estados Unidos como una sociedad de inmigrantes, en que cada grupo cultural es libre de defenderse a sí mismo, si bien no cuenta con el Estado para el apoyo o reconocimiento de sus proyectos culturales". (A. Guttman, 2003, pp. 9 y 10)

Esta obra está bajo una Licencia Creative Commons

Atribución-NoComercial-SinDerivar 4.0 Internacional, IIJ-UNAM.

Boletín Mexicano de Derecho Comparado, núm. 160, enero-abril de 2021, pp. 237-276. 
ben ser cubiertos por el Estado a favor de aquellos que lo requieran, como medio para cumplir el objetivo del pleno desarrollo de la persona en la sociedad (J. Rawls, 1971).

También aquí aparece la conexión del DMV con la inembargabilidad de los recursos y bienes materiales vitales, que establece limitantes a ciertos derechos con el objeto de proteger a la persona humana. Al mínimo vital suele denominársele mínimo inembargable o exento, por constituir una restricción en favor de proteger el patrimonio de los individuos. El punto central es proteger a los individuos de caer en una situación de insubsistencia y vulnerabilidad por cuestiones económicas.

Observamos pues como el DMV mantiene un claro nexo con conceptos como renta básica universal o rentas mínimas de inserción, sin embargo, el DMV no tiene el grado de concreción del que disfrutan los otros conceptos. ${ }^{8}$ Pese a que nosotros nos alineamos con aquella parte de la doctrina que destaca la necesidad de especificidad del mínimo vital como un derecho propio e individualizado, otra parte entiende que del concepto general del mínimo existencial no se desprende la obligación indiscutible de incorporar dentro del marco normativo estas prestaciones. El mínimo vital desde su teoría si implica ciertas obligaciones y libertades en favor del gobernado por parte de los poderes públicos, pero estas pueden consistir únicamente en la prestación de servicios como por ejemplo salud, o el acceso al agua, pero no explícitamente en el otorgamiento de seguros o prestaciones monetarias en forma de transferencia económica directa desde el Estado a los individuos. En otras palabras: no hay unanimidad doctrinal en cuanto a que el DMV deba garantizar inevitablemente el IMV.

El DMV es un concepto más abstracto que instituye la obligación del Estado de garantizar las necesidades fundamentales para la subsistencia, pero sin constreñirse o limitarse a actividades específicas. Sin embargo, que se trate de un concepto amplio no quiere decir que no se puedan exigir o demandar medidas determinadas para concretar los fines perseguidos por el mínimo vital. En definitiva, se trata de un derecho humano con un alto grado de inconcreción, lo que por otro lado estimula su flexibilidad y adaptabilidad.

8 Y por supuesto no podemos confundir el mínimo vital con dádivas y demás subvenciones políticas comunes en nuestro país (L. A. Petit, 2019).

Esta obra está bajo una Licencia Creative Commons Atribución-NoComercial-SinDerivar 4.0 Internacional, IIJ-UNAM. Boletin Mexicano de Derecho Comparado, núm. 160, enero-abril de 2021, pp. 237-276. 


\section{EL INGRESO MÍNIMO VITAL EN ESPAÑA}

La causa fundamental que motiva la elaboración de este trabajo es la aprobación del Real Decreto-ley 20/2020, del 29 de mayo, que es la norma española que instituye el IMV, y que será la norma de referencia para la primera parte de nuestro estudio comparado. La elección del caso español como referencia para el estudio de una potencial aplicación en México no es baladí. Ambas sociedades comparten importantes rasgos que hacen que las recetas aplicadas en una puedan tener éxito también en su aplicación en la otra. Los lazos históricos y culturales comunes entre España y México, fruto de un pasado común y de una comunicación y vínculos firmes, explican que la percepción social de determinados valores como la solidaridad, o el concepto de familia, sean similares y desde luego mucho más cercanos entre ellos que respecto a los países anglosajones o nórdicos. Y lo mismo sucede en los aspectos negativos: los países latino-mediterráneos tenemos una estructura político-institucional más frágil y unos aparatos públicos asistenciales más débiles y peor dotados que implican, por lo general, una mayor vulnerabilidad social, haciendo que en estos países la red de protección social no provenga de los poderes públicos, sino de las familias. En definitiva, para México, no es tan fácilmente extrapolable una solución escandinava o anglosajona, como una española. Con España existe un lenguaje común (no sólo idiomático, sino sociológico) que facilita la comprensión, y además sirve de puente entre Europa y América Latina. En lo jurídico formamos parte de la misma familia y tradicionalmente España ha suministrado una puerta de entrada a las novedades del viejo continente. Por todo ello planteamos que puede ser una buena referencia para la regulación en México del derecho que nos ocupa y de las políticas públicas que lo materializan.

Previamente a la aprobación del citado Real Decreto-ley, en España ya existía una regulación de esta herramienta jurídica. Pero limitada únicamente en el ámbito autonómico (estatal en el estándar mexicano), y adoptando modelos muy diferentes entre sí, tanto en su diseño y denominación como en los grados de protección. Esta heterogeneidad hacía necesaria una uniformización en aras de la igualdad y del alcance de la cobertura social. Ya hemos hablado de la resolución de 2017 del Parlamento Europeo sobre la renta mínima, pero es que en el mismo año se 
instituyó en la Cumbre social en favor del empleo justo y el crecimiento, el Pilar Europeo de Derechos Sociales, cuyo principio 14 está consagrado a este propósito. ${ }^{9}$

En su preámbulo, el Real Decreto-ley 20/2020 expone que España se encuentra entre los países de la Unión Europea con mayor desigualdad en la distribución de la renta, y con una de las tasas de pobreza más altas, ${ }^{10}$ debido, entre otras causas, al débil efecto redistributivo del conjunto de la intervención de los poderes públicos, y a que este país no cuenta con una prestación que cubra el riesgo general de pobreza como si hacen la mayoría de sus vecinos.

Por si todo esto fuese poco, en los primeros meses de 2020 la pandemia causada por el COVID-19 impactó fuertemente en España, convirtiéndolo en uno de los países más golpeados mundialmente. La crisis no fue únicamente de índole sanitaria, sino que tuvo su traslación en una grave crisis social y económica que provocó un enorme efecto negativo en la actividad laboral y la destrucción de buena parte del tejido productivo. Ante esta situación, el gobierno decidió acelerar la puesta en marcha de esta medida que ya llevaba tiempo incubándose. ${ }^{11}$ Sin embargo, aunque el establecimiento del IMV se haya visto anticipado de manera urgente como una fórmula para mitigar las profundas consecuencias de esta coyuntura, tiene una nítida vocación estructural.

9 Principio 14 del Pilar Europeo de Derechos Sociales, Cumbre social en favor del empleo justo y el crecimiento, Gotemburgo, noviembre de 2017: "Toda persona que carezca de recursos suficientes tiene derecho a unas prestaciones de renta mínima adecuadas que garanticen una vida digna a lo largo de todas las etapas de la vida, así como el acceso a bienes y servicios de capacitación. Para las personas que pueden trabajar, las prestaciones de renta mínima deben combinarse con incentivos a la (re)integración en el mercado laboral".

10 En 2018, el último año para el que Eurostat ofrece datos comparados, el coeficiente de Gini en España es casi tres puntos superior a la media de la Unión Europea, y los ingresos del veinte por ciento de los hogares de renta más baja representan solo una sexta parte de los ingresos del veinte por ciento con renta más alta, mientras en la Unión Europea esta proporción es solo de una quinta parte.

11 En febrero de 2017, el Parlamento español tomó en consideración una Iniciativa Legislativa Popular, a propuesta de los dos sindicatos más importantes del país, con el objetivo de establecer una prestación de ingresos mínimos. Se trata de la primera propuesta relevante en este ámbito, que, sin duda, supuso un fuerte impulso para el desarrollo del ingreso mínimo vital. 
Respecto al debate sobre la aprobación de esta medida en España podemos establecer dos ámbitos, siendo el primero de ellos el doctrinal y, el segundo, el político-parlamentario. En ninguno de ellos han surgido polémicas o discusiones reseñables. En 2015 los principales sindicatos españoles (CCOO y UGT) comenzaron una campaña de recogida de firmas para llevar a cabo una iniciativa legislativa popular sobre una renta mínima para aquellos sin ingresos y sin derecho a prestaciones por desempleo u otras ayudas sociales. Se ponía de esta manera encima de la mesa la cuestión que ya había sido implementada en varios países del entorno español, y que estaba siendo demandada desde las instancias europeas $^{12}$ ya que suponía una anomalía entre las economías más potentes de la Unión Europea. ${ }^{13}$ En este sentido, y como corresponde a su función de vanguardia, la doctrina ha venido estudiando concienzudamente el asunto y dilucidando cuál sería el instrumento más idóneo para la realidad española (F. Goerlich Gisbert, 2016).

Los partidarios de la RBU añaden a los argumentos ya analizados anteriormente como ventaja frente al IMV la no estigmatización de los receptores (T. Sala Franco y A. Martín Pozuelo, 2020, p 73 y M. Ramos Quintana, 2020, p. 303). Bajo nuestro criterio, la opción de un instrumento incondicional y absoluto no encontraría un problema en este punto (consideramos más grave la estigmatización causada por la pobreza), y si más bien en el temor manifestado por algunos respecto a las consecuencias desincentivadoras que pueda causar una medida de este tipo en los receptores de ésta como presagian desde determinados espectros políticos liberales (J. L. Monereo Pérez y G. Rodríguez Iniesta, 2020, p. 24). Temor que una herramienta condicionada y no-universal como el IMV, ostenta el mérito de alejar, e incluso servir como incentivo al empleo en el difícil contexto actual, tal como muestra L. Martínez Virto (2019).

El mayor o menor éxito de experiencias de RBU ya ensayadas en lugares como Finlandia (analizado magistralmente por P. Van Parijs 2020)

12 Recomendación del Consejo relativa al Programa Nacional de Reformas de 2020 de España y por la que se emite un dictamen del Consejo sobre el Programa de Estabilidad de 2020 de España.

1315 de los 27 Estados miembros de la Unión Europea cuentan con un instrumento similar que garantiza al menos un ingreso mínimo de 200 euros mensuales, siendo Dinamarca y los Países Bajos los que proporcionan cifras más altas: 1.515 y 992 euros respectivamente.

Esta obra está bajo una Licencia Creative Commons

Atribución-NoComercial-SinDerivar 4.0 Internacional, IIJ-UNAM.

Boletín Mexicano de Derecho Comparado, núm. 160, enero-abril de 2021, pp. 237-276. 
o Alaska ${ }^{14}$ no son trasladables directamente a España. No dudamos de sus buenos resultados, pero circunscritos a sus contextos específicos (Finlandia es uno de los mejores ejemplos de socialdemocracia escandinava con una consolidada tradición basada en una verdadera redistribución de la renta, poderes públicos capaces y eficientes, y sistemas asistenciales fuertes, mientras que Alaska basa su éxito en los enormes ingresos procedentes de sus recursos petrolíferos), contextos de los que España (al igual que México) carece. Todos estos factores hicieron que la opción del gobierno español por el IMV fuese mayoritariamente bienvenida por la doctrina. Añadiendo a esto la situación de precariedad económica y vulnerabilidad social provocada por la crisis pandémica, se generó la oportunidad perfecta para que el gobierno llevase a cabo una de sus medidas estrella contenida en el acuerdo de coalición. ${ }^{15}$ El gobierno ya planeaba, por tanto, la aprobación de la medida a lo largo de la legislatura, pero la emergencia social a que aludimos urgió su aprobación.

14 Merece la pena contemplar un momento la experiencia particular alasqueña descrita magistralmente por Tena Camporesi en los siguientes términos: "Desde el año 1982 lleva activo en Alaska el Permanent Found Dividend, la única "verdadera" experiencia en la práctica de RBU llevada a cabo en un territorio, no de manera experimental, sino como derecho subjetivo ciudadano y de forma continuada en el tiempo. Desde entonces cada año una parte de los ingresos que genera el petróleo que se extrae en esa zona se ingresa en este fondo. La idea era transformar de manera permanente los ingresos derivados del petróleo en un flujo de dinero y capital hacia los residentes en Alaska. Las únicas condiciones para poder optar a este dividendo son la ciudadanía, la residencia y rellenar un formulario. El Alaska Permanent Found es el único caso existente hoy en día de una RBU individual universal e incondicional explícitamente como política de Estado. Los dividendos se pagan de manera anual y aunque son variables en función del precio del petróleo en el mercado, los promedios que se calculan van en torno a los 1.200 dólares al año, es decir, para una familia de cinco personas unos 6000 dólares (Widerquist y Sheahen, 2012). Ahora mismo Alaska es el estado más igualitario de los Estados Unidos en cuanto a distribución de la renta, con un índice de Gini del 0.408 con respecto al 0.481 de media del país, y el más alto del país es el del Distrito de Columbia con un 0.54 (Noss, 2014). El problema más obvio en términos de sostenibilidad sigue siendo su relación directa con un recurso determinado: el petróleo, que se calcula que pueda empezar a terminarse entre 15 y 30 años, lo cual pondría obviamente en peligro el sistema (Widerquist, 2012). Hoy el Permanent Found es un fondo fideicomiso que gestiona la Alaska Permanent Found Corporation, que es propiedad del estado de Alaska, y opera con el 15\% del dinero que se genera de la explotación del petróleo de la región". (A. Tena Camporesi, 2018, pp. 859 y 860)

15 El gobierno español surgido de las elecciones generales de noviembre de 2019 que conformaron las Cortes Generales de la XIV legislatura es el primer gobierno de coalición español a nivel estatal desde la II República en los años treinta del siglo XX. 
En definitiva, tampoco existió controversia parlamentaria al respecto. La medida fue votada en favor por todos los grupos parlamentarios salvo uno que se abstuvo. ${ }^{16}$ Semejante concordia se explica por dos motivos: en primer lugar, la urgente necesidad que de esta medida reclamaban amplios sectores de la sociedad española (sumados a las presiones europeas e incluso de la ONU); ${ }^{17}$ y, en segundo lugar, las especiales y difíciles circunstancias en que se aprobó. Bien es cierto que el Real Decreto-ley, será tramitado como proyecto de ley y puede ser debatido y modificado en fase de enmiendas, pero todo hace indicar que, salvo breves concesiones, ${ }^{18}$ el diseño del gobierno saldrá adelante.

Entrando ya en el análisis de la regulación del IMV en España, observamos cómo el objetivo es "garantizar, por medio de la satisfacción de unas condiciones materiales mínimas, la participación plena de toda la ciudadanía en la vida social y económica, rompiendo el vínculo entre ausencia estructural de recursos y falta de acceso a oportunidades en los ámbitos laboral, educativo, o social de los individuos. La prestación no es por tanto un fin en sí misma, sino una herramienta para facilitar la transición de los individuos desde la exclusión social que les impone la ausencia de recursos hacia una situación en la que se puedan desarrollar con plenitud en la sociedad". ${ }^{19}$ Del mismo modo, se aclara que el IMV "no es una política dirigida a grupos o individuos concretos, sino que, atendiendo a aquellos que en un momento determinado sufren situaciones de exclusión y vulnerabilidad, protege de forma estructural a la sociedad en su conjunto". ${ }^{20}$

Respecto a su anclaje constitucional, el IMV encuentra fundamento en el reconocimiento del carácter social del Estado español que promul-

\footnotetext{
16 El grupo parlamentario correspondiente al partido ultraderechista Vox se decantó por la abstención.

17 Declaración del relator especial de las Naciones Unidas sobre la extrema pobreza y los derechos humanos, Philip Alston, sobre la conclusión de su visita oficial a España, 27 de enero-7 de febrero de 2020.

18 El Partido Popular (principal grupo de la oposición) pretende que la percepción de la prestación esté vinculada a la "búsqueda activa de empleo".

19 Punto III del Preámbulo del Real Decreto-ley 20/2020, del 29 de mayo, por el que se establece el ingreso mínimo vital, España.

20 Idem.
}

Esta obra está bajo una Licencia Creative Commons

Atribución-NoComercial-SinDerivar 4.0 Internacional, IIJ-UNAM.

Boletin Mexicano de Derecho Comparado, núm. 160, enero-abril de 2021, pp. 237-276. 
ga el artículo 1.1 de la Constitución Española de $1978 ;{ }^{21}$ en el mandato de promoción de la igualdad y remoción de los obstáculos que la dificultan del artículo $9.2,{ }^{22}$ y en el régimen público de seguridad social garantizado por el artículo $41^{23}$ y refrendado como "función de Estado" por el Tribunal Constitucional de aquel país. ${ }^{24}$

Tal y como lo regula el Real Decreto-ley 20/2020, el IMV es una

prestación dirigida a prevenir el riesgo de pobreza y exclusión social de las personas que vivan solas o integradas en una unidad de convivencia, cuando se encuentren en una situación de vulnerabilidad por carecer de recursos económicos suficientes para la cobertura de sus necesidades básicas. (Real Decreto-ley 20/2020, art. 1o.).

De este modo, y como ya indicábamos en el apartado correspondiente, el IMV se configura como el derecho subjetivo a una prestación de naturaleza económica que garantiza un nivel mínimo de renta a quienes se encuentren en situación de vulnerabilidad económica (Real Decreto-ley 20/2020, art. 2.1). El IMV constituye la materialización del DMV, institución jurídica cuyo fin es garantizar una mejora de oportunidades reales de inclusión social y laboral de las personas beneficiarias.

Las características de este instrumento vienen definidas en el artículo 3o. de la citada norma y establecen que se trata de una "acción protectora", cuya duración se prolongará mientras persista la situación de vulnerabilidad económica y se mantengan los requisitos que originaron el derecho a su percepción, que tiene como objetivo garantizar un nivel mínimo de renta que favorezca el tránsito desde una situación de exclusión a una

21 Artículo 1.1. "España se constituye en un Estado social y democrático de Derecho, que propugna como valores superiores de su ordenamiento jurídico la libertad, la justicia, la igualdad y el pluralismo político".

22 Artículo 9.2. "Corresponde a los poderes públicos promover las condiciones para que la libertad y la igualdad del individuo y de los grupos en que se integra sean reales y efectivas; remover los obstáculos que impidan o dificulten su plenitud y facilitar la participación de todos los ciudadanos en la vida política, económica, cultural y social".

23 Artículo 41. "Los poderes públicos mantendrán un régimen público de Seguridad Social para todos los ciudadanos que garantice la asistencia y prestaciones sociales suficientes ante situaciones de necesidad, especialmente en caso de desempleo. La asistencia y prestaciones complementarias serán libres".

24 Sentencia 37/1994. Tribunal Constitucional de España.

Esta obra está bajo una Licencia Creative Commons Atribución-NoComercial-SinDerivar 4.0 Internacional, IIJ-UNAM. Boletín Mexicano de Derecho Comparado, núm. 160, enero-abril de 2021, pp. 237-276. 
de participación en la sociedad, que es intransferible, y que además implica una red de protección que contiene en su diseño incentivos al empleo y a la inclusión, articulados mediante distintas fórmulas de cooperación entre administraciones.

Pero, además, la norma resulta destacable en lo que respecta al alcance de su acción protectora, su ámbito subjetivo de aplicación, y otros aspectos de esta herramienta jurídica, que a continuación pasamos a estudiar.

La cuestión de quién puede ser titular de la materialización en la que se transforma el DMV cuando se plasma como IMV, es una de las claves de la regulación de este derecho. En España el IMV se traduce en una prestación económica recibida por el beneficiario mes a mes (Real Decreto-ley 20/2020, art. 9o.). La determinación de la cuantía de la prestación, y de las personas que la reciben es una de las cuestiones más interesantes que nos aporta la experiencia española, y de la cual podemos extraer importantes lecciones para una potencial aplicación en el ámbito mexicano.

Para el legislador español el IMV es un derecho subjetivo a una prestación económica que aplica a quién se encuentre en riesgo de vulnerabilidad económica. Esto significa que el IMV se configura como un derecho que actúa únicamente para todos aquellos que se encuentren en una situación específica. Definir esta situación específica de "vulnerabilidad económica" es uno de los puntos clave en los que el legislador español ha debido esforzarse en resolver, cosa que hace en torno a criterios económicos precisos muy bien detallados en su artículo 8o. estableciendo un mínimo de ingresos y rentas a partir del cual se es apto para solicitar el IMV; ${ }^{25}$ pero es que además también ha establecido una doble jerarquía entorno al ejercicio y disfrute de este derecho: personas beneficiarias, y personas titulares del IMV.

25 Artículo 8.2: "Se apreciará que concurre este requisito cuando el promedio mensual del conjunto de ingresos y rentas anuales computables de la persona beneficiaria individual o del conjunto de miembros de la unidad de convivencia, correspondientes al ejercicio anterior, en los términos establecidos en el artículo 18, sea inferior, al menos en 10 euros, a la cuantía mensual de la renta garantizada con esta prestación que corresponda en función de la modalidad y del número de miembros de la unidad de convivencia en los términos del artículo 10. A efectos de este real decreto-ley, no computarán como ingresos los salarios sociales, rentas mínimas de inserción o ayudas análogas de asistencia social concedidas por las comunidades autónomas, y otros ingresos y rentas de acuerdo con lo previsto en el artículo 18".

Esta obra está bajo una Licencia Creative Commons

Atribución-NoComercial-SinDerivar 4.0 Internacional, IIJ-UNAM.

Boletín Mexicano de Derecho Comparado, núm. 160, enero-abril de 2021, pp. 237-276. 
Las personas beneficiarias se dividen en dos categorías: aquellas que integren una unidad de convivencia y aquellas que vivan solas ((Real Decreto-ley 20/2020, art. 4o.). La unidad de convivencia es un concepto que lejos de estar indeterminado, queda descrita en el artículo 6.1 de la citada norma en los siguientes términos:

Se considera unidad de convivencia la constituida por todas las personas que residan en un mismo domicilio y que estén unidas entre sí por vínculo matrimonial o como pareja de hecho (...), o por vínculo hasta el segundo grado de consanguinidad, afinidad, adopción, y otras personas con las que conviva en virtud de guarda con fines de adopción o acogimiento familiar permanente.

A esta descripción se añaden importantes excepciones relativas a fallecimientos (6.1), víctimas de violencia de género (6.2, inciso a), separación o divorcio (6.2, inciso b), y una muy interesante referida a los cohabitantes que no entren en los casos anteriores (6.3, inciso c); entendiéndose también todas ellas como unidades de convivencia, y también la exigencia de un tiempo mínimo de convivencia continuada de un año previo a la solicitud (artículo 7.3).

Para aquellas personas que viven solas se establece un rango de edad (comprendido entre los 23 y los 65 años) fuera del cual no pueden ser considerados beneficiarios, además de ostentar el estado civil de soltería y de no formar parte de otra unidad de convivencia. Destaca en este punto la no exigibilidad de estos requisitos para las mujeres víctimas de violencia de género o de trata de seres humanos y explotación sexual decretadas en el artículo 4.1, inciso b, segundo párrafo del Real Decreto-ley 20/2020. Por el contrario, quedan excluidas todas aquellas personas que ya estén percibiendo de modo permanente otras prestaciones de servicio residencial, de carácter social, sanitario o socio sanitario.

Pero ser beneficiario del IMV, no implica ser titular de éste (artículo 5o.). La titularidad, en el caso de la solicitud por parte de una unidad de convivencia, queda reservada para un único representante de la citada unidad. En el caso de aquel beneficiario que vive sólo si coinciden ambas categorías. Esta separación entre beneficiario y titular evita duplicidades y posibles abusos picarescos alrededor de este recurso público.

Además de encontrarse en la ya descrita "situación de vulnerabilidad económica", los beneficiarios deben cumplir con otros requisitos, tales 
como ostentar la residencia legal y efectiva en España durante al menos el año inmediatamente anterior a la solicitud, y, en el caso de los desempleados mayores de edad o emancipados, figurar inscritos como demandantes de empleo (Real Decreto-ley 20/2020, art. 7o.).

Es posiblemente en estos dos puntos en donde la normativa española nos resulta más relevante: definición de "vulnerabilidad económica" en función de criterios económicos tangibles y concretos, y segmentación del ámbito subjetivo de aplicación en dos categorías diferentes (titular y beneficiario), junto con el establecimiento del concepto de "unidad de convivencia".

Respecto a la acción protectora, ésta queda concretada en una prestación económica, efectiva mensualmente, para cuya determinación se han fijado rígidos criterios que estructuran de modo escalonado la cuantía a percibir por el beneficiario individual o unidad de convivencia (Real Decreto-ley 20/2020, arts. 10 y 18), la cual puede ir desde los 460 hasta los $1015 €$.

La duración del derecho a percibir esta prestación económica se supedita a que los criterios que dieron lugar a ella continúen vigentes (Real Decreto-ley 20/2020, art. 12). Del mismo modo, la cuantía de la prestación se puede ver modificada y actualizada anualmente, si cambian las circunstancias personales, económicas o patrimoniales del beneficiario del IMV o de alguno de los miembros de la unidad de convivencia (Real Decreto-ley 20/2020, art. 12). Asimismo, la normativa española prevé la suspensión, o incluso extinción, del derecho si se pierden algunos de los requisitos necesarios, si se incumplen las obligaciones asumidas (descritas en el artículo 33) o las condiciones asociadas a la compatibilidad del IMV con las rentas e ingresos propios, o si se renuncia al derecho (Real Decreto-ley 20/2020, arts. 14 y 15). Para ello, se establecen también una serie de infracciones y sanciones que aseguren el cumplimiento adecuado de la medida (Real Decreto-ley 20/2020, capítulo VIII).

En aras a hacer efectiva la debida ejecución de este derecho, y a evitar los abusos e infracciones en torno al mismo, se crea un nuevo organismo denominado "Comisión de seguimiento del IMV" (Real Decreto-ley 20/2020, art. 30), la cual evalúa el impacto del IMV como instrumento para prevenir el riesgo de pobreza y exclusión social de las personas en situación de vulnerabilidad económica, da seguimiento a la cooperación 
intra e interadministrativa necesaria para el desarrollo y aplicación de la norma, y vigila el buen funcionamiento de esta herramienta jurídica.

Respecto al aspecto del costo económico que conllevará la implementación del IMV español y la proyección del número de beneficiarios, el Ministerio de Inclusión, Seguridad Social y Migraciones (departamento encargado de la medida) hizo una estimación inicial de un millón de hogares, ${ }^{26}$ que finalmente acabo rebajando a 850.000 donde residen 2.3 millones de personas, y la Ley de Presupuestos Generales del Estado para $2021^{27}$ ha destinado 3017 millones de $\operatorname{euros}^{28}$ para el IMV, de un total consolidado de 550.484 millones de cuantía total (es decir, un 1.82\% del gasto público total para el año entrante). El costo económico de esta medida no supone por lo tanto un esfuerzo inasumible para las arcas públicas, se constituye como una prestación social no contributiva y se financia a través de la recaudación impositiva.

Debido al corto periodo de vida de la medida (el Real Decreto-ley 20/2020 del 29 de mayo entro en vigor el 1o. de junio de 2020, y el IMV se pudo reclamar a partir del 15 de junio; mientras que este artículo se entregó para su publicación el 1o. de julio de 2020 y se revisó a finales de noviembre del mismo año) falta perspectiva suficiente y datos fácticos (y por supuesto jurisprudenciales) para poder llevar a cabo un análisis más profundo de su funcionamiento y puesta en práctica. Hasta el momento, los aspectos criticables del IMV español se centran en la dificultosa labor burocrática que afecta al particular que desea realizar la solicitud, y en cierta rigidez en los requisitos de acceso. Los obstáculos percibidos por los ciudadanos que más se repiten son las quejas de imposibilidad de concreción de citas en el Servicio Público de Empleo Estatal (SEPE) (organismo público mediante el cual se tramita la prestación), y la lentitud en la tramitación, así como la larga espera para la recepción del ingreso económico.

26 Declaraciones del ministro José Luis Escrivá en la entrevista realizada en la Cadena Ser el 16 de abril de 2020.

27 En el momento de redacción de este trabajo la Ley de Presupuestos Generales del Estado todavía no ha sido aprobada por el Congreso de los Diputados Español, pero el Gobierno ya ha asegurado los votos necesarios para para su aprobación. La votación definitiva se celebrará entre el 30 de noviembre y el 3 de diciembre de 2020.

28 El equivalente a 72,400 millones de pesos mexicanos. 
Por lo que concierne a los datos sobre su efectividad, en los escasos meses que la medida lleva operando, el Instituto Nacional de la Seguridad Social (INSS) ha recibido más de un millón de solicitudes. No obstante, de ellos 40.000 estaban duplicados o vacíos, reduciendo de esta manera los expedientes válidos a 975.000. De estos se han tramitado 488.000, de los cuales 328.000 han sido resueltos, y a 160.000 se les ha pedido que subsanen errores. De los resueltos, se concedieron 136.000 (correspondientes a 400.000 beneficiarios, ya que se concede por hogar), por el contrario, 192.000 solicitudes fueron denegadas. Entre las causas más comunes de rechazo figuran errores en el empadronamiento, fallos en la declaración de la renta o superar niveles de renta y patrimonio. ${ }^{29}$

Ante el alto nivel de solicitudes denegadas (casi un 20\%), y las quejas antes especificadas, se corre el riesgo de que esta política pública sea percibida como mera propaganda vacía, o al menos como una contradicción permanente entre los grandes anuncios gubernamentales, y la falta de recursos administrativos a disposición del ciudadano para que efectivamente se resuelva su demanda. Por otro lado, una lenta y tardía evaluación de ésta implicará irremediablemente fallos en su eficacia y en la consecución de la finalidad para la que fue diseñada.

Por ello, el gobierno español llevo a cabo en septiembre de 2020 (sólo 3 meses después de su entrada en vigor) un ajuste en los requisitos de acceso a la prestación para flexibilizarlos. ${ }^{30}$ Esta rápida reacción demuestra, a nuestro juicio, un verdadero interés por parte del gobierno en que la medida tenga éxito, no en vano era una de las medidas estrella del gobierno de coalición.

En definitiva, aunque la adopción del IMV como un derecho de alcance general para toda España sea reciente (no así para el ámbito auto-

29 Todo ello según datos ofrecidos por el secretario de Estado de la Seguridad Social y Pensiones, Israel Arroyo en sede parlamentaria ante la Comisión de Trabajo, Inclusión, Seguridad Social y Migraciones del Senado español el 25 de noviembre de 2020.

30 Ajustes localizados en disposiciones transitorias cuarta (de procedimientos para el reconocimiento del ingreso mínimo vital iniciados antes de la entrada en vigor del presente real decreto-ley en los que no se haya dictado resolución expresa) y final undécima (de la modificación del Real Decreto-ley 20/2020, del 29 de mayo, por el que se establece el ingreso mínimo vital) del Real Decreto-ley 28/2020, del 22 de septiembre, de trabajo a distancia.

Esta obra está bajo una Licencia Creative Commons

Atribución-NoComercial-SinDerivar 4.0 Internacional, IIJ-UNAM.

Boletín Mexicano de Derecho Comparado, núm. 160, enero-abril de 2021, pp. 237-276. 
nómico), y por lo tanto resulte prematuro valorar sus efectos, ${ }^{31}$ observamos una coincidencia en las circunstancias que propician la implementación de este instrumento en España con las de la situación social mexicana, más extremas aún en términos de desigualdad y riesgo de exclusión y vulnerabilidad económica. Por todo ello, y porque la concurrencia con el estado español en cuanto a vocación de protección social se infiere de nuestros textos constitucionales y de la propia concepción del estado social democrático de derecho que compartimos, entendemos esta regulación como una fuente de inspiración para el potencial desarrollo en nuestro país de una institución jurídica semejante.

\section{EL DMV EN MÉXICO}

En este apartado abordamos el otro sujeto del estudio comparado: el tratamiento y regulación del DMV (y su consiguiente materialización en ingreso mínimo vital) en México. Para ello, analizaremos en primer lugar de qué manera este derecho encuentra acogida de forma innominada en nuestra Constitución; posteriormente, cómo se regula en algunas de las diferentes legislaturas estatales; para finalizar con el análisis de su alcance según los criterios de la Suprema Corte de Justicia de la Nación (SCJN).

\section{El DMVy la Constitución Política de los Estados Unidos Mexicanos (CPEUM)}

¿Se encuentra reconocido el DMV en nuestra carta fundamental? Aunque nuestra Constitución data de 1917 ha sido objeto de reforma en numerosas ocasiones, la más importante tuvo lugar en 2011 cuando se incorporó el nuevo paradigma de los derechos humanos. Mediante esta reforma se dejaron de considerar los derechos dentro del texto constitucional como garantías individuales, asignándose como derechos humanos, lo cual resulta un concepto más amplio y menos limitativo que el anterior. Además, la misma norma amplía el espectro de reconocimiento de derechos y su interpretación no sólo derechos establecidos en la norma

31 Debido a la inmediatez entre la aprobación de la medida y la redacción del artículo no disponemos de datos fácticos o jurisprudencia alguna para enriquecer nuestro análisis. 
fundamental, sino también en los tratados internacionales reconocidos por México; incluyendo también la posibilidad de interpretar los derechos fundamentales en materia de derechos humanos de forma exegética y teleológica, lo que implica terminar con la antigua teoría de que solamente los derechos enumerados dentro del texto de la ley son verdaderos derechos.

Decimos esto, porque según nuestro criterio el DMV en el marco constitucional es un derecho innominado, es decir: este derecho no aparece como tal enunciado en la CPEUM, pero si se puede deducir de la misma. Ahora bien, para comprenderlo es necesario analizar el texto constitucional de manera hermenéutica junto con las normas sobre derechos humanos aceptadas por México. Siguiendo la lógica de la norma, aunque los tratados internacionales no hagan mención literal de este derecho puede inferirse de igual forma de nuestra Constitución. Incluso partiendo desde la óptica que otros Estados ya lo han inferido de estos tratados se puede concluir que también es posible hacer lo mismo en nuestro país. El deducir o desprender de los tratados internacionales reconocidos por México o de los propios preceptos constitucionales el DMV es legítimo según el mandato constitucional. Queda claro que al tratarse de un derecho innominado manifiesta problemas sobre sus dimensiones, pero esto no le resta valor normativo: limitar un derecho por dicha problemática atenta contra el espíritu de la norma.

El primer parámetro para considerar al DMV como un verdadero derecho es el artículo primero constitucional. Las reglas para la interpretación jurídica que se instauran en este precepto, junto con las directrices y obligaciones que establecen apoyarían esta incorporación. Resultando que la interpretación de estas normas debe ser congruente con el principio pro persona, y en el caso que nos ocupa aplicar al concepto de dignidad humana la interpretación más favorable (CPEUM, art. 1o.).

Abundando en este sentido, debemos recordar que los derechos humanos son indivisibles, interdependientes, se implican los unos a los otros, y deben ajustarse teniendo en cuenta el principio de progresividad. En observancia de los principios rectores enunciados resulta lógico que para tener garantizada una protección real de la dignidad humana no se pueda apartar al individuo de los derechos que le permitan un desarrollo óptimo. Para que dicho desarrollo sea posible se requiere el goce real de las condiciones necesarias que le permitan el ejercicio, no solamente de un grupo

Esta obra está bajo una Licencia Creative Commons

Atribución-NoComercial-SinDerivar 4.0 Internacional, IIJ-UNAM.

Boletín Mexicano de Derecho Comparado, núm. 160, enero-abril de 2021, pp. 237-276. 
de derechos, sino de los derechos en general. En este caso el mínimo vital es el núcleo esencial para que los demás derechos puedan satisfacerse de acuerdo con los fines perseguidos al establecer la dignidad humana como una base y un fin en sí mismo.

Encontramos a lo largo de nuestro texto constitucional una serie de referencias en su parte dogmática que refuerzan esta óptica que proponemos.

El artículo 3o. de la CPEUM, aunque centrado principalmente en la educación, fija un principio que coincide con las bases y fines de un Estado social y democrático de derecho cuando en su fracción segunda inciso a establece que el sistema educativo "será democrático considerando a la democracia no solamente como una estructura jurídica y un régimen político, sino como un sistema de vida fundado en el constante mejoramiento económico, social y cultural del pueblo". Así pues, la vida democrática no puede ser ajena a los fenómenos sociales, económicos y culturales que afectan a los ciudadanos. Por lo que problemas como la pobreza, la marginación y las dificultades para acceder a los bienes primarios y al desarrollo adecuado afectan a la calidad de nuestra democracia y se encuentran en relación directa con el DMV y en su consolidación como derecho humano (J. F. González Salas, 2013).

El artículo 4o. de la CPEUM garantiza por parte de los poderes públicos distintos derechos de contenido social, económico y cultural, entre los que destacan el derecho a una "alimentación nutritiva, suficiente y de calidad"; el derecho a la protección a la salud; el derecho al "acceso, disposición y saneamiento de agua para consumo personal y doméstico en forma suficiente, salubre, aceptable y asequible"; y el derecho "a disfrutar de vivienda digna y decorosa". Todos ellos son derechos que incluyen, afectan, se relacionan y se engloban en el DMV.

El artículo 5o., aunque desde el enfoque de la libertad de trabajo o de actividad productiva, establece el derecho a una justa retribución. Este precepto debe interpretarse de forma relacionada con el artículo 123, ya que en él se perfeccionan los derechos de los trabajadores, entre ellos el salario mínimo. En este sentido, cabe destacar que el artículo 123 fija como principio la justicia social y la distribución equitativa de las riquezas, lo cual se encuentra reconocido en distintos ordenamientos internacionales, entre ellos la Carta Social de las Américas (Asamblea General de la OEA, 4/06/2012). 
Los artículos 25, 26, 27 y 28 de la CPEUM son de suma importancia para la aplicación por parte del Estado de los derechos económicos, sociales y culturales. En virtud que en ellos se fijan los principios de la economía nacional, y el papel del Estado frente a los sectores sociales y privados. Particularmente, el artículo 28, párrafo tercero, que suele identificarse por la prohibición de prácticas monopólicas, contiene ciertas obligaciones para proteger el consumo de artículos necesarios y fija bases para proteger a las personas en general el acceso a los productos y artículos de consumo necesario. Por otra parte, el artículo 31 enumera las obligaciones de los ciudadanos mexicanos, y en su fracción IV contiene las de carácter fiscal. Las contribuciones deben satisfacer dos condiciones: que sean proporcionales y equitativas, además de cumplir con el principio de legalidad. Por lo tanto, las contribuciones para ser consideradas constitucionales deben tomar en cuenta la capacidad contributiva de los individuos, lo que en relación con el DMV se referiría a la afectación o la disminución del patrimonio o capital de los gobernados. La norma constitucional establece la obligación de contribuir, pero también establece limitantes. Otro principio que se deriva de la interpretación de este precepto, según lo fijo la SCJN, es la razonabilidad tributaria que consiste en que el tributo sea razonable con la finalidad que perseguida (S. F. de la Garza, 2008). Esto con la finalidad de dar coherencia a las contribuciones que fije el Estado, las cuales deben respetar los derechos de los contribuyentes.

De este modo, observamos como la CPEUM se configura como un texto plagado de referencias constitucionales en las que anclar este reconocimiento como derecho innominado del DMV por el que abogamos. Nuestra carta magna se encuentra trufada de menciones y enumeraciones de la mayor parte de las prerrogativas que componen el DMV según su concepción en el ámbito internacional. Interpretar la misma a la luz de las diversas normas internacionales de los que el Estado mexicano constituye una obligación y un compromiso adoptado por nuestra Constitución.

\section{Reconocimiento del DMV en el ámbito estatal}

$\mathrm{Al}$ estructurarse México como un Estado de tipo federal, nuestro sistema normativo comprende también la multitud de regulaciones que se desarrollan en las 32 entidades federativas. Por ello, ahora dedicamos 
nuestra atención al modo en el que el objeto de nuestro estudio ha sido abordado por algunas de las constituciones locales.

En este ámbito podemos encontrar aportaciones de elementos para la conceptualización e incorporación del DMV dentro del marco normativo de nuestro país. Es importante puntualizar que los órdenes jurídicos de las entidades federativas, por los principios del pacto federal y supremacía constitucional deben respetar la Constitución federal. Por ende, las constituciones y las autoridades locales deben respetar este compromiso de cumplimiento de las normas sobre derechos humanos. Pero es que, además, las constituciones locales pueden ampliar o especificar con mayor detalle los derechos humanos y las obligaciones para las autoridades tanto estatales como municipales, así como extender la protección a los derechos humanos en toda aquella materia que no se encuentre de forma exclusiva para la competencia federal.

En efecto, el cambio de garantías individuales a derechos humanos no se ha reducido al ámbito federal, y su asimilación no ha sido de forma homogénea, como expone Juan Manuel Acuña:

A nivel local, y desde hace unos años, inició un proceso análogo, aunque asimétrico, respecto al proceso federal. Algunos estados reformaron sus Constituciones para robustecer el catálogo de derechos e incorporar mecanismos de justicia constitucional local. (2015, pp. 1-15)

En estas circunstancias, lo que las constituciones locales pueden aportar para el derecho al mínimo existencial, varía según la entidad federativa. En la mayoría de las constituciones estatales el DMV sigue siendo un derecho innominado al igual que en la Constitución federal. Aun así, algunas constituciones locales establecen de forma más detallada la adopción y cumplimiento de los derechos sociales.

Dadas las limitaciones de extensión que este artículo plantea, sumadas al inmenso número de constituciones locales (32) excede por mucho de nuestro propósito llevar a cabo un análisis pormenorizado de cada una de ellas. Por eso, hemos seleccionado, a nuestro juicio, la más relevante: Ciudad de México, como la más avanzada y explícita.

Dentro de su carta de derechos (correspondiente con su título primero), y en su capítulo II dedicado a los derechos humanos, la Constitución Política de la Ciudad de México (CPCDMX), dispone en su artículo 9.1 
denominado "Ciudad solidaria" como parte del derecho a la vida digna que "las autoridades adoptarán las medidas necesarias para que progresivamente se erradiquen las desigualdades estructurales y de pobreza", con el fin de conseguir una "justa distribución de la riqueza y del ingreso entre personas, familias, grupos sociales y ámbitos territoriales". Específicamente el artículo 9.2 reconoce de modo explícito el DMV con la siguiente redacción: "Todas las personas tienen derecho a un mínimo vital para asegurar una vida digna en los términos de esta Constitución". Dicho artículo además agrega en su apartado tercero que se garantizaran los derechos progresivamente "hasta el máximo de los recursos públicos disponibles".

En su artículo 17 sobre el "Bienestar social y economía distributiva" la CPCDMX plantea algunas obligaciones y principios que deben seguir las autoridades para regir la vida social y económica. Resulta destacable el hecho de incorporar en dicho precepto el concepto de Estado social y democrático como aspiración. En su apartado A, dedicado a la política social, refiere lo siguiente sobre el DMV:

Se establecerá y operará un sistema general de bienestar social, articulado, incluyente, participativo y transparente vinculado a la estrategia de desarrollo redistributivo, al que concurrirán las instancias encargadas de las materias correspondientes. El sistema considerará al menos los siguientes elementos: (...) Los mecanismos para hacer efectivo el derecho al mínimo vital para una vida digna, dando prioridad a las personas en situación de pobreza, que se establecerán de conformidad con los criterios de progresividad, con los indicadores que determine el organismo constitucional federal competente y las metas evaluables que fije el organismo local correspondiente (...).

En este inciso pues, la CPCDMX establece el mínimo vital como un derecho universal, proponiendo otorgar prioridad a las personas en estado de pobreza. Es preciso apuntar que el texto en cuestión establece varios indicadores, pero no ofrece una definición limitada o exacta de qué es el mínimo vital. Esto empuja a que la comprensión de la dimensión teleológica de este derecho sea indispensable para su debida aplicación, y del mismo modo podemos entenderlo también como un mayor margen para ejercer su aplicación. Con la inclusión de los aspectos señalados, la CPCDMX se muestra como el mejor ejemplo del reconocimiento e in-

Esta obra está bajo una Licencia Creative Commons

Atribución-NoComercial-SinDerivar 4.0 Internacional, IIJ-UNAM.

Boletin Mexicano de Derecho Comparado, núm. 160, enero-abril de 2021, pp. 237-276. 
corporación del DMV, no en vano se trata de uno de los textos más avanzados y modernos en lo que a derechos sociales se refiere.

En definitiva, el marco normativo local no es ni mucho menos idéntico en cuanto a la regulación de los derechos humanos en general ni por supuesto del DMV en particular. El margen de creación y adaptación normativo estatal no suele aprovecharse o entenderse de la misma forma. Las constituciones locales pueden ser vistas como instrumentos para hacer palpable el reconocimiento a los derechos esenciales a un nivel de interacción más cercano a la población, encontrando su máximo exponente en la CPCDMX que tan inspiradora puede resultar para una regulación federal a estos efectos.

\section{El DMV según los criterios de la $S 7 C \mathcal{N}$}

La SCJN es el más alto tribunal de nuestro país, el cual ejerce el control concentrado para resolver las controversias que existan en torno a las leyes, y su interpretación de acuerdo con la carta fundamental, marcando la pauta por la que se regirán el resto de las instancias jurisprudenciales.

La evolución en torno al reconocimiento del mínimo vital despunta a partir de la reforma constitucional del 2011. El DMV no aparece explícitamente en nuestro texto constitucional, por lo que los tribunales mexicanos deben partir de la interpretación para incorporarlo a nuestro régimen jurídico. Es oportuno señalar que en la actualidad la SCJN no ha emitido una tesis de jurisprudencia que defina al mínimo vital. Existen, sin embargo, tesis jurisprudenciales donde se menciona el mínimo vital y por tanto colaboran para establecerlo en el sistema jurídico. No obstante, se pueden encontrar tesis aisladas que han dado dimensiones y definiciones para comprender este concepto, y en base en estas se han pronunciado las jurisprudencias mencionadas.

Tempranamente, en 2007, encontramos que la Primera Sala de la SCJN realizó una definición del DMV en la tesis aislada 1a. XCVII/2007 (Gaceta del Seminario Fudicial de la Federación. Décima Época). Dicha tesis señala que el mínimo vital "cobra plena vigencia de la interpretación sistemática de los derechos fundamentales", haciendo énfasis en que en un Estado democrático de derecho se requiere que los individuos cuenten con un punto de partida para desarrollar un plan de vida autónoma. Esto 
guarda similitud con lo propuesto por E. Carmona Cuenca (2012), al vincular el Estado democrático con que el ciudadano cuente con un mínimo vital a partir del cual pueda realmente emprender un desarrollo autónomo. La Primera Sala agrega que para que el individuo pueda llevar una vida libre del temor y la miseria, el Estado debe tomar tanto las medidas que sean necesarias, fijándose la necesidad de evitar que el ser humano se vea reducido inconstitucionalmente en su dignidad por no contar con las condiciones materiales que le permitan una vida digna. Esta tesis con nombre "Derecho al mínimo vital en el orden constitucional mexicano" menciona que este derecho humano resulta particularmente de la interpretación de los artículos 1o., 3o., 4o., 6o., 13, 25, 27, 31 fracción IV y 123.

Con ocasión del foro "Derechos Fundamentales de las Personas Físicas Contribuyentes" (E. Carmona Cuenca, 2012), el ministro José Fernando Franco González Salas trató junto con otros juristas, el DMV (aunque enfocándose dentro del ámbito fiscal), ofreciendo una aproximación a su significado de la cual cabe destacar lo siguiente:

No debe perderse de vista que todas las acciones directas destinadas a satisfacer el mínimo vital de todos los mexicanos requieren de la disposición de los recursos necesarios y que la vía de las exenciones o deducciones tributarias, siendo probablemente muy efectivas para lograr ese objetivo, no son las únicas. El Estado también lo hace a través de los servicios de salud, educación, alimentación, becas y subsidios de diferentes tipos, que implican la erogación de enormes cantidades de dinero que provienen del erario, que se conforma principalmente con los impuestos que pagamos.

De la forma en que se planteó, observamos que el mínimo vital se cumplimenta por medio de diferentes servicios y prestaciones.

En 2009 se incorporó al sistema de tesis el concepto de mínimo exento como una forma de exceptuar de las cargas tributarias a los contribuyentes tomando como referencia la esencia del mínimo vital. Inclusive considerándose como equivalentes o sinónimos ambos conceptos. En cuanto a este mínimo exento de todo gravamen la Primera Sala (Tesis 1a. XVI/2009 sostuvo que es aplicable para aquellos que no cuentan con una capacidad contributiva suficiente, de la siguiente forma:

[...] en razón de que la capacidad económica trasciende a la configuración de dicho mecanismo liberador de pago únicamente en los casos de aquellos

Esta obra está bajo una Licencia Creative Commons

Atribución-NoComercial-SinDerivar 4.0 Internacional, IIJ-UNAM.

Boletín Mexicano de Derecho Comparado, núm. 160, enero-abril de 2021, pp. 237-276. 
causantes que no tienen la capacidad idónea para soportar la imposición que solamente se legitima constitucionalmente cuando la persona supera el nivel del mínimo vital o mínimo exento. (Tesis 1a. X/2009. Gaceta del Semanario fudicial de la Federación. Novena Época, p. 547)

En esta tesis se dispuso que el principio de generalidad tributaria tiene como fin que todas las personas sin distinción aporten al gasto público. Aun así, no debe entenderse que no se tengan excepciones, en este caso el mínimo vital, ya que se debe partir de la capacidad real para contribuir, destacando entre otros aspectos que la dignidad humana prevé que se cuente con un punto de partida para alcanzar un plan de vida autónoma. Esta protección deriva del hecho que las personas cuyos ingresos apenas resulten suficientes para subsistir no deberían verse requeridas a hacer aportaciones, ya que esto "agravaría su ya precaria situación". Conforme a esta tesis se puede apreciar que el mínimo vital está ligado tanto a la dignidad humana, incluso desde un punto de vista económico, como con los principios de solidaridad.

La primera tesis jurisprudencial, con carácter obligatorio que se incorporó en el Semanario fudicial de la Federación y su Gaceta haciendo mención literal del mínimo vital fue en materia tributaria. Esta jurisprudencia fue dictada por la Primera Sala, sosteniendo que la proporcionalidad tributaria debe observarse en relación con la capacidad contributiva atendiendo como limite el mínimo vital. La tesis jurisprudencial 1a./J. 77/2011 (Gaceta del Seminario Fudicial de la Federación. Novena Época) que lleva por nombre: "Proporcionalidad tributaria. El legislador cuenta con un margen amplio de configuración, al definir tasas y tarifas" menciona que "los principios constitucionales de la materia tributaria no permiten asumir que exista un sistema de tasas o tarifas justas per se". Podemos concluir que estas tarifas gozan de validez al cumplir con el principio de legalidad, proporcionalidad y equidad, pudiendo existir tarifas distintas siempre y cuando no se agote el patrimonio del causante y no afecte el mínimo vital.

Por otra parte, el mínimo vital también ha aparecido en resoluciones de la SCJN en materia de seguridad social, concretamente en materia de deducciones y disminuciones sobre las pensiones, jubilaciones y otras formas de retiro. En virtud de una tesis aislada (Tesis P. XXXIX/2013. Gaceta del Semanario Judicial de la Federación. Décima Época) derivada del amparo 
en revisión 32/2011 el Pleno de la SCJN se pronunció sobre las deducciones a diversas formas de retiro, donde tomó como referencia el mínimo vital, sosteniendo que las deducciones realizadas en apego a la Ley del Impuesto sobre la Renta vigente hasta mayo de 2012 no eran contrarias al DMV y respetaban el artículo 31, fracción IV constitucional, ya que dicha ley establecía una exención al pago del impuesto hasta por un monto diario de nueve veces el salario mínimo., considerando esta cantidad suficiente para no violentar el mínimo de subsistencia. ${ }^{32}$

En otra tesis aislada (Tesis P. XXXVII/2013. Gaceta del Semanario Judicial de la Federación. Décima Época) emitida por el Pleno se resolvió en el mismo sentido sobre la exención comentada de la Ley del Impuesto sobre la Renta abrogada, pero haciendo hincapié en artículo 123 aparado A y $B$ en lo relativo a la inembargabilidad del salario mínimo y su relación con las contribuciones y apuntando que la prohibición constitucional de embargar el salario mínimo no se hace extensiva a las prestaciones del retiro. De igual forma señaló que se respetaba un margen de ingresos libre de gravámenes para satisfacer las necesidades más elementales caracterizado como DMV.

El Pleno de la Suprema Corte en la tesis P. VII/2013 (Gaceta del Semanario Fudicial de la Federación. Novena Época) manifestó que el mínimo vital se ha reconocido como un derecho derivado del artículo 31 fracción IV y también como una prerrogativa de no embargabilidad del salario derivado del artículo 123. Aun así, el mínimo vital también abarca un conjunto de medidas negativas y positivas a cargo del Estado, que permitan respetar la dignidad humana en términos del artículo 25 constitucional, referente al desarrollo nacional, por lo que el Estado se encuentra obligado a garantizar la disponibilidad de prestaciones de "procura existencial o asistencia vital".

Por otro lado, el DMV en relación con la materia penitenciaria fue abordado en una acción de inconstitucionalidad. El Pleno de la Suprema Corte dictó una tesis jurisprudencial identificada con el número P./J. 35/2013 (Gaceta del Semanario Fudicial de la Federación. Décima Época), sosteniendo que la Ley que Establece Normas Mínimas sobre Re-

32 Finalmente es oportuno aclarar que la Ley del Impuesto sobre la Renta de 2016 y vigente establece otra cantidad en el artículo 93, fracción IV, siendo de quince veces el salario mínimo el monto exento.

Esta obra está bajo una Licencia Creative Commons

Atribución-NoComercial-SinDerivar 4.0 Internacional, IIJ-UNAM.

Boletín Mexicano de Derecho Comparado, núm. 160, enero-abril de 2021, pp. 237-276. 
adaptación Social de Sentenciados ${ }^{33}$ actualmente abrogada, violentaba el mínimo vital en su artículo 10 párrafo segundo. En otra jurisprudencia derivada de la misma acción de inconstitucionalidad, el Tribunal Pleno se pronunció de nuevo sobre el mínimo vital en relación con el descuento a los reclusos para cubrir su sostenimiento realizado a la cantidad recibida por su trabajo penitenciario (P./J. 30/2013. Gaceta del Semanario Fudicial de la Federación. Décima Época).

La Segunda Sala de la Suprema Corte (2014) también decidió sobre el DMV en materia de trabajo, al resolver sobre la embargabilidad del salario derivado de la contradicción de tesis $422 / 2013,{ }^{34}$ en observancia de las normas protectoras del salario, dictaminando una protección sobre el mínimo vital. ${ }^{35}$

En resumen, observamos como la SGJN ha dictado diversas tesis vinculadas al mínimo vital enfocado en diferentes materias. También los tribunales colegiados han resuelto cuestiones importantes en materia del mínimo vital. ${ }^{36}$ El hecho de que la jurisprudencia en torno al DMV se haya desarrollado más en determinadas materias no priva de que la protección constitucional al mínimo vital pueda ampliarse y fijar su alcance y límites, algo que estamos seguros de que sucederá como consecuencia de la interpretación evolutiva y progresiva de los derechos humanos.

33 Publicada en el DOF el 19-05-1971, abrogada en el DOF 16-06-2016.

34 Tesis: 2a./J. 42/2014. Gaceta del Semanario Fudicial de la Federación. Décima Época.

35 En este caso dictaminó que las autoridades jurisdiccionales pueden ordenar el embargo sobre el excedente del salario mínimo. Siendo posible el embargo sobre el treinta por ciento de este excedente, tratándose de obligaciones de carácter civil o mercantil, a excepción de los casos en que se ordene el embargo por parte de una sentencia para asegurar una pensión alimenticia, en cuyo caso puede ser sobre el total del excedente del salario mínimo. Ahora bien, consideró que, para asegurar el mínimo vital de un trabajador, si el salario se encuentra afectado por una pensión alimenticia, sólo puede embargarse por otra deuda sobre el treinta por ciento del salario mínimo que no se encuentra afectado.

36 Destaca la del Noveno Tribunal Colegiado en Materia Administrativa del Primer Circuito: Tesis I.9o.A.1 CS. 2016. Gaceta del Semanario fudicial de la Federación. Décima Época.

Donde al interpretar la tesis emitida por la Primera Sala del alto tribunal constitucional, "Derecho al mínimo vital en el orden constitucional mexicano", se resuelve que el mínimo vital está dirigido a las personas físicas. 


\section{CONCLUSIÓN: UNA APUESTA POR LA IMPLEMENTAGIÓN DEL DMV EN MÉXICO}

Hemos observado que el DMV se manifiesta como la sublimación de los derechos humanos de segunda generación, en concreto se erige en epitome de los derechos sociales. Pero la cuestión aquí está en dilucidar si lo hace configurándose como culminación del desarrollo de los derechos humanos económicos, sociales y culturales, o si lo hace a modo de paraguas que contuviese los más básicos de estos derechos (salud, educación, vivienda, alimentación, entre otros) para proporcionarles una especial protección y blindaje. Esto es, si el DMV debe considerarse como un derecho en exclusiva, con un reconocimiento específico, o si es un referente innominado que da cobijo a estos citados derechos que se entienden como "mínimo".

Nuestra postura tiende a ser bastante holística, pero nos decantamos por el reconocimiento del DMV como un derecho independiente y concreto. No obviamos su esencia compleja y poliédrica, más entendemos que el verdadero avance surge al dotar a este derecho de una identidad propia que propicie su materialización efectiva la cual implique su justiciabilidad. Compartimos su doble naturaleza, pero ponemos el acento en las condiciones que garantizan su exigibilidad ante los poderes públicos.

Para todo aquel Estado que se defina a sí mismo como un Estado social y de derecho, la exigibilidad de los derechos humanos por el garantizados es un mínimo ligado inherentemente a su propio ser., deviniendo pues en una obligación fundamental de los Estados asegurar su cumplimiento, y también un parámetro de observancia del cumplimiento de las normas internacionales a las que se encuentre suscrito. México se cuenta entre los Estados que han firmado y ratificado el Pacto Internacional de Derechos Económicos Sociales y Culturales, el cual reconoce y protege estos derechos humanos, entendidos igualmente como indispensables para el ejercicio de otras categorías de derechos humanos por su carácter indivisible. Así pues, es posible concluir que la exigibilidad del DMV es además una forma de hacer efectiva la reclamación de otros derechos humanos. 
En 2018 el Comité de Derechos Económicos Sociales y Culturales realizó unas observaciones a México ${ }^{37}$ derivado de los informes presentados por nuestro país, y aunque se reconocieron aspectos positivos en defensa de estos derechos, también se señalaron varias preocupaciones relativas a la justiciabilidad de los mismos. Entre ellas destaca las "dificultades para acceder a recursos judiciales efectivos", por lo que recomienda tomar las medidas necesarias para hacer exigibles estos derechos en todos los niveles de nuestro sistema judicial. En materia fiscal el Comité recomendó al Estado mexicano aumentar los esfuerzos para lograr una política fiscal más equitativa desde un enfoque social que le permita asegurar recursos necesarios para lograr de acuerdo con el principio de progresividad la efectividad de los derechos económicos, sociales y culturales. En cuanto a la aplicación del presupuesto, debe implementarse y formularse de manera que garantice a todos los individuos los derechos en cuestión, en especial los desfavorecidos y marginados. En materia de seguridad social indicó que se deben continuar los esfuerzos por conseguir una protección social universal, y que dicha protección social incluya "garantías sociales universales esenciales". El Comité también dio recomendaciones para efecto de combatir la pobreza: solicitó que se establezcan metas específicas y se implementen mecanismos de coordinación entre las instituciones, así como que los programas sociales de lucha contra la pobreza sean acordes a los principios de los derechos humanos, y que deben contar con los recursos suficientes para efectuar su exigibilidad. En materia de trabajo, se agregaron diligencias sobre el salario mínimo, salud, la economía informal o el acceso y saneamiento de agua. Pero, ante todo, es importante señalar que se exhortó a nuestro país para a ratificar el Protocolo Facultativo del Pacto Internacional de Derechos Económicos, Sociales y Culturales.

En la actualidad, y como respuesta a los efectos económicos adversos causados por la pandemia, la CEPAL también ha propuesto que se distribuya un ingreso básico temporal de emergencia y un bono contra el hambre durante seis meses para combatir el problema de la pobreza extrema generada por el COVID-19. (CEPAL, 2020)

37 Observaciones finales a los informes periódicos quinto y sexto combinados de México. 28 Sesión del Comité de Derechos Económicos, Sociales y Culturales de la ONU, 29 de marzo de 2018. 
Atendiendo a estas observaciones, y como herramienta de solución de estas deficiencias, proponemos la regulación en México del DMV en un modo similar al adoptado por España: mediante la implementación del IMV. A nuestro juicio, resulta más factible, equilibrador de desigualdades y justa la implementación del IMV en lugar de la RBU Afirmamos esto en base a las razones aportadas en el apartado correspondiente que pueden resumirse en una concepción social de lo público frente a la redistribución igualitarista liberal. Para nosotros, el único instrumento que garantiza el desarrollo del DMV es el IMV.

Venimos de contemplar como en el país europeo (con el que nos vemos unidos a través de fuertes lazos y similitudes, entre ellas una semiótica social y jurídica común) el IMV ha sido concebido como un instrumento de satisfacción de unas condiciones materiales mínimas que desencadene la transición de aquellos que se encuentran en un escenario de exclusión social, hacia otro en la que se puedan desarrollar con plenitud en la vida social y económica, rompiendo el vínculo entre ausencia estructural de recursos y falta de acceso a oportunidades. El DMV se configura no sólo como una política dirigida a grupos concretos en situación de vulnerabilidad extrema, sino como una forma de protección estructural de la sociedad en su conjunto (Real Decreto-ley 20/2020, preámbulo, punto III). Si bien todavía carecemos de datos suficientes como para poder llevar a cabo una crítica completa de la experiencia española, en nuestra humilde opinión entendemos que, dadas las circunstancias actuales, se presenta la ocasión perfecta para abrir el debate, y tomar la experiencia española como referencia puede ser un buen punto de partida.

En la reciente reforma de la constitución local de Ciudad de México, se ha incluido el DMV. Es el momento de emprender el mismo camino a nivel federal.

\section{FUENTES}

ACUÑA, J. M. (2015). Constitucionalismo local, federalismo judicial y derechos humanos. En Héctor FIX-Fierro, Miguel CARbonell y Diego VALADÉS (coords.), Estado constitucional, derechos humanos, justicia y vida universitaria. Estudios en homenaje a Forge Carpizo. Derechos humanos, vol. 1, (pp. 1-15). México: UNAM, Instituto de Investigaciones Jurídicas. 
Guttman, A. (2003). En Taylor, C. El multiculturalismo y la política del reconocimiento. Fondo de Cultura Económica.

Carmona Cuenca, E. (2017). El derecho al mínimo vital y el derecho a la renta básica. Anuario de Derechos Humanos, 199-209.

Carmona Cuenca, E. (2012). El derecho a un mínimo vital con especial referencia a la Constitución Española de 1978. Estudios Internacionales, 61-85.

DuQue Quintero, S. P., Duque Quintero, M. y González Sánchez, P. (2019). Sobre el derecho fundamental al mínimo vital o a la subsistencia: análisis jurisprudencia. Encuentros, 17(1), pp. 80-95.

Espinoza de los Monteros, J. (2013). Los desafios del constitucionalismo social del siglo XXI. En César Astudillo Reyes y Jorge Carpizo (coords.), Constitucionalismo. Dos siglos de su nacimiento en América Latina (pp. 375-391). México: UNAM, Instituto de Investigaciones Jurídicas.

Ferrajoli, L. (2011). Principia iuris. Teoría del derecho y de la democracia. Trotta.

Gala DurÁn, C. (2020). Los desafíos del nuevo ingreso mínimo vital. IUSLabor. Revista d'anàlisi de Dret del Treball (2), 1-4.

GarZA, S. F. de la (2008). Derecho financiero mexicano. Porrúa.

Goerlich Gisbert, F. (2016). Distribución de la renta, crisis económica y politicas redistributivas. Fundación BBVA.

GOnZÁlez SALAS, J. F. (2013). Derechos fundamentales de las personas físicas contribuyentes. Memorias del Foro: "Derechos Fundamentales de las Personas Físicas Contribuyentes". CDMX.

InDACOECHEA PREVOST, Ú. (2011). El derecho al mínimo vital. Un análisis de su posible fundamentación como derecho humano. En P. GRANDÉZ, El derecho frente a la pobreza. Los desafios éticos del constitucionalismo de los derechos (pp. 259, 265, 266 y 283).

MARTíNEZ VIRTO, L. (2019). Nueva pobreza, precariedad y rentas mínimas: respuestas para incentivar el empleo en el actual contexto sociolaboral. Cuadernos de Relaciones Laborales (37), 155-175.

Monereo PÉrez, J. L. y RodríGuez Iniesta, G. (2020). El derecho social fundamental a la existencia digna y el ingreso mínimo vital. Revista de Derecho de la Seguridad Social. Laborum (24), 13-35.

Pelayo Möller, G. M. (2012). El "mínimo vital” como estándar para la justiciabilidad de los derechos económicos, sociales y culturales. $R e^{-}$ vista Electrónica Méthodos (3). 
Pérez González, E. y Nettel Barrera, A. (2017). El derecho al mínimo vital frente a la inactividad administrativa en la protección a los derechos humanos. Revista Digital de Derecho Administrativo, 317-337.

Petit Guerra, L. A. (2019). ¿En qué estado del debate se encuentra la jurisprudencia latinoamericana en cuanto al desarrollo del derecho al mínimo vital? Entre la vanguardia y la retaguardia. Revista furídica Derecho, 8(10), 56-67.

Ramos Quintana, M. I. (2020). El ingreso mínimo vital como instrumento para combatir la pobreza y la exclusión desde el sistema de la seguridad social. Hacienda Canaria (53), 295-319.

RAWLS, John (1971). Teoría de la justicia (2e. ed.), trad. de M. D. González. The Belknap Press of Harvard University Press.

REY PÉREZ, J. L. (octubre 2020-marzo 2021). Renta básica universal. Eunomía: Revista en Cultura de la Legalidad (9), 237-257.

Rodríguez Camarena, C. (2014). La exigibilidad de los derechos sociales a partir de su estructura. Ciencia furídica, 3(6), 52.

Rosales García, C. M. (2016). Reconociendo y comprendiendo la naturaleza del mínimo vital. Criterio furídico, 16(2), 113-140.

Sala Franco, T. y Martín-POzUelo López, Á. (2020). El ingreso mínimo vital. El sistema español de rentas mínimas. Tirant lo Blanch.

Silva MezA, J. (2014). El derecho al mínimo vital: su contenido y relevancia. En Magdalena Cervantes AlCAYde et al. ¿Hay justicia para los derechos económicos, sociales y culturales? Debate abierto a propósito de la reforma constitucional en materia de derechos humanos (pp. 213-240). México: UNAM-Suprema Corte de Justicia de la Nación.

Tena Camporesi, A. (2018). La renta básica universal basada en la evidencia. Política y Sociedad, 55(13), 851-871.

VAN PARIJS, P. (1996). Libertad real para todos (qué puede justificar el capitalismo si hay algo que pueda hacerlo). Paidós.

VAn PARIJS, P. (2001). Basic Income: a Simple and Powerful Idea for the 21 st Century. Politics E Society, 32(1), 7-39.

Van Parijs, P. (2020). Basic income: Finland's final verdict. Social Europe. https://wrere.socialeurope.eu/basic-income-positive-results-from-finland

WALZER, M. (1983). Spheres of justice: A defense of pluralism and equality. Blackwell. Trad. cast. (1991). Las esferas de la justicia. una defensa del pluralismo y la igualdad. Fondo de Cultura Económica. 


\section{Criterios judiciales}

Sentencia 37/1994 del Tribunal Constitucional de España.

Tesis 1a. X/2009. Gaceta del Semanario fudicial de la Federación. Novena Época.

Tesis 1a. XVI/2009. Gaceta del Semanario Fudicial de la Federación. Novena Época.

Tesis 1a./J. 77/2011. Gaceta del Semanario Judicial de la Federación. Novena Época.

Tesis aislada 1a. XCVII/2007. Gaceta del Semanario Fudicial de la Federación. Novena Época.

Tesis I.9o.A.1 C.S. Gaceta del Semanario fudicial de la Federación. Décima Época.

Tesis P. VII/2013. Gaceta del Semanario Judicial de la Federación. Novena Época.

Tesis P. XXXIX/2013. Gaceta del Semanario Judicial de la Federación. Décima Época.

Tesis P. XXXVII/2013. Gaceta del Semanario Fudicial de la Federación. Décima Época.

Tesis P./J. 30/2013. Gaceta del Semanario Fudicial de la Federación. Décima Época.

Tesis P./J. 35/2013. Gaceta del Semanario Fudicial de la Federación. Décima Época.

Tesis: 2a./J. 42/2014. Gaceta del Semanario Fudicial de la Federación. Décima Época.

Legislación

Carta Social de las Américas, 2012, Asamblea General de la OEA.

Constitución Española 1978.

Constitución Política de la Ciudad de México, 2020.

Constitución Política de los Estados Unidos Mexicanos, 1917 (2020).

Declaración Universal de los Derechos Humanos, 10 de septiembre de 1948, Asamblea General de Naciones Unidas.

Observaciones finales a los informes periódicos quinto y sexto combinados de México. 28 Sesión del Comité de Derechos Económicos, Sociales y Culturales de la ONU, 29 de marzo de 2018. 
Asamblea General de Naciones Unidas (1966). Pacto Internacional de Derechos Económicos, Sociales y Culturales.

Principio 14 del Pilar Europeo de Derechos Sociales, Cumbre social en favor del empleo justo y el crecimiento, Gotemburgo, noviembre de 2017. Real Decreto-ley 20/2020, del 29 de mayo, por el que se establece el ingreso mínimo vital, España.

Resolución del Parlamento Europeo del 24 de octubre de 2017, sobre las políticas encaminadas a garantizar la renta mínima como instrumento para luchar contra la pobreza.

Otros

Declaración del Relator Especial de las Naciones Unidas sobre la extrema pobreza y los derechos humanos, Philip Alston, sobre la conclusión de su visita oficial a España, 27 de enero-7 de febrero de 2020.

CEPAL. Estudio Económico de América Latina y el Caribe 2020: principales condicionantes de las políticas fiscal y monetaria en la era pospandemia de COVID-19. 


\title{
TENDENGIAS POLÍTICO-CRIMINALES FRENTE A LA TRATA DE PERSONAS Y SUS CONSEGUENGIAS TÍPICAS*
}

\author{
POLITICAL-CRIMINAL TRENDS WITH REGARD TO HUMAN \\ TRAFFICKING AND ITS TIPICAL CONSEQUENCES
}

\section{Clara MOYA GUILLEM**}

REsumen: En 2020 se ha cumplido el vigésimo aniversario del Protocolo de Palermo contra la trata de personas. Desde su aprobación, y especialmente en los últimos diez años, son muchos los países que han tipificado penalmente este fenómeno o han reformado su regulación en este ámbito. Entre ellos se encuentran los Estados cuyas legislaciones conforman el objeto de la primera parte del trabajo: Alemania, Argentina, Chile, Colombia, España, Francia, Italia, México, Reino Unido y Uruguay. Sin embargo, a pesar de haber firmado y ratificado todos ellos este instrumento normativo internacional, no se ha alcanzado la pretendida armonización legislativa. Por el contrario, se pueden distinguir hasta cuatro tendencias político-criminales distintas con importantes repercusiones en la determina-
ABSTRACT: 2020 was the twentieth anniversary of the Palermo Protocol against trafficking in human beings. Since its approval, and especially in the last ten years, many countries have criminalized this phenomenon or have reformed its regulation in this area. Among them are the States whose laws constitute the object of the first part of this work: Argentina, Chile, Colombia, France, Germany, Italy, Mexico, Spain, the United Kingdom and Uruguay. However, despite the fact that all of them have signed and ratified this international normative instrument, the purported legislative harmonization has not been achieved. On the contrary, up to four different political-criminal trends with important impacts on the determination of the protected legal right and the second part of this work is dedicated to them.

* Registrado el 16 de junio de 2020; aprobado el 2 de febrero de 2021.

La realización de este trabajo se enmarca en el proyecto de investigación "Manifestaciones de desigualdad en el actual sistema de justicia penal: examen crítico de las razones de necesidad, oportunidad y peligrosidad para la diferencia (EQUALITAS)" financiado por Ministerio Español de Ciencia, Innovación y Universidades (RTI2018-096398-B-I00), dirigido por el catedrático Antonio Doval Pais.

** ORCID: 0000-0002-1791-8323. Profesora de Derecho penal y vicedecana de Criminología de la Facultad de Derecho de la Universidad de Alicante; magistrada suplente de la Audiencia Provincial de Alicante. Correo electrónico: clara.mg@ua.es.

Boletín Mexicano de Derecho Comparado, nueva serie, año LIV, núm. 160, enero-abril de 2021, pp. 277-307.

Esta obra está bajo una Licencia Creative Commons Atribución-NoComercial-SinDerivar 4.0 Internacional, IIJ-UNAM. 
ción del bien jurídico protegido a las que se dedica la segunda parte del trabajo.

Palabras clave: trata de personas, Protocolo de Palermo, consentimiento, explotación, bien jurídico protegido.
Key words: trafficking in persons, Palermo Protocol, consent, exploitative, protected legal right.

\begin{abstract}
Sumario: I. Introducción. II. El Protocolo de Palermo. III. La tipificación penal de la trata de personas en el derecho comparado. IV. Tendencias políticocriminales frente a la trata de personas. V. Consecuencias típicas. VI. Conclusiones.

VII. Bibliografia.
\end{abstract}

\title{
I. INTRODUCCIÓN
}

El Protocolo para prevenir, reprimir y sancionar la trata de personas, especialmente mujeres y niños (en adelante, Protocolo de Palermo), que complementa la Convención contra la delincuencia organizada transnacional, aprobado en el 2000 y suscrito por un total de 176 países, exige la criminalización de la trata de personas (arts. 3o. y 5o.). Por esta razón, entre otras, este fenómeno criminal está tipificado como un ilícito penal en la práctica totalidad de los Estados. Según el último Global report on trafficking in persons de la United Nations Office on Drugs and Crime (UNODG), publicado en 2018, casi en $90 \%$ de los 179 países participantes en el informe lo contemplan.

Sin embargo, para alcanzar los objetivos fijados en dicho instrumento normativo los Estados parte no sólo deben incorporar el delito de trata de personas a sus respectivas legislaciones, sino que deben hacerlo en términos equivalentes a los contenidos en la norma internacional, tal y como recomiendan las Model legislative provisions against trafficking in persons de la propia UNODG (2020). Esto se debe a que la armonización de las normas domésticas, especialmente en el ámbito de la delincuencia transnacional, desempeña un papel fundamental, puesto que la fragmentación dificulta la consecución del objetivo de asistencia mutua en los asuntos penales (Ana Valverde Cano, 2019, p. 21) y crea espacios de impunidad.

La hipótesis de la que parte la presente investigación es que, pasados ya más de veinte años desde la aprobación del Protocolo de Palermo y considerando el gran respaldo que consiguió, todos los países que lo han firmado y ratificado han incorporado a sus respectivas legislaciones

Esta obra está bajo una Licencia Creative Commons

Atribución-NoComercial-SinDerivar 4.0 Internacional, IIJ-UNAM.

Boletín Mexicano de Derecho Comparado, núm. 160, enero-abril de 2021, pp. 277-307. 
el delito de trata de personas en los términos establecidos en este instrumento jurídico internacional.

Para confirmar esta hipótesis o rechazarla (total o parcialmente) en este trabajo, en primer lugar, se identifican y examinan los tres elementos que componen la definición jurídico-penal de trata de personas en el Protocolo de Palermo: la conducta, los medios de doblegación de la voluntad de la víctima y la finalidad de explotación. En segundo lugar, se describen las disposiciones de naturaleza penal en la materia que han previsto cinco países europeos (Alemania, España, Francia, Italia y Reino Unido) y cinco latinoamericanos (Argentina, Chile, Colombia, México y Uruguay) con el propósito de evaluar cómo han incorporado dichos elementos del Protocolo de Palermo a sus respectivas legislaciones penales. Revisadas tanto la legislación internacional como las regulaciones nacionales, y descartada la hipótesis de partida, se exponen en la última parte del trabajo las cuatro grandes tendencias político-criminales que se pueden observar en este ámbito, así como su influencia en la determinación del bien jurídico-penal protegido y las repercusiones que derivan de esta.

\section{El Protocolo de PALERMo}

La Organización de las Naciones Unidas (ONU) es una de las instituciones que más atención ha prestado a la trata de personas en las últimas décadas. De hecho, en la conocida "Agenda 2030" (A/RES/70/1) esta organización ha establecido como objetivos prioritarios

adoptar medidas inmediatas y eficaces para erradicar el trabajo forzoso, poner fin a las formas contemporáneas de esclavitud y la trata de personas, y asegurar la prohibición y eliminación de las peores formas de trabajo infantil, incluidos el reclutamiento y la utilización de niños soldados, y, de aquí a 2025, poner fin al trabajo infantil en todas sus formas.

Aunque en el ámbito de la ONU son varios los instrumentos relacionados con la trata de personas (entre otros, el Protocolo facultativo de la Convención sobre los derechos del niño relativo a la venta de niños, la prostitución infantil y la utilización de niños en la pornografia; la Convención sobre la eliminación de todas las formas de discrimina- 
ción contra la mujer; y la Convención suplementaria sobre la abolición de la esclavitud, la trata de esclavos y las instituciones y prácticas análogas a la esclavitud), el documento más relevante en la materia es el ya mencionado Protocolo de Palermo.

Su objetivo es triple: de una parte, prevenir y combatir la trata de seres humanos y, en especial, de mujeres y niños; de otra, proteger y ayudar a las víctimas; y, por último, promover la cooperación entre los Estados. Por ello, "se conoce a esta aproximación estratégica a la trata como política de 3P, porque cubre tanto el flanco de la prevención de estas conductas, cuanto el de la protección de las víctimas, además de la persecución criminal de las mismas" (Carolina Villacampa Estiarte, 2014, p. 4).

Como puede observarse, uno de los tres objetivos expresamente establecidos en el texto normativo es la promoción de la cooperación entre los países, pues se entiende que sólo de este modo se pueden alcanzar los dos propósitos restantes. Así pues, se invita a los Estados a que incorporen a sus respectivos ordenamientos jurídicos el delito de trata de personas en los términos establecidos en el Protocolo de Palermo, exigiendo el castigo de la tentativa y la participación en estas conductas.

Concretamente, en el artículo 5o. se establece que "cada Estado Parte adoptará las medidas legislativas y de otra índole que sean necesarias para tipificar como delito en su derecho interno las conductas enunciadas en el artículo 3o. del presente Protocolo, cuando se cometan intencionalmente". Y en el artículo 3o. se define la trata de personas como

la captación, el transporte, el traslado, la acogida o la recepción de personas, recurriendo a la amenaza o al uso de la fuerza u otras formas de coacción, al rapto, al fraude, al engaño, al abuso de poder o de una situación de vulnerabilidad o a la concesión o recepción de pagos o beneficios para obtener el consentimiento de una persona que tenga autoridad sobre otra, con fines de explotación. Esa explotación incluirá, como mínimo, la explotación de la prostitución ajena u otras formas de explotación sexual, los trabajos o servicios forzados, la esclavitud o las prácticas análogas a la esclavitud, la servidumbre o la extracción de órganos.

A continuación, se aclara que el consentimiento dado por la víctima de la trata de personas a toda forma de explotación intencional no se tendrá en cuenta cuando se haya recurrido a cualquiera de los medios

Esta obra está bajo una Licencia Creative Commons

Atribución-NoComercial-SinDerivar 4.0 Internacional, IIJ-UNAM.

Boletin Mexicano de Derecho Comparado, núm. 160, enero-abril de 2021, pp. 277-307. 
enunciados en dicho apartado. Y, en relación con los menores de edad, el Protocolo de Palermo matiza que el consentimiento no tendrá validez, aun cuando no se recurra a los medios de doblegación de la voluntad mencionados.

Por tanto, el concepto jurídico de trata de personas que se facilita desde el derecho internacional se caracteriza por la concurrencia de tres elementos: la conducta (captar, transportar, trasladar, acoger o recibir personas), el modo (la amenaza o al uso de la fuerza u otras formas de coacción, al rapto, al fraude, al engaño, al abuso de poder o de una situación de vulnerabilidad o a la concesión o recepción de pagos o beneficios para obtener el consentimiento de una persona que tenga autoridad sobre otra) y la finalidad (como mínimo, la explotación de la prostitución ajena u otras formas de explotación sexual, los trabajos o servicios forzados, la esclavitud o las prácticas análogas a la esclavitud, la servidumbre o la extracción de órganos).

En cuanto a las conductas, con esta multiplicidad de acciones se pretende sancionar con la misma intensidad cada una de las fases que conforman el proceso de la trata de personas. Así, se exige la tipificación, en primer lugar, de la captación de la víctima, que constituiría la primera fase del proceso; en segundo lugar, de su transporte o traslado, que formarían parte de la segunda fase; y, en tercer lugar, de su acogida o recepción (Inés Olaizola Nogales, 2013, pp. 474 y 475).

Además, el Protocolo de Palermo determina que para poder apreciar el delito de trata de personas la conducta se ha de llevar a cabo mediante modos violentos, fraudulentos o abusivos, excepto en el caso de víctimas menores de edad. Se distinguen, por ende, tres formas de trata de personas, según el medio empleado para su ejecución: la trata forzada, que presupone el empleo de violencia o intimidación sobre el sujeto pasivo; la trata fraudulenta, que exige la presencia de un engaño como forma de viciar su consentimiento, y, finalmente, la trata abusiva, en la que el sujeto activo se aprovecha de las especiales condiciones que sufre la víctima o logra el consentimiento de quien ya la controla mediante pagos o beneficios (Alberto Daunis Rodríguez, 2013, p. 92). De este modo, se presume la validez del consentimiento de la víctima mayor de edad cuando no intervengan estos medios comisivos.

$\mathrm{Al}$ respecto, la reciente Legislative guide for the Protocol to prevent, suppress and punish trafficking in persons, especially women and children de la UNODG 
(2020) afirma que "los Estados Parte pueden optar por introducir otros medios además de los indicados en la definición del artículo 3.a) y pueden reconocer nuevas formas de coacción con el tiempo". Sin embargo, no se contempla la posibilidad de prescindir de los medios comisivos en el tipo básico, pues, como ha observado la doctrina, "la eliminación de los medios comisivos de la estructura del delito de trata distorsiona la naturaleza autónoma del fenómeno de trata y difumina las fronteras con la inmigración ilegal y, en definitiva, dificulta el establecimiento de un régimen efectivo de cooperación internacional" (Ana Valverde Cano, 2019, p. 25).

Por último, se determina que para que el delito de trata de personas se considere consumado la conducta típica ejecutada mediante alguno de los medios de doblegación de la voluntad de la víctima indicados debe realizarse con fines de explotación, pero sin que sea necesario que dicha explotación se materialice. Específicamente, indica algunos de los fines de explotación más habituales tras la expresión "incluirá, como mínimo".

Sobre cómo debe interpretarse este elemento, la ya citada Legislative guide for the Protocol to prevent, suppress and punish trafficking in persons, especially women and children establece que

el apartado a) del artículo 3 establece una lista no exhaustiva de ejemplos de lo que constituye explotación. Al mantener esta lista no exhaustiva, el Protocolo contra la trata de personas permite incluir otras formas de explotación nuevas o menos comunes en el alcance de la trata. En la legislación nacional los Estados Parte deben abordar, como mínimo, aquellos ejemplos de explotación que se enumeran en el protocolo.

En consecuencia, la propia oficina de la ONU declara que el listado abierto por el que se opta en el Protocolo de Palermo permite incluir toda forma de explotación, lo que parece sumamente aconsejable teniendo en cuenta lo cambiante del fenómeno. Pero, a continuación, explica que los Estados parte pueden acoger en sus normativas sólo aquellos ejemplos de explotación que se enumeran expresamente en el Protocolo u optar por ampliar el listado. Sin embargo, en las Model legislative provisions against trafficking in persons, también publicadas en 2020 por la UNODC, se afirma que los Estados parte deben tipificar como delito la trata de personas tal y como se define en el artículo 3o. del Protocolo de Paler- 
mo y añade que recomiendan redactar los fines de explotación de forma abierta.

Bajo mi punto de vista, si atendemos a la pretensión del Protocolo de Palermo de "prevenir y combatir la trata de personas" y no sólo algunas de sus modalidades, en efecto, parece conveniente no establecer un $n u^{-}$ merus clausus de finalidades de explotación en los tipos penales que reprimen la trata de personas. Si se adopta el criterio de confeccionar una lista cerrada, la cooperación judicial y la eficacia de la tipificación penal se ven sumamente mermadas. Téngase en cuenta que, por ejemplo, en cuanto a la asistencia mutua en asuntos penales, como se sabe, el principio de la doble tipificación de los hechos impide extraditar al sospechoso cuando los hechos que presuntamente ha cometido no están incriminados en los dos países implicados. Con todo, para cumplir con lo dispuesto en el Protocolo de Palermo, en principio, basta con contemplar los fines de explotación expresamente señalados.

Finalmente, debe tenerse en consideración que en su artículo 4o. el Protocolo de Palermo determina que "se aplicará a la prevención, investigación y penalización de los delitos tipificados con arreglo al artículo 5o. del presente Protocolo, cuando esos delitos sean de carácter transnacional y entrañen la participación de un grupo delictivo organizado, así como a la protección de las víctimas de esos delitos". Así pues, el mandato de tipificación penal contenido en este instrumento normativo, vinculante para todos los Estados cuyas legislaciones van a revisarse en este trabajo, se circunscribe únicamente a la trata de personas que sea manifestación de la delincuencia organizada transnacional.

Sentado lo anterior, a continuación, va a examinarse la normativa de cinco Estados europeos (Alemania, España, Francia, Italia y Reino Unido) y cinco, latinoamericanos (Argentina, Chile, Colombia, México y Uruguay). Este análisis permitirá rechazar (al menos parcialmente) la hipótesis de partida, pues, como se verá, se han empleado diferentes políticas criminales frente a la trata de personas, que se resumen en la figura 1.

Con la finalidad de simplificarla, se distingue, en la primera fila, entre la trata forzada, la trata fraudulenta y la trata abusiva. Por su parte, en la segunda fila, en cuanto a los fines de explotación, se diferencian los siguientes fines contemplados en el Protocolo de Palermo: a) la explotación sexual, b) los trabajos o servicios forzados, c) la esclavitud o las prácticas análogas a ésta, d) la servidumbre y e) la extracción de órganos. Ad- 
viértase, no obstante, que la mayoría de los Estados también contemplan en sus legislaciones otros fines de explotación, que no se mencionan en la tabla por no haberse establecido en el Protocolo de Palermo. Me refiero a la mendicidad (Alemania, España, Francia, Italia, Colombia y México), la comisión de actos delictivos (Alemania, España, Francia, Italia y México), la celebración de matrimonios forzados (España, Argentina, Colombia y México) y sólo en el caso de México, a la adopción ilegal y la experimentación biomédica ilícita. Además, se especifica en esta parte de la tabla si se regulan "como mínimo" estos fines de explotación o si se prevé un numerus clausus de tales propósitos.

No se incluyen en la tabla, por el contrario, las conductas que conforman el primer elemento de la definición jurídico-penal de trata de personas porque, como se observará a continuación, se han regulado de un modo completamente homogéneo, sin diferencias sustanciales que puedan tener implicaciones en la determinación del bien jurídico protegido. Todos los países analizados recogen, en definitiva, las tres fases que conforman el proceso de la trata de personas.

\section{Figura 1: Tabla comparativa entre el Protocolo de Palermo y las legislaciones nacionales}

\begin{tabular}{|c|c|c|c|c|c|c|c|c|c|c|}
\hline PROTOCOLO & ALEMANIA & ESPAÑA & FRANCIA & ITALIA & REINO UNIDO & ARGENTINA & CHILE & COLOMBIA & MÉXICO & URUGUAY \\
\hline Trata forzada & & Trata forzada & Trata forzada & Trata forzada & & & Trata forzada & & & \\
\hline $\begin{array}{c}\text { Trata } \\
\text { fraudulenta }\end{array}$ & & $\begin{array}{c}\text { Trata } \\
\text { fraudulenta }\end{array}$ & $\begin{array}{c}\text { Trata } \\
\text { fraudulenta }\end{array}$ & $\begin{array}{c}\text { Trata } \\
\text { fraudulenta }\end{array}$ & & & $\begin{array}{c}\text { Trata } \\
\text { fraudulenta }\end{array}$ & & & \\
\hline Trata abusiva & Trata abusiva & Trata abusiva & Trata abusiva & Trata abusiva & & & Trata abusiva & & & \\
\hline $\begin{array}{l}\text { La explotación } \\
\text { incluirá, como } \\
\text { mínimo: }\end{array}$ & $\begin{array}{l}\text { Con fines de } \\
\text { explotación: }\end{array}$ & $\begin{array}{l}\text { Con fines de } \\
\text { explotación: }\end{array}$ & $\begin{array}{l}\text { Con fines de } \\
\text { explotación: }\end{array}$ & $\begin{array}{l}\text { Con fines de } \\
\text { explotación: }\end{array}$ & $\begin{array}{l}\text { La explotación } \\
\text { incluirá, como } \\
\text { mínimo: }\end{array}$ & $\begin{array}{l}\text { Con fines de } \\
\text { explotación: }\end{array}$ & $\begin{array}{l}\text { Con fines de } \\
\text { explotación: }\end{array}$ & $\begin{array}{l}\text { La explotación } \\
\text { incluirá, como } \\
\text { mínimo: }\end{array}$ & $\begin{array}{l}\text { Con fines de } \\
\text { explotación: }\end{array}$ & $\begin{array}{l}\text { La explotación } \\
\text { incluirá, como } \\
\text { mínimo: }\end{array}$ \\
\hline Sexual. & Sexual. & Sexual & Sexual. & Sexual. & Sexual. & Sexual. & Sexual. & Sexual. & Sexual. & Sexual. \\
\hline $\begin{array}{l}\text { Trabajo o } \\
\text { servicios } \\
\text { forzados. }\end{array}$ & Laboral. & $\begin{array}{l}\text { Trabajo o } \\
\text { servicios } \\
\text { forzados. }\end{array}$ & $\begin{array}{l}\text { Trabajo o } \\
\text { servicios } \\
\text { forzados. }\end{array}$ & Laboral. & $\begin{array}{l}\text { Trabajo o } \\
\text { servicios } \\
\text { forzados. }\end{array}$ & $\begin{array}{l}\text { Trabajo o } \\
\text { serviclos } \\
\text { forzados. }\end{array}$ & $\begin{array}{l}\text { Trabajo o } \\
\text { servicios } \\
\text { forzados. }\end{array}$ & $\begin{array}{l}\text { Trabajo o } \\
\text { servicios } \\
\text { forzados. }\end{array}$ & $\begin{array}{l}\text { Trabajo o } \\
\text { serviclos } \\
\text { forzados. }\end{array}$ & $\begin{array}{l}\text { Trabajo o } \\
\text { serviclos } \\
\text { forzados. }\end{array}$ \\
\hline $\begin{array}{l}\text { Esclavitud o } \\
\text { prácticas } \\
\text { similares. }\end{array}$ & $\begin{array}{l}\text { Esclavitud o } \\
\text { prácticas } \\
\text { similares. }\end{array}$ & $\begin{array}{l}\text { Esclavitud o } \\
\text { prácticas } \\
\text { similares. }\end{array}$ & Esclavitud. & & Esclavitud. & Esclavitud. & $\begin{array}{l}\text { Esclavitud o } \\
\text { prácticas } \\
\text { similares. }\end{array}$ & $\begin{array}{l}\text { Esclavitud o } \\
\text { prácticas } \\
\text { similares. }\end{array}$ & Esclavitud. & $\begin{array}{l}\text { Esclavitud o } \\
\text { prácticas } \\
\text { similares. }\end{array}$ \\
\hline Servidumbre. & & Servidumbre. & Servidumbre. & & Servidumbre & Servidumbre & Servidumbre & Servidumbre & Servidumbre & Servidumbre \\
\hline $\begin{array}{l}\text { Extracción de } \\
\text { organos. }\end{array}$ & $\begin{array}{l}\text { Extracclón de } \\
\text { órganos }\end{array}$ & $\begin{array}{l}\text { Extracción de } \\
\text { órganos. }\end{array}$ & $\begin{array}{l}\text { Extracción de } \\
\text { uno órganos. }\end{array}$ & $\begin{array}{l}\text { Extracción de } \\
\text { órganos. }\end{array}$ & $\begin{array}{l}\text { Extracción de } \\
\text { órganos. }\end{array}$ & $\begin{array}{c}\text { Extracción de } \\
\text { organoso o } \\
\text { tejidos. }\end{array}$ & $\begin{array}{l}\text { Extracción de } \\
\text { organos. }\end{array}$ & $\begin{array}{l}\text { Extraccıón de } \\
\text { organos. }\end{array}$ & $\begin{array}{l}\text { Extracción de } \\
\text { órganos, } \\
\text { tejidos y } \\
\text { células. }\end{array}$ & $\begin{array}{l}\text { Extraoción de } \\
\text { órganos. }\end{array}$ \\
\hline
\end{tabular}

FUENTE: Elaboración propia.

Esta obra está bajo una Licencia Creative Commons

Atribución-NoComercial-SinDerivar 4.0 Internacional, IIJ-UNAM.

Boletín Mexicano de Derecho Comparado, núm. 160, enero-abril de 2021, pp. 277-307. 


\section{LA TIPIFICACIÓN PENAL DE LA TRATA \\ DE PERSONAS EN EL DERECHO COMPARADO}

Los países europeos que van a examinarse para el desarrollo de este trabajo (Alemania, España, Italia, Francia y Reino Unido) han reformado recientemente (entre 2013 y 2016) los ilícitos penales relativos a la trata de personas. A pesar de ello, como se observará seguidamente, existen algunas diferencias entre ellas que impiden que pueda alcanzarse el concierto legislativo pretendido tanto en el Protocolo de Palermo como en la Directiva 2011/36/UE, del Parlamento Europeo y del Consejo, del 5 abril de 2011, que en el marco de la Unión Europea vincula de manera directa.

Igualmente, a pesar de que los países latinoamericanos cuyas legislaciones van a referenciarse más adelante (Argentina, Chile, Colombia, México y Uruguay) también han modificado sus normas en los últimos años (entre 2011 y 2018), las discrepancias que pueden detectarse entre ellas y también con respecto a las disposiciones contenidas en el Protocolo de Palermo son manifiestas. Y ello a pesar de contar con un valioso instrumento en este ámbito: la Guía de actuación regional para la detección temprana de situaciones de trata de personas en pasos transfronterizos del Mercosur y Estados Asociados (2016).

Debe advertirse, en cualquier caso, que el estudio cuyos resultados se muestran a continuación se limita al análisis de las legislaciones en vigor. Un examen doctrinal en este ámbito excedería con mucho del objeto del presente trabajo.

\section{Alemania}

La trata de personas en Alemania se criminaliza entre los delitos contra la libertad personal. Específicamente, desde que entró en vigor la Ley para mejorar la represión de la trata de seres humanos, el 15 de noviembre de 2016, en el parágrafo 232 de la $S t G B$ se sanciona con la pena de prisión de seis meses a cinco años a quien capte, traslade, acoja o reciba a otra persona, aprovechando su situación personal o económica o la vulnerabilidad de permanecer en un país extranjero, o que esa persona sea menor de 21 años de edad, siempre que se haga con una de las siguientes finalidades 
de explotación: a) la sexual, b) la laboral, c) el ejercicio de la mendicidad, d) la comisión de actos delictivos; o bien, cuando se le pretenda someter a esclavitud o una situación similar; o bien cuando se le quieran extirpar órganos ilegalmente (A. Spitzer, 2018).

Las penas, no obstante, podrán llegar a los diez años de prisión, por ejemplo, si estos comportamientos se llevan a cabo mediante violencia o intimidación; si se secuestra a la víctima; si la víctima es menor de 18 años; si se ha puesto en peligro o se ha lesionado su salud; o si el autor pertenece a un grupo criminal. Específicamente, la ley alemana establece que

quien capte, transporte, transfiera, acoja o reciba a la víctima mediante el uso de la fuerza, la amenaza de daño grave o el engaño, o secuestre a la víctima u obtenga el control físico sobre ella o aliente a un tercero a obtenerlo, será condenado a una pena de prisión de entre seis meses y diez años. Incurrirán en esta misma pena los responsables de la trata de seres humanos cuando la víctima sea menor de 18 años, cuando maltraten a la víctima o la pongan, aunque sea imprudentemente, en peligro de muerte o de daños graves para su salud y cuando actúen sobre una base comercial o como miembros de una organización cuyo propósito sea la continuación de la comisión de estos delitos.

Si comparamos esta legislación penal con el mandato contenido en el Protocolo de Palermo, observamos que el único mecanismo para limitar la libertad de la víctima previsto en el tipo básico alemán es el abuso, pero, en cambio, no se han contemplado la violencia ni la intimidación. También debe subrayarse que en Alemania se ha considerado que todo consentimiento prestado por un menor de 21 años resulta inválido, mientras que en el Protocolo de Palermo sólo se considera inválido el prestado por el menor de 18 años. Finalmente, en la ley alemana se han previsto a modo de numerus clausus los fines de explotación que sugería el instrumento normativo internacional, aunque en vez de referirse al "trabajo o servicios forzados" se ha aludido a la explotación laboral, por lo que cabe entender integrada la servidumbre, que no se contiene de un modo expreso. Pero las conductas previstas son exactamente las mismas contenidas en el Protocolo de Palermo (Clara Mora Guillem, 2016). 


\section{España}

Mediante la Ley Orgánica 5/2010, del 22 de junio, se incorporó al Código Penal español el artículo 177 bis, que sanciona la trata de personas. Tras la reforma operada en este precepto mediante la Ley Orgánica 1/2015, del 30 de marzo, el precepto determina, en su tipo básico, que

[s]erá castigado con la pena de cinco a ocho años de prisión como reo de trata de seres humanos el que, sea en territorio español, sea desde España, en tránsito o con destino a ella, empleando violencia, intimidación o engaño, o abusando de una situación de superioridad o de necesidad o de vulnerabilidad de la víctima nacional o extranjera, o mediante la entrega o recepción de pagos o beneficios para lograr el consentimiento de la persona que poseyera el control sobre la víctima, la captare, transportare, trasladare, acogiere, o recibiere, incluido el intercambio o transferencia de control sobre esas personas, con cualquiera de las finalidades siguientes: a) La imposición de trabajo o de servicios forzados, la esclavitud o prácticas similares a la esclavitud, a la servidumbre o a la mendicidad. b) La explotación sexual, incluyendo la pornografía. c) La explotación para realizar actividades delictivas. d) La extracción de sus órganos corporales. e) La celebración de matrimonios forzados.

La pena se agravará, pudiendo alcanzar los 12 años de prisión, en el caso de peligro para la vida o la integridad física o psíquica de las víctimas, en el caso de que los actos de trata de seres humanos se realicen sobre víctimas especialmente vulnerables, cuando se lleven a cabo prevaliéndose de su condición de autoridad, agente de ésta o funcionario público y cuando pertenezca a una organización o asociación que se dedique a la realización de tales actividades (art. 177 bis.4). Por el contrario, la provocación, la conspiración y la proposición para cometer el delito de trata de seres humanos serán castigadas con una pena inferior en uno o dos grados a la prevista en el tipo básico (art. 177 bis.8); es decir, consistirá en una pena de prisión que podrá oscilar entre el año y tres meses y los cinco años.

Esta regulación reproduce los tres tipos de trata de personas previstas en el Protocolo de Palermo en atención a los medios violentos, abusivos y fraudulentos que se empleen. Asimismo, incrimina las conductas que en él se establecen. Y, por último, concreta los fines de explotación señalados en el instrumento normativo internacional. Pero, a diferencia de lo 
que sería, a mi juicio, lo más adecuado (recomendado, además, por la propia UNODG en 2020), se establecen de un modo cerrado, lo que impide la sanción de otras modalidades de trata de personas.

\section{Francia}

Desde la reforma que supuso la Ley 2013-711, del 5 de agosto de 2013, el artículo 225-4 del Código Penal francés prevé el delito de trata de personas entre los delitos contra la dignidad humana. Para quienes lleven a cabo alguno de los comportamientos descritos en esta figura delictiva está prevista la pena de prisión de siete años y multa de $150.000 €$.

En particular, en el mencionado precepto se determina que

la trata de personas consiste en la captación, el transporte, la transferencia, el alojamiento o la acogida de una persona con fines de explotación en cualquiera de las siguientes circunstancias: con el uso de amenaza, coerción, violencia o maniobra fraudulenta dirigida a la víctima, a su familia o a una persona relacionada con la víctima; por un ascendente de esa persona o por una persona que tenga autoridad sobre él o abuse de la autoridad que le confieren sus deberes; abusando de una situación de vulnerabilidad debido a su edad, enfermedad, dolencia, deterioro físico o psíquico o a un estado de embarazo; o a cambio o mediante la concesión de una remuneración o cualquier otro beneficio o una promesa de remuneración o beneficio.

Y, seguidamente, se concreta que la explotación consistirá en el hecho de que la víctima esté a disposición del sujeto activo o a disposición de un tercero, sea o no identificado, con el fin de llevar a cabo delitos de proxenetismo, agresión o abuso sexual, reducción de la esclavitud, sumisión al trabajo o servicios forzados, reducción de la servidumbre, extirpación de alguno de sus órganos, explotación de la mendicidad, o la comisión de otros delitos (Bénédicte Bourgeois, 2017).

Pero estas penas pueden ir aumentando según las circunstancias en las que se hayan cometido los hechos. Específicamente, la trata de seres humanos se castigará con diez años de prisión y una multa de $1.500 .000 €$ cuando se hayan cometido dos de las circunstancias mencionadas en el tipo básico o una de las siguientes circunstancias adicionales: que se haya llevado a cabo respecto de varias personas; respecto de una persona 
que se encontrara fuera del territorio nacional o a su llegada a este; cuando la persona haya sido captada mediante la difusión de mensajes a un público no especificado por una red de comunicación electrónica; en circunstancias que expongan a la víctima con un riesgo inmediato de muerte o lesión que provoque una mutilación o una enfermedad permanente; con violencia que haya causado a la víctima una incapacidad total para trabajar más de ocho días; por una persona llamada a participar, por sus deberes, en la lucha contra la trata o el mantenimiento del orden público; o cuando el delito haya colocado a la víctima en una situación material o psicológica grave. El delito de trata de seres humanos, por su parte, será castigado con 20 años de prisión y multa de 3.000 .000 euros cuando se cometa en el seno de una banda organizada. Y cuando se haya cometido mediante tortura o actos de barbarie será castigado con cadena perpetua y una multa de 4.500.000 €. Además, debe tenerse en cuenta que la tentativa se sanciona con las mismas penas.

Se prevé, no obstante, que toda persona que haya intentado cometer el delito de trata de personas estará exenta de castigo si, habiéndolo notificado a la autoridad administrativa o judicial, ha impedido su ejecución e identifica, en su caso, al resto de autores o cómplices. Si la notificación se realiza cuando el delito se ha producido, pero permite detener a los autores la pena se reducirá a la mitad (cuando la pena sea a cadena perpetua, se reducirá a veinte años de prisión).

Tal y como sucede en la legislación española acabada de revisar, en la francesa se sanciona la trata de mayores de edad de un modo coherente con el Protocolo de Palermo: cuando se realiza una de las conductas que conforman las fases del proceso de trata de personas y median modos abusivos, fraudulentos o violentos. Igualmente, se contemplan los fines de explotación que prevé esta norma internacional, aunque en este caso no se han incluido las prácticas análogas a la esclavitud. Por último, conviene apuntar que los fines de explotación, lamentablemente, se han insertado en un listado cerrado.

\section{Italia}

Desde el 25 de marzo de 2016, la trata de personas en Italia se sanciona en el artículo 601 del Código Penal con la pena de prisión de ocho a veinte años. Este precepto establece expresamente que 
será sancionado con la pena de ocho a veinte años de prisión quien capte, introduzca en el territorio nacional, lleve fuera del mismo, transporte, ceda la autoridad sobre la víctima o la acoja mediante engaño, violencia, amenaza, abuso de una situación de superioridad o vulnerabilidad, o mediante promesa o entrega de dinero o de otro beneficio, con la finalidad de explotarla laboralmente, sexualmente, para la mendicidad, realizar actividades delictivas o la extracción de órganos. La misma pena se aplicará a cualquier persona que, incluso fuera de los medios a los que se refiere el primer párrafo, lleve a cabo la conducta prevista en una persona menor de edad.

Las únicas excepciones a esta previsión penológica son las siguientes: por un lado, la sanción para el comandante u oficial del buque nacional o extranjero que cometa cualquiera de estos hechos, que será un tercio mayor a la prevista en el tipo básico. Y, por otro lado, la sanción para el miembro de la tripulación del buque nacional o extranjero destinado al tráfico antes de la salida o durante la misma, que será de tres a diez años de prisión.

Consecuentemente, la conclusión que debe alcanzarse en relación con esta figura delictiva es muy similar a la obtenida acerca de los tipos penales regulados en España y en Francia. El delito italiano reprime la trata de personas abusiva, fraudulenta y violenta, tal y como se pide en el Protocolo de Palermo, cuando se realice mediante alguna de las conductas en él previstas. Pero, frente a lo que hubiese sido deseable para conseguir la pretendida armonización legislativa, regula los fines de explotación a modo de numerus clausus. La diferencia entre la regulación italiana y la contenida en las leyes española y francesa es la relación de fines de explotación porque Italia no ha previsto "la esclavitud o prácticas similares", en contra de lo estipulado en el instrumento normativo internacional.

\section{Reino Unido}

La trata de personas en Reino Unido se recoge actualmente en la $\mathrm{Mo}^{-}$ dern slavery act 2015. En esta norma se entiende que "una persona comete un delito si organiza o facilita el viaje de otro con fines de explotación. Será irrelevante si la víctima da su consentimiento (tanto si es un adulto como si es un niño)" (art. 2o.). Las sanciones previstas para estas conductas son de hasta cadena perpetua, en caso de condena en juicio ordinario; 
y de prisión de hasta 12 meses, multa o ambas penas, en caso de condena en juicio sumario.

A continuación, la ley aclara que una persona puede, en particular, organizar o facilitar el viaje mediante la captación, el transporte, la transferencia, la acogida o la recepción, incluido el intercambio del control sobre la víctima. E, igualmente, determina que, a los efectos de esta ley, se entenderá que una persona organiza o facilita el viaje de la víctima con fines de explotación si tiene la intención de explotarla o si sabe que otro lo hará. Por su parte, "viaje" significa entrar en el país, salir de él o desplazarse por el interior de éste.

Los fines de explotación a los que se refiere esta norma son los siguientes: "esclavitud, servidumbre y trabajo forzoso u obligatorio; explotación sexual; extirpación de órganos, etc.". Por lo tanto, en este caso sí se deja abierto el listado de fines de explotación. Sin embargo, la discrepancia surge en relación con los medios de doblegación de la voluntad de la víctima, que no aparecen en la regulación inglesa. Esto permite sancionar la trata de personas, aun cuando la víctima haya prestado un consentimiento válido a la misma. De hecho, incluso se determina, expresamente, que el consentimiento resulta irrelevante en todo caso. Y parece obvio que ello es así porque se estima que el bien jurídico protegido en este ilícito penal debe considerarse indisponible en todo caso (Francisca Barros Sánchez, 2018, p. 143).

La misma conclusión cabe alcanzar en relación con la legislación de Irlanda del Norte y Escocia, que sancionan este fenómeno en los mismos términos que la ley inglesa (concretamente, en los artículos 2o. y 1o., respectivamente, de sus Human trafficking and explotation act, ambas de 2015) (Cecilia Della Penna, 2019).

\section{Argentina}

Argentina aprobó una de las primeras normas mundiales para combatir la trata de personas en 1913 (la Ley 9.143). Casi cien años después, en 2008, la sancionó mediante la implementación de la Ley 26.364. Sin embargo, ante los obstáculos procesales que conllevaba la previsión de medios comisivos en el delito y la falta de mecanismos de asistencia a las víctimas, se reformó su regulación por medio de la Ley 26.842, 
prevención y sanción de la trata de personas y asistencia a sus víctimas, de 2012, modificada en 2015 (Christian Sommer, 2017, p. 408).

Estas leyes han incorporado al Código Penal dos figuras delictivas entre los delitos contra la libertad. La primera, prevista en el artículo 145 bis, es el tipo básico y castiga al que realice conductas de trata de personas con la pena de prisión de cuatro a ocho años. Concretamente, el precepto determina lo siguiente: "[s]erá reprimido con prisión de cuatro a ocho años, el que ofreciere, captare, trasladare, recibiere o acogiere personas con fines de explotación, ya sea dentro del territorio nacional, como desde o hacia otros países, aunque mediare el consentimiento de la víctima”. Esta pena se agravará (se impondrá la pena de prisión de ocho a doce años) si tiene lugar la explotación efectiva a la que se encamina la trata. Y, seguidamente, se aclara que "se entiende por trata de personas el ofrecimiento, la captación, el traslado, la recepción o acogida de personas con fines de explotación, ya sea dentro del territorio nacional, como desde o hacia otros países".

A los fines de esta ley se entiende por explotación la configuración de cualquiera de los siguientes supuestos, sin perjuicio de que constituyan delitos autónomos respecto del delito de trata de personas:

a) cuando se redujere o mantuviere a una persona en condición de esclavitud o servidumbre, bajo cualquier modalidad; b) cuando se obligare a una persona a realizar trabajos o servicios forzados; c) cuando se promoviere, facilitare o comercializare la prostitución ajena o cualquier otra forma de oferta de servicios sexuales ajenos; d) cuando se promoviere, facilitare o comercializare la pornografía infantil o la realización de cualquier tipo de representación o espectáculo con dicho contenido; e) cuando se forzare a una persona al matrimonio o a cualquier tipo de unión de hecho; y f) cuando se promoviere, facilitare o comercializare la extracción forzosa o ilegítima de órganos, fluidos o tejidos humanos.

El artículo 145 ter contiene un subtipo agravado que castiga con la pena de prisión de cinco a diez años a quien realice el comportamiento tipificado en el artículo 145 bis con la concurrencia de determinadas circunstancias, entre las que se encuentra "el engaño, fraude, violencia, amenaza o cualquier otro medio de intimidación o coerción, abuso de autoridad o de una situación de vulnerabilidad, o concesión o recepción de pagos o beneficios para obtener el consentimiento de una persona

Esta obra está bajo una Licencia Creative Commons

Atribución-NoComercial-SinDerivar 4.0 Internacional, IIJ-UNAM.

Boletín Mexicano de Derecho Comparado, núm. 160, enero-abril de 2021, pp. 277-307. 
que tenga autoridad sobre la víctima". El resto de circunstancias previstas son las siguientes: que la víctima esté embarazada o sea mayor de setenta años; que la víctima sea una persona discapacitada, enferma o que no pueda valerse por sí misma; que las víctimas sean tres o más; que en la comisión del delito participaren tres o más personas; que el autor sea ascendiente, descendiente, cónyuge, afín en línea recta, colateral o conviviente, tutor, curador, autoridad o ministro de cualquier culto reconocido o no, o encargado de la educación o de la guarda de la víctima; o que el autor sea funcionario público o miembro de una fuerza de seguridad, policial o penitenciaria.

Son dos, por ende, las diferencias entre la regulación argentina y la del Protocolo de Palermo: la primera, que en el tipo básico de la ley argentina no se establecen los mecanismos que excluyen la libertad de la víctima como elemento constitutivo del delito (se contemplan en el subtipo cualificado) y, la segunda, que, entre los fines de explotación, que están tasados, no se han previsto las prácticas análogas a la esclavitud.

\section{Chile}

Por lo que se refiere a Chile, la Ley 20.507, por la que se tipifican los delitos de tráfico ilícito de migrantes y trata de personas y establece normas para su prevención y más efectiva persecución criminal, de 2011, añadió al Código Penal el título "De los delitos de tráfico de inmigrantes y trata de personas", que sanciona con la pena de reclusión mayor en sus grados mínimo a medio (es decir, con la pena de prisión de cinco a quince años) y multa a quienes cometan trata de personas (art. 411 quáter).

La figura delictiva en cuestión establece, expresamente, que

el que mediante violencia, intimidación, coacción, engaño, abuso de poder, aprovechamiento de una situación de vulnerabilidad o de dependencia de la víctima, o la concesión o recepción de pagos u otros beneficios para obtener el consentimiento de una persona que tenga autoridad sobre otra capte, traslade, acoja o reciba personas para que sean objeto de alguna forma de explotación sexual, incluyendo la pornografía, trabajos o servicios forzados, servidumbre o esclavitud o prácticas análogas a ésta, o extracción de órganos, será castigado con la pena de reclusión mayor en sus grados mínimo a medio y multa de cincuenta a cien unidades tributarias mensuales. 
Así pues, igual que las legislaciones de España, Italia y Francia, la norma chilena respeta la exigencia de previsión de las conductas típicas y de los medios de doblegación de la voluntad de la víctima contenida en el Protocolo de Palermo. Pero contiene un numerus clausus de fines de explotación, que impide sancionar otras modalidades de trata de personas (Clara Moya Guillem, 2016).

\section{Colombia}

En Colombia se prohíbe expresamente la trata de personas en la carta fundamental de 1991 (art. 17). Con base en esta previsión constitucional la trata de personas se regula en la Ley 67, de 2001. Por su parte, la Ley 800 de 2003 es la que incorporó al ordenamiento jurídico el Protocolo de Palermo (Melissa Jiménez-Rojas y Gerardo Figueredo-Medine, 2015). Pero el delito de trata de personas se incorporó al Código Penal mediante la Ley 985, de 2005, por medio de la cual se adoptan medidas contra la trata de personas, y normas para la atención y protección de las víctimas de la misma, entre los delitos contra la autonomía personal (art. 188.a). Esta previsión está en vigor desde febrero de 2016.

El tipo penal dispone, literalmente, que:

[e]l que capte, traslade, acoja o reciba a una persona, dentro del territorio nacional o hacia el exterior, con fines de explotación, incurrirá en prisión de trece a veintitrés años y una multa de ochocientos a mil quinientos salarios mínimos legales mensuales vigentes. Para efectos de este artículo se entenderá por explotación el obtener provecho económico o cualquier otro beneficio para sí o para otra persona, mediante la explotación de la prostitución ajena u otras formas de explotación sexual, los trabajos o servicios forzados, la esclavitud o las prácticas análogas a la esclavitud, la servidumbre, la explotación de la mendicidad ajena, el matrimonio servil, la extracción de órganos, el turismo sexual u otras formas de explotación. El consentimiento dado por la víctima a cualquier forma de explotación definida en este artículo no constituirá causal de exoneración de la responsabilidad penal.

Y el artículo 188.b) del Código Penal, introducido mediante la Ley 747 , del 29 de julio de 2002, contempla la agravación de la pena de una tercera parte a la mitad cuando la trata de personas se realice en per- 
sona que padezca inmadurez psicológica, trastorno mental, enajenación mental y trastorno psíquico, o sea menor de edad; cuando, como consecuencia, la víctima resulte lesionada en su salud física o psíquica; cuando el responsable sea pareja estable o pariente de la víctima; y cuando el autor o partícipe sea servidor público.

Siendo ello así, la legislación colombiana se distancia del Protocolo de Palermo en la regulación de los medios de determinación de voluntad, que no se prevén en el tipo básico, aunque coincide con este instrumento internacional en las conductas típicas y en la forma abierta de establecer las finalidades de explotación (María Isabel Henao Trip, 2008).

\section{México}

México, por su régimen político federado, tiene 35 códigos penales y en el pasado, en la mayoría de ellos, se regulaba el delito de trata de personas. En 2007, en cambio, se aprobó la primera ley nacional en la materia, aunque no consiguió la unificación del ilícito penal; convivían en el país 29 tipos penales de trata de personas (13 en leyes especiales estatales y 16 en códigos penales locales). Esta situación sólo se logró superar cuando se modificó la Constitución Política federal para que existiera una sola ley en el país sobre la trata de personas (Gilberto Martiñón Cano, 2019).

Fue entonces cuando se aprobó la Ley general para prevenir, sancionar y erradicar los delitos en materia de trata de personas, y para la protección y asistencia a las víctimas de estos delitos, de 2012, que ha sido modificada en enero de 2018 (Xochithl Guadalupe Rangel Romero, 2020). A pesar de este avance, se estima que el cumplimiento de la ley resulta difícil por la falta de capacitación de las autoridades y funcionarios públicos, así como por la corrupción (María Rita Chávez-Gutiérrez y María Antonia Chávez-Gutiérrez, 2018).

$\mathrm{El}$ artículo 10 de la ley establece que “[t]oda acción u omisión dolosa de una o varias personas para captar, enganchar, transportar, transferir, retener, entregar, recibir o alojar a una o varias personas con fines de explotación se le impondrá de 5 a 15 años de prisión y de un mil a veinte mil días multa". Y este mismo precepto aclara que 
se entenderá por explotación de una persona a: la esclavitud; la condición de siervo; la prostitución ajena u otras formas de explotación sexual; la explotación laboral; el trabajo o servicios forzados; la mendicidad forzosa; la utilización de personas menores de dieciocho años en actividades delictivas; la adopción ilegal de persona menor de dieciocho años; el matrimonio forzoso o servil; tráfico de órganos, tejidos y células de seres humanos vivos; y experimentación biomédica ilícita en seres humanos.

En consecuencia, se sanciona toda trata de personas, sin tener en cuenta el consentimiento de la víctima en ningún caso y estableciendo un listado cerrado (aunque sumamente extenso) de finalidades de explotación.

\section{Uruguay}

Finalmente, en Uruguay la Ley de migraciones 18.250, de 2008 (modificada en 2014 mediante la Ley 19.254), sanciona con la pena de cuatro a dieciséis años de prisión a "quien, de cualquier manera o por cualquier medio, participare en el reclutamiento, transporte, transferencia, acogida o el recibo de personas para el trabajo o servicios forzados, la esclavitud o prácticas similares, la servidumbre, la explotación sexual, la remoción y extracción de órganos o cualquier otra actividad que menoscabe la dignidad humana" (art. 78). De manera que se establece, acertadamente, un listado abierto de fines de explotación.

Los procedimientos violentos, intimidatorios o abusivos se integran en un subtipo agravado, que aumenta la pena de un tercio a la mitad. En concreto, el artículo 80 de la ley establece que

[s]e consideran agravantes especiales de los delitos descritos en los artículos 77, 78 y 79 de la presente ley y se incrementarán de un tercio a la mitad las penas en ellos establecidos cuando medien las siguientes circunstancias: cuando se hubiere puesto en peligro la salud o la integridad física de los migrantes; cuando la víctima se trate de un niño o un adolescente o el agente se haya prevalecido de la incapacidad física o intelectual de una persona mayor de dieciocho años; cuando el agente revista la calidad de funcionario policial o tenga a su cargo la seguridad, custodia o el control de las cuestiones relativas a la migración de personas; cuando el tráfico o la trata de personas se efectuara con violencia, intimidación o engaño o abusando de la inexperien- 
cia de la víctima; y cuando el agente hiciere de las actividades mencionadas en los artículos 77, 78 y 79 de la presente ley su actividad habitual.

Ésta sería, entonces, la diferencia entre esta legislación y la regulación contenida en el Protocolo de Palermo: que los mecanismos para doblegar la libertad de la víctima no aparecen previstos en el tipo básico, sino en el subtipo agravado.

Además, debe tenerse en cuenta que se regula un tipo híbrido entre la trata de personas y la inmigración ilegal en el artículo 79. Este precepto castiga el favorecimiento o la facilitación de la entrada, el tránsito interno o la salida de personas del país, con las mismas finalidades, pero fuera de los comportamientos anteriores (César Correa Borges, 2019, p. 134).

\section{TENDENCIAS POLÍTICO-CRIMINALES FRENTE A LA TRATA DE PERSONAS}

Los diez países cuyas regulaciones han sido examinadas en el presente trabajo están obligados a reprimir penalmente la trata de personas en sus respectivos ordenamientos jurídicos en los términos establecidos en el Protocolo de Palermo, puesto que todos ellos lo han firmado y ratificado.

Precisamente por esta razón sorprende que, a pesar de las recientes reformas, la mayoría de las normas nacionales no exijan para la aplicación del tipo básico de trata de personas el empleo de medios violentos, intimidatorios o abusivos, tal y como se demanda en el instrumento normativo internacional. En este sentido, cabe diferenciar dos grupos de países. El primero estaría conformado por los que definen el tipo básico únicamente por la realización de alguna de las conductas características del proceso de trata de personas con fines de explotación, por lo que no resulta necesaria la concurrencia de ningún medio de doblegación de la voluntad de la víctima (Reino Unido, Argentina, Colombia, Uruguay y México) o, a lo sumo, como sucede en Alemania, sólo contemplan la situación abusiva, mientras que la violencia y la intimidación se prevén en un tipo autónomo. Y el segundo grupo estaría compuesto por los países que, por el contrario, tal y como exige la normativa internacional en este ámbito, sí definen la trata de personas jurídico-penalmente con base en sus tres elementos característicos: la acción, el medio de determinación de la vo- 
luntad de la víctima y la finalidad de explotación (España, Francia, Italia y Chile).

Por otro lado, los fines de explotación previstos en los preceptos examinados no son los mismos en todos los Estados. Además, el Protocolo de Palermo exige que las conductas de trata de personas deben perseguir, "como mínimo, la explotación de la prostitución ajena u otras formas de explotación sexual, los trabajos o servicios forzados, la esclavitud o las prácticas análogas a la esclavitud, la servidumbre o la extracción de órganos". Sin embargo, sólo Reino Unido, Colombia y Uruguay parecen haber regulado el fenómeno criminal de un modo abierto. El resto de los países referenciados en el trabajo, en cambio, ha establecido un numerus clausus de finalidades de explotación que, por lo general, suelen coincidir con las establecidas en el Protocolo de Palermo, pero cierran el paso a otras. Así, por ejemplo, en España sólo se puede sancionar penalmente la trata de personas que se lleve a cabo con fines de explotación sexual, la imposición de trabajo o de servicios forzados, la esclavitud o prácticas similares a la esclavitud, a la servidumbre o a la mendicidad, la explotación para realizar actividades delictivas, la extracción de sus órganos y la celebración de matrimonios forzados. En cambio, no se puede sancionar en aplicación del artículo 177 bis del Código Penal, por ejemplo, la trata de seres humanos con fines de adopción ilegal o experimentación biomédica ilícita.

Por último, llama la atención la diversidad de penas previstas para sancionar la trata de personas. En este sentido, por un lado, en cuanto a las penas mínimas de prisión a imponer, pueden distinguirse tres grupos de Estados: aquellos en los que se puede imponer una pena de prisión inferior a los doce meses o incluso una pena de multa (Alemania y Reino Unido); los que prevén una pena de prisión de entre uno y cinco años (Argentina, Chile, España, México y Uruguay), y, por último, los que contemplan penas mínimas superiores a los cinco años de prisión (Italia, Francia y Colombia). Por otro lado, pueden diferenciarse tres grupos de países en función de las penas máximas de prisión a imponer en casos de trata de personas: en primer lugar, aquellos Estados cuya pena máxima oscila entre los diez y los veinte años de prisión (Alemania, Argentina, Chile, España, México y Uruguay); en segundo lugar, los que contemplan penas superiores a los 20 años de prisión (Italia y Colombia), y, en tercer lugar, los que prevén incluso la cadena perpetua en este contexto (Reino Uni-

Esta obra está bajo una Licencia Creative Commons

Atribución-NoComercial-SinDerivar 4.0 Internacional, IIJ-UNAM.

Boletín Mexicano de Derecho Comparado, núm. 160, enero-abril de 2021, pp. 277-307. 
do y Francia). Finalmente, sólo Francia, Reino Unido, Chile, Colombia y México contemplan penas pecuniarias entre las sanciones penales para la trata de personas.

Las dos primeras divergencias expuestas, a su vez, permiten concluir que el bien jurídico protegido en las figuras delictivas previstas en los Estados examinados difiere. Se pueden distinguir, específicamente, cuatro posibilidades que son el resultado de la combinación de los siguientes dos factores: a) la relevancia otorgada al consentimiento prestado por la víctima del delito mayor de edad y b) la determinación de los fines de explotación en un listado abierto o cerrado.

Combinando ambos aspectos, la primera tendencia político-criminal identificada es la establecida en el Protocolo de Palermo, que, por un lado, sólo considera irrelevante el consentimiento prestado por la víctima mayor de edad cuando este se preste bajo condiciones abusivas, fraudulentas o violentas, y, por otro lado, regula los fines de explotación de un modo abierto al indicar que "esa explotación incluirá, como mínimo, la explotación de la prostitución ajena u otras formas de explotación sexual, los trabajos o servicios forzados, la esclavitud o las prácticas análogas a la esclavitud, la servidumbre o la extracción de órganos".

La segunda tendencia político-criminal que se puede distinguir es la que se desprende de las legislaciones de Alemania, España, Francia, Italia y Chile. En todos estos países el delito de trata de personas gira en torno a tres ejes, tal y como exige el Protocolo de Palermo: la conducta típica, los medios de doblegación de la voluntad de la víctima (sólo el abuso en el caso alemán) y los fines de explotación. Pero, en estos países, a diferencia de lo establecido en el Protocolo de Palermo, los fines de explotación se han ubicado en un listado cerrado que impide sancionar la trata de seres humanos cometida con otras finalidades de explotación que no estén en él establecidas.

La tercera tendencia político-criminal observada sería la llevada a cabo en este ámbito por Reino Unido, Colombia y Uruguay, que no dan relevancia alguna al consentimiento prestado por la víctima. En estas legislaciones, en contra de lo exigido en el Protocolo de Palermo, la sanción penal no se limita a la trata abusiva, violenta y fraudulenta, sino que se reprime todo tipo de trata de personas. Por el contrario, han establecido una lista abierta de fines de explotación, lo que resulta sumamente 
adecuado para una eficaz persecución y enjuiciamiento de la trata transnacional de personas.

Por último, la cuarta tendencia político-criminal identificada sería la implementada por Argentina y México, que se distancian del Protocolo de Palermo en los dos elementos a los que se está haciendo referencia; es decir, no prestan atención en ningún caso al consentimiento prestado por las víctimas mayores de edad ni permiten la sanción de la trata de personas con cualquier finalidad de explotación.

\section{CONSECUENGIAS TÍPICAS}

Para poder determinar el bien jurídico-penal tutelado en las figuras delictivas que han previsto las legislaciones penales examinadas en el presente trabajo, conviene recordar, de forma previa, que la trata de personas consiste en la conversión de la persona en cosa u objeto de intercambio o disposición plena por parte de su propietario o poseedor. Esta relación fáctica de dominio, que permite a un sujeto gozar y disponer de la víctima como si se tratara de un bien de su propiedad, es la que dota de singularidad al fenómeno y, en definitiva, la que justifica que se le dé un tratamiento jurídico-penal autónomo (Esteban Pérez Alonso, 2008, p. 177).

La proscripción de una instrumentalización de otra persona que puede entenderse como vejatoria, humillante o degradante sólo se garantiza por medio de un bien jurídico-penal que en algunos países se identifica con la dignidad humana y en otros, con la integridad moral. Este sería un bien jurídico que se tutelaría en todos los tipos penales analizados.

Sin embargo, para proteger exclusivamente la dignidad o la integridad moral de la víctima y evitar su cosificación no era necesaria la referencia en los delitos a ciertos medios comisivos, como los contenidos en las legislaciones de Alemania, España, Francia, Italia y Chile. La exigencia de que concurra violencia, engaño o abuso tiene una gran trascendencia en la delimitación del bien jurídico protegido, ya que permite detectar la existencia de otro interés tutelado.

Estos delitos de trata de personas no prohíben exclusivamente la cosificación de la víctima, sino que, además, prohíben que se doblegue su voluntad hacia alguno de los fines de explotación previstos. En consecuencia, en estos casos, el desvalor de la acción constitutiva de trata de personas 
no se agota en la conducta misma, sino que requiere que esta sea impuesta a la víctima haciendo uso de medios violentos, fraudulentos o abusivos (Juan Antonio Martos Núñez, 2012, p. 101).

Por ello, parece razonable sostener que la lesión de la libertad forma parte del injusto de las figuras delictivas previstas en Alemania, España, Italia, Francia y Chile, junto con la dignidad o la integridad moral (Clara Moya Guillem, 2020, pp. 142-160).

Específicamente, al prohibir la trata forzada de seres humanos (en particular, la realizada con violencia) se ampararía la libertad de obrar; es decir, el mismo bien jurídico tutelado en los delitos de coacciones. Adviértase que el delito de trata forzada de seres humanos comparte el fundamento de las coacciones, pues el núcleo de ambas figuras consiste en imponer con violencia una conducta a otro por medio de diversas modalidades de actuación. Como afirma Gonzalvo Quintero Olivares (2011), "en los delitos contra la libertad son elementos esenciales la intención de doblegar la voluntad de la víctima y el uso de la violencia o la intimidación por parte del autor para realizar su acción" (p. 211), y estos son también los elementos que configuran el delito de trata violenta de personas.

En cambio, con la incriminación de la trata fraudulenta o de la trata abusiva de personas se protegería la libertad de decisión, ya que mediante el engaño, así como también abusando de la situación de necesidad o de vulnerabilidad de la víctima, o aprovechándose de una situación de superioridad, se interfiere, sin duda alguna, en el proceso deliberativo.

Finalmente, la prohibición penal de la trata de personas empleando intimidación tutelaría, dependiendo del caso, la libertad de decisión o la libertad de obrar de la víctima, según si adopta la forma de amenaza o de coacción (Dulce Santana Vega, 2011, p. 106).

Así pues, debería considerarse que el delito de trata de personas previsto en Alemania, España, Italia, Francia y Chile absorbe, según el caso, las coacciones, amenazas o detenciones ilegales que formen parte del proceso. Por el contrario, en los delitos previstos en Reino Unido, Colombia y México deberían aplicarse, además de los correspondientes delitos de trata de personas, los ilícitos penales que tutelen la libertad en el caso de que se ataque la misma. Y, por su parte, en Argentina y en Uruguay se debería apreciar el subtipo agravado y no el tipo básico si la trata de personas se lleva a cabo empleando medios violentos o fraudulentos. 
Ahora bien, existe una razón que impide concluir que sólo estos (la dignidad o integridad moral y, en su caso, la libertad) son los intereses amparados en las figuras delictivas previstas en España, Italia, Francia, Alemania, Chile, México y Argentina. Y es que el legislador penal de esos países ha establecido un numerus clausus de finalidades de explotación (Clara Moya Guillem, 2020, pp. 118-160).

En el artículo 3o. del Protocolo de Palermo se exige la prohibición penal de la trata de personas con fines de explotación. Y, a continuación, se establece que la explotación incluirá, como mínimo, ciertas modalidades. Considero que, a pesar de que no era vinculante, resultaba aconsejable sancionar toda trata de personas con fines de explotación y no sólo algunas de sus modalidades. Al menos, esta sería la interpretación adecuada si se pretenden alcanzar los objetivos expresamente delimitados en el instrumento normativo internacional. En ese caso, se trataría de evitar la comisión de un delito de esclavitud como el regulado en Reino Unido, precisamente junto con el de trata de personas. En dicho país el delito de trata de personas tutelaría, exclusivamente, la dignidad o integridad moral de la víctima. Este interés se lesionaría y, además, se pondría en peligro, en la medida en que el delito de esclavitud protege este mismo bien jurídico de un ataque todavía mayor. Así pues, el posterior delito de esclavitud absorbería el delito de trata de personas.

Pero España, Francia, Italia, Alemania, Chile, México y Argentina se han apartado de esta interpretación y han tipificado la trata de personas sólo cuando se cometa con ciertos fines de explotación. No se ha cumplido la previsión de Borja Mapelli Caffarena (2012):

a la vista de la evolución expansiva seguida en los últimos años por el concepto jurídico de trata de personas es previsible que pronto se prescinda de concretas referencias de explotación para que no se generen estas impunidades injustificables y se entienda por trata el traslado para la explotación, entendiéndose por explotación utilizar en provecho propio alguna circunstancia que pone a otro en desventaja (p. 54).

La inserción de estas concretas finalidades es el principal argumento para sostener que la prohibición penal de la trata de personas no sólo persigue la tutela de la libertad del sujeto pasivo y de su dignidad o integridad moral, sino que, además, pretende amparar otros bienes que se po- 
nen en peligro con estos comportamientos. Así, por ejemplo, en el delito de trata de seres humanos con fines de explotación sexual se protegería de manera mediata la libertad sexual de la víctima.

\section{CONCLUSIONES}

El Protocolo de Palermo aprobado por la ONU hace ya más de veinte años exige la tipificación penal de la trata de personas sobre la base de tres elementos: en primer lugar, las conductas típicas; en segundo lugar, los medios de determinación de la voluntad de la víctima, que pueden ser violentos, fraudulentos o abusivos, y, en tercer lugar, los fines de explotación configurados de un modo abierto para dar cabida a cualquiera.

Esta composición permite considerar que la pretensión era, por un lado, que el consentimiento prestado por la víctima mayor de edad tuviese absoluta validez, excepto si se presta en un contexto de ilicitud o nulidad, y, por otro lado, hacer frente a toda forma de trata de personas con fines de explotación y no sólo a la dirigida a algunos de ellos.

De los diez países cuyas legislaciones han sido examinadas en este trabajo, ninguno ha trasladado estas dos ideas a sus respectivas legislaciones en materia de trata de personas. Así pues, como sostiene Ana Valverde Cano (2019), "a pesar de los avances hacia una armonización penal que allanan el camino de la cooperación interestatal, el amplio margen de discrecionalidad de los Estados no ha impedido, en la práctica, la subsistencia de un régimen fragmentado en la lucha contra la trata” (p. 21). En este sentido, cabe diferenciar tres tendencias político-criminales distintas a la seguida por el Protocolo de Palermo y, en consecuencia, tres objetos de protección distintos.

En primer lugar, aquellas legislaciones en las que el consentimiento prestado por la víctima es válido excepto si concurren ciertos medios de doblegación de su voluntad, pero cuyos fines de explotación han sido establecidos de forma tasada (es decir, las legislaciones de Alemania, España, Francia, Italia y Chile) tutelarían la dignidad o integridad moral de la víctima, su libertad y otros bienes que se ampararían de forma indirecta.

En segundo lugar, estarían las regulaciones que han previsto que el consentimiento prestado por la víctima mayor de edad siempre es inválido, pero han establecido el listado de finalidades de explotación de un 
modo abierto. Serían las legislaciones de Reino Unido, Colombia y Uruguay. En los delitos de trata de personas de estos países sólo se ampararía la dignidad o la integridad moral de la víctima.

Por último, en tercer lugar, aquellas regulaciones que no otorgan relevancia al consentimiento de la víctima en ningún caso ni establecen los fines de explotación de un modo abierto, como las de Argentina y México, serían las más alejadas de la regulación contenida en el Protocolo de Palermo. En ellas se ampararían la dignidad o integridad moral de la víctima junto con otros intereses que se pondrían en peligro con la realización de la trata de personas.

Esta conclusión acerca del bien jurídico tutelado tiene importantes consecuencias, especialmente, sobre las relaciones concursales entre el delito de trata de personas y otros ilícitos penales. Conlleva, por ejemplo, que ante la captación de una víctima mediante amenaza con fines de explotación sexual existan dos respuestas penales según el país en el que se enjuicie esta práctica ilegal: se apreciaría un delito de trata de personas en Chile o en Italia, mientras que en Reino Unido o en Argentina habría que sancionar por el delito de trata de personas y también por el correspondiente delito de amenazas, pues estas no quedarían absorbidas por la primera figura delictiva. Otro ejemplo de las consecuencias que derivan de la distinta configuración de las figuras delictivas, conectado en este caso con los fines de explotación, haría referencia a la relación entre el delito de trata de personas y los correspondientes delitos de explotación. Si en alguno de estos últimos se prevé la sanción para la puesta en peligro del mismo bien jurídico-penal que se tutela de manera indirecta mediante la trata de personas (como sucede, por ejemplo, en los delitos de tráfico de órganos, al sancionarse los actos tendentes a su obtención ilegal), en el caso de España o de Francia habría un concurso de normas entre ambos ilícitos penales (el de trata de personas y el de tráfico de órganos) que se resolvería por el principio de especialidad en favor del delito de trata de personas. En cambio, por ejemplo, en Uruguay o en Colombia también debería sancionarse en aplicación del ilícito penal que tutele el bien jurídico puesto en peligro; es decir, en un caso como el expuesto se sancionaría tanto en aplicación del delito de trata de personas como en aplicación del delito de tráfico de órganos. Habría que resolver en este supuesto el correspondiente concurso de delitos. 
Pero los problemas más serios que plantea tal disparidad legislativa se observan en sede procesal. La discordancia en este ámbito impide una adecuada cooperación judicial y crea lagunas normativas. Igualmente, imposibilita la recopilación de datos a nivel mundial y su correcto análisis.

Por todas estas razones parece aconsejable una reforma penal por parte de todos los Estados cuyas legislaciones han sido estudiadas en este trabajo con el propósito de prever los medios de doblegación de la voluntad de la víctima en el tipo básico de trata de personas y establecer los fines de explotación de un modo abierto. Como sostiene Borja Mapelli Caffarena (2011), "mientras que se presente un panorama diverso, los sistemas seguirán teniendo graves dificultades para hacer ágiles los traslados de condenados, la euro-orden o el reconocimiento mutuo de sentencias penales de otros países y, consiguientemente, los delincuentes alcanzarán la impunidad mediante estrategias de deslocalización” (p. 44).

\section{BIBLIOGRAFÍA}

BARros SÁnchez, F. (2018). La trata de personas: comparación y evaluación de las políticas en Chile. Revista Política y Estrategia (132), 125-159. https://doi.org/10.26797/rpye.v0i132.242

Bourgeois, B. (2017). Statutory Progress nd obstacles to achieving an efective criminal legislation against the Modern-Day forms of slavery: the case of France. Michigan Fournal of International Law, 38(3), 455-496. https://repository.law.umich.edu/mjil/vol38/iss3/3

Chávez-Gutiérrez， M. R. y Chávez-Gutiérrez， M. A. (2018). La situación de la trata de personas con fines de explotación sexual en México. Revista Espiga, 17(35), 31-44. http://dx.doi.org/10.22458/ re.v17i35.1806

Correa Borges, C. (2019). Legislación penal para la lucha contra la trata de personas en la región de Unasur. En E. PÉREz Alonso y E. POMARES CinTaS (coords.), La trata de seres humanos en el contexto penal iberoamericano (pp. 117-139). Tirant lo Blanch.

DAunis Rodríguez, A. (2013). El delito de trata de seres humanos. Tirant lo Blanch. 
Della Penna, C. (2014). Aspectos fundamentales sobre la trata de personas. Algunas particularidades del caso argentino. URVIO. Revista Latinoamericana de Estudios de la Seguridad (14), 28-47. https://doi.org/10.17141/ urvio.14.2014.1342

Jiménez-Rojas, M. y Figueredo-Medina, G. (2017). Implementación de estándares internacionales de prevención de trata de personas en el control migratorio. Inciso, 19(1), 17-32. https://doi.org/10.18634/ incj.19v.1i.663

HenaO TRIP, M. I. (2008). Lucha contra la trata de personas: desafío para Colombia en el siglo XXI. Revista Criminalidad, 50(1), 385402. $\quad h t t p: / /$ wrwe.scielo.org.co/scielo.php. script=sci_arttextEpid $=S 1794$ 31082008000100013 Elng =en Enrm =iso

Mapelli Caffarena, B. (2011). Las consecuencias jurídicas del delito. Civitas.

Mapelli Caffarena, B. (2012). La trata de personas. Anuario de Derecho Penaly Ciencias penales (65), 25-62.

MartiÑón Cano, G. (2019). El delito de trata de personas en México. Análisis comparativo con la tipología propuesta en el Protocolo de Palermo. En E. Pérez AlOnso y E. Pomares CinTAS (coords.), La trata de seres humanos en el contexto penal iberoamericano (pp. 175-199). Tirant lo Blanch.

MARTOS NúÑEZ, J. A. (2012). El delito de trata de seres humanos: análisis del artículo 177 bis del Código penal. Estudios penales y criminológicos (32), 97-130. https://revistas.usc.gal/index.php/epc/article/view/896

Moya Guillem, G. (2020). La trata de seres humanos con fines de extracción de órganos. Análisis criminológico y jurídico-penal. Tirant lo Blanch.

Moya Guillem, C. (2016). Los delitos de trata de seres humanos en España y Chile. Bien jurídico protegido y relaciones concursales. Política Criminal, 11(22), 521-547. http://dx.doi.org/10.4067/S071833992016000200006

Olaizola Nogales, I. (2013). A vueltas con la inmigración ilegal y el nuevo delito de trata de personas. En J. G. Fernández TERUELO (dir.). Estudios penales en homenaje al profesor Rodrigo Fabio Suárez Montes, Editorial Constitutio Criminalis Carolina, 459-490.

Pérez Alonso, E. (2008). Tráfico de personas e inmigración clandestina, Tirant lo Blanch. 
Quintero Olivares, G. (2011). Título VI: Delitos contra la libertad. En G. Quintero Olivares (dir.). Comentarios a la parte especial del derecho penal, Aranzadi, 183-229.

RAngel Romero, X. G. (2020). El tipo penal de trata de personas en México. Tlatemoani. Revista Académica de Investigación (34), 174-183. https:// wrere.eumed.net/rev/tlatemoani/34/trata-personas. html

Santana Vega, D. (2011). El nuevo delito de trata de seres humanos. Cuadernos de Política criminal (104), 79-108.

Sommer, C. (2017). Trata de personas en Argentina. Sus recientes implicancias de persecución y asistencia a las víctimas. Boletín Mexicano de Derecho Comparado (148), 393-425. http://dx.doi.org/10.22201/ iij. 24484873 e.2017.148.11005

SpITZER, A. (2018). Strafbarkeit des Menschenhandels zur Ausbeutung der Arbeitskraft, Springer.

Valverde Cano, A. B. (2019). Reexaminando la definición de trata de seres humanos del Protocolo de Palermo. La trata como forma de explotación. Estudios de Deusto, 67(2), 15-29. http://dx.doi.org/10.18543/ ed_67(2)-2019pp15-29

Villacampa EstiaRTe, G. (2014). Víctimas de trata de seres humanos: su tutela a la luz de las últimas reformas penales sustantivas y procesales proyectadas. Indret (2), 1-31. https://wrwr.raco.cat/index.php/InDret/ article/view/289825/378134 


\title{
CONTRIBUIÇÕES DAJURISDIÇÃO DA CORTE INTERAMERICANA NA EFETIVAÇÃO DO DIREITO À EDUGAÇÃO NA AMÉRICA LATINA*
}

\author{
APORTES DE LA JURISDICCIÓN DE LA CORTE INTERAMERICANA \\ EN LA REALIZACIÓN DEL DERECHO A LA EDUCACIÓN EN \\ AMÉRICA LATINA
}

\section{Celso de Oliveira Santos**}

\section{Beatriz MENDES NIYAMA****}

RESUMO: Compreendido como um direito social e previsto nas fontes documentais do sistema interamericano de direitos humanos, o acesso à educação é resguardado pela ordem internacional no continente americano. Considerando a necessidade de efetivação deste direito, o problema enfrentado
RESUMEN: Entendido como un derecho social y previsto en las fuentes documentales del sistema interamericano de derechos humanos, el acceso a la educación está protegido por el orden internacional en el continente americano. Teniendo en cuenta la necesidad de hacer cumplir este derecho,

* Recibido el 26 de junio de 2020; el 17 de enero de 2021.

** ORCID: 0000-0002-8759-0538. Doutorando em Direito Internacional pela UERJ, bolsista da Fundação Carlos Chagas Filho de Amparo à Pesquisa do Estado do Rio de Janeiro (FAPERJ), e mestre em Direito Interancional e Comparado pela FDUSP, graduado em direito pela UFRRJ-ITR; membro da Comissão dos Direitos dos Imigrantes e Refugiados e da Comissão de Relações Internacionais da OAB/SP e da Comissão da Diversidade Sexual e de Gênero da OAB/RJ; estagiário-docente do Núcleo de Estudos e Pesquisa em Direito Internacional da UERJ (NEPEDI/UERJ); coordenador-adjunto do Núcleo Democracia, Direitos Humanos e Direito Internacional no Centro Internacional de Direitos Humanos de São Paulo, e membro da Sub-Comissão Regime Constitucional e Responsabilidade Internacional, ambos vinculados à Cadeira San Tiago Dantas da Academia Paulista de Direito; pesquisador honorário do Núcleo de Estudos sobre Tribunais Internacionais da FD-USP, e associado ao Núcleo de Pesquisa em Direito e Descolonização da USJT. Correo electrónico: osantoscelso@gmail.com.

*** ORCID: 0000-0002-1896-2596. Mestranda em Direito Internacional na Faculdade de Direito da Universidade de São Paulo; bacharel em direito pela PUC-Campinas e pedagogia pela Universidade Estadual de Campinas (UNICAMP). Pesquisadora da Fundação de Amparo à Pesquisa de São Paulo (nº 2018 / 21273-9) e do Núcleo "Democracia, Direitos Humanos e Direito Internacional" no Centro Internacional de Direitos Humanos de São Paulo, e membro da Sub-Comissão Regime Constitucional e Responsabilidade

Boletín Mexicano de Derecho Comparado, nueva serie, año LIV, núm. 160, enero-abril de 2021, pp. 309-334. 
pelo presente artigo se traduz na seguinte pergunta: a Corte Interamericana de Direitos Humanos, através de sua função jurisdicional, é capaz de auxiliar na implementação do direito à educação? Foi adotado o método documental (jurisprudencial) combinado com uma análise qualitativa dos julgados delimitados. Os resultados atingidos permitiram a identificação de três sentenças em que a Corte Interamericana condenou estados membros por não cumprirem com as obrigações educacionais previstas nas fontes internacionais. $\mathrm{O}$ artigo conclui que a Corte Interamericana contribui para a delimitação do conteúdo normativo do direito à educação, e que sua atuação, em geral, visa reparações individuais e mudanças estruturais no sistema educacional dos países, porém, as dificuldades de implementação das sentenças ainda representam uma limitação da eficácia na atividade jurisdicional interamericana.

Palavras-chave: educação, Corte Interamericana de Direitos Humanos, políticas públicas educacionais. el problema que enfrenta este artículo se traduce en la siguiente pregunta: ¿puede la Corte Interamericana de Derechos Humanos, por medio de su función jurisdiccional, ayudar en la implementación del derecho a la educación? El método documental (jurisprudencial) se combinó con un análisis cualitativo de los juicios demarcados. Los resultados alcanzados permitieron la identificación de tres oraciones en las cuales la Corte Interamericana condenó a los Estados miembros por no cumplir con las obligaciones educativas establecidas en las fuentes internacionales. El artículo concluye que la Corte Interamericana contribuye a la delimitación del contenido normativo del derecho a la educación, y que su desempeño, en general, apunta a reparaciones individuales y cambios estructurales en el sistema educativo de los países, sin embargo, las dificultades para implementar las sentencias aún representan un limitación de efectividad en la actividad jurisdiccional interamericana.

Palabras clave: educación, Corte Interamericana de Derechos Humanos, políticas públicas educativas.

SuMÁriO: I. Introdução. II. A construção documental do direito à educação no sistema interamericano. III. Caso "Instituto de reeducação do menor" vs. Paraguai (2004). IV. Caso das crianças Yean e Bosico vs. República Dominicana (2005). V. Caso Gonzales Lluy e outros vs. Equador (2015). VI. Conclusão. VII. Referências bibliográficas.

\section{INTRODUÇÃO}

O direito humano à educação, que em sua multidimensionalidade pode ser observado em sua provisão formal e abstrata, qualitativamente, ou ain-

Internacional, ambos vinculados à Cadeira San Tiago Dantas da Academia Paulista de Direito. Correo electrónico: biamendees91@gmail.com.

Esta obra está bajo una Licencia Creative Commons

Atribución-NoComercial-SinDerivar 4.0 Internacional, IIJ-UNAM.

Boletín Mexicano de Derecho Comparado, núm. 160, enero-abril de 2021, pp. 309-334. 
da na perspectiva do acesso universalizado, consagrou-se, no Sistema Interamericano de Direitos Humanos (Sistema Interamericano) como um direito social a partir dos artigos 49 da Carta da Organização dos Estados Americanos (Carta da OEA), 26 do Convenção Americana de Direitos Humanos ("Convenção") e 13 do Protocolo de San Salvador.

Entretanto, sabidamente a efetivação do direito à educação na região ainda é uma realidade distante, seja na perspectiva do acesso concreto às instituições educacionais, seja na temática da qualidade dos sistemas educacionais públicos no continente americano.

Por outro lado, o Sistema Interamericano oferece a seus jurisdicionados - indivíduos dos 35 estados membros que compõe a OEA - algumas ferramentas para efetivar o direito à educação, ao proporcionar a atuação da Corte Interamericana de Direitos Humanos (Corte Interamericana), assim como da Comissão homônima, na defesa deste direito, e outros, na América Latina.

Neste sentido, o presente estudo se dedica a analisar a jurisprudência da Corte Interamericana sobre educação, com foco em casos que o tribunal constatou a violação deste direito, como forma de compreender se o Sistema Interamericano contribui para a interpretação e aplicação do direito à educação, conforme as decisões proferidas.

Para tanto, se observou que a Corte Interamericana possui somente três sentenças em que se condenou o Estado por violar o direito à educação, sendo que o presente estudo se dedicou a análise qualitativa de cada decisão para o fim de compreender se o Sistema Interamericano tem logrado êxito em seu dever de fazer cumprir no continente, no limite da inércia inerente aos tribunais internacionais, este direito.

\section{A GONSTRUÇÃO DOCUMENTAL DO DIREITO À EDUGAÇÃO NO SISTEMA INTERAMERICANO}

Delimitado como um direito social, a educação é essencial para formação integral do ser humano, conforme C. Cury (2002) e Frederick Breed (1962), e fator decisivo para a capacitação do indivíduo em uma sociedade democráticamente organizada, segundo Bell Hooks (1994), John Dewey (1979) e Paulo Freire (1971). 
Historicamente, a proteção ao direito à educação foi objeto de uma série de fontes documentais do Sistema Interamericano, que já no seu tratado constitutivo, a Carta da OEA (1948), pretendeu a salvaguarda de todas as etapas do sistema educacional, e o estímulo do ensino para a consolidação democrática:

Artigo 47 Os Estados membros darão primordial importância, dentro dos seus planos de desenvolvimento, ao estímulo da educação, [...] orientadas no sentido do melhoramento integral da pessoa humana e como fundamento da democracia, da justiça social e do progresso.

Artigo 49: Os Estados membros empreenderão os maiores esforços para assegurar, de acordo com suas normas constitucionais, o exercício efetivo do direito à educação, observados os seguintes princípios:

a) O ensino primário, obrigatório para a população em idade escolar, será estendido também a todas as outras pessoas a quem possa aproveitar. Quando ministrado pelo Estado, será gratuito;

b) O ensino médio deverá ser estendido progressivamente, com critério de promoção social, à maior parte possível da população. Será diversificado de maneira que, sem prejuízo da formação geral dos educandos, atenda às necessidades do desenvolvimento de cada país; e

c) A educação de grau superior será acessível a todos, desde que, a fim de manter seu alto nível, se cumpram as normas regulamentares ou acadêmicas respectivas.

A importância da educação para o sistema interamericano se reflete na Declaração Americana de Direitos e Deveres do Homem (1948), que define, em seu artigo 12, que "toda pessoa tem direito à educação, que deve inspirar-se nos princípios de liberdade, moralidade e solidariedade humana".

O caráter social do direito à educação é posteriormente confirmado pela Convenção Americana, que no artigo 26 reitera que os Estados membros devem "comprometer-se a adotar providências [...] a fim de conseguir progressivamente a plena efetividade dos direitos que decorrem das normas econômicas e sociais sobre educação".

O direito à educação, então, ultrapassa a temática político-pedagógica, e se incorpora, na jurisprudência da Corte Interamericana, como um marco normativo da interdependência e indivisibilidade dos direitos econômicos, sociais e culturais, sendo base de importantes votos proferi-

Esta obra está bajo una Licencia Creative Commons

Atribución-NoComercial-SinDerivar 4.0 Internacional, IIJ-UNAM.

Boletín Mexicano de Derecho Comparado, núm. 160, enero-abril de 2021, pp. 309-334. 
dos por juízes da Corte IDH como: o de A. A. Cançado Trindade no caso "Yean e Bosico vs. República Dominicana (2005), ao se referir ao direito à educação, o de Ferrer Mac-Gregor, no caso Suárez Peralta vs. Equador (2013), sobre a amplitude do direito à saúde, e, ainda, o de García Ramírez, em seu voto concorrente no caso Acevedo Buendía vs. Peru (2009).

Posteriormente, em uma fonte documental anexa à Convenção, o Protocolo adicional à Convenção em matéria de direitos econômicos, sociais e culturais (Protocolo de San Salvador), o direito à educação é novamente resguardado, pelo artigo 13, que em cinco incisos aprofunda e detalha quais dimensões educacionais se pretendem acolher no sistema interamericano.

No primeiro inciso do artigo 13, se dispõe genericamente que "toda pessoa tem direito à educação", o segundo inciso descreve os objetivos e os fins que a educação deve atingir no continente americano:

2. Os Estados Partes neste Protocolo convêm em que a educação deverá orientar-se para o pleno desenvolvimento da personalidade humana e do sentido de sua dignidade e deverá fortalecer o respeito pelos direitos humanos, pelo pluralismo ideológico, pelas liberdades fundamentais, pela justiça e pela paz. Convêm, também, em que a educação deve capacitar todas as pessoas para participar efetivamente de uma sociedade democrática e pluralista, conseguir uma subsistência digna, favorecer a compreensão, a tolerância e a amizade entre todas as nações e todos os grupos raciais, étnicos ou religiosos e promover as atividades em prol da manutenção da paz.

Reforçando a proteção de todas as etapas do sistema educacional, o inciso três reitera o caráter obrigatório do ensino primário e a progressividade do ensino médio e universitário, mas inova ao dispor o acesso à educação para jovens e adultos e a obrigação de incluir deficientes no sistema público educacional. Os incisos quatro e cinco consolidam a liberdade de escolha de qual educação proporcionar aos filhos e de criação de instituições de ensino.

Em conjunto, as fontes documentais permitem delimitar que do plano formal interamericano, o direito à educação assume o papel de potencializar ideais democráticos e principiológicos, e concretamente se incorpora em duas modalidades: o ensino primário - composto por pré-escola 
e fundamental - na forma obrigatória e universal, e o ensino médio e universitário, que deve ser implementado progressivamente.

A mera existência de um tratado internacional não permite a dedução que existe uma obrigatoriedade em cumprir com as disposições educacionais, pois os Estados membros somente possuem vínculo legal com fontes documentais ratificadas. Todavia, em vista, da ratificação como "vinculação jurídica de um estado ao tratado e ao cumprimento de sua disposição" (Paulo Casella, 2019, p. 182), é possível, de fato, considerar que os 35 Estados membros da OEA devem garantir o direito à educação, visto que todos ratificaram, ao menos, uma das quatro fontes documentais supracitadas que tratam da temática.

De forma, a visualizar o exato momento que cada estado membro se tornou internacionalmente responsável por efetivar o direito educacional, a seguinte linha do tempo indica o ano que cada país ratificou, pela primeira vez, fonte documental sobre a temática: ${ }^{1}$

Cronología: ano em que o estado membro se comprometeu, via ratificação de fonte documental, a garantir o direito à educação (universalização de ensino primária e progressividade de ensino médio) em seu território

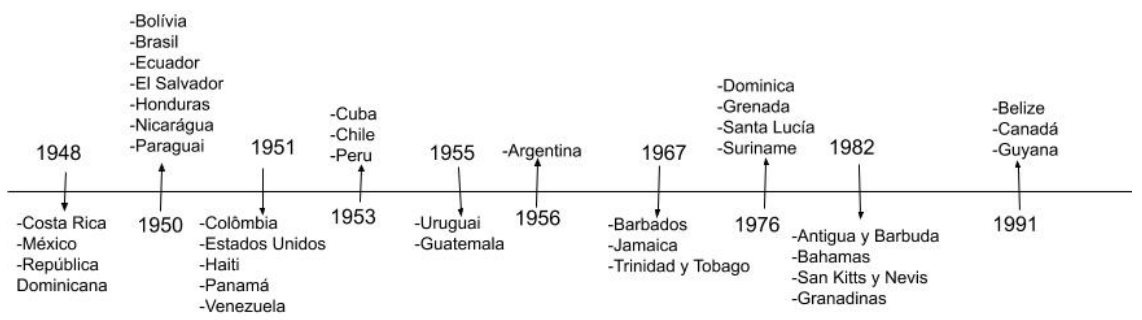

Com isso, o direito à educação é uma obrigação internacional para todo continente desde 1991, ou seja, há 29 anos. Não obstante essa garantia no plano formal, a realidade fática do continente demonstra que infelizmente o acesso à formação escolar ainda não é uma realidade para

1 Se destaca que a linha cronológica, criada para fins elucidativos e didáticos, foi construída a partir da sistematização das informações sobre ratificação do instrumento disponível nos próprios tratados: Tratado Constitutivo http://werere.oas.org/es/sla/ddi/trata dos_multilaterales_interamericanos_A-41_carta_OEA_firmas.asp, Pacto de San José http://wrere. oas.org/dil/esp/tratados_B-32_Convencion_Americana_sobre_Derechos_Humanos_firmas.htm e Protocolo de San Salvador http://wrerw.oas.org/juridico/spanish/firmas/a-52.html.

Esta obra está bajo una Licencia Creative Commons

Atribución-NoComercial-SinDerivar 4.0 Internacional, IIJ-UNAM.

Boletín Mexicano de Derecho Comparado, núm. 160, enero-abril de 2021, pp. 309-334. 
todos os indivíduos e grupos nos países americanos, consoante afirma G. Pope Atkins (1995).

Dados oficiais da OEA estimam que 90\% das crianças, entre a faixa etária de 4 a 15 anos, têm acesso ao ensino primário, e somente 58\% dos adolescentes do continente têm acesso ao ensino médio (OEA, 2018).

Cabe destacar que dados não enfrentam a questão da qualidade do ensino no continente americano - questão igualmente importante-, porém demonstram uma realidade alarmante: a universalidade do ensino primário não é cumprida e a progressividade de implementação do ensino médio ainda não atingiu parte substancial de jovens do continente.

Em face do descumprimento dos tratados e declarações, o sistema interamericano prevê a possibilidade de atuação de certos órgãos, dentre eles, a Corte Interamericana, que é regida pela Convenção Americana e possui uma finalidade dupla: jurisdição contenciosa e consultiva.

No tocante a primeira função, a Corte Interamericana se encarrega de julgar possíveis violações da Convenção Americana de 21 Estados membros da OEA, que reconheceram sua jurisdição. ${ }^{2}$ Igualmente, a Corte Interamericana é eleita como a responsável por julgar casos de violação do Protocolo de San Salvador:

Artigo 19: Caso os direitos estabelecidos na alínea a do artigo 8, e no artigo 13, forem violados por ação imputável diretamente a um Estado Parte deste Protocolo, essa situação poderia dar lugar, mediante participação da Comissão Interamericana de Direitos Humanos e, quando cabível, da Corte Interamericana de Direitos Humanos, à aplicação do sistema de petições individuais regulado pelos artigos 44 a 51 e 61 a 69 da Convenção Americana sobre Direitos Humanos.

Como pontuado por Ramos (2019) o sistema interamericano se inspirou no paradigma europeu de proteção aos direitos humanos, e optou por adotar um procedimento bifásico, em que o indivíduo ou grupo indica uma violação, via petição, para a Comissão Interamericana de Di-

2 Apesar da Corte somente julgar estados membro que reconheceram a sua jurisdição, como disposto por André de Carvalho Ramos (2017) no contexto internacional os países são constantemente pressionados — por outros estados, seus cidadãos nacionais e a própria mídia - a acatarem com as disposições internacionais e a aceitaram a jurisdição de cortes não nacionais, como a Interamericana. 
reitos Humanos (Comissão), que analisa o alegado pela vítima e negocia uma conciliação com o estado infrator.

Caso a solução amistosa não seja possível, e a demanda da vítima cumpra com requisitos, a Comissão realiza uma denúncia perante a Corte Interamericana, que exercerá sua capacidade jurisdicional sobre o caso.

Como não foram identificados pareceres sobre o direito à educação, não será explorado essa atuação da Corte, mas vale a ressalva que essa via poderia ser utilizada por um Estado membro para requisitar uma elucidação da Corte sobre esse tópico. Entrando na atuação contenciosa, foram identificados e analisados três casos em que a violação do direito à educação foi constatada pela Corte Interamericana. Porém, como se verá — na conclusão - não se deve ignorar que a Corte tenha perpassado pela temática educacional em outros julgados, embora em caráter residual, como desdobramento de outras demandas e sem uma análise focalizada desse direito. De forma a exemplificar a apreciação conjunta da educação com outros direitos, se elegeu, como exemplo, o caso Comunidade Indígena Xákmok Kásek vs. Paraguay (2010).

\section{Caso Instituto de ReEduCaÇÃo DO \\ Menor vs. Paraguai (2004)}

Tendo como foco a discussão da violação de direitos humanos de menores em situação de cárcere no Instituto "Panchito López", o caso faz parte de um conjunto de outros julgados da Corte Interamericana que promove o debate sobre o direito à integridade pessoal no sistema penal. ${ }^{3}$ Todavia, o presente caso possui o diferencial de discutir o acesso à educação pública pela população carcerária.

Em linhas gerais, prévio ao procedimento da Corte Interamericana, que se iniciou em 2002, o caso foi iniciado quando duas Organizações Não Governamentais (ONG ou representantes), o Centro pela Justiça e o Direito Internacional (CEJIL) e a Fundação Tekojoja (Fundação), apresentaram em 1996 uma petição a Comissão sobre a situação dos reclusos do Instituto "Panchito López".

3 Caso Durand e Ugarte vs. Peru; Caso Bámaca Velásquez vs. Guatemala; Caso Hilaire, Constantine e Benjamin e Outros vs. Trinidade e Tobago; Caso Caesar vs. Trinidad e Tobago; Caso do Presídio Miguel Castro; Caso Mendoza e outros vs. Argentina.

Boletín Mexicano de Derecho Comparado, núm. 160, enero-abril de 2021, pp. 309-334. 
A estrutura do Instituto, planejada para ser uma residência, foi transformada precariamente em um centro de detenção, com celas insalubres e sem ambientes para recreação ou exercícios. Em conjunto com os problemas estruturais, o Instituto não disponibilizava camas e bens de higiene básica aos reclusos, o que ensejou uma série de rebeliões internas.

Ao longo do período de tramitação pela Comissão, os representantes não chegaram a uma solução amistosa com o Estado paraguaio, que somado aos incêndios que ocorreram no Instituto (fevereiro de 2000, março de 2001 e junho de 2001), levaram a apresentação de uma denúncia pela Comissão à Corte Interamericana.

Em 2002 se inicia o trâmite perante Corte Interamericana que, a pedido da Comissão e dos representantes, analisou se houve violação do artigo 5 (direito à integridade pessoal), artigo 7 (direito à liberdade pessoal), artigo 19 (direitos da criança), artigo 8 (garantias judiciais) e artigo 25 (proteção judicial), todos da Convenção Americana, em detrimento dos meninos internos no Instituto.

Inicialmente, a Corte IDH não foi requisitada a analisar a violação do direito à educação no caso, porém a produção de provas ao longo do processo indicou que a precariedade estrutural do Instituto gerava a impossibilidade do acesso à educação pelos reclusos.

Apesar de existir o espaço físico para uma escola anexa ao Instituto, o acesso ao local exigia a locomoção supervisionada por guardas que "não tinham interesse em ajudá-los" (CIDH, 2004, p. 14), a parte minoritária dos reclusos que eram matriculados eram "alvos constantes dos guardas que impediam a continuidade das aulas como forma de castigo" $(\mathrm{CIDH}$, 2004, p. 16).

Além das dificuldades impostas pelos guardas do Instituto, a escola somente oferecia o ensino fundamental - mesmo que vasta maioria estivesse entre os 15 a 17 anos - a ausência de oferecimento de ensino médio impedia a continuidade da escolarização de parte majoritária dos reclusos.

Mesmo que a escola estivesse dentro de um programa específico coordenado pelo Ministério de Educação e Cultura e pela Pastoral Educacional, a falta de recursos impossibilita o seu pleno funcionamento, situação que foi definida por Emílio Arturo García Méndez, assessor da UNICEF e perito no caso, como "um abandono absoluto no aspecto educativo" (CIDH, 2004, p. 45). 
A partir de sua jurisprudência ${ }^{4}$ e do princípio da iura novit curia (juiz conhece a lei), a Corte Interamericana deliberou que a inexistência de citação expressa da violação do direito à educação na denúncia, não seria um impedimento para o julgamento desta questão, pois o "o julgador possui a faculdade e, inclusive, o dever de aplicar as disposições jurídicas pertinentes em uma causa, mesmo quando as partes não as invoquem expressamente" (CIDH, 2004, p. 59).

Frente a precariedade do acesso à educação no Instituto, a Corte considerou que o Paraguai violou o artigo 19 (direitos da criança) da Convenção. ${ }^{5}$

O artigo 19 define genericamente que "toda criança tem direito às medidas de proteção que a sua condição de menor requer", na análise da Corte Interamericana deste dispositivo, o órgão definiu que este "excede o campo estrito dos direitos civis e políticos" e abarca "aspectos econômicos, sociais e culturais que fazem parte principalmente do direito à vida". Como forma de delimitar o conteúdo social do artigo 19, a Corte Interamericana utilizou como parâmetro o Protocolo de San Salvador - tratado focado em direitos sociais - especificamente o artigo 13 que indica o direito à educação.

Logo, pela hermenêutica da Corte Interamericana, o artigo 19 abrangeria o conteúdo do direito social à educação, sendo o exposto pelos menores em situação de cárcere uma prova testemunhal da violação do citado artigo pela Estado membro.

Por conseguinte, a Corte Interamericana indicou como forma de reparação a criação, pelo governo do Paraguai em conjunto com a sociedade civil, de uma política pública de curto, médio e longo prazo em matéria de detenção de menores, que deveria obrigatoriamente dispor de "estratégias, ações apropriadas e a designação dos recursos indispensáveis para a criação de programas de educação".

Combinado com medidas de mudanças estruturais, a Corte Interamericana indicou que o Estado deveria proporcionar um "programa

4 Em detalhe a Corte Interamericana citou os casos "Irmãos Gómez Paquiyauri", "Cinco Aposentados" e "Cantos".

5 A título de curiosidade se indica que a Corte também condenou o Paraguai pelas violações dos 4.1, 5.1, 5.2 e 5.6 da Convenção Americana sobre Direitos Humanos e que geraram uma série de reparações, que frente ao recorte temático do presente artigo não será detalhado.

Esta obra está bajo una Licencia Creative Commons

Atribución-NoComercial-SinDerivar 4.0 Internacional, IIJ-UNAM.

Boletín Mexicano de Derecho Comparado, núm. 160, enero-abril de 2021, pp. 309-334. 
de educação especial" para os ex-detentos do Instituto, como forma de reparações individuais.

É inegável a amplitude da sentença na temática da educação, na forma macro de criação de políticas públicas e individual no atendimento direto aos ex-detentos do Instituto. Porém, novamente ocorre a dificuldade de efetivação da proteção ao direito à educação: a Corte Interamericana realizou em três momentos a supervisão de sentença - sendo a última realizada em 2009 - e constatou que o Paraguai continua omisso na concretização das reparações individuais impostas.

No tocante a implementação da política pública, a última supervisão de sentença constatou que o estado paraguaio, em parceria com a UNICEF, havia elaborado uma "Estratégia ISAI: proposta metodológica para a elaboração da política pública de atenção a adolescentes infratores" e constituído uma "Junta Interinstitucional e Multissetorial" que teria o objetivo de desenvolver uma política pública criminal juvenil da ISAI com atendimento escolar especializado.

Infelizmente, em decorrência da falta de novos andamentos na execução da sentença e a falta de informações institucionais do governo do Paraguai, não é possível concluir se houve ou não a efetivação das políticas públicas ou se ocorreu as reparações individuais.

Ressalvados os problemas identificados no cumprimento da sentença, a atuação da Corte foi pioneira em realizar uma condenação pelo descumprimento do direito à educação e por, através da atividade hermenêutica conceder a interpretação sobre a extensão normativa abarcada no artigo 19 (direito da criança) da Convenção.

\section{CASO DAS GRIANÇAS YEAN E BOSICO vs. REPÚBLICA DOMINICANA (2005)}

Centrado no debate sobre a questão dos apátridas, ${ }^{6}$ o caso visava reparar os danos sofridos por Dilcia Yean e Violeta Bosico, ambas dominicanas de ascendência haitiana, que em março de 1997 tentaram realizar o Registro Civil tardio. As meninas, que tinham respectivamente, 11 meses e 12

6 O artigo $1^{\circ}$ da Convenção sobre o Estatuto dos Apátridas, de 1954, assim define: "1. Para efeitos da presente Convenção, o termo apátrida designará toda a pessoa que não seja considerada por qualquer Estado, segundo a sua legislação, como seu nacional". 
anos, tinham nascido em território dominicano, país este que adota o critério ius solis ${ }^{7}$ para o reconhecimento de nacionalidade.

Apesar de atenderem o critério estabelecido para serem consideradas nacionais dominicanas, o Cartório de Registro Civil tomou a decisão administrativa de negar a emissão de certidão de nascimento para as menores, com a justificativa de que os genitores das menores eram imigrantes ilegais:

A licenciada Thelma Bienvenida Reyes, Oficial do Estado Civil, negou-se a aceitar a documentação porque filhos de imigrantes haitianos não podiam ser registrados, já que seus pais são ilegais. Se os pais são haitianos, as crianças também são haitianas, já que os pais estão em trânsito. A Oficial acrescentou que estas eram ordens superiores, as quais tinha por escrito, apesar de ter se negado a mostrar o documento. E procedeu a comentar sobre a natureza "estranha", "africanizada" ou haitiana dos sobrenomes das crianças. (CIDH, 2005, p. 26)

Os entraves para a emissão tardia dos documentos de nascimento e nacionalidade fizeram com que as meninas permanecem na situação de apátridas, gerando a impossibilidade de acessarem serviços de saúde, assistência social e de cursarem escolas públicas.

As vítimas tiveram como representantes as ONG Movimiento de $\mathrm{Mu}$ jeres Domínico-Haitianas e o Centro pela Justiça e o Direito Internacional (CEJIL) e a clínica de direitos humanos International Human Rights Law Clinic da Universidade da Califórnia no trâmite perante a Comissão. Posteriormente, com o início do julgamento da Corte Interamericana, outros 8 movimentos da sociedade civil organizada atuaram como amici curiae $^{8}$ em favor das menores.

7 "Fus soli: o indivíduo é nacional do Estado onde nasceu. Esta predominância tem suas raízes na organização econômica e social do feudalismo medieval. A terra era considerada a maior riqueza e símbolo de poder". (Celso Mello, 2004, p. 994)

8 Atuaram em favor das menores: a) Centre on Housing Rights and Evictions (COHRE); b) Associação Civil de Centros Comunitários de Aprendizagem (CECODAP); c) Comitê Latino-Americano e do Caribe para a Defesa dos Direitos da Mulher (CLADEM); d) Minority Rights Group International (MRG); e) professora Katarina Tomasevski; f) Secretaria Ampliada da Rede de Encontro Dominicano Haitiano Jacques Viau (RED), formada pelo Centro Cultural Dominicano Haitiano (CCDH), o Movimento Sociocultural dos Trabalhadores Haitianos (MOSCTHA), o Serviço Jesuíta de Refugiados e Migrantes (SRJM-RD), o Centro Dominicano de Pesquisa Jurídica (CEDAIL) e a 
A participação das entidades da sociedade civil organizada no presente caso se justifica pelo fato de que a situação de apatridia das vítimas não foi um caso isolado na República Dominicana. Ao contrário, os representantes das vítimas demonstraram que "as autoridades dominicanas, conscientes dos limites dos imigrantes haitianos, dificultavam a obtenção de documentos oficiais por meio de burocracias" (CIDH, 2005, p. 45).

O estado de apátrida das meninas era um obstáculo em diversos sentidos, Tiramen Bosico, genitora da vítima Violeta Bosico, concebeu uma declaração, por meio de produção de prova, que todos os seus seis filhos - todos nascidos em território dominicano de descendência haitiana- não puderam cursar o ensino básico público em decorrência da falta de documentos de nascimento.

Em 3 de julho de 2003, a Comissão submeteu a demanda à Corte Interamericana, acusando o Estado da República Dominicana de ter violado o artigo 3o. (direito ao reconhecimento da personalidade jurídica), o artigo 8o. (garantias judiciais), o artigo 19 (direitos da criança), artigo 20 (direito à nacionalidade), o artigo 24 (igualdade perante a lei) e o artigo 25 (proteção judicial), todos da Convenção Americana.

Em sua defesa preliminar à Corte Interamericana, a República Dominicana definiu que inexistia razões para a continuidade do julgamento, pois em 21 de setembro de 2001 emitiu "certidões temporárias de estadia no país que concedem status migratório para as menores" (CIDH, 2005, p. 26), o que possibilitou que as vítimas se matricularem em escolas públicas.

Porém, como indiciado pela Comissão na denúncia, e atestado pela produção de provas, no momento da negativa do Cartório de Registro civil em 1997 até a emissão da certidão em 2001, as menores foram extremamente prejudicadas. Principalmente, Violeta Bosico que em detrimento da falta de documentação foi impedida de se matricular em escola

\footnotetext{
Associação Pró-Desenvolvimento da Mulher e do Meio Ambiente, Inc. (APRODEMA); g) Comparative International Education Society (CIES); h) Themis Foundation, em cooperação com a University of Ottawa School of Law; i) Open Society Justice Initiative, e j) Centro de Estudos Legais e Sociais (CELS), Serviço de Apoio e Orientação a Imigrantes e Refugiados (CAREF), Clínica Jurídica para os Direitos de Imigrantes e Refugiados (Faculdade de Direito da Universidade de Buenos Aires, GELS e CAREF) e senhor Christian Courtis, professor da Universidade de Buenos Aires e do Instituto Tecnológico Autônomo do México.
} 
pública diurna em 1997, e forçada a estudar no período noturno em uma instituição de adultos nos quatro anos seguintes.

Ademais a Comissão destacou que era "inaceitável qualificar as vítimas do presente caso como estrangeiros em trânsito" (CIDH, 2005, p. 32) e que, frente a continuidade de irregularidades no processo de registro civil, e a ausência de instrumentos de acesso à educação na República Dominicana, ainda era necessária a atuação da Corte Interamericana no caso.

Com isso, a Comissão afirmou que em conjunto com desrespeito com o direito à nacionalidade, "o Estado faltou com seu dever de assegurar o direito à educação, tendo em vista que Violeta foi impedida de se matricular na escola diurna por carecer da certidão de nascimento" (CIDH, 2005, p. 37). Complementarmente, os representantes das vítimas alegaram que:

O artigo 19 da Convenção requer que sejam tomadas medidas especiais de proteção para garantir o direito à educação das crianças, em razão de sua situação específica de vulnerabilidade e porque não podem proteger seu direito sem assistência especial por parte de sua família, da sociedade e do Estado. O direito à educação constitui um dos direitos protegidos pelo artigo 26 (Desenvolvimento progressivo) da Convenção Americana (CIDH, 2005, p. 38).

Como forma de reparação da violação do artigo 19, os representantes alegaram como medidas reparatórias "a eliminação da apresentação de certidões de nascimento para matrícula e/ou quaisquer obstáculos que impeçam as crianças de exercerem seu direito à educação".

Em matéria de defesa, a República Dominicana alegou que "existe um princípio de ordem pública insuperável para a escolarização, que faz necessária a matrícula dos estudantes com sua certidão de nascimento", justificativa incompatível com as normativas interamericanas de proteção ao direito à educação.

Face aos argumentos das partes e a vasta produção de provas, a Corte Interamericana - considerando sua construção jurisprudencial prévia no caso Instituto de reeducação vs. Paraguai - delimitou que o Estado descumpriu o artigo 19 ao restringir o acesso das vítimas à escolas públicas.

Porém, no tocante à reparação, a Corte Interamericana foi negativamente objetiva ao afirmar que o "o Estado deve cumprir sua obrigação 
de garantir o acesso à educação primária e gratuita a todas as crianças, independentemente de sua ascendência ou origem, o que se deriva da especial proteção que se deve oferecer às crianças", sem impor a medidas específicas, como a criação de políticas públicas ou legislação protetiva ao acesso à educação.

A sentença somente foi descritiva nas reparações individuais das menores, que envolveu um valor monetário em decorrência dos danos emocionais, e a concessão de bolsas de estudos.

A falha da Corte Interamericana em se omitir de impor medidas estruturas específicas para o Estado gera duas consequências: a) a impossibilidade de meios de qualificar via cumprimento de sentença a evolução da temática no país e b) não auxilia na delimitação do conceito normativo de educação, pois não indica quais seriam os procedimentos que garantiriam a universalização de ensino para comunidades formadas por imigrantes e seus descendentes.

Como resultado, apesar da Corte Interamericana ter realizado ao todo quatro supervisões de sentenças, sendo a última em 2019, a República Dominicana não relatou mudanças estruturais em seu sistema educacional, omissão, que surpreendente, não foi questionada pela Corte, em que pese parte da condenação versar especificamente sobre violação ao direito à educação.

Se de um lado a temática educacional foi preterida, do outro a Corte Interamericana exigiu ao longo das supervisões periódicas ${ }^{9}$ que o Estado demonstrasse ter realizado uma série de mudanças internas relacionadas ao registro de nacionalidade tardia, que se reverteu em alterações legislativas e a criação de uma "Unidad Central de Declaraciones Tardías de Nacimiento".

A diferença de tratativa entre os dois pontos exauridos desta sentença pode ser parcialmente explicada pela ausência de uma condenação detalhada e especificada sobre quais mudanças a República Dominicana deveria adotar para garantir o acesso à educação, o que demonstra, por si, uma falha - evitável - na análise da Corte Interamericana sobre o direito à educação neste caso.

9 Em detalhes, as supervisões ocorreram em 2007, 2009, 2010, 2011 e 2019. 


\section{Gaso Gonzales lluy E outros vs. EQUAdor (2015)}

No presente caso, a Corte realizou uma importante ressignificação do conceito de deficiência e sua correlação ao acesso à educação. Iniciado em 7 de agosto de 2009 perante a Comissão Interamericana, o caso buscava a reparação pelos danos sofridos por Talía Gabriela Gonzales Lluy, nascida em 8 de janeiro de 1995 e portadora da doença púrpura trombocitopenia, e que aos 3 anos de idade, em decorrência de um sangramento intenso na via nasal, recebeu uma transfusão de sangue contaminado por HIV.

Como resultado desta situação, a vítima se tornou HIV positiva, o que levou a um agravamento de sua saúde já previamente delimitada pela doença autoimune. O contágio com a HIV, combinado com seu quadro médico prévio, foi utilizado como justificativa para impedir que a vítima se matriculasse no sistema escolar público do Equador.

A Comissão submeteu o caso à jurisdição da Corte Interamericana em 18 de março de 2014, sob o argumento de que o Estado teria violado o artigo 4 (direito à vida), o artigo 5 (direito à integridade pessoal), o artigo 8 (garantias judiciais), o artigo 25 (proteção judicial) e o artigo 19 (direitos da criança), todos da Convenção, e o artigo 13 (direito à educação) do Protocolo de San Salvador.

A condição da vítima como HIV positivo, além de ser resultado direto da atuação errônea do Estado, ${ }^{10}$ impactou seu acesso à educação pública. Detalhadamente, a vítima se inscreveu em setembro de 1999 no primeiro ano do ensino primário em uma escola pública da região de sua moradia, onde assistiu aulas normalmente por dois meses até ter sua matrícula suspensa pela direção da escola, sob a justificativa de que, em decorrência do fato de a vítima ter apresentado um sangramento nasal - sintoma da doença púrpura trombocitopênica - e ser portadora de HIV, ela seria um perigo à saúde dos demais alunos da sala.

Apesar de a direção escolar ter sustentado a suspensão com o argumento de perigo de contágio, funcionários do departamento de saúde regional informaram a impossibilidade de contágio. Mesmo com este dire-

10 A título de curiosidade se informa que a vítima foi infectada por HIV, em decorrência de uma transfusão de sangue não devidamente testada pelo sistema público de saúde, esse fato foi determinante para a condenação do Equador nos artigos 4 e 5 da Convenção Americana.

Esta obra está bajo una Licencia Creative Commons

Atribución-NoComercial-SinDerivar 4.0 Internacional, IIJ-UNAM.

Boletín Mexicano de Derecho Comparado, núm. 160, enero-abril de 2021, pp. 309-334. 
cionamento técnico, em fevereiro de 2000 a direção escolar confirmou o cancelamento da matrícula e deliberou que a vítima não poderia frequentar a escola.

A decisão da direção foi confirmada pela via judiciária. O Tribunal Distrital, ao denegar o prosseguimento do recurso constitucional, argumentou que

Houve [um] conflito de interesses entre os direitos e as garantias individuais da [Talía] contra os interesses de um conglomerado estudantil, uma colisão que fez predominância [social] ou social ou coletiva, como é, o direito à vida versus o direito à educação. (CIDH, 2015, p. 32)

Ademais, o Tribunal indicou que a vítima poderia prosseguir seus estudos em instituição particular à distância, ignorando o contexto social de Talía, que não possuía recursos financeiros para dar continuidade a sua formação em escola particular ou a distância.

Apesar da sentença judicial ter "anulado" o direito à educação pública da vítima, Talía foi amparada no ensino primário por uma escola pública cuja equipe gestora não concordava com as deliberações do judiciário. Todavia, a vítima cursou o ensino fundamental e médio de maneira fragmentada, sendo sistematicamente discriminada por professores e direções escolares por ser portadora de HIV.

A Corte Interamericana ponderou que as provas produzidas indicaram que as constantes mudanças escolares ocasionaram uma série de dificuldades para a família da vítima, o que por conseguinte prejudicou a continuidade de seu tratamento de saúde, de modo que a vítima, na época da conclusão dos autos para sentença da Corte Interamericana em 2015, ainda encontrava dificuldades de se manter no curso universitário por sua saúde debilitada.

A fim de delimitar o que seria o cumprimento do direito à educação, a Corte Interamericana utilizou como ponto referencial um parecer do Comitê de Direitos Econômicos, Sociais e Culturais da Organização das Nações Unidas $(\mathrm{ONU})^{11}$ que indica que todos os níveis educacionais

11 Se esclarece que o citador parecer que foi utilizado pela Corte se trata do documento "Informe sobre os períodos de seção $20^{\circ}$ e $21^{\circ "}$. Organização das Nações Unidas. (1999). Informe sobre os períodos de seção $20^{\circ}$ e $21^{\circ}$ do Comitê de Direitos Econômicos, Sociais e Culturais da Organização das Nações Unidas. Relatório. http://docstore.ohchr.org/SelfServices/FilesHandler.ashx?en- 
devem cumprir as seguintes características: i) disponibilidade, ii) acessibilidade, iii) aceitabilidade e iv) adaptabilidade.

A partir dos referenciais do parecer da ONU, a Corte Interamericana interpretou que "disponibilidade" significa o oferecimento de instituições e programas em quantidade suficiente, que possua condições físicas adequadas e um corpo docente preparado. A "acessibilidade" seria a obrigação de que as instituições e programas educacionais estejam acessíveis e sem discriminação, consistindo, pela interpretação da Corte Interamericana, em três níveis: a) não discriminação, b) acessibilidade material e c) acessibilidade econômica. Também se ponderou que a

dimensão da acessibilidade é condicionada pelas diferenças na redação do artigo 13, parágrafo 2, do Protocolo de San Salvador, com relação ao ensino fundamental, médio e superior: embora o ensino primário deva ser gratuito para todos, os Estados partes são solicitados a implementar gradualmente o Ensino secundário e superior gratuito. (CIDH, 2015, p. 40)

No tocante à aceitabilidade, a Corte Interamericana indica a obrigatoriedade do Estado parte de garantir programas e instituições de ensino em níveis aceitáveis de qualidade, considerando as particularidades culturais. Por fim, a Corte Interamericana delimitou que "adaptabilidade" abrangeria a obrigatoriedade da escola em se adaptar às necessidades dos estudantes em contextos culturais e sociais variados. Igualmente, se concluiu que as citadas características são essenciais e inter-relacionais, sendo "os meios de análise de implementação do direito à educação" (CIDH, 2015, p. 42).

Tendo em vista a condição da vítima com HIV positiva, e suas particularidades fáticas, físicas e patológicas, a Corte Interamericana definiu Talía como deficiente física e estipulou que o Equador não cumpriu com as obrigações educacionais, ao não garantir um sistema escolar inclusivo e não discriminatório para a deficiência da vítima. Logo, a Corte Interamericana concluiu que a vítima, como mulher, HIV positiva, deficiente e baixa renda, sofreu restrição indevida do acesso à educação, tendo ocorrido por parte do Estado a violação do artigo 13 do Protocolo de San Salvador.

$c=4$ slQ6QSmlBEDzFEovLCuW32xfls8SPstay $\% 2$ BrmvyyleezA $\% 2 F T$ TiOrV $\% 2 F 0 v 5 \% 2 F e 2 t c c E-$ jTPuFIeVk6\%2FqlO4PzGVefgFNtw5AIrwymmejkfubUlW\%2Bc\%3D. Acesso em 04/06/2020.

Esta obra está bajo una Licencia Creative Commons

Atribución-NoComercial-SinDerivar 4.0 Internacional, IIJ-UNAM.

Boletín Mexicano de Derecho Comparado, núm. 160, enero-abril de 2021, pp. 309-334. 
Em que pese a constatação da violação do direito à educação, a Corte Interamericana ponderou que o Equador possuía uma política pública na área da educação que incluía a universalidade do ensino básico e legislação interna que prevê a não discriminação aos portadores de HIV, logo a reparação foi de âmbito exclusivamente individual, sendo deliberado que o Estado garantisse uma bolsa de estudos à nível universitário e de pós graduação à vítima. ${ }^{12}$

Críticas à parte, a atuação da Corte Interamericana no caso Gonzales Lluy vs. Equador, dentro da temática da violação ao direito à educação, representa um marco jurisprudencial por utilizar - pela primeira vezo conceito de interseccionalidade, o que virá a ser um marco em outros casos, como Trabalhadores da Fazenda Brasil Verde vs. Brasil e, mais recentemente, no voto do Juiz Ricardo C. Pérez Manrique, no caso "Empregados da Fábrica de Fogos de Santo Antônio de Jesus vs. Brasill":

Corte IDH utilizou pela primeira vez o conceito de "intersecionalidade" na análise da discriminação sofrida por uma menina, no acesso à educação, no Caso Gonzales Lluy e outros Vs. Equador. Afirma-se que, no caso, "incidiram de forma intersecional diversos fatores de vulnerabilidade e risco de discriminação, associados a sua condição de menina, mulher, pessoa em situação de pobreza e pessoa com HIV.

\section{GONCLUSÃO}

O principal motivo que levou à análise conjunta dos três casos examinados até então é o fato de que a Corte Interamericana ponderou - diretamente e explicitamente - os elementos que levam a considerar que um

12 Em acompanhamento de sentença realizado pela Corte Interamericana em 2018, o Estado demonstrou o cumprimento deste ponto da decisão, que incluía: "Este Tribunal nota que en la referida resolución se establecen los detalles del otorgamiento de la beca, entre ellos: i) la forma y período del "financiamiento"; ii) los "rubros de cobertura" de "manutención" y "material bibliográfico y materiales de estudio"; iii) la no inclusión de "rubro para matrícula, colegiatura y otros que pudieren generarse" puesto que son asumidos por la Universidad de Cuenca, iv) las obligaciones de la becaria, v) la no sujeción de la beca a "la obtención de un puntaje mínimo [...] para mantener[la]", entre otros aspectos relacionados con su funcionamiento. También se establece cuál es la entidad encargada de su "seguimiento y control" y disposiciones ante posibles eventualidades o cambios que pudieran surgir". 
Estado violou o direito à educação. Apesar das dessemelhanças no que cabe às condenações, ou mesmo as bases jurídicas utilizadas, os três casos têm este aspecto comum de delimitar o dever-ser da educação no continente americano.

É fato, porém, que a Corte Interamericana, em outros casos, perpassou pela temática educacional, mesmo que de maneira acessória e colateral, apesar de não ter feito uma análise própria do direito à educação apesar de muitas vezes o contexto fático apontar um cenário de desrespeito a este direito.

Exemplificadamente ${ }^{13}$ no caso Comunidade Indígena Xákmok Kásek vs. Paraguai existia uma conjuntura que apontava que o Estado não garantiu o acesso à educação para as vítimas, sendo um ponto reiterado pelas Comissão ao longo do julgamento, todavia a Corte Interamericana não condenou o Estado pelo descumprimento do direito à educação, se limitando a apontar que a temática educacional é parte integrante do direito à vida digna, previsto no artigo 4o. da Convenção Americana. ${ }^{14}$

Por sua vez, o artigo identificou e examinou os três julgados da Corte Interamericana em que foi constatado que um Estado membro violou obrigações e garantias educacionais, a fim de verificar como o Sistema Interamericano atua na efetivação e interpretação do conteúdo normativo do direito à educação.

Em conjunto com a exposição e análise da atuação jurisdicional da Corte Interamericana, o presente artigo parte da perspectiva que o texto normativo no direito internacional representa um "projeto de sentido" (Eduardo Bittar, 2010, p.125) envolto numa pluralidade de possibilidades semânticas.

13 O caso Comunidade Indígena Xákmok Kásek vs. Paraguai foi escolhido a título de exemplo, e por sua relevância (como delimitado na nota 14), pois, em outras decisões da Corte Interamericana a temática da educação foi analisada subsidiariamente, como em Menino de rua (Villagrán Morales e Outros) vs. Guatemala, Presídio Miguel Castro vs. Peru e Caso dos empregados da Fábrica de fogos de artifício em Santo Antônio de Jesus e seus familiares vs. Brasil.

14 Apesar de não ter analisado a violação ao direito à educação em sua completude, a Corte Interamericana realizou a importante ponderação da necessidade da "perspectiva etnoeducativa" (p. 50) no cumprimento do direito à educação para comunidades indígenas. Em termos práticos, a sentença dispôs na argumentação que o Paraguai deveria, no futuro, garantir a implementação de escolas em comunidades indígenas, com aulas ministradas em respeito às tradições culturais e na própria língua da comunidade.

Esta obra está bajo una Licencia Creative Commons

Atribución-NoComercial-SinDerivar 4.0 Internacional, IIJ-UNAM.

Boletín Mexicano de Derecho Comparado, núm. 160, enero-abril de 2021, pp. 309-334. 
Logo, de acordo com Menezes (2013) a atuação da Corte Interamericana objetiva diretamente a reparação pelo direito internacional dos danos sofridos pelas vítimas, e resulta indiretamente na delimitação do conteúdo normativo educacional das fontes normativas do Sistema Interamericano.

De forma que a atuação jurisdicional não só produz resultado para as partes envolvidas, mas também contribui para o desenvolvimento do direito internacional, que adquire como referencial a análise da Corte.

Se observa que o presente artigo, por meio dos resultados descritos, identifica uma corte internacional preocupa em fortalecer a universalidade do ensino primário, etapa da escolarização que somente pode ser restringida em situações extremas. Exemplificadamente, os argumentos propostos pelo Estado da República Dominicana e pelo Equador não foram aceitos como justificativas válidas para impedir o acesso das vítimas ao ensino primário público.

No tocante ao ensino médio, em que a previsão normativa internacional permite a implantação progressiva, a Corte Interamericana impõe que a gradual implementação desta etapa escolar deve acolher o sistema detenção de menores. A relevância deste julgado é exaurida ao se considerar que os Estados da América Latina possuem uma faixa expressiva de menores, entre 15 a 18 anos, em situação de reclusão, de acordo com Nils Christie (1999).

As propostas de reparações demonstram uma sensibilidade da Corte Interamericana em não limitar a violação ao direito à educação em um âmbito individual das vítimas, ao contrário, uma das sentenças balizou a educação dentro de uma perspectiva dos direitos sociais que exige mudanças estruturais e implementação de políticas públicas respectivas, conforme argumenta Moraes (1995).

Os procedimentos burocráticos necessários ao cumprimento das sentenças demonstram os desafios para a implementação das decisões da Corte Interamericana, ${ }^{15}$ especialmente as que visam mudanças estruturais em prol de direitos sociais. Como a temática se restringiu a investiga-

15 Vale destacar que a temática já foi analisada anteriormente em outras produções: Basch F. et al. (2010). A eficácia do Sistema Interamericano de Proteção de Direitos Humanos: uma abordagem quantitativa sobre seu funcionamento e sobre o cumprimento de suas decisões. Sur - Revista Internacional de Direitos Humanos, (7)12, pp. 9-35; Bernardes, Márcia Nina (2011). Sistema Interamericano de Direitos Humanos como esfera pública 
ções teóricas, vale destacar a importância de futuros estudos que adotem metodologias empíricas para averiguar a questão de eficácia das decisões da Corte.

Por ora, o artigo - em uma análise restringida aos relatórios de supervisão de sentença elaborados pela Corte - se limita a constatar que o próprio mecanismo do sistema interamericano tem limitações, afinal, como aponta André Ramos (2019), Fabián Omar Salvioli (1996) e Taí Mariana Pereira (2013) a Corte encontra-se "ilhada" como único órgão a realizar a supervisão das sentenças, apesar do artigo 65 do Pacto de San José estipular o auxílio da Assembleia Geral da OEA, como mecanismo de coerção política aos Estados condenados. Todavia, tanto a Assembleia Geral quanto o Conselho Permanente se omitem em sua função de contribuir para o cumprimento das sentenças da Corte Interamericana.

A aparente limitação na eficácia das sentenças não diminui a relevância da construção de referenciais interpretativos pela Corte Interamericana, na temática de direitos sociais e econômicos. A atuação jurisdicional, nos casos analisados promoveu uma importante leitura do artigo 13 do Protocolo de San Salvador ao estipular: a) critérios de identificação, a partir da orientação do Comitê de Direitos Econômicos, Sociais e Culturais, sobre o que deve ser cumpridas nos níveis educacionais; b) mensuração do cumprimento destes critérios, porque possibilita que seja medido o nível de conformidade do sistema educação de um Estado membro com um padrão definido de características que devem ser cumpridas.

Sem negar os avanços da atuação jurisdicional da Corte Interamericana, uma ressalva se torna necessária, em dois julgados, Instituto de reeducação vs. Paraguai e Yean e Bosico vs. República Dominicana, as infrações educacionais foram analisadas pela junção do artigo 19 (direito da criança) da Convenção Americana, com o conteúdo social do artigo 13 do Protocolo de San Salvador. Esta interpretação fortalece a obrigatoriedade da disponibilização do ensino para crianças e adolescentes, mas por outro, se abstém de contribuir para o fortalecimento da universalidade do ensino para todas as fases da vida, faceta também resguardada nas fontes documentais interamericanas. Indaga-se, por outro lado, se não

transnacional: aspectos jurídicos e políticos da implementação de decisões internacionais. Sur, (15), pp. 135-156.

Esta obra está bajo una Licencia Creative Commons

Atribución-NoComercial-SinDerivar 4.0 Internacional, IIJ-UNAM.

Boletín Mexicano de Derecho Comparado, núm. 160, enero-abril de 2021, pp. 309-334. 
teria a Corte cometido excesso em sua jurisdição caso tivesse o feito, visto que a controvérsia não debruçava-se sobre este aspecto.

Conclui que, a Corte Interamericana realiza uma importante contribuição para a delimitação do conteúdo normativo do direito à educação, e que sua atuação, em geral, procura tanto a reparação individual quanto mudanças estruturais no sistema educacional dos países, porém, as dificuldades de implementação das sentenças proferidas limitam sua atuação jurisdicional, que ainda não encontra meios para atender sua plena potencialidade, sem o auxílio de setores estratégicos da OEA, como a Assembleia Geral, que reforcem a aplicabilidade das sentenças da Corte.

Entende-se, também conclusivamente, que além da necessidade de maior integração com outros órgãos da OEA, o Sistema Interamericano poderia se beneficiar, no plano da ampliação concreta do direito à educação, de propostas normativas que endossem, no plano convencional, e, consequentemente, também no doméstico, a ampliação proposta jurisprudencialmente para o escopo do direito à educação na região, passando a abranger determinações mais específicas relativas à qualidade dos sistemas educacionais, bem como ao dever estatal de promoção da universalidade do acesso à educação.

É fato que ainda há um longo caminho a trilhar até que o direito à educação nas Américas se torne uma realidade plena, no patamar da universalização da sua concretude, porém, até o momento atual, a Corte Interamericana demonstrou estar rumando nesta direção e produzindo contribuições para que se atinja o referido objetivo ao, diante da oportunidade, aprofundar o alcance e harmonizar a aplicação das fontes de direito internacional respectivas.

Afinal, a Corte Interamericana, em conjunto com outros tribunais internacionais, possui o papel de proporcionar uma interpretação "propriamente internacional dos direitos humanos" (André de Carvalho, 2008, p. 452), com referenciais interpretativos que ultrapassam o "inter partes" e se tornam referências de aplicação do conteúdo internacionais aos Estados, exercendo influência inclusive no que diz respeito à construção de políticas públicas, sendo o processo legislativo permeado pela vigência dos estándares interamericanos e, como no caso do direito brasileiro, contemplando o status supralegal ou constitucional das normas de direitos humanos. 
Por outro lado, é possível também visualizar a ampliação, no plano da concretude, do alcance do direito à educação, através da instituição de instâncias internacionais de fomento, seja por meio de financiamento, conforme proposto por Claudia Loureiro (2019), ou pela via da integração regional, como ocorre em iniciativas como o MERCOSUL Educacional, voltadas à integração temática entre estados pelas vias burocráticas e infraestruturais. Nenhuma destas propostas encontrou, por ora, implementação no âmbito da OEA. Não obstante, depreende-se que a Corte vem cumprindo seu papel, nos limites da sua atuação, ${ }^{16}$ ao harmonizar a aplicação das normas interamericanas que visam à ampliação do acesso à educação, tendo ainda suscitado questões sofisticadas que, como tema central ou residual, demonstraram representar avanços em direção à universalidade do direito à educação.

\section{REFERÊNCIAS BIBLIOGRÁFICAS}

Atkins, G. Pope (1995). Latin America in the International Political System. Westview Press.

BASCH, F. et al. (2010). A eficácia do Sistema Interamericano de Proteção de Direitos Humanos: uma abordagem quantitativa sobre seu funcionamento e sobre o cumprimento de suas decisões. Sur - Revista Internacional de Direitos Humanos, São Paulo, 7(12), pp. 9-35. https://sur.conectas. org/wp-content/uploads/2017/11/sur12-port-fernando-basch.pdf

Bernardes, Márcia Nina (2011). Sistema Interamericano de Direitos Humanos como esfera pública transnacional: aspectos jurídicos e políticos da implementação de decisões internacionais. Sur - Revista Internacional de Direitos Humanos, 8(15), pp. 135-156. https://core.ac.uk/download/ pdf/16033946.pdf

BitTAR, Eduardo C. B. (2015). Linguagem jurídica. Saraiva.

BREED, Frederick S. (1962). Filosofia de la educación. Losada.

16 Destaca-se a relevante consideração realizado pelo Juiz Patrício Pazmiño Freire, em seu voto concorrente no caso Empregados da Fábrica de Fogos de Santo Antônio de Jesus vs. Brasil, ao considerar os possíveis impactos da Emenda Constitucional 95 na implementação de direitos sociais no Brasil, como saúde e educação, e a necessidade de que mesmo alterações orçamentárias estejam alinhadas aos compromissos que o Estado realizou na esfera internacional.

Esta obra está bajo una Licencia Creative Commons

Atribución-NoComercial-SinDerivar 4.0 Internacional, IIJ-UNAM.

Boletín Mexicano de Derecho Comparado, núm. 160, enero-abril de 2021, pp. 309-334. 
Casella, Paulo Borba, Silva, Geraldo do Nascimento e AcGioly, Hildebrando (2019). Manual de direito internacional público (24a. ed.). Saraiva.

Christie, Nils. (1999). Elementos para uma geografia penal. Revista de Sociologia e Politica, 1(13), pp. 51-57. https://wrere.scielo.br/pdf/rsocp/n13/ a05n13.pdf

Caso Instituto de reeducação vs. Paraguai (2004). Corte IDH. Sentença. https:// wrere.cnj.jus.br/wp-content/uploads/2016/04/1384a89a0996f1ea1767dc35 33187a82.pdf

Caso Rean e Bosico vs. República Dominicana (2005). Corte IDH. Sentença. https://wrwr.cnj.jus.br/wp-content/uploads/2016/04/d147e8e6485dbelfedded517fe67972f.pdf.

Gonzales lluy e outros vs. Equador (2015). Corte IDH. Sentença. http://wrwre. mpf.mp.br/atuacao-tematica/sci/dados-da-atuacao/corte-idh/GonzalesLluyvE quadorRevisaovf.pdf/@@download/file/Gonzales\%20Lluy\%20v\%20Equa dor\%20-\%20Revisa\%CC\%830\%20vf\%20.pdf

GuRY, G. R. J. (2002). Direito à educação: direito à igualdade, direito à diferença. Cadernos de Pesquisa, 2(116), pp. 245-262. https://wrere.scielo. $b r / p d f / c p / n 116 / 14405$

Dewey, John (1979). Democracia e educação, trad. Anísio Teixeira. Cia. Ed. Nacional.

Freire, Paulo (1971). Educação como prática da liberdade. Paz e Terra.

HoOKs, Bell (1994). Teaching to Transgress: Education as the Practice of Freedom. Routledge.

Mello, Celso D. de Albuquerque (2004). Curso de direito internacional público (15a. ed.). Renovar.

Menezes, Wagner y Geromel, Vitor (2013). El ejercicio de la función judicial internacional. Memorias de la Corte Interamericana de Derechos Humanos. Boletim da Sociedade Brasileira de Direito Internacional, 119124, pp. 1-273.

MORAIS, José Luis Bolzan de (1996). Do direito social aos interesses transindividuais: o Estado e o direito na ordem contemporânea. Liv. do Advogado.

LOUREIRO, Claudia R. M. S. (2019). O direito humano à educação como patrimônio da humanidade e como fundamento para o ativismo social. Em Wagner Menezes (org.), Tribunais internacionais e ativismo social (pp.7181). Belo Horizonte: Arraes Editores. 
Organización de Estados Americanos (2018). Relatório final do Grupo de Trabalho de San Salvador. Washington.

Organização das Nações Unidas (1999). Informe sobre os períodos de seção $20^{\circ}$ e $21^{\circ}$ do Comitê de Direitos Econômicos, Sociais e Culturais da Organização das Nações Unidas. Relatório. http://docstore.ohchr.org/SelfServices/FilesHandler.as hx? enc $=4$ slQ6OSmlBEDzFEovLCuW32xflsoSPstay\%2BrmvyyleezA\%2FTr iOrV\%2F0v5\%2Fe2tccEjTPuFIeVk6\%2FqlO4PzGVefgFNtw5AIwymmejkfu bUlW $\% 2 B c \% 3 D$

PereirA, Taís Mariana Lima (2013). O cumprimento das decisões da Corte Interamericana de Direitos Humanos pelo Brasil. Espaço Jurídico: Fournal of Law, 14(2), pp. 315-348. https://dialnet.unirioja.es/servlet/ articulo?'codigo $=4546933$

Ramos, André de Carvalho (2017). Curso de direitos humanos (4a. ed.). Saraiva.

Ramos, André de Carvalho (2008). Direitos humanos na integração econômica. Renovar.

Ramos, André de Carvalho (2019). Processo internacional de direitos humanos (6a. ed.). Saraiva.

SALVIOLLI, Fabián Omar (1996). Los desafíos del sistema interamericano de protección de los derechos humanos. Estudos básicos de derechos humanos (4a. ed.). Instituto Interamericano de Derechos Humanos. https:// wrwre.corteidh.or.cr/tablas/a12009.pdf

Esta obra está bajo una Licencia Creative Commons

Atribución-NoComercial-SinDerivar 4.0 Internacional, IIJ-UNAM.

Boletín Mexicano de Derecho Comparado, núm. 160, enero-abril de 2021, pp. 309-334. 


\section{LOS IMPACTOS DE LA IMPUNIDAD EN MÉXICO. REFLEXIONES DESDE UNA PERSPECTIVA DE GÉNERO*

\author{
IMPUNITY IMPACT IN MEXICO THOUGHTS FROM A GENRE \\ PERSPECTIVE
}

\section{Alicia Elena PéRez DUARTE y NOROÑA**}

RESUMEN: En este artículo se pretende mostrar los componentes de una normatividad que rige un Estado moderno de derecho en un marco de intercambios y compromisos internacionales cuyo objetivo es el desarrollo de lo que hoy conocemos como derechos humanos, entre cuyos principios está la responsabilidad de ese Estado de garantizar la seguridad de todas las personas que integran su población. Una responsabilidad que, desde el punto de vista de las mujeres, es incumplida de manera sistemática por la frecuencia en que los hechos de violencia contra las mujeres quedan en la impunidad y lo que ello significa para las víctimas en sus vidas debido al impacto tanto de la violencia misma como del significado de la falta de protección del Estado del conjunto de sus derechos humanos.

Palabras clave: derechos humanos, seguridad, impunidad, perspectiva de género, violencia contra las mujeres.
ABSTRACT: In this article we pretend to show the composite parts of the normativity that rules the Modern Law State in the frame of international exchanges and treaties whose goal is to develop what we know now as Human Rights, among whose principles is the State responsability to guarantee the safety and security of every person that integrates the state's population. A responsability that, from the women's point of view, is constantly and systematically broken by the frequency in which acts of gendered violence are left unpunished and what this means for the victims's lives due to the impact the violence had on them as well as what it means to lack the protection that the State should give them as part of their human rights.

Key words: human rights, security, impunity, gender perspective, violence against women.

* Recibido el 6 de octubre de 2020; aprobado el 17 de enero de 2021.

** ORCID: 0000-0001-5695-854X. Feminista; doctora en Derecho por la UNAM; investigadora titular en el Instituto de Investigaciones Jurídicas de la UNAM. Correo electrónico: alicia.elena@comunidad.unam.mx.

Boletín Mexicano de Derecho Comparado, nueva serie, año LIV, núm. 160, enero-abril de 2021, pp. 335-359.

Esta obra está bajo una Licencia Creative Commons Atribución-NoComercial-SinDerivar 4.0 Internacional, IIJ-UNAM. 
SUMARIO: I. Introducción: la seguridad responsabilidad del Estado. II. La seguridad desde la perspectiva de las mujeres. III. La percepción social de la impunidad: violencia contra las mujeres. IV. Concepto de impunidad en el ámbito internacional. $\mathrm{V}$. Las recomendaciones de los órganos de control y vigilancia de derechos humanos.

VI. Colofón a manera de conclusiones. VII. Bibliografia.

\section{INTRODUGGIÓN: LA SEGURIDAD RESPONSABILIDAD DEL ESTADO}

Hace algunos años, consideraba que estudiar Derecho, así con mayúsculas, permite tejer certezas, convicciones, verdades absolutas, uno que otro dogma y dejarlos correr por el mundo tratando de esconder todas las dudas que nos asaltan en cada esquina de la vida, porque es más fácil vivir con la seguridad de que las cosas son así porque lo dice la ley, la Constitución, el código o el reglamento, que estar preguntándonos a cada momento ¿es cierto?, ¿puedo?, ¿tiene/tengo/tenemos derecho a, derechos de?

En esta línea de inquietudes alguna vez me pregunté sobre la razón fundamental de ser del Estado moderno, del Estado de derecho, y para tratar de entender esta razón busqué al padre del derecho positivo y de la teoría del Estado: Hans Kelsen. En sus libros, encontré la respuesta, que se puede trasmitir tal cómo la escribió él con cita de pie de página y todo o parafraseando a Antonio Machado: el Estado, estructura político-jurídica, existe porque dondequiera hay gente que quiere danzar, jugar, labrar su palmo de la tierra, beber vino, donde hay vino y donde no, pues agua fresca y alguien o algo tiene que garantizar que puedan hacerlo con toda tranquilidad.

Sí, así es, la base fundamental del Estado moderno es la seguridad. Sobre esta base, se construye toda una estructura institucional que debería garantizar entre otros, los principios de igualdad, no discriminación y respeto por la dignidad y la libertad de las personas, así como están marcados en Ley General de Acceso de las Mujeres a una Vida Libre de Violencia (en adelante Ley General) en relación con las mujeres, porque estos cuatro principios sólo son posibles si todas las personas cuentan con la seguridad de vivir con tranquilidad y sin violencia, en su diversidad.

Sin embargo, cabe preguntar si actualmente esta base está funcionando o bien necesitamos cambiar sus reglas para tener la seguridad que requerimos. La respuesta es más que evidente: en México, bajo muchos 
pretextos, como la guerra contra el narcotráfico y el crimen organizado emprendida en el gobierno calderonista, la militarización abierta del gobierno de Peña Nieto que se legaliza y continúa en el presente, por ejemplo, tenemos la percepción de que la inseguridad se ha instalado en nuestros espacios, que las instituciones del Estado que deberían garantizarnos esa seguridad son insuficientes.

En el caso de las mujeres, esta percepción tiene una connotación especial cuando se visualiza la inseguridad desde una perspectiva de género, pues las mujeres, sólo por el hecho de serlo, vivimos en una permanente sensación de peligro e inseguridad ahí donde desarrollamos nuestras vidas, el hogar, las escuelas, los centros de trabajo, las iglesias, la vía pública, el transporte también público; es una percepción de constante riesgo, las últimas cifras del secretariado ejecutivo de Seguridad Pública ${ }^{1}$ no dejan mentir: más de diez feminicidios diarios entre enero y octubre de 2020 es aterrador.

En ambos sentidos: la inseguridad social y la inseguridad de las mujeres, son prueba de que existe una fractura que deslegitima toda la estructura del Estado, precisamente porque la impunidad de los actos de violencia - tanto social como de género contra las mujeres - deja sin sentido real tanto las leyes como las instituciones que supuestamente deben servir para prevenir la violencia, para sancionar los hechos violentos y reparar los daños ocasionados.

Es este sentido se han manifestado, también desde otras ciencias. Es el caso de Cabrera:

Desde una perspectiva psicosocial, la legitimidad tiene su anclaje en las creencias sobre el mundo [...] Desde esta perspectiva, nos interesa comprender si la impunidad cuestiona el sentido de la ley y de la justicia, cuando la experiencia de las víctimas queda sometida a un contexto de reiterada impunidad político-legal, manejada por hilos invisibles para evitar o distorsionar la justicia en el enjuiciamiento de las violaciones a los derechos humanos en Guatemala. Esto significa que la negación u obstrucción de justicia impide ejercer la función social de reparación del daño, asumiendo todas las consecuencias psicológicas y políticas que esto implica en la construcción de la democracia (Luisa Cabrera, 2001, p. 39).

1 Información sobre violencia contra las mujeres Incidencia delictiva y llamadas de emergencia 9-1-1. Centro Nacional de Información. Corte al 31 de octubre de 2020.

Esta obra está bajo una Licencia Creative Commons Atribución-NoComercial-SinDerivar 4.0 Internacional, IIJ-UNAM. Boletín Mexicano de Derecho Comparado, núm. 160, enero-abril de 2021, pp. 335-359. 
Reflexión válida para la situación de impunidad que existe en los casos de violencia contra las mujeres en el país, en especial cuando esta impunidad es también un obstáculo a la libertad, en el sentido más amplio que en los últimos años ha retomado la Organización de Naciones Unidas, es decir, esa que "incluye la idea de que el desarrollo, la seguridad y los derechos humanos van de la mano" (Naciones Unidas, 2005; en adelante $\mathrm{ONU})$. Concepto que todavía no es una realidad para cientos de millones de personas en el mundo, por tanto, la impunidad es un atentado no sólo a la seguridad sino también a la libertad, a la igualdad, al desarrollo y, en general, a los derechos humanos.

\section{LA SEGURIDAD DESDE LA PERSPECTIVA DE LAS MUJERES}

Colocando la violencia contra las mujeres como el eje de la reflexión es importante recordar que entre los pactos sociales que construyeron el concepto de Estado tal y como se le entiende actualmente, se determinó, en un momento de la historia, que mediante el matrimonio las mujeres tendríamos seguridad, solidaridad y apoyo, a cambio de nuestros servicios reproductivos. ${ }^{2}$ Sin embargo, en la actualidad, observamos que este acuerdo no ha funcionado pues, si hemos de creer a los llamados datos duros existentes en México - y en el mundo-, cerca de la mitad de las mujeres casadas viven en la inseguridad y el temor precisamente a partir de su matrimonio, ${ }^{3}$

2 Este es el sentido de la obra de Engels El origen de la familia, la propiedad privada y el Estado, sentido y orientación reflexiva que han seguido otras personas estudiosas de las relaciones humanas y que, desde mi punto de vista, se ha desvirtuado porque la inseguridad empieza precisamente en ese ámbito del matrimonio con la idea de que el hombre, por razón de esa protección, asumió el cargo de jefe de la familia y, por tanto tiene derecho a corregir tanto a la mujer/esposa como a sus hijas e hijos; también tiene derecho a manifestar sus frustraciones e enojos de manera violenta o agresiva.

3 En la Encuesta Nacional sobre la Dinámica de las Relaciones en los Hogares (ENDIREH, 2016), se afirma que: "De los 46.5 millones de mujeres de 15 años y más que residen en el país, se estima que 30.7 millones de ellas $(66.1 \%)$ han padecido al menos un incidente de violencia emocional, económica, física, sexual o discriminación en los espacios escolar, laboral, comunitario, familiar o en su relación de pareja. De estos porcentajes, se señala que $43.9 \%$ de la proporción de mujeres de 15 años y más han experimentado violencia por parte de su actual o última pareja, esposo o novio, y que esta violencia incrementa cuando se treta de la segunda o ulterior pareja. Esta violencia lejos de disminuir ha aumentado, como se puede observar en las tres precedentes encuestas. Los datos recabados por la

Esta obra está bajo una Licencia Creative Commons

Atribución-NoComercial-SinDerivar 4.0 Internacional, IIJ-UNAM.

Boletín Mexicano de Derecho Comparado, núm. 160, enero-abril de 2021, pp. 335-359. 
pues es su cónyuge/pareja, su agresor primario, de ahí que el tema de la violencia contra las mujeres haya sido puesto en la agenda pública precisamente a partir de esta relación y de la conjugación del binomio violencia familiar/violencia sexual (véase Organización Mundial de la salud, 2010; 2013a y 2013b).

Desde otro ángulo, reconocemos al derecho penal y a las políticas públicas sobre seguridad y combate al crimen, como una parte del complejo engranaje del control social al que Michel Foucault (1975, pp. 299 y ss.) critica porque no se limita, según él, a actuar sobre el cuerpo de las personas, sino que actúa directamente sobre el "alma" y, según él, la crea.

Reconozco el valor relativo de las afirmaciones de Foucault, y si bien no comparto con él el determinismo rígido y represor que atribuye a las normas de derecho, sí es cierto que, en un Estado moderno, el derecho es el conjunto de reglas, prohibiciones y sanciones que crean una determinada organización del poder, establecen mecanismos de control y vigilancia, así como los sistemas de legitimación de estos mecanismos que dan contenido al concepto de cultura.

Así pues, el derecho es el elemento de lo social que regula la vida de mujeres y hombres y es un conjunto de reglas que uniforma, de una u otra manera, a personas y grupos ofreciéndoles, a cambio, seguridad.

Independientemente de las críticas que podamos hacer al derecho como reproductor de modelos sociales bipolares y excluyentes, la realidad es que por medio de las normas jurídicas tenemos el conjunto de reglas que hacen una voluntad a la que se puede llamar común, pero, para las mujeres, para el ejercicio de nuestro derecho a vivir sin violencia, no es suficiente, el aparato represor no es suficiente para garantizar nuestra seguridad pues se convierte, literalmente, en cómplice protector de los agresores.

Pareciera que reconoce el lenguaje de los mandatos de masculinidad a los que hace referencia Rita Segato (2003), pero no logra interpretar la voz de las mujeres que definen la violencia que se escribe en nuestros cuerpos con conceptos tan claros como "cualquier acción u omisión, basada en su género, que les [a las mujeres] cause daño o sufrimiento psi-

Secretaría de Gobernación, el Instituto Nacional de las Mujeres y ONU Mujeres México indican que esta proporción en 2016 fue de 59\% (La violencia feminicida en México, aproximaciones y tendencias 1985-2016). 
cológico, físico, patrimonial, económico, sexual o la muerte tanto en el ámbito privado como en el público" (Ley General, art. 5o., fracción IV).

Efectivamente, la ineficiencia del aparato del Estado para imponer las sanciones previstas en su normatividad por las instituciones de justicia desde la policía investigadora hasta la Suprema Corte de Justicia de la Nación (SCJN), opera como una educación en sentido inverso que puede ser definida como la socialización de la impunidad.

Lo mismo puede decirse de las políticas públicas preventivas. La mayoría de ellas, referidas a prevención de la violencia contra las mujeres, se enfocan a la construcción de instrucciones (protocolos) dirigidos a las mujeres y niñas sobre medidas que deberían ser eficientes para evitar la violencia en su contra; las llamadas políticas de atención a víctimas son un listado de lo que tiene que hacer la propia mujer o niña que es víctima después de haber vivido el hecho violento ante cada autoridad. ${ }^{4}$

El proceso de esta socialización funciona, en el macrocosmos social, exactamente igual como funciona en el microcosmos familiar. En este sentido, lo público y lo privado se dan la mano y se asemejan porque, cuando una regla se incumple sistemáticamente y la sanción prevista por la autoridad no llega (autoridad, llámese: papá, mamá, sacerdote, rabino, policía o juez), los valores se trastocan y se fortalece la cultura del "al fin y al cabo, aquí no pasa nada"; se socializa, como señalé hace un momento, la impunidad; se fortalece una cultura en la que las normas no son importantes y priva la ley del más fuerte; ahí en donde, la sistemática inoperatividad de la justicia impide también la reparación del daño y, algo más grave, la construcción y consolidación de la ciudadanía.

En otras palabras, la impunidad fortalece un tipo de cultura en la que conceptos como el de ciudadanía y bien común no tienen cabida; una cultura - $\mathrm{O}$ anticultura - que se opone a los conceptos de respeto, dignidad, libertad para hacer valer la ley del más fuerte.

4 A partir del 2007 el Instituto Nacional de las Mujeres ha promovido en las entidades federativas de nuestro país la creación de protocolos de prevención, atención o sanción de la violencia contra las mujeres; hay ya una cantidad importante de ellos, como se puede constatar en el Centro de Documentación de este Instituto o en la Comisión Nacional para Prevenir y Erradicar la Violencia Contra las Mujeres, en donde, por ejemplo, se encuentra el Protocolo para la Prevención, atención y sanción del hostigamiento sexual y acoso sexual en la administración pública federal, del 9 de noviembre de 2016. Me refiero a la mayoría porque sería demasiado largo nombrar a cada uno, en mi opinión.

Esta obra está bajo una Licencia Creative Commons

Atribución-NoComercial-SinDerivar 4.0 Internacional, IIJ-UNAM.

Boletín Mexicano de Derecho Comparado, núm. 160, enero-abril de 2021, pp. 335-359. 
Corresponde al Estado tener políticas públicas que aseguren sistemas de procuración y administración de justicia eficientes de tal suerte que las normas cumplan con su función de control y garanticen eso que andamos buscando: la multicitada seguridad. Cuando el aparato del Estado no persigue las conductas antisociales y los delitos, cuando permite que la impunidad se convierta en una constante social, no sólo se hace cómplice de ellos, sino que es cómplice de la socialización de la violencia, de los agravantes de la violencia y de la inseguridad.

Patricia Duarte y Gerardo González (1995) señalan, con razón, que, en el marco del pacto social, la búsqueda de la justicia y la lucha contra la impunidad son una cuestión de orden, democracia, ciudadanía y sentido social. A ello, es preciso añadir que para las mujeres es cuestión de sobrevivencia, simple y llanamente. Por tanto, la medición debe ser no sólo numérica, debe abarcar la percepción misma de la experiencia de la justicia o de la otra cara de la moneda: impunidad.

Sin embargo, tanto la percepción como la experiencia se insertan en una serie de principios calificados como jurídicos que han prevalecido en nuestros sistemas normativos y de justicia sin ser cuestionados: la igualdad de las personas ante la ley - entendida en el sentido de idéntico- y la neutralidad de la norma jurídica.

Dos supuestos a los que identifico como parte de los obstáculos que enfrentamos en la construcción de una democracia sustentada y arraigada en la ciudadanía; entendida ésta como un sentido de pertenencia a una comunidad a la que tengo derecho de exigir justicia y que ésta me sea dada; a la que tengo derecho de exigir protección y con la cual tengo derecho de interactuar para que se construya y estructure de manera en que la regla de oro contenga los principios que ya señalé: igualdad, no discriminación, respeto por la dignidad y la libertad de las personas y si esta regla no se cumple, justicia y reparación del daño.

En realidad el binomio de la igualdad jurídica formal y la neutralidad de la ley, oculta el carácter clasista y patriarcal de nuestro sistema jurídico, porque obliga a hacer tabla rasa ahí donde hay enormes diferencias marcadas por enormes inequidades que son históricas y parecen formar irremediablemente parte de las vidas de las mujeres agravadas por sus propias condiciones como el color de la piel, su clase social, el idioma o lengua en el que se expresan, la religión que profesan, las decisiones que hayan tomado sobre su sexualidad y sobre su capacidad reproductiva, su nacio- 
nalidad, si son migrantes o están establecidas en un lugar determinado, y el largo etcétera que define la diversidad en el vocablo mujeres.

Vale la pena retomar las expresiones de una comunidad indígena " $\mathrm{La}$ ley es la que dice que se haga justicia por la persona, pero ¿será que hay una ley con los ricos y aparte es una ley con los indígenas?" (Luisa Cabrera, 2001, p. 37). Expresiones que se pueden parafrasear: ¿una ley para las mujeres y otra para los hombres?

Es cierto que no podemos pretender que la sola disposición normativa restituya un equilibrio que un sinfín de factores culturales, económicos y sociales obstaculiza; tampoco podemos pretender que la aplicación de esa disposición normativa puede ser neutra porque la sociedad no es neutra, porque mujeres y hombres no somos neutros, nuestras acciones tampoco lo son. Por tanto, la generalidad y neutralidad de la norma son principios que deben ser cuestionados y analizados a partir de la realidad que se impone: existe una diversidad de seres humanos con necesidades específicas y la normatividad no necesariamente reconoce esa diversidad y esas necesidades múltiples.

Sin embargo, sabemos - o intuimos - que sólo entendiendo a las mujeres y a los hombres como parte de todo un sistema de relaciones - poder, sumisión, opresión, solidaridad, ayuda, compromiso- que se mueven en el ámbito público y en el privado; en la pareja, en la familia, en el grupo y en la sociedad; que interactúan en un contexto histórico bajo valores y creencias que no necesariamente han sido repensadas y replanteadas, sólo así - pensando en este cosmos construido de una pluralidad de cosmos - se puede hablar de justicia en el sentido más amplio y apropiado para todas las personas.

Lo sabemos - o lo intuimos-, pero todavía no podemos dar el paso definitivo para plasmar en la norma esa igualdad de oportunidades ante las diferencias reales; no podemos convencernos de que la neutralidad de la ley es una forma de discriminación por omisión, por ignorancia o por prepotencia.

La impunidad de los actos de violencia contra las mujeres tiene una connotación importante de discriminación (ONU, 1992) de género precisamente porque las estructuras jurídicas tienen como base la supuesta neutralidad de la norma y la concomitante imparcialidad de jueces y magistrados, con lo cual se desconoce una realidad: no sólo la violencia contra las mujeres no es neutra y sí es un acto de abuso de poder, sino

Boletín Mexicano de Derecho Comparado, núm. 160, enero-abril de 2021, pp. 335-359. 
que las personas que trabajan e interactúan en los espacios de procuración y administración de justicia forman parte de la sociedad que permite, tolera y regenera esa violencia, con valores que privilegian lo económico y el poder sobre la vida y la seguridad, sobre el respeto y la solidaridad.

Es decir, estamos frente a una estructura de control y represión insensible a la forma de funcionar de la violencia contra las mujeres y, por lo tanto, incapaz de reconocer los actos punibles y sancionarlos, lo que se traduce en inseguridad creciente para las mujeres.

En este sentido, hablando del objetivo de la justicia de hacer los equilibrios necesarios frente a la violencia que se tolera a partir de esos controles y represiones de las estructuras sociales, se afirma que:

El procesamiento judicial sería una forma de afrontar el trauma ocasionado por la violencia; en este sentido se convierte en una forma de resistencia activa y colectiva. Pero la impunidad tejida para impedir la justicia convierte esta lucha por la vida en una prolongación de la violencia y, por tanto, en la re-experimentación del trauma originalmente sufrido (Luisa Cabrera, 2001, p. 39).

En el espacio en donde se reconoce "al ciudadano", ${ }^{5}$ al que está involucrado en el quehacer común, el quehacer político y la seguridad, esto es en el ámbito público, las categorías demográficas del sexo o la edad, no son relevantes, por tanto, no se contemplan o no son escuchadas, de ahí que las tasas de impunidad de los delitos cometidos en contra de mujeres e infantes sean más altas que en otros como los delitos patrimoniales; tasas de impunidad que corresponden a las políticas públicas y a las convicciones sociales definidas en las propias normas penales. ¿Qué pensar, pues, del alcance de la impunidad que cuestiona una y otra vez, el sentido de las leyes y de la propia justicia? ¿Qué pensar de la reiterada, repetitiva, permanente, impunidad de los actos de violencia contra las mujeres? Impunidad legal, política, social. ¿Es necesario consignar los porcentajes comparativos o basta escuchar a las mujeres víctimas, a los reclamos socia-

5 El uso del genérico masculino no responde a la regla gramatical que indica que éste incluye a las mujeres, hago referencia, de manera exclusiva a los hombres, es decir, al género masculino de la especie humana. 
les constantes cada 8 de marzo y 25 de noviembre, por lo menos, en este país? ${ }^{6}$

Recordemos dos detalles: hasta hace no mucho tiempo, finales del siglo XX, en nuestro país el robo de una vaca era más sancionado que la violación de una mujer en casi todas las entidades federativas, por no decir en todas (Alicia Elena Pérez Duarte y Noroña y Laura Salinas, 1997); hoy sucede lo mismo en varias entidades federativas, con el hostigamiento sexual o la violencia familiar frente al robo de autos, al robo o traslado de más de diez vacas, caballos o mulas o la extorsión. ${ }^{7}$

Los candados para la integración de los cuadernos de investigación, los requisitos de las pruebas, los manuales de procedimientos insensibles a la categorías edad y sexo, hacen que las puertas de la justicia estén prácticamente clausuradas para las mujeres y niñas víctimas de actos de violencia contra las mujeres, como si existieran hilos invisibles que manejan la justicia, los registros y el seguimiento de los casos, de tal manera que es fácil distorsionar la justicia en los casos de violencia contra las mujeres. ${ }^{8}$

¿Cómo resolver este problema? Desde luego, los primeros pasos se han dado desde hace ya varios de lustros en todo nuestro país: hacer visible la violencia contra las mujeres. Es cierto que el trabajo realizado ha sido casi todo enfocado a la violencia en el ámbito familiar y hacia un tipo de violencia: la sexual, descuidando otras modalidades como la existente en instituciones, en las comunidades, en el trabajo y las escuelas, o pretendiendo confusiones frente a los diversos tipos de violencia como el patrimonial, económico, psicológico.

6 Baste referir que, en el Diagnóstico nacional sobre todas las formas de violencia contra las mujeres, realizado por la Facultad de Derecho de la Universidad Nacional Autónoma de México por encargo de la Secretaría de Gobernación (2009), se ponen en evidencia que el denominador común de los actos de esta violencia es su falta de registro y seguimiento, a pesar de que la normatividad lo exige.

7 Sólo por citar algunos ejemplos, esta afirmación se puede constatar en los códigos penales de Guanajuato, San Luis Potosí, Sonora y Sinaloa en donde el abigeato o robo de ganado merece de dos a 10 años de prisión y el hostigamiento o acoso sexual de dos meses a dos años.

8 Luisa Cabrera (2001) utiliza esta imagen para las violaciones a los derechos humanos de las mujeres en Guatemala que es válida también para el caso de México en el tema de la violencia de género contra las mujeres. Ejemplos de impunidad tenemos miles, desde los que simplemente no llegan a las autoridades hasta casos emblemáticos como el de Marisela Escobedo Ortiz y de su hija Rubí Marisol.

Esta obra está bajo una Licencia Creative Commons

Atribución-NoComercial-SinDerivar 4.0 Internacional, IIJ-UNAM.

Boletín Mexicano de Derecho Comparado, núm. 160, enero-abril de 2021, pp. 335-359. 
Sí, es cierto, pero, lo hemos logrado, a partir de $2007^{9}$ hemos avanzado, a pesar de todo y muchas veces contra todos, lo hemos hecho. Hoy se habla y discute el tema y se buscan formas y modelos de prevenir, atender, sancionar y erradicar este problema que ya nadie se atreve a calificar públicamente como normal; se destinaron recursos económicos importantes para diseñar políticas públicas adecuadas y pensar en reestructurar los espacios de procuración y administración de justicia desde la base, desde ahí en donde se genera la ciencia del derecho y se forman las personas que han de actuar en dichos espacios, para tratar de remover los obstáculos que impiden el acceso de las mujeres a la justicia y a la reparación del daño, ocultando, además, sus dimensiones en un manto de reglas sobre supuesta discreción en aras de "derechos humanos" de las personas procesadas. También hay decisiones emblemáticas que generan esperanza, algunas arrancadas a fuerza de manifestaciones, pero ahí están, como es la decisión de la SCJN por la que la investigación de la muerte violenta de Mariana Lima Buendía fuera llevada bajo la hipótesis el feminicidio (Amparo en revisión 554/2013; véase también Karla I. Quintana, 2018).

\section{LA PERCEPCIÓN SOCIAL SOBRE LA IMPUNIDAD}

En el marco de los trabajos que desarrolló la Comisión Especial del Senado para dar Seguimiento a las Investigaciones de los Asesinatos de mujeres en Ciudad Juárez, Chihuahua, durante la LIX Legislatura (2005) se realizó un cuadro comparativo entre el programa del gobierno federal para atender la problemática que se vive en esa ciudad fronteriza, conocido como el Programa de 40 puntos, y las recomendaciones de organismos intergubernamentales y no gubernamentales internacionales para atender este caso paradigmático de violencia contra las mujeres y de los efectos de una sistemática impunidad.

En este documento se observa cómo, si bien cada organismo, según su vocación, hace énfasis en cierto tipo de medidas, todos coinciden en dos necesidades fundamentales: contar con un marco jurídico apropiado para evitar la impunidad y el fortalecimiento de capacidades del funcionariado

9 Señalo este año por ser el de la promulgación de la Ley General. Independientemente, desde luego, de que hoy se señala que esta ley ha seguido el mismo camino de otras en su tipo: el de la ineficacia. Por tanto, no ha sido suficiente para combatir la impunidad. 
público encargado de la procuración y administración de justicia ${ }^{10}$ pues es evidente que, hasta ahora, la perspectiva de género es una materia pendiente, en estas tareas fundamentales para evitar la impunidad de los actos de violencia contra las mujeres, a pesar de los años ya transcurridos desde la publicación de protocolos de actuación con perspectiva de género, tanto en el Poder Judicial federal como en los locales y en los ministerios públicos. ${ }^{11}$

Hoy estamos en el momento en que podemos reflexionar de manera conjunta en el significado de la impunidad de los actos de violencia contra las mujeres; sobre las diferencias entre la percepción social y los datos duros; explicar las razones de la percepción generalizada que señala la disfuncionalidad - por no decir inutilidad - de los sistemas de justicia, tanto como señalar y delimitar con claridad las responsabilidades sobre esa percepción social.

Sería conveniente recordar que precisamente en el ámbito internacional se han adoptado una serie de recomendaciones para combatir la impunidad tanto la general como la relativa a la violencia contra las mujeres y que, en los términos de la Ley General y su reglamento, perfilan un verdadero modelo de sanción que permite dimensionar la impunidad de manera que se entiendan sus causas y consecuencias.

Es decir, un modelo que atiende los requerimientos de un sistema jurídico por medio de evaluaciones permanentes y sistemáticas sobre la aplicación de esta ley y de las diversas normas jurídicas que regulan los tipos y modalidades de la violencia, que debe contener como mínimo:

- Las directrices de apoyo para las y los servidores públicos que conozcan de los tipos y modalidades de violencia contemplados en la Ley, para facilitar su actuación en la aplicación de sanciones conforme a la legislación aplicable que corresponda.

- Las medidas de atención y rehabilitación para los agresores.

10 En lenguaje de aquel entonces, hoy se diría encargado a las y los operadores del sistema de justicia penal, en especial a quienes tienen a su cargo la investigación de los delitos.

11 Es el caso, por ejemplo, del Protocolo para Juzgar con Perspectiva de Género (SCJN, 2013); Cuaderno de buenas prácticas para juzgar con perspectiva de género (Ana Elena Fierro y Adriana García, 2014); Protocolo para la atención de personas que han sufrido el delito de violación, entre muchos otros (Secretaría de Seguridad Pública, 2009).

Esta obra está bajo una Licencia Creative Commons

Atribución-NoComercial-SinDerivar 4.0 Internacional, IIJ-UNAM.

Boletín Mexicano de Derecho Comparado, núm. 160, enero-abril de 2021, pp. 335-359. 
- La capacitación especial necesaria para la aplicación del Modelo de Sanción dirigida al personal que integran las corporaciones de seguridad pública y del sistema de procuración y administración de justicia.

- Los mecanismos de notificación al órgano de fiscalización correspondiente, para el caso de incumplimiento de la Ley o el Reglamento por parte de los servidores públicos.

- Los lineamientos que faciliten a la víctima demandar la reparación del daño u otros medios de compensación o resarcimiento económico a cargo del agresor, en términos de la legislación aplicable.

- Los indicadores de factores de riesgo para la seguridad de la víctima tales como los antecedentes violentos del agresor o el incumplimiento de las órdenes de protección de éste, entre otros.

- Las prevenciones necesarias para evitar que las mujeres que han sufrido violencia vuelvan a ser víctimas de ésta, y

- Los lineamientos que faciliten a la víctima demandar una reparación del daño u otros medios de compensación o resarcimiento económico a cargo del Estado, cuando haya responsabilidad de éste, en términos de la legislación aplicable.

Requerimientos que surgen de una serie de recomendaciones internacionales que puede ser clasificada en dos grupos: el primero de estos grupos lo constituyen las recomendaciones generales emanadas de las comisiones orgánicas de Naciones Unidas o de la Organización de los Estados Americanos, el segundo, las recomendaciones particulares hechas a nuestro país por órganos de vigilancia y control de los derechos humanos, ya sea contractuales o no contractuales.

Sin embargo, basta una pequeña ojeada a las redes para encontrar palpable el descontento social por la impunidad que impera en nuestro país sobre las violencias contra las mujeres.

Dos organizaciones del Observatorio Nacional sobre Feminicidio, en 2012, presentaron al Comité de la Convención para la Eliminación de todas las Formas de Discriminación contra la Mujer (en adelante CEDAW por sus siglas en inglés), un informe sobre feminicidio e impunidad en México (Católicas por el Derecho a Decidir y Comisión Mexicana de Defensa y Promoción de los Derechos Humanos, 2012) en el que se 
resume que los mecanismos legales existentes no garantizan la protección a la vida y la integridad de las mujeres en el país; que ocupamos el lugar 16 en la incidencia de homicidios contra mujeres a nivel mundial; que estos homicidios han registrado un aumento sostenido desde 2007, año que se registró el menor número de feminicidios desde 1985; que existe un patrón de impunidad sistémica, reflejo de la falta de acceso a la justicia para las mujeres; que con frecuencia las víctimas, al intentar acceder al sistema de justicia, son maltratadas y discriminadas; que la mayoría de los casos de violencia contra las mujeres no son investigados como es debido ni juzgados ni sancionados por el sistema de justicia tanto federal como de las entidades federativas.

Se señala que en el país se observa una resistencia considerable para investigar los asesinatos de mujeres como feminicidio; ${ }^{12}$ que es común que cuando existe una muerte violenta de mujer se afirme en primer lugar que se trata de suicidio $;^{13}$ que $97 \%$ de los actos de violencia contra las mujeres quedan en la impunidad. Todo ello, según se puede concluir tanto de las referencias en las redes sociales como de las cada vez más numerosas manifestaciones de protesta que se dan en el país, es percibido como el desconocimiento de la perspectiva de género en las instituciones públicas, así como la falta de voluntad política de los órganos del Estado para prevenir y sancionar la violencia feminicida.

\section{CONCEPTO DE IMPUNIDAD EN EL ÁMBITO INTERNACIONAL}

El primer acercamiento normativo a la lucha contra la impunidad tiene su fundamento, en el ámbito internacional, en la Declaración Universal de los Derechos Humanos y en el Pacto Internacional de los Derechos Civiles y Políticos. Ambos instrumentos contemplan como parte del catálo-

12 El Observatorio Ciudadano Nacional del Feminicidio (2018) afirma que entre 2014 y 2017 fueron asesinadas un total de 8904 mujeres, sólo 2188 casos fueron investigados como feminicidios. Consultable en https://92eab0f5-8dd4-485d-a54f-b06fa499694d.filesusr. com/ugd/ba8440_66cc5ce03ac34b7da8670c37037aae9c.pdf

13 Como ejemplo de ello es los casos emblemáticos del feminicidio de Mariana Lima Buendía (véase Amparo en revisión 554/2013) y de Lesvy Berlín Rivera Osorio (Recomendación 01/2018 de la CDHDF. Caso: Falta de debida diligencia reforzada en la investigación del posible feminicidio de Lesvy Berlín Rivera Osorio, y negligencia en la atención a sus familiares).

Esta obra está bajo una Licencia Creative Commons

Atribución-NoComercial-SinDerivar 4.0 Internacional, IIJ-UNAM.

Boletín Mexicano de Derecho Comparado, núm. 160, enero-abril de 2021, pp. 335-359. 
go de los derechos humanos el acceso a una justicia pronta y completa, tal como se recoge, también, en la Constitución federal de nuestro país. ${ }^{14}$

La ubicación de este derecho, en el ámbito de la lucha por prevenir, sancionar y erradicar la violencia contra las mujeres tiene su fundamento en la Convención Interamericana que lleva ese nombre y se conoce como Convención do Belém do Pará, de la cual México es parte, en donde, aunque no se hace explícito el concepto de impunidad, se definen medidas concretas para combatirla, y proteger a las mujeres víctimas de violencia, estén donde estén.

La Subcomisión de Prevención de Discriminaciones y Protección de las Minorías, ${ }^{15}$ en 1997, realizó dos estudios relacionados con la impunidad de los autores de las violaciones de los derechos humanos relativos a los derechos civiles y políticos. Trabajo que es aplicable, en toda su extensión al tema de la violencia contra las mujeres, precisamente porque entre los derechos civiles y políticos se encuentran el derecho a la vida, a la seguridad personal y el derecho al acceso a la justicia, tres de los cuales son sistemáticamente violados cuando una mujer que ha sido víctima de violencia no puede obtener la reparación que le es debida. Expertos de ese órgano, señalan que la impunidad viola (Louis Joinet, 1997), por el sólo hecho de existir, tres tipos de derechos que tienen alcances tanto individuales como colectivos: el derecho a saber, a la justicia, y a la obtención

14 Es a propósito que elimino el concepto de imparcialidad como característica de la justicia pues esta presunta imparcialidad ha hecho mucho daño a la causa de las mujeres, aunque es cierto que se trata de una característica consagrada en nuestra la Constitución y, durante mucho tiempo, fue la piedra de toque de la justicia porque se tuvo que hacer un contrapeso a la parcialidad que existía al inicio del surgimiento del Estado de derecho. Hoy, esa imparcialidad está haciendo mucho daño a la causa de las mujeres precisamente porque no se reconoce la realidad de sus desventajas ni la discriminación que padece, y así lo dicen los expertos internacionales con quienes coincido plenamente (véase Ana Messuti, 2008).

15 Fue establecida por la Comisión de Derechos Humanos de Naciones Unidas en su primera sesión, en 1947, bajo la autoridad del Consejo Económico y Social, como el principal órgano consultivo en esta materia. Conforme a la decisión del 27 de julio de 1999 del Consejo Económico y Social, el nombre de la Subcomisión de Prevención de Discriminaciones y Protección a las Minorías se ha cambiado a Subcomisión para la Promoción y Protección de los Derechos Humanos. Actualmente este órgano fue sustituido por el Comité Asesor del Consejo de Derechos Humanos mediante resolución del propio Consejo 5/1. Funciona como "grupo de reflexión” y trabaja, como lo hacía la Subcomisión, bajo la dirección del multicitado Consejo. 
de una reparación, independientemente de los derechos que son violentados por el delito que queda sin sanción.

El derecho a saber, en lo individual, comprende el derecho que asiste a toda víctima o sus familiares de conocer de manera verídica lo que ocurrió, por muy doloroso que ello sea; en lo colectivo este derecho "hunde sus raíces en la historia, para evitar que puedan reproducirse en el futuro las mismas violaciones", por tanto, al Estado "le incumbe el deber de recordar".

El derecho a la justicia, en lo individual, implica, que toda víctima o sus familiares deben tener la posibilidad de hacer valer sus derechos beneficiándose de un recurso equitativo y efectivo, de tal suerte que quien violentó sus derechos sea juzgado y, al mismo tiempo, obtenga una reparación por todos los daños y perjuicios sufridos.

En lo colectivo, estos derechos, a la justicia y a la reparación, son piedra fundamental en el cumplimiento de los fines de un Estado democrático de derecho, pues comprende medidas de cuyo carácter simbólico da fuerza y cohesión a las instituciones llamadas democráticas.

Estos conceptos han sido recogidos en un documento conocido como Principios para la protección de los derechos humanos mediante la lucha contra la impunidad, en el cual se define a la impunidad como

...la inexistencia, de hecho o de derecho, de responsabilidad penal por parte de los autores de violaciones de los derechos humanos, así como de responsabilidad civil, administrativa o disciplinaria, porque escapan a toda investigación con miras a su inculpación, detención, procesamiento y, en caso de ser reconocidos culpables, condena, incluso a la indemnización del daño causado a sus víctimas.

Concepto que se puede aplicar de manera directa a la inexistencia de la responsabilidad penal por actos de violencia contra las mujeres.

Por su parte, la Comisión de Naciones Unidas para la prevención del Delito y la Justicia Penal ha trabajado el tema de la impunidad por medio de los conceptos de prevención del delito y de los derechos de las víctimas. Desde 1985 aprobó un documento denominado 'Declaración sobre los principios fundamentales de justicia para las víctimas del delito y del 
abuso de poder" ${ }^{16}$ en el cual se definen los derechos de las víctimas a la justicia y a la reparación del daño.

En el manual elaborado para la aplicación de estos principios, se indica que las medidas para combatir la impunidad y para perseguir a los criminales son, al mismo tiempo, el "sine qua non de la justicia" y "la correcta reparación a las víctimas".

Otro documento importante en el combate a la impunidad que fue producto de los trabajos de esa comisión orgánica son las Medidas de prevención del delito y de justicia penal para la eliminación de la violencia contra la mujer. ${ }^{17}$ En estas medidas, entre otras recomendaciones, se reitera la necesidad de revisar, evaluar y enmendar periódicamente las leyes, códigos y procedimientos nacionales "para cerciorarse de su utilidad y eficacia en lo que respecta a la eliminación de la violencia contra la mujer y supriman toda disposición que permita o condone la violencia contra la mujer". ${ }^{18}$

\section{LAS RECOMENDACIONES DE LOS ÓRGANOS DE CONTROL Y VIGILANCIA DE LOS DERECHOS HUMANOS}

El Comité para la Eliminación de Todas las Formas de Discriminación en Contra de la Mujer, órgano de vigilancia de la Convención del mismo nombre, elaboró una recomendación específica $(\mathrm{ONU}, 1992)^{19}$ sobre la violencia contra las mujeres en la cual señala de manera puntual la obligación que tienen los Estados partes de la CEDAW de adoptar medidas apropiadas y eficaces para combatir todo tipo de violencia basada en el sexo, ejercida mediante actos públicos o privados y de velar por que las leyes contra la violencia y los malos tratos en la familia, la violación, los ataques sexuales y otro tipo de violencia contra la mujer protejan de manera adecuada a todas las mujeres y respeten su integridad y dignidad.

16 Aprobados por Asamblea General de Naciones Unidas en la resolución 40/34, del 29 de noviembre de 1985. Ver anexos.

17 Aprobadas por la Asamblea General de Naciones Unidas en su resolución 52/86 de 1998 (Documento A/RES/52/86, 1998).

18 Ibidem, p. 5.

19 Recomendación 19 del CEDAW, actualizada en 2015 con la Recomendación 35 sobre la violencia por razón de género contra la mujer del mismo Comité. 
Desde luego, estas dos medidas deben ir acompañadas de una adecuada capacitación al funcionariado encargado de los órganos de justicia a fin de que el derecho de las mujeres a una vida libre de violencia sea efectivo y que las violaciones a este derecho sean debidamente sancionadas, así como de procedimientos eficaces de denuncia y reparación, incluida la indemnización por los daños y perjuicios sufridos y de las medidas necesarias para dar protección inmediata a las mujeres víctimas de violencia sea esta familiar o extra familiar.

En la Recomendación 35 de este Comité, se señala que "la opinio juris y la práctica de los Estados dan a entender que la prohibición de la violencia por razón de género contra la mujer ha pasado a ser un principio del derecho internacional consuetudinario" (CEDAW/C/GG/35, 2017, párrafo 2); sin embargo, se afirma que sigue siendo generalizada en todos los países y, sobre todo, con un alto grado de impunidad. Se pone sobre la mesa un tema preocupante y vigente en México: la reducción "significativa" del gasto público destinado la prevención y la judicialización de los actos de violencia contra las mujeres, "a menudo como parte de las denominadas medidas de austeridad tras las crisis económicas y financieras, contribuyen a debilitar todavía más las respuestas de los Estados" (CEDAW/GC/35, 2017, párrafo 7) realidad tristemente dolorosa en este aciago 2020.

Este Comité, en las tres últimas revisiones de informes periódicos de México ${ }^{20}$ solicitó que se proporcionara información sobre los mecanismos que existen para que las mujeres puedan apelar judicialmente con base en la Convención, y recomendó que se aplicara en el país la Recomendación General 19, que ahora debe ir actualizada por la número 35 ya citada.

Por otra parte, el Comité de Derechos Humanos, en la evaluación del quinto Informe periódico del gobierno de México, ${ }^{21}$ manifestó una preocupación - basada tanto en el derecho a la seguridad e integridad personal como en el derecho al acceso a la justicia - por el nivel de violencia

20 El 17 de mayo de 2011 , el gobierno de México presentó al CEDAW el sexto informe periódico el 23 de enero de 2006 (Documento CEDAW/C/MEX/6), los informes séptimo y octavo consolidados en donde abarca el periodo agosto 2006-septiembre 2010 (Documento CEDAW/C/MEX/7-8) y el noveno informe periódico el 2 de febrero de 2017 (Documento CEDAW/C/MEX/9).

21 Véase Documento de Naciones Unidas CGPR/C/MEX/5, 2008.

Esta obra está bajo una Licencia Creative Commons

Atribución-NoComercial-SinDerivar 4.0 Internacional, IIJ-UNAM.

Boletín Mexicano de Derecho Comparado, núm. 160, enero-abril de 2021, pp. 335-359. 
que existe en el país contra las mujeres, incluyendo los muchos casos denunciados de secuestro y asesinato que no han conducido a arrestos o procesamiento de los culpables, y las numerosas quejas de violación o tortura perpetradas por las fuerzas de seguridad a las mujeres detenidas, que éstas no se atreven a denunciar y recomendó que se tomaran medidas eficaces para garantizar la seguridad de las mujeres y para asegurar que no se ejerza ninguna presión sobre ellas con el fin de disuadirlas de denunciar tales violaciones y asegurar que todas las quejas de abusos sean investigadas y que los autores de estos actos sean llevados ante la justicia.

Por su parte el Comité de Derechos Económicos, Sociales y Culturales en el examen del tercer informe periódico de México, desatacó la necesidad de combatir las causas que originan la violencia contra las mujeres, entre las que se encuentra la impunidad.

En mayo del 2001, el relator especial sobre la independencia de abogados, jueces y magistrados estuvo en México en visita oficial. Este funcionario afirmó que era necesario tomar una serie de medidas para que las mujeres víctimas de violencia tuvieran acceso a los medios de procuración y administración de justicia, entre estas medidas señaló que se debería dar formación especial a la policía y los agentes del Ministerio Público quienes han de recibir formación sobre la forma de tratar a las víctimas de la violencia sexual y examinar la posibilidad de establecer unidades especiales que se ocupen de los delitos de violencia contra las mujeres. ${ }^{22}$ Esta recomendación se repitió diez años después cuando la entonces Relatora Especial en esta misma materia, visitó a México. ${ }^{23}$

Durante la segunda semana de febrero del 2007, el gobierno de México se presentó ante el Examen Periódico Universal sobre la situación de los derechos humanos en el país ante el Consejo de Derechos Humanos. ${ }^{24}$ Tema obligado fue precisamente la impunidad en materia de vio-

22 El relator especial fue Dato'Param Coomaraswamy; la misión se llevó a cabo del 13 al 23 de mayo de 2001. Véase el informe en el Documento de Naciones Unidas E/ CN.4/2002/72/Add.1 (2002).

23 Esta misión oficial se llevó a cabo del 1o. al 15 de octubre de 2010. En esta ocasión la relatora especial fue la señora Gabriela Carina Knaul de Alburquerque y Silva. Véase el informe en el Documento de Naciones Unidas A/HRC/17/30/Add (2011).

24 Este Consejo es un órgano intergubernamental creado en el marco del sistema de las Naciones Unidas, en sesión del 15 de marzo de 2006, de la Asamblea General de las Naciones Unidas. Está compuesto por 47 Estados miembros responsables del fortalecimiento 
lencia contra las mujeres: Ciudad Juárez, Atenco, Lydia Cacho, casos emblemáticos en el país que subrayan la necesidad de dimensionar y atender de manera diferente, sin discriminación, a las mujeres que buscan atención, apoyo y justicia, fueron temas que estuvieron en la agenda de trabajo (ONU, A/HRG/WG.6/4/MEX/1; A/HRG/WG.6/4/MEX/2; A/ HRC/WG.6/4/MEX/3). ${ }^{25}$

En el informe presentado por el gobierno de México, se reconoce que el sistema de justicia debe depurarse y se pretende justificar - o explicar- el porqué del disfuncionamiento de nuestros espacios de procuración y administración de justicia que son causa, origen y razón de la dimensión de la impunidad en cualquier materia, pero aún más en esta que nos ocupa.

Desde luego, las recomendaciones ahí están. Dos muy importantes, la primera en materia de armonización legislativa, precisamente para revertir y corregir el disfuncionamiento a que se hacer referencia en el párrafo anterior y el trabajo para la erradicación de la violencia contra las mujeres que implica un esfuerzo en el que se conjugan los ejes de trabajo que nos unen en este momento: prevención, atención y sanción. Ejes que deben tener una base sólida de comprensión y dimensión del fenómeno (ONU, A/HRG/WG.6/4/L.13).

Cabe recordar, para concluir este punto, que el Comité de Derechos Humanos en julio de 2018 condenó a México por lo que calificó como un patrón de violencia sexual contra las mujeres detenidas en México, conductas que por lo general quedan impunes, al revisar el caso de la periodista Lydia Cacho que fue sometido a su consideración por primera vez por violencia contra las mujeres cometida por el Estado en contra de una mujer periodista.

de la promoción y la protección de los derechos humanos en el mundo. Uno de sus objetivos principales es el estudio de las situaciones de violaciones de los derechos humanos en los países y hacer recomendaciones en esta materia.

25 Es de recordar que el Comité de Derechos Humanos de Naciones Unidas condenó a México.

Esta obra está bajo una Licencia Creative Commons

Atribución-NoComercial-SinDerivar 4.0 Internacional, IIJ-UNAM.

Boletín Mexicano de Derecho Comparado, núm. 160, enero-abril de 2021, pp. 335-359. 


\section{COLOFÓN A MANERA DE CONCLUSIONES}

La violencia contra las mujeres es un acto de abuso poder, similar a la tortura. Así ha sido reconocido por la Organización Mundial de la Salud pues, se señala, se trata de un abuso de poder en el cual las agresiones están destinadas a lesionar la salud psicológica de la mujer al igual que su cuerpo, y suelen ir acompañadas de humillación y violencia física. Estas agresiones son impredecibles y guardan poca relación con el comportamiento de las mujeres. El único dato significativo es que están bajo el poder de un hombre agresor.

A pesar de lo que digan; si una mujer, en su hogar, su trabajo, la escuela, la calle, tiene la desgracia de cruzar su camino con un agresor que desee ejercer este tipo de violencia para sentir su poder, será torturada, humillada, vejada, violada y, posiblemente, hasta asesinada, sin importar cómo se comporte o cómo esté vestida.

Lo menos que se puede pedir, es justicia y protección para la víctima y sus familiares. Justicia que va desde la sanción a los responsables del delito o de la conducta violenta, si se trata de violencia familiar no sancionada por la ley penal, hasta la sanción de las autoridades que, al incumplir con su tarea, permiten la impunidad y la reproducción de estas conductas que laceran la dignidad de las mujeres.

Protección que implica una nueva visión de todo el sistema de justicia en la cual se reconozca la desigualdad real que tiene una mujer frente a su agresor; una nueva visión que reconozca los factores ideológicos reflejados tanto en una norma jurídica como en una acto abusivo de poder; una nueva visión que impida a policías, ministerios públicos, jueces y magistrados, hacer tabla rasa de las diferencias entre las víctimas y los agresores; que no les permita pretender una igualdad donde no existe ni reproducir ideologías discriminatorias en contra de las mujeres víctimas; que no les permita exigir demostrar las circunstancias de tiempo, modo y lugar en situaciones que sabemos es imposible hacerlo.

La impunidad en general, la impunidad de los actos de violencia en contra de las mujeres, en lo particular, y la falta de reparación del daño, ${ }^{26}$ son elementos que juegan un papel medular como factor

26 Felipe Gómez Isa (2008) afirma que "La reparación a las víctimas de violaciones de los derechos humanos es otro de los elementos centrales de la lucha efectiva contra la im- 
de deterioro de la dignidad de las personas y del bienestar social e impide el ejercicio de la ciudadanía pues obstaculiza la capacidad que una persona tiene de perseguir a quien la ha agredido y para exigir que le sean restituidos sus derechos.

La violencia y el crimen medran cuando no existe igualdad, democracia, respeto por los derechos humanos y buen gobierno. El reto para acabar con la impunidad de la violencia contra las mujeres, ahí en donde se dé, es la reconstitución y el fortalecimiento del Estado de derecho dado que este concepto y la constitución de la ciudadanía están estrechamente vinculados con la concepción del ejercicio de los derechos y la seguridad para ejercerlos.

El trabajo para dimensionar la impunidad y luego erradicarla es la base de un modelo exitoso de sanción de la violencia contra las mujeres, cuyo contenido pasa por un marco jurídico adecuado, respetuoso de los derechos humanos, elaborado desde una perspectiva de género, formación de personal para los espacios de procuración y administración de justicia con esta visión y el reconocimiento de la propia problemática, pues es evidente que esta impunidad empieza porque en los espacios en donde se juzga y se procura la justicia no se cree que las mujeres digamos la verdad cuando denunciamos los actos de violencia en nuestra contra.

Parafraseando a Margherite Yourcenard (1985): posiblemente yo no crea como ellos creen, no viva como ellos viven, no ame como ellos aman, y si bien moriré como ellos mueren, en el camino, soy mujer, soy ciudadana y sé que junto a mi hay millones de mujeres que exigimos a una sola voz que afrontemos el reto de acabar con la impunidad de la violencia que se ejerce contra nosotras sólo por el hecho de ser mujeres y unamos nuestras energías para hacer una realidad el derecho a vivir una vida libre de violencia.

\footnotetext{
punidad. Debemos reconocer que en este ámbito se han producido avances considerables en los últimos años tanto a nivel universal como, sobre todo, en América Latina, como nos vamos a encargar de demostrar a continuación. En primer lugar, debemos subrayar que la reparación no es una panacea que va a solucionar todos los problemas relacionados con el pasado a los que se enfrentan las sociedades en transición. Ciertas secuelas de graves violaciones de derechos humanos son irreparables, tanto en su dimensión individual como colectiva; en ocasiones, las heridas son de tal naturaleza que a lo máximo a que se puede aspirar es a que las víctimas aprendan a vivir con ese dolor, ya que una total recuperación no es algo a lo que se pueda aspirar realistamente".
}

Esta obra está bajo una Licencia Creative Commons

Atribución-NoComercial-SinDerivar 4.0 Internacional, IIJ-UNAM.

Boletin Mexicano de Derecho Comparado, núm. 160, enero-abril de 2021, pp. 335-359. 


\section{BIBLIOGRAFÍA}

Amparo en revisión 554/2013. Primera Sala de la SCJN. 25/03/2015. Microsoft Word - CASO MARIANA LIMA.doc (fiscaliatabasco.gob.mx)

Cabrera, Luisa (2001). Efectos de la impunidad en el sentido de justicia. Psicología Política (23), pp. 37-58.

Católicas por el Derecho a Decidir (CDD) y Comisión Mexicana de Defensa y Promoción de los Derechos Humanos (CMDPDH) (2012). Feminicidio e impunidad en México: un contexto de violencia estructural y generalizada. GDD y CMDPDH.

Cobo, Rosa (1995). Fundamentos del patriarcado moderno. Jean Jaques Rousseau. Cátedra.

DuARTe SÁnchez, Patricia y GonzÁLez, Gerardo (1995). La lucha contra la violencia de género en México. De Nairobi a Beijing 1985-1995. COVAC.

Facultad de Derecho de la UNAM (2009). Diagnóstico nacional sobre todas las formas de violencia contra las mujeres.

Fierro Ferráez, Ana Elena y García García, Adriana (2014). Cuaderno de buenas prácticas para juzgar con perspectiva de género. Consejo de la Judicatura Federal.

FOUCAULT, Michel (1975). Surveiller et punir. Gallimard.

GÓmEz IsA, Felipe (2008). El fenómeno de la impunidad: luces y sombras. Pensamiento Iberoamericano (2): pp. 163-185.

Internacional Victimology Website. Manual de justicia sobre el uso y aplicación de la declaración de principios básicos de justicia para víctimas de delito y abuso de poder. 11/10/2020. http://wrere.worldsocietyofoictimology.org/publications/ Handbook\%20on\%20Justice\%20Sp.pdf

JOINET, Louis (1997). Informe final revisado acerca de la cuestión de la impunidad de los autores de violaciones de los derechos humanos (derechos civiles y políticos). Documento de Naciones Unidas E/CN.4/ Sub.2/1997/20/Rev.1. Del 2 de octubre de 1997. https://undocs.org/ es/E/CN.4/Sub.2/1997/20/Rev.1

INEGI (2016). Guarta Encuesta Nacional sobre la Dinámica de las Relaciones en los Hogares. https://www.inegi.org. $\mathrm{mx} / \mathrm{rnm} /$ index.php/cata$\log / 286$

Messuti, Ana (2008). La justicia deconstruida. Bellaterra. 
Naciones Unidas (1985). Declaración sobre los principios fundamentales de justicia para las víctimas del delito y del abuso de poder. https://wwre.ohchrorg/sp/professionalinterest/pages/victimsofcrimeandabuseofpower.aspx

Naciones Unidas (2005). Informe del Secretario General. Un concepto más amplio de la libertad: desarrollo, seguridady derechos humanos para todos. Documento de la Asamblea General A/59/2005.

Naciones Unidas (2009). Informe nacional presentado de conformidad con el párrafo 15 a) anexo a la resolución 5/1 del consejo de derechos humanos. Documento de Naciones Unidas A/HRC/WG.6/4/ $\mathrm{MEX} / 1$.

Naciones Unidas (1998). Medidas de prevención del delito y de justicia penal para la eliminación de la violencia contra la mujer. Aprobadas por la Asamblea General de Naciones Unidas en su resolución 52/86. Documento A/RES/52/86.

Naciones Unidas (1992). Recomendación General 19 del Comité para la Eliminación de Todas las Formas de Discriminación en Contra de la Mujer. Documento de Naciones Unidas A/47/38.

Naciones Unidas (2008). Recopilación preparada por la oficina del alto comisionado para los derechos humanos con arreglo al párrafo $15 \mathrm{~b}$ ) del anexo de la resolución 5/1 del Consejo de Derechos Humanos. Documento de Naciones Unidas A/HRG/WG.6/4/MEX/2.

Naciones Unidas (2008). Recopilación preparada por la Oficina del Alto Comisionado para los Derechos Humanos con arreglo al párrafo 15 b) del anexo de la resolución 5/1 del Consejo de Derechos Humanos. Documento de Naciones Unidas A/HRG/WG.6/4/L.13.

El Observatorio Ciudadano Nacional del Feminicidio (2018). Informe Implementación del Tipo Penal de Feminicidio en México: Desafios para Acreditar las Razones de Género 2014-2017. Católicas por el Derecho a Decidir. https://92eab0f5-8dd4-485d-a54f-b06fa499694d.filesusr.com/ugd/ba8440 _66cc5ce03ac34b7da8670c37037aae9c.pdf

Organización Mundial de la Salud (2013a). Global and regional estimates of violence against women. Prevalence and health effects of intimate partner violence and nonpartner sexual violence. https://apps.who.int/iris/handle/10665/85239

Organización Mundial de la Salud (2011). Prevención de la violencia sexual y violencia infligida por la pareja contra las mujeres. Qué hacer y cómo obtener evidencias. Organización Panamericana de la Salud.

Esta obra está bajo una Licencia Creative Commons

Atribución-NoComercial-SinDerivar 4.0 Internacional, IIJ-UNAM.

Boletín Mexicano de Derecho Comparado, núm. 160, enero-abril de 2021, pp. 335-359. 
Organización Mundial de la Salud (2013b). Violence against women. The health sector responds. https://apps.who.int/iris/handle/10665/87060

Pérez DUARTE y Noroña, Alicia Elena y SALinAS Beristain, Laura (1997). Análisis comparativo de legislación nacional e internacional relativo a la mujer y a la niñez. Comisión Nacional de Derechos Humanos.

Quintana Osuna, Karla I. (2018). El caso de Mariana Lima Buendía: una radiografía sobre la violencia y discriminación contra la mujer. Cuestiones Constitucionales (38): pp. 143-168. https://doi.org/10.22201/ iij.24484881e.2018.38.11878

SEGATO, Rita Laura (2003). Las estructuras elementales de la violencia. Ensayos sobre género entre la antropología, el psicoanálisis y los derechos humanos. Universidad Nacional de Quilmes.

Suprema Corte de Justicia de la Nación (2013). Protocolo para Juzgar con Perspectiva de Género. Suprema Corte de Justicia de la Nación.

Secretaría de Seguridad Pública (2009). Protocolo para la atención de personas que han sufrido el delito de violación. Secretaría de Seguridad Pública.

Yourcenar, Marguerite (1985). Fuegos (7a. ed.). Ediciones Alfaguara, p. 26. 


\title{
LA LEGÍTIMA Y LA CAUSA DE DESHEREDAMIENTO POR ABANDONO FAMILIAR. ¿HACIA UNA MAYOR LIBERTAD DE TESTAR?*
}

\author{
THE RESERVED PORTION AND THE DISINHERITANCE CAUSE \\ FOR FAMILY ABANDONMENT. TOWARDS GREATER FREEDOM \\ TO MAKE WILLS?
}

\section{Gerard RINCÓN ANDREU**}

RESUMEN: En derecho de sucesiones, el testador no goza de libertad absoluta para disponer sobre su patrimonio, configurándose un sistema de derechos forzosos presidido por la legítima. Tanto en derecho positivo catalán, español como colombiano hay una arraigada tradición socio-jurídica que sustenta la legítima a partir del principio de solidaridad interfamiliar, lo cual dificulta aplicar teorías radicales como las de supresión de dicha institución con carácter de orden público o su configuración bajo estrictos parámetros de necesidad del legitimario. Con todo, la previsión de nuevas causales de indignidad y desheredamiento como el abandono familiar, así como la reducción de la cuota de legítima en Colombia avecinan una mayor libertad de testar como tendencia lógica en la sociedad actual.

Palabras clave: derecho de sucesiones, herencia, legítima, testamento, desheredamiento, abandono familiar.
ABSTRACT: In inheritance law, the testator does not enjoy absolute freedom to dispose of his assets, configuring a system of mandatory law presided by the reserved portion. Both in Catalan, Spanish and Colombian positive law, there is a deep-rooted socio-legal tradition that supports the reserved portion based on the principle of interfamily solidarity, which complicates the application of radical theories such as the suppression of said public order institution or its configuration under strict need parameters of the heir-at-law. However, the legal provisions of new causes of indignity and disinheritance such as family abandonment, as well as the reduction of the reserved portion in Colombia glimpse a greater freedom to make wills as a logical trend in today's society.

Keyzerds: inheritance law, inheritance, reserved portion, will, disinheritance, family abandonment.

* Registrado el 23 de enero de 2020; aprobado el 27 de enero de 2021.

** ORCID: 0000-0001-8201-1683. Profesor de Derecho civil, Universidad Santiago de Cali; profesor colaborador Grado de Derecho, Universitat Oberta de Catalunya. Abogado

Boletín Mexicano de Derecho Comparado, nueva serie, año LIV, núm. 160, enero-abril de 2021, pp. 361-385.

Esta obra está bajo una Licencia Creative Commons Atribución-NoComercial-SinDerivar 4.0 Internacional, IIJ-UNAM. 
SUMARIO: I. Introducción. II. En pro de una legítima corta. III. Ausencia de relación familiar como causa de desheredamiento. IV. ¿Hacia una mayor libertad de testar? V. Conclusiones. VI. Bibliografia.

\section{INTRODUCGIÓN}

El avance y variabilidad del derecho es incesante, apareciendo nuevas realidades, aplicaciones e interpretaciones que nos obligan a un constante estudio y actualización tanto en el ámbito jurisprudencial como dogmático.

Las nuevas tendencias en derecho privado nos han conducido, en los últimos años, hacia la materialización de novedades jurídicas importantes. En este sentido, el derecho de sucesiones no es una excepción, avecinándose una propensión global hacia una mayor libertad para testar. En primer lugar, esto deviene de una sólida teoría conducente a la necesidad de reconfigurar la institución de la legítima, a fin de que sea coherente con la nueva realidad y necesidad social. En segundo lugar, porque la introducción de una nueva causal para el desheredamiento, como es el abandono o falta de relación familiar, ya viene otorgando, de facto, una mayor autonomía de la libertad para el testador.

En suma, el objetivo de esta investigación es argüir una clara apuesta por el modelo de legítima corta regulado en el Código Civil de Cataluña (en adelante, CGCat), no siendo óbice para cuestionar la propia naturaleza y utilidad actual de la institución de la legítima, planteándose luces y sombras ante una posible supresión o cambio de configuración de ésta. Además, también cabrá destacar el carácter pionero del derecho civil catalán en la previsión de la causal de desheredamiento por abandono familiar; conduciéndonos, todo ello, a formular un alegato final que aboga por una más amplia libertad testamentaria.

De este modo, la metodología utilizada para el desarrollo de este estudio es la propia de la investigación jurídica de carácter hermenéutico, analizándose esencialmente - de forma sistematizada - la normativa y doctrina en el sí de tres ordenamientos jurídicos: el catalán, el español y el colombiano. Por tanto, estas breves reflexiones que se pretenden exponer están basadas en un estudio de micro-comparación en derecho

del Ilustre Colegio de Abogados de Barcelona; investigador del Grupo de Investigación GICPODERI. Correo electrónico: gerardrincon@usc.edu.co.

Esta obra está bajo una Licencia Creative Commons

Atribución-NoComercial-SinDerivar 4.0 Internacional, IIJ-UNAM.

Boletín Mexicano de Derecho Comparado, núm. 160, enero-abril de 2021, pp. 361-385. 
privado, más concretamente en derecho sucesorio. A mayor concreción, la primera parte del texto es de carácter normativista, partiendo de la comparación de disposiciones normativas en materia sucesoria de los códigos civiles de los tres ordenamientos estudiados. Sin embargo, en su recta final se asume una metodología argumentativista y no meramente descriptiva, pues se analizará la idoneidad de la misma legislación, proponiéndose un deber ser de la vigencia interpretativa de la legítima.

\section{EN PRO DE UNA LEGÍTIMA CORTA}

La sucesión tiene una gran relevancia social y económica, ya que da sentido a la acumulación de patrimonio y su posible traspaso garantiza un sistema económico fundamentado en la propiedad privada de bienes perdurables. La transmisión de titularidades, derechos y obligaciones mediante la sucesión es una decisión básica del ordenamiento jurídico, la cual en España, incluso goza de reconocimiento constitucional explícito, al prever la Constitución Española (art. 33) que "se reconoce el derecho a la propiedad privada y a la herencia". 1

Además, el derecho a la herencia tiene una innegable función social en estrecha correlación con la protección de los intereses familiares, con el reconocimiento de derechos legitimarios a los hijos y, otorgando también, con carácter defectivo, protección al cónyuge o a la pareja estable. ${ }^{2}$

Si bien el derecho a la herencia parte fundamentalmente del principio básico de "libertad" para testar, esta facultad del causante no es plena,

1 Como vemos, el reconocimiento constitucional de la herencia se vincula con el derecho a la propiedad privada. En Colombia, también se concede reconocimiento constitucional al derecho a la herencia, a tenor del contenido del artículo 58 de su Constitución Política: "Se garantizan la propiedad privada y los demás derechos adquiridos con arreglo a las leyes civiles, los cuales no pueden ser desconocidos ni vulnerados por leyes posteriores".

2 Ya sea, en Cataluña, con el derecho a la cuarta vidual (CGCat, art. 452-1) o, en Colombia, por medio de la porción conyugal (CGco, art. 1230) como mecanismo de protección al cónyuge o conviviente sobreviviente que carece de lo necesario para su congrua subsistencia. 
puesto que se encuentra restringida, en parte, por un sistema de derechos forzosos en el cual destaca esencialmente la legítima. ${ }^{3}$

Antes de desgranar los principales caracteres de la institución de legítima en la legislación comparada, es preciso hacer una breve referencia a sus orígenes, ya que no es ni mucho menos una figura que apareciera en España o Colombia en sus respectivos códigos civiles de 1889 y 1887. En efecto, ya en el derecho romano, a partir del siglo II se empieza a entender que los hijos y parientes cercanos no pueden apartarse de la sucesión. (Alejandro Platero, 2017, p. 289)

Por reproducción literal del Código Civil colombiano (en adelante, CGco, art. 1239) la "legítima es aquella cuota de los bienes de un difunto que la ley asigna a ciertas personas llamadas legitimarios". Prosigue este precepto disponiendo, in fine, que "los legitimarios son, por consiguiente, herederos". Precisamente, aquí radica el quid de la cuestión, vislumbrándose una diferencia capital entre derecho sucesorio colombiano y catalán que acto seguido intentaré esbozar.

En Cataluña los legitimarios no coinciden necesariamente con los herederos, hay una separación rigurosa entre ambas figuras. De hecho, cabe destacar como principio particular del derecho sucesorio catalán la necesidad de la "institución de heredero" - como sucesor a título universalpara que un testamento sea válido (CCCat, art. 423-1). Es más, como regla general, un testamento que no contenga la institución de heredero devendrá nulo (CCCat, art. 422-1.3), si bien este principio admite dos excepciones: el nombramiento de "albacea universal", de forma que toda la herencia se reparte en legados o bien es líquida y se destina a la finali-

3 Como recuerda el profesor Jesús Delgado (2006, pp. 124 y 125), "hay que tener en cuenta que las previsiones legislativas sobre derechos sucesorios forzosos cumplen la finalidad de subvenir a las desviaciones no deseadas o no compartidas socialmente del testador medio". No obstante, "habitualmente los testadores se guían por sus vínculos familiares y afectivos y favorecen a sus allegados, y sólo de manera poco frecuente el causante favorece a extraños con los que carece de todo vínculo desamparando a su propia familia".

4 El libro IV del CGCat mantiene este principio tradicional y prevé reglas de interpretación y de integración de la voluntad del testador cuando la institución del heredero no es suficientemente clara. (Albert Lamarca, 2009b, p. 57)

5 Este artículo 423-1 del CCCat, en su primer apartado, dispone que "El testamento debe contener necesariamente institución de heredero". Por su parte, el artículo 421-2 expresa que "en testamento, el causante ordena su sucesión mediante la institución de uno o más herederos" pudiendo, lógicamente, establecer también legados y otras disposiciones.

Esta obra está bajo una Licencia Creative Commons

Atribución-NoComercial-SinDerivar 4.0 Internacional, IIJ-UNAM.

Boletín Mexicano de Derecho Comparado, núm. 160, enero-abril de 2021, pp. 361-385. 
dades previstas por el testador; o el hecho de que el testador esté sometido al específico derecho de Tortosa, ámbito en el cual también se admite distribuir toda la herencia mediante legados.

\section{De los legitimarios}

Sin necesidad de mayor detenimiento en cuanto a la definición de la legítima, y a sabiendas de la configuración de la "institución de heredero" como característica propia del derecho catalán, procede determinar los legitimarios y la distribución de sus cuotas en los tres ordenamientos jurídicos objeto de estudio, a fin de apreciar un mínimo común denominador y, a la vez, sus rasgos diferenciales.

Por un lado, en Cataluña el círculo de legitimarios solamente incluye a los parientes en línea directa del causante, sin límites en la descendiente y restringido a los padres o progenitores en la línea ascendiente. ${ }^{6}$ El cónyuge o conviviente, pues, no puede ser considerado como legitimario, aunque sí tiene derecho a la cuarta viudal como atribución legal (Albert Lamarca, 2009 a, p. 264). Asimismo, a tenor del redactado del CCCat (art. 451-3.1), los legitimarios son todos los hijos del causante por partes iguales. La previsión de legítima para los progenitores será única y exclusivamente en el supuesto de que el causante no tenga descendientes que le hubieran sobrevivido, siendo en este caso legitimarios los progenitores por mitad. ${ }^{7}$

Por otro lado, en España, según regulación del Código Civil español (en adelante, CCesp, art. 807), son legitimarios los hijos y descendientes; a falta de los anteriores, los padres y ascendientes; en tercer lugar, "el viudo o viuda en la forma y medida que establece este Código". ${ }^{8}$

\footnotetext{
6 Véase CCCat (arts. 451-3 y 451-4).

7 Es más, estos no tienen derecho a legítima si el causante tiene descendientes pero han sido desheredados justamente o declarados indignos (CCGat, art. 451-4.1).

8 En este sentido, si el cónyuge del difunto concurre a la herencia con descendientes, tendrá derecho al usufructo del tercio de mejora (CCesp, art. 834); si concurre con ascendientes tendrá derecho al usufructo de la mitad de la herencia (CCesp, art. 837), y no existiendo descendientes ni ascendientes, el cónyuge sobreviviente tendrá derecho al usufructo de los dos tercios de la herencia (CCesp, art. 838).
}

Esta obra está bajo una Licencia Creative Commons Atribución-NoComercial-SinDerivar 4.0 Internacional, IIJ-UNAM. Boletín Mexicano de Derecho Comparado, núm. 160, enero-abril de 2021, pp. 361-385. 
Finalmente, en lo que a Colombia se refiere, el CGco (art. 1240) determina el rango de los llamados a ser legitimarios, disponiendo primeramente a los descendientes personalmente o representados - con independencia de que los hijos sean matrimoniales, extramatrimoniales o adoptivos- . Acto seguido, serán legitimarios los ascendientes. ${ }^{9}$

Así pues, vale la pena enfatizar que tanto en España como en Colombia se yuxtapone la institución de heredero con la de legitimario, derivando este en heredero forzoso, ${ }^{10}$ lo cual viene a suponer una anomalía y una intolerable coerción a la libertad de testar.

En contraposición al modelo anterior, se destaca la singularidad del CCCat, en el cual los herederos no tienen que ser, forzosamente, los hijos o parientes del causante, pudiéndose instituir como heredero cualquier otra persona, por lo que se disocia la institución de heredero de la de legitimario. Por esa razón, aunque en Cataluña cabe calificar la legítima como un derecho de crédito, más congruente con el principio de libertad testamentaria, ${ }^{11}$ en general

la legítima admite una doble configuración, como herencia forzosa, en el sentido que los legitimarios adquieren un derecho en bienes de la herencia, o como derecho de crédito a un valor de los bienes de la herencia que debe ejercitarse frente a los herederos o los representantes de la herencia y se percibe en metálico. (Antoni Vaquer, 2007, p. 7)

En definitiva, en Cataluña, sólo en el supuesto de sucesión ab intestato operará un orden sucesoral predeterminado que favorecerá que los

9 El CGcol (art. 1240) ha sido modificado por el artículo 3o. de la Ley 1934 de 2018, por medio de la cual se reforma y adiciona el Código Civil. Anteriormente, el precepto contenía una prelación de legitimarios de forma que - tras los descendientes - primaba, en primer lugar, los ascendientes, y tras ellos, los padres adoptantes y los padres de sangre del hijo adoptivo de forma simple.

10 Esta yuxtaposición heredero-legitimario se desprende de forma nítida del CGco (art. 1239, in fine), el cual recoge que "los legitimarios son, por consiguiente, herederos". También del CCesp, cuando en su capítulo segundo, sección quinta "De las legítimas", se denomina a los legitimaros propiamente como "herederos forzosos". (CCesp, art. 807)

11 "La apuesta por una legítima de naturaleza crediticia se corresponde mejor con una más amplia libertad de testar que si se otorga un derecho sobre los bienes hereditarios, pues esto supone que parte de la herencia siga en manos de la familia del causante con independencia de que esa fuera la voluntad del causante o no". (Antoni Vaquer, 2007, p. 7)

Esta obra está bajo una Licencia Creative Commons

Atribución-NoComercial-SinDerivar 4.0 Internacional, IIJ-UNAM.

Boletin Mexicano de Derecho Comparado, núm. 160, enero-abril de 2021, pp. 361-385. 
familiares del causante devengan herederos, ${ }^{12}$ puesto que, en la sucesión testada será la figura de la legítima la garante de la solidaridad intergeneracional entre los miembros de la familia.

\section{De la cuota legitimaria y su disparidad}

En cuanto a la cuota a repartir para los legitimarios, en Colombia la legítima se encuentra regulada en el CGcol (arts. 1239-1264). Hasta ahora se entendía dividido el caudal hereditario en dos mitades: la primera venía a ser la legítima rigurosa, reservada para los legitimarios, mientras que la otra mitad, en caso de inexistencia de descendientes, era de libre disposición, siendo apenas una cuarta parte la libre asignación cuando existían los descendientes. En tal caso, se proponía que no se hiciese la división en dos mitades sino en cuatro partes, dos de las cuales vendrían a ser las legítimas, una cuarta sería para mejorar a descendientes del causante y la otra vendría a ser de libre disposición. (Ramiro Rodríguez, 2012, p. 162)

Recientemente, encomiable ha sido la labor del senador de la República de Colombia Rodrigo Lara Restrepo, quien presentó una iniciativa de ley para ampliar la libertad sucesoral. Finalmente, este proyecto ha obtenido luz verde por el Congreso y se ha aprobado como Ley 1934 de 2018, el 2 de agosto, por medio de la cual se reforma y adiciona el CGcol, modificando y derogando múltiples artículos en materia legitimaria. ${ }^{13}$

En resumen, con la mencionada reforma del CCcol se elimina la cuarta de mejoras ${ }^{14} \mathrm{y}$ la herencia se divide en dos grandes partes: la mitad para los legitimarios (legítima rigurosa) y la mitad de libre disposición. ${ }^{15}$ En cuanto a las legítimas efectivas, acrece a las legítimas rigurosas

12 Tamayo (2008, p. 93) afirma que la noción de orden sucesoral hace referencia a un "grupo de personas que tiene prelación sobre otro grupo para recoger la herencia de un causante".

13 Las disposiciones de esta nueva normativa están en vigor a partir del 1o. de enero de 2019, no siendo aplicables a los testamentos que hayan sido depositados en notaría antes de su vigencia.

14 Con la Ley 1934 de 2018 se derogan los artículos 1243, 1252, 1253, 1259 y 1262 del CGcol, relacionados con la cuarta de mejoras.

15 Véase la nueva redacción del CGcol (art. 1242), por el cual, en todo caso la cuota legitimaria será de la mitad de los bienes, tras las deducciones ex art. 1016 y las agregaciones que indican los arts. 1243 a 1245. Prosigue disponiendo que los bienes "se dividen 
"toda aquella porción de los bienes de que el testador ha podido disponer con absoluta libertad, y no ha dispuesto, y si lo ha hecho ha quedado sin efecto la disposición". (CGcol, art. 1249)

A modo de crítica, hay que decir que la agudeza del legislador en la promulgación de la Ley 1934 de 2018 brilla por su ausencia. Sorprende y es particularmente desafortunada la mención a la "cuarta de mejoras" en el CGcol (arts. 1242, 1254, 1261 y 1264) a pesar de ser una figura eliminada tras la mencionada reforma, lo cual no generará sino confusiones. Del mismo modo, desacertada es la redacción de la nueva Ley (art. 21), el cual dispone que "cuando vaya a disponerse testamentariamente de predios rurales de extensión inferior a cuatro (4) Unidades Agrícolas Familiares (UAF), no será aplicable el régimen de las legítimas". El alcance de este precepto no es diáfano, por no quedar claro si este tipo de predios rurales son de libre disposición, o bien si en presencia de esta clase de bienes es la totalidad de la herencia la que deviene de libre disposición. En consecuencia, vaticino que la interpretación no será pacífica y se derivaran debates interpretativos de gran calado jurídico.

Por su parte, en España opera un sistema de legítima de 2/3 en favor de los hijos: un tercio estricto - que se puede grabar con sustitución fideicomisaria en favor de un hijo incapacitado - ${ }^{16}$ y el otro tercio de mejora entre los legitimarios cuando son hijos o descendientes (CGesp, art. 808). Por tanto, solamente la tercera parte restante será de libre disposición. Cuando los legitimarios sean los padres o ascendientes constituirá la legítima "la mitad del haber hereditario de los hijos y descendientes, salvo el caso en que concurrieren con el cónyuge viudo del descendiente causante, en cuyo supuesto será de una tercera parte de la herencia” (CCesp, art. 809). En resumen, en España estas cuotas legitimarias "fluctúan, tras la realización de las pertinentes operaciones de cálculo de relictum y donatum, entre un cuarto y las cuatro quintas partes (del valor) de la herencia". (Antoni Vaquer, 2007, p. 15)

De lo contrario, en Cataluña la legítima confiere a los legitimarios el derecho a percibir una cuarta parte del patrimonio hereditario (relicto,

por cabezas o estirpes entre los respectivos legitimarios, según las reglas de la sucesión intestada; lo que cupiere a cada uno de esta división es su legítima rigurosa".

16 Según el actual párrafo 3o. del art. 808 del CCesp, introducido por la Ley 41/2003, del 18 de noviembre, de protección patrimonial de las personas con discapacidad.

Esta obra está bajo una Licencia Creative Commons

Atribución-NoComercial-SinDerivar 4.0 Internacional, IIJ-UNAM.

Boletín Mexicano de Derecho Comparado, núm. 160, enero-abril de 2021, pp. 361-385. 
líquido; descontando las deudas). Así, la libertad de disposición alcanza el $75 \%$, ya que solamente un $25 \%$ está predeterminado por ley de forma forzosa en favor de los legitimarios (CCGat, art. 451-5). En consecuencia, el derecho catalán confiere mayor margen de lo que se viene denominando "libertad para testar", como reflejo de la libertad civil (CGCat, art. 111-6) o autonomía privada (CGesp, art. 1255).

Con todo, la evolución histórica de la legítima es la de su progresivo debilitamiento para dejar mayor libertad de disposición al causante y para evitar la fragmentación del patrimonio. Además, como se verá, el debate en la actualidad incluso va más allá, existiendo posiciones doctrinales, como las de Josep Ferrer (2008), que plantean la supresión de la legítima o su reforma para convertirla en un derecho que responda mejor a situaciones de necesidad. ${ }^{17}$ Es decir, lo que plantean estos autores es que los legitimarios tengan derecho a una cuota fija del caudal relicto, pero únicamente si estos se encuentran en la coyuntura de necesidad. En este caso, operaría la legítima en supuestos como los de legitimarios discapacitados o incapaces para trabajar, descendientes menores de edad, o en cumplimiento de una función similar al derecho de alimentos.

En suma, en los tres ordenamientos estudiados, en mayor o menor medida, la legítima se configura como una categórica limitación a la libertad testamentaria, suponiendo una injerencia del Estado en la esfera decisional de los ciudadanos. En España y Colombia porque los legitimarios se constituyen como herederos forzosos ${ }^{18}$ y, en Cataluña, por interpretarse la legítima como una sucesión forzosa. Tan forzosa es que existe en toda sucesión — testada e intestada-, está plenamente protegida (preterición) y sólo puede ser privada por justa causa de desheredamiento, sin que el testador la pueda prohibir o eliminar a su libre albedrío.

17 Se destaca que Josep María Puig (1984, p. 211 ) ya viene desde lejos abogando por su evanescencia, proclamando que "en Cataluña, a pesar de ser más bien corta, la legítima sigue su lento camino hacia la desaparición”.

18 Alejandro Platero (2017, p. 289), recuerda que ni esta denominación está exenta de polémica, ya que autores autorizados como Lacruz Berdejo, Acedo Penco o Román García, matizan que no es correcto llamar herederos forzosos a los legitimarios, dado que la legítima puede ser satisfecha en vida del causante por medio de donación o legado, sin que exista herencia alguna. 


\section{AUSENCIA DE RELACIÓN FAMILIAR COMO CAUSA DE DESHEREDAMIENTO}

La desheredación se define como aquel acto por el que el causante despoja al legitimario del caudal hereditario inmanente a la legítima. ${ }^{19}$

La desheredación se define como una sanción civil privada que debe hacer valer el causante si concurre una causa legal. Este estrecho margen para la libertad del causante implica que no caben otras vías indirectas para privar a los legitimarios de su derecho. (Paloma de Barrón, 2016, p. 11)

Pero, sin duda, este mecanismo de la desheredación presenta un amplio margen de discrecionalidad al causante, debiéndose prever obligatoriamente como cláusula testamentaria, la cual dependerá de su voluntad (María Elena Cobas y Christian de Joz, 2017, pp. 43 y 44).

Se desprende del CCesp (art. 849) que la desheredación sólo podrá hacerse en testamento. También el CGcol comparte esta versión, añadiendo (art. 1267) que no valdrá ninguna de las causas de desheredamiento si no se expresa en el testamento específicamente, "y si además no se hubiere probado judicialmente en vida del testador; o las personas a quienes interesare el desheredamiento no lo probaren después de su muerte". No obstante, el CGCat prevé dos instrumentos sucesorios, distintos al testamento que también habilitan a la desheredación: el codicilo y el pacto sucesorio (CGCat, art. 451-18.1).

Paloma de Barrón (2016) expone con precisión que la "cláusula de desheredación debe designar nominalmente al desheredado o, por lo menos, designarlo de forma individual e inequívoca, porque la naturaleza formal del desheredamiento impide que sea un acto genérico" (p. 12). Además, como antedicho, "tiene que expresarse la causa legal de desheredación, es decir, encajar la situación personal que se está viviendo en alguno de los preceptos legales que describen las causas de desheredación”. (p. 12) ${ }^{20}$

19 Ccesp (arts. 848 y ss), CGCat (art. 451-17.1). Y a diferencia de los otros dos ordenamientos comentados, el art. 1265 CGcol concreta que el desheredamiento podrá conllevar la privación "del todo o parte" de la legítima.

20 CGesp (art. 849), CGCat (V art. 451-17), CGco (art. 1266).

Esta obra está bajo una Licencia Creative Commons

Atribución-NoComercial-SinDerivar 4.0 Internacional, IIJ-UNAM.

Boletín Mexicano de Derecho Comparado, núm. 160, enero-abril de 2021, pp. 361-385. 
En Cataluña y España los efectos de la desheredación serán los mismos: si el legitimario desheredado es único, se extingue la legítima, no dando lugar a acrecimiento si hay otros legitimarios. Si el desheredado tuviese descendientes, estos devienen legitimarios por derecho de representación. ${ }^{21}$ Sin embargo, a diferencia de los dos ordenamientos mencionados, en Colombia sí habrá derecho de acrecimiento en caso de desheredamiento; ${ }^{22}$ no damnificando el desheredamiento, por regla general, los alimentos necesarios, exceptuando los casos de injuria atroz (CCcol, art. 1268).

El CGcol (art. 1268) expresa que "los efectos del desheredamiento, si el desheredador no los limitare expresamente, se extienden no sólo a las legítimas (...)". Mientras que, del CGCat (art. 451-17.1) se desprende que "el causante puede privar a los legitimarios de su derecho de legítima si en la sucesión concurre alguna causa de desheredación". En consecuencia, el redactado del precepto catalán nos podría llevar a pensar en la antinomia de que el causante solo puede privar, por vía del desheredamiento, de la legítima, y no propiamente de la herencia. No obstante, existiendo en Cataluña la libertad de erigir un heredero distinto a los familiares legitimarios, ¿alguien puede pensar que, por ejemplo, un testador quiera impedir la percepción de la legítima al hijo vía desheredación, pero simultáneamente lo instituya como heredero en su testamento?

Acometiendo ya la causal concreta de ausencia de relación familiar, en Cataluña, el CGCat (art. 451-17.1) establece que "se puede desheredar a los legitimarios por la ausencia manifiesta y continuada de relación familiar entre el causante y el legitimario, si es por una causa exclusivamente imputable al legitimario". En este sentido, "el legislador catalán se sitúa con esta postura en un término medio, entre los conceptos de libertad de testar, sucesión y protección de la familia; además de ir en consonancia con el resto de los derechos en el ámbito internacional que también optan por seguir esta corriente doctrinal". (María Elena Cobas y Christian de Joz, 2017, p. 22)

La adición de esta nueva causa se incorporó con la entrada en vigor el 1o. de enero de 2009 del libro cuarto del CCCat, relativo a las sucesio-

21 CCesp (art. 929), CCCat (art. 451-3.2), CGco (art. 1043).

22 Véase CCCat (art. 451-25.3). En cambio el CCcol (art. 1248) dispone que si un legitimario es desheredado y no tiene descendencia con derecho de representarle "dicho todo o parte se agregará a la mitad de legítimas, y contribuirá a formar las legítimas rigurosas de los otros, y la porción conyugal en el caso del artículo 1236, inciso 2". 
nes. ${ }^{23}$ Igualmente, el legislador catalán hizo un inciso significativo en el apartado VI del preámbulo del citado Libro, apreciando que este precepto podía ser "fuente de litigios por la dificultad probatoria de su supuesto de hecho", así como "conducir al juzgador a tener que hacer suposiciones sobre el origen de desavenencias familiares". Sin embargo, prosigue justificando tal previsión declarando que "se ha contrapesado este coste elevado de aplicación de la norma con el valor que tiene como reflejo del fundamento familiar de la institución y el sentido elemental de justicia que es subyacente".

En cambio, en derecho común español, la posibilidad de desheredar por falta de relación entre legitimario y ascendente todavía pasa en la actualidad por una interpretación extensiva del maltrato de obra que recoge como causa de desheredación el artículo 853.2 CCesp. (Hilario Mondragón, 2018, p. 17)

En este sentido, el Tribunal Supremo, viendo la inacción del legislador español y las escasas expectativas de que hubiera una reforma en materia de desheredación, decidió entrar en juego con una virtuosa labor hermenéutica, forzando la interpretación del "maltrato de obra" y el "maltrato psicológico" para amparar al causante ante supuestos de abandono familiar. Esto sucede cuando el Tribunal Supremo, a partir de su sentencia del 3 junio de 2014 (STS),

equipara el maltrato psicológico, que supuestamente deriva del hecho de haber sido abandonado el testador, con el maltrato de obra. En el caso enjuiciado, entiende que su desatención por parte de los legitimarios le provoca un menoscabo o lesión de su salud mental y que además tal conducta atenta contra su dignidad. (Esther Arroyo y Esther Farnós, 2015, p. 7) ${ }^{24}$

23 Publicado en el Diario Oficial de la Generalitat de Cataluña (DOGG) núm. 5175, del $17 / 07 / 2008$.

24 Concretamente, la susodicha STS, Sala la., núm. 258/2014, del 3 junio recoge, literalmente, lo siguiente: "En el presente caso, y conforme a la prueba practicada, debe puntualizarse que, fuera de un pretendido abandono emocional, como expresión de la libre ruptura de un vínculo afectivo o sentimental, los hijos, aquí recurrentes, incurrieron en un maltrato psíquico y reiterado contra su padre del todo incompatible con los deberes elementales de respeto y consideración que se derivan de la relación jurídica de filiación, con una conducta de menosprecio y de abandono familiar que quedó evidenciada en los últimos siete años de vida del causante en donde, ya enfermo, quedó bajo el amparo de su

Esta obra está bajo una Licencia Creative Commons

Atribución-NoComercial-SinDerivar 4.0 Internacional, IIJ-UNAM.

Boletin Mexicano de Derecho Comparado, núm. 160, enero-abril de 2021, pp. 361-385. 
Esta nueva línea doctrinal se confirma con la STS del 30 de enero de 2015, la cual siguiendo el mismo iter argumentativo, supone la consolidación de una interpretación flexible del maltrato de obra, incluyendo el maltrato psicológico como justa causa de desheredación.

Como aprecia Hilario Mondragón (2018, pp. 17 y 18) citando a Represa Polo, de ello se puede entender que el maltrato psicológico es una modalidad del maltrato de obra y que a su vez el abandono familiar es una modalidad del maltrato psicológico. Por lo tanto, la desatención familiar podría, en principio, considerarse dentro del dinamismo conceptual del maltrato de obra, lo cual es verídico. De hecho, el Tribunal Supremo, en las relevantes sentencias comentadas de 2014 y 2015, no habilita directamente la falta de relación familiar o el abandono emocional como causa autónoma de desheredación.

En todo caso, el abandono, el ingreso en un centro asistencial o dejación y abandono en cualquier ubicación fuera del ámbito familiar, el desafecto y la desatención son causas de desheredación subsumibles en el artículo 853.2 del CGesp como un claro maltrato psíquico, en tanto constituyen causa directa de la angustia y sufrimiento para el ascendiente, que, en ocasiones, viene acompañado también de su vertiente física. (Berrocal, Ana Isabel, 2015, p. 942) $)^{25}$

Asimismo, cabe recordar que la doctrina del Tribunal Supremo, hasta tiempos muy recientes, no admitió que el abandono sentimental a los progenitores pudiese ubicarse dentro del maltrato de obra. Ello se debía a la rigidez que ha existido a la hora de interpretar las causas de desheredación. (Gómez-Cornejo, Lourdes, 2016, p.1615)

No obstante, a partir de 2011, ${ }^{26}$ Mondragón, Hilario (2018, p. 14) detecta una mutación de la doctrina del Tribunal Supremo hacia una interpretación extensiva y con posibilidad de analogía de las causas de desheredación. Este autor, citando a Carrau Carbonell, expone que la propia jurisprudencia más reciente dispone que no se pueden ni añadir ni quitar

hermana, sin que sus hijos se interesaran por él o tuvieran contacto alguno; situación que cambió, tras su muerte, a los solos efectos de demandar sus derechos hereditarios".

25 En otras palabras, Lourdes Gómez-Cornejo (2016, p. 1614) asevera que el incumplimiento de deber de cuidado y atención de los padres debe dar lugar a la posibilidad de desheredar, ya que, como sabemos, la legítima tiene como una de sus causas la solidaridad familiar.

26 Prueba de ello es la SAP de Málaga, Sec. 5a., núm. 130/2011, del 30 marzo. 
causas de privación de su derecho a un legitimario. En cambio, lo que sí se puede es hacer más extensivas las causales contempladas por los artículos 852 a 855 del CCesp.

Valiosa mención merece el legislador colombiano, quién finalmente - a diferencia de España - se ha atrevido a incorporar el abandono familiar como causa de indignidad sucesoral en el apartado 6 del artículo 1025 del CGco, en los siguientes términos: "El que abandonó sin justa causa a la persona de cuya sucesión se trata, estando obligado por ley a suministrarle alimentos. Para los efectos de este artículo, entiéndase por abandono: la falta absoluta o temporal a las personas que requieran de cuidado personal en su crianza, o que, conforme a la ley, demandan la obligación de proporcionar a su favor habitación, sustento o asistencia médica". Tal reforma ha entrado en vigor por medio de la Ley 1893 de 2018, del 24 de mayo, por medio de la cual se ha modificado el citado artículo.

Hay que aclarar que se excluye de los efectos de la norma el abandono que se origine en una justa causa o si, pese a haber ocurrido, el causante perdonó dicha situación. A mayor concreción, en Cataluña el perdón deberá ser concedido por el causante en escritura pública - tanto si la reconciliación o el perdón son anteriores o posteriores a la desheredación-, siendo los mismos irrevocables (CGCat, art. 451-1).

Vemos pues, comparando, que el derecho de sucesiones ha tendido a incorporar la causa de desheredación por ausencia de relación familiar. El germen de esta innovación lo encontramos en la nueva realidad social, constatándose un aumento de la esperanza de vida de la población, pero también, este envejecimiento está acompañado de un auge de enfermedades neurodegenerativas generadoras de escenarios de dependencia de los ancianos (a menudo no atendidos en el ámbito familiar). A ello, hay que añadir nuevas formas de modelos familiares, la incorporación de la mujer en la vida laboral, la movilidad laboral misma y, por qué no decirlo, un incremento del individualismo en las relaciones intrafamiliares que lleva aparejado un desamparo tanto material como afectivo de los ascendientes por parte de sus hijos. Todo ello, ha llevado a la ciencia jurídica a reinterpretar las causas de desheredación y adecuarlas al nuevo contexto. (Berrocal, Ana Isabel, 2015, p. 931)

Como se ha mostrado, después de examinar la desheredación de descendientes por ausencia de relación familiar, Luis Javier de Almansa (2012, p. 36) concluye de forma certera que

Esta obra está bajo una Licencia Creative Commons

Atribución-NoComercial-SinDerivar 4.0 Internacional, IIJ-UNAM.

Boletín Mexicano de Derecho Comparado, núm. 160, enero-abril de 2021, pp. 361-385. 
Códigos modernos y jurisprudencia reciente tienden a reducir los derechos de los legitimarios, ajustándose a la realidad de la sociedad contemporánea en la que prevalece el interés en procurarle una formación a los hijos, sobre el interés en garantizarles un valor patrimonial cuando falten los progenitores.

Finalmente, en cuanto a la libertad testamentaria, un aspecto esencial que, de paso, incidiría en la reforma del sistema legitimario, radicaría en la inclusión de las "causas abiertas para desheredar". Estas causas son aquellas que agrandan la libertad de testar admitiendo un elevado margen interpretativo. Sin embargo, vale la pena puntualizar, como exponen Galicia, Gorka y Castellanos, Sandra (2018, p. 33), que el aumento de dicha libertad no puede producirse a costa de una mayor inseguridad y de una judicialización de las relaciones familiares, como ocurriría de adoptarse un modelo marco a partir de cláusulas de desheredamiento flexibles y abiertas.

En resumen, resulta interesante la reflexión de las profesoras Esther Arroyo y Esther Farnós (2015, p. 22), las cuales al referirse a la cláusula de desheredación por abandono familiar observan que

la necesidad de incrementar la libertad de testar exige derogar la legítima y allanar el camino hacia su conversión en un derecho de alimentos. Cualquier intento de debilitarla mediante la actualización de las causas de desheredación genera más problemas que los que pretende solucionar.

\section{IV. ¿HAGIA UNA MAYOR LIBERTAD DE TESTAR?}

"La libertad de testar material puede considerarse como una manifestación de la dignidad de la persona y del libre desarrollo de la personalidad aplicado al derecho de sucesiones". (Paloma de Barrón, Paloma, 2016, p. 11)

Precisamente en el fenómeno sucesorio, Ángel María López y López (1994, p. 31) aprecia intereses en conflicto, entre los cuales: a) de orden individual patrimonial y b) de orden familiar. El primero, correspondiente al titular fallecido y a su facultad discrecional sobre el destino de sus bienes; el segundo, correspondiente a los intereses inherentes que ostentan, según este autor, los familiares del de cuius en relación con la distribución de su patrimonio. Es aquí donde apreciamos un conflicto de intereses, dimanando contradicciones fundamentales para mantener la coexistencia 
de dichos intereses de autonomía de libertad del causante y los intereses de solidaridad interfamiliar.

Como indica Ernest J. Weinrib (2017, pp. 256 y 257), el modo de como las formas de justicia son efectivizadas en los sistemas jurídicos se halla sujeto a las variaciones inherentes a su interpretación y aplicación públicas. Así, las formas de la justicia coexisten con indeterminaciones cuya resolución puede variar de época a época y de cultura a cultura. Por tanto, este teórico del derecho, desde la vertiente filosófica del "formalismo", asegura que entendiendo el derecho positivo como un orden coherente, este no puede ignorar la historia, la positividad y la realidad social del derecho.

Concretamente en materia sucesoria, no podemos olvidar que

las leyes que regulan las sucesiones por causa de muerte pueden y deben cambiar, sobre todo a la vista de los cambios que se están produciendo en la familia y en el derecho de familia, y también en las fortunas y en los modos de transmisión de la riqueza en la sociedad actual. (Paloma de Barrón, 2016, p. 11$)^{27}$

Carlos Lasarte (2015) razona que "la existencia de la legítima implica una restricción de la libertad de testar testamentaria, que se trata de una imposición establecida por el legislador al causante, en beneficio de las personas más cercanas o allegadas a él y que forman parte, en consecuencia, de su círculo familiar" (p. 163).

Precisamente en relación con la concepción de círculo familiar, trazando una línea hacia una mayor libertad para testar, Ángel María López y López (1994), a partir de un juicio de constitucionalidad, observa que nuestra sociedad considera que el "mínimo de familia" está formado alrededor de la pareja, sus descendientes y ascendientes, y tal vez los hermanos de ambos cónyuges o pareja. Con esta premisa, propone que

más allá de los descendientes y los ascendientes, y los propios cónyuges, nada impediría al legislador suprimir cualquier llamamiento forzoso, y con amplia posibilidad de configurar el quantum, la forma y el lugar del llamamiento; y también configurar un orden de llamamiento ab intestato que se extienda tan solo al primer grado de los colaterales. (p. 57)

27 Citando a otros autores de relieve como Fuentes Martínez, Delgado Echeverría, Magariños Fuentes.

Esta obra está bajo una Licencia Creative Commons

Atribución-NoComercial-SinDerivar 4.0 Internacional, IIJ-UNAM.

Boletín Mexicano de Derecho Comparado, núm. 160, enero-abril de 2021, pp. 361-385. 
Alejandro Platero (2017, p. 289) cita a autores como Aguilar Díaz, quien da argumentos a favor de la legítima, en cuanto a la justificación de su origen y finalidad, de suerte tal que

somos de la idea de que lo que el legislador quiso asegurar incorporando el sistema de legítima, es acertado si su fin es el de garantizar la continuidad de la familia respecto de quienes están en potestad del padre de familia, es decir, de quienes aún no están en condiciones de garantizar su independencia económica. (Aguilar, Richard, 2015, p. 79)

Es más, asevera Ramiro Rodríguez (2012, pp. 188 y 189) que hay autores que, con el propósito de proteger a los hijos, incluso han llegado a sostener que debería eliminarse la libertad de testar.

Alejandro Platero (2017, p. 317) admite que muchas voces de importancia manifiesta critican la permanencia en pleno siglo XXI de la legítima, aunque considera acertada esta figura y defiende su subsistencia por ser "su fin último el de garantizar la estabilidad de lo más importante de la vida de un ser humano, aunque a veces no se dé cuenta de ello, su familia"; argumento este, no compartido por lo endeble de su exposición y la concepción plenamente subjetiva que tiene este autor en cuanto a la importancia de la familia, sin que nadie pueda, a mi juicio, conocer ni imponer las prioridades vitales de otra persona.

Por el contrario, el autor Valverde y Valverde cita opiniones según las cuales debería, en todo caso, garantizarse al testador absoluta libertad para disponer de sus bienes después de su muerte, por cuanto que la voluntad individual claramente expresada encarnaba el ideal de justicia, reservándose la operancia de la ley únicamente para en caso de sucesión ab intestato. (Ramiro Rodríguez, 2012, pp. 188 y 189).

Los partidarios de esta posición, que contrasta de forma radical con la previsión legal actual, son proclives a remitirse al derecho angloamericano, "por ser el exponente de una libertad de testar irrestricta e ilimitada en la que los padres no tenían que hacer previsión ni provisión testamentarias en favor de sus hijos" (Aurelio Barrio, 2007, p. 2730). Sin embargo, Oughton, erigiéndose como la doctrina más autorizada en la materia, matiza que "la libertad de testar absoluta en sentido estricto solo se conoció en Inglaterra desde 1891 ("Mortmain \& Charitable Uses Act") hasta 1938 ("Inheritance [Family Provision] Act")" (Aurelio Barrio, 2007, p. 2736). 
Con todo, la realidad jurídica en Cataluña, España y Colombia - y por extensión a la práctica totalidad de sistemas jurídicos-, no es otra que la de conceder libertad para testar, aunque instituyendo las legítimas o asignaciones forzosas ${ }^{28}$ para garantizar a los parientes más cercanos al causante la herencia o, al menos, parte de ella.

En términos de aparente lógica jurídica, indica Ramírez Rodríguez (2012, p. 189) que en Colombia el testamento viene a ser una manifestación de voluntad libre y consciente de una persona, para que se produzcan determinadas consecuencias jurídicas después de su fallecimiento, derivado de la autonomía de la voluntad y con raíces en el derecho de propiedad y en la libertad de las personas. Ahora bien, ¿es suficiente la libertad para testar que rige en el derecho de sucesiones colombiano y, por extensión, en el español? ¿O se puede cuestionar por un excesivo constreñimiento del testador por vía de una legítima excesivamente larga, con el subterfugio del principio de solidaridad o protección familiar?

Si bien lo cierto es que hay doctrina dispar en la restricción a la libertad de testar que supone la legítima, siendo cuestión controvertida que ha ocasionado profundos debates y críticas, se converge en la posición de aquellos autores que están en total desacuerdo con la configuración actual de la legítima, considerando que

la actual regulación de la legítima del Código Civil no tiene cabida en una concepción de la persona y familia propias del siglo XXI, que nada tienen que ver con la que existía en el tiempo de la Codificación, por lo que, consideramos que la legítima debería desaparecer por completo, siendo desterrada de las leyes, dejando a salvo, eso sí, la protección de los menores e incapacitados, única justificación que encontramos hoy a la institución. (Ángel Acedo, 2014, p. 155) $)^{29}$

Esto es así, porque

28 En Colombia, las asignaciones forzosas previstas en el art. 1226 del CGcol, tras la reforma operada por la Ley 1934 de 2018, son: los alimentos que se deben por la ley a ciertas personas, la porción conyugal y las legítimas.

29 Además, para comprender la obsolescencia del sistema legitimario - en referencia al CCesp- - es de gran interés ver las consideraciones a nivel sociológico y estadístico que exhibe Aurelio Barrio (2007), constatando un amplio consenso doctrinal en cuanto a la necesidad de revisión del Código en esta materia.

Esta obra está bajo una Licencia Creative Commons

Atribución-NoComercial-SinDerivar 4.0 Internacional, IIJ-UNAM.

Boletín Mexicano de Derecho Comparado, núm. 160, enero-abril de 2021, pp. 361-385. 
admitiendo que el fundamento de las legítimas se halla en el principio de solidaridad intergeneracional en el seno de la familia, la realización de este principio aboga por rechazar una legítima uniforme para una categoría de parientes, sean los descendientes o los ascendientes (Antoni Vaquer, 2007, p. 14).

Ahondando en la cuestión de concebir la legítima como figura protectora que operase en casos de "necesidad familiar" de los legitimarios, Antoni Vaquer (2007, pp. 4-10) expone, como solución intermedia, que los legitimarios tengan derecho a una cuota fija de los bienes de la herencia o de su valor, única y exclusivamente si se encuentran en tal circunstancia de menesterosidad, por la cual "la solidaridad intergeneracional esté llamada a jugar un papel efectivo. Así ocurre con los descendientes menores de edad y con quienes están afectados por discapacidades o son incapaces para el trabajo".

Sin embargo, el mismo Antoni Vaquer (2007, p. 15) prosigue señalando que este tipo de configuración conllevaría múltiples inconvenientes: determinar hasta cuándo cabría ejercer la pretensión a la legítima, sus mayores costes de transacción, una mayor litigiosidad familiar con múltiples pleitos, así como una complejidad a nivel probatorio; pues obligaría a las partes a proporcionar elementos de prueba suficientes de detalles íntimos de sus vidas, por lo general, escasamente documentados.

Además, en caso de aplicarse la legítima solamente en caso de necesidad, habría que apreciar una incongruencia que debilitaría el fin último de este cambio de paradigma. En este sentido, si concurriese un "supuesto de desheredación con causa justa con una situación de necesidad en el legitimario desheredado, esta circunstancia no activaría ningún tipo de mecanismo de solidaridad que condujera a emplear la herencia del causante para solucionar dicha situación de necesidad" (Paloma de Barrón, 2016, p. 15), por lo que quedarían consolidadas las causales de desheredamiento como preponderantes frente a la legítima. Con todo, el hecho que aquél que con su proceder haya merecido la desheredación, independientemente de su situación económica, quedase fuera de la herencia del causante, no sería una cuestión que generase gran controversia, puesto que se asumiría como una consecuencia plenamente lógica y defendible ética y jurídicamente.

En definitiva, con la institución del desheredamiento — más habiendo emergido la nueva causal por abandono familiar- 
incluso podría suceder que todos los legitimarios fueran susceptibles de ser desheredados conforme a la ley y no se dieran las circunstancias para que opere el derecho de representación. En este caso desaparecería la legítima, y el causante sería absolutamente libre para decidir el futuro de su entero patrimonio hereditario. (Paloma de Barrón, 2016, pp. 14 y 15).

A colación de cuanto expuesto, sea como sea, lo que se debe replantear es el concepto de "solidaridad intergeneracional". Hoy, vemos como la legítima sólo responde a razones de parentesco por consanguinidad o por afinidad. No obstante, como aprecia Paloma de Barrón (2016, p. 15), si se parte de que, "técnicamente, para poder ejercer la solidaridad es precisa una situación previa de necesidad, deberíamos concluir que este fundamento solo lo es en los casos en que se prevé un derecho de alimentos sucesorios". Esta autora fundamenta su crítica al sistema actual en detectar que la legítima se atribuye a los legitimarios sin reparar en sus necesidades económicas, transmitiéndose generalmente a la futura generación en un momento en que los perceptores ya detentan suficientes recursos para su subsistencia.

A mayor abundamiento, es constatable empíricamente que "en la mayoría de los casos, a la muerte del causante, sus ascendientes habrán fallecido o tendrán una edad muy avanzada, mientras que sus hijos estarán en una franja de edad comprendida entre los 40 y los 55 años" (Antoni Vaquer, 2007, p. 9). Al respecto, la mayoría de los doctrinantes que se han ocupado de esta materia han reiterado cuanto comentado por Valladares Rascón, señalando que "la herencia no tiene ya la función de transmitir de padres a hijos los medios de sustento de la familia, sino que suele ser un bienvenido complemento a la jubilación" (Aurelio Barrio, 2007, p. 2713).

Asimismo, Antoni Vaquer (2007, p. 8) cita a Magariños Blanco y Cobas Cobiella, quienes centran con dureza su crítica al sistema de legítima tildando su carácter de absurdamente obligatorio "ya que con independencia de la fortuna o ingresos familiares los padres están obligados a designarles en el testamento la legítima estricta por lo menos (...) que en muchos casos no lo merecen y en otros ni siquiera lo necesitan".

Llegados a este punto, sin intención de polemizar pero sí de llevar el debate y la reflexión hacia la más estricta radicalidad, Aurelio Barrio (2007, p. 2719), citando a Navarro Viñuales, enumera como posible hi- 
pótesis "la instauración de la libertad de testar. Esto es, un sistema puro de libre disposición mortis causa sin ningún género de restricción o cortapisa, ni tan siquiera suavizado por prestaciones de carácter asistencial en beneficio de los más próximos parientes del causante o de su cónyuge". Siendo pragmático, el contraste tan severo que supondría la libertad absoluta con la enraizada tradición en nuestro derecho sucesorio - tanto en Cataluña, España, como en Colombia - complica esta opción, por lo que difícilmente el atrevimiento del legislador llegará a tal extremo.

\section{CONCLusiones}

1. Pese a sopesar que la legislación colombiana y española todavía no deja suficiente autonomía de la voluntad al testador, todos los considerandos expuestos a lo largo de este estudio nos llevan a concluir que la libertad de testar está cobrando, cada día más, una inconmensurable fuerza y razón de ser.

2. Concretamente, se constata la tendencia en derecho sucesorio de admitir como causal de desheredamiento el abandono o ausencia de relación familiar con el causante. En este ámbito, he de destacar el papel pionero que ha jugado el derecho civil catalán, con la introducción de dicha causal en 2008 mediante la aprobación del libro cuarto de su Código Civil. Finalmente, aunque diez años más tarde, el legislador colombiano también ha tomado esta senda, a fin de preservar la coherencia de su derecho con la nueva realidad y contexto social.

Por el contrario, sorprende que en derecho común español todavía no se haya reformado el Código Civil en aras de incluir, explícitamente, esta causal de desheredamiento; si bien se viene aplicando, de facto, a partir de la envidiable y meritoria labor hermenéutica del Alto Tribunal desde su sentencia del 3 de junio de 2014, confirmada por la del 30 de enero de 2015.

3. Consiguientemente, de una forma u otra, en los tres ordenamientos jurídicos analizados ya opera esta nueva previsión legal de desheredamiento por abandono familiar, lo cual sugiere la actual predisposición en derecho de sucesiones de atenuar la "sagrada" institución de la legítima, siendo un síntoma más conducente hacia una mayor libertad para el futuro causante. 
Sin embargo, la libertad de testar no puede producirse a partir de un modelo de cláusulas de desheredamiento flexibles y abiertas, puesto que la inseguridad jurídica y la elevada judicialización son contraproducentes y supondrían un coste demasiado elevado. Por tanto, es más conveniente reformar el sistema sucesorio a partir de atemperar la legítima, regulando una legítima corta, que mantener una elevada cuota legitimaria pero ampliando las causas de desheredación.

4. No podemos seguir justificando la institución de la legítima con base en un principio de "solidaridad intergeneracional". Se concluye en tal sentido a partir de las siguientes premisas:

En primer lugar, porque actualmente se atribuye la legítima sin seguir ningún criterio que tome en consideración los legitimarios necesitados, si los hubiere. Asimismo, tampoco la desheredación tiene en cuenta si el desheredado está o no en situación de necesidad.

En segundo lugar, porqué en nuestros días la legítima se transfiere a la subsiguiente progenie en un momento intranscendente para sus necesidades de sustento, por estar el legitimario en una edad avanzada más pronta a la jubilación que en su etapa inicial de desarrollo personal autónomo.

A sabiendas de esta incongruencia sistémica, se vislumbran dos opciones:

Suprimir la legítima por la carencia de justificación alguna de la perdurabilidad de una institución, que sin justa causa lo que hace es limitar la libertad para testar, contraponiéndose a un principio básico en derecho privado como es el de la libre autonomía de la voluntad.

O bien reconfigurarla exclusivamente para situaciones de necesidad del legitimario, operando de forma extensiva el principio de solidaridad intergeneracional.

Imponer la segunda tesis nos llevaría, por ende, a la modificación no sólo del sistema legitimario, sino de otras figuras en derecho sucesorio como la del desheredamiento, imponiendo una barrera a los efectos de éste en los casos que se pruebe la situación de necesidad del legitimario desheredado.

A mayor abundamiento, se presentan dificultades para reformular la legítima en pro, única y exclusivamente, de aquellos legitimarios en situación de necesidad: como la propia inseguridad jurídica para el beneficiario de la legítima, la obligación de probar la situación de necesidad de éste y el aumento de la judicialización de las sucesiones mortis causa.

Esta obra está bajo una Licencia Creative Commons

Atribución-NoComercial-SinDerivar 4.0 Internacional, IIJ-UNAM.

Boletín Mexicano de Derecho Comparado, núm. 160, enero-abril de 2021, pp. 361-385. 
5. A colación de cuanto expuesto, parece tambalearse la propia institución de la legítima, lo cual, ciertamente no es cuestión baladí. Entonces, lo que difícilmente puede ser cuestionable es que la tendencia en este ámbito conduce inexorablemente a otorgar un mayor peso a la libertad testamentaria del causante. Consiguientemente, los ordenamientos jurídicos español y colombiano, al menos, deberían introducir reformas de cierto calado en el sentido de reducir las cuotas y aproximarse a la apuesta de legítima corta (un cuarto) vigente en derecho civil catalán.

\section{BIBLIOGRAFÍA}

Acedo Penco, Ángel (2014). Derecho de sucesiones. El testamento y la herencia. Madrid. Dykinson.

Aguilar DÍAZ, Richard (2015). De la libertad para testar con la legítima. La Ley Derecho de Familia: Revista Jurídica sobre Familia y Menores (6), 75-84. ARroyo I AMAYUElaS, Esther y FARNÓs AMORÓs, Esther (2015). Entre el testador abandonado y el legitimario desheredado ¿A quién prefieren los tribunales? InDret (2), 1-32.

Barrio Gallardo, Aurelio (2007). Atemperar la rigidez de la legítima. Revista Doctrinal Aranzadi Civil-Mercantil (3), 2711-2738.

Berrocal Lanzarot, Ana Isabel (2015). El maltrato psicológico como justa causa de desheredación de hijos y descendientes. Revista Crítica de Derecho Inmobiliario (748), 928-952.

Cobas Cobiella, María Elena y Joz Latorre, Christian de (2017). La modernización del derecho de sucesiones. Algunas propuestas. Cuestiones de Interés furídico, IDIBE, 1-68.

Almansa MORENO-BARRERA, Luis Javier de (2012). ¿Debe introducirse en el derecho civil común la "falta de relación familiar" como causa para desheredar a hijos y otros descendientes? Aletheia: Cuadernos Críticos del Derecho (1), 27-37.

BARrón Arniches, Paloma de (2016). "Libertad de testar y desheredación en los derechos civiles españoles. InDret (4), 1-57.

DELGADO ECHEvERRÍA, Jesús (2006). Una propuesta de política del derecho en materia de sucesiones por causa de muerte. Derecho de sucesiones: presente y futuro: XI [i.e. XII] Fornadas de la Asociación de Profesores de Derecho 
Civil. Santander, 9 a 11 de febrero de 2006. Murcia. Universidad de Murcia, Servicio de Publicaciones, 13-172.

FERRER RIBA, Josep (2008). El nuevo derecho catalán de sucesiones. InDret.

Galiaia Aizpurua, Gorka y Castellanos Cámara, Sandra (2018). Últimas reformas y propuestas de reforma en derecho de sucesiones. Revista Doctrinal Aranzadi Civil-Mercantil (3), 27-70.

Gómez-CORnejo Tejedor, Lourdes (2016). El cambio de sesgo en la jurisprudencia en torno a las causas de desheredación en el derecho común español. Revista Crítica de Derecho Inmobiliario (755), 1609-1629.

LAMARCA MARQUÈS, Albert (2009a). Relacions familiars i atribucions successòries legals. Novetats en la regulació de la llegítima i la quarta vidual. Quinzenes Fornades de Dret Català a Tossa. El nou dret successori del Codi Civil de Catalunya. http://civil.udg.es/tossa/2008/textos/pon/index.htm [consultado el 2 de septiembre de 2019].

LAMARCA MARQUÈS, Albert (2009b). El Llibre IV del Codi Civil de Catalunya. Actualitat Parlamentària (16), 54-73.

Lasarte Álvarez, Carlos (2015). Principios de derecho civil VII, Derecho de sucesiones (10a. ed.). Marcial Pons.

LóPEZ Y LóPEZ, Ángel María (1994). La garantía institucional de la herencia. Derecho Privado y Constitución (3), 29-62.

Mondragón Martín, Hilario (2018). Ampliación de las causas de desheredación de hijos y descendientes. Vlex (167), 8-33.

Platero Alcón, Alejandro (2017). Las injustas diferencias existentes en la libertad de testar dentro del territorio español. Vniversitas (135), 283324.

Puig SALELLAS, Josep Maria (1984). Notes sobre una eventual reforma de la llegítima. Materials de les III Jornades de Dret Català a Tossa. La reforma de la Compilació: el sistema successori. Tossa de Mar. Càtedra de Dret Civil Català Duran i Bas.

RoDRÍGUEz LóPEz, Ramiro (2012). Las sucesiones en el siglo XXI: nuevas tendencias doctrinales y jurisprudenciales. Bogotá. Universidad La Gran Colombia.

VAQUER AlOY, Antoni (2007). Reflexiones sobre una eventual reforma de la legítima. InDret (3), 1-25.

Weinrib, ERnest J. (2017). La idea de derecho privado. Madrid. Marcial Pons.

Esta obra está bajo una Licencia Creative Commons

Atribución-NoComercial-SinDerivar 4.0 Internacional, IIJ-UNAM.

Boletín Mexicano de Derecho Comparado, núm. 160, enero-abril de 2021, pp. 361-385. 


\section{Furisprudencia}

España. Tribunal Supremo. (2015). Sentencia 59/2015, del 30 enero. España. Tribunal Supremo. (2014). Sentencia 258/2014, del 3 junio.

España. Audiencia Provincial de Málaga. (2011). Sentencia 130/2011, de 30 marzo.

\section{Legislación}

Colombia. "Código Civil". Ley 57 de 1887. http://bit.ly/3c6xOrT

Colombia. Ley 1893 de 2018, del 24 de mayo, por medio de la cual se modifica el artículo 1025 del Código Civil. http://bit.ly/3pgb4cX

Colombia. Ley 1934 de 2018, del 2 de agosto, por medio de la cual se reforma y adiciona el Código Civil. http://bit.ly/3s TpVMy

España. "Código Civil". Real Decreto del 24 de julio de 1889 por el que se publica el Código Civil. http://bit.ly/21dWGFW

España, Cataluña. "Código Civil de Cataluña”. Ley 10/2008, del 10 de julio, del libro cuarto del Código Civil de Cataluña, relativo a las sucesiones. http://bit.ly/39dzttS 